DET VILLRÅDIGA SAMH ÄLLET 


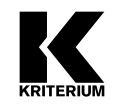




\section{Det villrådiga samhället}

Kungliga Vetenskapsakademiens politiska och ekonomiska ideologi, 1739-1792

Mathias Persson

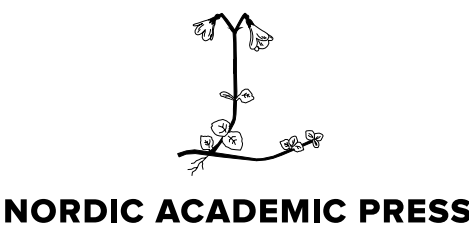




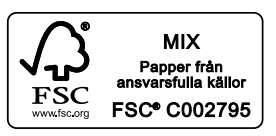

(C) Nordic Academic Press och Mathias Persson 2020

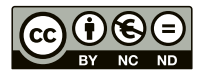

Denna bok är en utgåva från Nordic Academic Press Checkpoint - en serie för böcker som genomgått peer review enligt specifika riktlinjer.

Den är samtidigt utgiven inom Kriterium, ett konsortium som sakkunniggranskar svensk vetenskaplig litteratur. Samtliga böcker utgivna inom Kriterium finns tillgängliga open access via hemsidan www.kriterium.se.

Kopiering eller annat mångfaldigande av denna inlaga kräver förlagets särskilda tillstånd.

\author{
Nordic Academic Press \\ Box 148 \\ 221 oo Lund \\ www.nordicacademicpress.se
}

Sättning: Aina Larsson/Sättaren

Omslag: Fugazi form/Cia Björk, PCG Malmö

Omslagsbild: Vy över Stockholm från Gustav Adolfs torg.

Etsning av Johan Fredrik Martin, ca 1797.

Foto: Uppsala universitetsbibliotek

Tryck: Livonia Print, Riga 2020

ISBN 978-91-88909-44-2

ISBN 978-91-88909-54-1 (epdf)

ISSN 2002-2131 Kriterium (Online)

DOI 10.21525/kriterium.27 


\section{Innehåll}

1. Inledning 11

Prolog - Stockholm, den 3 oktober $1739 \quad 11$

En akademi i samhällets mitt $\quad 13$

$\begin{array}{ll}\text { Presidietal och politik } & 17\end{array}$

Samhällssyn, ideologi, karisma $\quad 20$

Vetenskapsakademien och samhällsledningen 30

2. Det borgerliga tillståndet $\quad 35$

Natur och samhälle $\quad 35$

Gemenskapens gestaltning $\quad 50$

$\begin{array}{ll}\text { Samhället i bilder } & 61\end{array}$

3. Myndiga makthavare, omyndig menighet 71

$\begin{array}{ll}\text { De vaksamma rörarna } & 71\end{array}$

Det oresonliga folket $\quad 86$

4. Hattarnas akademi $\quad 105$

Hattvänlig hushållning $\quad 105$

Mössorna vid makten $\quad 119$

Hattarnas återkomst $\quad 133$

Gustaviansk ekonomi $\quad 145$

5. Konungarnas akademi 159

Frihetstidens kungliga konjunkturer $\quad 159$

Den tredje Gustavens dagar $\quad 171$ 
6. Vetenskapsakademien, samhället och makten 197 Den samhällsnyttiga akademien 197

Approprieringar och smicker $\quad 205$

Övertalning och kritik 222

7. Det villrådiga samhället 233

Noter 243

Källor och litteratur $\quad 315$

$\begin{array}{ll}\text { Personregister } & 337\end{array}$ 


\section{Författarens tack}

Jag vill rikta ett stort tack till

* Handelsbankens forskningsstiftelser, som finansierat det forskningsprojekt som legat till grund för denna monografi och därmed gjort den möjlig.

^ Ekonomisk-historiska institutionen vid Uppsala universitet, som utgjorde min primära vetenskapliga hemmiljö under projekttiden. Jag är tacksam inte minst mot institutionens prefekt Lars Magnusson, som lät mig förlägga mitt projekt där, och mot hans efterträdare Sofia Murhem, Jan Ottosson och Fredrik Sandgren, som visade stor förståelse under forskningsarbetets avslutande fas.

๑ De kollegor som läst, kommenterat och hjälpt till att förbättra de olika kapitlen: Hanna Hodacs, Måns Jansson, Anders Lundgren, Annie Mattsson, Jacob Orrje och Hedvig Widmalm.

* Mina kollegor i den insomnade forskningsnoden "1700-tal: Sverige i världen - världen i Sverige" vid Historisk-filosofiska fakulteten, Uppsala universitet, för givande samtal om allehanda aspekter av 1700-talet: Marie-Christine Skuncke, Annie Mattsson, Tim Berndtsson och Vera Sundin. Ett varmt tack går också till Ann Öhrberg, dåvarande prefekt för Litteraturvetenskapliga institutionen, där noden var baserad, samt till de forskare och masterstudenter som ingick i denna fruktbara tvärvetenskapliga miljö.

* Medlemmarna i "Jean-Jacques Rousseau och Sverige ca 1760-1830: Ett nätverk för studier av Rousseaureceptionen i Sverige från den sena 
frihetstiden till och med den tidiga romantiken" och dess avläggare "Rousseau and the negotiation of enlightenment in Sweden", som jag hade förmånen att få samarbeta med under några år. Ingen nämnd, ingen glömd.

* Knut Ove Eliassen, som ansvarat för den vetenskapliga granskningen av Det villrådiga samhället, och de två anonyma norska granskare som liksom han givit kärnfulla och konstruktiva synpunkter på manuset.

* Kriterium och dess redaktionsråd, i synnerhet Åsa Arping och Maja Pelling, för det arbete de lagt ned på boken.

^ Thomas Kaiserfeld, som bidrog med ett viktigt vetenskapligt utlåtande om monografin när jag ansökte om olika tryckbidrag.

^ Förlagsredaktören Annika Olsson för gott samarbete och språkgranskaren Tove Paulsson Holmberg för en ingående genomgång av Det villrådiga samhället.

^ Alla vänner, på Carolina Rediviva och utanför, som jag diskuterat min forskning och mitt bokprojekt med under årens lopp.

^ Sist, men ingalunda minst, bokutgivningens finansiärer: Kungl. Patriotiska Sällskapet, Letterstedtska föreningen, Magnus Bergvalls Stiftelse, Stiftelsen Konung Gustaf VI Adolfs fond för svensk kultur samt Åke Wibergs stiftelse. 
Ordning är nyttig i all ting. ${ }^{*}$

Furstanom och Regeringen åligger det, at rätt handhafva förmynderskapet öfver det villrådiga Samhället, at främja dygden ock utrota odygderne. ${ }^{* *}$

* Clas Alströmer, Tal, om den fin-ulliga får-afveln [...] (Stockholm, 1770), 100.

** Henrik Jakob Wrede, Tal om et borgerligit samhälles eller et land ock rikes rätta styrka, samt sätt ock utvägar at komma der til [...] (1743) (Stockholm, 1747), 17. 



\section{Inledning}

\section{Prolog - Stockholm, den 3 oktober 1739}

Den 3 oktober 1739 avgick Carl von Linné (Linnæus) från posten som ordförande, preses, i Kungliga Svenska Vetenskapsakademien, som grundats nästan på dagen fyra månader tidigare, den 2 juni samma år. Det högtidliga tillfället kröntes med ett anförande, Tal, om märkvärdigheter uti insecterna, vilket i en återblick av bergsrådet Samuel Sandels (Sandel) uppgavs ha "gifvit anledning til alla de nyttiga och Academien hedrande Afhandlingar, hvarmed afgående Praesides slutat deras Ämbetes förvaltning". ${ }^{1}$ Talet hade vid sidan av den entomologiska ansatsen iögonenfallande religiösa inslag som förmedlade författarens övertygelse att de minsta djuren utgjorde de bästa bevisen för Skaparens vishet och att insekterna prisade Gud på ett oöverträffat sätt. ${ }^{2} \mathrm{Tal}$, om märkvärdigheter har framställts som ett typexempel på linneansk och frihetstida fysikoteologi, en idéströmning som utgick från att studier av den sinnrika, ändamålsenliga och välbalanserade skapelsen kan ge kunskaper om dess gudomliga upphov. ${ }^{3}$ Talet blev den mest lästa av Linnés fysikoteologiska skrifter och översattes till flera europeiska språk. ${ }^{4}$ Det hade dock även en tydlig politisk dimension, som inte ägnats lika mycket uppmärksamhet som den religiösa.

Gunnar Broberg har visat att världsordningen i Linnés texter ofta påminde om samhällets rangordning och att han betonade naturens hierarki snarare än dess kontinuitet. ${ }^{5}$ Tal, om märkvärdigheter lånar sig lätt till sådana tolkningar. Det gestaltade världen som en gigantisk kedja, i vilken varelser tilldelats olika kognitiva egenskaper och människan intog en särställning tack vare sin överlägsna tankeförmåga och odödliga själ. Ett grundantagande var att ingenting existerade för 
sin egen skull - allting hade skapats för att tjäna någonting utöver sig självt. ${ }^{6}$ Samhället följde denna princip i lika hög grad som naturen: sjömän riskerade sina liv för att bringa andra vinst, soldater offrade sig för sina landsmäns frihet och välstånd, ämbetsmän vigde sina liv åt att verka för folkets väl, styresmän åsidosatte sitt eget välbefinnande för det allmänna bästa och de starka, intelligenta och lärda använde sina begåvningar till medmänniskornas gagn. Här kan utsagorna om ämbetsmännens och de styrandes osjälviska vedermödor läsas som en legitimering av deras samhällspositioner, och yttrandet om de lärda som ett försök att uppvärdera Linnés egen grupp, de kunskapsägande, vilka dessutom sades ha uppoffrat sig för andra samhällsinvånare genom att instifta Vetenskapsakademien. ${ }^{7}$

Linnés parallellisering av naturen och samhället utmynnade i ett moraliskt imperativ: "Här af se wi, MINE HERRAR, uti denna Werldsens, af Skaparen sielf giorde Hushåldning, hur al ting skapat är ei för sig sielf, utan ock äfvven [sic] för andra. En vis man slutar här af den skuld sielfva naturen giör oss skyldig til i alt vårt väsende.” Denna plikt var den mänskliga gemenskapens fundament och en praktisk nödvändighet. Människorna hade direkt efter världshushållningens tillkomst förenat sina krafter för att uppnå målsättningar som inte kunnat förverkligas av dem var och en för sig. ${ }^{8}$

I talet identifierades ett antal företeelser - kopparplåt, hus, slott, Ostindienresor, krig, vetenskaper - som en ensam person inte kunde få till stånd, lika litet som en "allena [...] styra land och rike, om han sielf alt regera skulle; men alt detta giöre flere med samblad hand och kraft lätteligen”. Detsamma var sant för tillvaron överlag. När något stort skall uträttas behöver åtskilliga hjälpas åt, oaktat om det rör sig om naturen eller om konsterna och vetenskaperna. Linné frågade retoriskt hur många tusen som måste arbeta för att göra en konung mäktig och ett rike lyckligt. ${ }^{9}$ Anmärkningarna om allenastyre och tusentals arbeten bör ha alluderat på frihetstidens politiska system, med dess formella folkstyre och begränsade kungamakt. Samma positiva värdering av det rådande styrelseskicket kan spåras i Tal, om märkvärdigheters avslutande kommentar om samtidens långvariga fred och dess uppsving i lärdom, vishet och lysande institutioner. ${ }^{10}$ 
Den samhällsgemenskap som framträdde i Linnés tal korresponderade mot världen som helhet och kännetecknades liksom den av ömsesidighet, harmoni och gudomliga avsikter, vilket implicerar att radikala samhällsförändringar ansågs vara svåra eller omöjliga att åstadkomma. ${ }^{11}$ Frihetstidens styrelseskick återspeglade den kosmiska ordningen och fick därmed en naturlig och gudomlig sanktion.

Den statiska och samhällsbevarande tonen torde ha spelat eliten och makthavarna i händerna, och som den följande analysen kommer att åskådliggöra var varken talets ton eller dess teman unika för Linné. Tidigare forskning har visat att tidigmoderna vetenskapsmän formulerade "socially usable patterns of natural hierarchy, order, and the due submission of ranks". Naturen försågs med strukturer som användes för att legitimera sociala sammanhang. ${ }^{12}$ Linnés presidietal kan betraktas som ett uttryck för denna vetenskapens politiska funktion, som även återfinns i texter författade av andra i Vetenskapsakademien. Då akademien var en inflytelserik inrättning i 1700-talets lärda värld och svenska samhälle, lämpar den sig väl för en analys av det tidigmoderna samspelet mellan politik och vetenskap.

\section{En akademi i samhällets mitt}

Syftet med föreliggande bok är att undersöka Vetenskapsakademiens politiska och ekonomiska ideologi, från organisationens grundande och hattpartiets maktövertagande 1739 till mordet på Gustav III 1792. Fokus ligger på Vetenskapsakademiens samhällssyn och hur den förändrades med tiden, samt på hur akademiens band till samhällsledningen - makthavarna och eliten - reflekterades i dess idéskapande kring samhället. Hur beskrevs samhället, "den organiserade mänskliga samlevnaden"? 13 På vilket sätt tänktes det hänga samman och hur relaterades samhället till naturen och världen i stort? Hur framställdes de samhällsledande, folket och förbindelsen dem emellan? Hur påverkades de ideologiska ståndpunkterna av mössornas maktövertagande 1765 och av Gustav III:s statsvälvning 1772? I vad mån kan idéerna om samhället kopplas till samröret med rikets styrande skikt, och hur förhöll sig ledamöterna till detta? Vilket utrymme fanns för kritik av samhällsledningen och 
ståndssamhället? Den sista frågan anknyter till samhällsdebattens radikalisering i slutet av frihetstiden och till den växande oppositionen mot det gustavianska väldet under 1780 -talet. ${ }^{14}$

I denna undersökning skärskådas Vetenskapsakademiens samhällssyn mot bakgrund av dels mer allmängiltiga tidigmoderna föreställningar om samhället, dels den nära interaktion mellan politik och vetenskap som karaktäriserade 1700-talets Sverige och ofta varit för handen i historien..$^{15}$ Akademien har beskrivits som en av den lärda kulturens två grundpelare, vid sidan av universiteten, och befann sig som Sten Lindroth påpekat "mitt i sin tids svenska ståndssamhälle", varför organisationen kan anses ha varit representativ för vidare tänkesätt. I likhet med motsvarande utländska institutioner hade Vetenskapsakademien täta kontakter med den sociala, ekonomiska och politiska eliten, och att åtskilliga personer ur den var medlemmar illustrerar politikens symbios med kulturen och lärdomen under svenskt 1700-tal. Akademien såg gärna höga och mäktiga herrar på ordförandeposten, vilken vid ett antal tillfällen bekläddes av riksråd. ${ }^{16}$

Som samtida iakttagare konstaterade var det inget sammanträffande att Vetenskapsakademien grundades samma år som hattpartiet tog makten. Det var inte heller något sammanträffande att de ideal som den nya regimen omfattade - patriotism, nytta, handel, manufakturer - omhuldades av ledamöterna. Akademien utgjorde ett viktigt led i den satsning på konst, litteratur och vetenskap som hattarna, Sveriges härskare 1739-65 och 1769-72, lanserade för att öka rikets anseende och välstånd..$^{17}$ Vetenskapsakademien var ett av deras redskap och associerades med partipolitik inte minst genom att den fungerade som remissinstans för myndigheterna. Medlemmarna stödde i allmänhet hattpartiets näringspolitik, merparten av grundarna var hattsympatisörer och ledande hattar var tongivande medlemmar i organisationen, medan kontroversiella anhängare av det konkurrerande politiska partiet, mössorna, inte valdes in. I samtiden betraktade många Vetenskapsakademien som en hattinstitution. Mösspolitiker ifrågasatte dess privilegier efter hattarnas fall på riksdagen 1765-66, och akademien undgick inte att dras in i den kritik som på 1760-talet riktades mot hattpartiets ekonomiska politik. ${ }^{18}$ 
Allt detta gör det rimligt att förutsätta att den samhällssyn som Vetenskapsakademien gav uttryck för generellt sett bidrog till att bevara och rättfärdiga samhällets ledning och utformning. Den befintliga forskningen ger vid handen att ledamöterna ofta förespråkade en ingripande statsmakt och stödde företeelser makthavarna månade om, som kyrkan och statlig styrning av näringslivet. ${ }^{19}$ Akademimedlemmen, hattpolitikern och landshövdingen Henrik Jakob Wrede fångade sammanslutningens statsinterventionistiska ådra väl när han hävdade att det ålåg "Furstanom och Regeringen [...] at rätt handhafva förmynderskapet öfver det villrådiga Samhället”. ${ }^{20}$ Ledamöternas politiska ställningstaganden var inte alltid explicita. Till exempel finns det fog för att tolka deras förespråkande av en rågång mellan näringar och industrigrenar som ett försvar av ståndssamhället, vilket allmänt uppfattades som en organisk och moralisk ordning, skapad av Gud och förkroppsligad och upprätthållen av staten. ${ }^{21}$

Undersökningsperiodens början avgränsas av Vetenskapsakademiens grundande 1739 och behöver därför inte ges någon mer utförlig förklaring. Valet av kungamordet 1792 som bortre gräns motiveras av att organisationens ställning som central samhällelig arena kan antas ha försvagats när akademiens status, betydelse och räckvidd avtog vid århundradets slut i samband med den naturvetenskapens reträtt och förskjutning mot vitterhet som utmärkte det sena 1700-talets Sverige. Den ekonomisk-politiska diskussionen inom Vetenskapsakademien avstannade också väsentligen i det mer repressiva klimat som kom att råda vid denna tid. ${ }^{22}$ Gustav III tappade inemot 1770 -talets slut intresset för akademien och närvarade under det följande decenniet endast sporadiskt vid dess möten, något som både speglade och förstärkte den negativa utvecklingen. ${ }^{23}$

Den historiska forskningen om 1700-talets vetenskapsakademi kan sägas sönderfalla i tre kategorier. De två första utgörs av verk inriktade på organisationens uppkomst och utveckling, som Bengt Hildebrands Kungl. Svenska Vetenskapsakademien (1939) och Sten Lindroths Kungl. Svenska Vetenskapsakademiens historia 1739-1818 (1967), samt av biografier över enskilda ledamöter, som N. V. E. Nordenmarks Pehr Wilhelm Wargentin (1939) och Carl Wilhelm Oseens Johan Carl Wilcke (1939). 
Den tredje kategorin består av undersökningar som behandlar ämnen med kopplingar till sammanslutningen och dess medlemmar, som Karin Johannissons Det mätbara samhället (1988) och Mattias Legnérs Fäderneslandets rätta beskrivning (2004). ${ }^{24}$

Vetenskapsakademiens tal har tidigare förekommit i en lång rad studier och utretts mest gediget av Lindroth, varom mera nedan. Mest nyligen har presidietalen analyserats av bland andra Magnus Ekblad i "Den naturkunnige akademieledamoten" (2003), Peter Hallberg i Ages ofliberty (2003) och Leif Runefelt i Dygden som välståndets grund (2005). Ekblad granskar akademiens samröre med hattarna med utgångspunkt $i$ partiledaren Carl Gustaf Tessins sociala nätverk, medan Runefelt belyser idéer om dygd och nytta i texter författade av flera av organisationens ordförande. Hallberg närmar sig 1700-talets tänkande genom Vetenskapsakademiens samhällssyn, som han tolkar i ljuset av inrättningens egalitarism. Han argumenterar för att ledamöterna såg akademien som ett mönster av jämlikhet för samhället generellt, en tes som dock bara underbyggs med historikern Olof von Dalin (Dalin), som inte var någon typisk företrädare för Vetenskapsakademien. Hallbergs uppfattning att medlemmarna "idealistically but in different degrees conceived of society as equivalent to the egalitarian society of scholars" bemöts i den föreliggande boken med en motsatt tolkning, enligt vilken samhället snarare utgjorde en utgångspunkt för hur sammanslutningen föreställdes. ${ }^{25}$

Vetenskapsakademiens syn på samhället och kontakter med samhällsledningen har i övrigt ådragit sig mindre intresse än organisationens ekonomiska ståndpunkter, som diskuterats av en mängd forskare. ${ }^{26} \mathrm{I}$ den mån banden till de styrande uppmärksammats har det främst handlat om samröret med hattarna, medan förhållandet till mössorna och till Gustav III väsentligen lämnats obeaktat. Frånvaron av en substantiell och sammanhållen analys av akademiens samhällssyn kan sättas i förbindelse med Sven-Eric Liedmans påstående att ledamöterna, till skillnad från de samtida universitetsekonomerna, inte behövde ge "en bild av samhället i dess helhet. Det innebar bl a att de i stort sett kunde hålla sig till de nyttiga tingen och bortse från olika klassers och gruppers nytta och frihet". ${ }^{27}$ Citatet pekar på att Vetenskapsakademien bortom sin vetenskapliga gärning huvudsakligen betraktats som en ekonomisk och 
nyttofokuserad miljö inom den historiska forskningen. Som prologen indikerar och undersökningen kommer att belägga, var akademiens medlemmar emellertid alls inte främmande för att resonera kring samhället, varken som det hölls för att vara eller som det ansågs böra bli.

Bokens inledningskapitel vigs åt redogörelser för presidietalen och de teoretiska ramarna samt en översiktlig bakgrundsteckning av Vetenskapsakademiens relation till samhällsledningen. Själva studien tar sin början med presidietalens fundamentalantaganden om tillvaron och samhället (kapitel två) och fortsätter med deras skildringar av i tur och ordning samhällsledningen och folket (kapitel tre), den ekonomiska politiken (kapitel fyra), monarkerna (kapitel fem) samt de lärda, akademien och deras samhällsuppgift (kapitel sex). Den övergripande strukturen i kapitel två, tre och sex är tematisk. Eftersom dessa delar av boken uppehåller sig vid tankegods som väsentligen förblev sig likt över tid spelar kronologi och kontextualisering en mindre roll i dem. Kapitel fyra och fem har däremot en företrädesvis kronologisk och kontextualiserande karaktär, då de idéer som står i centrum genomgick tydliga förändringar under den undersökta perioden. Boken avslutas med en sammanfattning av resultaten och en återkoppling till inledningens frågeställning (kapitel sju).

\section{Presidietal och politik}

Vetenskapsakademien kan ses som en del av en politisk kultur, i bemärkelsen ett diskursivt fält som hålls samman av de bidragande aktörernas gemensamma referenspunkter och målsättningar. ${ }^{28}$ Den politiska kulturen hänför sig till all aktivitet som har med samhällets bevarande och legitimitet att göra, varför den dels omsluter ett brett spektrum av föreställningar och handlingar, dels gör det möjligt att urskilja lärda politiska yttringar och knyta dem till statsmakten..$^{29}$ Nils Ekedahl tillhandahåller en beskrivning som passar väl in på Vetenskapsakademien när han definierar politisk kultur som "de retoriska och rituella iscensättningar av begrepp, symboler och myter som en viss grupp av aktörer framför på den offentliga scenen i syfte att tolka sin omvärld 
och förläna kraft och legitimitet åt den ordning och de värden som den menar bör råda i samhället". 30

Ett presidietal hölls varje gång en ordförande lämnade sitt tre månader långa ämbetsinnehav och publicerades i nästan samtliga fall tillsammans med ett svar från akademisekreteraren. Källmaterialet består av de tryckta talen, vilka från den politiska kulturens horisont framträder som iscensättningar av idéer med bäring på samhället i det offentliga rummet.

Presidietalen var tänkta att bidra till akademiens mål att odla modersmålet och en ny svensk vältalighetsgenre. De utgick från såväl den politiska som den lovprisande eller klandrande retoriken, genus deliberativum och genus demonstrativum. Båda frodades i frihetstidens Sverige, där vältaligheten utvecklades i forum som riksdagen, kyrkan, universiteten och Vetenskapsakademien. Den politiska retoriken hänförde sig till föreställningar om förändring och motsatsparet nytta-skada, den lovprisande eller klandrande retoriken till den förefintliga situationen och människors upplevda värde. ${ }^{31}$

Vetenskapsakademien publicerade förutom presidietal även inträdestal och åminnelsetal, när medlemmar tog säte respektive avled. Presidietalen tenderade liksom inträdestalen att uppehålla sig vid generella och principiella teman, och det var i presidie- och inträdestalen som ledamöterna tog ett helhetsgrepp om rikets hushållning. Till skillnad från inträdestalen hade presidietalen en lika framskjuten plats i sammanslutningens skriftutgivning som de folkbildande och praktiskt inriktade Kungliga Vetenskaps Academiens Handlingar. Akademiens sekreterare 1749-83, astronomen Pehr Wilhelm Wargentin, hävdade att presidietalen ärade organisationen lika mycket som Handlingarna gjorde och "nästan begärligare läsas af Allmänheten: ty de föreställa angelägna, nyttiga och nöjsamma ämnen på et behageligare sätt, än uti Rön och lärda Afhandlingar kan ske". ${ }^{2}$

Presidietalen har också tillmätts en särställning inom tidigare historisk forskning. Marie-Christine Skuncke har konstaterat att de var "bärare av en vital intellektuell debatt", medan Lindroth framhållit att de hör till Vetenskapsakademiens värdefullaste lämningar, fångar sin tids kultur och ekonomiska diskussion samt innehåller de mest preg- 
nanta uttrycken för organisationens näringspolitiska linje; "Där yttrade sig, förhållandevis fritt och otvunget, de höga herrarna, ämbetsmännen och företagarna inom Akademien i de stora patriotiska frågorna. I regel var svaren på förhand givna, dikterade av hattarnas merkantilistiska politik." 33

Presidietalen framstår när frekvens, popularitet, tyngd och samhällsorientering vägs samman som det bästa studieobjektet för att komma åt Vetenskapsakademiens politiska och ekonomiska ideologi. ${ }^{34}$ Varken akademiens övriga texter eller de enskilda ledamöternas skrifter kan beredas speciellt mycket utrymme i analysen, som icke desto mindre inbegriper ett omfattande och mångfasetterat källmaterial som kan antas ha speglat inrättningens allmänna hållning. ${ }^{35}$

Studien är idéhistorisk, inte begreppshistorisk, låt vara att det ibland finns orsak att gå in på begreppsliga faktorer. Den beaktar sociala, ekonomiska och politiska idéer om samhällsgemenskapens väsen, ursprung, utveckling, organisering, komponenter, inre samband och förhållande till naturen. Ambitionen är att koppla ett så brett grepp som möjligt om Vetenskapsakademiens tänkande kring samhället. För att få fram presidietalens dominerande tendenser har relevanta utsagor aggregerats genom en närläsning som på hermeneutiskt manér pendlat mellan talen och den korpus de tillsammans bildar. ${ }^{36}$

Det görs ingen metodologisk distinktion mellan samhälls- och naturinriktade presidietal, eftersom även de sistnämnda kommunicerade ideologiska budskap, eller mellan tal av lärda respektive politiker och högre ämbetsmän, eftersom båda grupperna hjälpte till att formulera Vetenskapsakademiens samhällssyn. Ingen skarp gräns dras heller mellan deskriptiva och normerande utsagor; en beskrivning har inte sällan till syfte att utöva makt över sitt föremål, vilket innebär att den inte endast reflekterar verkligheten utan också är föreskrivande och övertalande. Detta gäller inte minst framställningar av samhället: "Descriptions of what groups constitute'society' and how it is organized tend to also be prescriptive commentaries on how societies in general or a particular society ought to be constituted [...] our perception of reality, in this case 'society', is affected by the language that is used to make it intelligible to us." ${ }^{37}$ 
Skillnaden mellan vara och böra var ofta nog så tunn under en epok präglad av visioner om förbättring och reform. ${ }^{38}$ Till det kom att tidigmoderna ekonomisk-politiska texter upphöjde statsmakten och idealiserade tillvaron, liksom att de strategiskt ställde sina författare i ett gynnsamt ljus och hade till ändamål att utverka förmåner åt dem. ${ }^{39}$ Akademimedlemmarna använde, som den följande analysen visar, presidietalen på samtliga dessa sätt, inklusive för att bearbeta makthavarna och gestalta sin egen betydelse för det samhälle som de tecknade.

Undersökningen fäster sig varken vid själva talakterna eller det ritualiserade sammanhang som omgärdade dem, utan vid deras litterära lämningar, som inte behöver vara identiska med de muntliga framförandena. ${ }^{40}$ Boken beaktar endast undantagsvis talens retoriska element, som dock aldrig helt kan särskiljas från idéstoffet och aldrig enbart är ett utanverk. Talens mottagande lämnas utan avseende, likaså frågan om deras överensstämmelse med upphovsmännens egentliga åsikter; innehållet förmedlade ställningstaganden och hade påverkanskraft oavsett om det var situationsbundet och inte svarade mot vad ledamöterna verkligen tyckte. ${ }^{41}$

\section{Samhällssyn, ideologi, karisma}

På 170o-talet betecknade termen "samhälle" och synonymen "samfund" dels partikulära sammanslutningar som skrån, bolag och akademier, dels den helhet de ingick i, alltså vad som numera vanligen avses med "samhälle". Bestämningen "borgerligt" kunde läggas till "samhälle", som därmed tydligare avgränsades gentemot de mindre sammanslutningarna. ${ }^{42}$ "Borgerligt samhälle" var en översättning av det latinska societas civilis, antingen direkt eller via tyskans bürgerliche Gesellschaft, och förekom liksom "samhälle" ofta i anknytning till naturrätten, som tas upp i nästa kapitel. ${ }^{43}$ Samhället fattat som helhet kom under seklets gång att tillerkännas allt större vikt och bli den mänskliga samvarons väsentliga ontologiska referensram. ${ }^{44}$ Det är ingen tillfällighet att de moderna samhällsvetenskapernas rötter går att spåra till 170o-talet, med dess intresse för samhällsgemenskapen som totalitet liksom för olika aspekter av den. ${ }^{45}$ 
Samhället begripet som helhet beskrevs också med ordet "stat", medan det som idag kallas staten täcktes in av termer som "kronan" och "överheten". 46

Bo Lindberg har apropå 1700-talet anmärkt att:

"samhället" i regel används i framställningar och diskussioner av statsrättsliga frågor om den politiska gemenskapens uppkomst och orsak och om var makten ligger. "Samhället" associerar omedelbart till de människor som ingår i gemenskapen [- - - "Stat" å andra sidan bär med sig tydligare associationer till regering, administration och även utrikespolitik: i de fall dessa associationer är synliga är det ett mer juridiskt och abstrakt ord för den politiska gemenskapen. Men skillnaden är inte tydlig, ofta är de båda orden utbytbara. ${ }^{47}$

"Stat" i meningen "samhälle" uppträder här fortsättningsvis uteslutande i citat ur källmaterialet, i övrigt är "stat" en analytisk term som betecknar de samlade maktutövande offentliga institutionerna. ${ }^{48}$

Enligt Martin Melkersson består en samhällssyn av idéer om människans väsen, samlevnadens gestaltning och relationen mellan å ena sidan samhällets komponenter, å andra sidan komponenterna och helheten. ${ }^{49}$ Hans definition kan jämföras med Charles Taylors teoretiska begrepp social imaginary, som innefattar "the ways people imagine their social existence, how they fit together with others, how things go on between them and their fellows, the expectations that are normally met, and the deeper normative notions and images that underlie these expectations". ${ }^{50}$ Som denna undersökning kommer att demonstrera var Vetenskapsakademiens syn på samhället kopplad till ledamöternas förståelse av världen, som många gånger betraktades genom ett religiöst raster. Samhällssynen häftade också i föreställningar om landet Sverige, vilka här bara kommer att beröras i den mån de har bäring på idéerna om det svenska samhället.

Även om 170o-talets samhällssyn inte var enhetlig och rivaliserande tolkningar av den sociala och politiska verkligheten förelåg pekade mycket av det gängse idégodset åt samma traditionalistiska håll. Samhället framställdes generellt i funktionalistiska, holistiska, organiska och statiska termer, men både det och samhällssynen förändrades 


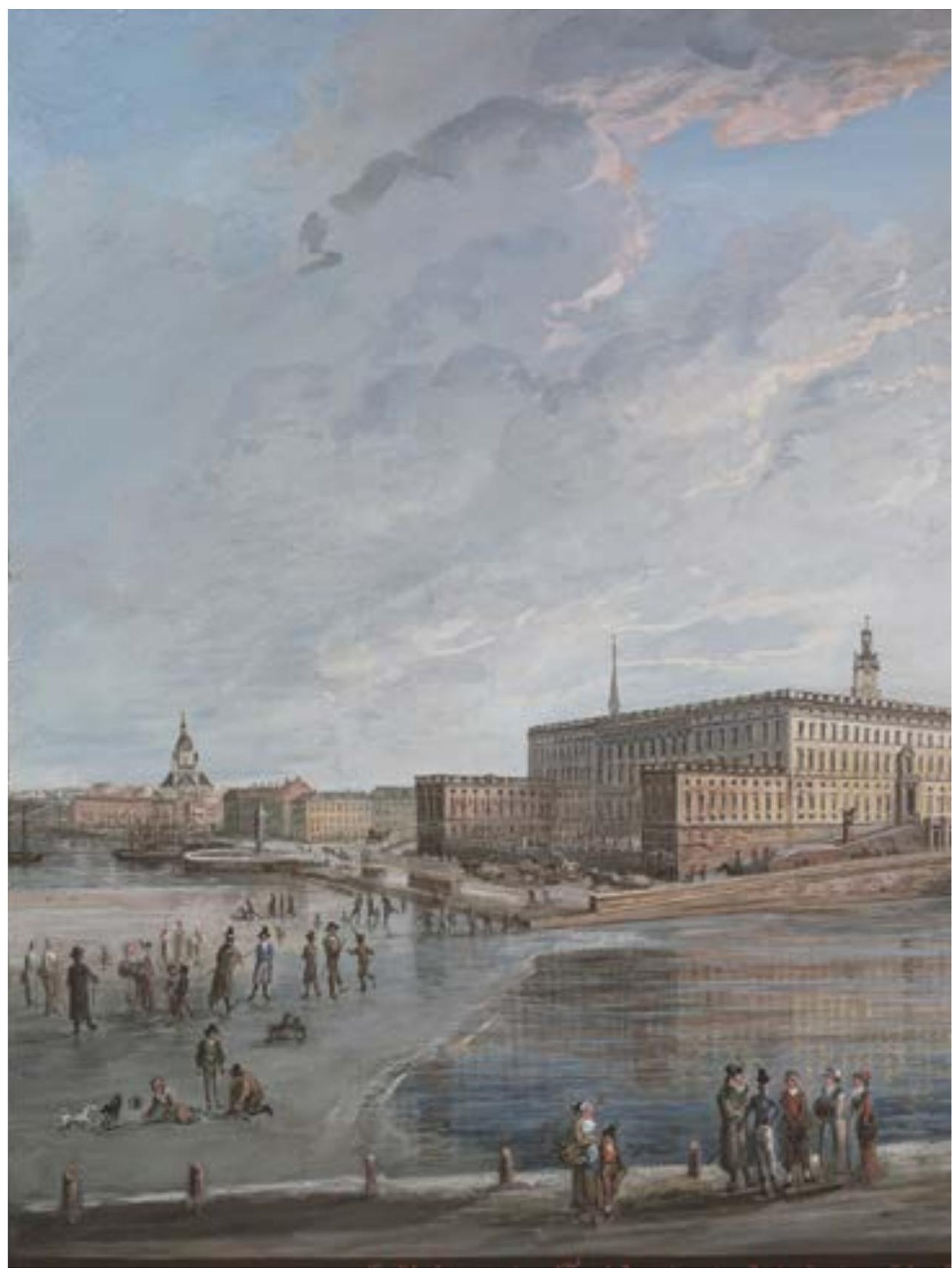

Bild 1. Elias Martin, Stockholmsvy. Utsikt från Fersenska terrassen. Foto: Nationalmuseum. Kungliga 
avsevärt under århundradet, då medborgaren och folksuveräniteten vann mark på undersåtens och furstesuveränitetens bekostnad. En nyhet var föreställningar som satte individen och spontaniteten före korporationerna och statsmakten. Med utgångspunkt i detta växte en tilltagande kritik av statlig reglering av och inblandning i näringslivet, som intill 1700-talets mitt med självklarhet underställdes staten och samhällsgemenskapen. Den nedärvda ordningen baserad på stånd, skrån och hushåll förblev likväl tongivande, medan människan fortfor att tänkas som en odygdig och ofullkomlig "korporationsvarelse" $\mathrm{i}$ samhällshelhetens skugga; också "atomistiska samhällsteorier fick [...] korporativa drag, eftersom samhället såg ut som det gjorde". Varken privilegieekonomin eller statsmaktens paternalistiska involvering $\mathrm{i}$ hushållningen ifrågasattes på allvar. ${ }^{51}$

För att tydliggöra att samhällssynen har starka värderande inslag och är förankrad i ett visst segment beskrivs den i termer av politisk ideologi och ekonomisk ideologi, som fångar olika men kompletterande sidor av tänkandet kring samhället. Med politisk ideologi avses ett huvudsakligen medvetet idésystem som rymmer många sammanflätade föreställningar, utgör en sinnebild av tillvaron, är baserat i en grupp och korresponderar mot dess samhällsställning samt vägleder och rättfärdigar agerande..$^{52}$ Med ekonomisk ideologi avses här efter Joseph Schumpeter en serie utsagor och förutfattade meningar om en upplevd ekonomisk verklighet, vilka bildar ett system och skyddar den grupp som ansluter sig till dem. Vetenskapen fungerar ur hans perspektiv som en teknik vars resultat tillsammans med preferenser eller värdeomdömen ligger till grund för rekommendationer. ${ }^{53}$ Fastän Schumpeter knappast hade den tidigmoderna perioden $i$ åtanke när han konstruerade sin modell kan den helt klart tillämpas på presidietalen, som genererade ekonomisk-politiska och politiska rekommendationer utifrån en kombination av rön och värderingar.

Vetenskapsakademien graviterade kraftigt mot nytta och hushållning och hade inledningsvis till främsta syfte att gynna den ekonomiska tillväxten. Akademien var ursprungligen tänkt att benämnas"Oeconomisk vetenskapssocietet" och kom i praktiken att tjäna som en sådan under huvuddelen av 1700-talet. ${ }^{54}$ Enligt protokollet från den första samman- 
komsten var intentionen att för det allmänna bästas skull utveckla och utbreda "kunskapen uti Mathematique, Naturkunnighet, Oeconomie, Handel, nyttiga Konster och Manufacturer" ${ }^{55}$ Ledamöterna hade en benägenhet att begripa verkligheten ekonomiskt och spelade en ledande roll i spridandet av den frihetstida nyttokulturen. ${ }^{56}$ Det publicistiska flaggskeppet Kungliga Vetenskaps Academiens Handlingar, en tidskrift där människor från olika samhällsskikt och landsändor kunde bidra och bli "nyttiga medlemmar av en stor, osynlig krets av fosterlandsvänner", har träffande kallats en centralinstitution för det svenska 1700-talets ekonomisk-patriotiska ansträngningar. ${ }^{57}$

"Ekonomi" var i likhet med "samhälle" en flertydig term. Den hade dock ofta innebörden av "hushållning", varvid den kunde omfatta allt från enskildas kroppar eller bärgning till Guds förnuftiga ordnande av Skapelsens materiella resurser. Den ekonomi eller hushållning 1700-talets människor föreställde sig var integrerad i ett helhetssammanhang och oupplösligt förenad med världsbild, människosyn, religion och moral. Inom dess ramar samsades naturstudier, statsfinanser och konster, i betydelsen sysselsättningar som krävde speciella färdigheter och insikter. ${ }^{58}$ Inte heller "ekonomi" motsvarade således den nutida terminologin, något som måste bäras i minnet när ordet påträffas i tidigmoderna texter.

Det finns skäl att erinra om Karl Forsmans observation att 1700-talets svenska hushållningsanstalter "under den brokiga ytan av idéer och uppslag" byggde på ett outtalat och undflyende mentalt ramverk, "en grundåskådning, vilken samtiden endast bristfälligt kunde ge form åt och eftervärlden inte fullt förstått" ${ }^{59}$ Dit kan räknas de underförstådda premisserna bakom olika samhällsvisioner, liksom kontursvaga försanthållanden om verklighetens beskaffenhet.$^{60}$ Studien söker kasta ljus över denna ekonomins djupdimension, som lika litet som Vetenskapsakademiens samhällssyn eller förhållningssätt till samhällsledningen gjorts till föremål för regelrätt analys.

Om "ideologi" används för att belysa Vetenskapsakademiens idéskapande kring samhället ringar "karisma" in organisationens samröre med makten. Enligt Edward Shils är karisma en kvalitet som tillskrivs handlingar, roller, personer, grupper, inrättningar och artefakter som 
uppfattas stå i kontakt med en grundläggande kosmisk och samhällelig ordning, "the ultimately 'serious' elements in the universe and in human life". Han fastslår att det alltid finns en lågintensiv, institutionell och förmedlad karisma, som är associerad med uttryckandet av makt och skänker legitimitet åt samhället och dem som anses befinna sig i, eller nära, tillvarons centrum, inte minst ämbetsmän inom statsförvaltningen. ${ }^{61}$ Clifford Geertz betonar sambandet mellan aktörers symboliska laddning och samhällsordningens aktiva centrum i meningen "concentrated loci of serious acts [...] the point or points in a society where its leading ideas come together with its leading institutions to create an arena in which the events that most vitally affect its members' lives take place”. Karisma förvärvas genom positiv eller negativ interaktion med sådana arenor och deras skickelsedigra tilldragelser, med verklighetens kärna. ${ }^{62}$

Då Vetenskapsakademien de facto var underställd statsapparaten kan den ses som en exponent för institutionell karisma, och dess närhet till arenor för högtidliga och samhällsrelevanta handlingar - riksdagen, kollegierna, Kungliga slottet - innebar att den fick del av deras nimbus. ${ }^{63}$ Samtidigt gör ledamöternas skärskådande av den gudomliga världsordningen, deras strävan att bemästra naturen och deras hantering av brännande samhällsfrågor att akademien kan förstås som ett centrum som alstrade karisma genom att positionera människor nära tillvarons hjärta. ${ }^{64}$ En ledamot förkunnade att han i Vetenskapsakademien stod "likasom i Cirkelens medel-punct af alt hvad Riket äger i kunskap och vitterhet”. Enligt en annan var medlemmarnas egentliga värv djupsinnigt begrundande av Guds och naturens lagar, som gjorde ordningen till ändamålet för människans hela väsen. Wargentin uppgav dels att akademien ägnade sig åt oföränderliga och fullkomliga lagar som Skaparen stiftat i naturens rike, dels att den hade nära anknytning till de samhälleliga lagarna, exempelvis genom att vetenskaperna kom till nytta inom lagstiftningen. ${ }^{65}$

Samhällsordningens aktiva centrum är trots att de ställer upp en enad front i form av berättelser, insignier, ceremonier, konventioner och identifikationer ofta behäftade med inre spänningar. ${ }^{66}$ Vetenskapsakademien var lika litet som andra inrättningar och grupperingar i sin 


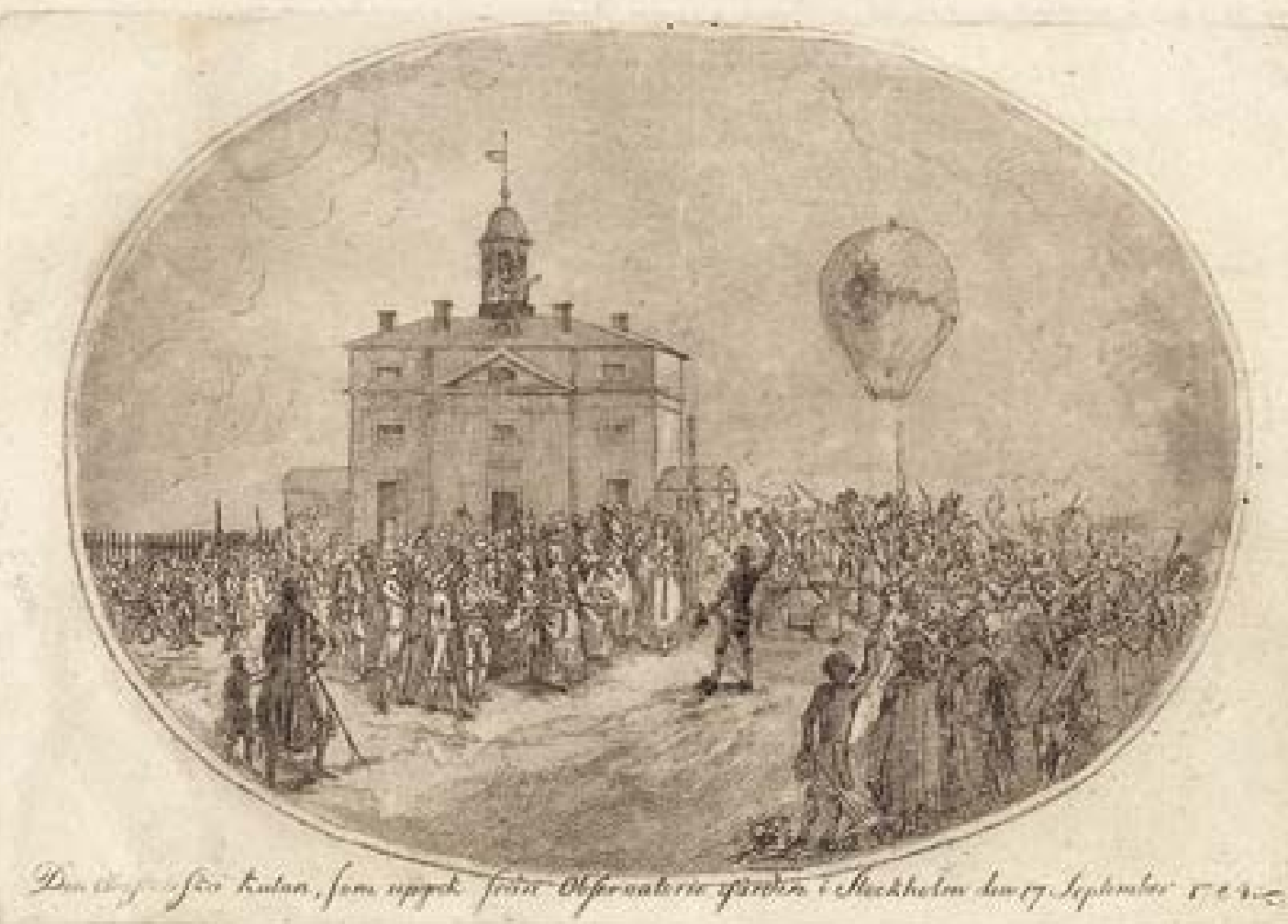

Bild 2. Den Aerostatiska Kulan, som uppgick från Observatoriegården i Stockholm den 17. September 1784. Foto: Uppsala universitetsbibliotek. Vetenskapsakademiens utforskande av skapelsen, här i form av en ballonguppsändning, innebar att den förknippades med karisma.

samtid åsiktsmässigt homogen. ${ }^{67}$ Den utgjorde särskilt under frihetstiden ett forum för diverse myndighets-, grupp- och företagsintressen och kan därmed betraktas som en paraplyorganisation eller "trading zone", en plats där olika "subkulturer" möts. ${ }^{68}$ Föreliggande analys söker följaktligen belysa ideologiska ledmotiv inom akademien, inte belägga den med allmängiltiga, programmatiska ståndpunkter.

Några språkliga anmärkningar är nödvändiga innan bakgrunds- 
avsnittet om Vetenskapsakademiens band till samhällsledningen vidtar. Distinktionen mellan manufakturer och hantverk är långt ifrån alltid klar i källmaterialet. Termerna "manufaktur" och "slöjd" har haft likartade innebörder och är närbesläktade. Svenska Akademiens ordbok förbinder "handslöjd" och "slöjd" med hantverk och handarbete och hänvisar i båda fallen till "manufaktur" som utgör en sammansättning av latinets manus ("hand") och factura ("tillverkning", "bearbetning”). Ett av presidietalen föreställde inte för inte manufakturerna som "Handaslögds verk". ${ }^{69}$ När ledamöter nämnde såväl manufakturer som (hand)slöjder innefattade den sistnämnda termen rimligen enbart hantverksproduktionen, som på det juridiska planet nogsamt hölls isär från manufakturverksamheten. ${ }^{70}$

Beteckningarna "utilism", "merkantilism" och "kameralism" förekommer i denna undersökning bara när andra forskare refereras eller citeras, eftersom de är diffusa och vida samt riskerar att reifieras och låsa fast analysen i en viss bild av det förflutna. Framför allt har de tidigare medfört att den ekonomiska debattens innehåll beretts otillräcklig uppmärksamhet. ${ }^{71}$

"Inbördes" betydde "ömsesidigt", "sinsemellan" eller "gemensamt", det som var "enfaldigt" var enkelt och med "författning" åsyftades en lag eller reglering. ${ }^{72}$ Ordet "politi" var förknippat med den administrativa praktiken och avsåg huvudsakligen samhällets inre ordning, men kunde därtill fungera som ett samlingsnamn för makthavarnas strävanden att befordra välståndet och välfärden. ${ }^{73}$

Folkflertalet gick under en mängd olika benämningar; undersökningen använder "folk", "allmoge", "menighet" och "gemene man" synonymt. ${ }^{74}$ En annan beteckning för folket, "allmänhet", reflekterar alltid det exakta ordvalet i det resonemang som återges, då den har en annorlunda färgning i kraft av sin koppling till "det allmänna" ${ }^{75}$ Kategorin "ståndspersoner" kunde inkludera alla som stod över de breda befolkningslagren men åtskildes också från adeln, borgerskapet respektive prästerskapet. ${ }^{76}$ "Medborgare" var en komplex term, som inte nödvändigtvis hade ett moderniserande innehåll och i sin äldsta tappning vanligen syftade på relationer mellan undersåtarna; de som var "medborgare i förhållande till varandra var undersåtar i förhål- 
lande till överheten”. Fastän alla invånare i teorin omfattades av den förblev termen länge i praktiken snäv, eftersom folkflertalet sågs som undersåtar för de styrande att befalla. ${ }^{77}$

"Lycksalighet" var ett mångfasetterat ord med teologisk resonansbotten som sträckte sig över olika religiösa strömningar. Det kom att få ett inomvärldsligt och känslomässigt innehåll: lycksalighet gick att erfara här och nu, på det affektiva planet. ${ }^{78}$ I det följande begagnas "lycksalighet", "lycka" och "sällhet" synonymt med varandra, i linje med presidietalens terminologi.

"Vetenskap" hade en vidare och vagare innebörd än idag. Termen överensstämde ungefär med latinets scientia och hänförde sig till systematisk kunskap och de kunskapsområden denna härrörde från. Vetenskapsakademien omspände förutom fält som fysik, matematik och naturalhistoria även sådana som ekonomi, historia och juridik. När ledamöterna skrev och talade om vetenskap menade de följaktligen kunskap som gick utöver dagens naturvetenskaper. De förstod dessutom vetenskap som nyttigt, praktiskt och säkert vetande. ${ }^{79}$

Stora män, enkannerligen furstarna, skulle enligt en från antiken nedärvd och under 1700-talet ännu utbredd tankefigur fungera som uppbyggliga moraliska föredömen ("efterdömen") för människor i alla samhällsskikt. Detta synsätt hörde hemma inom den klassiska retoriken och dess tradition av exempla, personer eller händelser som befanns vara exponenter för universella sanningar - främst dygder och laster - och som skulle imiteras eller avskräcka från imitation..$^{80}$

Personnamn stavas mot bakgrund av 1700-talets brist på uniformitet $\mathrm{i}$ enlighet med Kungliga bibliotekets nationella söktjänst LIBRIS eller, när någon saknas där, Svenskt biografiskt lexikon. En person som adlades går konsekvent under sitt nya namn, medan det ursprungliga efternamnet anges inom parentes första gången den omnämns i boken. Presidietalens titlar har standardiserats såtillvida att betoningar och versaler för allt utom egennamn tagits bort liksom - för att spara plats - den del av titeln som meddelar vem som hållit talet och när. 


\section{Vetenskapsakademien och samhällsledningen}

För att ge relief åt Vetenskapsakademiens samhällssyn behövs en översiktlig redovisning inte enbart av akademiens förhållande till samhällsledningen och dess position i det svenska institutionella landskapet, utan även av de lärdas politiska och sociala villkor under 1700-talet. $\AA ̊ ㇒$ ena sidan ingick tidigmoderna kunskapsägande i en transnationell gemenskap känd som "de lärdas republik" - ett nätverksbaserat system av människor, föremål, texter och information som idealt skulle präglas av jämlikhet, meritokrati, ömsesidighet, tolerans, kosmopolitism, yttrandefrihet samt obehindrat sanningssökande. ${ }^{81} \AA$ andra sidan tillhörde de stater som gjorde anspråk på deras färdigheter och lojaliteter. Svenska lärdoms- och vitterhetsutövare tenderade att inneha ämbeten, räknas som ståndspersoner och knytas till eliten genom sociala nätverk. ${ }^{82}$ Wargentin ansåg symptomatiskt nog att en längre tjänstgöringstid än tre månader var olämplig för Vetenskapsakademiens ordförande, då "större delen af Ledamöterna hindras af andra trägna ämbets-syslor" ${ }^{83}$

De lärdas politiska och sociala omständigheter inverkade helt naturligt på deras hållning till samhället och världen. Lisbet Rausing (förut Koerner) har identifierat en "Östersjöupplysning" ("Baltic Enlightenment") som bars upp av lärda ämbetsmän och dominerades av lutheranism och nyttotänkande. Knut Ove Eliassen laborerar istället med en "nordlig upplysning" ("Northern Enlightenment") kännetecknad av statstjänande vetenskap, luthersk tro och ett antiradikalt eller "konservativt" drag. Båda dessa upplysningsriktningar är kompatibla med den tyska "ständerupplysning" (ständische Aufklärung) som enligt Jonathan Knudsen utmärktes av statscentrering, de lärdas långtgående kompromissande med myndigheterna, kristendom och paternalism. ${ }^{84}$ De tre upplysningsvarianterna täcker in samma företeelse i 1700-talets Östersjöområde och samtliga kan appliceras på det svenska riket, vars upplysning har beskrivits som kristen, antiradikal, nyttoivrande, kunskapsinriktad och tyskinfluerad. ${ }^{85}$

Vetenskapen kom under 1700-talet att socialiseras och integreras i samhällslivet. Eftersom de vetenskapliga sällskapen ofta var officiella och beständiga inrättningar som erkändes och stöddes av makthavarna 
kan de sägas ha förkroppsligat denna process och befunnit sig "on the cutting edge of relations between science and the state". De var många gånger urbana elitinstitutioner som stod i samklang med statsmakten och återkommande värvade medlemmar från samhällets toppskikt. ${ }^{86}$

Den svenska Vetenskapsakademien hämtade inspiration från bland andra Royal Society for the Promotion of Natural Knowledge i London, Académie des Sciences i Paris och Societas Regia Scientiarum i Berlin, som alla upprätthöll nära förbindelser med staten och eliten. ${ }^{87}$ Vetenskapsakademiens förtrolighet med samhällsledningen framgick av att organisationen samlade åtskilliga höga herrar och av att en person som Linné inte var mera självskriven än någon som Tessin. ${ }^{88}$ Enligt astronomen Eric Prosperin föll ordförandevalen "antingen på Dem, som genom sin börd och välstånd gifva Henne anseende, eller Dem, som genom sina ämbeten befordra Hennes tilväxt, eller Dem, som genom sin driftighet gifva lif och styrka åt Hennes göromål, ock Dem, som med sit snille och sina insigter pryda och uplysa Henne. Ofta finner Kongl. Vetenskaps Academien alla dessa egenskaper förenade" ${ }^{89}$ Det är tänkvärt att börd, välstånd och ämbeten kom först i Prosperins uppräkning, medan snille och insikter förtecknades sist.

Vetenskapsakademien hade trots att kärnan bestod av universitetsprofessorer en "merkantilt-aristokratisk" framtoning och även om den formellt saknade hedersledamöter återfanns åtskilliga medlemmar av sådan karaktär, låt vara att de ofta i någon mån ägnade sig åt lärda spörsmål. ${ }^{90}$ Förutom att delta aktivt i verksamheten vinnlade sig dessa höga herrar om akademiens välgång, till exempel genom att stödja uppförandet av dess astronomiska observatorium och utverkandet av dess almanacksprivilegium, det vill säga ensamrätt på publicering av almanackor. Sådana medlare var under frihetstiden för det mesta anknutna till hattpartiet. ${ }^{91}$ Mösspartiets kanslipresident Carl Gustaf Löwenhielm hjälpte visserligen till med att skaffa fram medel för studiet av Venuspassagen 1769, men han var samtidigt en före detta hattpolitiker och ensam bland det senare 1700-talets mössriksråd om att ingå i organisationen under frihetstiden. ${ }^{92}$

Mycket av Vetenskapsakademiens sociala samspel med samhällsledningen skedde inom nätverk som sammanstrålade i akademien. ${ }^{93}$ 
Ett nätverk kretsar kring de sociala kontakterna i sig och präglas av varaktighet, slutenhet, informalitet, frivillighet och jämlikhet. Tillit, gemensamma värden och intressen samt ömsesidiga beroenden som yttrar sig i utbyten av gåvor och tjänster utgör de sammanhållande kitten. ${ }^{94}$ Ekblad har kartlagt ett frihetstida nätverk med stark ställning i Vetenskapsakademien som formerades runt hattledarna Clas Ekeblad, Anders Johan von Höpken, Nils Palmstierna och Tessin. Det hade en yttre krets av ledamöter som arkitekten och överintendenten Carl Hårleman, Linné, Wargentin och den framtida mössledaren Löwenhielm. Många av frihetstidens presides rekryterades från denna grupp, liksom från hattpartiet i allmänhet. ${ }^{95}$ Tessin, Höpken och Ekeblad beklädde i tur och ordning kanslipresidentposten och var viktiga magnater i den frihetstida akademien. ${ }^{96}$ Först ut som ledare och kanslipresident - regeringschef - för hattarna var Carl Gyllenborg, som efterträdde mössan Arvid Horn vid riksrodret.

Vetenskapsakademien var fullt ut inlemmad inte bara i maktens nätverk utan även i dess institutionella landskap. Den enrollerade aktörer från och sysselsatte sig med samma eller liknande frågeställningar som andra offentliga eller halvoffentliga inrättningar som Bergskollegium, Kommerskollegium och handelskompanierna. Ett exempel på det förra är att flera bemärkta medlemmar - Johan Fredrik Kryger, Erik Salander och Johan Liljencrantz (Westerman) - var befattningshavare vid Manufakturkontoret, vilket i likhet med Vetenskapsakademien tillkom under riksdagen 1738-39. Ett exempel på det senare är att akademien enligt Bergskollegiums president Jean George Lillienberg genom sitt engagemang för bergshanteringen stod "uti nära gemenskap och förtroende" med denna myndighet. ${ }^{97}$

Vetenskapsakademiens sociala, politiska och institutionella inbäddning speglade ett normaltillstånd i 170o-talets Sverige, där verksamhetssfärer gick in i varandra och gränsen mellan privat och offentligt var oklar..$^{98}$ Åtskilliga ledamöter och ordförande var ämbetsmän, politiker och välbeställda näringsidkare från samhällets och statens övre skikt, varför presidietalen i hög grad utgjorde arenor för dialog inom samhällsledningen. Talen kommer här dock att behandlas som uttryck för Vetenskapsakademien, en kollektiv och publik aktör i egen rätt som 
tillhandahöll ett betydelsefullt och tydligt ramverk som upphovsmännen hade att förhålla sig till och anpassa sina budskap efter. James McClellan har gjort gällande att 1700-talets relation mellan statsmakt och lärda kan förstås som ett transaktionssystem varigenom bekräftelse, privilegier och ekonomiskt bistånd byttes mot specialiserade kunskaper som ofta hade politiska övertoner. ${ }^{99}$ Vetenskapsakademien framstår ur detta perspektiv mer som en förhandlingspart än ett passivt objekt eller instrument för makten. ${ }^{100}$ 



\section{Det borgerliga tillståndet}

Detta kapitel belyser fundamentalantagandena om samhället och tillvaron i Vetenskapsakademiens politiska ideologi. Det första avsnittet analyserar presidietalens redogörelser för förhållandet mellan den mänskliga samlevnaden och naturen samt deras föreställningar om samhällets ursprung, bevekelsegrunder och utveckling. Det andra avsnittet behandlar framställningarna av samhällsgemenskapens organisering och bindemedel, det tredje de organiska, mekaniska och arkitektoniska bilder som användes för att åskådliggöra den.

\section{Natur och samhälle}

Enligt Charles Taylor vilar de underliggande och normgivande tankar och bilder som en samhällssyn utgår från på försanthållanden om en metafysisk eller moralisk ordning, som utgör en central aspekt av den meningsskapande bakgrund alla normer och normstyrda handlingar ytterst är inbäddade i. Samhällssynens vidare resonansbotten har även uppmärksammats av Edward Harrison: "Where there is a society of human beings [...] there we find a universe; and where there is a universe, of whatever kind, there we find a society. Both go together, the one does not exist without the other. A universe unifies a society, enabling its members to communicate and share their thoughts and experiences."101 Dessa iakttagelser är särskilt giltiga för en tid som 170o-talet, då samhället ansågs ingå i världens gudagivna, naturliga ordning med dess balans och harmoni. Eftersom det förmodades dröja länge innan denna ordning av egen kraft skulle uppenbara sig i samhället rekommenderades ett aktivt och statligt dikterat strävande mot ett idealt, statiskt 


\section{P tens=}

Bild 3. Elias Martin, Aspa Bruk. Foto: Nationalmuseum. Samhälle och natur sågs som sammanlänkade inom ramarna för en gudomligt bestämd ordning.

jämviktsläge. Varken världen eller samhället var självreglerande i det tidigmoderna tänkandet. Liksom världens jämvikt ytterst garanterades av en vaksam och interventionistisk Gud som kunde korrigera de annars konstanta naturlagarna garanterades samhällets dito av aktsamma och justerande makthavare som kompletterade Skaparens verk. ${ }^{102}$

Så kallad stadieteori var en vedertagen tankefigur under undersökningsperioden och basen för dess tro på framsteg. ${ }^{103}$ Enligt denna kunde varje folk placeras in i en universell hierarki med ledning av sin upplevda materiella och kulturella utvecklingsnivå. Antalet föreställda stadier varierade, men den vanligaste modellen laborerade med fyra, vart och ett definierat av en viss försörjningsmetod: jakt och samlande, betesdjurhållning, jordbruk och handel. En annan variant delade in mänskligheten i vildar, barbarer och civiliserade, som svarade mot i tur och ordning jakt och samlande, betesdjurhållning samt lantbruk och handel. ${ }^{104}$ Stadieteoretiska resonemang var nära förknippade med den 
utbredda dikotomin mellan civilisation och vildhet, två sammanflätade begrepp med slående och viktiga funktionella likheter. Båda formade snarare än beskrev verk ligheten och var integrerade delar av det koloniala projektet. ${ }^{105}$ Om civilisationens markörer var förfining och upplysning var vildhetens en församhällelig eller embryonisk samhällelig existens i eller nära naturtillståndet. Vildar frånkändes historia och egendom och uppfattades ofta som det kultiverade livets yttersta motsats. ${ }^{106}$

Såväl stadieteori som dikotomin mellan civilisation och vildhet gick igen i Vetenskapsakademiens presidietal. Arkitekten och överintendenten Carl Fredrik Adelcrantz förkunnade att ju "flera naturliga beqvämligheter och nöjen et Lands Invånare nödgas beröfva sig, ju fattigare är det, ju närmare nalkas det djurliga tilståndet och följakteligen ju uslare är det; men däremot, ju flere och väsendteligare förmoner et folk sig kan tilskynda, ju rikare är det, ju närmare nalkas det den timeliga sällheten, hvarmed den Högstas ändamål vid verldenes skapelse varit förknippad". ${ }^{107}$ Linnélärjungen och naturalhistorikern Anders Sparrman tecknade ett mörkt porträtt av djuriska folkgrupper som drev omkring och jagade eller fiskade för att överleva, samtidigt som han skildrade ett samhälle som utvecklades mot allt högre höjder för att till sist nå ett civiliserat läge där städer och altaren uppfördes och haven utforskades $i$ sökandet efter kunskap. Längs vägen dit tillkom jordbruk, manufakturer och vetenskap. ${ }^{108}$ Ytterligare exempel på ledamöters tänkande i sådana banor återfinns längre fram i kapitlet.

"Natur" var ett normativt och mångtydigt begrepp under 1700-talet som ofta användes för att kontrollera och legitimera faktorer som idag bedöms vara socialt skapade. Genom att naturen likställdes med Guds skapelseordning och med "det goda" fungerade den som ett moraliskt imperativ. ${ }^{109}$ Flera av Vetenskapsakademiens medlemmar beskrev explicit naturen som en modell eller norm för samhället. ${ }^{110}$ Lycka skulle uppnås om människan utifrån naturens anvisning förkovrade sitt gudagivna förnuft, som satte henne över djuren, och det var generellt bäst att ha naturen som förebild vid förbättrandet av samhällets moraliska halt. Barnuppfostran borde inrättas "efter Naturens bild ock föreskrift", medan lagstiftningen skulle följa de premisser för människans lycksalighet som naturen stakat ut. Människans hushållning blev bättre 
ju närmare hon efterlevde naturens direktiv och hennes fullkomlighet ökade ju mer den jordiska hushållningsordningen efterliknade Guds ekonomiska ordning. ${ }^{11}$

Sådana utsagor gick tillbaka på idén om en fullgången, ideal och gudomlig ordning som band samhälle och natur till varandra i harmonisk förening. Föreställningen att de var sammanvävda enligt Guds plan bäddade för slutsatsen att alla hade sin förutbestämda plats i den mänskliga gemenskapen liksom allting hade det i naturen, och för att naturens rike kunde tjäna som ett mönster för harmoni och stabilitet $i$ samhällslivet. ${ }^{112}$ Natur och samhälle befann sig enligt hattriksrådet Carl Didrik Ehrenpreus tack vare Guds vishet "tilsammans uti et väsende". Hans ämbetskollega Carl Gustaf Löwenhielm, som sedermera övergick till mössorna, menade att människan och naturen var underkastade samma gudagivna, fysiska lagar och ingick i ett kontinuerligt men skiktat hushållningssystem som kännetecknades av jämvikt. Löwenhielm identifierade tre nivåer inom detta system: för det första naturens ekonomi, varigenom allt tjänade till nästans uppehälle, till släktets fortbestånd och till alltings förökande; för det andra samhällsekonomin, varigenom allting inrättades så att den mänskliga gemenskapens lemmar och sammanslutningar kunde bestå utan att tillfoga varandra skada; för det tredje den enskilda ekonomin, där varje hushåll eller samhällsmedlem på ett lämpligt sätt nyttjade och förmerade naturresurserna. ${ }^{113}$

Den natur Vetenskapsakademien laborerade med var inte en skådeplats för snabba eller långtgående förändringar. Det kan sägas vara signifikativt att endast två medlemmar, filosofen Nils von Rosenstein (Rosenstein den yngre) och matematikern Daniel Melanderhielm (Melander), kommenterade franska revolutionen, som Melanderhielm 1792 i förbifarten kallade "nu varande catastrophe i Frankrike". ${ }^{14}$ Ledamöter omtalade istället hur allting skedde i en naturlig ordning och utan plötsliga språng, som naturen helst undvek. Hur enkel och jämn naturen var i sin verkan. Hur naturen gick jämnt och sakta fram, särskilt när stora ting skulle ske, eftersom hast oftast för med sig senfärdighet. Hur den tenderade mera åt beskedlighet än häftighet och hur dess våldsamma verkningar lyckligtvis var kortvariga. ${ }^{115}$

Gustav III:s justitiekansler Joachim Wilhelm Lilliestråle (Broms) 
tog tydligt avstånd från abrupta samhällsförändringar. Han slog fast att sådana omställningar var riskabla och att ett ofördelaktigt slutresultat inte alltid kunde undvikas ens när dessa grundade sig i verklig rättvisa. Rättsutvecklingen skulle vara långsam och omärklig och de dåliga lagarna försvinna liksom av sig själva. Fördelen med ett varaktigt juridiskt ramverk och av enhetliga och systematiska lagar framhölls: "När en Lag är så inrättad, då är all ändring deruti förderfvelig, och ju äldre den då är, ju mera kräfver han vördning: Ja, änskönt ock skulle tyckas, at den til förmon i vissa delar omändras kunde; bör man dock häldre tåla en mindre olägenhet, än skynda til rubbning och ombyte; ty sjelfva tiden gifver det gamla, ehuru på någon sida skröpligt, et slags värde, aktning och anseende, som det nya icke så lätteligen vinner.”116

Lilliestråles traditionalism yttrade sig också i att han uppmärksammade problem med förändringar överlag, speciellt ifråga om vad som blivit hävdvunnet och gynnade vissa grupper. Han ogillade "Nyhetsandan", som hade destruktiva effekter och därför måste tyglas; det var förmånligt om denna anda inte väcktes till liv förrän det var absolut nödvändigt, men även då behövde den dämpas och styras, annars kunde förbättringen bli omogen, obeständig eller rentav fördärvlig. Argumentationen utmynnade i slutsatsen att stor försiktighet måste iakttas när lagar stiftas för att de inte skall komma att utsättas för förändringar, speciellt omfattande sådana. Lilliestråle tillstod dock att ett tillstånd med en oföränderlig lag och styrelse var ett ouppnåeligt ideal, varför målet istället var att med utgångspunkt i den aktuella situationen motverka oseder och åstadkomma nytta. Lagarna borde revideras om det allmänna bästa och utvecklingen krävde det. ${ }^{117}$

Liknande ståndpunkter uttrycktes av fler ordförande, framför allt under den gustavianska tiden, något som kan ses i ljuset av såväl 1760-talets motsättningar och oroligheter som statsvälvningen 1772 . Till exempel tänkte sig Rosenstein den yngre ett optimalt samhällstillstånd med en dito lagstiftning och argumenterade för att existerande konstitutioner och samhällen i mycket kunde förbättras, samtidigt som han beskrev det som oövertänkt, skadligt och dåraktigt att sträva efter en fullständig omstöpning. ${ }^{118}$ Den sista kommentaren kan relateras till franska revolutionen, i vars skugga Rosensteins tal framfördes (1789) 
och trycktes (1793). ${ }^{119}$ Samme preses förfäktade att ett varaktigt lugn skulle nås genom människors lycka och upplysning: "Man säge hvad man vill om deras lättsinnighet och ostadighet, de önska icke at ändra det, de äro öfvertygade vara godt och nyttigt. Vid hvart steg derföre, som Lagstiftningen tager til sin förbättring; vid hvart steg människorne göra til en större lycksalighet, tilknytes förenings-bandet, stadgas Samhällets lugn, och försäkras dess och Lagarnes bestånd."120

Liksom naturen utmärktes samhällsgemenskapen i ledamöternas ögon av stadighet och saktfärdighet. Detta synsätt kan knytas till den samtida idén att stabilitet och lugn överensstämde med Guds diktat; ordning betraktades som naturlig och moralisk, oordning som onaturlig och omoralisk. Social harmoni upplevdes som statsmaktens förnämsta åliggande och utgjorde ett allmänt ideal som medverkade till att värna det bestående. Tankemässig konformitet värderades högt, liksom nedärvda institutioner som uppfattades garantera samhällsordningens fortbestånd. ${ }^{121}$

Presidietalens föreställningar om samhällets ursprung och utveckling tog spjärn i den inflytelserika naturrätten, "en lära om samhällets uppkomst och upprätthållande och om människans plikter som samhällsvarelse". Naturrättens företrädare utgick från att människan inledningsvis levde i ett naturtillstånd av frihet och jämlikhet. Samhället antogs ha uppstått genom att otryggheten i detta tillstånd fick människor att sluta sig samman i grupper, vilka över tid blev till samhällen. Genom ett fördrag eller kontrakt avstod människorna från en del av sitt medfödda oberoende och underställde sig den politiska makten i utbyte mot beskydd, varvid naturlig frihet ersattes av borgerlig. ${ }^{122}$ Annorlunda formulerat överlämnades alla rättigheter till den styrande instansen som denna behövde för att förverkliga statens ändamål. ${ }^{123}$

Naturrätten var trots sina radikala implikationer övervägande samhällsbevarande, statsorienterad och korporativistisk. Statsmakten upplevdes som garanten för den förnuftiga samhällsgemenskapens - på ett elementärt plan uppdelad i folket eller de lydande och den högsta makten eller de styrande - fortbestånd. Samhällets inrättande och de enskildas underordnande ansågs ha till syfte att tämja affekterna. Plikter sattes framför rättigheter och ömsesidig pliktuppfyllelse utgjorde ett ledmotiv: 
[A]n objective moral order was supposedly demonstrated empirically to be the telos of moral life as we know it [...] Realization of this moral order would consist of the perfect discharge of the myriad of complementary roles or 'offices' - that is, duties with matching rights - that make up human life. The activity of being a public moralist inculcating the virtues of fulfilling one's office in the communal life of one's group was therefore securely anchored in the natural law theory of duties. ${ }^{124}$

Även om presidietalens redogörelser för samhällets historia inte gav röst åt någon utpräglad pliktmoral var de genomgående kompatibla med det naturrättsliga försvaret av den rådande ordningen. ${ }^{125}$

Ett flertal akademiledamöter lade ut texten om samhällets historia. Anders Johan von Höpken noterade att enskilda människor i begynnelsen lämnats åt sig själva och fått sin bärgning på ett sätt som liknade hur samtidens samer och khoikhoifolk i Afrika försörjde sig. Han fastställde att samhället instiftats av och för människor först när begären och sederna förändrats, samt att människans förnuft och begär gjorde att hon sedan inte kunde trivas utan samhället eller en mängd förnödenheter. Detta utgjorde grunden för vetenskaperna, som ökade i takt med behoven, utbredde sig i stora och inskränktes i mindre samhällen, samt dog ut hos de som led av villfarelser och i isolering. Det var i synnerhet habegäret och yppigheten som fört utvecklingen framåt: "Girugheten å ena sidan, öfwerflöd å den andra, äro bägge föräldrar til makt och rikedom, til slögder, til Wetenskaper, och Konster”. ${ }^{126}$

Andra presides hänförde samhällets uppkomst till människans behov och nödlidande. Det hette att de usla villkoren efter syndafallet jämte människosläktets tillväxt givit upphov till samhället, varvid behov och arbete förmerats och enskilda börjat bidra till det gemensamma bästa. Urtillståndets nöd hade drivit fram rudimentära handslöjder och konster som svarade mot de mest basala behoven, varpå följde "hushåld, bolag och större samfund" och därmed nya försörjningskrav. ${ }^{127}$ Enligt fysikern och biskopen, sedermera ärkebiskopen, Carl Fredrik Mennander var det snarare en strävan efter allmän och enskild välfärd som låg bakom samhället. Han menade att individerna var skyldiga att i görligaste mån förbättra sin situation, och att ett samhälle var än mer förpliktigat 
att förbättras då det grundats för att befordra "allmän sällhet", vilken inbegrep den enskilda invånarens trevnad. ${ }^{128}$

Ett annat tema som framhävdes av vissa ledamöter var naturtillståndets osäkerhet. Befolkningstillväxt och Guds försyn "eller ock en bedröfvelig förfarenhet af öfverdåd och våldsverkan" hade fått människorna att förena sig till ömsesidig säkerhet och hjälp. Inget folk torde ha avstått sin naturliga och medfödda frihet i annat uppsåt än att förvärva den trygghet, den lycka och de fördelar som med nödvändighet saknades utanför det borgerliga samhället. Folket underkastade sig fursten frivilligt först när denne övertygat dem om att han eftersträvade dessa fördelar. ${ }^{129}$ Den församhälleliga tillvaron kunde emellertid också skildras i ljusare färger. Manufakturidkaren Jonas Alströmer (Alström) beskrev ett ursprungstillstånd där människan var fri att förse sig vid behov $i$ en värld som skapats till hennes fromma. Situationen förändrades när behoven inte längre motsvarade de tillgängliga resurserna, något som gjorde det nödvändigt för mänskligheten att utvidga sin kontroll över världen. Hans son Clas Alströmer uppgav att människorna livnärde sig av det naturen gav när de levde i ett gynnsamt klimat och var fåtaliga. Med tiden och när befolkningen tillväxte tvingades de till jordbruk och andra innovationer. Också folkomflyttningar genererade behov som tillgodosågs genom nya grepp. De första samhällena sades ha varit kraftlösa och utan "hogen för en beqvämligare lefnad, snygghet och prakt [...] Uprinnelsen til stora ting måste sökas hos stora och höfsade folkslag”. ${ }^{130}$ Detta kan tolkas som att skillnaden mellan den församhälleliga och den tidigsamhälleliga existensen uppfattades vara mindre än skillnaden mellan tidiga och senare samhällen.

Naturtillståndet hade, som antytts ovan, emellanåt påtagliga religiösa förtecken. Till exempel konstaterade hattpolitikern och officeren, sedermera fältmarskalken, Augustin Ehrensvärd att Gud placerat människan i samhället, och att världen efter syndafallet inte längre kunde utgöra ett enat samhälle, varför varje rike var tvunget att försvara sig. Ehrensvärd definierade samhället främst med utgångspunkt i säkerhet och försvar: "Den första nytta et Samhälle söker, är Samhällets säkerhet. Det hela går i borgen för hvar Medlems. Är det då icke hvar Medlems skyldighet, at försvara det hela? Och det sker sällan oftare, än i Krig. At 
klandra Krig, då det görs för Samhällets säkerhet, är ju då det samma, som at klandra Samhällets säkerhet och varelse."131

Under den gustavianska eran blev diskussionerna om samhällets väsen och syftemål mer abstrakta, komplexa och individinriktade samtidigt som lag och säkerhet, två paradteman i Gustav III:s propagandabild av sin egen regering, tillerkändes stor betydelse för samhällsgemenskapen. ${ }^{132}$ Strax efter statsvälvningen 1772 hävdade det före detta hattriksrådet och konungens förtrogne Carl Fredrik Scheffer i egenskap av Vetenskapsakademiens ordförande att politiska samhällen inrättats för att vinna lycksalighet och att all erfarenhet från skapelsen och framåt vittnade om att denna emanerade ur lagarna, särskilt grundlagarna. Andra gustavianska presides meddelade att äganderätten var det borgerliga samhällets grundpelare och lagarnas fokalpunkt, och att lycksaligheten hängde på "Statens inrättning och lagar", vilka måste grundas i människans natur och samhällets ändamål. ${ }^{133}$

Lagen skulle på kontraktsteoretiskt manér reglera både makthavarna och folket. Det slogs fast att den säkraste makten var den som begränsade sig själv och att den bäste lagstiftaren var den som föreskrev sig själv lagar. Grundlagarna dikterade både de befallandes och de underlydandes ömsesidiga rättigheter och skyldigheter, och regenten och undersåtarna bands samman av en gemensam håg för lagens fortbestånd; ingen av dem kunde ensidigt upphäva den. Skolväsendet skulle inpränta såväl invånarnas rättigheter och skyldigheter som det oupplösliga intresse vilket förenade alla samhällets lemmar och sammanslutningar. Lag upplevdes således ha ett nära samband med social harmoni. ${ }^{134}$

Ingående resonemang kring samhällets förutsättningar återfinns hos den ekonomiske skriftställaren Edvard Fredrik Runeberg och hos Lilliestråle. Runeberg förde en naturrättslig argumentation som utgick från den enskildes preferenser: "Hvar människa hyser inom sig en benägenhet för sig sjelf, som i all jämförelse med välviljan emot andra altid har öfverhanden; af denna källan utspringa sedan många andra grenar; hon vil altid förse sig emot alt hvad som kan göra henne skada eller afsaknad: hon bemödar sig om at erhålla det nödiga, nyttiga, beqvämliga, med mera. Hon vil altså vara emot alt öfvervåld beskyddad, och söker varaktighet i sin välmåga samt beständig tilväxt deri.” 
Ur sammanjämkandet av enskilda viljor flöt den allmänna viljan eller samhällets vilja, "hvilken, i jämförelse med benägenheten at befordra andra Samhällens välstånd, likaledes altid har öfverhanden; härifrån leda sig alla de anstalter, som Samhällen vidtaga til sina gemensamma vilkors förbättring”. Viljornas harmoniering i och genom samhället berodde på att människorna uppfattade att denna hjälpte dem uppnå, behålla och förmera personligt välstånd. ${ }^{135}$ Samhällsgemenskapen var alltså resultatet av individers rationella och materiellt motiverade beslut och speglade i sitt förhållande till andra samhällen den enskilda invånarens relation till sina medmänniskor.

Lilliestråle höll före att det borgerliga samhällets grundande var den största av alla mänskliga bedrifter och att regeringsläran var förankrad i naturen och det sunda förnuftet, som båda var osvikliga. Styrelsekonsten sades vara en av människosläktets ansenligaste välgörare och ta de visastes odelade uppmärksamhet i anspråk. Det åvilade utövarna av denna konst att resa en beständig samhällsbyggnad, kanalisera de mänskliga böjelserna och samhällskroppens styrka i nyttiga ändamål, anvisa varje "Class" dess plats i helheten samt bereda människorna ett fädernesland och största möjliga välmåga och säkerhet med minsta kostnad av naturlig frihet. Hos Lilliestråle framträdde ett mer självgående samhälle. Inget folk kunde enligt honom vara lyckligt utan dygd, religion, lojalitet och ära, vilka ledde samhällslemmarnas föresatser och gärningar till det gemensamma bästa och till ömsesidig hängivenhet och rättskaffenhet. Han anmärkte att tvångsmedel förslog att regera slavar men inte fria män och att den borgerliga frihet som höll "en Stats-kropp" vid liv endast kunde bevaras genom dygden, varpå medborgarandan, samhället och fäderneslandet byggde. Dygden var liksom riksstyrelsen och lagen avhängig ungdomens riktiga fostran och undervisning, som var ägnad att kuva de skadliga begären. ${ }^{136}$ Som senare kapitel kommer att visa var Lilliestråles uppfattning inte typisk för Vetenskapsakademien, där tron på internaliserade normer som regel fick stå tillbaka för idéer om aktiv detaljreglering av samhället.

Samme preses hemföll åt historiska reflektioner över Sparta och de gamla svenskarna. Han förklarade att spartanernas konster varit embryoniska och att det mesta hos dem saknat stadga, och att fornsvenskarna 
inriktat sig på att uppfylla de mest pressande behoven och levt i en så fullständig frihet som var förenlig med ett samhälles upprättande:

Säkerhet $\mathrm{i}$ besittning, och inbördes värn emot våld, var hela samfunds föremålet, och Borgerliga sambandet bestod egenteligen deruti, at de voro förente, i en Guda-lära, under en Höfding, som de sig valdt til anförare i krig; til högsta Domare at beskydda friden i manna samvaro, den han svor dem at hålla; och til högsta föreståndare af Gudstjensten; men för öfrigt ansågs hvar husfader för enväldig $i$ sitt hus, at derinom styra och befalla med fullkomlig myndighet öfver sitt och de sina. Drottens åtgärd sträckte sig altså föga til folkets enskilte ärender och handlingar, som ej oftare skedde, än då någon betydelig tvist emellan husfäder föreföll, hvari hans utslag begärtes, eller allmänna roen genom något märkeligt [betydande] brott var förstörd, och samhällets rätt kräfde hämd.

Lilliestråle tycks ha värderat den svenska forntiden högt, eftersom han uppgav att befolkningens välmåga och tillväxt bevisade inrättningarnas förmånlighet, styrelsens stabilitet och grundsatsernas naturenlighet. Han hävdade också att den borgerliga samlevnaden, trots sina många fördelar, vållade mycket ont som hade kunnat undvikas om människan förmått livnära sig i det fria naturtillståndet. ${ }^{137}$ Inte heller dessa ståndpunkter var typiska för Vetenskapsakademien, vars medlemmar mestadels satte det samhälleliga tillståndet och den borgerliga friheten över naturtillståndet och den naturliga friheten.

Flera av Lilliestråles gustavianska ledamotskollegor uttryckte en direkt negativ inställning till den församhälleliga tillvaron. En uttrycklig kritik av visionen om det lyckliga naturtillståndet och dess kände förespråkare filosofen Jean-Jacques Rousseau formulerades av kemisten Torbern Bergman, som kontrasterade en djurisk, rå, ogudaktig människa utan tillgång till vetenskap mot en förädlad, förnuftig, from människa i besittning av vetenskap. Den förra tvingades uteslutande sysselsätta sig med "de naturlige behofven, nödtorftigt uppehälle, försvar och fortplantning [...] enligt en egen naturens drift, utan öfverläggning". Den senare realiserade sin gudagivna potential och bemästrade världen. Ett angrepp på Rousseau går också att urskilja hos Sparrman, som redogjorde för de nomadiserande, jagande och fiskande folkens 
ömkansvärda elände och hoppades att det måtte "leda vissa förvände Philosopher ifrån en för all mänsklighet vanhedrande och farlig villfarelse, som nemligen skulle det civiliserade tilståndet vara mindre lyckeligt, än det vilda”. Sanningen var den omvända: förenade av språk och samhörighetskänsla kunde människor skapa starka samhällen, vilka gjorde det möjligt för dem att betvinga såväl djuren som sin egen vilda, omänskliga sida. Den därigenom ökade välfärden och ordningen gav upphov till medborgerliga dygder, som i sin tur befordrade lantbruket, slöjderna och vetenskaperna, varvid klivet till att bli ett civiliserat folk, en rätt naturen avsett för människosläktet, var kort. ${ }^{138}$

Liksom under frihetstiden beskrevs behoven och otryggheten som centrala för den mänskliga utvecklingen. Ett rudimentärt ursprungstillstånd där människors behov hade begränsat sig till livets nödtorft tänktes ha upphört genom tillkomsten av nya bekvämligheter som blivit till nödvändigheter som knappt de striktaste lagar kunnat motverka. ${ }^{139}$ Enligt ett annat synsätt hade människorna förökat sig så mycket att de för säkerhetens eller andra behovs skull börjat sluta sig samman i större samhällen och bo i städer. ${ }^{140}$ Astronomen Bengt Ferrner skildrade i stadieteoretisk anda en utveckling som alla folkslag antingen genomgått eller skulle komma att genomgå. Människan hade initialt troligen levt av vad naturen kunde ge, varefter hon för att trygga sin försörjning skaffat tamdjur och ägnat sig åt herdelivet, som dock inte möjliggjorde uppkomsten av något avancerat samhälle. I nästa utvecklingsfas uppträdde förmodligen jordbruk, bofasthet och fädernesländer, längre fram byar och städer som ledde till gemensamt försvar och någon form av konstitution. Ferrner såg människan som ett socialt djur, av naturen benäget att imitera sina likar, och underströk socialiseringens betydelse för samhällsgemenskapen: "Hvar som hälst et antal menniskor äro förenade uti en politisk kropp, där äro tilfällen til umgänge nästan ouphörlige, at öfverlägga om inbördes försvar, om handel och vandel samt om Regeringen, så at dessa menniskor måste, jämte et och samma språk, nödvändigt förvärfva sig likhet i lefnads- och tankesätt m. m. och således få en allmän det folkslagets charactere, äfven som hvar enskild hafver sin egen." ${ }^{141}$ Ferrner intresserade sig i likhet med Runeberg och 
Lilliestråle för samhällets minsta beståndsdelar, de enskilda människorna, och för deras bevekelsegrunder som samhällsvarelser.

När vissa presidietal betonade naturforskningens roll i historien, kan det ha varit ett sätt att framhäva betydelsen av Vetenskapsakademiens och dess medlemmars egen verksamhet. För fysikern och teologen, sedermera biskopen, Jacob Gadolin var mänsklighetens utveckling synonym med vetenskapens uppstigande från en rudimentär fysik, där människan i sitt resursutnyttjande härmade eller tävlade med de oförnuftiga djuren. Naturkunskapen fokuserade inledningsvis på sådant som främst bidrog till överlevnad, men för att göra sig till naturens mästare hade människan omsider börjat utforska alla sorters kroppar, vilket frambringat naturalhistorien. Nästa steg var att svinga sig ännu högre med hjälp av samtidens mer avancerade fysik. ${ }^{142}$

Rosenstein den yngre, som skärskådade samhällets ursprung och väsen mer utförligt än någon annan preses, förklarade att det funnits historiska epoker då kunskaperna varit obefintliga eller bara svarat mot de mest grundläggande behoven. Människorna hade emellertid snart lagt detta bakom sig genom sin kapacitet att förbättra sina förmögenheter och den böjelse som fick dem att göra bruk av denna, genom behovens påbud och tillväxt och genom tillfälligheternas spel. Den praktiska verksamheten hade givit liv och rörelse och flera kunskapsgrenar hade med politikens bistånd på kort tid kommit mycket långt, även om de förblivit ofullkomliga. ${ }^{143}$

Enligt Rosenstein var det människans unika fallenhet för att förkovra sina medfödda färdigheter, öka sina behov och ändå tillfredsställa dem, samt förändra och förbättra sin situation som frammanat samhället och dess mest väsentliga växlingar samtidigt som hennes natur utvecklats. Genom att förmögenheterna och böjelserna omvandlades skedde ett framåtskridande, som naturen ledde människorna till när de väl förenats i samhällen. Framåtskridandet innebar att människan gradvis utvecklades från vildhet till vett, ett förlopp som de flesta nationer sades ha genomgått. Rosenstein föreställde sig att den mänskliga naturens utveckling och samhällets framåtskridande ägde rum i stadier. Varje fas hade en egen uppsättning seder - "vissa medfölja vildheten, andra det råa tilståndet, andra Samhällens barndom, andra deras manna-ålder, 
andra deras sträfvande til magt och anseende; vissa medfölja sjelfva magten, vissa fattigdomen, andre rikedomarne; vissa okunnigheten, andra kunskaperne: vissa åter synas föregå och föreboda Rikens och Nationers fall". ${ }^{144}$

Rosenstein ställde i ett utpräglat naturrättsligt resonemang människan som naturvarelse mot medborgaren, den medfödda friheten i en vild och rå tillvaro mot den i det borgerliga samhället samt naturliga begär mot sådana som uppstod i samhället, huvudsakligen tillfredsställdes av medmänniskor och inte hänförde sig till nödvändiga behov. Han menade att människan om hon lämnats åt sig själv skulle ha genomgått en oavbruten och jämn utveckling och erkänt bara de hinder som "känslan af andras jemnlika rättigheter, och behofvet af andras hjelp kunnat föreskrifva". Genom att det råa naturtillståndet övergivits hade samhällen uppstått och därmed "vissa band, samt nödvändigheten at för allmän sällhet inskränka, stundom upoffra den enskilta. Regeringar och Lagar hafva härifrån sin uprinnelse, åtminstone sin enda rättmätiga grund”. Människans natur, begär och behov av andra var konstanter, oaktat om okunnighet eller upplysning rådde, låt vara att de uttryck begären tog varierade med det mentala ramverket. Då det var omöjligt att eliminera de mänskliga böjelserna var det mer naturligt att utgå från deras fria utövande än att bekämpa dem vid grundandet av ett samhälle. ${ }^{145}$ Rosenstein förespråkade således, liksom Lilliestråle, ett stort mått av naturlig frihet i samhället samtidigt som hans värdering av naturtillståndet var mer negativ än dennes.

Samhället hade enligt Rosenstein människornas lycksalighet till ledstjärna. Det militära försvaret var en primär uppgift, vilket gjorde makten till ett annat av samhällets ändamål. Därur flöt lag, regering, "stats-klokhet" och krigskonst, vilka åtföljdes av näringar, handel och pengar, liksom av regeringens omsorg om hushållningen. ${ }^{146}$ En annan av samhällets uppgifter var att bekämpa lasterna, som fick invånarna att tillfoga sina medmänniskor och samhällsgemenskapen skada. Det var sådana utbrott människan velat tygla och förhindra genom att skapa borgerliga samhällen - närmare bestämt genom lagarna, genom den omsorg om det egna anseendet som kännetecknade en upplyst allmänhet och genom medborgarandan. Medborgarandan förankrades säkrast i 
upplysning och omfattade patriotism, strävan efter det allmänna bästa samt medvetenhet om rättigheter och skyldigheter ${ }^{147}$ Rosenstein framhöll i likhet med Ferrner socialiseringens gemenskapande funktion:

Det behof, hvaruti vi äro af andras hjelp, har pålagt oss nödvändigheten at inskränka vårt sträfvande efter eget väl. Begrep om rätt och orätt, om plikter emot andra, hafva genom sammanlefnaden blifvit alstrade. Det är äfven detta behof, den kraft, som drager oss til umgänge med våra likar, de känslor, som genom detta umgänge födas, de sinnesrörelser, som andras lidande eller sällhet upväcker; det är alt detta sammanlagt, som drifver oss at upfylla våra plikter, som med begrepet om eget väl förenat begrepen om rättvisa och dygd. ${ }^{148}$

Om Rosenstein själv hade varit delaktig i grundandet av ett borgerligt samhälle skulle han ha rekommenderat att enbart förenings- och lydnadsbanden och tanke- och skrivfriheten lagfästes, den sistnämnda dock med vissa begränsningar. Han menade å andra sidan att föreningen och lydnaden var omistliga för samhället respektive den samhällsviktiga regeringen. ${ }^{149}$ I linje med detta påtalades medborgarnas skyldighet att fortlöpande göra avsevärda och oundgängliga uppoffringar för samhället, ett krav som upplysningen skulle övertyga dem om värdet av. ${ }^{150}$ Rosenstein avvisade vidare, liksom Lilliestråle, drastiska förändringar. Alla häftiga och hastiga skiften var vanskliga, det goda skulle förverkligas med försiktighet, klokhet och fridsamhet och fursten var skyldig att stävja det onda, "at förekomma skakningar och våldsamma brytningar". Samhällslugnet skulle säkerställas och destruktiva oroligheter förebyggas genom varaktiga och respekterade lagar, medborgerlig dygd, patriotism, pliktkänsla och en beredvillighet till försakelser. Rosenstein slog fast att beständighet var önskvärd och att den ytterst garanterades av upplysning och sann övertygelse, medan onaturliga samhällsinrättningar och ogynnsamma lagar som inte harmonierade med dessa egenskaper måste gå under. ${ }^{151}$

Rosenstein vände sig bestämt mot dem som utnyttjade enfalden och förvandlade människors medvetenhet om sin rätt till en nedbrytande kraft. De ogenomtänkta uppviglarna kunde varken kontrollera eller förutsäga utgången av sin subversiva verksamhet. De borde hålla i sinnet 
"at Staters grundläggning, tilväxt, förbättring, bevarande fordrat Seclers möda: at deras förstöring ofta varit et ögnablicks verk, och en följd af et enda obetänkt och förhastadt steg: at Revolutioner lättare börjas, än föras til slut: at den kloke icke kullrifver utan säkerhet at åter kunna upbygga. [...] at rättelsen ofta varit svårare än det onda”. De rättsinnade inväntade den tid då försakelser kunde ske utan svårighet, då rättelser inföll av sig själva och då de upplysta förlitade sig på sanningen och förstod vad de ville uppnå. Den underförstådda hänsyftningen på och kritiken av franska revolutionen gjordes explicit i en utläggning om att vad som gick att få till stånd på en plats inte med automatik kunde åstadkommas på en annan, där Rosenstein anmärkte att det amerikanska exemplet inte var tillräckligt relevant för Frankrike, troligen inte hade bäring på alla riken och kunde tänkas bli avskräckande. ${ }^{152}$

Rosenstein förenade ett motstånd mot tvångsmedel och ett insisterande på allmän upplysning med traditionalistiska åsikter som var mer representativa för den samhällssyn som övriga ledamöter av Vetenskapsakademien bekände sig till. Det är rimligt att anta att hans intryck av franska revolutionen låg till grund för flera av de utsagor som graviterade mot det bestående och att händelserna i Frankrike tempererade de radikala tendenser som hans idé om folkupplysning var behäftad med. Alldeles oavsett överensstämde Rosensteins framhävande av behovens betydelse för den mänskliga utvecklingen och hans motvilja mot hastiga samhällsförändringar med många av de andra presidietalens innehåll, medan hans mer positiva inställning till den naturliga friheten endast hade en motsvarighet i Lilliestråles tal.

\section{Gemenskapens gestaltning}

Såväl samhället som världen som helhet tillskrevs under 1700-talet komplementaritet; samhällsgemenskapen hölls samman inte bara av över- och underordning utan även av en ömsesidighet som i någon mån mildrade dess hierarkiska struktur. Samhällsmedlemmarna och stånden var beroende av varandra och det åvilade makthavarna att bistå undersåtarna. Samtliga stånd var nödvändiga för att samhället skulle fungera korrekt. ${ }^{153}$ Ömsesidigheten utgjorde en central tankefigur 
inom den naturrättsliga teorin, vars företrädare beskrev samhället som resultatet av en överenskommelse. ${ }^{154}$ Försanthållandet att samhällsinvånarna lika litet som skapelsens övriga beståndsdelar existerade för sin egen skull gick igen i dygdetiken, där moralisk resning tillkom dem som var utåtriktade och månade om medmänniskorna. Att låta sig vägledas av samhällsbevarande förnuft, dygd och allmännytta istället för av samhällsupplösande oförnuft, affekter och egennytta var det riktiga uppförandet. ${ }^{155}$

Ömsesidighet var ett återkommande tema i presidietalen, både med avseende på de mellanmänskliga relationerna och på förhållandet mellan olika samhällsföreteelser. Ledamöter argumenterade för att samhällelig samvaro krävde inbördes hjälpsamhet, och för att sed och lag förstärkte varandra samt gav ett samhälle ansenlig kontinuitet och stabilitet när de var förenade på så sätt att den ena inte kunde utövas om den andra föraktades och försummades. ${ }^{156}$

Ett antal akademimedlemmar gjorde ömsesidigheten till en grundläggande princip genom att koppla den till Gud eller naturen. Enligt läkaren Abraham Bäck bjöd såväl den gudomliga som den naturliga lagen att människorna skulle stå varandra till tjänst och ge varandra understöd - däri låg varje samhälles fundament och styrka. Manufakturkommissarien Johan Fredrik Kryger ansåg att ämbetsverken skulle räcka varandra handen och att det förhöll sig i "Politiska Stater, som i Naturen, at ingen verkan är utan sin gen-verkan: som sederne verka på Näringar; så verka dessa tilbaka på sederne”. Mennander förklarade att samhällets många arbetsuppgifter var goda och nyttiga "då de i en rätt proportion förenas, verka inbördes, och fylla hvars annars behof. Därföre har ock Naturens HERRE fördelt människorna i hvarjehanda smak och böjelse, at de, under en förnuftig styrsel i Samhällen tilhopafogade, skulle göra et sammanstämmande helt”. Välståndet blev större ju fler som levde under ett och samma styre, ju närmare varandra de bodde och ju mer de bistod varandra. Därigenom blev samhällsbanden fastare och invånarna kunde enklare umgås förnuftigt och hjälpa och tjäna varandra. ${ }^{157}$

Naturen attribuerades således också ömsesidighet. ${ }^{158}$ Ledamöterna beskrev ofta denna ömsesidighet i termer av en mer allmän komple- 
mentaritet, varvid kedjan kom att utgöra en åskådliggörande bild. Världsalltet hade alltsedan antiken utmålats som en "varandets stora kedja", en kosmisk rangordning av otaliga och i olika grad fullkomliga nivåer som sträckte sig från den döda materien upp till Gud. Kedjans länkar formade tillsammans en helhet som var skapelsens huvudändamål. Människans relativa oansenlighet i denna hierarki kunde verka hämmande på föresatsen att förändra samhället, och framställningar av varandets kedja som normerande för samhället kunde få till följd att ojämlikheten definierades som nödvändig och att jämlikhet och social mobilitet tonades ned eller förkastades. Samtidigt underbyggde idén om kedjan tanken att skapelsen till själva sitt väsen var komplementär, eftersom varje enskild länk bidrog till att fullända den serie av former Skaparen hade haft för avsikt att förverkliga. Ingen fanns till enbart eller främst för dem som var situerade ovanför. Varje varelse hade sitt värde och existensberättigande och varje nivå i rangordningen rätt till självbestämmande och aktning, låt vara att varandets kedja överlag var mer tillfredsställande för de högre än de lägre länkarna. ${ }^{159}$

I Vetenskapsakademien diskuterades naturens gudomliga hushållning, där ingen länk saknades eller var obehövlig, ensam eller isolerad. Varje led sågs som grundligt förenat med de övriga leden och med skapelsen i sin helhet, varför alla länkars verkningar konvergerade i en enda verkan som utgjorde deras övergripande ändamål. Den allvisa gudomen hade liksom i en kedja satt den ena kraften till att upprätthålla och tjäna den andra. Länkarna i den naturens stora kedja som naturföremålen formade gick i varandra och var otydligt avgränsade, vilket innebar att de mänskliga kategoriseringarna av dem utgjorde ofullkomliga konstruktioner. ${ }^{160}$

Kedjetänkandet applicerades även på det mänskliga livet. Till exempel uppgav historikern och hattpolitikern Anders Schönberg att hushållen ingick i en varaktig kedja till medborgares underhåll, medan Carl Fredrik Scheffer meddelade att skyldigheterna gentemot medmänniskorna, fäderneslandet och Gud hos kineserna var sammanlänkade i en synnerligen kompakt kedja och därför uppfylldes samtidigt. ${ }^{161}$

Ömsesidighetsprincipen kom för samhällets del till uttryck inte minst i presidietalens redogörelser för näringarna. Det hette att jordbruket, 
handeln och slöjderna skulle räcka varandra en hjälpande hand, att näringarna borde dra jämnt och vara ömsesidigt understödjande, att rikets näringar aldrig hade nått så långt som de gjort om inte den ena bistått den andra samt att omsorg om flera näringar gjorde att dessa stärkte varandra. ${ }^{162}$ Den samhälleliga ömsesidigheten kläddes också i geografiska termer. Provinser biträdde varandra genom handelsutbyte, stad och landsbygd sörjde för varandras nödtorft. Schönberg framhöll att städernas och landsbygdens välståndsskapande kom an på att deras respektive hanteringar bistod varandra. Han knöt detta till reciprociteten mellan de enskilda människorna: "At Närings-medlen behöfva inbördes biträde, är så tydeligt af sig sjelft, at det icke fordrar många bevis. At människor inbördes tarfva hvarandras hjälp, är altid et af de starkaste band, som håller mänskeliga Samhället tilhopa." 163

Vetenskaperna och de vetenskapliga sällskapen befanns operera efter samma princip. Rosenstein den yngre meddelade att alla kunskaper stöttade varandra, att kunskaperna om naturen vägledde och upplyste varandra samt att teori och tillämpning sträckte varandra handen inom de praktiska vetenskaperna. Samuel Sandels tog sin utgångspunkt i att människans behov och välfärd fordrat att hon bildade samhällen. Lärda borde förena sig i samfund inom vilka alla kunde hjälpas åt att uppodla vetenskaper och slöjder till mänsklighetens fromma. Sandels drog en regelrätt parallell mellan det egentliga och det lärda samhället. Båda var beroende av "ett tilräckeligt antal skickelige arbetande lemmar, af den handräckning de gifva hvarandra, af välgrundade Lagar, af deras handhafvande och af Regeringens omvårdnad". Båda hölls ihop av en ordning och gick under när de var oförsiktigt inrättade eller inte vinnlade sig om lagarna. Vetenskapliga samhällen var "at anse i den lärda, nästan såsom fria Stater i Politiska verlden", låt vara att de till skillnad från dem gynnade hela mänskligheten. ${ }^{164}$

Ett varnande exempel på hur det kunde gå utan ömsesidighet i det mänskliga livet återfinns hos Sparrman, som förklarade att Söderhavets invånare vittnade $\mathrm{om}$

hvad som försämrat och förbättrat Folkslagen; nemligen, huru de, som lefva söndrade i enkla Familler eller små flockar, sakna den inbördes 
hjälp och handräckning, de hvarken kunna få eller gifva, tils ändteligen de ej känna en del af Mänsklighetens behof. Slögderne härigenom försummande och förgätne, vanvårdas, äfven som deras aflinge [avkomma], Åkerbruket; födan brister, och svält gör både kropps och sinnes egenskaper slöa, eller uptager all tid med at tilskaffa magens oumgängeligaste behof, utan at lemna tid til omtanka för Vetenskaper til sin uplysning, eller för Handa-slögder til beqvämlighet.

Ett likartat perspektiv anlades av Lilliestråle, som angav att människorna i en samvaro utan språk skulle förpesta varandras tillvaro istället för att vara till ömsesidig nytta. ${ }^{165}$

Sambandet mellan allmän och enskild nytta var ett ledmotiv i 170o-talets ekonomiska tänkande, där individens lycksalighet många gånger förutsattes sammanfalla med kollektivets. ${ }^{166}$ Enligt ett utbrett synsätt förhöll det sig så att samhällets välstånd byggdes underifrån och utgjorde summan av inbyggarnas välmåga ${ }^{167}$ Vetenskapsakademiens ledamöter tenderade i linje med detta perspektiv och sin förkärlek för komplementaritet att uppfatta enskilt och allmänt som analoga. Skillnaden mellan den enskilda och den allmänna hushållningen var bara en fråga om skala. Grundsatser gällande enskildas förmögenheter gick i somliga fall att tillämpa på näringarna, som likaså hade sina tillgångar och behov, och ett rike kunde likställas med och falla tillbaka på samma tillvägagångssätt som en enskild, räntebärande egendomsinnehavare. Rosenstein den yngre ansåg att det han apropå upplysning konstaterat om enskilda också var giltigt för nationer och tidsperioder, och att samhället i relation till varje invånare befann sig "i samma belägenhet, som en enskild mot en enskild, det vill säga, utan rättighet, at för sin egen nytta tilfoga den andra skada". ${ }^{168}$

Det gemensammas väl ställdes ofta jämsides den enskildes. ${ }^{169}$ Ledamöter diskuterade samhällets fortbestånd och de enskildas därav beroende välfärd, att styrelsekonsten skulle göra enskildas trygghet, egendom och liv till pant för allmän välfärd och frid, att yppighetens onödiga slöseri omvandlade enskild fattigdom till "Riks-skulder" och underskott i utrikeshandeln samt att jordbrukets upphjälpande hängde på övertygelsen om att det egnas och det allmännas väl inte gick att skilja 
åt. ${ }^{170}$ Förhållandet mellan samhällsgemenskapen och dess medlemmar utmärktes, liksom de mellanmänskliga relationerna, av harmoni och gemensamt ändamål.

Vetenskapsakademiens ledamöter fann vanligen inte att allmänt och enskilt automatiskt eller nödvändigtvis konvergerade med varandra. En av dem ville att skolväsendet skulle inpränta vikten av att alltid tänka på det egna i samband med det allmänna och se det understöd andra uppbar som förmånligt för egen del. En annan anförde att näringarna skulle tjäna till allmänt och enskilt väl och att både samhället och den enskilde fick lida av uselhet respektive bedrövelse dem förutan. Det var önskvärt att medborgarna, som i England, genom förnuftig upplysning samlades kring det som kunde få näringarna att trivas och att "icke hvarje Närings-gren må få arbeta, för enskild fördel, [så] at man skulle förgäta sammanstämmandet med det helas bästa”. En ledamot, prästen och mösspolitikern Pehr Högström, argumenterade för att varje individ skulle tillåtas följa sina egna böjelser, vilket skulle göra att människor i högre grad gynnade såväl sig själva som andra. ${ }^{171}$

Några gustavianska ledamöter menade att samhället var summan av sina beståndsdelar. Enligt Ferrner kunde samhället likställas med en mångfald enskilda, varför de moraliska orsaker som verkade på individen - bland annat religion, regeringssätt, krigslycka och allmänna förhållanden - hade potential att förändra hela folket. Runeberg fastställde att samhällsgemenskapens vilja, eller den allmänna viljan, utgjorde ett aggregat av samtliga invånares individuella viljor och åtminstone delvis var analog med den enskilda viljan. ${ }^{172}$

Rosenstein den yngre deklarerade att en nation bestod av enskilda, vilkas upplysning var av "stor vigt för Staten". Samhällets bästa var enbart "en sammansättning af de enskiltas lycksalighet. Där de enskilte äro olycklige, är Staten det äfven". ${ }^{173}$ Han medgav att individers och "Classers" intressen ofta stod i motsatsställning till helhetens, men ansåg samtidigt att det allmänna bästa hade företräde. Rosenstein formulerade liksom Runeberg en idé om folkvilja som för tankarna till den rousseauanska allmänvilja som svarade mot allmänintresset och kontrasterades mot allas vilja, summan av samhällets särintressen. Medborgaren måste ur Rosensteins synvinkel mestadels vilja fäderneslandets bästa och det var 
inte möjligt för folket, i bemärkelsen totaliteten av alla medborgare, att ha något annat intresse än det allmänna bästa. En nation kunde lika litet som en individ vilja någonting annat än sin egen lycksalighet. Rosenstein trodde att förstånd och upplysning inte bara skulle leda medborgarna till genuin lycka utan också reglera deras beteende mot nästan och samhället när individens väl överensstämde med eller i alla fall inte stod i direkt motsatsställning till andras och det allmänna bästa. Han förlitade sig på att politisk upplysning skulle förse styrande och medborgare med en samhällsdygd som handlade om att älska medmänniskorna, befordra deras lycksalighet och inte störa deras sällhet eller kränka deras rättigheter. Denna dygd inbegrep även att kuva individuella begär, efterleva lagarna och anpassa sina gärningar till samhället, liksom att arbeta och uppoffra sig för det allmännas väl. Rosenstein beskrev hur medborgaren fann sig sörja för en del av det hela och sin välgång i hög grad bero på helhetens, varvid denne anpassade sitt uppförande och erfor den heligaste av känslor, patriotismen. Rosenstein hävdade till och med att det gick att "göra människor til Domare öfver sit eget intresse, och en Nation öfver det allmänna bästa" och att allt borde prövas av allmänheten, vilket skulle medföra en informationsfördel för regeringen och förhindra att enskilda intressen dolde sanningen. ${ }^{174}$

Inte heller Rosenstein räknade med automatisk harmoni mellan enskilt och allmänt. Förutom till upplysningen satte han sitt hopp till lagarna, som sades ha till ändamål att bringa allmän och enskild lycka genom att bestämma individens uppoffringar för det allmänna och i möjligaste mån förena det enskilda och det allmänna intresset. Rosenstein hävdade i denna kontext att lagsystemet skulle utgå från människans natur och utnyttja hennes böjelser och passioner, samt att goda lagars verkan garanterades av den mäktigaste av krafter, egennyttan, som överskuggade strävandet efter andras bästa och oftast kärleken till det gemensammas väl. ${ }^{175}$ Han såg de enskildas passioner, böjelser och egennytta som redskap för snarare än hämskor på det allmänna bästa, en tes som kan kopplas till den samtida föreställningen att känslor och lidelser var människans förnämsta drivkrafter och skulle tas i anspråk av samhället. ${ }^{176}$ 
Rosenstein var, som Höpkens positiva värdering av habegäret $\mathrm{i}$ avsnittet "Natur och samhälle" ovan demonstrerar, inte den ende preses som bejakade egennyttan som ett verktyg i allmännyttans tjänst. Under frihetstiden företräddes detta perspektiv även av Kryger och Schönberg, vilkas synpunkter diskuteras i kapitel 4 , medan ett antal gustavianska ledamöter betraktade den enskilde som Guds verktyg, individens böjelse att nyttja allting för att främja den egna välgången som ett prov på Hans bevågenhet och en rätt dimensionerad egennytta som ett instrument för det allmänna bästa. ${ }^{177}$ Betraktelsesättet kan relateras till den nederländske tänkaren Bernard Mandevilles kontroversiella åsikt att välstånd uppstår ur egennytta, begär och laster, en ståndpunkt som under 1730-talet fångades upp av den ekonomiske skriftställaren Anders Nordencrantz (Bachmanson). ${ }^{178}$

Vissa ledamöter framförde den ståndsapologetiska tanken att olika människor var ämnade för olika ting. Gud hade givit människorna håg för skilda men kompletterande värv och nedlagt större eller mindre kompetens och intelligens i envar. Hela samhällskroppen kunde inte vara vid god vigör om inte alla lemmar hade hälsan, styrkan och förmågan att var för sig fullgöra de sysslor naturen avsett dem för. Var och en skulle bli duglig "til de göremål, hvilka honom uti sitt särskildta stånd åligga", och både styrande och underlydande borde besitta ansenliga kunskaper, varje grupp utifrån sitt ändamål, för att samhällets behov skulle uppfyllas. ${ }^{179}$ Ett av de mer oförblommerade försvaren av samhällshierarkin återfinns hos Ehrensvärd: "En är fallen at arbeta under en blind lydnad i alla sina dagar; En annan åter är föd till högre ting. Skaparen har underligen delt menniskans gåfvor: Sedan han satt oss uti samfund, så är det för oss lika orimmeligt at truga många pund på den som äger quintin, som det är att giöra andras quintin til skeppund. Vår skyldighet är, at nyttia hvars och ens pund uti sin krets." 180 De två kategorierna framstod som gudagivna och oföränderliga. Det gick inte att förändra människors karaktärsgåvor, bara att på bästa sätt använda dem i sina specifika, fixa sammanhang.

En motsvarande funktionalistisk differentiering urskildes i naturen. I ett presidietal beskrevs hur varje djur efter Skaparens intention hade 


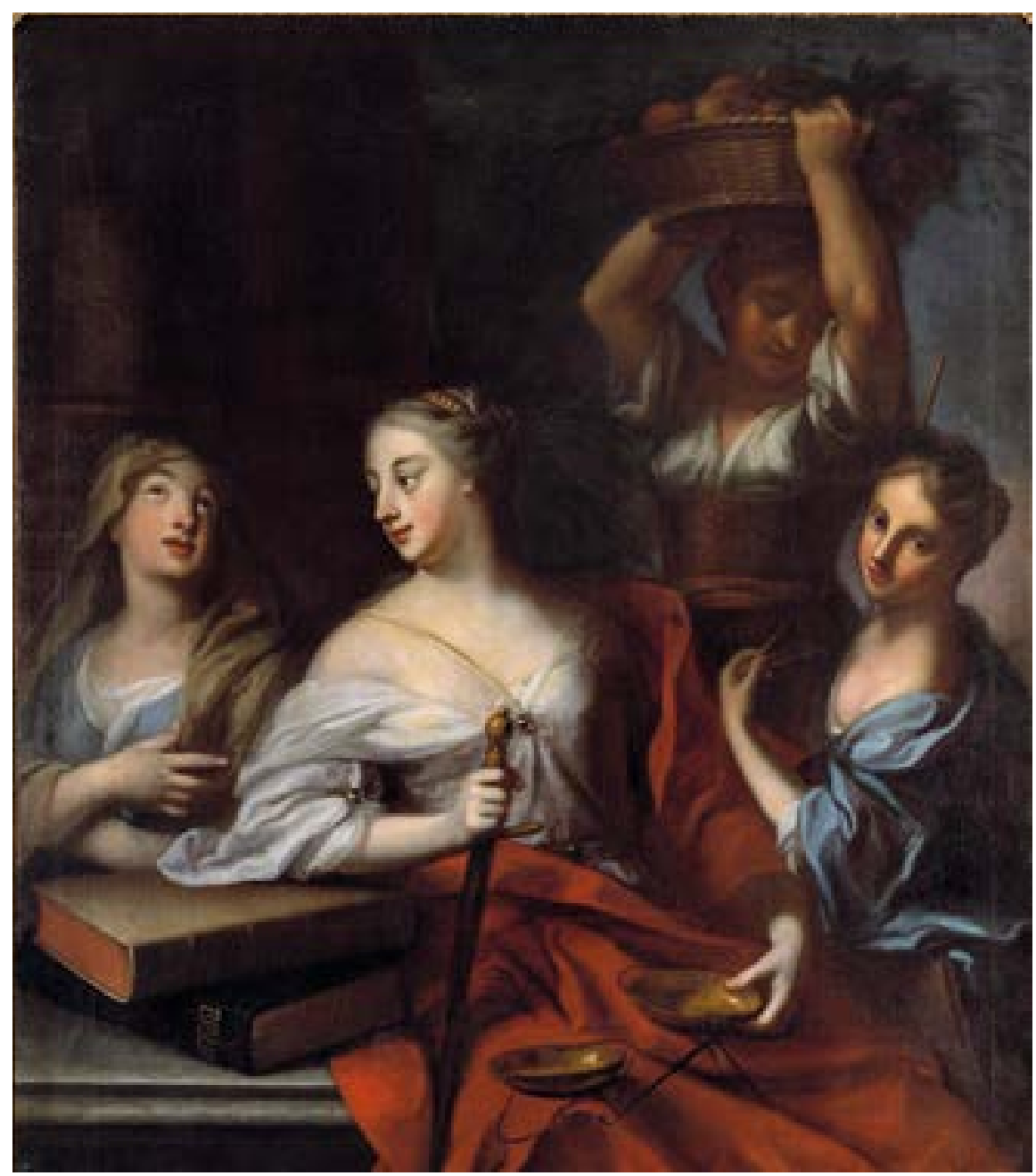

Bild 4. Georg Engelhard Schröder, Allegori över de fyra riksstånden. Foto: Nationalmuseum. Enligt gängse uppfattning hade varje stånd sin särskilda funktion att fylla i och för samhällshelheten.

tilldelats en speciell läggning och färdighet samt särskilda och olikartade lemmar och organ som var nogsamt lämpade till dess ändamål och levnadssätt. I ett annat tal ställdes den retoriska frågan om inte Guds vishet och makt krävts för allt Han velat uppbringa om varje skapat ting 
skulle fylla sitt syfte. ${ }^{181}$ Samhället och naturen korresponderade också i detta hänseende mot varandra, liksom mot en gudomlig ordning.

En del ledamöter framhöll att det ålåg makthavarna att leda undersåtarna till rätt sysslor. Det hette att en kärleksfull regering såg till att de arbetande händerna fördelades mellan näringarna i enlighet med befolkningens storlek. Samhället gestaltades som ett stort politiskt skepp vars byggmästare hade ofantligt många beståndsdelar att hopfoga och jämka om allting skulle hamna på rätt plats och samverka adekvat. Det var upp till styrelsekonsten att anvisa "hvar särskild Class, ibland en myckenhet til vilkor, förmåga och begär skilde människor, sin bestemda rörelse-krets, så at de, likt hjulen i et ur-verk, uti samband, dock utan at häfta hvarandra, inbördes bidraga til hvarderas särskilda fortgång, men derunder gemensamt til det [sic] stora hela Konstbyggnadens påsyfte". ${ }^{182}$

Det hände att människornas samhällsfunktioner knöts till deras yttre betingelser, vilket implicerade social föränderlighet. En ledamot menade att levnadssättet och människokroppens därav följande beskaffenhet var utslagsgivande för den enskildes plats i samhällsgemenskapen. En annan betonade samhällets inverkan på invånarna; deras karaktär bestämdes av deras sysslor, och den enskildes naturliga böjelser kunde omstöpas grundligt av moraliska orsaker som regeringssätt och religion. ${ }^{183}$ Flera presides anslöt sig till det så kallade snillevalet, en populär och nyskapande idé som gick ut på att makthavarna skulle avgöra ungdomars utbildning och levnadsbanor utifrån deras anlag, utan hänsyn till börd. Valet var tänkt att bidra till en korrekt balans mellan näringarna och mellan närande och tärande samhällsmedlemmar. ${ }^{184}$ En av förespråkarna i Vetenskapsakademien, fysikern och biskopen Johan Browallius, ansåg att ett barns naturliga förmåga, inte föräldrarnas stånd och förutsättningar, skulle bestämma dess destination i livet. Som ett led i argumentationen påpekade han att det inte var ovanligt att en underordnad styrde sin överordnade, varvid han indirekt relativiserade samhällshierarkin. ${ }^{185}$ Idén att den enskilde skulle slå in på den bana denne var bäst lämpad för behövde dock inte innebära ett ifrågasättande av samhällsordningen. Löwenhielm tyckte förvisso som nybliven kanslipresident för mössorna att alla skulle vara jämlika vad beträffade rätten att utifrån gärningar, kunskaper och själsförmögenheter nå den största 
välmåga och ryktbarhet. Däremot kunde inte "någon förnuftig önska, en sådan jämlikhet, at alle lemmar i Riks-kroppen skulle äga lika anseende, lika myndighet och lika förmåga; ty sådant är mot sjelfva naturen och all ordning" ${ }^{186}$ Snillevalet behövde lika litet som de naturrättsliga resonemangen utmynna i radikala ställningstaganden.

Ett par gustavianska ledamöter, Stockholms överståthållare Carl Sparre och Rosenstein den yngre, underströk att alla samhällsmedlemmar hade rättigheter. Sparre meddelade i en redovisning av arbetares och tjänares villkor att samhällsbanden härrörde ur den allmänna och enskilda säkerhetens upprätthållande och att den "tjenande flocken" bestod av underkategorier med olika ändamål som medförde särskilda skyldigheter och straff. Samtidigt som Sparre diskuterade denna korporativa ordning hävdade han att alla, hög som låg, skulle beredas rättvisa:

Den rätt och det skydd Politien hvar man skyldig är, tillåter ej heller deraf någon minskning, i lika afseende på tjenaren som på husbonden. Den sednare bör, genom Politiens försorg, skaffas åtnjutande af tjenarens arbets-förmögenhet, tid, lydnad och redlighet; och den förra, såsom undergifven, hållas rätt och rätter til fullt mått. Han njuter verkan af Lagen til både Väl och Ve, på det han således må sakna orsak til grämelse öfver olikhet i vilkoren ibland med-människor. ${ }^{187}$

Här märks ekon av naturrätten, inklusive dess traditionalistiska slagsida. Underkastelse byttes mot respekt så att ingen upprorsanda manifesterade sig.

Enligt Rosenstein skulle i ståndsfunktionalistisk anda varje person inom sin krets känna till sina rättigheter och förpliktelser samt besitta de kunskaper och begrepp som krävdes för lycksalighet, nämligen vetskap om samhällets syfte och de medel som kunde förverkliga det. Samma funktionalistiska ansats kan skönjas i hans yttrande att graden av upplysning kom an på "hvar och ens serskilte kall och belägenhet". ${ }^{188}$ Rosenstein laborerade å andra sidan med allmänmänskliga rättigheter. Han konstaterade bland annat att rätten till lycksalighet var helig och att de tider var lyckligast när människornas rätt var väl bevarad och lycksaligheten stod på säker och naturlig grund. ${ }^{189}$ Rosenstein rörde 
sig, liksom Sparre, med både nedärvda och nya föreställningar, med ståndssamhället och en individbaserad ordning där varje människa tillerkändes elementära rättigheter. I det avseendet var de inte ensamma inom akademien, som dock helt klart graviterade mot de förra synsätten.

\section{Samhället i bilder}

För att åskådliggöra samhällsgemenskapen tog Vetenskapsakademiens ledamöter, i likhet med många av sina samtida, till ett bildspråk som ofta hade antika rötter. ${ }^{190}$ David Dunér har uppmärksammat att metaforer, tankeredskap som etablerar samband och översätter mellan fenomen, var ett vedertaget inslag under den tidigmoderna eran. ${ }^{191}$ Pasi Ihalainen talar istället om analogier, som var allmängods inom 1700-talets elit och manifesterade den politiska kulturens grundläggande tänkande. Han intar ståndpunkten att dåtidens författare ofta inte bara drog paralleller på det språkliga planet utan faktiskt trodde på verkliga överensstämmelser mellan natur och politik eller natur och ekonomi. ${ }^{192}$

Hur 1700-talets bildspråk skall tolkas är inte helt lätt att avgöra. ${ }^{193}$ Några av Vetenskapsakademiens presides tycks ha uppfattat de paralleller de drog som enbart språkliga konstruktioner. Till exempel anmärkte bergsrådet och landshövdingen Daniel Tilas att de norsk-svenska gränsbergen tog sig ut som en ryggrad med kotor och revben för att därpå framhålla att detta var en liknelse och ett talesätt. ${ }^{194}$ Deras reflektioner kan emellertid inte tas till intäkt för att övriga ledamöter delade denna synpunkt eller att alla kopplingar upplevdes på samma sätt. Det är svårt att veta i vad mån akademiens medlemmar såg sina associationer som språkliga konventioner eller som symboliska representationer av djupare och verkligt existerande samband. Det senare alternativet bör dock i ljuset av den förhärskande världsbilden ha varit ganska vanligt. Klart står att bildspråket bidragit till att forma människors föreställningsvärldar. Som Deirdre McCloskey påpekat är bildliga uttryck inte enbart ett utanverk: "Figures of speech are not mere frills. They think for us." ${ }^{195}$ Det bildliga har erbjudit fruktbara ingångar till antaganden och världsbilder som legat till grund för maktens offentliga ceremonier, vilkas symboliska aspekter kommunicerat viktiga innebörder och 
haft en konkret relevans som sentida betraktare kan ha svårigheter att greppa ${ }^{196}$ I det följande begagnas för enkelhetens skull den generiska termen "bild" istället för de mer belastade och kontroversiella termerna "metafor" eller "analogi".

Från de föregående århundradena ärvde 1700-talet en förkärlek för att urskilja strukturlikheter mellan tillvarons olika nivåer. ${ }^{197}$ Denna yttrade sig bland annat i att monarken liknades vid en far för sitt folk och samhället vid ett hushåll. Samhällsgemenskapen framställdes också som en kropp, vars huvud eller hjärta utgjordes av konungen och extremiteter av stånden. ${ }^{198}$ Bilderna av samhället som en kropp var framträdande och lätta att förena med tankar om rangordning och lydnad. Även om de kunde tas i anspråk för att ifrågasätta det bestående, korresponderade de regelmässigt mot monarkin och den traditionella samhällsåskådningen med dess tydliga sociala gränsdragning och ideal om harmoni. Stånden betraktades som lemmar med hierarkiskt bestämda uppgifter, och samhällsorganismens fortlevnad ansågs kräva samförstånd mellan lemmarna och mellan dem och huvudet. ${ }^{199}$

Kroppsbilderna var ett återkommande inslag i presidietalen, som bland annat fastslog att individerna utgjorde ledamöter av rikskroppen och beskrev det romerska samhället som en rikskropp där medborgarna formade lemmarna. ${ }^{200}$ Flera akademimedlemmar uppehöll sig vid samhällskroppens inre rörelser. Hushållning och handel var de ådror som förmedlade livssaften - flitens alster - genom hela rikskroppen, och en snabb och lätt rörelse inom ett rike var lika viktig för den gemensamma välfärden som blodets fria lopp i kroppen var för hälsan. ${ }^{201}$ Kryger liknade samhällets näringar och rörelser vid människokroppens blod och förband rikskroppens sundhet med en adekvat arbetsfördelning; näringarnas varsamma differentiering var av största vikt eftersom deras ömsesidiga stöd föranledde nyttiga och hälsosamma rörelser mellan rikskroppens lemmar. ${ }^{202}$

En av de mest fullödiga blodomloppsbilderna formulerades av riksrådet Nils Adam Bielke när han diskuterade inrikeshandel:

Den verkan och nytta, som blodet gör i menskliga kroppen, den gör handelen i den Politiska. Han [handeln] ikringförer lifsandarna i jämn 
afpassad ordning til alla lemmarne, tildelar dem sin erforderliga föda och styrka: dess ordenteliga lopp är säkraste måttstocken af välmåga, och dess aftagande bådar största äfventyr [risk] för hälsa och lif, hvarföre den ock förtjenar den ömaste vård och omtanka. Men äfven som blodet, då det af osunda vätskor är sammansatt, eller igenom et oordenteligt lefnadssätt blifvit bårtskämdt [förstört], fördärfvar kroppen och åstadkommer tärande febrar, rötsår, blodstörtningar och oboteliga sjukdomar, så blir ock handelen högst fördärfvelig, om den ej med kunskap och eftertanka inrättas, med kärlek för det allmänna och försiktig frimodighet drifves. ${ }^{203}$

Även samhället kunde drabbas av sjukdomar, något som behandlas mer utförligt lite längre fram i detta kapitel.

Vissa akademimedlemmar utredde samhällskroppens funktionalistiska dimension mera i detalj. Henrik Jakob Wrede konstaterade att samhällets behov var så mångfaldiga "at somliga lemmar skola göras skickeliga til fötter ock ben, somliga til armar ock händer, somliga til hufvudets delar ock stycken, eller til andra ledamöter af kroppen". Envar skulle fås och hållas till att avvinna naturen nyttigheter efter sitt kall. Lantmäteridirektören och den tillförordnade akademisekreteraren Jacob Faggot använde människokroppen som mönster för skapelsens och vetenskapernas funktionella uppdelning. Vetenskapsakademiens lilla samhälle var enligt honom likt det stora och hade i likhet med det kropp, lemmar och huvud. Han lade nogsamt ut den funktionalistiska ordningens principiella grund: "Människans kropp har många lemmar, hvar lem har sin sysla, hvar sysla sit gagn: om en lem kunde göra alt, så behöfdes ej flera, om hvar lem vore skickelig til alt, så vore de hvarandrom til hinder; men Skaparen har så visligen bygt den Lilla, som den Stora Verlden.” Det var därför otillåtet att i strid med rättfärdigheten begränsa en persons verksamhet eller mot det rätta måttet utsträcka en annans dito. ${ }^{204}$ Faggots beskrivning kan förmodas ha anspelat på ståndssamhällets uppgiftsfördelning, vilken alltså i kraft av sin gudomliga sanktion inte borde överskridas.

Samhället tillmättes ibland en lekamlig karaktär utan att uttryckligen liknas vid en kropp. Exempelvis inlät sig flera presidietal på dess lemmar, som förklarades vara närande eller tärande, och på dess "invärtes" 
tillstånd och rörelse. ${ }^{205}$ Till det kom att andra företeelser än samhället vidhäftades kroppsbilder - inte minst hushållningen. ${ }^{206}$ En förutsättning för välstånd uppgavs vara att den ena näringen bistod den andra, liksom en lem bistod en annan i en frisk kropp. Idealt skulle var och en sköta sin syssla medan näringssektorerna understödde varandra på samma sätt som lemmarna gjorde i människokroppen. ${ }^{207}$ Kroppsbilderna applicerades även, som Faggots nyssnämnda utsaga om Vetenskapsakademien redan indikerat, på lärdomen. Vetenskaperna sades ha kommit att upplevas som armar och akademien ha "inympat" svenska begåvningar i sin kropp. De lärda sällskapens insatser beskrevs i termer av alstring, sköte och frukt. ${ }^{208}$ En ledamot, Carl Hårleman, framställde Paris som en väldig kropp upplivad av ministern René Louis de Voyer de Paulmy d'Argenson. ${ }^{209}$

Den geologiska världen åskådliggjordes också med kroppsbilder, något som kan förbindas med äldre naturfilosofiska idéer om överensstämmelser mellan människokroppen och jordklotet. ${ }^{210}$ Tilas förkunnade att hällebergets stadgande funktion motsvarade benens i kroppen och att en analogiprincip genomsyrade tillvaron: "Det går så gemenligen med all ting i werlden [...]: Nytt husbondefolck nya ordningar, Ny öfwerhet nya lagar, nyttt [sic] folck nya seder, nya Riken nya inwånare, Nytt stenrike nya stenslag."211

Det var vanligt att samhällskroppen tillskrevs olika sorters smittor i 170o-talets Sverige och i presidietalen. ${ }^{212}$ De ekonomiska problem som rådde i Sverige före Gustav Vasas regeringstid utmålades som sjukdomar i rikskroppen och landet under hans styre som en konvalescent. Ett samhälle vars medborgare led brist på sann övertygelse likställdes med en sjuk människa, medan införseln av överflödsvaror - och i förlängningen all varuimport - framställdes som en tärande sjukdom. När fenomenet lyx och de åtskilliga moraliska fel som den alstrade diskuterades, hette det att "et skabbugt får kan besmitta hela Hjorden" och en omoralisk person locka många lättrogna medmänniskor in i den värsta och menligaste dårskap. Om de befallande utgjorde dåliga exempel för sina underlydande tenderade lasterna att bli lika smittsamma som pesten. ${ }^{213}$

Samhällets sjukdomar hade liksom de som drabbade människan läkare och botemedel. Ett syfte med bilderna av social harmoni och 
balans i samhällskroppen var att bereda mark för den helande kunskap som de lärda kunde tillhandahålla. ${ }^{214}$ Handelsmannen Johan Clason lade ett medicinskt raster på åtgärder hattarna vidtagit för att förbättra landets ekonomiska belägenhet: "Om desse kostelige botemedel hade blifvit brukade efter Rikskroppens beskaffenhet, så hade nyttan kunnat blifva ansenlig, men dosis togs för stor, och verkan vardt lik den, som för stor dosis medicamenter har på en svag människo-kropp." De ordinerade läkemedlen var för potenta och rikskroppen för medtagen för behandlingen. Rikskroppen skulle rentav ha avlidit om inte Adolf Fredrik ingripit och räddat dess liv. Clason förfäktade också att Växelkontoret varit en palliativ, till skillnad från kurativ, insats mot en sjukdom som rikskroppen lidit av i två sekler och som riksdagen, med Guds goda minne, förhoppningsvis skulle finna verksamma botemedel mot. Lilliestråle betraktade på traditionalistiskt manér lagarnas föränderlighet som ett allvarligt politiskt ont och ett beklagligt tecken på "Stats-kroppens" opasslighet och förestående undergång. Han parallelliserade kroppen och samhället genom att göra gällande att politiska och naturliga kroppar alltid bär på frön till sin egen undergång, varför gagneliga botemedel blir nödvändiga. Det gäller att på ett tidigt stadium korrekt identifiera det onda och ta till de mest effektiva medlen för att återställa och bevara hälsan. ${ }^{215}$

Sjukdomsbilderna kunde i likhet med kroppsbilderna användas för att fånga en mängd aspekter av tillvaron. Det moraliska fördärvet liknades vid en farsot, den europeiska silverinförseln vid en frätande cancer ("kräfta"), den omåttliga kunskapstörsten vid "en sjukdom i de lärdas samfundskropp". Svenska språket kunde infekteras av främmande element, men hade i allmänhet och på djupet inte påverkats av någon utländsk smitta. ${ }^{216}$

Andra presidietal hämtade sitt bildmaterial från naturen, vilket kan sättas i samband med att naturalhistorien under 1700-talet knöts till politiken genom att erbjuda liknelser som tillämpades på samhället. ${ }^{217}$ Några tal utgick från djurriket när de gestaltade det mänskliga livet. Arbetarna var som myror, slöjderna som bin vilka försvann eller dog när honungen tröt. Invånarna i de länder Jonas Alströmer besökte under sina europeiska resor beskrevs som krälande myror med olika 
uppgifter att fylla eller duktiga bin som hämtade honung och vax från utlandet. ${ }^{218}$ Akademiledamöter framställdes som "rätta Verk-Bi" och akademien som en bistock där varje individ efter förmåga bidrog till helheten och fäderneslandets nytta. ${ }^{219}$

Presidietalen åskådliggjorde dock oftare samhälleliga fenomen med växtbilder. Till exempel beskrev fysikern Johan Carl Wilcke, Vetenskapsakademiens sekreterare 1784-96, hur befolkningen tilltog av sig själv och liksom en grönskande skogspark fick frodiga grenar på sin stam och sina rötter bara den beskyddades och sköttes varsamt. Barnen liknades vid späda plantor och livliga telningar som hade potential att bli fruktbärande träd. ${ }^{220}$

Växtbilderna förekom liksom de andra bilderna i anslutning till hushållning och lärdom. Ekonomins grenar planterades och tillväxte, och handeln och hushållningen utgjorde "telningar af en gren uti samhäldets välgång”. Om de båda senare inte sköttes och ansades på rätt sätt, tillkom vildskott som hämmade de riktiga kvistarna och slutligen drog saften ur och förstörde stammen. Inte heller manufakturerna klarade sig på egen hand - i likhet med människorna fordrade de oupphörligen mycken hjälp och ans för att inte duka under eller bli skadliga. I ett fall likställdes näringarna såväl med lemmar i en kropp som med plantor som rotade sig och tillväxte tillsammans. ${ }^{221}$ Vetenskapsakademien liknades vid en späd telning som planterades, rotade sig, växte, ansades, mognade och blomstrade. ${ }^{222}$ Dess nyttiga och genuint fruktbara vetenskaper var som de bästa frukterna, vilka härrörde från små frön och tog lång tid på sig att komma till skott. De lärda visste också att förkasta agnarna till förmån för säden. En ledamot, Melanderhielm, förklarade att vetenskaperna uppodlades, tillväxte och gick tillbaka i perioder men att Gustav III lade grunden för att vackra konster och nyttiga vetenskaper skulle grönska länge än i riket. ${ }^{223}$

Utöver kroppar och växter var maskiner och instrument frekventa i presidietalens bildspråk. Löwenhielm hävdade dels att en gemensam strävan efter det allmänna bästa var kraften som skulle driva rikshjulet till ett samfällt ändamål, dels att regeringsmaskinen behövde dras upp och hade komponenter som förnöttes; dess drivfjädrar måste härdas när de med tiden försvagades och stelnade. Enligt Kryger gjorde despo- 
tiska regimer att påhittigheten liksom ett urverk förlorade sin rörelse när drivfjädern, ett livligt och rappt sinne, bröts sönder. Jonas Alströmer menade att handslöjderna och konsterna fungerade som en vikt eller ett lod på ett ur och gav liv och rörelse till samhället. Han liknade samtidigt, i linje med en bildblandning som flera andra ledamöters tal visade prov på, bergverken vid ett hjärta, manufakturväsendet vid ett långsamt växande träd och sina egna manufakturer vid foster. ${ }^{224}$

Så skilda ting som näringarna, det mänskliga handlandet, de fysiska vetenskaperna, stora snillens verk och respekten för goda lagar uttrycktes med mekaniska bilder. ${ }^{225}$ Världen var ett urverk med fädrar som höll det i en jämn gång, bergshanteringen hade drivfädrar som bestod i tävlan, förtjänst och kunglig nåd. ${ }^{226}$ Vetenskapsakademiens drivfjädrar gav organisationen verkan, liv och rörelse, medan vetenskaperna rullade omkring "likasom uppå et sagta gående hjul". ${ }^{227}$ Det hände att människokroppen framställdes som en maskin eller utrustades med mekaniska kännetecken som pumpar, tänger och hakar. ${ }^{228}$

En fjärde kategori bilder föll tillbaka på byggnader och skepp. ${ }^{229}$ Samhället liknades vid ett fartyg där rätt och lag var tyg och tackel, antikens grekiska och romerska samhällen vid snabba skepp som krävde en myckenhet pumpar och arbete och Gustav III:s lagstiftning vid en välkonstruerad, välproportionerad och beständig byggnad. ${ }^{230}$ De arkitektoniska bilderna applicerades liksom de andra på ett brett spektrum av områden. Världen jämfördes med en sinnrik och gigantisk byggnad och den organiska kroppen med en naturens byggnad som konsten inte kunde ta efter. Hjärnan tillmättes broar, valv, bågar, pelare och trattar. ${ }^{231}$ Inte heller vetenskapen och Vetenskapsakademien undgick att åskådliggöras med detta bildspråk. Lärda kunskapssystem och det vetenskapliga sanningssökandet kläddes i arkitektoniska termer, och akademien gestaltades som ett lättseglat skepp med fullärda sjömän. ${ }^{232}$

Som framgått ovan kunde olika sorters bilder figurera i en och samma text. Ett presidietal utmålade människokroppen som en ypperlig byggnad för att i nästa stycke omnämna dess mekaniska konstitution. I ett annat tal hette det att pengar var en viktig drivfjäder på alla områden, att Vetenskapsakademiens Handlingar givit sammanslutningen egenplanterad frukt samt att Adolf Fredrik haft akademiens väl i åtanke då 
han blivit kansler för Uppsala universitet och kommit att sköta om "en plantering, som skulle gifva stammar åt denna inrättning". Lilliestråle liknade samhället vid en kropp, ett urverk, ett skepp och en byggnad. Han proklamerade att Gustav III skulle återge rikskroppen hälsan men riktade sig också till regenten med en förhärligande växtbild. ${ }^{233}$

Bruket av en specifik slags bild innebar sålunda inte ett exklusivt anammande av någon där emot svarande verklighetsåskådning. Eklekticismen kan ses mot bakgrund av att såväl naturen som människokroppen och samhället under tidigmodern tid tillskrevs mekaniska attribut, vilket gav upphov till potenta bildblandningar som gjorde det möjligt att förstå dessa företeelser med utgångspunkt i varandra. De olika bilderna formade en komplex helhet som kunde tas i anspråk för att rättfärdiga den hierarkiska samhällsordningen. ${ }^{234}$ Samtliga bildkategorier som förekom i Vetenskapsakademien användes på ett sätt som svarade väl mot den tongivande ståndsfunktionalismen. Bilderna hade därtill ofta en biton av långsam förändring eller stasis som harmonierade med det gängse förhållningssättet till samhällsförändring.

Avslutningsvis skall en typ av bild uppmärksammas som låg på en annan nivå än de redan avhandlade och hänförde sig till liv och rörelse. Akademiens presides tillkännagav att allt skulle vara i en rörelse när näringarna utformades och samspelade på rätt sätt, att bergverken givit mest liv och rörelse till riket samt att bergshanteringen och handeln var angelägna rörelser. ${ }^{235}$ Wargentin slog fast att den långa frånvaron av sunda rörelser hade medfört att vetenskaperna sent fått fotfäste i riket och att rörelsen var all hushållnings liv och nödvändig för samhällets välmåga. Handeln skänkte vetenskaperna liv varpå dessa i sin tur genererade nyttiga rörelser. ${ }^{236}$ Rörelser och krafter blev inte för inte vanliga redskap för att beskriva samhället i den tidigmoderna, cartesianska och newtonianska, fysikens efterföljd. Den vetenskapliga referenspunkten var "ett system av kroppar i rörelse, där alla kroppar påverkar varandra mer eller mindre och där varje kropp funnit en rörelse, som står i överensstämmelse med dess egenskaper och tillsammans med alla andra rörelser upprätthåller balansen i systemet”. ${ }^{237}$ 
Vetenskapsakademiens politiska ideologi gynnade, såsom den framträdde i presidietalens fundamentalantaganden om samhället och tillvaron, överhuvudtaget samhällsledningen och det bestående.

Den mänskliga samlevnaden reflekterade och skulle vägledas av naturen, som var sammanlänkad med samhället inom ramarna för en gudomligt bestämd totalitet. Såväl natur som samhälle ansågs präglas av rangordning, stabilitet, saktfärdighet, komplementaritet och ömsesidighet. Allmänt och enskilt utgjorde analoga storheter och det gemensammas väl sammanföll med individens, låt vara inte per automatik eller med nödvändighet. Envar hade sin särskilda roll att fylla i helheten. Människor var liksom andra Guds skapelser avsedda för olika ting och det ålåg makthavarna att styra alla till rätt göromål; underförstått skulle varje samhällsinvånare vara nöjd med sin lott och förbli vid sin läst. Flera ledamöter förespråkade visserligen social rörlighet i form av snillevalet, som gick ut på att ungdomars utbildning skulle avgöras av deras anlag och inte deras härkomst, men detta behövde inte ha radikala implikationer. Samhället framställdes på det stora hela i hierarkiska och ståndsfunktionalistiska termer. Jämvikt och harmoni var ständigt närvarande mellan raderna.

Samhällets ursprung och utveckling betraktades i ett naturrättsligt och stadieteoretiskt ljus. Dess uppkomst förklarades ofta med de mänskliga behoven och naturtillståndets otrygghet, och med något undantag värderades det församhälleliga lägre än det samhälleliga. Ett par gustavianska ledamöter, Lilliestråle och Rosenstein den yngre, hade en mer positiv attityd till naturtillståndets frihet, annars vilade framstegs- och civilisationstron tung över presidietalens utblickar mot samhällets historia.

Gustavianska ledamöter uppvisade ett större intresse för de enskilda människorna, deras bevekelsegrunder som samhällsvarelser och deras rättigheter. Några framhöll att samhället utgjorde summan av sina beståndsdelar, och fler anslöt sig till en gynnsam syn på egennyttan än under frihetstiden. Gustavianska ordförande tenderade samtidigt att vara mer uppenbart skeptiska till förändringar och att betona lag och säkerhet i högre grad än vad de frihetstida föregångarna gjort. I båda fallen skymtar den sena frihetstidens slitningar, Gustav III:s statsvälv- 
ning och franska revolutionen i bakgrunden. Rosenstein den yngre och Carl Sparre tecknade en individbaserad ordning där alla åtnjöt ett grundläggande skydd.

Akademiemedlemmarna illustrerade och förstärkte den föreställda världs- och samhällsordningen med olika typer av bilder, som inte sällan förekom parallellt. Bilderna utgick från människokroppen, djur och växter, maskiner och instrument, byggnader och skepp. Gemensamt för dem var att de underströk samhällets funktionalistiska dimension och gjorde den mänskliga gemenskapen mer effektiv och rationell än i verkligheten. Mest populära var de kroppsrelaterade bilderna, vilka också enklast torde låtit sig förenas med det korporativa ståndssamhället. Samhällskroppen kunde i likhet med människokroppen lida av sjukdomar, vilka krävde botemedel som de lärda händelsevis kunde ställa till förfogande.

Akademiens uppslutning bakom makten och det rådande blir ännu tydligare i nästa kapitel, när dess idéer om samhällsledningen och folket adresseras. 


\section{Myndiga makthavare, omyndig menighet}

I detta kapitel fortsätter utforskandet av Vetenskapsakademiens politiska ideologi genom en studie av ledamöternas föreställningar om samhällsledningen och folket. Kapitlet består av två avsnitt. Det första behandlar inställningen till samhällsledningen och de återkommande utsagorna om övervakning och kontroll, ett framskjutet tema såväl inom som utom akademien. Det andra avsnittet ägnas åt synen på folket $\mathrm{i}$ bemärkelsen menigheten, till skillnad från ett stiliserat svenskt folk - den svenska nationen - som kunde vara nog så uppskattat och idealiserat under 1700 -talet. ${ }^{238}$ Som analysen kommer att åskådliggöra lånade sig det faktiska folket $i$ väsentligt mindre utsträckning till välvilliga omdömen. Trots sin folkbildande ambition och optimism inför den allmänna kunskapsspridningens möjligheter ställde sig Vetenskapsakademien överlag kallsinnig till gemene man och dennes förståndsgåvor.

\section{De vaksamma rörarna}

Vetenskapsakademiens ordförande talade ofta om "överheten", men det står inte alltid klart vad termen mer specifikt avsåg. Det är till exempel svårt att veta exakt vad det före detta hattriksrådet Carl Rudenschöld (Rudeen) syftade på då han uppgav att akademimedlemmarna inte låg sin överhet till last. ${ }^{239}$ Många gånger var överheten dock uppenbarligen eller antagligen liktydig med monarken, som när presidietal meddelade att en nådig överhet bistått den nybildade Vetenskapsakademien och att Sverige behövde "en nådig ock mild Öfverhet, som biuder, hielper 
ock befordrar alt det som kan lända Riket ock alla des Inbyggare til säkerhet, styrka ock vältrefnad". ${ }^{240}$ Ordet "nåd" gör det troligt att ett yttrande handlade om majestätet och inte om en vidare grupp uppsatta personer, eftersom nådighet var en framträdande kunglig egenskap. ${ }^{241}$

Jonas Nordin har menat att "överhet" på 1700-talet egentligen betecknade monarken fast som regel innefattade "åtminstone de översta befallande lagren i samhället". Under frihetstiden åsyftade termen den verkställande maktens utövare - konungen, riksråden och generalguvernörerna - men inte ständerna och riksdagsmännen, som likväl kunde kritiseras för att de förhävde sig själva och därigenom nådde ställning av överhet. Uppslagsverket Geschichtliche Grundbegriffe anger att den tyska motsvarigheten "Obrigkeit" kunde hänföra sig till den offentliga maktens innehavare och vilken ämbetsman, hög person eller grupp av höga personer som helst. ${ }^{242}$

Alldeles oavsett ordets precisa innebörd föreställde sig Vetenskapsakademiens ledamöter att näringarnas och hushållningens välgång, och därmed samhällets liv och rörelse, var avhängig överhetens insatser. Jonas Alströmer kungjorde att alla ekonomins grenar kunde öka ett folks makt, "men, ingen af dem planterar sig sjelf, eller når behörig tilväxt, utan publik vård och skötsel. De vantrifvas, utan Öfverhetens skydd och upmuntran”. Pehr Wilhelm Wargentin hävdade att handel, konster och kunskaper var av godo så länge missbruk avvärjdes genom överhetens omsorg, i form av lagar och exemplariskt agerande. ${ }^{243}$

I överensstämmelse med en sedan länge vedertagen föreställning om att suveränen bar ansvaret för det allmänna bästa framstod Sveriges monarker ofta som samhällsutvecklingens motor, inte minst genom att de beskrevs som nyttiga förebilder, exempla, för folket. ${ }^{244}$ Frihetstida presidietal deklarerade att konungen hade att ombesörja samhällets förbättring, som främst berodde på höga överhetens beskydd och hjälp, och att vetenskaperna inte kunde trivas utan stora regenters omsorg och flit, som gav alla samhälleliga handlingar rätt liv och fart. ${ }^{245}$ Fredrik I och Ulrika Eleonora skildrades som förebilder och kärleksfulla föräldrar för sina undersåtar, vilka tacksamt skulle bidra till kungaparets ära genom hårt arbete i deras efterföljd; "en jordbrukare, enär han svettas vid sit bruk, må välsigna dem, som bära fast drygare börda af och för 
det allmänna, och [...] han må drista sig anse sin träskötsel såsom en ringa liknelse af vår nådigste Öfverhets hand, som planterar och vårdar alla Rikets gagneliga inrättningar”. Kronprinsen Adolf Fredrik beskrevs som mån om Sveriges upphjälpande, och som ett verksamt exempel för undersåtarna genom sitt lantbruk på Ekholmsund. Mot bakgrund av sin insikt om att regenter med sina böjelser och sitt föredöme formade undersåtarnas kynne sökte han som konung befordra slöjderna med sitt och sin gemåls exempel genom att anlägga fabriker vid Drottningholm..$^{246}$

Samma tankegods fördes fram under den gustavianska perioden. Det hette att furstar i allmänhet hade makten över länders öden, medan folket tillskrevs en negativ agens, benäget som det var att vålla sin egen olycka och undergång. Trots att vissa monarker betraktades som vekliga eller likgiltiga inför undersåtarnas väl bedömdes ändå deras riken vara långt bättre än de där ordning, lag, rättigheter och frihet satts ur spel. Fursten tillmättes ett särskilt ansvar för folkets karaktär, som hade sin grund i föränderliga moraliska orsaker, däribland religion, regeringssätt och uppfostran. Givet att regenten kunde åstadkomma en förnuftig och väl utformad konstitution berodde folkets egenskaper alltid på suveränen. Det gick följaktligen att förutspå en lysande tid av snillrikhet, djärvhet, högsinthet, patriotism, måttfullhet och ärlighet hos svenskarna, som hade den ovärderliga lyckan att ledas av Gustav III. ${ }^{247}$

Det var inte bara monarkerna som aktiverade eller skulle aktivera samhället. Riksdagen föreställdes under frihetstiden som en vårdare av det gemensamma bästa och en drivkraft i riksförbättringen. ${ }^{248}$ Det förkunnades att ständerna ömsint såg till gemensamt väl och att de genom konungen föranstaltat om schäferiernas, manufakturernas och landets upphjälpande. De hade visat diger omsorg om ekonomin och alla nyttiga näringar och befrämjat dem med tillbörliga medel. Inte minst hade de ivrat för det allmänna bästa på 1738-39 års riksdag, som uppmuntrat näringar, rörelser och vetenskaper intensivt. Dessa utsagor rörde primärt de styrande hattarna. En ledamot - Jonas Alströmer noterade dock att rikets och manufakturernas förbättring inletts redan 1727 , alltså under de förra makthavarna, som den samtida politiska oppositionen utgick från. ${ }^{249}$

Riksdagen och konungen gavs ibland tillsammans status av samhälls- 
förbättrare. Presidietalen tog upp deras samfällda strävan att förbättra sjukvården och framhöll att överheten i bemärkelsen den lagstiftande makten, regeringen och Kongl. Maj:t hade gemensamma uppgifter: att öka folkmängden, uppfostra undersåtarna till kapabla lemmar i samhällsgemenskapen samt understödja näringarna och alla andra samhällsnyttiga företeelser. ${ }^{250}$

De gustavianska talen uppehöll sig av förklarlig anledning sällan vid riksdagens ansträngningar, vilka endast berördes i samband med historiska återblickar på frihetstiden. Det handlade då om anekdotiska detaljer som att riksdagen beslutat inrätta en oljekvarn i Åbo eller att Kommerskollegium och Manufakturkontoret delat upp spinnandet mellan landsorterna. Det frihetstida rådets förbättringsarbete uppmärksammades av matematikern Fredric Mallet, som nämnde att uppfostringsväsendet efter stora nordiska kriget prioriterats av konungen och rådet och att en mycket bättre ordning inom kort antagits för de lägre utbildningsnivåerna. ${ }^{251}$ Det ter sig symptomatiskt att Mallet utelämnade ständerna och lät rådet och monarken substituera för dem.

En tredje instans som tillerkändes en drivande funktion i samhället under frihetstiden var regeringen. Presides slog fast att regeringens kloka och ömma omvårdnad utgjorde förutsättningen för slöjdernas, och i förlängningen rikets, välgång, liksom att inte enbart de nitiska ständernas utan också den vaksamma regeringens hängivenhet för jordbruket garanterade landsbygdens utveckling på längre sikt. ${ }^{252}$ Carl Hårleman porträtterade regeringarna i Holland och Hannover som föredömliga samhällsförbättrare. Den hannoverska regeringen hade tillgång till ingående information om det egna riket och skötte allt lika tillgivet, noggrant och livligt som den ombesörjde lag och rätt: invånarnas giftermål och reproduktion, sjukdomsbekämpningen, ungdomens uppfostran och tilldelning av sysslor, markuppodlingen, skogarna, gruvorna, salpetersjuderierna, slöjderna, manufakturerna, handeln och städerna. Detta borgade enligt Hårleman för positiv handelsbalans, penningöverflöd och välstånd. Annorlunda förhöll det sig i Münster och Westfalen, vilkas avsaknad av ansatser till riksförbättring föranledde brist på livsmedel och utkomstmöjligheter, och därmed vantrivsel. Deras regeringar gav varken uppmuntran eller exempel, vilket berövade undersåtarna lust 
och förmåga att ta sig an sådant som krävde högt beskydd och publikt understöd. ${ }^{253}$

Hårlemans utblick mot Europa torde ha syftat till att övertyga de svenska styresmännen om att imitation av deras hannoverska och holländska motsvarigheter och undvikande att ta efter de negativa tyska exemplen skulle få gynnsamma konsekvenser för riket. En liknande ansats kan skönjas hos Anders Schönberg när han förfäktade att näringarnas förkovran och samordning till ömsesidigt bistånd var villkoren för allmän välmåga:

Alla uplyste Stats-Cabinetter förlora aldrig detta vigtiga föremålet utur ögnasigtet, vid alla Ministeriella värf, som därmed äga något det minsta sammanhang; och den Patriotiske Statsmannen, som är syslosatt med et Lands inrikes Styrelse, förgäter aldrig at bemöda sig, til att förvärfva häruti åt sitt Samhälle de största fördelar, som vore möjeligt at vinna. Man skulle eljest i vårt mera uplysta tidehvarf utvisa, at man antingen icke kände, eller icke ville känna medlen til sitt Fäderneslands sällhet. ${ }^{254}$

Givet Vetenskapsakademiens närhet till makten är det rimligt att anta att Schönberg och Hårleman var ute efter att påverka makthavarna, varför deras utsagor kan ses som uttryck för en furstespeglande tradition, även om de med tanke på frihetstidens politiska ordning bör ha vänt sig till riksråden snarare än monarken. Furstespeglarna utgjorde en sorts föreskrifter och dygdeförteckningar för regenter där kontrasten mellan den moraliske monarken och den lastbare tyrannen var central. Genren hade såväl kristna som grekisk-romerska rötter och förblev livskraftig under 1700-talet. ${ }^{25}$

Flera frihetstida presides tillskrev de förmögna och förnäma en viktig roll i och för samhället. Det överskott som genererades av förmögna inbyggare - förnäma, borgare och besuttna bönder - liknades vid rikskroppens blod. Den viktiga inhemska metallindustrin troddes inte kunna blomstra utan hedervärda och rika mäns avkomlingar, som skulle få rätt utbildning inom området och lockas att ge sig in i näringen. Schönberg uppfattade välbärgade näringsidkare som en välsignelse för samhällsgemenskapen: "Det är [...] en skatt för det allmänna, för 
Bild 5. Pehr Hilleström den äldre, Spelparti hos statssekreterare Elis Schröderheim. Foto: Nationalmuseum. Ögonblicksbild från en högreståndsmiljö, akademiledamoten Schröderheims bostad på Nybrogatan i Stockholm.

Näringarne och för deras förbindelse, då någon större förmögenhet hos några kan samlas och til Närings medlens gagn användas. [- - - ] Om et enda förmöget hus, som uplifvar många Närings-grenar, drages ifrån Närings-driften, är det en ganska stor förlust för Samhället och den blifver ofta oärsättelig, om det händer med flera." Samme preses menade att de rikare lantbrukarna kunde ge utkomst åt en stor mängd 
arbetare, som därmed bereddes möjlighet att ingå äktenskap. Till följd av det fylldes befolkningen på med närande medborgare och tillväxte "Statens allmänna rikedom och styrka". ${ }^{256}$ Under den gustavianska tiden talades det om den kraftfulla inverkan magnaters uppmuntrande föredöme hade på allmänheten och om att rikets större jordägare stått bakom betydelsefulla förbättringar som i högsta grad gjort dem förtjänta av det allmänna. Låt vara att det fanns en farhåga om att de arbetsamma och förståndiga ståndspersonernas ättlingar skulle överge jordbruket för mindre nyttiga värv. ${ }^{257}$

Det förflutna fungerade i presidietalen som en projektionsyta för idén att monarkerna utgjorde en central samhällelig drivkraft. Detta kan kopplas till den antikt förankrade föreställningen att historien var livets läromästare, där det förgångna presenterades som ett mönster för nuet och en källa för normerande exempel. Historieskrivningen och dess exempla hade ofta en samtidsrelevant, värderande och politisk sida som maskerades av deras föregivet induktiva karaktär. ${ }^{258}$

Vetenskapsakademiens medlemmar redovisade forntida och medeltida regenters insatser för infrastrukturen, ekonomin och lärdomen. Till exempel hade sagokungarna Yngve Frej och Bröt-Anund på ett förträffligt vis beflitat sig om jordbruket och genom både författningar och exempel skapat förutsättningar för en lyckosam lanthushållning. Magnus Ladulås hade visserligen infört utländska seder och fördärvlig yppighet, men likväl uppodlat Sverige och upplivat de fria konsterna. ${ }^{259}$

Särskilt Gustav Vasa, Gustav II Adolf och Karl XI tog sig ut som framstående samhällsförbättrare i talen. Johan Clason infogade de båda första furstarna i ett ekonomisk-politiskt kontinuum som omfattade frihetstiden: "omkring år 1520, började Konung GUSTAF reformera Sveriges Hushållning, omkring 1620 började Konung GUSTAF ADOLPH förbättra det som hans Farfader ej hade medhunnit, och omkring 1720 kan räknas början af de författningar, som tillika med frihet blifvit tagne til befordran af Handel och Näringar hos oss". Jean George Lillienberg anmärkte att bergshanteringen alltid uppmuntrats och beskyddats av regeringen, och att förflutna konungar, speciellt Gustav Vasa och Gustav II Adolf, gynnat näringen. Lillienberg upprättade i likhet med Clason en kontinuitet mellan dåtid och samtid när 
han slog fast att Gustav Adolfs författningar och uppmuntran bringat ordning i stångjärnsmidet, och att eftervärlden utan tvekan skulle förlägga metallförädlingens verkliga början till Gustav III:s patriotiska styre. ${ }^{260}$ Det finns här anledning att erinra om den samtida bilden av Gustav III som "den tredje Gustaven", vilken från hans födelse utgjorde ett återkommande tema som betonade hans blodsband till samt symboliska och moraliska affinitet med företrädarna med samma namn, Gustav Vasa och Gustav II Adolf. Lillienbergs associering av Gustav III med Gustav II Adolf kan betraktas mot bakgrund av detta motiv, som var en integrerad del av den gustavianska epokens politiska språk och konungens självuppfattning. ${ }^{261}$

Några gustavianska presidietal ägnade sig åt utförliga redogörelser för Gustav Vasas gärning, troligen med ett öga på Gustav III:s symboliska band till och appropriering av nämnda reformationsfurste. Ledamöter uppgav att Gustav Vasa hade gynnat fliten, rörelserna och produktionen, månat om lärdomen och velat skänka riket beständig styrka genom att förbättra samtliga näringar, inte minst handeln, som förändrades $i$ fördelaktig riktning. Den store, vise och upplyste konungen lyckades på kort tid dra Sverige ur stoftet och göra det välmående och ansett. Han frälste fäderneslandet och grundlade dess välbefinnande genom att öppna upp för förnuft och kunskaper - det vill säga genom reformationen - varefter de olägenheter som länge hindrat regeringen från att befordra Sveriges bästa betvingades. Riket hade vunnit mycket på Gustav Vasas stora och förträffliga åtgärder. Samtidigt var turbulensen efter hans död skadlig för den allmänna hushållningen, om än vissa nyttiga författningar för lant- och bergsbruket tillkom under hans närmaste efterträdare. ${ }^{262}$

Skildringarna av Gustav II Adolf hade en lika andäktig ton. Även han knöts till ekonomiska stordåd och nyttiga insatser, däribland uppmuntran av en mångfald näringar och verksamheter. Rörelserna fick liv, näringarna liv och ordning, riket sina "mästa och bästa inrättningar". Konungens nyttiga författningar var ett tidlöst föredöme och gav honom, jämte hans militära bragder, en odödlig ryktbarhet. Å andra sidan förde hovets ökade prakt, trettioåriga kriget och Gustav Adolfs död på slagfältet med sig negativa konsekvenser. I det förstnämnda fallet gjorde 
den älskade regentens smak och dess intryck på de mest förmögna och förnäma att övriga undersåtar åsidosatte förbuden mot lyx. ${ }^{263}$ Karl XI beskrevs analogt med Gustav Vasa och Gustav II Adolf. Det konstaterades bland annat att den store hushållaren och oförliknelige monarken fått Sveriges sjöfart att blomstra som aldrig förr och att hans konstanta och livgivande omsorger om ekonomin fått påtagliga resultat. ${ }^{264}$

Mindre ekonomiskt framgångsrika regenter hölls också ansvariga för samhällets allmäntillstånd, som bedömdes reflektera deras bristfälliga hushållning. Till dem hörde drottning Kristina, Karl X Gustav, den omyndige Karl XI och framför allt Karl XII, vilken framstod som den i särklass mest misslyckade av Sveriges historiska monarker. ${ }^{265}$ Presides målade hans styre i mörka färger. Det hade präglats av en politi utan upplivande omvårdnad, en handel som lämnats åt sig själv, sjöfartens förkvävande och ett makalöst elände, låt vara att konungen även tillskrevs nyttomedvetenhet och viss initiativförmåga ifråga om handeln och politin. ${ }^{266}$

Historiska svenska regenter framställdes också som gynnare av lärdom och utbildning. De hade sett en grundmurad lärdom som användbar i alla viktiga riksangelägenheter, etablerat skolor över hela landet samt vinnlagt sig om gagneliga studier och vetenskaper som delvis resulterat i nyttiga institutioner. ${ }^{267}$ Gustav II Adolf lät Uppsala universitet få del av sin omtanke i lika hög grad som andra offentliga inrättningar, medan Kristina var en konsternas och vetenskapernas furstinna som ivrade för deras tillväxt och förbättring. Karl XI understödde likaledes lärda och bemödade sig om kunskapsspridning, som han förnyade på ypperliga sätt. ${ }^{268}$

Främmande länders historia tillhandahöll i likhet med den inhemska en projektionsyta för idén om furstarna som samhällsutvecklingens motor. ${ }^{269}$ Referaten av Frankrikes förflutna är särskilt illustrativa på den punkten. Fransmännen fattade enligt uppgift ett större intresse för vetenskaper och konster under Frans I, men inbördeskrig och de efterföljande styresmännens defekter gjorde att landvinningarna inte blev varaktiga. Konsterna och vetenskaperna hade dock fått ett uppsving under senare regenter, speciellt Ludvig XIV, till stor del på grund av makthavarnas inspirerande omvårdnad. ${ }^{270}$ 
Utländska historiska furstar tillskrevs på samma sätt som sina svenska motsvarigheter en prominent roll med avseende på kunskap och lärdom. Ludvig XIV föreställdes vid flera tillfällen som en lyckosam gynnare av såväl slöjder och konster som vetenskaper och vitterhet. ${ }^{271}$ Historien ansågs bekräfta att inget förkovrade vetenskaperna - stora värv och sant kungliga aktiviteter vid konsternas och slöjdernas sida - lika mycket som regenternas omsorg. Denna tes styrktes med både inhemska och främmande exempel, bland dem Elisabet I av England och Henrik IV av Frankrike. Anders Johan von Höpken fastställde att vetenskaperna och konsterna befrämjats av friheten, religionen, militära segrar och de mäktigas uppmuntran. Den sista faktorn var väsentlig för vetenskapernas renässans i Europa efter medeltidens katolska dunkel, genom den mäktiga florentinska furstedynastin de Medicis försorg. ${ }^{272}$

Härskarnas stora inverkan på samhället innebar att deras utbildning och kunskaper var av stor vikt. Ett presidietal kritiserade regenter som försummade de medel som skapade länders välstånd i tron att folkets goda egenskaper var avhängiga klimatet, samt underströk att en upplyst monark betydde mycket för att komma till rätta med problemet att ett folk upplevde sig vara förfördelat av sitt klimat. Ett annat tal anmälde dels att reformationsfurstar som Gustav Vasa bringat ljus till Europa, dels att många samhällsnyttiga sanningar anammats och verkställts av de styrande, en utveckling som hade "gått fortare eller långsammare, alt efter som uplysningen hunnit tränga til de Stora". ${ }^{273}$

Historien befolkades liksom samtiden av nyttiga förnäma och besuttna. ${ }^{274}$ Flera ledamöter tog upp Ludvig XIV:s minister Jean Baptiste Colbert, som förbättrat Paris avsevärt och öppnat en sjöförbindelse mellan Medelhavet och Atlanten, vilken utgjorde det största minnesmärke över konungen, men även hedrade Colbert själv. Frankrikes status och makt under 1700-talet förklarades med att den store Colbert lagt grunden för näringarnas välbefinnande, varefter landet tillsammans med England och Holland demonstrerat att ett rikes kraft berodde på det skick dess näringar befann sig i ${ }^{275}$ De besuttna och förnäma tillmättes en kollektiv agens i den historiska samhällsförbättringen av kommerserådet Johan Liljencrantz, som anförde att köpmän undsatt sina fädernesländer och monarker, vilket han för Sveriges vidkommande exemplifierade med 
bland andra bruksägaren Louis De Geer och handelsmannen Sebastian Tham. Få riken saknade erfarenhet av "hvad en förmögen och välsinnad Handlande kan uträtta til ett Riks-Samhälles förmån och räddande, vid sådane äfventyrlige händelser, då oftast ingen annan hjelp för Staten varit at tilgå" ${ }^{276}$

Det var samhällsledningen som skulle förse den mänskliga tillvaron med liv och rörelse och driva utvecklingen framåt. Lycksalighetens förverkligande krävde också att samhällsgemenskapen gavs stadga, inte minst genom att menigheten hölls under noggrann uppsikt. Presidietalen återkom ofta till idén om vaksamma och reglerande auktoriteter. Denna tendens kan relateras till 1700-talets nyttotänkande och strävan att kanalisera enskildas handlingar på ett för statsmakten optimalt vis, samt till tanken att monarken i egenskap av rikskroppens huvud skulle garantera ordningens fortbestånd genom att se och greppa alla samhälleliga skeenden. I bakgrunden anas den djupare föreställningen om att samhället inte kan fungera av sig självt utan oupphörligen måste kontrolleras för att inte regrediera till ett naturligt och rått urtillstånd. Det kunde därtill vara opportunt för resurssvaga lärda i behov av beskydd att torgföra visioner om övervakning och ordning. ${ }^{277}$

Mineralogen och ämbetsmannen Carl Leijell förde ett ingående resonemang om överhetens ansvar för den svenska bergsnäringen i ett tal om nyttan av stollgångar, eller dagorter. Dessa hade alltid vidmakthållits tack vare sin nytta och att överheten för det mesta tagit sig an dem och upplivat gruvbrytningen: "En sådan berömmelig Öfverhetens omsorg för bärgverkens upkomst och tilväxt, har sedan upmuntrat många enskildta bolager at också anlägga stoller, i hopp, at med tiden få njuta frukten af sin flit, och med det samma, at andra derigenom tjenas, äfven sjelfva sin rätmätiga belöning uphämta.” Denna observation var giltig även för Sverige, där ett slags skola för stollgångsbyggande borde tillskapas och bli ett hälsosamt och prisvärt föredöme. Leijell lyfte vidare fram gruvägarnas och bergsämbetsmännens betydelse, och vikten av stollgångarnas detaljreglering. Han diskuterade befattningshavarnas rigorösa omtanke och slog fast att övervakning var central för tilltron till nyttiga anstalter. ${ }^{278}$

Paternalistiska uppfattningar om bergshanteringen var ingen bristvara 
i Vetenskapsakademien eller hos personer sysselsatta inom näringen. Det gjordes gällande att mycket hängde på goda bergsmän, speciellt på dem som skulle styra och hålla uppsikt över hela hanteringen. Nödvändigheten av god hushållning och oavbruten tillsyn från handlingskraftiga, kunniga och erfarna styresmän inom bergsnäringen betonades, samtidigt som ämbetsmännens konstanta uppsikt sades ha åstadkommit förbättringar hos den motsträviga bergsallmogen. Den bruksägare som utövade otillräcklig kontroll över sina underställda, inkomster och utgifter var en dålig sådan. Ämbetsmännen pekades ut som huvudanledningen till framgångarna för de tyska bergverken, vilkas hierarkiska organisation av allt att döma uppskattades: "Bärgs-domaren med Magistraten afgifver förslag för invånarnes behof. Skogs-Ämbetet står [...] i ansvar, at alt riktigt blifver framskaffat. Visse arbetare sköta så timmer som vedhygget jämte kolningen, under sträng upsigt, och faller således af sig sjelft, at alla fördelar äro sökte, jämt underhållas och handgrep samt arbets-sätt förbätras."279

En välvillig attityd till övervakning kan urskiljas också i samband med andra verksamheter. Ledamöter meddelade att lyckosamt takläggande liksom mycket annat i hög grad kom an på byggherrens eller hans representanters nitiska överinseende, att en adelsman som lett Kungsholmens glasbruk därvid uppvisat "ej mindre flit och vaksamhet, än tro- och upriktighet" samt att de spanska anläggningarna för fårklippning var så reglerade att varken folk eller djur kunde lämna dem utan att husbönderna märkte det och att schäferiägarnas iakttagande av sina anställda uppmuntrade dem till idoghet. När läkaren Johan Lorens Odhelius redogjorde för direktionens, föreståndarens och läkarnas övervakande roll vid Serafimerlasarettet menade han att det ålåg en underkirurg att ständigt passa på sjuksköterskorna och patienterna. ${ }^{280}$

Många presidietal beskrev och var vänligt stämda till vakna och regleringsivrande makthavare, ett tema som tenderade att uttryckas mest pregnant av Vetenskapsakademiens ämbetsmän och politiker. Under frihetstiden hette det att regeringen var oförtröttligt uppmärksam på välfärden och att lantbruket och handslöjderna hade riskerat att utplånas av all okunskap om inte en nådig överhet och vaksamma ständer givit dem livet åter. Överheten skulle i enlighet med sitt gudomliga mandat 
att härska vara vaksam och se till att alla områden den rådde över hölls "uti sitt rätta skick, uti en jämn ock stadig gång". Makthavarna i ett fritt samhälle besatt fullkomlig kunskap om landet och vakade över näringarna, som de beskyddade från allt intrång. ${ }^{281}$

Samma ledmotiv gav sig tillkänna i de gustavianska presidietalen, inte minst när de berörde konungens roll och insatser. Akademimedlemmar hävdade att Gustav III alert arbetade för Sveriges bästa och att grundlagen skulle få förmånlig verkan under hans vakande och skarpa ögon, vilka avslöjade lasten var än den gömde sig. Egennyttiga, klenmodiga, smädare och lågsinta hade inget att hämta under Gustavs styre. Grannlaga tillsyn från en vaken politi presenterades som ett skäl till Stockholms hälsomässiga försteg framför andra storstäder, medan stadens styresmän gestaltades som observanta och nitiska. I Carl Sparres presidietal associerades politin genomgående med vaksamhet. Sparre angav att lagens upprätthållare ständigt vaktade på dess utövande och citerade en "uplyst Auctor" som underströk behovet av kontinuerlig uppsikt över författningarna så att inte vårdslöshet resulterade i tygellöshet och allvarliga överdrifter. ${ }^{282}$

Idén och idealet om kontrollerande makthavare gick liksom föreställningen om en drivande samhällsledning igen i presidietalens historiska utblickar. Till exempel andades Nils Adam Bielke beundran inför Gustav Vasas regeringstid, som framträdde som en period av statlig reglering, inte sällan på detaljnivå, av samhällslivet och hushållningen. Konungen sades ha vunnit undersåtarnas kärlek genom att övertyga dem om att han oförtrutet bevakade deras bästa. Han betraktade "med skarpsynte ögon [...] på en gång det hela i all sin vidd, och skådade alla dess delar, så väl i deras sammanstämning med hvarandra, som i deras olika förhållande sins imellan [...] Intet undföll Hans upmärksamhet. Ingen slags undervisning, varning, upmuntran och bestraffning lät Han fela: Han ansåg ej under sin värdighet, at granska äfven de minsta omständigheter, då de voro ländande til Dess [hans] Stora föremål”. Denna allseende furste införde en politiordning i huvudstaden som inbegrep nogsam tillsyn över alla yrkesgrupper, och han sträckte sin omsorg ända till biskötseln och böndernas avlöning av drängarna. Ingen visste bättre än Gustav Vasa "hvad husbondens öga gifver för drift och styrka åt verk- 
ställigheten" inom bergsnäringen, varför han inte bara själv frekvent besökte bergslagen utan också instruerade sina söner om vikten av att noga besiktiga den. ${ }^{283}$

Hårleman projicerade övervakningstemat på utländska förhållanden när han framhävde de samtida parisiska ämbetsmännens kontroll av bland annat näringarna och samhällets tärande element. Den franske ministern René Louis de Voyer de Paulmy d'Argenson fick förkroppsliga tillsynsverksamheten: "knapt något steg kunde göras eller någon så ringa eller liten gerning utöfvas, hvarom han ej ägde fullkomlig kunskap. Dess [hans] skarpsynta vaksamhet ingick [...] uti det aldrahemligaste, igenfant det mäst fördolda och uplyste med dess sken, alt hvad i mörkret kunde vara invekladt och undanstuckit". Det står klart att Hårleman tilltalades av denne "Vaktare", som han hyllade samtidigt som han fann den noggranna uppsikten vara nödvändig. ${ }^{284}$ Hårlemans redogörelse för d'Argenson hade tydliga paralleller med Bielkes skildring av Gustav Vasa; den styrandes samhällsövervakning framstod i båda fallen som exemplarisk och eftersträvansvärd.

Även vetenskaperna och Vetenskapsakademien förknippades med övervakning, något som kan ses i ljuset av den betydelse som under 1700-talet tillskrevs naturforskarens intervenerande och ordnande blick. Wargentin tackade en ledamot för hans tvåfaldiga tjänstgöring som vaksam ordförande, medan andra akademimedlemmar förkunnade att den ideala naturforskaren kännetecknades av öppna och uppmärksamma ögon och den ideala mekanikern av att ingenting viktigt undgick honom. ${ }^{285}$ De kunskapsägande var dessutom liksom resten av samhället underställda makthavarnas kontroll. Regeringen uppgavs varsebli hela samhällets nytta och behov, varför den sedan länge fördelat vetenskaperna mellan lärda och fått kunskapen att stegvis skjuta i höjden. Vetenskaperna hade efter reformationen kommit att gynnas och ställas "under den skäliga och noga upsigt, som himlalärans försvarande i sin renhet, dygdens beskydd i sit värde, regeringssättets stadgande i sin jämna gång, samt allmänna roens bibehållande i sit lugn, nödvändigt fordra. Sådant hindrar icke utan befordrar Vetenskapernas framgång”. ${ }^{286}$ Sorgfällig övervakning av vetenskaperna var ett villkor för att de skulle utgöra en konstruktiv kraft i samhället. 
Sympatierna för övervakning och reglering var kongeniala med en auktoritär inställning till gemene man som tidvis låg i öppen dager. Under frihetstiden förfäktade Carl Didrik Ehrenpreus att hörsamhet gentemot överheten var avgörande för ett rikes välgång och att historien påvisade den lycka som ackompanjerade folk som bemödade sig om det gemensamma bästa, knöt starka samhälleliga kärleksband och vandrade "i en obrotslig och helig lydnad emot sin öfverhet". Dessa egenskaper var gudagivna förutsättningar för mänsklig välfärd och den som satte sig upp mot dem bröt mot Guds ordning och vållade olycka, fattigdom och sorg. En av Ehrenpreus ledamotskollegor ville att de allmänna skolorna skulle inpränta gudsfruktan, patriotism, viljan att nyttigt bidra till samhället och högaktning för överheten. En annan menade att regeringen måste hålla undersåtarna till nytta och arbete för att göra riket starkare och undvika samhällets förstörelse. Det var också nödvändigt att den fördelade näringarna bland invånarna och noga såg till att de utkomster som bäst passade landet befordrades. ${ }^{287}$

Liknande synsätt formulerades av de gustavianska ledamöterna. Presidietal underströk att samhällsmedlemmarna skulle besitta en livfull känsla för sin plikt mot överheten och fäderneslandet, och argumenterade för att Sverige hade goda utsikter när inbyggarna styrdes av Gustav III och av den hörsamhetens och enighetens anda som präglade lojala undersåtar och rättskaffens medborgare. Carl Sparre hävdade att alla var överens om behovet och nyttan av ordning - samhällets garant och kärna, som Guds och naturens lagar gjort till ändamål för människans hela väsen och som stabiliteten och välbefinnandet utgick från. Utan ordning utlämnades Guds jordiska avbild regenten åt maktlöshet och osäkerhet och folket åt elände och oreda. Varje undersåte var ålagd att arbeta för samhällets nytta, sköta sig och underlätta för konungen genom att vara lydig och hålla sams med nästan. ${ }^{288}$

Många av Vetenskapsakademiens ledamöter föreställde sig sålunda ett samhälle grundligt kontrollerat av makthavarna. Härnäst är det på sin plats att reda ut vad för slags människosyn och åsikter om folket detta förhållningssätt åtföljdes av, speglade och förstärkte. 


\section{Det oresonliga folket}

Människan ansågs under 170o-talet vara formbar samtidigt som hon enligt aristoteliskt, wolffianskt och naturrättsligt tänkande graviterade mot egennytta och irrationalitet. En åskådning som utgick från den inflytelserike filosofen Samuel von Pufendorf föreskrev att de flesta i brist på ett uppövat förnuft endast bryr sig om nuet och sina begär. Rikets ekonomiska problem kunde enligt detta synsätt förklaras med människors oriktiga handlande, som berodde på okunnighet och en naturlig fallenhet att välja fel och fördärvligt. De orätta valen utgjorde ett argument för menighetens omyndighet och för statlig inblandning $i$ hushållningen som syftade till att leda folket till dygd och allmännytta. ${ }^{289}$

Presidietalen hade ofta en pessimistisk grundsyn på människan, som kopplades till syndafallet, en fördärvad natur och det ofrånkomliga ödet döden. Hon beskrevs som från födseln förbunden med "en kejda af vanskapligheter, osund ställning, bräcklig bygnad, otaliga sinnets och kropps sjukdomar, hvilken icke förr, än i sista andedraget affaller". Läkare fick se fler vittnesbörd om människans bräcklighet, sjukdomar, olyckor, uselhet och elände än någon annan. Det fastslogs att människan av naturen var hågad för det onda, samt uppfylld av en myckenhet mörker, oreda och oordning i förståndet, viljan respektive begären, varför undervisning och uppfostran skulle förse henne med dygd, kunskap och ordningsamhet så att hon kunde formas till en nyttig samhällsinvånare. Då människan led av oskicket att följa sina begär var det upp till styrelsekonsten att tukta lustarna, föra dem från deras destruktiva normaltillstånd och göra dem nyttiga. Det bästa människan kunde hoppas på var dock en begränsad och villkorad välmåga. ${ }^{290}$ De förordade insatserna harmonierade tydligt med presidietalens förkärlek för övervakning och reglering och uttryckte i likhet med dem en utpräglad paternalism som det finns skäl att återvända till längre fram i detta avsnitt.

Människan definierades vidare av instabilitet, kortsiktighet och själviskhet. Hennes begär ansågs vara styrda av ombytlighet och nycker, och befinna sig i ständig förändring. Hon hade en naturlig tendens att inte anstränga sig bortom behovstillfredsställelsen, och såg möda och 
arbete som "brister af beqvämlighet, hvilka med ledighet botas". Hennes naturliga begär var så beskaffade att hon glatt arbetade på om det fanns utsikt att få mera av det hon åtrådde, medan frånvaron av vinstmöjlighet stillade hungern och fick trängtan och förnöjelsen att övergå i tristess och missnöje. Människosläktet vanärades dessutom av att tankeförmågan inte sällan användes för att dra nytta av och förtrycka andra. Inget var vanligare än missbruk av det bästa och mest oskyldiga - låt vara att det onda utgjorde en nödvändig relief till det goda och att ett korrekt tillämpat förnuft kunde stävja bedrägliga fantasier. De "ädelmodiga Samhälls-dygderne, som i rättan tid veta upoffra sin egen fördel för högre ändamål, för Fäderneslandets och Medborgares välfärd" var "allestädes de minst allmänna i verlden, och man kan äfven så litet bygga et Närings-Systeme på dem, som man i allmänhet må grunda Borgerliga Författningar på blotta hoppet om dygder". ${ }^{291}$

Några presides uppställde en dikotomi mellan förståndigt fåtal och oförståndigt flertal. Det konstaterades att kvicktänkthet och klokhet inte var alla förunnade, samt att enbart rättsinnade medborgare med större själsförmögenheter kunde fullfölja sin dygd och plikt att vara nyttiga. Även om mänskligheten var dåraktig, behärskad av begär och förlorad utan Försynen var somliga mer oförnuftiga än andra, och liksom de flesta bin utgörs av drönare lämpade sig folkflertalet för arbeten och slöjder som krävde föga vett eller insikt. Menigheten var därutöver inskränkt och envis, inte minst i sin vägran att ta till sig ny kunskap. Folkmajoritetens egenskaper beskrevs förvisso som tillbörliga och dess sysslor som de nyttigaste, men någon äreräddning av gemene man rörde det sig knappast om. ${ }^{292}$ Samma motsatspar kunde klädas i termer av kunskap, förstånd och upplysning. Höpken deklarerade explicit att ett av hans tal var ämnat för de förnuftiga åhörarna, inte den tanklösa och enfaldiga menigheten, som var ur stånd att hantera stoffet och brydde sig mera om "sagor och otroliga ting, än en mindre underbar sanning", varför Höpken inte skulle dra sig för att måla upp "en Platonisk Republique" - det vill säga ett verklighetsfrämmande statsskick - inför den. ${ }^{293}$

Folket tillskrevs otaliga ofördelaktiga karaktärsdrag, vilket kan sättas i samband med en från antiken nedärvd "litania över mängdens svagheter" som reproducerades under den tidigmoderna perioden. ${ }^{294}$ Menighetens 


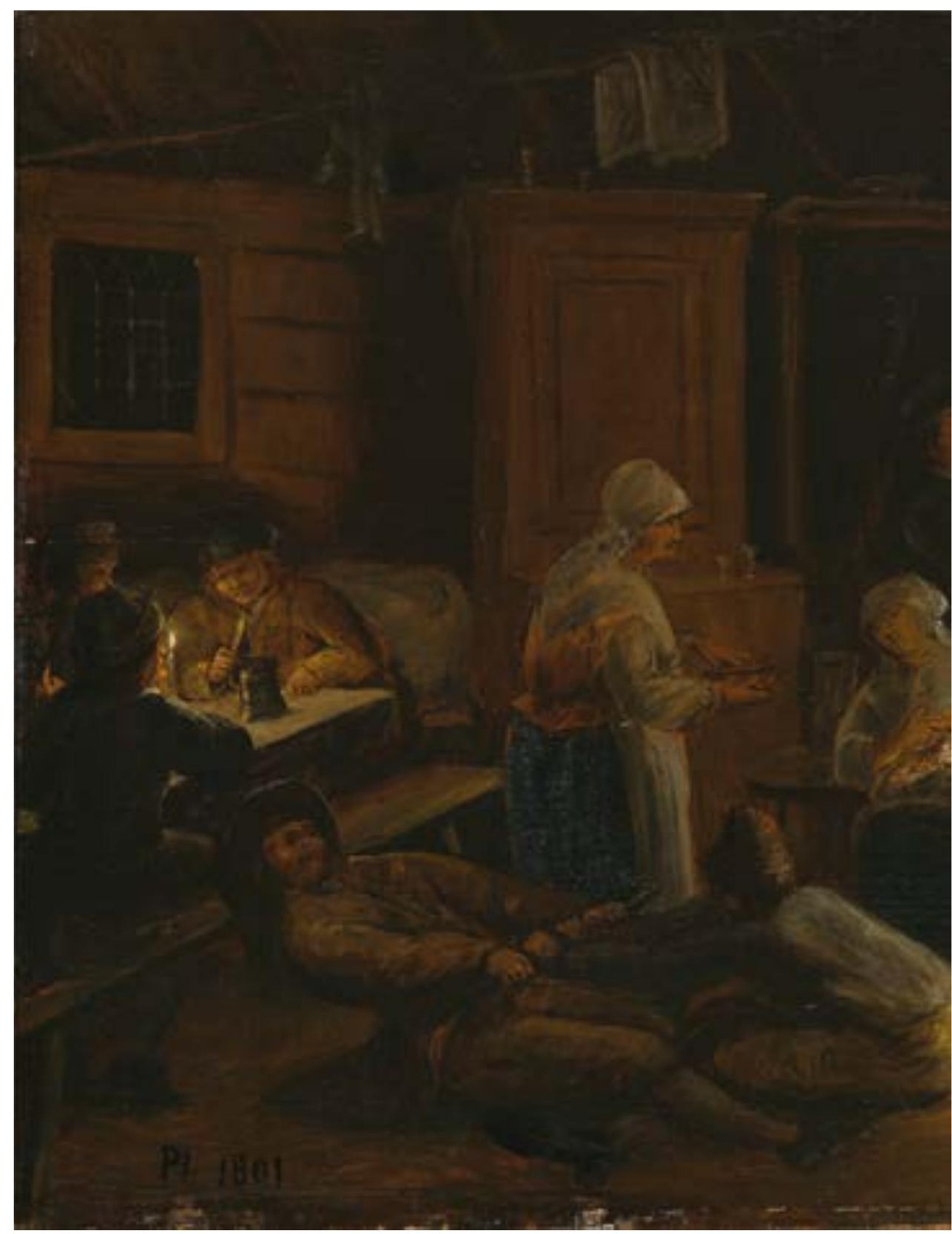

Bild 6. Pehr Hörberg, Interiör av en småländsk bondstuga. Foto: Nationalmuseum. Ögonblicksbild 


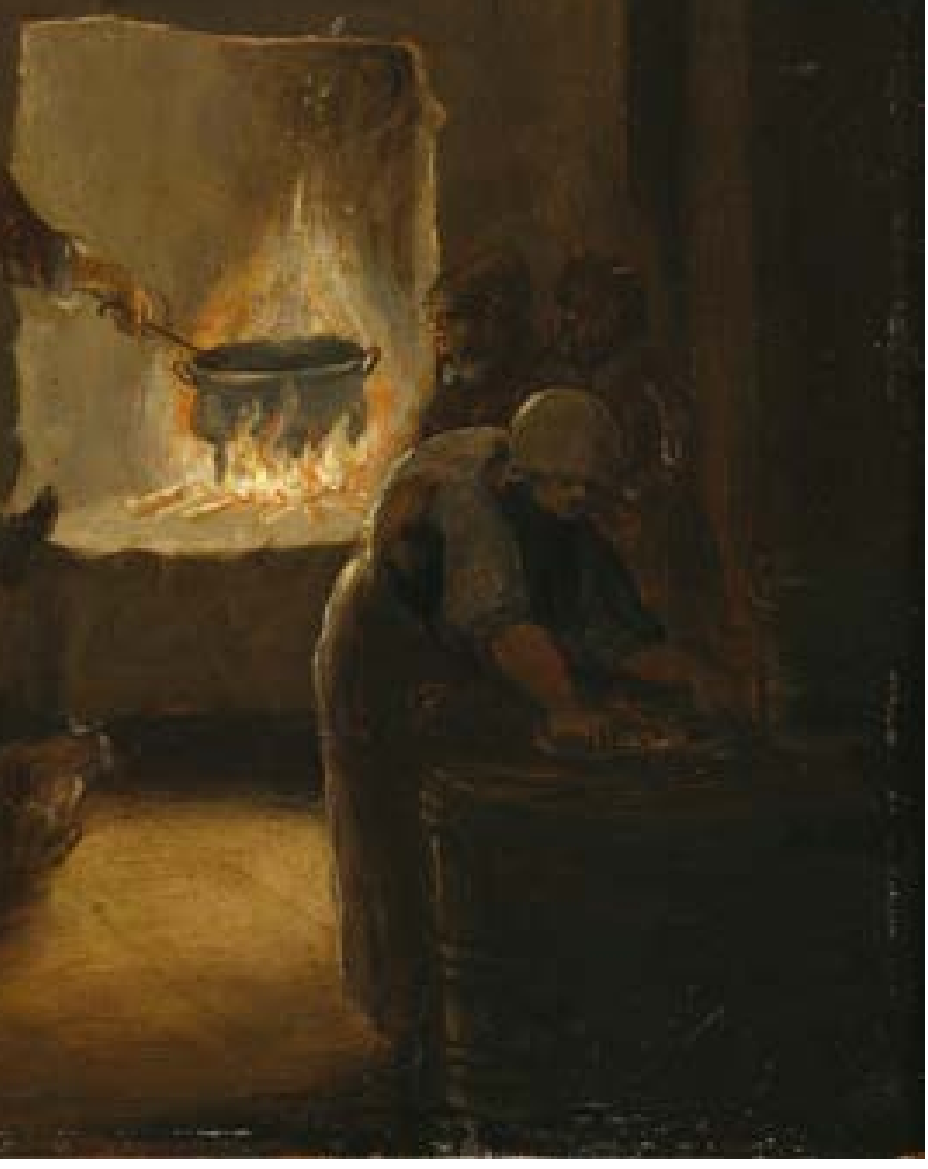

från en lägreståndsmiljö. 
okunnighet och oförstånd var närmast axiom i presidietalen. Bland de övriga egenskaperna märktes lättja, initiativlöshet, äregirighet, arrogans, egenintresse, otacksamhet, envishet och avoghet. ${ }^{295}$ Negativa attribueringar förekom ofta i diskussioner om hushållningen, framför allt jordbruket och skogshanteringen. Ett tal höll före att menigheten inte var särskilt kompetent att sköta ängarna fastän den hade tillgång till vederbörlig kunskap. Den utbredda vanvården förklarades med otillräckliga åtgärder och fasthållandet vid förfädernas tillvägagångssätt, och bonden i gemen tillskrevs kallsinnighet, obekymmersamhet, vårdslöshet och ingrodda fördomar. I samma text kontrasterades den inskränkte svensken mot den upplysta utlänningen, som visste att bruka jorden på ett adekvat och lönande vis och i egenskap av uppmuntrande exempel skulle väcka det inhemska folket ur dess obetänksamhet. ${ }^{296} \mathrm{Ett}$ annat tal angav att gemene man ogärna accepterade undervisning eller rättelse i hushållningen utan vanligtvis bet sig fast vid förfädernas sedvanor, låt vara att ämbetsmännens ideliga kontroll förbättrat allmogens arbete. Talet uppehöll sig vid samtidens skogsödande - det omåttliga sågandet, det oorganiserade och oförståndiga kolandet samt det oskäliga och ytterst vådliga svedjebruket, som sammantagna orsakade en enorm förlust för riket. Hemmansägarna anklagades för den oaktsamma och utarmande sedvänjan att avverka allting i sin närmaste omgivning, medan riksdagarnas bejakanden av menighetens strävanden att utöka svedjandet inte sågs med blida ögon. ${ }^{297}$

En av de största kritikerna av folkets hushållningsmetoder var läkaren och naturalhistorikern Peter Jonas Bergius, som bedömde att gemene mans tillkortakommanden skulle ta lång tid att korrigera. Rikets "sämre folkhop" hade gjort sig väl förtjänt av beskyllningen att den på grund av envishet, liknöjdhet eller kortsynt slapphänthet klamrade sig fast vid gamla seder som visat sig göra liten nytta eller till och med vara fördärvbringande. Allmogen verkade inte lita på något som avvek från förfädernas bruk och det gjorde ingen skillnad för "mången enfaldig och feg Bonde" att mer upplysta landsmän erbjöd exempel på omsorgsfull och skicklig driftighet. Bergius tillmätte gemene man kortsiktighet, otålighet, ointresse, tröghet, oförstånd, okunnighet, felaktiga föreställningar, ogrundade farhågor, dåligt självförtroende och den fördelaktiga 
egenskapen huslighet. Han framhöll menighetens rådvillhet inför fruktträdgårdar, som den varken fattade nyttan av eller kunde sköta på rätt sätt. I motsats till sin tyske motsvarighet var den svenske bonden, i likhet med åtskilliga obetänksamma ståndspersoner, så ovarsam och räddhågad att han inte förmådde fundera igenom saken ordentligt. Landsbygdens invånare hade visserligen nyligen liksom vaknat ur sin dvala och planterat en mängd fruktträd efter ekonomisk uppmuntran från lärda sällskap, men situationen lämnade ändå mycket att önska; "Huru ohyggeligt är det icke annars på de fleste Bonde-hemman i Riket". ${ }^{298}$

Gemene mans oförmåga eller ovilja att tillägna sig kunskaper och beteendemönster var ett vedertaget tema bland Vetenskapsakademiens ledamöter. Det fastställdes att huvuddelen av alla jordägare inte kunde eller inte ville tillgodogöra sig rön som ett mindre antal upplysta lantbrukare vurmade för. Klara rön gjorde föga intryck på dem som mottagit villfarelsen med modersmjölken. och många av dessa hade försummat att ta efter ståndspersonernas lyckosamma anstalter. Skillnader mellan olika landsdelar förelåg visserligen, men bönderna följde generellt inte de goda exempel som fanns till hands. ${ }^{299}$

Det folkliga motståndet hade konsekvenser för makthavarnas möjligheter att påverka samhället. Sådant som rörde gemensamt väl och god ordning föreföll inte "kunna göras nog bekant för dem, som skola dertil allmänt bidraga". Stor försiktighet borde iakttas ifråga om förändringar av politins regler, eftersom folket annars inte skulle hänga med. Föreskrifter som stred mot en hos menigheten så djupt rotad vana att den nästan blivit en naturlig böjelse fallerade för det mesta, och jordbruket förlorade på att övergivandet av gamla sedvänjor med all säkerhet skulle ta lång tid, tveklöst mer än en generation. ${ }^{300}$

Folket betraktades också som vidskepligt, fördomsfullt och godtroget. Det hette att medeltida medicinska vidskepelser fortfarande var i svang hos menigheten och att domare genom kunskap om naturen skulle komma ifrån "hos allmänheten från barndomen inplantade fördomar om trulldom, vidskepelse, sympatier med mera". Vanliga människors okunnighet var så stor att de förklarade vissa ofördelaktiga företeelser inom hushållningen med trollkonst, vilket resulterade i oförnuftiga och skadliga utvägar. Det hårdaste omdömet stod läkaren Olof af Acrel 
(Acrelius) för: "huru härskar icke vidskepelsen öfver de råa och enfaldiga sinnen? De anse naturliga ting för vördsamma trulldomar: tro sig hafva ormar och grodor i buken [...]: maskar i hufvudet [...]: at de burit döda Foster i många år bårtåt, och flera dylika galenskaper [...]. Sådant kan dock hvarken Läkare eller Själasörjare dem betaga" ${ }^{301}$

Med allt detta sagt förmedlade presidietalen tidvis en mer positiv syn på gemene man. Ledamöter uppgav att allmänheten trots sina brister blivit mer övertygad om fördelarna av vetenskapernas uppodling, att de ädlaste ofta måste söka sin säkerhet och lycka hos de föraktliga och ringa samt att de fattiga inte inletts i en försvagande veklighet, till skillnad från dem som fötts med likvärdigt stark hälsa men skämts bort och blivit sjukligt klena. Pehr Högström framställde allmogen som insiktsfull, kompetent och initiativtagande, då den förstod att odla rätt sädesslag, kunde tillverka diverse produkter och bekostade gemensamma nyttigheter. Menigheten omfattade rentav "ämnen til Philosopher, af Naturen sjelf med särdeles egenskaper och gåfvor utrustade". ${ }^{302}$

Gynnsamma och ogynnsamma omdömen om folket blandades i flera fall med varandra. Bergmästaren och ämbetsmannen Samuel Gustaf Hermelin knöt det allmännas välfärd till gemene mans. Han beskrev allmogen som flitig och kapabel inom näringarna och målade upp ett scenario där folket tillväxte och drev näringar med ihärdighet och kunskap. Hermelin klargjorde samtidigt att nit inte låg för alla i menigheten, liksom att nitiska ämbetsmän skulle uppmuntra de strävsamma samt bemästra den ur fördomar och vana springande naturliga trögheten hos vissa allmogepersoner och andra medborgare. Olof von Dalin menade inom ramarna för ett angrepp på ämbetsmännens företräden i det sociala umgänget dels att gemene man levde ordnat utan formaliteter och ofta visade mer respekt för nästan än den förnämare gjorde, dels att vanligt folk var lättlett och borde förbli vid sin läst: "Falsk glants af et högsäte, utstakadt efter en klingande Titul, glittrar gemene man i ögonen, gifver honom förakt för de nedra rummen och lockar honom, at vilja klifva up til Tjenster och inbillade äroställen: derigenom minskas årligen den Närande hopen [...] och den Tärande föröks.” De sämre vetande borde mot bakgrund av det ges ett begrepp om verklig ära, vilken i första rummet handlade om patriotiskt förbättringsarbete. ${ }^{303}$ 
Dalin var inte ensam om att värdesätta folkets föregivet okonstlade tillvaro, en inställning som hämtade näring i samtidens idealisering av lantlivet, inte minst de pastorala idyllerna. Akademimedlemmar förhärligade allmogens stillsamma liv och kontrasterade landsbygdens renhet och enkelhet mot storstadens sedesfördärv. Lantlivet ansågs stärka såväl hälsan som temperamentet och bönderna vara nyttigare och mer hedervärda än många av sina landsmän. Den som brukade åkern borde få skälig utkomst, stöttas och äras så att hans lycka, frihet, glada sinne och oskuldsfulla seder trädde fram. Men uppskattningen av menigheten tenderade som så ofta annars i presidietalen att ha tydliga gränser. ${ }^{304}$

Inte ens åsiktsmässigt avvikande ledamöter som Carl Gustaf Löwenhielm och Nils von Rosenstein ställde sig odelat positiva till folkflertalet. Löwenhielm skildrade som kanslipresident under ståndsmotsättningarnas 1760-tal hur tusentals människor slet för att upphjälpa landet, försörja sig själva och andra samt skänka monarken makt och lycka. Han konstaterade att "de störste strömmar hänleda sit ymnoge vatten ifrån trånga källsprång och små bäckar”. Bönder besatt ibland nyttig kunskap som lärda saknade, ädlingar och präster var inte alltid bättre hushållare än gemene man och folkliga fördomar kunde utgöra starka drivkrafter till goda ändamål. Löwenhielm beskrev likväl också allmogen som bestående av enfaldiga och förbättringsresistenta vanedjur som gjorde sig illusioner om nedärvda metoder och brukade jorden utan egentliga kunskaper. Folket utmärktes av lättja, obetänksamhet, okunnighet, oförstånd och förvända idéer, men skulle förhoppningsvis komma att modifieras något genom Kongl. Maj:ts inrättningar. ${ }^{305}$

Enligt Rosenstein var människan född för och älskade sanningen. Han menade att bara ett fåtal klartänkta personer inledningsvis anslöt sig till denna, medan folkmajoriteten förblev trogen fördomarna. Riktiga resonemang gav icke desto mindre effekt så att allt fler omvändes och sanningen till sist blev gängse. Rosenstein påpekade att stöd från de mäktiga underlättade förloppet betydligt och framhöll de kunskapsägandes roll för upplysningen. Från de lärda spreds sanningarna och upplysningen med okuvlig kraft till hela allmänheten. Förnuftets diktat och fördomarnas tröghet gjorde dock att processen skedde långsamt; de upplysta borde se sig som ögonläkare och varsamt släppa in ljuset 
i ögonen de öppnat. Menigheten hyste visserligen fördomar, men var också en väsentlig aktör som gav avsevärd tyngd åt ståndpunkter, och den förväxlade inte upplysning med falska kunskaper när den väl hade klart för sig att de var osanna. Rosenstein bemötte argumentet att det var svårt att upplysa folket med frågan om vad ett förolämpande av denna viktiga och aktningsvärda del av samhället åstadkom..$^{306}$

Det fanns dock begränsningar med avseende på vad som kunde och skulle meddelas gemene man, vilken Rosenstein sade sig vilja adressera istället för regenten. Om än graden av vidgade begrepp hos menigheten stod i direkt proportion till samhällets lycka, givet att förtryck, oroligheter och villkorad lycksalighet var att vänta utan folkupplysning, kunde hela allmänheten inte vara bevandrad i all kunskap. Det stora flertalet måste ägna sig åt sysslor som inte erbjöd möjlighet att odla snillet. Ett upplyst folk var ett folk där en myckenhet medborgare kände sanningens grunder, visste att undgå villfarelser och ägde kunskap om de mest nödvändiga och praktiska sanningarna. De kloka ledde de övriga och befriade dem från fördomarnas, vidskepelsens och okunnighetens värsta följder. Alla skulle lära känna sina rättigheter och skyldigheter, samhällets syfte, ordning och behov samt vad som fordrades för att vara allmännyttig, samtidigt som de mer upplysta hade ett större ansvar för dessa huvudgrunders uttolkning. Plikten intog uppenbarligen en särställning hos Rosenstein, som inskärpte som evig sanning såväl att rättigheter förutsatte skyldigheter som att båda var lika heliga, flöt ur samma källa och hade samma ändamål i form av samhällets och människornas sällhet. Hans vision gick således ut på att folket skulle bli tillräckligt upplyst. Den enskilde skulle tillägna sig de kunskaper hans eller hennes bestämmelse i livet krävde och föras till lycksalighet och uppfyllandet av sina skyldigheter. ${ }^{307}$

Det kommande, upplysta folket skilde sig från det faktiskt existerande, vars laster fick människor att sätta sitt eget väl före samhällets, att stå i motsats till samhällsordningen och rättvisan samt att skymfa och skada sina nästa. Rosenstein diskuterade människornas ondska, okunnighet, dårskap och inkompetens, "de lågas råa och lätt förvillade och förförda enfald, deras slafviska undergifvenhet, blandad med et altid färdigt begär til ändringar”. Samtidigt uppvisade han stor tilltro 
till allmän upplysning som motmedel och kritiserade dem som hemföll àt negativa generaliseringar; varje "Class af Medborgare" innefattade mer eller mindre upplysta element, och inget stånd var att klandra. Folkets ombytlighet utgjorde ett argument för att det måste upplysas, i synnerhet under franska revolutionen, när enligt Rosenstein oklara och virriga begrepp enkelt kunde förföra allmänheten till villfarelser och utsätta fäderneslandet för fara. Menigheten höll, trots att den var lättledd och hade nära till starka känslor, fast vid somliga grundsatser. Folkets lydnad hängde på dess tänkande, och sann övertygelse - rätt upplysning - var det enda som kunde förhindra manipulation från skurkaktiga människor. Rosenstein identifierade till och med frånvaron av upplysning som anledningen till gemene mans oförmögenhet att styra. Denna tolkning betydde emellertid inte att han ansåg att demokrati borde införas: "Icke får man vänta at en menighet skall blifva så uplyst, at den kunde styra, icke en gång så uplyst, at den i alla fall kan döma om sine Styresmäns upförande. Det är nog at den känner, när de kränka dess rättigheter eller hufvudsakeligen handla mot Samhällets väl.”308

Rosenstein gav på tidstypiskt manér sitt budskap en historisk inramning och sanktion. Antikens demokratiska samhällen värderades lågt och kontrasterades mot samtidens, där styrelsen inte lämnades åt folket, utan i händerna på en eller flera som kände den medborgerliga andans band. Roms makthungriga folktribuner hade motiverats av egenintresse och stått för förtryck. Även om de ofta haft rätt i sak hade de för det mesta haft sämre karaktär än "Aristocraterna", något som många gånger varit fallet med "Chefer för Democratiska partier". Rosenstein ogillade överlag partier, vilka ur hans synvinkel många gånger "förstört friheten och kullkastat sjelfva Staten". Politiska partier var visserligen ett nödvändigt ont i fria samhällen, men kunde balanseras av en folkupplysning som fick enskilda att underordna sig det allmänna och uppsatte gränser ingen vågade kränka. ${ }^{309}$

Samhällsledningen framställdes vidare som en central komponent $\mathrm{i}$ förbättringsarbetet. Rosenstein frågade retoriskt om inte en ökad mängd genuint upplysta inom "de högre Classer af Medborgare" skulle kunna inverka på menighetens tänkande och beteende. En auktoritär ton går att skönja i uppfattningen att folket skulle kontrolleras med hjälp av 
undergivenhet och laggrundad lydnad, liksom i åsikten att förmedling av falska begrepp som syftade till uppvigling krävde ingripanden från regeringen, som om den var allvarsam och klok alltid hittade vägar att förebygga det onda, bestraffa brottslingen och bevara lugnet. Folket reste sig lyckligtvis sällan på egen hand utan brukade hålla sig stilla så länge förförare saknades och regeringen stod stark. En förståndig regering fattade ett grepp om båda dessa faktorer och skulle inte kritiseras när den förnuftigt gav akt på folkförförelse och avvärjde missbruk av rättigheten att upplysa medmänniskorna. De samhällsledande utgjorde likväl inte den primära motorn i samhällsutvecklingen. Denna drevs ytterst av upplysningen, vilken Rosenstein föreställde sig som en autonom kraft: "då det rätta är kändt, skall man af sjelfva Uplysningen kunna vänta dess verkställighet, om icke förr, dock när den rådande öfvertygelsen likasom våldför och tvingar de Mägtiga”. Han anlade ett snarlikt perspektiv på sanningen, jordens mest potenta kraft som borde följas, befordras och ledas till nytta, och på den medborgerliga andan, som skulle säkra lagarnas okränkbarhet, folkets rätt och samhällets sällhet. ${ }^{310}$

Rosenstein tecknade liksom Löwenhielm och andra ledamöter gemene man i både ljusa och mörka färger. Samtidigt lutade Rosenstein i likhet med dem och Vetenskapsakademien som helhet åt en negativ hållning till menigheten, trots att han gick mycket längre i sin förtröstan till den och dess potential. Detta är knappast ägnat att förvåna, med tanke på den pågående franska revolutionens återverkningar på Sverige och Europa. Rosenstein upplevde att allmogen hade möjlighet att formas till någonting bättre, men det var ännu lång väg kvar till ett upplyst stadium.

Presidietalens dominerande, kritiska, attityd till menigheten passade som hand $\mathrm{i}$ handske med de utsagor om styrning och påverkan som flera av dem förmedlade. Det slogs fast att de lärdas inventering av naturen ledsagade "den okunnoga, och blått födan sökande hopen [...] til en matkorg", att allmogen kunde göras nyttig med lirkande och uppmuntran samt att gemene mans dygdiga flit måste stimuleras genom uppfostran och uppmuntran. Det var på tiden att idoga personer i besittning av myndighet, insikt och förtroende bibringade gemene man hälsosammare hushållningsuppfattningar - ett livligt folk hörde gärna goda lärdomar och det fanns alltid några som tog intryck. Jonas 
Alströmer framhöll att folket var "böjeligt [och] skickeligt til allehanda snillen ock slögder" och att bondbarn blivit förfarna i ny teknik. Förutsättningen för att menigheten skulle anamma slöjder och vetenskaper var dock att den lotsades till dem. ${ }^{311}$

Idén om en plastisk menighet kom kanske tydligast till uttryck hos Johan Fredrik Kryger, som delvis ställde folket i ett positivt ljus, inte minst genom att hävda att det hade begåvning för snillrikhet och vetenskaper. Han gjorde likväl gällande att gemene man var okunnig och fast i gamla vanor och oseder samt att folkflertalet aldrig hyste de sundaste tankarna. Trots att nästan inget var svårare än att förändra invanda mönster hos ett helt folk utgjorde det ett villkor för effektiv samhällsförbättring; för när menighetens tänkande gick på tvärs mot regeringens författningar blev allt trögt och kostsamt. Människor formades av lagarna och alla kunde göras nyttiga av politin. Inbyggarna skulle inte lämnas åt sig själva utan förvandlas till förnuftiga och goda medborgare, medvetna om sina förpliktelser gentemot Gud, fäderneslandet, överheten, lagarna, landsmännen och det egna hushållets medlemmar. Indirekta uppmuntringar och frivillighet var härvidlag överlägsna tvångsmedel och träldom. ${ }^{312}$

Ledamöter betraktade kunskapsspridning som ett patriotiskt verktyg som skulle medföra att folket blev nyttigt och bättre kunde kontrolleras med förnuftsskäl. ${ }^{313}$ Offentliga funktionärer som lärare, präster och landshövdingar hade i hög grad ansvar för att allmogen fick behövliga och gagneliga kunskaper. ${ }^{314}$ De lärda och de besuttna hade också didaktiska uppgifter. ${ }^{315}$ Vetenskapsakademiens roll i den folkbildande processen uttrycktes emellanåt explicit. En ordförande hoppades med sitt presidietal få allmänheten att ta till sig något nyttigt eller uppmuntra den till flit. En annan förkunnade att ett fåtal med större förståndsgåvor och uppfinningsrikedom, däribland akademimedlemmarna, skulle vägleda och bistå de övriga som var desto talrikare: "få ämnen kunna igenletas, som äro rätt skickelige at leda och lära [ut]; deremot fins en myckenhet som behöfver ledas, lyda och följa”. Alla människor hade i någon utsträckning förmåga till kunskap men stora skillnader förelåg mellan dem, i överensstämmelse med Guds plan och samhällets behov. ${ }^{316}$ Kunskapsförmedling var inte den enda indirekta metod som före- 
språkades för att få gemene man att bete sig på önskvärt vis. Exempla utgjorde ett stående inslag i presidietalen, som förkunnade att älskade och högt respekterade personers föredöme hade mer effekt än lagarna. Den ytliga och formbara menigheten var benägen att härma de samhällsledande, som hade denna ställning i kraft av sin myndighet och sitt anseende. Det härskande fåtalet hade $i$ alla tider satt sitt avtryck på folket, och därigenom givit upphov till nationalkaraktären. Enligt riksrådet Sven Bunge existerade inget mer verkningsfullt medel för kunskapsförmedling än föredömen, speciellt när föredömet tillhörde samma grupp som den som skulle undervisas. Bunge begrundade exemplets makt i samband med bland annat de större jordägarna, som kunde inspirera sina underordnade till nit och omtänksamhet. ${ }^{317}$

I andra fall diskuterades ekonomiska incitament. Ledamöter tillkännagav att det bästa sättet att göra folket arbetsamt var att premiera ängsskötseln och att jordbruket kunde upphjälpas först om det gjordes lika lukrativt som de övriga näringarna, eftersom människor inte ägnade sig åt en syssla om de inte kunde förtjäna sitt uppehälle genom den. Det hette att Kongl. Maj:t sporrade lantbrukarna genom att låta dem slippa skatta för sina förbättringar, och att storskiftet förkovrade jordbruket genom att trygga äganderätten och ge den flitige en utväg att öka sin avkastning utan att hejdas av nästans kraftlöshet. ${ }^{318}$

Lagarnas inverkan på menigheten utgjorde ett ledmotiv i främst de gustavianska presidietalen, som resonerade kring författningarnas betydelse för fliten, befolkningstillväxten, jordbruket och näringarna. ${ }^{319}$ Det gjordes gällande att folket hade fått alla sina rättigheter av Gustav III och därmed åtnjöt bästa möjliga uppmuntran. Lagstiftaren skulle överväga framför allt vilken effekt de tänkta lagarna kunde få på invånarnas föreställningar och livsföring, och hur människorna kunde ledas till det allmänna bästas fördel. Rosenstein den yngre ansåg att lagarna genererade, inpräntade och konsoliderade begrepp om hörsamhet, skyldigheter och uppoffringar. Med hjälp av dem och tänkesätten gick det att föra människor i princip vart som helst, "från de naturligaste böjelser til de minst naturliga, från begäret efter hvila, beqvämlighet, nöjen til försakelse af alt hvad som förnöjer känslan, til upoffrande af all egen fördel, från sjelfva kärleken för lifvet til det största förakt för plågorne 
och döden". Goda lagar och rättvisa skulle förse folket med upplysning, lydnad, pliktmedvetenhet, patriotism, dygder och medborgaranda. ${ }^{320}$

Somliga ledamöter laborerade med både indirekta och direkta påverkansmedel. En av dem beskrev tillsyn, uppmuntran och förståndiga hushållningsföredömen som förutsättningar för att skapa ett riktigt beteende, en annan erinrade om att Gustav Vasa för att nå sina mål tillgripit "hårdare medel" jämte skattestyrning, förmaningar och undervisning. ${ }^{321}$

Men det var inte bara folket som skulle föras till samhällsnytta och kunskap, utan även de samhällsledande. Ämbetsmannen Samuel Schultze argumenterade för att ståndspersoner skulle uppmuntras att föregå med gott exempel. Om deras och den rikare allmogens barn fick vidare utbildning i lanthushållning, kunde de fungera som föredömen för de ringare och skaffa denna vetenskap mer stadga och status. Clason sökte av allt att döma påverka sina förnäma åhörare och läsare i en viss riktning när han rapporterade att det brittiska frälset lät sina barn lära sig olika näringar, vilket gynnade såväl de adliga själva som deras land och gjorde att de inte längre var hänvisade till statsmakten ("Kronan") för sin försörjning. ${ }^{322}$

Gestaltandet av de samhällsledande som exempla och ciceroner för folket var ett vanligt tema i akademimedlemmarnas texter och i dåtidens ekonomiska litteratur. ${ }^{323}$ Presidietal framförde åsikterna att den oföretagsamma menigheten enbart kunde aktiveras av exemplariska ståndspersoner och att ekonomiska missuppfattningar hos ämbetsmän och ståndspersoner var skadliga eftersom de utgjorde exempel "så snart uti ondt, som godt". Förnäma och förmögna tjänade eller borde tjäna som föredömen i diverse ekonomiska hänseenden. ${ }^{324}$ Vid flera tillfällen föreställdes ett slags ideala representanter för eliten, som kan antas ha varit ämnade för imitation. Till exempel definierade hattriksrådet Henning Adolph Gyllenborg de adelsmän som välsinnade vilka vidtog mått och steg som att röja äng, dika mossar och anlägga trädgårdar så att deras fattiga bönder och torpare kunde få sin utkomst. Han hade däremot "helt annan tanka om den, som sit goda bårtspelar, eller i annan, sin förmåga öfverstigande prakt, utarmar sig, och, til sina Borgenärers förnöjande, måste låta den ena redbarheten efter den andra gå utur huset". Gyllenborg önskade att de som genom sin värdighet befann sig 
i folkets blickfång skulle förstå värdet av att utgöra goda förebilder, så att handelsbalansen kunde rätas upp. ${ }^{325}$

Ståndsindelningen var inte den enda klassifikationsmodell som under 170o-talet tillämpades på samhället, utan dess medlemmar sorterades också exempelvis i besuttna och obesuttna, i ståndspersoner och allmoge samt $i$ adel och borgare respektive präster och alla andra ofrälse. ${ }^{326}$ Vetenskapsakademiens medlemmar tenderade, som den hittillsvarande analysen visat, att beskriva samhället dikotomiskt. Merparten av dem utgick från en grundläggande uppdelning $\mathrm{i}$ högt och lågt som formulerades på flera vis, även i termer av bland annat rika och fattiga eller ståndspersoner och menighet. ${ }^{327}$ Det hände att olika beteckningar förekom sida vid sida och delvis överlappade med varandra. Till exempel satte ett presidietal rika mot fattiga, förnäma mot sockenbor, bättre och förnämt folk mot sämre och gement samt människor "af yppare stånd" mot "menige man". ${ }^{328}$

En återkommande ståndpunkt som uttrycktes av ledamöterna var att makthavarna ansvarade för samhällsinvånarnas väl och ve. Gud och naturen ålade överheten att nogsamt försäkra sig om undersåtarnas välbefinnande, och främjandet av deras välmåga var regeringens primära syfte. Det poängterades att omtanken om folket kom de styrande till godo, inte minst genom att den gav fursten ära och trygghet. I kontraktsteoretisk anda diskuterades hur materiellt framgångsrikt samhället skulle bli "om Öfverheter höllo för synd, at försumma det minsta, uti omsorgen för sina undersåtares välfärd, och dessa, at upoffra någon af sina lefnads-dagar, åt lättjan och tidsspillan”. ${ }^{329}$ Reflektioner över makthavarnas ansvar för invånarnas välfärd återfanns ofta i presidietal som uppehöll sig vid läkekonsten. Pestsmittade framställdes som människor med rätt till samhällets bistånd och det sades vara upplysta regeringars plikt att ordna ett välfungerande medicinalväsende för att spara människoliv, ett "så dyrbart gods [...] för en Stat". ${ }^{330}$

Mest långtgående bland läkarna var Abraham Bäck, som menade att farsoternas härjningar hos folket fick varje ärlig medborgares hjärta att blöda och framkallade en vilja att bekämpa dem, samtidigt som hans tal angrep fattigdomen och livsmedelsbristen. Bäck intog överlag en starkt paternalistisk position. Smittorna liknades vid en varg och allmogen 
vid får som herden - makthavarna - skulle rycka undan rovdjurets käftar. Goda åtgärder behövdes från de befallandes sida, och det ålåg dem att motverka sjukdomar genom att tillhandahålla livsmedel till rimliga priser. Konungen skulle i linje med detta inom kort komma att eliminera det missbruk som det ekonomiska utnyttjandet av de fattiga utgjorde. Bäck lade stor vikt vid de myndighetspersoner som hade hand om menigheten och åtnjöt dess tillit. Präster och ståndspersoner skulle stå för myndighet, tillgivenhet, uppmärksamhet och välvilja samt inspirera landets vanmäktiga allmoge genom sina handlingar och utrusta den med nyttiga hjälpmedel. Herrar med underlydande borde förhålla sig till dem som kärleksfulla föräldrar, vilka betraktar sig som skyldiga att freda sina barn från armod och möjliggöra för dem att livnära sig. ${ }^{331}$

Ett antal ledamöter framhöll att de styrande skulle sörja för samhällets sämre bemedlade. Till denna grupp hörde barn och äldre, som hade svårt att försörja sig på egen hand och därför förtjänade regeringens omsorg. Det hette att mäktiga och patriotiska monarker som Gustav III såg till att hela befolkningen- inklusive de fattiga arbetarna - for väl, och att den medeltida furstespegeln Konunga- och höfdingastyrelsen hade rätt $i$ att en rik allmoge hedrade monarken samt att det var skamligt att regera över fattighjon och tiggare. ${ }^{332}$ En utpräglad altruism hittas i Carl Sparres tal, som yrkade på att samhällets ledare skulle låta sig vägledas av människokärlek och vara återhållsamma med hårda straff för brott mot politireglerna. Lagskipare borde utöver egenskaper som pondus och nit för det allmänna bästa besitta medkänsla, och bestraffningar borde ske med all den ömhet och omtänksamhet som brottslingars bristfällighet och medvetenheten om mänskliga svagheter krävde. Sparre ansåg att lindriga straff uppväckte desto mer vilja till det goda, aktning för lagen och respekt för rättsväsendet. Prov på lagskiparnas myndighet var mer effektiva än själva straffen och överdriven stränghet. Om lata hölls till arbete och fattigdomsbekämpningen motverkade bettleri skulle de arbetsoförmögna "räddas från at antingen besvära allmänheten, eller i elände, utan människo-hjelp, ömkeligen omkomma”. Politins förvaltning av fattigdomsinrättningar skulle utmärkas av både ömhet och skärpa. ${ }^{333}$

Presidietalens utsagor om makthavarnas uppgift att ta hand om invånarna i allmänhet och de fattiga i synnerhet kan relateras till en filan- 
tropisk ådra under 1700-talets senare hälft, som gjorde tydligt avtryck i Vetenskapsakademien. ${ }^{334}$ Medlemmar tog upp sammanslutningens "öma vård om den i hvarjehanda trångmål sväfvande Menskligheten" och deklarerade att samhället vann på att de välbeställda gav de sämre lottade möjlighet att ärofullt förtjäna sitt uppehälle av deras överflöd, något som också överensstämde med en välsinnad medborgares förpliktelse. Omsorgen om fattiga åldringar var ett medmänskligt imperativ och svenskarna klandervärda, eftersom de varken efterlevde sanningen att folkmängden var ett lands styrka eller imiterade de kristna länder som av kärlek till undersåtarna skötte om sina unga fattiga och sjuka så att dessa sedan kunde stå dem till tjänst. Wargentin åberopade sin egen och åhörarnas eller läsarnas skyldighet att i egenskap av människor, medborgare och kristna hjälpa dem som led nöd och slå vakt om samhällets mest värdefulla tillgång - en stor och arbetsvillig befolkning. ${ }^{335}$

Omhändertagandet av de fattiga hade en religiös aspekt som framgick av flera av presidietalen. Det uppgavs vara en kristlig skyldighet att rädda medellösa sjuka från den värsta nöd; Stockholms läkare och politi bistod de medellösa och Collegium medicum besökte av kristlig förpliktelse fattiga områden under farsoter. London och Paris hade sedan 160o-talet tävlat med varandra vad gällde institutioner som "utöfvade den rätta Christligheten, i Sjukas vård, fattiga faderlösa barns befriande ifrån undergång, och olyckeliga barnaföderskors hjelp och undsättning”. Rosenstein den yngre använde sig istället av en sekulär terminologi när han hävdade att vanan omvandlar moraliska känslor till passioner och att dessa känslor leder till dygdigt handlande mot, och empati med, medmänniskorna. Till de goda karaktärsdrag som enligt honom manifesterades i relation till nästan hörde människokärlek, medlidande, givmildhet och hjälpsamhet. ${ }^{336}$

Många av Vetenskapsakademiens medlemmar målade upp ett samhälle som drevs framåt av fursten, ständerna, regeringen, de förnäma och de förmögna, vilka utgjorde dess motor och garanten för invånarnas välmåga. Näringarnas, hushållningens och den mänskliga gemenskapens välgång var avhängig handlingskraftiga och alerta styrande 
som kontrollerade folket och fick det att bete sig korrekt. Den kontroll ledamöterna föreställde sig kunde vara nog så detaljerad och kopplades till såväl samhället som en rad områden inom detta. Presidietalen hade således en tydlig paternalistisk slagsida, som även yttrade sig i en omhändertagande och filantropisk hållning till gemene man.

Synen på menigheten kunde mot bakgrund av inställningen till samhällsledningen inte gärna vara annat än övervägande auktoritär och negativ, om än flera av akademiens medlemmar värderade folket positivt eller blandade ogynnsamma omdömen med gynnsamma. Allmogen skulle befallas, undervisas och vägledas av sina överordnade. Bland de egenskaper som frekvent tillskrevs den återfinns egennytta, kortsiktighet, lättja, oförnuft, okunnighet, förändringsresistens och vidskepelse. Vetenskapsakademien bekände sig visserligen till idén om en formbar människa, men det folk som var för handen i samtiden dög till skillnad från framtidens upplysta motsvarighet inte mycket till. Vissa presides förespråkade att också de samhällsledande borde föras till nytta och kunskap.

Samhällsgemenskapen beskrevs vanligtvis dikotomiskt: den bestod av närande och tärande, höga och låga, förståndiga, upplysta och kunniga respektive oförståndiga, oupplysta och okunniga. Det basala motsatsparet högt-lågt kunde gestaltas på olika sätt, men uttrycktes för det mesta i uppdelningen mellan ståndspersoner och menighet. Oavsett den exakta terminologin skulle samhällets högre skikt liksom monarkerna aktivera folket med sitt exemplariska agerande.

Vetenskapsakademiens paternalism svarade mot en förmyndarattityd i den ekonomiska litteraturen, enligt vilken statsmakten skulle ta ansvar för inbyggarnas välfärd och allmogen ges kunskap och ledas av de lärda, de styrande och insiktsfulla ståndspersoner. ${ }^{337}$ Akademien speglade vidare de övre samhällslagrens perspektiv på gemene man, som ofta var kluvet och mer eller mindre nedlåtande medan folket attribuerades ungefär samma kvaliteter som i presidietalen. En strävan att åtgärda menighetens upplevda brister genom utbildning och de högre samhällslagrens föredömen var utbredd inom eliten. ${ }^{338}$

Enligt tidigare forskning präglades 1700-talets andra hälft av en ny, mer förlåtande inställning till de lägre samhällsskikten, ett skifte som 
hängde samman med en uppvärdering av jordbruket och med skriftställare som fysiokraten Victor Riquetti de Mirabeau. Människan kom samtidigt att i större utsträckning betraktas som kapabel att styra sig själv och av egen kraft bidra till det allmänna bästa. Makthavarna var inte längre tvungna att hålla henne i tukt och förmaning, och civilsamhället framträdde som en arena jämte statsmakten. ${ }^{339}$ Någon sådan utveckling är inte påfallande i Vetenskapsakademiens skildringar av allmogen, utöver det filantropiska inslaget. Presidietalen uppehöll sig för det mesta inte vid folkets fördelaktiga egenskaper eller dess fri- och rättigheter, som utgjorde ledmotiv på andra håll under 1700-talet. ${ }^{340}$ Deras författare fortsatte istället att sluta upp bakom det inarbetade synsättet att folket var oförmöget och måste meddelas samhällsviktig dygd med hjälp av olika styrmedel, som lagarna. ${ }^{341}$

Vetenskapsakademiens politiska ideologi bekräftade och förstärkte samhällsledningens centrala status i den mänskliga samlevnaden genom att framställa makthavarna och eliten som samhällets kraftkälla och menighetens förmyndare. När akademien gick de samhällsledandes ärenden gick den även sina egna, eftersom organisationen och åtskilliga av dess medlemmar hade djupa försänkningar i den hierarkiska ordning som utlades.

De följande två kapitlen undersöker ledamöternas förhållningssätt till mer specifika aktörer i samhällspyramidens topp - hattarna, mössorna och regenterna. Härnäst skärskådas Vetenskapsakademiens ekonomiska ideologi i relation till 1700-talets politiska styren. 


\section{Hattarnas akademi}

Om de två föregående kapitlen har haft en företrädesvis tematisk struktur och fokuserat på det beständiga i Vetenskapsakademiens tänkande kring samhället, är detta kapitel huvudsakligen kronologiskt orienterat och mer inriktat på dess föränderlighet. Det undersöker akademiens åsikter och visioner om samhällets ekonomiska organisering, alltså den ekonomiska ideologin, och hur de samspelade med hattarnas, mössornas och Gustav III:s regimer. Kapitlet sönderfaller i fyra avsnitt, som behandlar sammanslutningens ekonomiska ideologi i anknytning till hattpartiets första maktinnehav, mössornas styre, hattarnas andra tid vid makten samt det gustavianska väldet.

\section{Hattvänlig hushållning}

Vetenskapsakademiens nära band till hattpartiet framgår redan av de sex grundarna. Hälften av dem - Sten Carl Bielke, Carl Wilhelm Cederhielm och Anders Johan von Höpken - var adliga ämbetsmän och politiker, de övriga - Jonas Alströmer, Carl von Linné och Mårten Triewald - var ofrälse lärda och entreprenörer, varav två adlades (Alströmer, Linné). Alla utom en av stiftarna sympatiserade med hattpartiet. Hovrättsjuristen Bielke hörde till oppositionen, men tilltalades av hattarnas näringspolitik och gynnades av regeringen; hans politiska hemvist reflekterade sannolikt vänners och släktingars ställningstaganden mer än någon personlig övertygelse. ${ }^{342}$ Cederhielm, Höpken, Alströmer och Triewald manövrerade inom de "ekonomiska, politiska och sociala nätverk som var grunden till hattpartiet". ${ }^{343}$ Cederhielm satt som riksdagsman för hattarna, medan Höpken, akademiens främsta tillskyndare och dess 


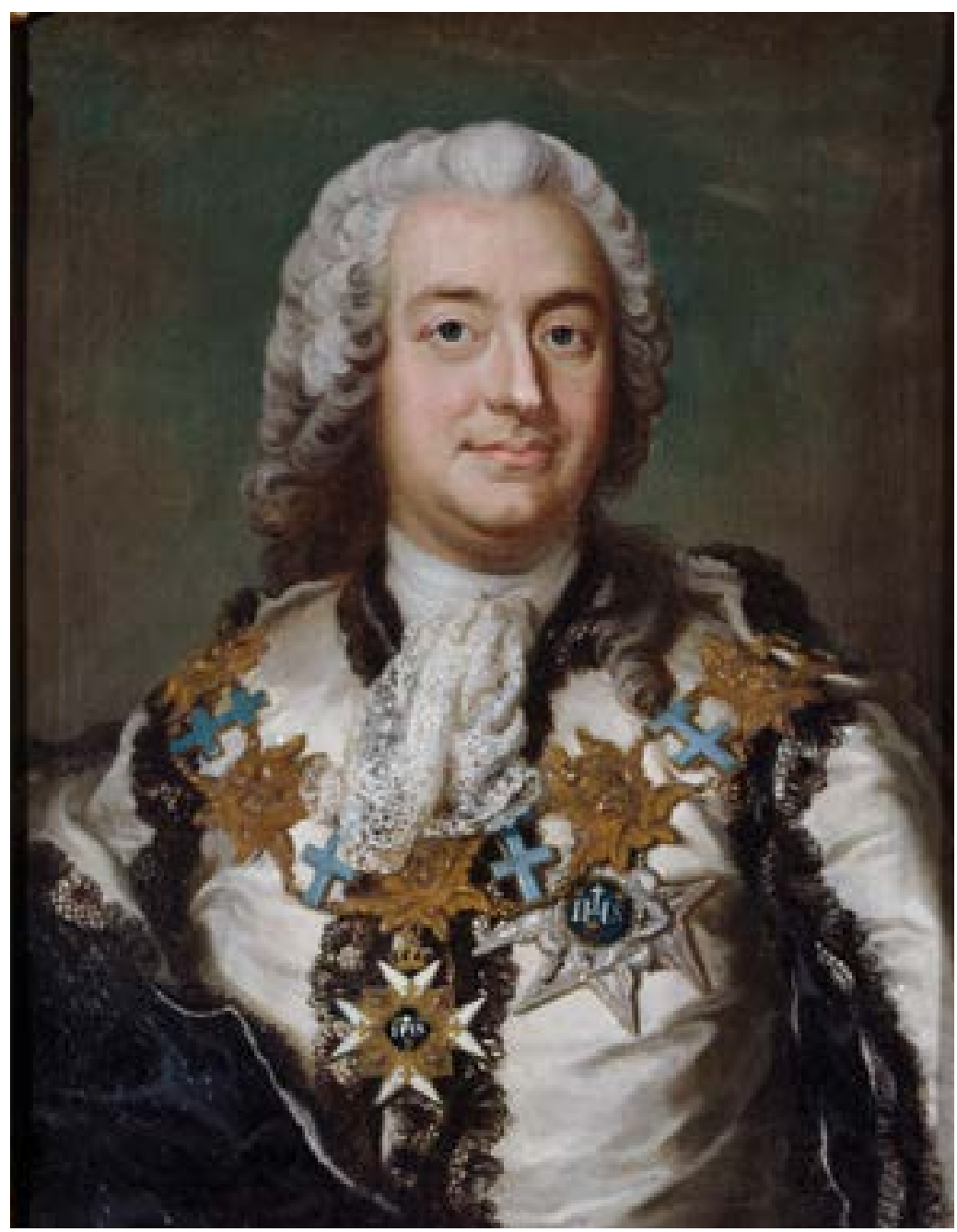

Bild 7. Carl Fredrich Brander, Anders Johan von Höpken, 1712-1789. Foto: Nationalmuseum. Hattledaren och akademigrundaren Höpken.

sekreterare 1739-41, krönte en lång bana i partiets tjänst med att bekläda riksråds- och kanslipresidentämbetena. ${ }^{344}$ Alströmer utnämndes till kommerseråd och bedrev näringsverksamhet som subventionerades av hattregimen. Triewald utgjorde den förmedlande länken mellan hat- 
tarna och Linné. ${ }^{345}$ Meningarna om Linnés politiska sida har förvisso varierat, och det står klart att han inte var särskilt hågad för politik. Hans försänkningar i hattpartiet ger ändå en tydlig fingervisning om var hans sympatier ytterst låg. ${ }^{346}$

Linné kan i detta hänseende jämföras med Pehr Wilhelm Wargentin, en av Vetenskapsakademiens nyckelaktörer och organisationens sekreterare 1749-83, som också hade påtagliga förbindelser med hattarna. Wargentin beskyddades som Uppsalastudent av hattpolitikerna Carl Gyllenborg, Fredrik Gyllenborg och Clas Ekeblad och som akademisekreterare av hatten Carl Hårleman, vars systerdotter han gifte sig med. ${ }^{347}$ Han var vän med både Höpken och Carl Gustaf Tessin; han och några andra ledamöter brukade regelbundet träffas hemma hos Tessin när denne vistades i huvudstaden. ${ }^{348}$

Wargentins band till makthavarna var inte enbart informella. Under hattväldet drogs han och Vetenskapsakademien in i det statligt regisserade arbetet med befolkningsstatistiken, som tillkom delvis på akademiens initiativ. Denna demografiska inventering utgjorde ett led i strävandet att förbättra Sverige genom att öka folkmängden, vilken hölls för att vara rikets främsta resurs. Kartläggningen av befolkningen resulterade i Tabellverket och Tabellkommissionen, där Wargentin spelade en framträdande roll. ${ }^{349}$ Akademisekreterarens politiska umgänge och lojaliteter straffade sig vid mössornas maktövertagande 1765, då han tvingades bort från den kommission som utsetts för byggandet av Trollhätte kanal, för att återinträda i den när hattarna kom tillbaka i regeringsställning 1769 . $^{350}$

Det skulle föra för långt att mera i detalj gå in på Vetenskapsakademiens kontakter med hattpartiet. För att nämna ytterligare några exempel gick flera tunga ledamöter verksamma vid Uppsala universitet - läkaren Nils Rosén von Rosenstein (Rosén; Rosenstein den äldre), matematikern Samuel Klingenstierna och astronomen Anders Celsius - i Carl Gyllenborgs ledband, medan Johan Carl Wilcke gynnades av Höpken och hattriksrådet Ulric Scheffer. ${ }^{351}$

Patrik Winton och Karin Sennefelt har kritiserat den traditionella betoningen av de frihetstida partierna. De polemiserar - med rätta mot en enkel uppdelning i partier och mot ett ensidigt intresse för dem 
på bekostnad av andra aspekter av frihetstidens politik och de vidare sociala faktorer som inramade den. Deras tyngdpunkt ligger i linje med detta på alternativa ingångar till periodens politiska liv, främst sociala nätverk. Winton går ett steg längre när han argumenterar för att partierna närmast var "diskursiva konstruktioner" och förnekar existensen av hierarkiska partiorganisationer med funktionärer, fasta anhängare och långsiktiga agendor. ${ }^{352}$

Det går emellertid inte att komma runt att de båda rivaliserande partierna var fokalpunkter i frihetstidens politiska liv, vilket analysen nedan inskärper. Det är förmodligen mest konstruktivt och rättvisande att betrakta dem som noder i överlappande nätverk, eftersom de var lösa uppsättningar av aktörer med sinsemellan bitvis olikartade föresatser. Det är inom dessa noder möjligt att urskilja relativt varaktiga och välorganiserade kärnor, som ännu mera än de omgivande nätverken hölls ihop av personliga förbindelser, grupplojalitet samt gemensamma tänkesätt, mål och sociala förutsättningar. ${ }^{353}$

Hattarnas långa maktinnehav medförde därtill att deras nätverk blev interfolierade med den institutionella ordningen, varför hattväldet kan betraktas som ett system där såväl nätverken som offentliga inrättningar som Jernkontoret, Riksbanken, Växelkontoret och Stockholms magistrat ingick. Partiet befolkades till stor del av ämbetsmän och hade ett fast grepp om statsförvaltningen, vilken beskrivits som dess "administrativa fasad". Kollegierna fortfor att vara hattrogna efter mössornas maktövertagande och intog en fientlig attityd till rikets nya styresmän, till den grad att ämbetsverken år 1768 bidrog till mössregeringens fall genom en arbetsnedläggning som framtvingade en urtima riksdag. ${ }^{354}$

Hattpartiet och ämbetsmännen var nära lierade med städernas förmögna entreprenörer: "Kommerskollegium drev i stort sett samma politik som skeppsbroadeln; intressena var gemensamma, personerna till någon del identiska. Bergskollegium och även kanslikollegium stod inte långt ifrån. De politiskt dominerande hattarna återfanns i samma läger, ja hörde hemma på kollegierna eller i den handelsidkande storfinansen." ${ }^{355}$ Den ekonomiska politiken var företags- och manufakturvänlig, protektionistisk och regleringsorienterad. Lån, subventioner, skyddstullar, importförbud och exportpremier utgjorde centrala element 
i hattarnas välfärdsprojekt, som syftade till att minska varuinförseln, åstadkomma en bättre handelsbalans samt göra landet mer oberoende, rikt och mäktigt. Utländska konsumtionsvaror skulle ersättas, substitueras, av inhemska och exporten ledas om från obearbetade råvaror till förädlade produkter. För att stärka manufakturväsendet, som uppbar privilegier och inte skulle utsättas för allvarlig konkurrens, befanns ökad arbetsfördelning mellan näringsgrenarna, speciellt städernas och landsbygdens näringar, vara nödvändig. ${ }^{356}$ Inom utrikespolitiken uppvisade hattarna en pro-fransk tendens och en patriotisk-revanschistisk ådra, vilken framför allt yttrade sig i deras olycksaliga ryska (1741-43) och pommerska (1757-62) krig. ${ }^{357}$

Samtidigt var hattpartiet lika litet som Vetenskapsakademien åsiktsmässigt homogent. Det fanns meningsmotsättningar om såväl jordbruket och handelsbalansen som de ekonomiska regleringarna och förbuden, vilka ifrågasattes när de förväntade resultaten uteblev. Till exempel företrädde riksrådet Carl Fredrik Scheffer, som senare kom att anamma den franska fysiokratismen med dess emfas på lantbruk, äganderätt och större näringsfrihet, en mer generös privilegiepolitik för manufakturerna. Under 1750-talet anslöt sig högt uppsatta politiker som Höpken och Tessin till de kritiska rösterna, och den förfelade inrikes- och utrikespolitiken fick till följd att hattarna och deras förenande band alltmer luckrades upp, även om partiet fortsatte hållas samman av "det beståendes makt och tyngden af det gemensamma förflutna". 358

Ekonomiska och ekonomisk-politiska spörsmål intog, som påpekades i inledningen, en framskjuten position inom Vetenskapsakademien. Wargentin definierade organisationen som "en Oeconomisk Vetenskaps Academie". Han liknade hushållningen och vetenskaperna vid barn som växt upp tillsammans, vårdats och handletts av samma ammor och fortfarande var i behov av kärleksfull omvårdnad för att nå mogen ålder, varför akademien inte "trodt sig [...] böra åtskilja så samse [likartade] syskon, utan snarare velat inom sig ännu mer förena dem, då hon tagit sig före, at med lika flit påyrka bägges deras tilväxt”. En snarlik uppfattning återfinns hos Johan Fredrik Kryger, som hävdade att konsterna, slöjderna, handeln, rörelserna och näringarna var vetenskapernas "samsyskon". 359 
Presidietalen lade sig under hattpartiets första period vid makten som regel nära regeringens ekonomiska politik, bland annat genom att de framhöll och förordade slöjder, produktförädling och exportpremier. ${ }^{360}$ Det hette att handslöjder vid sidan av vetenskaper och fria konster var "de största kännemärken af et förnuftigt Creaturs härliga förmoner", liksom att samtidens välfärd utgick från förstånd, handel och slöjder. De som ägnade sig åt konster och slöjder skaffade inte bara sitt eget uppehälle, utan tjänade också andra, eftersom hantverkarna och manufakturisterna försörjde många och mötte vardagslivets behov. Jordbrukets upphjälpande var avhängigt handeln, städerna och städernas näringar, låt vara att stadsväsendet för tillfället var otillräckligt. Handslöjderna borde i enlighet med det synsättet förbättras först, medan lantbruket förhoppningsvis skulle utvecklas i den takt som de övriga näringsfångens livaktighet tillät när dess hinder väl hade eliminerats. ${ }^{361}$

Vetenskapsakademiens uppslutning bakom manufakturerna och hantverket framgår tydligt av Wargentins hyllning av Jonas Alströmer, som han kallade upphovsmannen till Sveriges främsta slöjder. Wargentin frågade retoriskt om någon titel kunde vara mer hedervärd och fastställde att nästan ingen medborgare torde ha gjort mer nytta för samhället än Alströmer, varför denne med rätta var den första svensk att föräras en byst av riksdagen på Stockholms börs. Alströmer själv avstod från att rangordna näringarna. Han underströk att de alla krävde samma konstanta överhetens omvårdnad som manufakturerna för att riket inte skulle hamna i trångmål, och angav att samtliga ekonomins delar hade förmånen att understödjas av det allmänna och kunde göra ett land mäktigt. Alströmer menade dock även att Vetenskapsakademien avgjort debatten om näringarnas företräde till slöjdernas fördel, att slöjderna tack vare Försynen vunnit nationellt bifall och att främmande länders stora rikedom berodde på blomstrande manufakturer och schäferier. Sveriges förbättring avgjordes huvudsakligen av de omistliga handslöjderna, vilka jämte konsterna skulle ge samhället liv och rörelse. Detta skulle ske med bistånd från jordbruket och en handel som för Alströmer kretsade kring exporten av förädlade och umbärliga inhemska produkter och importen av utländska nödvändighetsvaror och råmaterial som fordrades i det svenska manufakturväsendet. ${ }^{362}$ 
Henrik Jakob Wrede lade i likhet med Alströmer tonvikten på såväl slöjderna som handeln med deras förädlade tillverkningar. Han förfäktade att handslöjder och handel var medlen till blomstring och välmåga, samt att den gudomliga hushållningsordningen förverkligades genom att Skaparens vishet ledde den civiliserade människan till varje slags slöjd, färdighet och snillebragd. Ett bättre resursutnyttjande förutsatte handslöjdernas dagliga tillväxt, medan en positiv och välståndsskapande handelsbalans förutsatte ofullkomliga råvarors förädling för export. Samma tematik påträffas hos manufakturkommissarien Erik Salander, som såg slöjderna som alla näringars motor. Han meddelade att de genererade många konster och kunskaper och stimulerade handeln och relaterade rörelser. Jordbruket och landsbygden kunde inte nå framgång utan draghjälp från slöjderna, handeln och städerna. Slöjderna förädlade en lång rad råmaterial och höll kvar rikedomar i landet som kom resten av näringarna till godo. De skulle föra med sig en drastisk exportökning som var svaret på det rådande importöverskottets skadliga effekter. Salander observerade att varuinförseln från utlandet berodde på en inhemsk produktbrist som skulle försvinna när lantbruket harmonierade med, istället för att strida mot, städernas verksamheter. Han förespråkade i linje med det en arbetsfördelning mellan land och stad, varförutan allmänt välstånd var ouppnåeligt. ${ }^{363}$

Några ledamöter såg jordbruket som viktigt men sekundärt i förhållande till slöjderna och manufakturerna. När ämbetsmannen och hattpolitikern Ulric Rudenschöld (Rudeen) diskuterade lantbrukets betydelse menade han att det knappast skulle förbättras förrän handslöjder och handel givit upphov till fler och större städer, som kunde öka böndernas avsättning och bereda dem fler näringsmedel. Därmed skulle landsbygden leva upp och förse städerna med mer livsmedel och resurser för handel och handslöjder; allmän uppodling kunde bara fås till stånd genom en sådan "cirkel-gång". Liknande tankar framfördes av Samuel Schultze, som hävdade att manufakturerna och deras tillväxt var villkoret för jordbrukets tillväxt och att lantbrukets förbättring vore gynnsam för slöjderna, som fungerade väl och besparade riket miljoner. Schultze anmärkte visserligen att jordbruket och slöjderna uppkommit nästan vid samma tidpunkt och tillsammans utgjorde "människans rätta 
näringsmedel", varför ingen konkurrenssituation rådde mellan dem. ${ }^{364}$ Hans fokus låg dock på handslöjderna, inte på lantbruket.

En del ledamöter identifierade någon av de andra näringarna som den mest väsentliga sektorn. Slöjdernas huvudrival om denna status var jordbruket. Vid 1750-talets början betraktade Kammarkollegiums president Carl Fredrik Piper lantbruket som de övriga näringarnas grundval, medan Carl Gustaf Löwenhielm slog fast att det inbegrep allt nödvändigt och utgjorde fundamentet för såväl enskilt välstånd som rikets makt. Liknande föreställningar dök upp igen ungefär ett decennium senare, omkring 1760. Enligt Wargentin var alla näringar likvärdigt värdefulla för Sverige, och jordbruket och handslöjderna lika förtjänta av tillbörlig uppmuntran och vård, fastän kostnaderna fått regeringen att dra sig för att rikta dylika åtgärder till lantbruket. Han kallade å andra sidan jordbruket "Rikets förnämsta pelare" och lanthushållningen "en af de angelägnaste Vetenskaper". Jacob Faggot framställde jordbruket som den främsta näringen, givet att de flesta fann sin utkomst där och att avkastningen var större än inom andra näringar samt kunde mångfaldigas. Lantbruket stärkte "de andra näringarnes lif och rörelse i samma mon, som han [det] får större eller mindre krafter. I följe häraf kan det slutas, at denna vår hufvud-näring, förtjänar den ömaste hjälp och omvårdnad”. Faggot, som erkände att han tidigare satt handslöjderna i första rummet, ville inte återuppliva kontroversen om näringarnas företräde, men riktade icke desto mindre kritik mot det ensidiga premierandet av slöjder och fabriker utifrån att födan borde värderas högre än kläderna. ${ }^{365}$

Dessa åsikter kan kopplas till ett långvarigt och starkt lantbruksintresse inom Vetenskapsakademien, vilket går att placera in i en europeisk och svensk agrar reformrörelse som utvecklades parallellt med fysiokratismen. Fysiokraternas program hade få officiella språkrör i det svenska sammanhanget, där traditionen var en vanligare utgångspunkt för jordbruksengagemanget. Allmänna yttranden om jorden som alla rikedomars källa kombinerades ofta med manufakturvänliga uppfattningar och behövde inte åtföljas av idéer om jordbrukets primat. Lantbruks- och manufakturvurm var överlag inte ömsesidigt uteslutande, om än debatter rörande näringarnas rangordning förekom, inte minst 
i akademien. ${ }^{366}$ Manufakturernas framgång och rikets välfärd ansågs vara avhängiga en stor befolkning som kunde erbjuda billig arbetskraft, något som i sin tur förutsatte en ansenlig tillförsel av billiga livsmedel, bland annat spannmål. ${ }^{367}$

Salanders yrkande på arbetsfördelning var ingen isolerad företeelse bland akademiledamöterna, vilka liksom hattarna ofta intog en negativ hållning till mångsyssleri. Det var, som kapitel tre i denna bok visat, närmast ett axiom att varken samhället eller ekonomin klarade sig utan makthavarnas försorg. Båda skulle ordnas i välbalanserade system där stånd och näringar nogsamt skildes från varandra. Motviljan mot gränsöverskridanden uppenbarade sig för hushållningens del tydligast i återkommande krav på rigorös arbetsfördelning, som gick tillbaka på en vision om jämvikt mellan näringarna - ett ledmotiv i 170o-talets ekonomiska tänkande - och kunde hämta stöd i naturrätten. ${ }^{368}$

Vetenskapsakademiens kanske mest hårdföra förespråkare för arbetsfördelning var Kryger, som med eftertryck vände sig mot den bristfälliga uppdelningen mellan lands- och stadsnäringar, varigenom det enskilda hushållet kom att likna "et särskildt och enstakat [enstaka] samhälle, hvilket sörjer för sig sjelft, det bästa det gitter och förmår: man undviker det mästa man kan, at nyttja hvarandras handräckning, ja anser den för den bäste hushållare, hvilken är sibi sufficiens [självförsörjande] [...] och gör innom sitt lilla samhälle all ting sjelf, hvad til föda, kläder och husgeråd fordras”. Näringsblandningen vållade fler ekonomiska bekymmer än det gick att förteckna; en korrekt arbetsfördelning skulle däremot befrämja rörelser som gynnade rikskroppens välmående. ${ }^{369}$ Kryger efterfrågade också arbetsfördelning och riktig balans mellan städernas företag, samt specialisering mellan städer och provinser. Om näringarna anpassades efter varje landsorts karaktär skulle liv och rörelse infinna sig, till allmän och enskild nytta. Hans aversion mot mångsyssleri sträckte sig till den interna strukturen vid inrättningar, då han argumenterade för en nogsam uppdelning av slöjdverksamheten genom styckarbete. Andra akademimedlemmar förklarade att en hantverkare skulle bedriva en enda syssla så att oordningen och klåperiet upphörde, att de urbana och de rurala näringarnas sammanblandning var till avsevärt förfång för riket samt att arbetare inom klen- och kniv- 
smidet "gör alt, sig sjelf til största last" och att de olika momenten vid produktionen av bössor "efter den naturligaste ordningen" hanterades av olika personer. ${ }^{370}$

Inte heller vetenskapligt mångsyssleri uppskattades i presidietalen. Idén att den lärde skulle behärska samtliga vetenskaper avfärdades med hänvisning till att detta var omöjligt och utmynnade i missanpassat klåperi på tvärs mot skapelseordningen. Det var bäst om varje vetenskapsidkare uppodlade sin del och höll sig "innom sin Sphere". ${ }^{371}$ Samma ledprincip hade alltså bäring på såväl hushållningen som vetenskapen och kan i båda fallen förbindas med det nischtänkande som dominerade ståndssamhället. ${ }^{372}$

Många ledamöter förhöll sig kallsinniga till import. Det gjordes gällande att den medförde ett ratande av naturliga till förmån för mindre naturliga produkter, och att ett klokt folk som ömmade för sin välfärd borde prioritera sämre och dyrare inhemska varor framför bättre och billigare utländska. Handslöjdernas förbättring skulle stämma den ådra som drog mest pengar ur landet. ${ }^{373}$ Carl Gustaf Tessin undrade om det inte var nog att svenskarna till nästan obotlig skada för sin handel "lånt kram af utlänningen”, utan även måste hämta sina ord från utlandet. Jonas Alströmer tillkännagav att han alltsedan han börjat förorda inhemska yllemanufakturer sökt få till stånd råmaterialets inrikes anskaffande, så att svenskarna en gång skulle kunna bära svenska kläder och slippa vända sig till sina grannar för allt. ${ }^{374}$

Vetenskapsakademiens hattvänliga ekonomisk-politiska linje färgade också påtagligt de presidietal som förde fram i ett eller annat hänseende avvikande åsikter om hushållningen. Tal som betonade bergsnäringen eller jordbruket åberopade samtidigt företeelser som manufakturer, handel och förädlade exportvaror. Detta kan exemplifieras med mösspolitikern och officeren, sedermera fältmarskalken, Matthias Alexander von Ungern-Sternberg, som efterlyste understöd till jordbruket och av allt att döma jämställde dess samhällsnytta med slöjdernas. Han noterade att hantverkets och handslöjdernas anstalter varit framgångsrika och att det nu gällde att stimulera deras tillväxt och göra dem mer förenliga med allmän och enskild nytta. Ungern-Sternberg pläderade i samma text mot import och underskott $i$ handeln och för förädling och 
export av inhemska varor. Svenskarna skulle i Adolf Fredriks efterföljd "förakta öfverflöd och främmande kram och endast finna behag i det vi sjelfve tilverka". ${ }^{375}$

Som den hittillsvarande undersökningen av Vetenskapsakademiens ekonomisk-politiska ställningstaganden demonstrerat var positiva utlåtanden om handel ett stående inslag under hattarnas styre. Presidietal förkunnade att den naturliga och sanna handeln orsakas av att länder saknar vissa produkter och att slöjderna inte kom i rörelse utan att stimuleras av andra verksamheter, enkannerligen handeln, vilken kunde ge liv och tillväxt åt alla slags slöjder. ${ }^{376}$ Enligt Wargentin hade forntidens människor knappast förväntat sig att astronomin skulle gynna "Communication och gemenskapen imellan de längst ifrån hvarandra skilde jordens inbyggare: hjälpa dem meddela hvar andra sina rikedomar och upfylla hvarandras nödtorfter; ja, at de[n] skulle gifva millioner människor tilfälle til näring, utkomst och gagnelig rörelse”. I likhet med slöjderna och konsterna gav handeln upphov till såväl välstånd som yppighet, men det utgjorde inget skäl att opponera sig mot dem - de var pålitliga förbättringsverktyg under förutsättning att överheten genom exempel och lagar förekom missbruk. ${ }^{377}$ Wargentins avslutande reflektion illustrerar tydligt en tendens som framträder i flera ledamöters argumentationer, nämligen att handeln skulle vara rätt utformad och lönsam för riket. Vad ett adekvat handelsutbyte ansågs vara framgår av presidietalens syn på import och export.

Även om en del ledamöter förde resonemang om ekonomisk självreglering förblev sådana åsikter marginella inom akademien under hattarnas första maktinnehav. Edvard Fredrik Runeberg påpekade att det var så mycket enklare för politin att upprätthålla den rätta handelsrörelsen då "rörelsens art och natur, vil sjelf befrämja densamma". Wargentin antydde att det skulle vara möjligt att släppa slöjderna "hand-löse" när de övervunnit sina problem och begrundade hur en stor folkmängd skulle göra att alla hushållningsverksamheter gick liksom av sig själva. Han lyfte å andra sidan fram regeringens betydelse och ansvar för befolkningstillväxten. ${ }^{378}$ Kryger förespråkade avreglering i samband med den förment stora svenska utvandringen, som skulle bekämpas genom rimliga friheter och avskaffandet av hindrande tvång. Refor- 
merna var emellertid begränsade och diskuterades vid sidan av beskydd och belöningar ovanifrån. Till exempel borde de svenskar som valde att återvända hem uppmuntras med offentliga medel och "anvisning til näringars idkande utan hinder". ${ }^{379}$

Somliga presidietal uppvisade en långtgående vilja till reglering. Det framställdes önskemål om att allmogen skulle åläggas att bearbeta sin säd väl och att hålla ordning och rent kring sina bostäder, liksom om att höga överheten skulle föreskriva städerna att nogsamt ta vara på sin gödsel och bönderna som sålde hö och halm där att ta med sig gödseln hem. Folket borde vidare ledas till trädplantering, varvid ett visst tvång torde vara av nöden innan den kunde fortgå av sig själv. ${ }^{380}$

En rad presidietal behandlade frihetstidens insatser och landvinningar, bland annat med avseende på fiske, stenkolsbrytning, handslöjder och järnförädling. ${ }^{381}$ Flera av dem tecknade tillsammans och var för sig en bild av frihetstiden som en period av lycksalighet och nytta. Patriotiska invånare kunde glädjas över manufakturernas och de övriga vackert uppodlade näringarnas uppsving - inte minst handeln och acklimatiseringen av utländska växter hade gått kraftigt framåt. Svenskarna hade börjat bli varse sin lycka och på allvar beakta kännedomen om fäderneslandets styrka och svagheter, medan tilltagande näringar och slöjder kommit att ses som fördelaktigare än folkförödande krig. ${ }^{382}$

En av de mest entusiastiska skildringarna kom från Carl Fredrik Scheffer, vars tal tog upp handslöjdernas och lärdomens förbättring, universitetens goda tillstånd och existensen av alla de påkostade inrättningar som behövdes för att bedriva vetenskap. En "ny och qvik lifs anda" hade enligt Scheffer spridit sig i hela rikskroppen; jordbruket och handeln hade förkovrats, manufakturer och förundransvärda segelfarter etablerats och alla gagneliga anläggningar befrämjats. En lika högstämd redogörelse tillhandahöll Faggot, som uppgav att Försynen väglett svenskarna till förbättring och ordnat så att den mulna himlen klarnat någotsånär. Åtgärder som hemmansklyvningen, storskiftet och lantmäteriverksamheten var de mest omfattande som någonsin vidtagits till den förfallna rikshushållningens förbättring. Riksdagen 1755-56 beslutade om så förträffliga författningar att den var att betrakta som "början til folkökning, Lands-cultur [lantbruk] och våra andra näring- 
ars lif". Året 1756 skulle förbli "i en kär åminnelse, och i vår Svenska Oeconomiska Histostoria [sic], en tid utan like". ${ }^{383}$

Faggot var inte ensam om att lyfta fram de styrande hattarnas roll i och för den gynnsamma utvecklingen. Vetenskapsakademiens höga herrar prisades för sin satsning på manufakturväsendet och regeringen för sitt nyttiga förbättringsarbete, som utgjorde grunden för slöjderna och framtiden skulle ha skäl att ära. Textilindustrin åstadkom utmärkta resultat med överhetens bistånd i form av uppmuntrande premier och omvårdnad om de flesta nya anstalter. Sunda författningar hade utfärdats till järnförädlingens fromma och "höga vederbörande" visat ömhet om den genom att till exempel motverka import. ${ }^{384}$

Särskilt Wargentin uppehöll sig vid de frihetstida framstegen. Akademisekreteraren hävdade att samtiden präglades av ett mer utbrett och förfinat hushållsvett. Patriotism hade gjort regeringen driftig och vetenskaperna nått så långt att Göta älv blivit farbar, ett projekt vars svårighetsgrad motiverat ständerna till förnyade och desto mer framgångsrika ansträngningar. Vetenskapsakademiens medlemmar sades glädja sig över att leva i en lycklig era där slöjderna noga hölls efter och liksom resten av näringarna var föremål för mycken uppmuntran och omsorg, vilket förebådade en ljus framtid. Wargentin framhöll den upplysta regeringens mått och steg för slöjdernas igångsättande och utveckling, låt vara att dessa fortfarande drogs med svårigheter och att allmänheten inte hunnit ta dem till sig. Såäl Adolf Fredrik som riksråden fokuserade på att förbättra handeln, och regeringen hade vinnlagt sig om att upphjälpa järnförädlingen. ${ }^{385}$

Wargentins svar till Carl Fredrik Scheffer bjöd på en veritabel lovsång över frihetstidens Sverige:

Uti hvad för et lyckligt tide varf hafve icke vi lefvat och lefve ännu? då under fridens lugn och frihetens skygd så mycket godt, til Fäderneslandets sanskyldiga nytta och heder, blifvit uträttat; så månge härlige inrättningar gjorde och i hast stadgade; så många stora snillen alstrats; så månge befordrare funnits [- - -] Glada tider! då det almännas och alla goda sakers välgång är de myndigaste Mäns käraste fägnad: då, at af dem blifva hedrad och ansedd, ej mer behöfves, än at vara til något godt skickelig; då alt, hvad dugeligt är, värderas och på sitt ställe nyttjas. 
Sådane äro våra tider; Sådana vänte vi, under en Nådig Konungs hägn och genom Deras tilskyndan, som tänka, tala och göra såsom I, Nådige Herre: som mäta den höga värdighet, hvaruti de sitta, allenast efter det goda de förmå bidraga, til at göra et helt Folk stort och lyckligt. ${ }^{386}$

De som gjorde, talade och tänkte som Scheffer bör ha varit hans kollegor i det hattdominerade rådet, vilka utsagorna om många befordrare och de myndigaste män sannolikt också hänförde sig till.

Presidietalens välvilliga omdömen om samtidens svenska samhälle kan utifrån bland annat de upprepade referenserna till manufakturerna i hög grad läsas som smicker av det inflytelserika hattpartiet, även om monarkerna och den tidiga frihetstidens råd också omfattades av dessa utsagor. Vetenskapsakademiens lojaliteter gentemot och närhet till de styrande färgade märkbart talens samtidshistoriska utblickar, som låg $\mathrm{i}$ linje med maktens och akademiens gemensamma ekonomiska ideologi.

Ledamöterna diskuterade även åtskilliga missförhållanden inom skogsskötseln, bergshanteringen, lantbruket, slöjderna, handeln och sjukvården, vilket kan förklaras med att Vetenskapsakademien i mångt och mycket instiftats just för att angripa landets problem. ${ }^{387}$ Vissa presidietal innehöll mer övergripande resonemang kring dem. Faggot beklagade sig över att svenskarna först sent - men bättre sent än aldrig - begripit att på rätt sätt måna om sin välfärd, fastän de länge känt till att deras näringar var särdeles svaga; han uppmärksammade exempelvis att lantbruket missgynnats och var behäftat med fel som inverkade negativt på Sverige som helhet. ${ }^{388}$ Kryger menade att de götiska förfäderna hade lämnat sina ättlingar ett rike som var mer vanvårdat än något annat europeiskt land och ännu stod kvar i "sånings-tiden". Det fanns dock ingen anledning att gräva ned sig i det förgångna:

Vi böre snarare fägna oss åt den tid, i hvilken vi nu lefve. Vi känne våra brister, och äre ei kallsinnige, eller rådlöse, vid omtankan om deras afhjelpande. Rikets Höglofl. Ständer spara hvarken möda, eller kostnad, til landets bättring; en Patriotisk Regering verkställer med nitisk drift Deras mogna författningar, och tröttnar ei vid, at vaka öfver vår välfärd: vetenskaperna uplifva Svenska snillen, och understödja våra späda inrättningar med mogna råd och fördelaktiga handgrep: vårt hopp växer, vid 
så många kännemärken til våra efterkommandes sällare tilstånd, och ökar vår hog, at efter råd och ämne bidraga til et så hälsosamt ändamål. ${ }^{389}$

Krygers optimism var karaktäristisk för akademiens allmänna inställning. Problemen var till för att övervinnas, inte minst av den hattregim som under sammanslutningens första decennier kontrollerade det frihetstida statsmaskineriet.

\section{Mössorna vid makten}

Sverige drabbades under 1760-talet av en ekonomisk kris med såväl inhemsk som internationell botten där hattregimens vidlyftiga bankoch subventionspolitik och pommerska krig utgjorde nyckelfaktorer. Statsskulden rusade, inflationen grasserade och krisen bröt tilltron till manufakturpolitiken genom att åskådliggöra dess tillkortakommanden. ${ }^{390}$

Kritiken av hattpartiets näringspolitik intensifierades, samtidigt som den offentliga debatten radikaliserades när kraftfulla ifrågasättanden av privilegiesystemet och krav på jämlikhet och folkligt politiskt deltagande framfördes. De regleringsskeptiska och näringsfrihetliga stämningar som missnöjet med och besvikelsen över hattarnas förfelade politik gav upphov till spred sig även inom deras egna led, om än merparten av dem fortfor att sluta upp kring det rådande. Mösspartiet, som tillkom som en reaktion på 1738-39 års riksdag, delade fram till 1760-talet väsentligen sina motståndares ekonomiska vision. Det förhöll sig dock mer skeptiskt till tonvikten på manufakturväsende och storskalig affärsverksamhet, vilket kan kopplas till dess ekonomisk-politiska ideal - sparsamhet och en balanserad budget. Istället betonades jord- och bergsbruket. Ifråga om det frihetstida styrelseskicket skilde sig mössorna från hattarna på flera punkter - bland annat genom åsikten att de styrande skulle vara ansvariga inför de styrda, en ståndpunkt som implicerade folkmakt. Utrikespolitiskt hade partiet en pro-engelsk, pro-rysk och mer försiktig profil. Mössorna kom under 1760-talet att stå för privilegiekritik, minskat manufakturskydd, färre handelsregleringar och allmän näringsfrihet, 
medan de brännmärkte hattarnas ekonomiska politik som destruktiv och egennyttig. ${ }^{391}$

Mösspartiets seger på riksdagen 1765-66 föranledde ingen grundläggande förändring av ekonomin, den ekonomiska politiken eller privilegiesystemet. Maktskiftet fick likväl effekter: näringssubventionerna blev knapphändigare, Manufakturkontoret och det exportbegränsande bottniska handelstvånget försvann och näringsrättigheterna utvidgades. Mössorna inriktade sig inte på den ekonomiska ordningen i sig, utan på en jämnare och bredare fördelning av rättigheter och resurser inom de befintliga ramarna. ${ }^{392}$

Vetenskapsakademien förblev i huvudsak trogen hattarna och deras agenda under denna turbulenta period. Ett exempel på akademiens ekonomisk-politiska ståndaktighet var avvisandet av ett bidrag till en pristävling om befolkningsfrågan som gjorde gällande att näringarna borde få sköta sig själva och att folkbristen och emigrationen berodde på privilegier och regleringar. ${ }^{393}$ Rikets ekonomiska svårigheter hade varit föga synliga i presidietalen före mösspartiets maktövertagande, låt vara att några ledamöter berört dem i förbigående. Det hette då att den begränsade inkomst almanacksprivilegiet gav akademien påverkats allvarligt av krisen och att organisationens verksamhet fortgått utan avbrott "oaktadt en lång kedja af både obehaglige och äfventyrlige skiften i det allmänna”. Abraham Bäck skyllde landets näringsmässiga vanmakt på en av farsoter vållad folkbrist. Han agerade förmodligen apologet för hattväldet när han anmärkte att välsinnade medborgares goda förslag som var omöjliga att genomföra på grund av Sveriges tillstånd skulle visa eftervärlden att hans samtida haft de bästa intentioner. ${ }^{394}$ Situationen härrörde alltså ur omständigheter som ingen, inräknat hattarna, kunde råda över.

En långtgående kritik av hattregimen levererades av Pehr Högström i maj 1765. Högström låg åsiktsmässigt nära sin ekonomisk-politiskt radikale prästkollega Anders Chydenius och företrädde liksom denne mösspartiet vid den pågående riksdagen, där oppositionen några månader senare vann övervikt. ${ }^{395}$ Högström inledde sitt presidietal med att räkna upp ett antal faktorer som kunde förhindra en korrekt och välståndsbringande arbetsfördelning i samhället: geografiska avstånd, 
undermålig initiativförmåga, fattigdom, överilade lagar, "konstlande med snillen och näringsfång, samt tryckande af hårda öfvervälden". Fastän Högström formulerade sig i generella termer är det givet tidpunkten för talet befogat att anta att han anspelade på hattarnas Sverige, som alltså tillskrevs ogenomtänkta lagar, otillbörliga statliga ingrepp och förtryck. En syftning på hattstyret kan anas också i Högströms förmenande att det var angeläget att identifiera grunderna för hur näringar och levnadssätt faktiskt brukade vara fördelade. Politik eller lagstiftning som ignorerade verkligheten var kontraproduktiv och ledde till oordning och felgrepp, till skillnad från den som utgick från verkliga förhållanden. ${ }^{396}$

Högström vände sig mot statlig repression, reglering och interventionism. Han uppfattade tvång i tankar och livsföring som oförenliga med Guds vilja, värdesatte konkurrens mellan fria medborgare och hävdade att "fritt anlagda näringar kunna genom blotta täflan bibehålla sig, utan minsta Öfverhetens åtgärd eller Ämbetsmanna-uträkningar och tvång”. Premissen för att uppnå en riktig arbetsfördelning var att människorna fick följa sina naturliga, gudomligt bestämda böjelser. Västerbottens uppdelning mellan stads- och lantnäringar sades ha tillkommit av sig själv, genom folkets snillrikhet och företagsamhet; de hade fördelat sig baserat på tillgångar, insikter och andra faktorer "utan at genom någon onaturlig blanning hindra eller ödelägga hvarandra". Omvänt hade de västerbottniska städernas brist på handelsfrihet medfört att vissa av deras näringar berövats rörelse och stadga, och det hade på flera håll visat sig vara omöjligt att med förbud utrota näringar som "lika som af sig sjelfve fått rota sig [...] när de annorstädes och hvarest man velat inrätta dem, med inga upmuntringar i stånd kunnat sättas”. ${ }^{397}$ Högström avvek även från sina hattsinnade ledamotskollegor genom att inte omfamna en rigid arbetsfördelning mellan stad och landsbygd. Han noterade apropå Västerbotten att bönderna fann det lukrativt att ägna sig åt hantverk, att sådant bisysslande inte var skadligt för jordbruket samt att städerna låg för långt borta för att deras tillverkning skulle vara relevant för landsbygdsbefolkningen. Allt detta hade givit många idén att separeringen av stads- och lantnäringarna inte i alla stycken skulle få lika goda följder som i de sydliga landskapen. ${ }^{398}$

Wargentins svar bestred inte Högströms ekonomisk-politiska försant- 
hållanden men rättade honom ifråga om Västerbottens lantbruk, vilket beskrevs som otillräckligt i talet. Akademisekreteraren framhävde de nordliga trakternas förtjänster och lycka och att Västerbotten i likhet med det övriga Sverige var helt kapabelt att föda sina inbyggare. Wargentin prisade Högströms kunskaper och insats för Vetenskapsakademien, vars trofaste och älskade medlem han uppgavs vara, samtidigt som svaret framställde honom som en "afsides boende" på tillfälligt besök vid organisationen. Wargentin avslutade med en önskan om att Gud skulle välsigna de rådslag riksdagsmannen Högström deltog i och styra dem till Sveriges bästa. ${ }^{399}$ Bemötandet av Högström kan ses som ett försök att distansera Vetenskapsakademien en aning från hans person och synsätt. Kommentaren om riksdagen går att läsa som ett försök att gestalta akademien som höjd över de infekterade partimotsättningarna inför ett maktskifte.

Kort efter mössornas maktövertagande gick Carl Fredrik Mennander till storms mot hattarnas politik. Biskopen räknade upp en rad aktuella problem, som folkbristen, jordbrukets och städernas undermålighet, fabrikernas nedgång, det tilltagandet antalet ståndspersoner samt den ekonomiska krisens verkningar. Förutom att kritisera väpnade konflikter i allmänhet lyfte han fram hattregimens och Karl XII:s krig; om bara riket fått behålla det manskap som gått förlorat genom dem skulle befolkningen och näringarna ha tagit sig radikalt annorlunda ut. Mennander kungjorde att tiderna blev allt svårare, att mycket återstod att göra och att de naturliga orsakerna till folkbristen var mindre viktiga än de moraliska, som kom sig av människornas begär, laster och förvända anstalter. Denna utsaga kan läsas som ett genmäle till Bäck, vilken året innan givit sjukdomar skulden för folkbristen, men även som klander av de störtade hattarna. Den senare tolkningen stöds av Mennanders kritik av deras krigsföretag och av hans tes att befolkningsökning hindrades "när inrättningar, som i sig sjelfve kunna vara nyttige och nödige, och tjena til större säkerhet och utvärtes anseende, framdrifvas skyndsamare och längre, än Statens krafter och förmåga tillåta”. Här avsågs troligen manufakturpolitiken och de förhoppningar som knutits till den. Mennanders skildring av hattväldet var dock inte alltigenom negativ, då han påtalade att samtliga hushållningsgrenar tillvuxit rejält, 
att uppmuntringarna av hemmansklyvning och skifte haft gynnsamma konsekvenser och att rikets tillstånd förbättrats betydligt. ${ }^{400}$

Samme preses framförde en del åsikter som korresponderade mot den fallna hattregimens ekonomiska politik. Han förespråkade export av förädlade produkter och förhöll sig avog till import. Nästan alla nödtorfter och bekvämlighetsvaror kunde anskaffas inom landet, och livsmedelsinförseln riskerade att ge upphov till den värsta uselhet. Statsmakten ("Kronan") tillmättes ansvar för befordrandet av vetenskaper, konster och alla anstalter som bidrog till näringarnas förbättring. Mennander frångick dock det gängse ekonomiska tänkandet när han karakteriserade jordbruket som slöjdernas grundval och den mest omistliga näringen, medan dess belackare utmålades som äregiriga och vällustiga. Detsamma kan sägas om hans synpunkt att var och en helst självmant skulle anpassa sin hushållning efter det allmänna bästa: "Tvångs-medel äro här just icke de nyttigaste, fast nöden kan göra dem oundvikelige."

Mennanders tal hade vidare en socialkritisk dimension. Han slog fast att ståndspersonerna levde på de närandes bekostnad och bekymrades av deras växande antal när den närande befolkningen försvagats. Ett sådant perspektiv var förvisso ingen nyhet i Vetenskapsakademien; till exempel hade Wrede tidigare argumenterat för att adeln genom undervisning skulle ledas från innehav av offentliga ämbeten till jordbruket och bli närande istället för tärande. ${ }^{402}$ Det kan kopplas till en allmän tankefigur som värdesatte de närande och ringare men inte de tärande och förnämare, vilka inte fick bli för talrika och rubba den rätta balansen mellan de två grupperna. Detta förhållningssätt kunde ha radikala implikationer, i form av just tanken att alltför många besuttna levde på gemene mans bekostnad. ${ }^{403}$

Mennander ogillade också att näringsmedlen samlades i få händer genom monopol och privilegier, och han ville att bönder med stora egendomar skulle bereda andra rätt att nyttja dem. Problematiken kring koncentrerat ägande illustrerades med antikens Rom, där det fört med sig befolkningsminskning och reducerad styrka, stora klyftor mellan fattiga och rika samt yppighet, oenighet och avund. ${ }^{404}$ Både Mennanders kritik av de tärande och hans yrkande på näringsspridning hade, väl att 
märka, instrumentella övertoner. Det handlade om nytta och effektivitet snarare än om egalitarism, som utifrån hans syn på samhället och folket knappast var aktuell.

Wargentin berömde i sitt svar Mennander och undvek liksom i repliken till Högström överlag politiska ämnen, något som bör betraktas mot bakgrund av det nyss timade maktskiftet. Sekreteraren nöjde sig med att nämna Mennanders delaktighet i riksdagsarbetet och instämma om behovet av befolkningstillväxt. ${ }^{405}$ Svaret på nästa anförande, som hölls av botanikern Erik Gustaf Lidbeck, var desto mer politiserat. Lidbeck uppmärksammade den samtida inflationen och arbetskraftsbristen och hoppades att Gud skulle ordna en lyckligare framtid. Hans tal uppvisade en importfientlighet kopplad till inhemsk odling av främmande växter, och förklarade dels att regeringen i flera år vinnlagt sig om skogarna, dels att en länge tilltänkt skogsordning nu underkastats ständernas prövning. ${ }^{406}$ Utsagorna om skogen kan tolkas som ett försvar av hattarna, som fick äran av det nya regelverk riksdagen hade att ta ställning till.

Wargentins svar på Lidbecks tal fastställde att hushållningen hade många brister - framför allt folkbrist, spannmålsbrist och skogsbrist - vilkas åtgärdande krävde en långtgående omtänksamhet. Trots att det inte saknades förslag med avseende på skogsbristen hade få av dem anammats och ännu färre verkställts av lagstiftarna, varför krafttag var av nöden. Dessa erinringar kan tolkas som en replik på Lidbecks uttalande om hattarnas omsorg om skogarna och som en kritik av deras politik på såväl detta som andra områden. Wargentin frammanade därtill en bild av en väsentligen självreglerande befolkningsutveckling:

Människan är altid benägen til sitt Slägtes fortplantning: derföre behöfvas ej särdeles många anstalter, intet tvång, ja icke ens upmuntringar eller förmaningar, utan endast frihet at följa Naturens drift, så tilväxer folkhopen snart nog, om han ock tillika ömt vårdas. Sant är väl det, at det lilla ordet Frihet har mycket at innebära, samt at rätta sättet och måttet deruti äro svåre at träffa: men eftertanka och förfarenhet gifva dem dock vid handen, och vi hafve skäl at hoppas, det [att] et Folk, som råder sig sjelft, säkert finner och vidtager dem. ${ }^{407}$ 
Akademiesekreteraren verkar här ha försökt att navigera i den förändrade politiska verkligheten och markera avstånd till hattarnas program, inte minst deras förkärlek för regleringar.

Lidbeck var långt ifrån den ende som gav röst åt ekonomisk-politiska ställningstaganden som utmärkt Vetenskapsakademien under hattväldet, låt vara att de i högre eller lägre grad tenderade blandas med nytt tankegods. Augustin Ehrensvärd menade att en ökad produktion var avhängig handeln, vilken om den vore utbredd skulle motverka emigrationen. Han tänkte sig ett idealsamhälle i form av en folkrik sjömakt som huvudsakligen försörjde sig själv: "De mästa behof finnas där merendels på egen botten. Man behöfver icke söka föda och beqvämlighet hos utlänningen, eller sin säkerhet uti andras beskydd. Idoghet, handaslögder, konster, handel, rikedom, förstånd, ära, säkerhet och et eget genie, få här sitt hemvist.” Även lantbruket hade hemortsrätt i det imaginära riket och var betydelsefullt för dess välmåga. Ehrensvärd beskrev hur sjömakten optimerade sitt jordbruk, förädlade dess produkter och tillämpade välståndsbringande arbetsfördelning. Specialisering kontrasterades mot mångsyssleri, som låste fast rörelserna i barndom och orkeslöshet och förhindrade deras fullkomlighet. ${ }^{408}$

Justitiekanslern och det senare hattriksrådet Eric von Stockenström (Stockenström) diskuterade handelns nödvändighet och handslöjdernas centrala roll, givet att exporten av deras produkter var enda sättet att skaffa fram pengar till livsmedel. Manufakturerna hade liksom fisket och trä- och tjärhanteringen hjälpt till att förstärka riket, och det föreföll som att Sverige borde fokusera på slöjdernas utbredande och förbättring, som landet hade goda förutsättningar för. Samtidigt fann Stockenström att järnhanteringen var den främsta exportnäringen och att både bergsbruket och jordbruket gav städerna vinst och rörelse. Han var tydligtvis angelägen om att försvara det av hattarna omhuldade och delvis av honom själv instiftade Jernkontoret, som sades ha gynnats av både ständerna och konungen. Det uppgavs ha emanerat ur en audiens där Fredrik I inspirerat en ädel strävan hos de närvarande bruksägarna att fullgöra sina skyldigheter och befrämja varandra. Den senaste riksdagen hade beslutat att bevara och reformera kontoret, vars nytta och framtida potential Stockenström framhöll. ${ }^{409}$ 
Stockenström konstaterade att olika näringsgrenar kunde orsaka problem för varandra och att en vis regering visste "at styra alt til det ändamålet, at missbruken af sig sjelfva qväfvas, och at den gränts, inom hvilken hvar och en närings-rörelse, i anseende til dess naturliga uprinnelse, fått sitt säte, ej måtte blifva så tilsluten, at ju icke den [näringsrörelsen], i mån af dess egen utvidgande drift må, enär det sker tillika med andre näringars befordran, få öka sig så långt, som den i sig sjelf kan komma och äga bestånd”. Näringarna hade följaktligen en viss självreglerande förmåga, och uppdelningen mellan dem fick inte bli för strikt. Stockenström avlägsnade sig än mer från Vetenskapsakademiens vedertagna ekonomiska ideologi när han inte fördömde att jordbruket och bergsbruket var sammanblandade, utan gjorde gällande att de trivdes väl tillsammans och stärkte varandra. Lika avvikande var åsikten att jordbrukaren själv skulle ansvara för hushållandet med sin skog och skepsisen mot lagreglering av böndernas skogsbruk, med hänvisning till att den riskerade förstöra en självgående näring i ett läge där nya utkomstmöjligheter inte var tryggade, vilket skulle inverka menligt på befolkningstillväxten. ${ }^{410}$

En regelrätt apologi för hattarnas manufakturpolitik formulerades av kanslirådet Carl Albrecht Rosenadler, som förfäktade att fabrikernas och handslöjdernas nytta var en obestridlig sanning belagd i praktik och teori: "Man hade trodt Handaslögders och Fabriquers ypperliga bidragande til et Rikes flor, vara i detta Seculo [sekel], genom et allmänt tänkesätt uti Europa och de mägtigaste Nationers efterdöme, så tydeligen å daga lagdt, at knapt något inkast däremot skulle vågas. Så många grundeliga Skrifter äro ock därom hos oss, de förledne fyratio åren, utkomne, och de hafva med så utmärkt bifall blifvit uptagne, at alt vidare utförande [redogörande] kunde synas öfverflödigt." Icke desto mindre spreds en tes om jordbrukets företräde som hotade övertygelsen att det var nödvändigt att bistå manufakturerna och slöjderna. ${ }^{411}$

Merparten av Rosenadlers presidietal viktes åt en uppgörelse med den jordbruksvänliga riktningen, vars förespråkare tillmättes smittosamma irrsatser. Främmande länder och statistiska beräkningar togs till intäkt för att manufakturväsendet genererade nytta, välstånd och makt. Rosenadler fastställde att det företrädesvis agrara Polen låg närmare sin 
råhet och det näringsmässigt mer differentierade Tyskland närmare sin förädling. Slöjder och fabriker hade bättre expansionsutsikter och var mer inbringande än lantbruket - de hade redan givit stor vinst. Han betvivlade inte att fabrikerna och slöjderna skulle åtnjuta beskydd och lovade att de snabbt skulle mogna om bara den dittillsvarande politiken upprätthölls. Dock ansåg han att en klok regering samtidigt banade väg för andra verksamheter, eftersom näringarna var organiskt sammanvävda och rikets förbättring kom an på deras samverkan. Ingen av dem fick undertryckas till förmån för en annan; även jordbruket hade ett värde och behövde uppmuntras. ${ }^{412}$

Rosenadler modifierade liksom Stockenström det tidigare ekonomiskpolitiska synsättet genom att uttrycka tilltro till begränsad självreglering. Alla var inte fallna för samma värv och envar borde, förutsatt att den älskade lagen och hembygden, tillåtas följa sin begåvning och håg, varvid de enskilda skulle bli optimalt nyttiga för sig själva och för det allmänna. Då skulle människorna beredvilligt söka sig till näringarna istället för att drivas utomlands av fördärvade utkomstmöjligheter: "Näringar likna en öpnad damm, dit vatnet af egen tryckning inflyter, och arbetare tryta icke där, hvaräst de med fördel sysselsättas." Rosenadler lovordade därutöver mössornas kanslipresident Löwenhielm, som till hans och Vetenskapsakademiens förnöjelse stod i färd att tillträda ordförandeposten. ${ }^{413}$

Smicker av Löwenhielm återfinns också hos Kryger, som bland annat kallade honom en av rikets ypperligaste styresmän. Kryger tycks annars ha riktat förebråelser mot både mössorna och hattarna: "Partier kunna strida med sådan häftighet, hvart för sina afsigter, at det allmänna därvid lider, at Näringarne blandas i spelet, och antingen aldrig upkomma, eller råka i vanhäfd." Utsagan röjer dessutom ett negativt förhållningssätt till partiväsendet, något som kan förbindas med den desillusionerade attityd till det politiska systemet som kännetecknade många hattar inemot frihetstidens slut. ${ }^{414}$

Mössregimen utgjorde sannolikt måltavlan för ett resonemang om despotier, som Kryger attribuerade godtycke, impulsivitet, misströstan, tarvlighet och trälaktig rädsla. Ämbetsmännen betedde sig i detta system som tyranner och invånarna hade knappt frihet att andas utan 
att bötfällas eller åtalas. Undersåtarnas egendomar och liv tillhörde inte dem själva, och nästan ingen värre förbrytelse existerade än att vara förmögen. Kryger underströk i kontrast äganderättens värde och redogjorde för hur den var av godo för olika grupper i samhället. Inte minst för borgaren, som visade sig flitig när han fick vara välbärgad utan att avundsjukan lade beslag på hans rikedomar eller omintetgjorde hans berömvärda vinstlystnad. Makthavarna borde betrakta den rike näringsidkaren som förtjänt av särskild aktning: "de hedra honom, efter han gjort sig därtil värdig, genom sin idoghet och sitt fruktbara snille; de anse honom som en Fader, för et stort antal barn, hvilka taga kläder och föda ur hans händer; de afundas ej på hans förmåner, utan skatta Staten lyckelig, at hafva en sådan nyttig Medborgare; och det är deras glädje, när de finna många, som äro begåfvade med samma Naturens och lyckans egenskaper”. ${ }^{115}$ Allt detta går att läsa som en kritik av de förföljelser mössorna utsatte en rad hattar för efter maktskiftet 1765, i synnerhet köpmännen som skött Växelkontoret, vilka anklagades för att ha skott sig på Sveriges bekostnad. Deras straff sträckte sig från böter till livstids fängelse och väckte förbittring. ${ }^{416}$

Andra kommentarer verkar ha avsett de förutvarande styresmännen och låg delvis nära Mennanders kritik av hattpartiet året innan. Kryger framställde samhället som sjukt och näringslivet som rudimentärt. Han anmärkte att en fri regering trots goda grundlagar kunde hamna snett: "Krigs- och äröfrings-lystnaden kan jämväl där få öfverhand [...] egennyttan kan blanda sig både i Lagars stiftande och skipande [...] upmuntringar, belöningar och enskilda friheter [privilegier], kunna utdelas, ej til det meniga bästa, utan efter mannamon [partiskhet]; den allmänna Crediten kan försvagas, genom felaktiga anstalter, och den enskilda, genom rättvisans senfärdiga, eller ojämna steg.” Verkligt näringsvänliga styresmän månade om krediten, bedömde löftesbrott som högmålsbrott och tog sig an varenda näringsgren, under det att bestickning inte var någon genväg till att få eller behålla en bärkraftig näringsverksamhet. ${ }^{417}$

Kryger förblev likafullt lojal mot den ekonomiska ideologi som dominerat Vetenskapsakademien under hattarnas långa maktinnehav. Han hävdade dels att ett förmånligt näringsklimat förutsatte att den som 
hellre använde utländska än inhemska produkter definierades som en fiende till fäderneslandet. Dels, och möjligtvis i klinch med Högström, att samhället skulle tillfogas obotlig skada om ämbetsmän och ståndspersoner lärde sig att betrakta näringar som växter som grönskade eller vissnade av sig själva. Regeringen skulle se till att näringsutövarnas vinst "må tillika blifva Statens", att "Staten" drog maximal nytta av landet och inbyggarna, att ingen näring blev menlig för riket samt att varje näring erhöll sin rätta, av naturen bestämda hemort. Samtidigt skulle frihetsandan åstadkomma frivilligt patriotiskt agerande, och regelverket som tyglade näringsidkarens laster och gjorde dem allmännyttiga fick inte bli för strängt: "Det är lika vådeligit för Näringar, at, genom författningar, afmäta alla steg för deras idkare, och liksom qväfva vinnings-lystnaden, genom Lagarnes tyngd, som at låta egennyttan rasa onäpst [ohämmad] [- - ] den fattige arbetaren, äfven som den penningerike Borgaren, vil ej drifvas som en machine." Det viktiga var att människors handlingar inte stred mot "Statens bästa". Mindre konventionellt var även att Kryger förstod tävlan mellan invånarna som någonting godartat, och att han föreställde sig yttrandefrihet som ett sätt att skapa kunniga samhällsmedlemmar och trygga konstitutionens fortbestånd. ${ }^{418}$

Akademisekreterarens svar till de hattorienterade ledamöterna var i varierande utsträckning politiserade. Wargentin deklarerade att Ehrensvärds tal var värdigt honom och vittnade om hans gynnsamma personlighetsdrag, men underlät att ta ställning till innehållet. Svaret till Stockenström var mer politiskt och hävdade att förekomsten av flera ömsesidigt förstärkande näringar lämnade utlänningarna minsta möjliga vinst. Wargentin betonade visserligen jordbruket men poängterade att andra näringar, som handslöjderna, handeln och bergsbruket, också behövdes och att de bidrog till att förbättra lantbruket. Ett liknande anslag kan identifieras i hans svar till Kryger, vilket förklarade att Vetenskapsakademien skulle biträda varje näring. ${ }^{419}$

Mest politiserat var svaret på Rosenadlers tal, som slog fast att allmänheten hade anledning att förvänta sig upplysning från akademien när skiljaktiga åsikter förelåg i betydelsefulla ekonomiska spörsmål. Även om kanske inte alla samtida iakttagare förstod akademiens utlåtanden som yttringar av välmening skulle framtiden inse faktum och 
hysa tacksamhet mot organisationen. Wargentin anslöt sig efter denna utvikning helhjärtat till Rosenadlers försvar av manufakturerna, vilka han synbarligen sökte få mössregeringen att fortsätta stödja: "Frågan om Handa-slögders nytta [...] är af stor vigt, och har tyckts redan vara så utredd, at den ej behöfde vidare bevis; men efter en och annan åter börjat draga deras nytta i tvifvelsmål, är väl at I [Rosenadler] med nya skäl bestyrkt sanningen. Vi böre hoppas, at en blidare Sol, efter några års oväder, skal befordra dessa angelägna Näringars tilväxt." ${ }^{\prime 220}$ I likhet med sina ledamotskollegor fortfor sekreteraren att färgas av hattperiodens ideologiska positioner samtidigt som dess ekonomisk-politiska hållning luckrades upp.

Löwenhielm höll 1767 ett presidietal om ungdomens uppfostran som tillmätte riket omfattande brister, varnade för ett förestående barbari och i radikal anda pläderade för folkundervisning. Utbildningsväsendets eländiga tillstånd berodde enligt uppgift i lägre grad på läroanstalterna än på yttre faktorer, framför allt författningarna. Mot bakgrund av detta och att han åberopade de åtgärder som med den äran vidtagits av mössriksdagen 1765-66 kan Löwenhielms utläggning förstås som ett angrepp på det kullkastade hattväldet. Han förde också en socialkritisk argumentation jämförbar med men mer utvecklad och långtgående än Mennanders. Löwenhielms tal diskuterade hur vällust, överflöd och lättja leder till en mängd laster, och hur den mytiske antike härskaren Minos av Kreta genom att eliminera dem lättare än genom egendomsomfördelning skapat en jämlikhet som utgjorde grunden för den rätta friheten. Talet andades beundran inför meritokratiska system som det $\mathrm{i}$ antikens Aten, där människor ärades efter förtjänst. Denna princip borde gälla inte minst vid ämbetsverken, där ingen borde utnämnas till någon tjänst som krävde kunskaper utan att dessa tillstyrktes av universiteten och ämbetsverken. ${ }^{41}$ Löwenhielm tyckte illa vara om att förmögna och förnäma av inbilskhet och fåfänga inte ville att deras barn skulle gå i skola med gemene mans, vilket innebar att de förvekligades och varken blev kunniga eller sedliga. Kanslipresidenten tillskrev barn från det högre samhällsskiktet ett lättjefullt leverne och tomma huvuden, och föreslog att deras undervisning skulle underställas tillsyn med hjälp av biskoparna och Kanslikollegium. ${ }^{422}$ 
Löwenhielms sociala kritik hade emellertid klara gränser. Han betraktade det som naturvidrigt att utgå från att alla rikskroppens lemmar hade samma förmåga, myndighet eller anseende. Den jämlikhet han föreställde sig handlade om att undanröja de destruktiva motsättningarna mellan stånden genom att ge alla möjlighet att sträva högre och efter mer i överensstämmelse med sin läggning, kapacitet och potential. Löwenhielm förkunnade vidare att den ostyriga och obetänksamma ungdomen kunde dra avsevärd nytta av i princip konstant lärarövervakning och att utbildningsväsendet skulle vänja denna vid ordning och underkastelse. Utbildningens övergripande mål var att förbättra sinnelaget, tukta viljan, inpränta gudsfruktan och dygd och förmedla ett begrepp om sann ära, vilken bestod "icke uti höghet, rikedom, börd med flere lyckans håfvor, utan uti et ständigt bemödande, at upfylla alla sina plikter emot Gud, sig sjelf, sin Nästa, sin Öfverhet och Fädernesland”. Den villkorade jämlikheten och underordningens didaktik ackompanjerades av en kallsinnig inställning till folket, som ansågs vara okunnigt och egenmäktigt. Den bakåtblickande menighetens deltagande i den romerska republikens styrelse uppgavs ha medfört en kunskapsfientlighet som talet beskrev i termer av "ouplyst välmening" och "det blinda allarmet". ${ }^{423}$ Löwenhielms socialkritiska ansats gick förvisso längre än Mennanders, men hade liksom den påtagliga instrumentella aspekter, som i mössledarens fall förenades med en auktoritär inställning.

Löwenhielm lade stor vikt vid konkurrens, som i hans ögon var alla stordåds moder och kunskapens och sedernas främsta drivkraft. Avundsjuka var till dels mer nyttig än skadlig eftersom den stimulerade tävlan, bringade sinnen i rörelse och framkallade en livlig handlingskraft. Historien och utlandet fick åskådliggöra konkurrensens nytta. Till exempel hade de skolor Sveriges konungar inrättat varit ämnade att generera vetenskapliga framsteg genom tävlan mellan eleverna, och "inbördes täflan i det goda" utgjorde hela den kinesiska styrelsens liv. ${ }^{424}$

Wargentins svar till Löwenhielm smickrade honom genom att ta upp bland annat hans förträffliga insatser för utbildningsväsendet och hans lysande förtjänster ifråga om riket och Vetenskapsakademien. Sekreteraren anknöt till presidietalets tema när han kungjorde att ungdomen skulle undervisas i dygd, gudsfruktan, patriotism samt respekt för lagar 
och överhet, och att den skulle förvissas om värdet av flit. ${ }^{425}$ Några ekon av Löwenhielms sociala kritik står däremot inte att finna.

Samlaren Bengt Bergius refererade och citerade strax innan hattarnas återkomst till makten Löwenhielms Tal, om landt-skötsel från 1751, under det att han prisade hattarna Höpken och Cederhielm. Bergius förklarade att den pågående riksdagen var en lyckosam och historiskt viktig händelse. Ständerna sammanträdde för att se till landets behov och efter moget övervägande sätta in de mest kraftfulla medel för att rädda det. Därigenom skulle vetenskaperna, konsterna och näringarna beredas en gynnsam framtid, och nå en blomstring som gjorde att Sverige åter avundades snarare än ömkades utomlands. ${ }^{426}$ Hänvisningarna till politiker från båda partierna och den allmänna förhoppningen att ständerna skulle röna framgång tyder på att Bergius sökte hålla sig väl med alla under den ännu oavgjorda kraftmätningen. Ekonomiskpolitiskt var talet ganska tunt; Bergius upphöjde jordbruket, vände sig emot import och förespråkade odling av främmande växter, med förbehåll om att vissa av dem inte gick att acklimatisera. Wargentins svar noterade bara att många inhemska djur och växter hämtats utifrån och att mycket antagligen återstod att göra på detta område. ${ }^{427}$

Presidietalen kom under mössornas regering att mera än förut präglas av social kritik och tankar om självreglering, samtidigt som hattväldets försanthållanden dröjde sig kvar. Som nästa avsnitt skall visa förstärktes den sociala kritiken under hattarnas andra tid vid riksrodret medan självregleringen tonades ned, låt vara att föreställningar om nyttofrämjande konkurrens vann mark. Konkurrens låg tematiskt nära avreglering och därmed nära idéer om ett mer självgående samhälle, varför uppslagen om tävlan kan ses som ett symptom på djupgående förskjutningar i den ekonomiska ideologin. ${ }^{428}$ Som nästa avsnitt ger vid handen var den konkurrens ledamöterna laborerade med dock som regel inte en kraft i egen rätt, utan en funktion av makten.

Den manufaktur- och regleringsvänliga ekonomiska politikens företrädare var skeptiska till konkurrens, vilken liksom en marknad lämnad åt sig själv upplevdes som någonting primitivt och som ett hot mot ordningen, säkerheten och sederna. Om dygden och affekterna antogs vara samhällsutvecklingens och ekonomins förnämsta drivkrafter fanns det 
inte mycket utrymme för att gestalta eller sätta sin lit till hushållningen som ett självständigt, lagbundet, opersonligt och förutsägbart system. ${ }^{429}$ Synen på tävlan och en autonom marknad som någonting primitivt kan knytas till en under 1700-talet gängse dikotomi mellan det naturliga och det människoskapade som i sin tur går att förbinda med naturrätten, vilken var sammanflätad med den ekonomisk-politiska diskussionen och för svenskt vidkommande framför allt uppträdde i Samuel von Pufendorfs tappning. Ur Pufendorfs perspektiv hade statsmakten till uppgift att "förbättra och civilisera med det otuktade samhället som råmaterial. Staten var förnuftets inkarnation och instrument och utan den skulle människan vara en vilde". ${ }^{430}$ I bakgrunden anas den aristotelisk-kristna tanken att naturen skapats som potentialitet och att dess aktualitet enbart kan förverkligas genom målmedvetet mänskligt handlande, vilket därvidlag uppfattats som en väsentlig del av vad det innebär att vara människa. ${ }^{431}$

\section{Hattarnas återkomst}

Flera ledamöter visade efter hattpartiets återtagande av makten prov på en i hög grad välvillig inställning till handel, kanske som en reaktion på manufakturpolitikens misslyckande. Det hette att samhället uppfyllde sina behov främst genom handeln, och att sjöfarten band samman världen och gjorde människorna delaktiga i alla dess härligheter, som vore de en enda samhällsgemenskap. Kritik riktades mot dem som i sin okunnighet och dårskap trodde att det som fordom skulle vara möjligt att undvara varuförädling, omfattande handel och mindre nödvändiga tillverkningar. ${ }^{432}$

Johan Liljencrantz gjorde gällande att handel gav liv och rörelse åt de övriga näringarna och ofta var nödvändig för att förbättra ett rike. Handeln hade en avgörande betydelse för välståndsutvecklingen i Sverige och skulle beford ra de tilltagande slöjderna. Liljencrantz menade att naturen försett länder med olika förmåner för att få till stånd handelsutbyten. Han attackerade mot bakgrund av denna tes, i ett resonemang som kan tolkas som ett ifrågasättande av den inplantering Bengt Bergius och Wargentin nyligen förordat, länders försök att producera allt själva: 
DET VILLRÅDIGA SAMHÄLLET

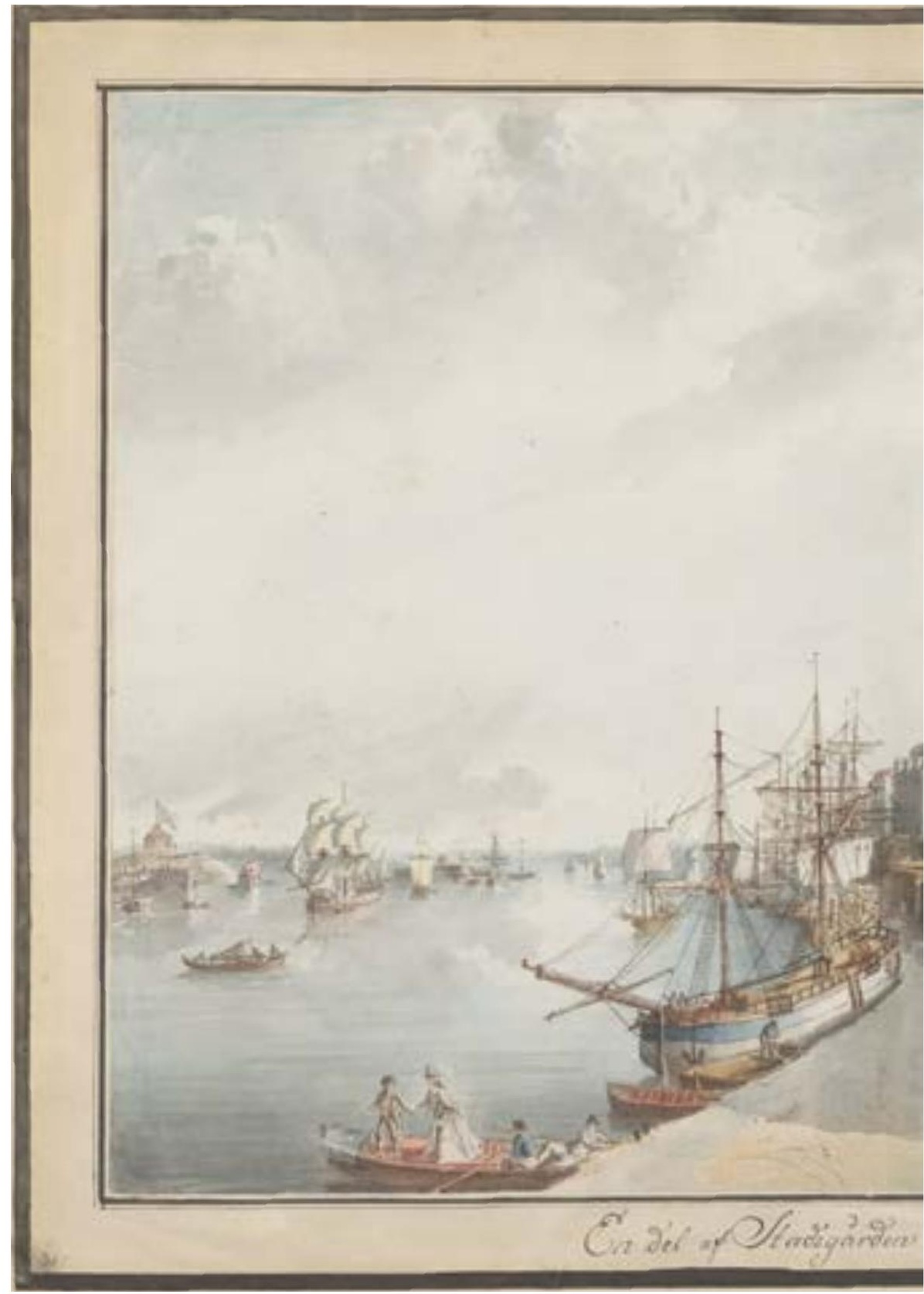

Bild 8. Martin Rudolf Heland, En del af Stadsgården kallad Barlastplaçen. Foto: Uppsala och bejakade export av förädlade produkter. 


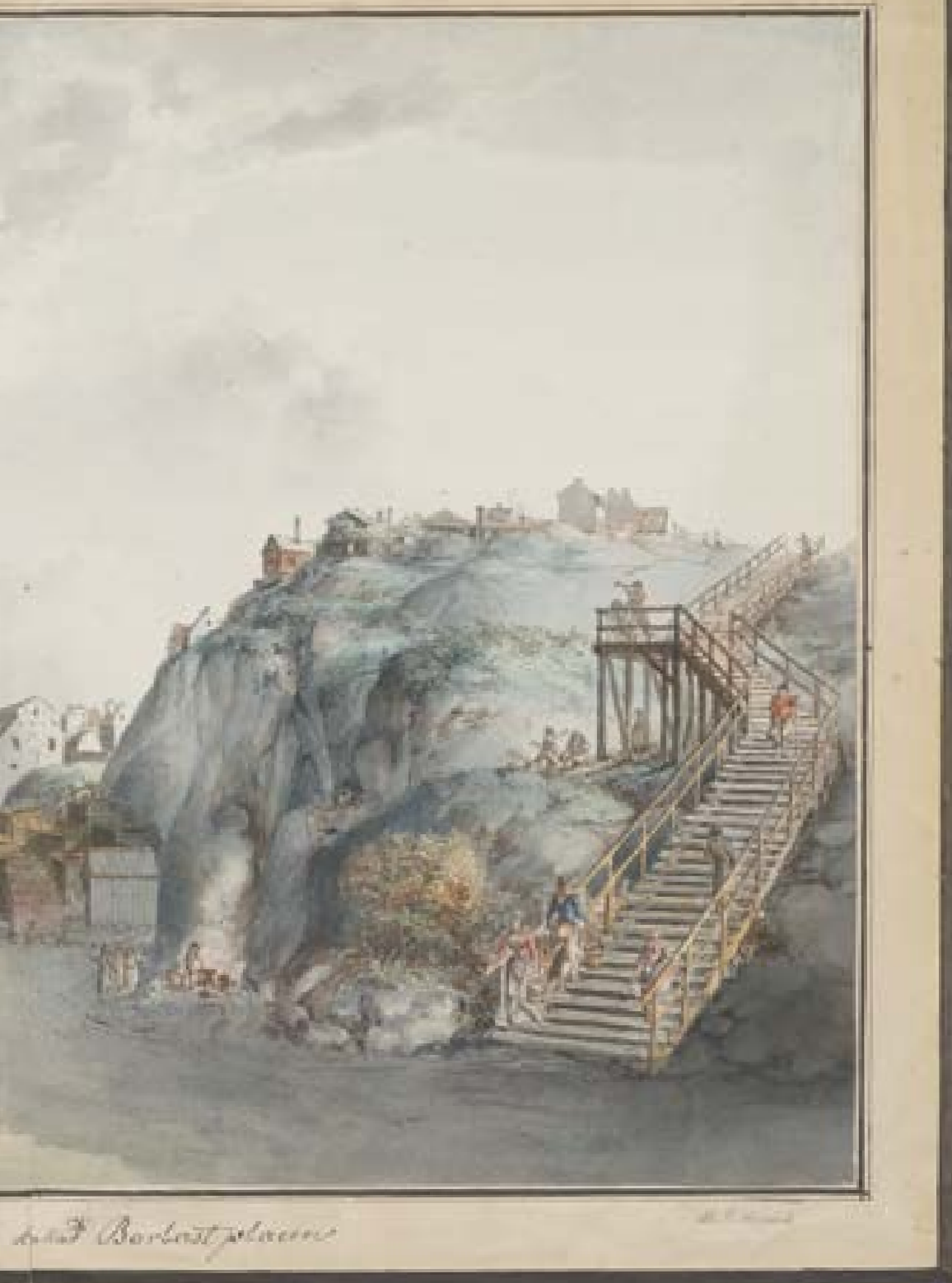

universitetsbibliotek. Vetenskapsakademiens medlemmar ställde sig avvisande till import 
"Det ser ut, som de fleste Riken tro sig ej kunna vara rätt lyckelige, utan at aldeles umbära hvarandra. Inga medel och utvägar, som härtil kunna bidraga, försummas. Och man vil i denna afsigt likasom tvinga sjelfva naturen.” Invånarna i ett kallt land lade trots att de saknade åtskilliga av livets väsentligheter energi på att odla "en växt, som endast är ämnad at förvandlas i rök, och med ringa möda och kostnad frambringas til långt bättre beskaffenhet i de varmare Länder, som naturen ämnat til den sammas rätta hemvist”. Sådant hade sannolikt ofördelaktiga konsekvenser för industrin och handeln, och kunde bara avhjälpas om människorna tröttnade på att gå emot naturen eller om en avancerad internationell konkurrens återställde allting till sin naturliga ordning. ${ }^{433}$

Enligt köpmannen Johan Clason fanns det inget som i sig självt var ett bättre uttryck för strävsamhet än handeln och inget som var så obetydligt att den inte kunde ta det $\mathrm{i}$ anspråk. För att kommersen skulle bli nyttig krävdes emellertid att den fick "sin egen skötsel" och att ett antal samhällsreformer genomfördes. Dit hörde lika rättigheter och skyldigheter, säkerhet för egendom och person samt opartisk och likvärdig rättskipning. Betonandet av jämlikhet åtföljdes av en adelsfientlighet som kan förbindas med det omgivande samhällets infekterade ståndsmotsättningar. Clason lutade sig mot historien och meddelade bland annat att förnämare och förmögnare kringgått överflöds- och yppighetsförordningarna, som dock tillämpats och ännu tillämpades strikt på gemene man. Drottning Kristinas regeringsperiod hade inneburit att de mäktigare inkräktat på de svagare; dess frälse beskylldes för självsvåld och egenintresse, och borgerskapets tillstånd tecknades i mörka färger. En liknande bild gavs av Karl X Gustavs och den efter hans död tillsatta förmyndarregeringens styren, då brist på näringar rådde och borgarna tyngdes av den fåfänga adelns stadsgrundanden. Clason lade skulden på Karl X Gustavs rådgivare, som gynnat sig själva och högfärdigt tryckt ned borgerliga aktörer men omsider tvingats göra eftergifter till det kuvade borgerskapet. ${ }^{434}$

Samme preses ställde sig däremot klart positiv till borgarna. Han framhävde att de svenska konungarna värderat dem som givit statsmakten ("Kronan") inkomst och landet näringar lika högt som dem som varit involverade i rikets styrelse och försvar. Köpmännens hårda 
slit hade gynnat riket och även om dessa inte lyckats förvärva strålande heder borde de åtminstone inte stämplas som farliga, eller som judar och blodiglar. Clason menade att samtidens handelsidkare försvagats och att de skulle vinna större förtroende om deras barn uppmuntrades gå i deras fotspår. Det ökade förtroendet skulle föra med sig stabil kredit och göra att handelsmännen uppfattades som den nationella skatt de verkligen var. Utländska förhållanden användes för att driva hem argumentationen; främmande länder värdesatte sina handelsmän, och engelsmännen och holländarna höll borgerskapet så högt att kungligheter inte tvekade att ingå i dess led. ${ }^{435}$

En likartad apologi för det svenska borgerskapet tillhandahölls av Liljencrantz, som förkunnade att tankar och gärningar, inte ståndstillhörighet, definierade stora män. Få hade bättre möjlighet att gynna samhället och visa människokärlek än köpmännen, varför förtjänta representanter för denna grupp i större utsträckning borde bli ihågkomna. De som omsatte betydliga summor, bedrev vidsträckt handel på avlägsna orter och livnärde tusentals kunde inte "tåla at blifva bortblandad[e] med små-folk”. Sådana köpmän skulle äras så till den grad att de inte längre behövde innehållslösa hederstitlar, och på samma sätt som andra medborgare som var samhällsnyttiga utöver vad deras allmänna plikter föreskrev. De skulle även tillåtas bli rika utan att utsättas för avundsjuka, under förutsättning att rikedomen inte förvärvades på nästans bekostnad. Liljencrantz lyfte fram historiska personer som bruksägaren Louis De Geer, vilka efterlämnat hedrande bevis för sina stora tjänster till riket samt för det förgångnas samvetsgranna belönande av sann förtjänst oavsett social status. Han nämnde också mer sentida, hattanstrukna entreprenörer - "GRILLAR, PLOMGRENAR, med många andra, hvilkas förtjenster af det allmänna äro bekante". Förutom ädel vilja förutsatte de gärningar den sortens aktörer utfört en tillräcklig förmögenhet, som inte kunde samlas om handeln var bristfälligt vårdad och associerad med osäkerhet, eller om köpmännen föraktades istället för att äras. ${ }^{436}$

Clasons och Liljencrantz välvilliga attityd till borgerskapet hade en förelöpare hos Carl Fredrik Adelcrantz. Denne åberopade i sitt presidietal 1757 den naturliga rättvisan, som tillät de ringare att eftersträva 
skicklighet, dygd, belöningar, ära och välmående i lika hög grad som de förnämare. Han underströk att konstnärer och konstkommers inte understöddes bara av monarkerna och de förnäma utan även av borgarna, som naturen berättigade till samma bekvämligheter och förnöjelser som adelsmännen. ${ }^{437}$ I detta sammanhang finns det skäl att erinra om att hattarna var en allians mellan nyadliga och borgare, samt om att de har betecknats som "på sitt sätt radikala", inte minst eftersom de fångade upp borgerskapets utvecklingspositiva strömningar. ${ }^{438}$

Ansatser till en mer subversiv åskådning återfinns i kanslirådet Sten af Rabbes (Rabbe) tal, som uttryckte sig uppskattande om republiker och jämn egendomsfördelning under antiken. Bland annat hyllades den spartanske regenten Lykurgos egalitära samhällsordning som ett mästerverk. Rabbes subversivitet skall dock inte överdrivas, då han inte stod främmande inför makthavare som höll uppsikt över och reglerade samhället. Riken som gick från expansion till begynnande stagnation behövde kloka och uppmärksamma styrande, som visste att i tid motverka dåliga exempel samt var förtrogna med landets resurser och förstod att förmera och fördela dem så att ingen lämnades utan bärgning eller gemenskap med det allmännas väl. ${ }^{439}$

Samtidigt som den sociala kritiken blev mer iögonenfallande vann idéer om nyttofrämjande konkurrens i styrka i den slutande frihetstidens presidietal. ${ }^{440}$ Konkurrensen hade emellertid en annorlunda prägel än hos Löwenhielm genom att den för det mesta förbands med makthavarna och inte framstod som en kraft i egen rätt. En ledamot ville att regeringen skulle uppamma näringarna och få dem att samspela så att riket stärktes i tävlan mellan de upplysta folken. En annan konstaterade att den befordran av näringar och vetenskaper som 1738-39 års hattriksdag beslutat om sammanfallit med en "synnerlig täflan [...] at upfylla ett prisvärdigt ändamål" och att akademiens lycka över Gustav III:s ynnest skulle manifesteras i snillrik tävlan mellan medlemmarna. Liljencrantz beskrev medtävlan som nyttig och uppfattade vid sidan av uppmuntringar inhemsk konkurrens som ett redskap i förbättringen av näringarna. Om svenska kläder fortfarande var för kostsamma borde det noga ses till att produktionskostnaden minskade och att all möjlig medtävlan sattes in. ${ }^{441}$ 
Presidietalen tenderade annars att med modifikationer utlägga det ideologiska arvet från hattpartiets glansdagar. När Liljencrantz fastslog att jordbruket utgjorde ett rikes sanna och säkraste rikedom påtalade han också handelns och slöjdernas värde. De borde värnas och premieras, då de var sammanflätade med lantbruket. Han hyste tilltro till klädindustrin och dess internationella konkurrenskraft, medan manufakturväsendet framställdes som lovande och framgångsrikt. ${ }^{442}$ Liljencrantz anmärkte att varken Levantiska kompaniet eller det understöd företaget uppburit varit behäftade med fel och tyckte illa om den fria handel som följt på bolagets avveckling. Även om handelns behov av frihet var allmänt känt och en fri handel på Levanten kanske kunde vara något för framtiden, hade samtiden behov av ett återupprättat handelskompani med ensamrätt på den tullfrihet som måste till för att förmögna skulle engagera sig. Detta kunde upplevas som inskränkning och tvång men var ändå bättre än en öppen och fri handel som sköttes av ett fåtal personer. Liljencrantz argumenterade i denna kontext mot import av förädlade produkter och för införsel av råämnen i utbyte mot förädlade svenska varor, samt för att export skulle inramas av generella uppmuntringar. ${ }^{443}$

Till Liljencrantz rättfärdigande av slöjderna, rehabilitering av Levantiska kompaniet, fientlighet mot import och tonvikt på export av förädlade produkter kom föreställningar om arbetsfördelning och statlig styrning. Han ansåg att handelsföretagen borde vara specialiserade, och opponerade sig mot den oordning och fördärvliga blandning som han menade var kännetecknande för Sverige. Det bästa vore om köpmännen själva tog itu med specialiseringen i överensstämmelse med den frihet handeln krävde; om så inte skedde borde dock ständerna ingripa och reda upp situationen. Samma interventionistiska inställning hittas i en diskussion om etablerandet av svenska handelskontor utomlands, vilket enligt Liljencrantz primärt var handelsmännens ansvar. Det fanns likafullt en risk att kontoren skulle dröja länge än om inte de styrande fullt ut vinnlade sig om och kraftfullt lade grunden för dem. Handelsmännen antogs dessutom inte bli patriotiska, samhällstillvända och nyttiga utan hjälp av goda författningar och maktens välgörande omvårdnad. 
Författningarna skulle utformas så att köpmännens strävan efter vinning gagnade det gemensammas väl. ${ }^{444}$

Den vedertagna ekonomiska ideologin besjälade också Clas Alströmer, som ogillade import, uppskattade manufakturer och framhöll makthavarnas inflytande över näringsverksamheten. Utländska historiska monarker betraktades som garanter för yllevävandets och fåravelns framsteg; till exempel hade den medeltida kastilianske konungen Alfonso XI:s beskydd av boskapshjordarna besannat ordspråket "Husbondens öga gör Hästen fet". Alströmer tilltalades av Spaniens reglerade fårskötsel och försvarade yllemanufakturerna, grundvalen för flera europeiska länders förbättring och blomstring, och en industri som alltid betytt mer än bergsbruket eller silkesodlingen. Han tvivlade inte på att "dessa slögders anläggande och sorgfälliga vård äfven så mycket å ena sidan stadgat Engelands välmåga, som obekymmersamma försummandet deraf å andra sidan bidragit til vår fattigdom”. Alströmers tal hade därtill mer okonventionella inslag. Han angav att friheten jämte handeln, råvarutillgången och regeringens omtanke låg bakom de brittiska yllemanufakturernas framgång och hyste viss tillförsikt inför ståndspersonernas och allmogens förmåga att på egen hand förbättra fåraveln. ${ }^{445}$

Några av presidietalen smickrade namnkunniga företrädare för hattpartiet. Liljencrantz, som var vänligt stämd till den pågående hattriksdagen 1769-70 och hoppades på dess finanspolitik, komplimenterade en av Höpkens bröder och ett antal hädangångna hattar, inte minst Tessin. Samuel Sandels tog upp Höpkens politiska, vetenskapliga, litterära och personliga fördelar samt positionerade hattfunktionärer som köpmannen Thomas Plomgren jämsides vetenskapsmän som Klingenstierna. Han ställde Plomgrens kollega och meningsfrände Claes Grill i gynnsam dager på grund av dennes insats för Vetenskapsakademiens astronomiska observatorium. ${ }^{446}$

Sandels levererade en regelrätt apologi för Carl Gyllenborgs maktövertagande och styre när han hävdade att ständerna vid 1738-39 års riksdag inte lät någonting

hindra sig, med mindre [än att] Riket måtte sättas i tilstånd, at nyttja sina naturliga förmåner, til vår egen förkofran och sällhet. [- - - Vetenska- 
per, Näringar och rörelser fingo vid den Riksdagen njuta de kraftigaste upmuntringar. En synnerlig täflan förmärktes, at upfylla ett prisvärdigt ändamål. Åtskilliga Snillen framlyste, som öfvat sig i mera, än den Scholastiska Philosophien. Vi njute i detta vårt ljufva Samqväm och sälla lugn en välsignad frukt deraf.

Talet uppställde en katalog över allmännyttiga åtgärder som hade vidtagits under Adolf Fredriks regering, varav många av hattarna, till exempel inrättandet av Åbos ekonomiprofessur och förbättringen av järnindustrin. Trots detta sade sig Sandels utelämna mycket som blivit gjort för vetenskapernas, slöjdernas och hushållningens upphjälpande. ${ }^{447}$

Alla var inte lika intagna av den politik som hattarna fört. Clason slöt upp bakom centrala inslag i deras ekonomisk-politiska program när han förhöll sig negativ till import och drog en lans för exportpremierna och manufakturerna, speciellt Jonas Alströmers Alingsåsverk. Han framförde dock samtidigt kritik mot det ryska kriget, som tillsammans med andra oroligheter varit förödande för Sverige och saboterat läkeprocessen efter stora nordiska kriget, samt mot det pommerska kriget, som förvärrat rikets ekonomiska bekymmer. Clason ställde sig även avvisande till Växelkontoret, som varit "et palliative" och inte ett botemedel. ${ }^{448}$

Frihetstidens sista presidietal, Anders Schönbergs Tal om näringarnas inbördes förbindelse, hölls i mitten av juli 1772, drygt en månad före statsvälvningen. Talet var på många vis ett fullödigt uttryck för hattpartiets åskådning, men hade på samma gång en stark frihetlig ådra. Schönberg tillkännagav här att samtliga näringar var nyttiga och nödvändiga, att slöjderna och lantbruket förutsatte varandra samt att alla näringar skulle gynnas och skapa välstånd med förenade krafter. Trots detta och att talet diskuterade de problem som tryckte jordbruket hade Schönberg ett extra gott öga till slöjderna, som förhindrade att stora ekonomiska belopp flöt ut ur landet. Den som betvivlade dem gick utlänningarnas ärenden och fronderade mot såväl erfarenheten som förnuftet. Fabrikernas nytta för riket bekräftades, och antipatin mot dem beskrevs som en skadlig och vederlagd fördom; upplysta styresmän såg alla slöjder som förmånliga och kände stolthet över fina 
inhemska varor. Å andra sidan framställde Schönberg handeln som hushållningens primus motor, då den gav liv och rörelse åt resten av näringarna, inklusive slöjderna. ${ }^{449}$

Schönberg var en förespråkare för befolkningstillväxt och arbetsfördelning. Han rörde sig med den gängse uppdelningen mellan råvaruanskaffande landsbygd och förädlande och handlande städer, även om han medgav att gränsdragningen inte alltid gick att upprätthålla. Schönberg satte i linje med sin manufakturvänliga inställning städerna och deras näringar främst: "Lantbrukets välstånd, och således äfven de öfrige Näringars i alt hvad däraf beror, härflyter förnämligast af StadsNäringarnas, Handelens och Slögdernes, hvilka följaktigt grundlägga Närings-medlens uphjälpande, och hvarförutan man altid tråkar i gamla spåret, utan at hinna särdeles längre på Närings-vägen." Han hänvisade också i detta sammanhang till erfarenheten, som enligt honom entydigt styrkte att rätt utformade stadsnäringar förbättrade hela näringslivet och gjorde näringarna kapabla att understödja varandra. Städernas undermålighet innebar att landsbygden inte kunde avyttra sina produkter, vilket återverkade på städerna och orsakade inkomstbortfall för bönderna. Resultatet blev att de måste ägna sig åt slöjder, som sköttes illa och kom i vägen för deras egentliga sysslor. ${ }^{450}$

Importfientlighet var ett annat ledmotiv hos Schönberg, som proklamerade att Gustav Vasas tid varit mörk eftersom konungen tvingats införa åtskilliga råämnen, att kortmakare borde räknas som nyttiga medborgare eftersom deras produkt dem förutan hade fått hämtas från utlandet samt att rikets fabriker medfört ansenliga besparingar. En motvilja mot fabrikerna var något för utlänningar som tjänade på frånvaron av inhemska näringar snarare än för svenskar. Schönberg ställde, föga förvånande, export av förädlade produkter i ett positivt ljus; det land var lyckligast som ägde flest åtråvärda varor för bearbetning och handel. ${ }^{451}$

Till det nyskapande stoffet i Schönbergs tal hörde föreställningen att näringarna samspelade bäst utan artificiella element och förordandet av en oinskränkt handelsfrihet som även borde omfatta jordbruket. Behovet av ömsesidigt bistånd mellan näringarna löste sig av sig självt "där vinnings-lystnaden gifver en ny drif-fjäder, at söka all möjelig 
förtjänst”, om bara makthavarna hjälpte till och röjde undan hindren. Den naturliga vinningslystnaden överskuggade samhällsdygdig självuppoffring och fliten behövde ingen annan uppmuntran än att den lönade sig: "idogheten skal då blifva allmän af sig sjelf, den skal belöna sig sjelf, och just igenom denna naturliga belöningen ständigt förökas". Vinningslystnaden skulle trots det hållas i schack och oskälig profit omöjliggöras exempelvis genom att den enskilde tilläts välja sitt eget värv. ${ }^{452}$

Schönberg anslöt sig vidare till synsättet att konkurrens var av godo för näringarna, vilkas framgång dock ytterst berodde på den säkerhet utövarna åtnjöt, som näringsidkare och som medborgare. Talet betonade i hög grad lagar och regleringar. De flesta problem näringarna mötte var avhängiga av eller kunde elimineras med författningar, medan det för deras del betydelsefulla förtroendet mellan medborgarna skulle vidmakthållas genom lagarna. Förutsägbarhet utgjorde av allt att döma en ledprincip för Schönberg, som ville att "alt beständigt" infogades "i en riktig kädja och Systeme, som icke altför ofta ryckes och förändras". Hans fokus på medborgerlig säkerhet kan ha influerats av hur mössorna behandlade hattarna i Växelkontoret. Schönberg menade att förlusten av välbärgade näringsaktörer kunde bli oersättlig, särskilt om skälen bakom var avskräckande, och att de borde tillförsäkras samma trygghet som alla andra "så at inga sken-grunder må vara möjeliga at emot Lag och billighet åtkomma deras förmögenhet, eller hindra dem at använda den til Näringarnas gagn". ${ }^{453}$ Det är svårt att befria sig från intrycket att detta resonemang hade en stark samtidskritisk udd.

En frihetlig hållning utmärkte även Schönbergs kritik av ansatser att dels förhindra eller detaljreglera landsbygdens hantverksproduktion, dels förverkliga sedoläran genom förbud och regleringar. Bestämmelser mot allmogehantverk var lika lönlösa som onaturliga, då det var en följd av städernas otillräcklighet. Om fler och mer tillgängliga städer erbjöd fler och bättre varor till lågt pris skulle uppdelningen mellan landsbygds- och stadsnäringar ske av sig själv. Vad beträffade sedoläran måste upplysta styrande inse att människan önskade "ledas vid sina naturliga böjelser, och icke våldföras til det goda". De lämnade medborgarnas privata övertygelser och uppförande i fred, så länge dessa inte skadade det allmänna bästa. Envar fick inrätta livet efter behag så 
länge han huvudsakligen konsumerade inhemska produkter och inte tog medmänniskors medel i anspråk. Medborgarna skulle dessutom informeras om näringarnas vikt och om sin patriotiska plikt att bidra till det gemensammas väl - i ett näringsidkande land sparades ingen möda på att få invånarna att flitigt ägna sig åt näringsverksamhet. ${ }^{454}$

Slutligen uppvisade Schönberg liksom Clason och Liljencrantz ett socialkritiskt anslag. Schönberg höll före att en låsning vid titlar och rang var menlig för näringarna och att näringssysslor borde ge lika hög status som ämbetssysslor. Han manade till respekt för de mindre välbeställda och ville att de förnäma skulle värdesätta näringsutövning och inspirera gemene man på det området. Schönberg värjde sig samtidigt, som tidigare Löwenhielm, mot idén om ett jämlikt samhälle: "Man förstår lätteligen, at jag icke ämnar förfäkta en dåraktig tanka, den [som] fåkunnighet och afund alstrat, om en oinskränkt likhet i stånd och vilkor uti Samhällen, en inbillad lycksalighet, äfven så omöjelig, som den skulle vara skadelig." ${ }^{455}$

Schönberg var efter Högström och Löwenhielm den som gick längst i ifrågasättandet av Vetenskapsakademiens ekonomiska ideologi. Självreglering och icke-interventionism utgjorde stommar i hans tal, vid sidan av betonandet av författningarnas roll - ett tema som förebådade den gustavianska era på vars tröskel han stod.

Wargentins svar fortsatte att smickra ordförandena och iaktta försiktighet med hänsyn till politiken, som sällan bereddes något utrymme i dem, förmodligen eftersom det politiska läget förblev ostadigt och polariserat. Svaret till köpmannen och hattpolitikern John Jennings nämnde både hans deltagande i riksdagens sekreta utskott och Vetenskapsakademiens tillfredsställelse över ständernas beslut att mer resolut gripa sig an konstruktionen av Trollhätte kanal. Det svar som ställdes till Schönberg lovprisade bland annat hans patriotism och kunskap om de rätta sätten att befordra medborgarnas samfällda lycka. Schönberg karakteriserades som en välsedd riksdagsledamot, som förhoppningsvis skulle få den enda belöning han eftertraktade, nämligen att dygd, tillit, endräkt, näringar, vetenskaper, konster och sann patriotism skulle tillta så att Sverige blev lyckligt. Det är tydligt att Wargentin i stor utsträckning instämde med Schönbergs ekonomisk-politiska ståndpunkter, 
medan omnämnandet av förtroende och enighet försonligt antydde möjligheten av en lösning på parti- och ståndsmotsättningarna. Mest politiskt uttalat var svaret till Clason, där sekreteraren hävdade att ett lands näringar inte fullt ut kunde trivas om de inte uppmuntrades av handeln, vilken borde ge dem liv och rörelse och var att anse som "Själen i Närings kroppen". Riksdagen skulle identifiera och tillämpa kraftfulla metoder för att uppliva näringarna i allmänhet och handeln i synnerhet. ${ }^{456}$

Genom statsvälvningen i augusti 1772 ritades den svenska politiska kartan väsentligen och oåterkalleligt om, något som hade en påtaglig inverkan på både den ekonomiska politiken och Vetenskapsakademiens ekonomiska ideologi.

\section{Gustaviansk ekonomi}

Gustav III:s regering innebar lika litet som mösspartiets styre någon drastisk omläggning av den ekonomiska politiken, vars frihetstida grundsatser låg fast under resten av 1700-talet, om än protektionismen och regleringsviljan mildrades en aning samtidigt som engagemanget för jordbruket ökade och manufakturpolitiken nedprioriterades. ${ }^{457}$ Nyttotänkandet förblev livskraftigt trots en allmän nyorientering i riktning mot vitterhet och sköna konster. ${ }^{458}$ Vetenskapsakademien kom under Gustavs spira att mindre än tidigare uppehålla sig vid ekonomiska principfrågor, som nu oftare hänsköts till makthavarna. Sven Bunges åsikt att de övergripande hushållningsförbättringar som kom an på överhetens författningar befann sig "utom den krets Kongl. Academien sig sjelf föreskrifvit" var symptomatisk för denna utveckling, som går att koppla till ett försvagat intresse för kontroversiella ämnen i den gustavianska offentligheten. ${ }^{459}$

Presidietalen rekommenderade liksom under frihetstiden arbetsfördelning mellan landsorter och näringar, men hade för det mesta en mer nyanserad syn på mångsyssleri. Bunge ansåg att förordningar inte gjorde människor nyttiga och att självreglering borde prägla det ekonomiska förhållandet mellan stad och land. Det allmänna bästa var oförenligt med en noggrann och av förordningar stipulerad gränsdrag- 
ning mellan stads- och landsbygdsnäringar - ömsesidiga behov och naturliga förmåner skulle "af sig sjelfve utsätta en sådan gräns, hvarvid et rådande hushålls-vett säkrast kan vägleda”. Enligt Samuel Gustaf Hermelin hade naturen sett till att provinserna koncentrerade sig på olika näringar, men vissa av dem var i alla fall ämnade till "blandade Närings-medel”. Han menade att allmogens bisysslande i samband med vävandet var nödvändigt och behövde utvidgas, låt vara att det på sina håll redan hade stor omfattning. De landsbygdsspinnerier som betjänade stadsindustrin hörde till de nyttigaste av inrättningar och gav allmogens kvinnor och barn utsikter till inkomst. Endast städerna skulle dock bedriva kommersiell tobaksodling och produktion som krävde dyra anläggningar eller kvalificerat arbete. Runeberg delade in folket i två grupper, stads- och lantborna, som förenades kring de sammanlänkade näringarna och täckte varandras brister. Denna deras gemenskap verkade av naturen forma sig själv och sätta sina egna gränser. Makthavarna fyllde likväl en viktig funktion, givet att "den naturliga relationen, som bör vara imellan dessa folkhopars antal, förändrar sig och kommer ur sit naturliga skick, om mödan och förmånerne å båda sidor icke varda bragte til någon jämnlikhet igenom författningar”. ${ }^{460}$

Andra ledamöter höll fast vid det starka motståndet mot näringsblandning. En av dem var Nils Adam Bielke, som uppgav att Gustav Vasa anslutit sig till den orubbliga sanningen att samhällets fortbestånd förutsatte ordning och därför vinnlagt sig om att skilja landsbygds- och stadsnäringarna åt. Reformationskonungen hade också upprätthållit en arbetsfördelning inom städerna, vilkas hantverkare inte skulle inveckla sig i handel. ${ }^{461}$ Arbetsfördelning fortfor att förknippas med kunskap i Vetenskapsakademien. Det hette till exempel att vetenskaperna inom akademien var "gemensamt vårdade, utan blandning, utan någonderas afsaknad" och att varje bergsman borde besitta såväl specialistkompetens som grepp om helheten. ${ }^{462}$

Även om gustavianska presidietal som regel var negativa till införsel av utländska produkter saknades vanligtvis de hårda omdömen som kännetecknade många frihetstida anföranden. ${ }^{463}$ Bergmästaren Bengt Qvist betraktade utrikeshandeln som ett nollsummespel. Han förespråkade att manufakturerna i första hand skulle nyttja inhemska råvaror 
och att import av mineraler som kunde brytas i Sverige inte skulle ske annat än för att förädla dem och återsälja dem till utlandet. Collegium medicum berömdes för sitt förståndiga beslut att stryka ett flertal poster från apotekens införskrivningslista. Jean George Lillienberg efterfrågade en nationell anda som tog avstånd från smuggling och "okyske begärelser til utlänskt [sic] kram", det största problemet för rikets metalltillverkning. Han målade upp en lycklig framtid där en säker grundval lagts för inrikes näringars upphjälpande och för deras frigörelse från utländska skulder och tvång. För Sandels vidkommande hade den svenska medeltidens största fel inom hushållningen varit att riket låtit utlänningar pracka på sig oumbärliga produkter som det själv kunnat framställa. Utan detta problem hade överflödsimporten inte varit beklagansvärd, lika lite som utrikeshandeln skulle ha medfört någon förlust om den varit måttfull och gått rätt till. Samme ordförande kontrasterade i ett tankeexperiment en evig svensk självförsörjning med vederbörlig hushållning och dito seder mot ett tillstånd där utbyte med omvärlden förändrade idéer och levnadssätt. Han konstaterade att det var olyckligt att ett folk oftast rörde sig mellan ytterligheter och att smaken riktades mot sådant som drog pengar ut ur riket. ${ }^{464}$

De gustavianska presidietalen intresserade sig mer än de frihetstida för acklimatisering av utländska växter, som var på modet under 1700talet och förekom framför allt inom ramarna för manufakturväsendet. Odling av silke och växter som användes för färgning hade haft en särställning under frihetstiden men gick samma oblida öde till mötes som manufakturpolitiken, samtidigt som försök med annan inplantering fortgick. ${ }^{465}$ Anders Sparrman meddelade att Gud placerat gagneliga och omistliga ting i färran världsdelar och att det är en mänsklig skyldighet att leta upp nyttigheter var de än befinner sig, vilket får den gynnsamma effekten att geografiskt vitt åtskilda folkslag kommer närmare varandra. Sparrman underbyggde resonemanget med exempel och påpekade att förståndiga svenska män, fäderneslandets och mänsklighetens välgörare, infört otaliga nya plantor i riket. Han förkunnade optimistiskt att växter går att överföra från ett klimat till ett annat, snarlikt och att mängden nyttiga växter kan utökas överallt. Vetenskapsakademiens roll i acklimatiseringen uppmärksammades av statssekreteraren Matthias 
Benzelstierna (Benzel), som rapporterade att organisationen funnit den under missväxtår tjänliga mangelroten gångbar i Sverige, låt vara att denna gjorde sig mindre väl i ett kallt klimat. Akademisekreteraren Wilckes svar underströk att det var och förblev organisationens föresats att för framtidens skull sätta nyttiga frön i fädernesjorden; därför hade den frekvent och med lyckosamma resultat fört in och demonstrerat förmånligheten av främmande plantor som tidigare varit helt eller delvis okända för svenskarna. ${ }^{466}$

Några akademimedlemmar hade en mer ambivalent hållning till introduktionen av främmande växter. Peter Jonas Bergius gjorde gällande att vissa frukter inte trivdes i det nordliga klimatet medan andra med framgång kunde inplanteras, däribland vinrankor, som han själv odlade. Hans bror Bengt rekommenderade acklimatisering av meloner, fastän Norden inte lämpade sig speciellt väl för dem, men noterade att fikon vantrivdes och att granatäpplen inte lät sig odlas i det kalla klimatet. Ett övervägande kritiskt perspektiv på acklimatiseringsprojekt anlades av Bunge, som slog fast att frihetstidens tilltro till utrikes plantor haft destruktiva konsekvenser: "Man betalar dyrt den ögonfägnaden, at frambringa en främmande växt, när brödet skal köpas. Kriget, näringarne imellan, måste uti så beskaffade omständigheter undfå nytt lif." Han anmärkte att det rått okunskap om klimatets och den geografiska belägenhetens för- och nackdelar, och att vissa trott allt vara möjligt. ${ }^{467}$

Ytterligare en ideologisk kontinuitet med frihetstiden var betonandet av förädlade varor. Wargentin framhöll vikten av inhemsk metallförädling och klandrade de förfäder som sålt stångjärn till utlandet för att sedan köpa tillbaka det i form av dyra bearbetningar. Lillienberg förklarade att bergshanteringen sökte höja mineralers och metallers värde genom förädling och att ingen torde ifrågasätta att de som upparbetade inrikes råmaterial hade företrädesrätt framför dem som drev rörelser baserade på utländska råämnen. England presenterades härvidlag som ett föregångsland, varifrån processer som mångdubblat det svenska järnets pris och gynnat dess export hämtats. Lillienberg redovisade Gustav III:s insatser för metallförädlingen och angav att en förteckning över alla de sentida manufakturer som hjälpt bergshanteringen skulle bli alltför lång. Han varnade för att exporten av grövre metallprodukter riskerade 
att drabbas av problem, varför det fanns desto större anledning att i tid gå in för den lukrativa och hedersamma förädlingen. ${ }^{468}$

Den frihetstida manufakturvänligheten fortlevde i somliga av de gustavianska presidietalen. Hermelin upplyste om att Härnösands linnefabrik hade åstadkommit ansenlig nytta genom att få människor att tillägna sig nya grepp, liksom om att Alingsåsverken varit ett viktigt exempel för den inhemska fabriksutvecklingen och gjort Älvsborgs allmoge begiven på fåravel. Hans manufakturförsvar framgick som tydligast när han insisterade att inte alla resurser som lagts på fabrikerna kastats bort och att riket tjänat mycket på satsningen, som bara skulle bli mer lönsam i takt med att dessa inrättningar tillväxte och förbättrades. En annan apologet för manufakturväsendet var Carl Sparre, som fann att allmän rikedom emanerade ur fria konster, handel och slöjder. Sveriges slöjd-och manufakturvaror var hedrande och lönande för sina upphovsmän, och väckte beundran utomlands. ${ }^{469}$

En del ledamöter riktade tvärtom kritik mot manufakturpolitiken. Ett yttrande hos Lillienberg om "en konstlad och ostadig rörelse-art" syftade av allt att döma på manufaktursystemet, som han även konfronterade mera explicit:

Vi måge icke klandra, hvad andre, i bästa välmening, gjordt; men önskeligt vore, at vi nu hade i behåll något af de stora Penninge-summor, som blifvit utgifne til andra, på utrikes rå-ämnen grundade, och redan til en stor del, kan hända, genom oförsiktig anläggning och drift, förfallne Fabriquer, at i stället kunna användas til Sjö- och Ström-rensningar, Canaler- och Slussbyggnader: Bergsbruket skulle derigenom få et nytt lif, och hushållningen öfver alt i hela landet, et bättre skick.

Bergsassessorn Gustaf Adolf Leijonmarck förefaller ha varit ute i ett liknande ärende då han konstaterade att det nyligen bevisats att oreda och misshushållning inom näringarna och rörelserna riskerade skada utrikeshandeln. Han hävdade också att mindre utvecklade näringar inte borde premieras på bekostnad av mer utvecklade, och att det var fördelaktigt att satsa på flera näringar som kunde förstärka varandra. Sandels både försvarade manufakturpolitiken och lyfte fram att den dragits med korruption, slöseri och missbruk av offentliga medel. ${ }^{470}$ 
Merparten av de gustavianska ledamöter som diskuterade frågan om näringarnas företräde hävdade jordbrukets primat. Lantbruket kallades för den äldsta och nyttigaste näringen, näringarnas moder samt "det säkraste medel, hvarigenom det första och nödvändigaste af alla behof kan upfyllas". Denna huvudnäring utgjorde den främsta grundvalen för rikets styrka och skulle förhoppningsvis snart nå sin högsta utvecklingsgrad, inte minst med tanke på att invånarna och de övriga näringarna led av att inhemsk spannmål var en begränsad handelsvara. ${ }^{471}$ Vetenskapsakademiens agrara ansträngningar berördes tidvis. Det uttrycktes att jordbruket var ett av akademiens stora syftemål och att dess förbättring alltid prioriterats av organisationen, som utlyst angelägna prisfrågor, delat ut uppmuntrande premier och förmedlat nyttig kunskap. Wargentin förklarade att en donation avsedd att befordra lantbruket hade det ädlaste ändamål och att Vetenskapsakademien såg sektorns upphjälpande som en huvuduppgift. Jordbruket var den näring "på hvars förbättring uti vårt kära Fädernesland, vår til de practiske Vetenskapers upodlande egenteligen stiftade Academie, för sin lilla del, troget arbetar, och derföre med största fägnad emottager alla derpå syftande goda råd och föreställningar”. ${ }^{472}$

Samtidigt framfördes liksom under frihetstiden åsikten att en näring inte ensam kunde skapa tillräcklig välmåga. Jordbruket var visserligen en huvudsektor, jämte bergshanteringen, och de verksamheter som förädlade inrikes råvaror stod över dem som utgick från utländska. Ändå måste samtliga nyttiga näringar förkovras för att Sverige skulle höja sig, och idealet var en situation där de samsades och samverkade med varandra. Den som visste sitt eget bästa önskade välgång åt dem alla. ${ }^{473}$

Ett antal presidietal reproducerade den senfrihetstida välviljan gentemot handeln, som påkallades av människors ömsesidiga behov och bevarade och utvidgade de andra näringarna, inte minst fabrikerna. Köpenskapen gestaltades som den politiska kroppens motsvarighet till människokroppens blod, som förde livsandarna till lemmarna; dess jämna lopp var det bästa måttet på välfärd och dess stagnation tämligen riskabel för hälsan och livet, varför denna förtjänade den största omsorg. Såväl Ostindiehandelns nytta och oumbärlighet som fördelarna med Ostindiska kompaniet behandlades. ${ }^{474}$ Rikets handelsmän beskrevs som 
aktningsvärda, snillrika och driftiga, och det allmännas väl som sammanvävt med de penningstarka handelsfirmornas. ${ }^{475}$ Handeln skulle liksom under frihetstiden vara inrättad på ett visst vis. Nils Adam Bielke förfäktade att den för att inte bli menlig måste präglas av eftertanke, kunskap, kärlek till det allmänna och varsam frimodighet. Under Gustav Vasas regering hade borgerskapet till skillnad från konungen haft föga insikt om hur en riktig handel bör bedrivas; denne lät därför införa god ordning bland köpmännen, "på det handelen rätteligen måtte tilgå och styras". ${ }^{476}$ Det yrkades i linje med akademiens importfientlighet på en balanserad handel eller ett handelsöverskott. Köpmannen Carl Christopher Arfvedson inskärpte betydelsen av förädling, export och gynnsam handelsbalans men uppfattade samtidigt ökad varuinförsel som en funktion av allmän välfärd och införseln i sig som godartad, eftersom den underlättade de inhemska tillverkningarnas avsättning och vidmakthöll fliten. ${ }^{477}$

Under gustaviansk tid vann idéer om en mer eller mindre spontan ordning och kritik mot tvång på nytt i styrka. Runeberg fann att utrikes- och inrikeshandeln har "en viss och beständig relation til hvarandra, om författningarna lemna dem båda två et fritt och naturligt lopp". Arfvedson skildrade hur pengar naturligt letar sig fram till den marknad där handeln ger dem deras högsta värde; de och ädla metaller söker liksom vattnet ständigt sin jämvikt och måste flyta dit flitiga människor producerar flest varor till lägst pris. Proberaren Peter Jacob Hjelm avfärdade belöningar för nyodlingar som obsoleta och ogillade att förordningarna mångfaldigades, eftersom det kunde medföra att de glömdes bort och hemmansklyvningen varit framgångsrik utan ett sådant överflöd. Han gav flera exempel på tvång som hämmade den mänskliga trevnaden, vilken "ofelbart beredes och vinnes med mindre konst [artificialitet], men med mera frihet och säkerhet: med mindre Formaliteter, men mera rättvisa". Säkerheten handlade bland annat om orubbliga arrenden och om att bönder och torpare "fritt och liksom af sig sjelfva" kunde starta nya hushåll på lika villkor. ${ }^{478}$

Mest radikal var Nils von Rosenstein, som menade att oreda, lagförakt och lagbrott uppstod om ett orimligt tvång lades på den mest utbredda passionen, begäret efter materiella fördelar. Onaturliga och ogenomtänkta 
bojor på köpenskapen inbjöd till bedrägerier, medan frihet genererade hederlighet: "Öpna alla vägar för idogheten och industrien, och var viss, at dana et arbetsamt och sedigt folk, där bofvar och skälmar äro mera sällsynte. Gör näringarne och handelen så frie, som möjligt är, och antalet af Lagbrytare och Lurendrägare [smugglare] skall aftaga.” Monopols exkluderande tvång utgjorde det bästa argumentet för nyttan av fri handel, som också kunde hämta stöd i historien. ${ }^{479}$

En del presidietal modererade förkärleken för avreglering. Enligt ämbetsmannen Eric Schröder fick tvång och inskränkningar handelsrörelserna att vantrivas och förfalla. Han fastställde apropå spannmålshandeln att Sveriges klimat och geografi gjorde alla begränsningar än mer skadliga, samt att ett allmänt och nyttigt inre handelsutbyte främst kom an på konkurrens och fullständig avsättningsfrihet. Förbud mot och höga tullar på utförsel av spannmål hade haft negativa följder för det svenska jordbruket, och främmande länder som England åskådliggjorde nyttan av fri spannmålsexport. Samtidigt ville Schröder att de styrande skulle uppmuntra handelns aktörer, reglera priset på spannmål som fördes utomlands och avvärja skadlig export och import. Wilcke poängterade i sitt svar till Schröder att en nyttobringande inrikes och utländsk spannmålshandel inte endast skulle vara fri utan även förståndigt styrd. Talets historiskt belagda förslag säkerställde rikets vinst på en vara som under rådande omständigheter gjorde svenskarna till utlänningarnas skattdragare. ${ }^{480}$

Sandels gjorde gällande att författningar ämnade att motverka export och dirigera eller tvinga inhemsk handel medverkat till sädesbristen genom att dämpa åkerbruket och göra intrång på de friheter som var grundade i näringarnas och handelns natur. Gustav III hade i ett lyckligt ögonblick lossat banden och återställt spannmålshandelns nyttiga friheter. Samme preses ställde sig kallsinnig till höga tullar, som drev upp priserna, föranledde smuggling och lade hämsko på näringar och rörelser. Han framhöll relevansen av att vissa hantverkare i 160o-talets Stockholm inte haft någon skråordning och uppskattade att kopparhandeln under detta sekel frigjorts från de delvis monopolistiska kompanier som ombesörjt den. Den gustavianska kopparförädlingen meddelades vara så framgångsrik att utförseln av ren koppar upphörde av sig själv, i 
kontrast till det föregående århundradets export av råkoppar som knappt kunnat stävjas av förordningar. Å andra sidan kopplades en försiktig hushållning till begränsningar och förbud avseende diverse exportvaror, och Karl XI sades ha sett till den långsiktiga nytta som kunde uppnås genom "utdelning af friheter, understöd och belöningar". ${ }^{481}$ Termen "frihet" bör här fattas som "privilegium", givet att den förekom vid sidan av subventioner. ${ }^{482}$ I frihetstida ekonomiska sammanhang hänförde sig "frihet" ofta till rätten att få utöva sina privilegier, inte till en allmän näringsfrihet. "Fri” handel avsåg många gånger den enskildes rätt att fullgöra sin påbjudna samhällsroll utan att störas av andra och ett reglerat varuutbyte inom ståndssamhällets skrankor. ${ }^{483}$ Denna terminologi levde uppenbarligen kvar under det gustavianska tidevarvet.

Konkurrens fortsatte att uppfattas som ett gynnsamt fenomen. Ledamöter anförde att inbördes tävlan gav lägre priser och motverkade smuggling, och att ståndspersonerna förmodligen skulle bli alltmer hågade för "ädel inbördes täflan" och beflita sig om såväl sin egen som rikets förbättring. ${ }^{484}$ Lillienberg betraktade tävlan och förtjänst som de huvudsakliga drivkrafterna bakom en bättre och mer arbetsintensiv bergshantering. När gruvbrytningen ställts om till betingsarbete hade de arbetsamma kommit att tjäna mera än de lata, "och i den mon förtjensten väckt en otvungen täflan, hafva färre arbetande händer kunnat åstadkomma, hvad som tilförene sysselsatt flera”. Lillienberg var dock också i hög grad regleringsorienterad. Han uppgav att både industrin och vetenskaperna krävde livgivande omsorg, medan konkurrensen liksom hos flera av frihetstidens ledamöter förbands med makthavarna. ${ }^{485}$ Konkurrens hade positiva förtecken även ifråga om lärdomen. Det hette bland annat att rivalitet inom lärda samhällen var stimulerande och underblåstes av pristävlingar som satte igång snillen och frambringade förträffliga studier. ${ }^{486}$ Vetenskapsakademien hade givit upphov till en tävlan om organisationens uppmärksamhet och de kloka stiftarna vetat att utnyttja människans naturliga längtan efter erkännande. Ledamöterna tävlade inte bara med varandra, utan med själva naturen. ${ }^{487}$

I några tal framträdde egennyttan som en drivkraft. Bunge menade att den primära orsaken till att stora monarkers och upplysta styres- 
mäns avsikter inte förverkligats i Sverige var gemene mans brist på övertygelse om sin personliga nytta av dem, vilket hade betydelse när hushållningsanstalter skulle verkställas. Schröder förklarade att det var lika överensstämmande med handelns natur att tonvikten lades vid varor med en välgrundad vinstkalkyl som det var överensstämmande med erfarenheten att människor drogs till handelsgrenar med tillfredsställande förtjänst. Vinningslystnad, konkurrens och den enskildes förmåga ställdes i ett gynnsamt ljus. ${ }^{488}$

Ytterligare ett frihetstida anslag som gick igen i de gustavianska presidietalen var den sociala kritiken. Joachim Wilhelm Lilliestråle anmärkte att aktandet på börd utgjorde en för riket oförmånlig vanära och ett oberättigat tvång vid försäljning av fast egendom, som borde ske fritt eftersom säljarens äganderätt var fullkomlig och ren. Det angick inte det allmänna vem som ägde en egendom så länge den sköttes korrekt. Sandels deklarerade att formella distinktioner mellan medborgare som inte utgick från meriter och duglighet resulterade i arrogans, fåfänga och avundsjuka. De kvävde fliten, skapade fler tärande och fick näringsidkarnas förmögenheter och barn att lämna deras företag. Bunge tecknade ett föga smickrande porträtt av adelsmän och rika ofrälse, som enligt honom ofta sökte sig bort från sina lantbruk på grund av äregirighet, fruktlösa nöjen och lyx. Om de besuttna konsumerade all sin avkastning och inget fanns kvar för att förbättra deras egendomar blev det desto mer angeläget att ta tillvara på kapaciteten hos den närande befolkningen, vars kapital bestod i dess arbete och måttfulla leverne. Bunge underströk dock att de närande förväntade sig undervisning och rimlig belöning för sin möda från de mer upplysta. ${ }^{489}$

Jacob Gadolin byggde in social kritik i en redovisning av den enskilda människans upptäckt av världen:

Då hon erfar, at alla menniskor födas til verlden på enahanda sätt, lika nakna och oförmögna, men det likväl händer, at den ena med våld eller list förhindrar den andra at i ostörd frihet jämte sig nytja den välgörande naturens förmoner til nödig bärgning och beqvämlighet, upkommer däraf hos henne den första känning och tanka om rätt och orätt. Skilnaden imellan onda och goda gerningar faller henne så mycket lättare i 
ögonen, som hon ofta icke utan ömaste invärtes rörelse kan åskåda, huru en starkare misbrukar sin styrka at oförrätta den svagare.

Utsagor om att alla föds jämlika och att de starkare förtrycker de svagare kan läsas som kommentarer till den ståndssamhälleliga ordningen. Detsamma gäller fortifikationsdirektören Axel Magnus von Arbins (Arbin) uppskattande iakttagelse att Karl XI förstått att betjäna sig inte bara av ädlingar, utan även av "dem af medelståndet" som genom sin begåvning varit till nytta för det allmänna. Tack vare denne konungs mästerliga förmåga att välja goda tjänare hade ingen tidsperiod "på kortare tid framalstrat flera stora Män, som blifvit stamfäder för nyare slägter, hvilka medelst stora bedrifter vunnit samma rättighet til allmän högaktning hos Samtid och Efterverld, som ättlingar af forntidens Herrsar [hövdingar] och Jarlar". ${ }^{490}$

Rosenstein den yngre, vars tal tillkom under franska revolutionen, stod för den mest uttalade sociala kritiken. Han beskrev hur de förnäma framförde överdrivna anspråk och ringaktade högmodet hos köpmännen, som i sin tur hyste förakt mot en adlig stolthet som ofta kom till korta i praktiken. Det stora folkflertalet urskilde enligt honom samma grundläggande vanvett hos bägge. Adelsmän som hävdade bördens företräde var fördomsfulla och lika oupplysta som vinningslystna köpmän. I båda fallen hade passionen - högmodet respektive egennyttan - en mer dominerande ställning än hos deras upplysta ståndsbröder. Rosenstein talade om "de högas frestelser, deras förfinade, men ock ytliga odling, deras glänsande dygder och sminkade fel" och ansåg att såväl adelsmännen som deras medtävlare köpmännen överlag var giriga och överdådiga. Allmänheten hade likväl en benägenhet att närma sig dem. Mot bakgrund av de högres och de lägres tillkortakommanden blev slutsatsen att "medel-classen" var den mest dygdiga samhällsgruppen. Denna likställdes med nationen och tillskrevs en upplysning förvärvad utanför "den bana, där begären [ut]öfva sit starkaste välde; utan at känna olägenheterne hvarken af de främsta eller lägsta rumen i Samhället". ${ }^{491}$

Trots dessa synpunkter föll Rosenstein som så många andra nytänkande akademimedlemmar tillbaka på invanda idéer. Resonemanget ovan kan kontrasteras mot hans teser att mänsklig behovstillväxt 
leder till ökad ojämlikhet och att en fullständig jämlikhet varken är förankrad i naturen eller nödvändig för lycksaligheten. Egenskapernas ojämna fördelning visar att olikhet ofrånkomligen följer av människans själva väsen. Till det kom att lycksalighet inte handlar om "bättre eller sämre vilkor; uselheten undantagen. Om vi räkna de rikas och de fattigas, de högas och de lågas förnöjda stunder, är ovisst, hvarest öfvervigten blifver". Rosenstein avvisade, med sannolik hänvisning till franska revolutionen, samtidens jämlikhetsyra och dem som inte kände jämlikhetens gränser, kanske till den grad att de inte skulle hejda sig förrän de förstört samhällsgemenskapen. Han framstod som en apologet för de besuttna när han urskuldade att vissa åtnjöt större fördelar så länge dessa flöt ur strävanden öppna för alla, inte innebar förtryck och inte vanns på nästans bekostnad. ${ }^{492}$

Vetenskapsakademiens kopplingar till hattarna reflekterades i att organisationen under partiets första, långa tid vid makten oftast positionerade sig nära regeringens ekonomiska politik, genom att presidietalen framhävde och förespråkade slöjder, produktförädling, arbetsfördelning, reducerad import och bättre handelsbalans. Slöjderna och handeln, som under 1700-talet kunde ställas i motsats till det ursprungliga och råa jordbruket, rankades högst av näringarna. Handeln skulle vara utformad på rätt sätt och lukrativ för Sverige; import sågs med oblida ögon och skulle begränsas eftersom den drog pengar ur riket och gynnade främmande länder, medan export av förädlade varor förordades. Konsensus rådde om nödvändigheten av en strikt och välståndsskapande arbetsfördelning, särskilt mellan stad och landsbygd. ${ }^{493}$ Den hattvänliga ekonomiska ideologin kan också spåras hos ledamöter som framförde i ett eller annat hänseende avvikande åsikter om hushållningen. Några diskuterade ekonomisk självreglering, men sådana idéer förblev marginella under hattarnas första maktinnehav. Presidietalen uppmärksammade vidare frihetstidens nyttiga landvinningar och de styrandes betydelse för den gynnsamma utvecklingen. De välvilliga omdömena kan, bland annat med tanke på de upprepade referenserna till slöjderna, 
i hög grad tolkas som smicker av hattpartiet, även om monarkerna och de förutvarande makthavarna delvis omfattades av dem.

Akademien fortsatte huvudsakligen att solidarisera sig med hattarna under det turbulenta 1760-talet, samtidigt som hårda angrepp kring och efter maktskiftet 1765 riktades mot partiets politik, framför allt från mössorna Högström och Löwenhielm. Både Högström och Löwenhielm fäste vikt vid konkurrens, vilken ur Löwenhielms perspektiv utgjorde en kraft i egen rätt. Konkurrens låg tematiskt nära avreglering och uppfattningar om ett mer självgående samhälle, varför förordandet av tävlan kan förstås som ett symptom på en bredare och djupare omvandling i den ekonomiska ideologin. Löwenhielm gav därtill röst åt en kritik av adeln som var mer långtgående än dess fåtaliga förelöpare i tidigare presidietal. Den sociala kritiken, som hade bäring på såväl ståndsmotsättningarna som hattarnas borgerliga och nyadliga profil, blev ett påtagligt inslag i presidietalen från mössornas regeringsinnehav och framåt. Dess språkrör förhöll sig negativa till det tärande frälset och betonade samhällets närande lemmar, i synnerhet borgarna. Kritiken hade dock instrumentella övertoner och klara gränser - det handlade om nytta och villkorad jämlikhet, inte om egalitarism.

Trots att presidietalen under mössregimen mer än förut kom att innehålla formuleringar om ekonomisk självreglering och delvis problematiserade hattpolitiken, hushållningen och aspekter av samhället, gav huvuddelen av dem uttryck för hattvänliga ställningstaganden, låt vara för det mesta i reviderad form. Akademisekreteraren Wargentin ådagalade under den sena frihetstiden politisk försiktighet och en vacklande hållning i ekonomisk-politiska frågor, vilket liksom attackerna mot och revisionerna av hattpartiets ståndpunkter kan tolkas i ljuset av det ekonomiska krisläget, manufakturpolitikens oinfriade löften och mössornas placering vid riksrodret.

Flera ledamöter företrädde efter hattarnas återtagande av makten 1769 en välvillig inställning till handeln, under det att föreställningar om nyttofrämjande konkurrens tilltog i styrka. Konkurrensen betraktades dock regelmässigt som en funktion av de styrande snarare än som någon autonom ekonomisk kraft. Den ekonomiska självregleringen tonades inte för inte ned i presidietalen. Ordförandena tenderade i övrigt att med 
modifikationer ansluta sig till det ideologiska arvet från hattpartiets glansdagar. Det mest särpräglade talet under hattarnas andra maktinnehav kom från Schönberg, som försvarade centrala delar av deras politik men ändå stod för självreglering och icke-interventionism. Han var förutom Högström och Löwenhielm den frihetstida ledamot som mest eftertryckligt ifrågasatte akademiens vedertagna ekonomiska ideologi.

Vetenskapsakademiens presidietal speglade den övergripande ekonomisk-politiska situationen under den gustavianska eran, då protektionismen och regleringsapparaten mjukades upp, intresset för jordbruket ökade och manufakturpolitiken hamnade i skymundan. Manufakturvänligheten sjönk undan i talen, som när de gav sig in på frågan om näringarnas företräde vanligtvis favoriserade jordbruket. Fastän importfientligheten och framhållandet av förädling bestod under hela undersökningsperioden saknade utsagorna om import överlag den skarpa ton som utmärkt många av de frihetstida talen, medan substituering av importvaror genom acklimatisering av främmande växter intog en mer framskjuten plats. Ledamöterna rekommenderade som förut arbetsfördelning mellan landsorter och näringar, men hade i allmänhet en märkbart mer nyanserad hållning till mångsyssleri. Akademimedlemmarna förde också de senfrihetstida attityderna till handel och konkurrens vidare. Frihetliga uppslag vann åter mark, då ett antal gustavianska presides - inte minst Rosenstein den yngre - vände sig emot tvång och ställde sig bakom en mer eller mindre spontan ordning.

En sammanvägning av Vetenskapsakademiens politiska och ekonomiska ideologi utifrån den hittillsvarande studien av presidietalen påvisar några gemensamma drag. För det första att de förenades av en tilltro till samhällsledningens ingripanden i och reglering av den mänskliga samlevnaden. För det andra att makthavarna och eliten tillmättes en central status i samhällsgemenskapen. För det tredje att 1700-talets samhälle upplevdes som "ekonomiskt dynamiskt men socialt statiskt" - lycksaligheten skulle nås genom bättre resursutnyttjande, inte genom samhällets omstöpning. ${ }^{49}$ Nästa kapitel, som klarlägger akademiens syn på kungahuset och monarkerna, adderar till dessa slutsatser, medan den inverkan som närheten till samhällsledningen hade på organisationens idéskapande ges ytterligare belysning. 


\section{Konungarnas akademi}

Detta kapitel kastar mer ljus över Vetenskapsakademiens politiska ideologi och hur närheten till makten färgade den genom att undersöka presidietalens framställningar av kungligheterna, i relation till relevanta politiska omständigheter. Kapitlet är kronologiskt strukturerat och uppdelat i två avsnitt, ett om frihetstiden och ett om den gustavianska tiden.

Liksom sina föregångare använde sig 1700-talets regenter av sköna konster, litteratur och lärdom för att gestalta sina politiska målsättningar och sin furstliga auktoritet. Beskyddandet av vetenskaperna erbjöd inte bara en arena för symbolisk manifestation av den egna makten utan även ett sätt att vinna aktning. ${ }^{495}$ Vetenskapsakademien fick kunglig status genom Fredrik I:s stadfästelse av stadgarna 1741, men han fattade aldrig något tycke för sammanslutningen och saknade ett personligt förhållande till den. Akademien stod desto närmare hans efterträdare Adolf Fredrik och Gustav III, vilka till skillnad från honom tjänade som organisationens beskyddare och närvarade vid dess sammankomster. Den senare var inte heller främmande för att vid ett antal tillfällen blanda sig i Vetenskapsakademiens inre angelägenheter. ${ }^{496}$ Båda regenterna sällade sig till akademiens namnkunniga donatorer, som inbegrep prominenta politiker, ämbetsmän och näringsidkare som Carl Albrecht Rosenadler, hovintendenten Fredrik Sparre, Ostindiekompanidirektören Niclas Sahlgren samt Jonas Alströmer och hans söner Patrick och Clas. ${ }^{497}$

\section{Frihetstidens kungliga konjunkturer}

Den frihetstida kungamakten var svag och kringskuren. Perioden har förståtts i termer av ständervälde och konungen liknats vid "högste kollegiechef i rikets råd". Monarken skulle ta beslut tillsammans med 
riksråden, som svarade inför riksdagen och fungerade som dess ombud. Samtidigt förblev hans symboliska makt stark, inte minst på det ekonomiska området. ${ }^{498}$ Barrington Moore Jr. har identifierat tre uppgifter och skyldigheter som vanligen ålegat härskare: beskydd, i synnerhet från utländska fiender; upprätthållande av inre lugn och ordning; samt vårdande om undersåtarnas materiella välfärd. ${ }^{499}$ Under frihetstiden stod det tredje uppdraget i centrum för Vetenskapsakademien, medan det andra i stånds-och partistridernas kölvatten blev framträdande under den gustavianska tiden.

Akademiledamöterna karakteriserade Fredrik I som en stor, vis, kärleksfull, mild, omsorgsfull och arbetsam konung som bemödade sig om att förkovra sitt rike och vars strålglans upplivade hela Sverige. Hans lovvärda och välsignade regering inbegrep en rad hälsosamma steg för att förbättra landet; slöjderna, konsterna och handeln tillväxte avsevärt och vetenskaperna utan motstycke, exempelvis genom införandet av ekonomiämnet vid universiteten. ${ }^{500}$ Carl Fredrik Piper vigde i april 1751 sitt tal till det nyss avlidna majestätet, "den mildaste Konung i verlden, under hvars Spira vår Frihet fått fästa sina rötter, och Landsens Lag börja et nytt Tide-hvarf”. Åtskilligt hade blivit bättre under hans styre, däribland lantbruket, handeln, bergsbruket, handslöjderna, vetenskaperna, uppfostringsväsendet och folkets krafter och dygder. Fredriks gemål Ulrika Eleonora var nästan osynlig i presidietalen. Den ende ledamot som uppehöll sig vid henne var Carl Wilhelm Cederhielm, som omnämnde drottningen tillsammans med hennes make och tillskrev dem delvis samma egenskaper - kärleksfullhet, omtänksamhet och idoghet. ${ }^{501}$

Flera medlemmar ställde vid frihetstidens konfliktfyllda slut Fredrik I i en fördelaktig dager. Samuel Sandels beskrev honom som upplyst och nådig, medan Johan Clason bland annat skyllde de finanspolitiska problemen under hans regering på Karl XII. Eric von Stockenström förklarade att Fredrik varit lika mycket en kännare av bergverken som framstående i kungliga egenskaper och att han kraftfullt bistått sekreta utskottets arbete med att upphjälpa järnhandeln. Stockenström hade själv beretts audiens hos honom och mindes väl det intryck en sådan vis och mild konungs vilja gjort på lojala undersåtar. ${ }^{502}$ Givet den tidsliga 
ramen kan Clason tänkas ha varit ute efter att friskriva hattarna från ansvar för rikets ekonomiska svårigheter och Stockenström efter att försvara deras handelspolitik.

Kronprinsparet Adolf Fredrik och Lovisa Ulrika uppmärksammades desto mer av Vetenskapsakademiens ordförande, vilka tog fasta på deras insatser för rikets förbättring och välfärd. Stockenström konstaterade i samband med bergshanteringens uppsving under Fredrik I att man hade "en stor förebådelse af vår dyra Arf-Furstes, Prints ADOLPH FRIDRICHS, samt des Gemåls, vår Hudaste [sic] Arffurstinnas, Princessan LOVISA ULRICAS stora och oförlikneliga samt öfver alt Svea Land vördade och älskade Dygd och Fursteliga egenskaper, om en tilkommande Regering, som skal göra oss sälla i denna och alla andra handteringar”. Ett liknande framtidsscenario formulerades av Samuel Schultze, som också presenterade Adolf Fredriks lantbruk på Ekholmsund som ett förträffligt föredöme för undersåtarna. Schultzes tillförsikt till kronprinsens lyskraft delades av Carl Gustaf Löwenhielm, som meddelade att gemene man skulle få fler förebilder och jordbruket befrämjas om bara de adelsmän som ännu inte förändrat sina gods till det bättre följde Adolf Fredriks exempel. ${ }^{503}$

Parets ansträngningar för lärdomen var ett annat tema i akademien. Olof af Acrel tog upp både den nytta vetenskaperna hade av Adolf Fredriks beskydd och Lovisa Ulrikas intellektuella engagemang, vilket behandlades av ett antal ledamöter. Acrel framställde henne som "Rikets ömmaste Klenod" och som avhållen av folket, och menade att hennes "vett-älskande dygder" skulle utgöra det mest utomordentliga riktmärke för landets barn. Löwenhielm frågade retoriskt vem som inte ville eller borde vilja lära känna naturen när den makalösa kronprinsessan vårdade sig om vetenskapen. ${ }^{504}$

Adolf Fredrik och Lovisa Ulrika figurerade för första gången som kungapar i Pipers tal om den hädangångne Fredrik I, där deras långvariga kärlek till undersåtarna berördes medan Piper enligt egen utsago förteg många övriga förebud om en lycklig regering. Den nye konungens goda egenskaper varslade om att det som inletts under Fredrik skulle fullföljas och bära frukt under Adolf Fredrik, vilken redan som kronprins varit som en far för undersåtarna. ${ }^{505}$ Andra presides kom att fortsätta på det 
paternalistiska spåret, bland annat genom att beteckna Adolf Fredrik som en far för landet och konsterna. ${ }^{506}$

Konungen Adolf Fredrik tillmättes storhet, mildhet, rättrådighet, vishet och föredömlighet, liksom en ömhjärtad, entusiasmerande och lyckosam omsorg om näringarna, Sveriges upphjälpande och den allmänna välmågan. Kungaparet ingav hopp för hushållningen, och deras omtanke och uppmuntran utlovade framsteg; inte minst skulle landet räddas från tyranni och utländskt tvång. De hade gjort en ingående inspektion av de svenska bergverken och finansierat Drottningholms fabriksanstalter med egna medel, eftersom Adolf Fredrik som beskyddare av en akademi hängiven nyttiga slöjder - alltså Vetenskapsakademien - ville framhäva dessa genom sitt och sin hustrus exempel. ${ }^{507}$

Förutom att spinna vidare på nyttotemat fortfor presidietalen även att diskutera Adolf Fredriks och Lovisa Ulrikas intresse för det konstnärliga, litterära och vetenskapliga. Konungen skildrades som de fria konsternas far och sades hysa kärlek till såväl dem som vetenskaperna och slöjderna, rikets sanna prydnader. Han sökte försköna Sverige, stimulera landets konstnärer och berika undersåtarna, och genom att uppliva vetenskaperna framkallade han en lycka som alltid åtföljde stora regenter. Ledamöterna inlät sig på Lovisa Ulrikas samlingar, kärlek till bergsvetenskapen och verksamma roll som förebild inom naturkunnigheten. Drottningens benägna stöd till de fria konsterna definierade det innevarande tidevarvet och skulle göra hennes namn vördat av en upplyst eftervärld. Två år efter Vitterhetsakademiens instiftande 1753 tillkännagav Carl Fredrik Scheffer att vitterhetens utsikter förbättrats markant sedan Lovisa Ulrika tagit den under sitt beskydd och att detta skulle bidra till dess snara uppgång. ${ }^{508}$

Adolf Fredriks och Lovisa Ulrikas son Gustav, Sveriges kronprins och den blivande Gustav III, uppträdde för första gången i ett presidietal 1747, där han fick epitetet "Rikets hopp ock ögnasten". Senare tal framställde prins Gustav som den återupplivade Vasastammens rot, rikets kära "Lifs-planta" och "Nordstjerna", en dyrbar telning och en älskad prins. Den unge tronföljaren bar löfte om storhet och skänkte hopp, glädje och styrka. ${ }^{509}$

Frihetstidens kringskurna kungamakt var ett sällsynt motiv i talen 


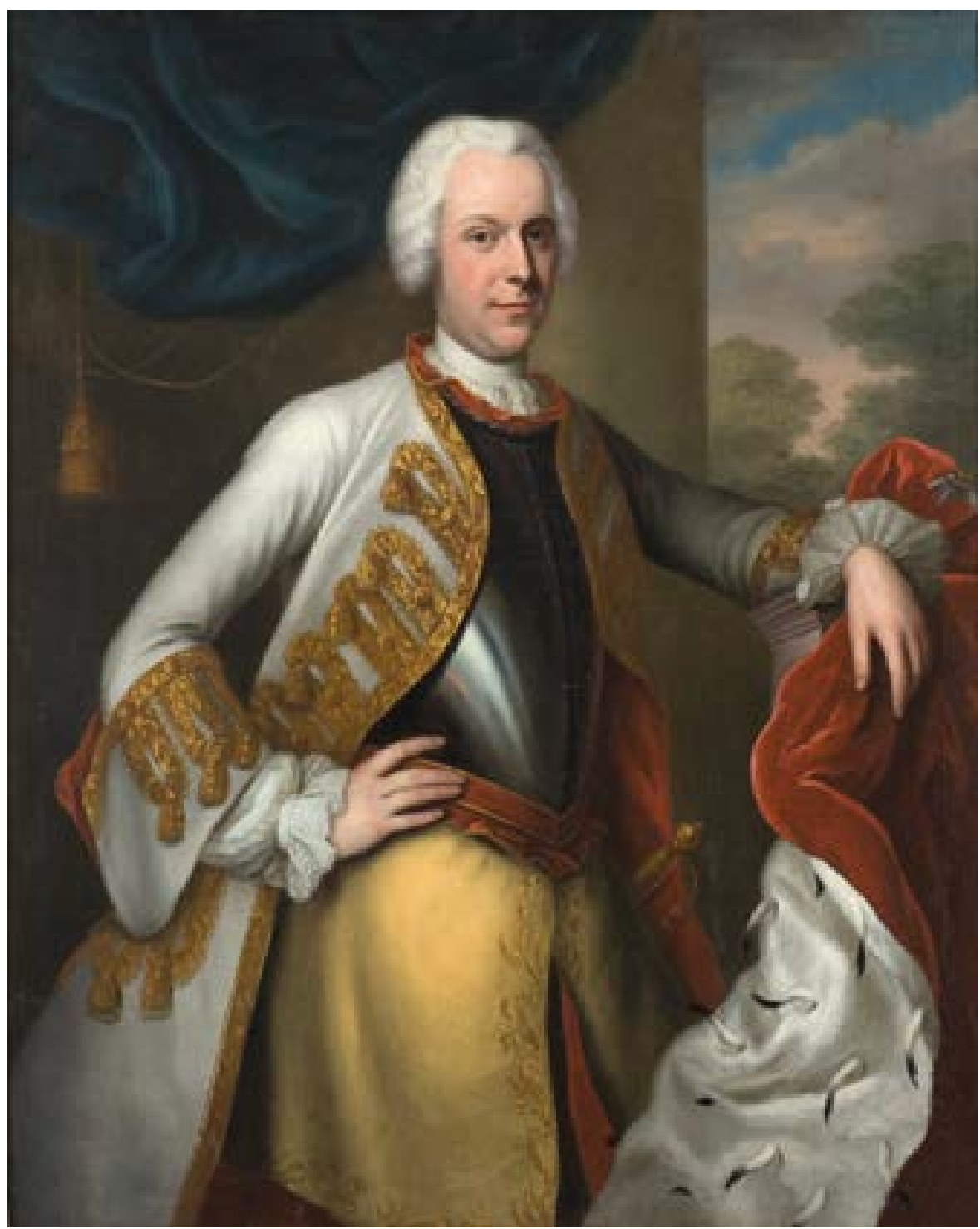

Bild 9. Balthasar Denner, Konung Adolf Fredrik. Foto: Nationalmuseum. 
under Fredrik I:s regering och kommenterades enbart av Henrik Jakob Wrede, som anförde att konungen rådde med folkets goda minne och att det var hans plikt att befordra dess väl. ${ }^{510}$ På 1750 -talet tilltog dock hänvisningarna till frihetstidens konstitutionella monarki, vilket bör ses mot bakgrund av att friktionen mellan kungaparet och hattregimen växte efter Adolf Fredriks trontillträde 1751. Denna utveckling sammanföll med att relationen mellan akademien och kungahuset försvagades för att slutligen avstanna. Motsättningen fick utlopp först på riksdagen 1755-56, där rådet och ständerna drabbade samman med Adolf Fredrik och Lovisa Ulrika om huruvida regenten hade rätten att godkänna rådets beslut, sedan i ett misslyckat rojalistiskt statskuppsförsök 1756. I skuggan av den eskalerande spänningen hävdade Erik Salander att kungligt envälde var oförmånligt för slöjderna, som den karolinska tidens varnande exempel visade. Hattarnas kanslipresident Anders Johan von Höpken gjorde gällande att såväl riksdagen som Gud satt Adolf Fredrik att styra. Han anmärkte att de som var framgångsrika vid hoven ofta blev det på grund av slumpen och ställde detta mot situationen $\mathrm{i}$ frihetstidens Sverige, där förtjänst och sanning omgav tronen tack vare konungens band till akademien. Vetenskaperna hade fått monarken att inse nyttan av sanning och kunskap respektive onyttan av falskhet och smicker, samt att en regent blev stor genom folkets seder och snille. ${ }^{511}$ Budskapet var klart nog: konungens makt och storhet kom från folket, låt vara att Gud fortfarande fanns med i bilden - åtminstone på det retoriska planet.

Ett par månader före kuppförsöket, som Lovisa Ulrika till skillnad från Adolf Fredrik hade viss kännedom om, uppmärksammade Carl Fredrik Mennander rikets "välsignade Frihets-regering". Hans presidietal slutade med iakttagelsen att Sveriges bokhandel snart skulle överskugga utlandets om denna bara kunde uppamma fler skrifter som den Vetenskapsakademien mottagit från ständerna och sedermera offentliggjort, "nämligen fullkomlig samling af de Bref, hvarmed en Svänsk Mentor leder vår dyra Cron-Prints steg från steg up til den rätta Konunga högden. Men en enda Bok, så hederlig [hedervärd] för vårt Språk, land och Folk, så nyttig för hela människo-slägtet, står ej at förmodas i hvar manna-ålder [generation]. Den delen, som af detta oskatbara arbetet 
tilförene utkommit, äger redan allmän högaktning, och är en klenod i alla Bibliotheker i Europa". Den svenske mentorn var hattpolitikern Carl Gustaf Tessin, kronprinsens lärare, som hamnat på kollisionskurs med kungaparet ifråga om Gustavs uppfostran. Riksdagens sekreta utskott lät 1756 akademien publicera Tessins korrespondens med tronföljaren som ett led i hans dispyt med Adolf Fredrik och Lovisa Ulrika. Mennanders hyllning av breven kan tolkas som en politisk handling och ett ställningstagande mot regenterna, även om han positionerade Adolf Fredrik nära Vetenskapsakademien genom att lyfta fram konungens funktion som dess beskyddare..$^{512}$

Efter att de rojalistiska stämplingarna uppdagats sommaren 1756, med utmätta dödsstraff mot flera av de inblandade och tillrättavisning av kungaparet som följd, dröjde det ett år innan konungen och drottningen förekom i något presidietal. Den talande tystnaden bröts av Carl Fredrik Adelcrantz i ett långtgående smicker av Adolf Fredrik och Lovisa Ulrika, samtidigt som han av allt att döma markerade mot dem genom att åberopa riksråden samt fältherren Agrippa och den franske ministern Jean Baptiste Colbert, vilka båda betonades på bekostnad av sina härskare Augustus och Ludvig XIV. Adelcrantz föreställde de två som stora och samhällsdrivande, och implicerade att de varit oundgängliga för sina herrar: "Där en AUGUST[US] och LUDVIG regera, felas sällan en AGRIPPA och en COLBERT til rådgivare." Johan Fredrik Kryger tycks ha agerat apologet för den frihetstida ordningen när han 1758, samma år som nya rojalistiska kupplaner avslöjades, hävdade att de svenska regeringslagarna besatt "alla de förmoner, som fordras til fria Samhällens trefnad, men i sig sjelfva ej sådana fel, som ofta sätta andra [samhällen] i förvirring och vilrådighet, emedan de [regeringslagarna] äro stridande emot sjelfva frihetens natur och ändamål". ${ }^{13}$

Ledamöternas referenser till kungahuset var därefter sparsamma, opersonliga och neutrala under några år. Adolf Fredrik gick under epitet som konungen och Kongl. Maj:t, medan presidietalen nämnde kronprinsens bibliotek och att höga överheten av iver för det allmänna bästa sökte befrämja schäferierna. ${ }^{514}$ Det korthuggna och distanserade förhållningssättet upphörde 1762, när konstruktören Carl Knutberg framhöll kungaparets föredömliga naturaliesamlande och kallade konungen 
Vetenskapsakademiens skyddsherre och nyttiga vetenskapers välgörare. Ett knappt halvår senare kungjorde instrumentmakaren Carl Lehnberg att han tillverkat ett teleskop som haft lyckan att hamna i kronprinsens ägo. ${ }^{515}$ Dessa utsagor kan betraktas i ljuset av att hattarna vid årsskiftet 1761-62 närmat sig kungahuset och bett Lovisa Ulrika förhandla fram ett slut på det pommerska kriget (1757-62), som fördes mot hennes bror Fredrik II av Preussen. Drottningens medling resulterade i en fred utan landavträdelser och ökade hovets prestige. ${ }^{516}$

Monarkerna gestaltades under en tid i samma anda som före 1750-talets slitningar. Peter Jonas Bergius trodde att hans tal om Loka källa skulle uppskattas av åhörarna med tanke på den hälsosamma inverkan kurorten haft på "hela Rikets Ögnasten" konungen. Akademimedlemmarna kunde inte med lätthet glömma den oro de känt över sin käraste landsfaders krasslighet eller den varma glädje de erfarit när han välsignats med full återhämtning. Pehr Wilhelm Wargentin redogjorde för Vetenskapsakademiens stolthet över Bengt Ferrners utnämning till lärare för Sveriges glädjeämne och hopp Gustav, en nåd som var angenäm för samtliga ledamöter. Ferrner skulle nu "få stadga den höga ynnest för Lärdom och Vetenskaper, som hos Hans Kongl. Höghet med Blodet är inplantad, som redan visat sig uti så många lysande prof, samt förvissar Fäderneslandet i gemen, men Vitterhet och Vetenskaper i synnerhet, om en blomstrande och lycklig framtid". Abraham Bäck förknippade höga överheten med ansatser att förbättra allmogens belägenhet och noterade att drottningen bistått en sjukdomsutsatt trakt genom dränering av ett träsk. Utsagor om den romerska republiken som en förebild i olika hänseenden kan dock ha rymt ekon av de tidigare motsättningarna. ${ }^{517}$

Under mössornas styre 1765-69 tonades kungahuset återigen ned i presidietalen, om än mindre dramatiskt än tidigare. Detta kan sättas i relation till att Adolf Fredrik och Lovisa Ulrika från 1765 var bundsförvanter till hattpartiet. ${ }^{518}$ Ordförandena nöjde sig förutom i ett par sammanhang med neutrala hänvisningar till konungen, Kongl. Maj:t och Adolf Fredriks regeringstid. Läkaren Zacharias Johan Strandberg slog fast att alla invånare för evigt kom ihåg Lokas nytta för Sveriges monark, medan Wargentins svar diskuterade den kungliga nåden $\mathrm{i}$ samband med Vetenskapsakademien. ${ }^{519}$ 
En förmaning till det hattlierade kungaparet går att läsa in i mösskanslipresidenten Löwenhielms Tal om ungdomens upfostran $i$ et välbestäldt Regemente (1767). Löwenhielm berömde Minos av Kreta och dennes lagar, vilka vördades av fria folk och föreskrev att

Konungen råder öfver Folket, men Lagarna öfver Konungen: At Konungen hafver full frihet at göra det goda; men har bundna händer, så snart han företager något ondt: At Lagarne lämna honom Folket i händer, såsom den dyraste skatt, med vilkor, at han skall vara dess Fader: At Gudarne ej upsatt honom til Konung för sin egen skull, utan för at vara Folkets Man: At en Konung är ovärdig Thronen, så snart han glömmer, det [att] hans skyldighet är, at upoffra sig sjelf, all sin tid och hela sin omsorg för det allmänna bästa och sitt Folk, som han är skyldig sin ömaste kärlek.

Minos upprätthållande av dessa grundsatser sades ha gjort hans rike dygdigt, lyckligt och mäktigt och honom själv gudomlig. Perserkonungarnas egenmäktighet, arrogans och krav på underkastelse hade däremot fått deras välde att duka under. ${ }^{520}$ De historiska exemplen tjänade antagligen som en inlindad varning till Adolf Fredrik och Lovisa Ulrika att inte försöka sig på något omstörtande i det sena 1760-talets antagonistiska atmosfär.

Hattpolitikern Stockenström var den ende ledamot som hemföll åt ett utpräglat hovsmicker under mösspartiets maktinnehav, när han angav att den nya regimens bevarande av Jernkontoret inte endast upphöjde Fredrik I utan också förstärkte

den glants, hvarmed vår nu varande Allernådigste Konungs och Drottnings hulda Regerings-tid [...] är omgifven, såsom lysande af Mildhet, Vitterhet och Vetenskapers samt Slögders förkofring; och et hägn, som i framtiden gifver vår nu Nådigste Arf-Furste och Dyra Kron-Prints [Gustav] tilfälle, at til detta Rikets sällhet utöfva de store och sällsynte Snilles-gåfvor, hvarmed Gud och Naturen Honom mildeligen och ymnigt utrustat. ${ }^{521}$

Efter hattarnas återerövrande av makten 1769 ökade kungahusets närvaro ännu en gång i presidietalen. Clason skildrade de prövningar som Adolf 
Fredrik fått utstå, inte minst de ekonomiska bekymren efter pommerska kriget, och höll före att hans nedläggande av spiran varit avgörande för rikets överlevnad. Clason alluderade här på Adolf Fredriks samverkan med de hattdominerade kollegierna vid deras arbetsnedläggning, som framtvingat den riksdag där hattarna återtagit makten. John Jennings prisade konungen med anledning av att Vetenskapsakademien tillåtits använda en av hans byggnader, men påpekade även att sekreta utskottet - som han själv händelsevis tillhört - varit betydelsefullt för utverkandet av denna favör. Jennings betecknade Adolf Fredrik som vetenskapernas och akademiens skyddsherre och påvisade regentens gunst gentemot organisationen. Han uppehöll sig därtill vid Lovisa Ulrikas dygd, nåd och enastående hedersbetygelse till Olof von Dalin och Samuel Klingenstierna, vilka hon förärat ett gemensamt gravmonument och i egen hög person strött jord över. Wargentins svar till Jennings tog också upp Adolf Fredriks upplåtande av lokaler och kungaparets kärlek till vetenskaperna, under det att sekreteraren registrerade ständernas välvilliga inställning till Vetenskapsakademien och att Jennings som medlem av sekreta utskottet bidragit till att sammanslutningen gynnats. ${ }^{522}$

De postuma omdömena om Adolf Fredrik fortsatte på det inslagna spåret. Arkitekten och överintendenten Carl Johan Cronstedt framställde några månader efter konungens död i februari 1771 honom som en patriotisk och omtyckt landsfader, vetenskapsälskare och svensk motsvarighet till den romerske kejsaren Titus, vars frånfälle bedrövade hela landet och uppfyllde akademimedlemmarnas tankar. Kärleken till och vördnaden för den framlidne monarken härrörde från hans rättvisa och milda styre liksom från de fredliga dygder som kännetecknat hans regering mer än någon annans; ingen furste hade varit ömmare om undersåtarnas välmåga och lagarnas helgd, eller lyckligare över riksförbättrande ansatser. Sandels deklarerade att Adolf Fredrik högaktats för sin människokärlek och sitt befrämjande av slöjder och vetenskaper. Konungen hade värdesatt dem och fria konster så till den grad att han "ville hafva det under arfs-rätt i sitt Hof besegladt: och med den kärlek Han således i sin Kongl. Famille fortplantade för desse Landets rätta prydnader, befästade Han vårt hopp och vår glädje både för den närvarande [tiden] och framtiden”. Ett flertal lovvärda och allmännyt- 
tiga inrättningar hade grundats under hans spira och uppmuntrats av riksdagen, vilken Sandels betraktade som drivande i välståndsarbetet efter stora nordiska kriget. Han uppgav därutöver att akademien på ständernas uppdrag publicerat Tessins brev till kronprinsen Gustav, som uppskattat dem. ${ }^{523}$ Huruvida dessa yttranden skall förstås som markeringar mot kungamakten är oklart, men det kan inte uteslutas att en sådan intention förelåg.

Den nyblivne konungen Gustav III gjordes till föremål för en hel del lovprisande, vilket kan kopplas dels till de stora förhoppningar som ställdes till honom under de rådande krisstämningarna, dels till en rojalism som låg $\mathrm{i}$ tiden och hade vunnit insteg bland hattpartiets anhängare. ${ }^{524}$ Gustav omgavs inte minst av religiös retorik. Cronstedt förkunnade att Försynen välsignat Sveriges kungahus och korat en tronföljare i besittning av de egenskaper som med Herrens bifall lovade fäderneslandet en lång och säll regering. Wargentins svar porträtterade Adolf Fredrik som en kärleksfull och djupt sörjd landsfader, och Gustav som en Försynens gåva som skulle göra riket lyckligt och få vetenskaper och konster att blomstra. Svaret avslutades med en önskan dels om konungens snara återkomst från Frankrike där han befann sig på resa vid faderns frånfälle, dels om att Gud skulle hålla sin hand över hans styre. ${ }^{525}$

Den nye fursten attribuerades kvaliteter som Vetenskapsakademien skulle komma att tillmäta honom under hela hans regeringstid - nåd, mildhet, kärleksfullhet, vishet, upplysning och engagemang för lärdom och nytta. Gustav ansågs vara en synnerligen upplyst domare som på ett lyckobringande och sällsynt begåvat sätt tog sig an de vetenskaper han understött redan som kronprins. Den nåd konungen lät vederfaras akademien varslade om dess fortgående kungliga beskydd och de goda konsekvenser hans visa styre skulle få för vetenskaperna och fäderneslandet. Tronen lyste mer än förut av kärlek till såväl vetenskaperna som de fria konsterna och hushållningen; Gustav återupplivade minnet av de stora Vasarnas omsorg om näringarna, varför hans namn skulle förevigas även genom ekonomin. ${ }^{526}$ Konungens kärlek riktade sig lika mycket till folket. Det hette att Gustav fattade ett helhetsgrepp om undersåtarnas lycka och månade om framför allt deras materiella välfärd, medan dessa i gengäld hyste en genuin och underdånig vördnad för sin monark. ${ }^{527}$ 
Panegyriken kunde vara nog så långtgående. Veckor före statsvälvningen hyllade Anders Schönberg Gustav III som "den bästa Konung, människo-slägtets Glädje, Thronens prydnad, främmande Folkslags förundran, och sitt folks ypperste Välgörare”, vars exempel skulle väcka patriotisk iver i alla hjärtan. Carl Rudenschöld menade att svenska språket aldrig haft större möjlighet till en guldålder, givet att Gud begåvat riket med en infödd regent som älskade och ärade modersmålet. Han hoppades att Gustav under många år skulle utgöra ett språkligt föredöme för undersåtarna och en förebild för andra regenter ifråga om furstliga karaktärsdrag. Rudenschöld fann vidare att den medeltida furstespegeln Konunga- och höfdingastyrelsen på flera punkter förtjänade att vara ett mönster för samtiden. Detta kan utifrån hans hovsmicker och nämnda furstespegels förespråkande av arvkungadöme som metod för att undvika söndring läsas som en kritik av den sena frihetstidens tvedräkt. ${ }^{528}$

Rudenschölds besvikelse över partiandan, ett "ohyggeligt ämne", var tydlig. Han hyste åsikten att språket hade gått från att vara ett gudasänt sammanhållande band till att ogenerat missbrukas för att förstöra samhället. En författning tänkt att bringa upplysning och sunda begrepp - av allt att döma 1766 års tryckfrihetsförordning - blev "på ett, för alt dygdigt folk, bedröfligt sätt, förvänd till att utgjuta bitterhet och hämd", en skamfläck för Rudenschölds "så kallade, uplysta Tidehvarf" som i görligaste mån borde döljas för eftervärlden..$^{29}$

Läkaren Nils Rosén von Rosenstein deklarerade några månader före statsvälvningen att Gustav var Guds gåva till riket och att den lärda världen länge sett honom som värdig tronen. Rosenstein bad att Gud skulle bevara konungen och hans värv, som syftade till nuets och framtidens bästa i form av egennyttans och avundsjukans fördrivande, oskuldens värnande och den riktiga frihetens säkrande - en frihet "förenad med vördnad för Konung, och inbördes förtroende Medborgare imellan". 530 Avogheten mot misshälligheter torde ha haft bäring på den sena frihetstidens förhållanden. Rosensteins resonemang om frihet förebådade akademiens politiska språkbruk efter statsvälvningen, där den rätta, gustavianska friheten kontrasterades mot ständerväldets falska dito.

Även andra ledamöter adresserade splittringen och dess olycksaliga effekter. Det konstaterades att den beklagansvärda oenigheten var 
en orsak till Sveriges svåra tillstånd, att motsättningen på riksdagen 1738-39 försvagat ständernas ansträngningar samt att det innevarande tidevarvet utmärktes av tvedräkt, egennytta och likgiltighet inför samhällets bestånd. ${ }^{531}$

En starkare kungamakt låg i luften, men den frihetstida friheten fortfor likväl att omfamnas i Vetenskapsakademiens presidietal där förflutna autokratier klandrades och därmed troligen fick tjäna som projektionsytor för antirojalistiska ståndpunkter. Clason tillkännagav att handeln under stora nordiska kriget lämnats åt sig själv och att Ulrika Eleonoras trontillträde inneburit att envälde förbytts i frihet genom en glädjefull "förlossning", som dövat smärtan från de ekonomiska problemen och haft en gynnsam inverkan på siden- och yllefabrikerna. Sandels liknade samma krig vid en ofantlig storm, efter vilken såväl freden som friheten återställts. Sten af Rabbe kan med tanke på det gängse historiebruket antas ha kommenterat samtiden när han jämförde de antika envåldsmakterna Thessalien och Epirus med övriga grekiska riken, vilka var fria småstater som tillsammans bildade en sorts republik. De förra låg efter trojanska kriget mestadels i mörker, de senare utgjorde det "rätta gamla Graekeland, som i Politiska- och Vitterhets-Historien har ett så lysande äreställe". ${ }^{532}$

Historikern Olof Celsius den yngre gav i frihetstidens elfte timme röst åt sin uppskattning av den fria regeringen, som bedömdes ha ett fördelaktigt inflytande på den intellektuella verksamheten, bland annat vältaligheten. ${ }^{533}$ Efter statsvälvningen kom akademimedlemmarna dock ganska omgående att företräda ett radikalt annorlunda synsätt, som utforskas i det följande.

\section{Den tredje Gustavens dagar}

Vetenskapsakademiens relation till regenten blev av förklarliga skäl mycket mer central efter den oblodiga statskuppen i augusti 1772, som satte stopp för de sociala stridigheterna och välkomnades av desillusionerade hattar som Höpken, Carl von Linné, Carl Fredrik Scheffer och Wargentin. ${ }^{534}$ De kungliga akademierna kom att gå regimens ärenden och utgöra "institutioner inom det kungliga nåde- och äre- 
förläningssystemet" med "viktiga ämbetsverksliknande uppgifter". Akademiernas pristävlingar och utmärkelser svarade mot regeringens ideal, invalen hade kunglig sanktion och ledamöterna arbetade officiellt för monarken. Svenska Akademien fungerade som ett informellt kollegium, Vitterhetsakademien som ett rojalistiskt organ och som en kontrollinstans för inhemska medaljer. Vetenskapsakademien förblev en kugge i statsmaskineriet, inte minst genom att makthavarna liksom tidigare gav den utredningsuppdrag. En kontinuitet med frihetstiden kan skönjas även i Gustav III:s syn på akademien som främst en nyttig och patriotisk inrättning. ${ }^{535}$

Den gode fursten förväntades under tidigmodern tid ikläda sig rollen av landsfader och vara ett dygdemönster i besittning av rättvisa, klokhet, fromhet, mildhet och nåd. Som det föreliggande avsnittet skall visa knöts Gustav III liksom sina företrädare till detta motivkomplex i Vetenskapsakademiens presidietal, vilkas upphovsmän i likhet med andra iakttagare också framställde monarken som upplyst, hjältemodig, patriotisk, välgörande och älskad av undersåtarna. Ledamöterna anslöt sig till den rojalistiska propagandans bild av konungen som en befriare och frälsare från oordning, vars styre präglades av samförstånd, trygghet och äkta frihet, till skillnad från frihetstida söndring, självsvåld och adelsdespotism. Regimens gestaltande av Gustav som en återupprättare av det förhållande mellan folk och monark som rått före det karolinska enväldets införande 1680 var däremot inte påtagbar i talen. "Frihet" gick från att avse ständernas oberoende av kungamakten till att handla om rikets självbestämmande och frånvaron av aristokratiskt förtryck genom ett styrelseskick som förbands med Gustav Vasa och särskilt Gustav II Adolf. Efter fem decennier av frihetsretorik var det lika omöjligt att ignorera den positivt laddade termen "frihet" som det offentliga samtal frihetstiden givit upphov till. ${ }^{536}$

Carl Fredrik Scheffers Tal, om förbindelsen, imellan grund-lagarnas art och folkets sällhet, som efter dem styras skal i oktober 1772 var det första presidietal som hölls efter Gustav III:s maktövertagande. Scheffer, en av konungens nära förtrogna, rörde sig med teman - frihetstidens fördärvlighet, Gustavs hjältemod, värdet av säkerhet och frihet - som kännetecknade såväl presidietalen som regimens propaganda 


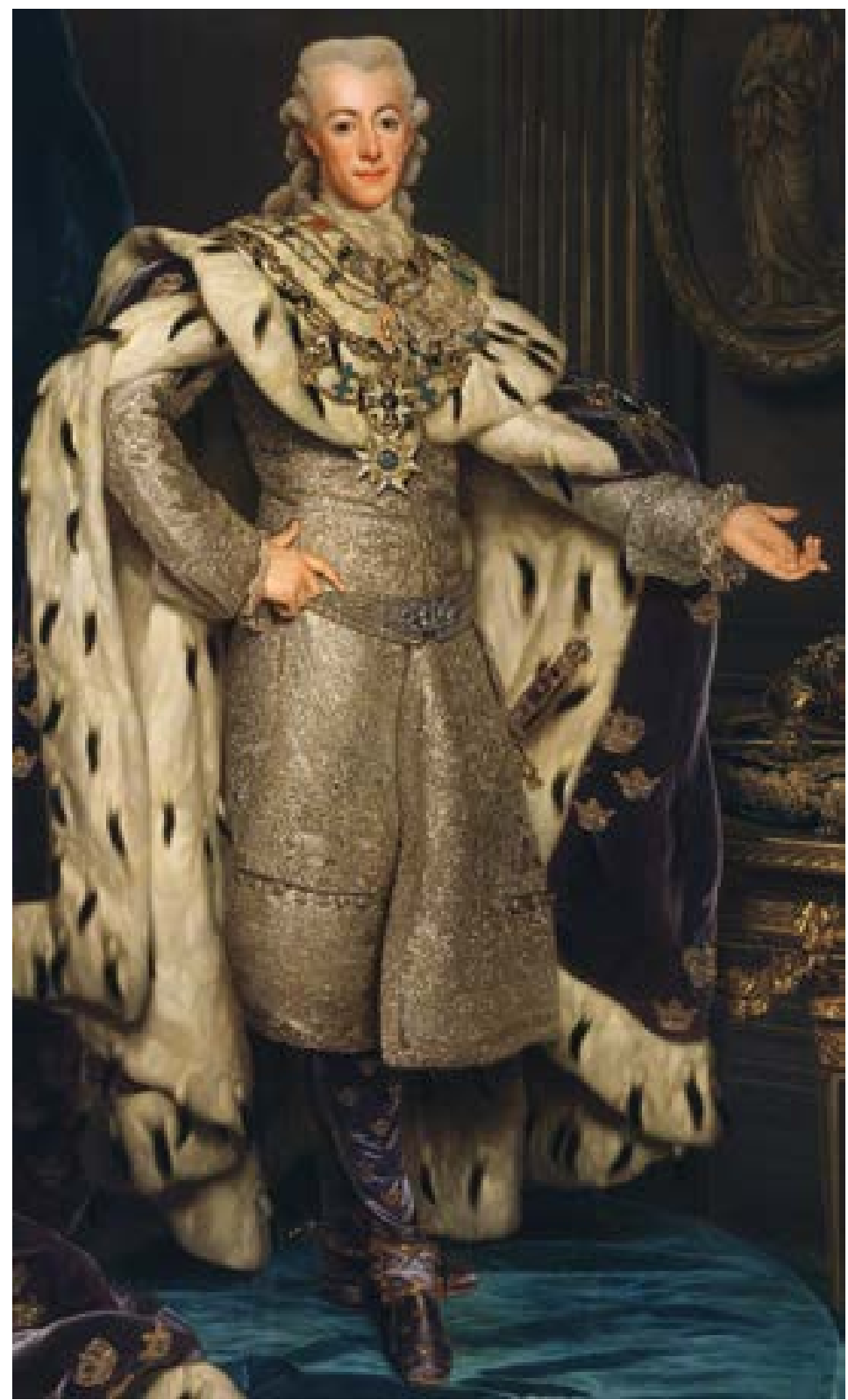

Bild 10. Alexander Roslin, Gustav III, 1746-1792, konung av Sverige. Foto: Nationalmuseum. 
och självbild under den gustavianska eran. Han fastslog att vetenskapen hade till uppgift att sätta ovanliga och stora händelser i rätt perspektiv. Ingen sådan händelse var mer betydelsefull eller förundransvärd än den gudagivna statsvälvningen, ty ett "helt Folk, som ryckes ur förderf och återställes i lycksalighet, genom et enda frimodigt beslut, genom en enda Hjeltemodig Bedrift, på en enda dag och utan et enda lifs spillande, är visserligen i den Moraliska Verlden, hvad man i Naturen kallar et underverk". Om det stämde att fred, lugn, privategendomens helgd och näringarnas frihet utgjorde den högsta lycka och att lagarna, speciellt grundlagarna, var förutsättningen för denna ägde Gustav "inom sig Sjelf den största förnöjelse, som någon Regent, ja, som någon dödelig här på jorden njuta kan”. Wargentin anmärkte i sitt svar att Försynen under Scheffers presidium skänkt svenskarna mer än de vågat önska eller kunnat förvänta sig. Regeringssättet hade förändrats till det bättre, en rättfärdig frihet förstärkts, den enskilda och allmänna säkerheten återinförts. Sveriges varaktiga sällhet var inom räckhåll och framtiden hade aldrig varit ljusare för näringarna, konsterna, vetenskaperna och Vetenskapsakademien, vilken fröjdade sig över detta. ${ }^{537}$

Det gudomliga mandat Scheffer och Wargentin attribuerade Gustav III återkom hos andra ledamöter. Konungen sades vara en himmelsk gåva som likt Gustav Vasa frälste riket från fara, och om Gud ville skulle hans strävanden efter förbättring bära frukt under en välsignad och lång regering. Allt förmånligt som riket upplevde från Gustavs tronbestigning och framåt skedde med Herrens goda minne. Monarken parallelliserades på hävdvunnet, kvasireligiöst manér med solen; liksom den vederkvickte och gladde naturen, upplivade en vis furste undersåtarna i deras utsedda sysslor. Gustavs tron, som lyste inte minst i vetenskapernas krets, avgav en värme som ingöt välvilja, patriotism och strävan efter oförgänglig ära i allas hjärtan. ${ }^{538}$

Presidietalen utmålade ofta Gustav III som nådig, antingen i hänvändelser till honom eller genom direkta eller indirekta karaktärsteckningar av och referenser till regenten. ${ }^{539}$ Ibland tillskrevs denna egenskap Kongl. Maj:t, som kunde ha en bredare syftning än konungen. ${ }^{540} \mathrm{Gustav}$ framstod också som mild, god, storsint, generös, välvillig, arbetsam, effektiv, stor och mäktig. ${ }^{541}$ Carl Sparre betecknade honom som rikets 
"store Ledare", medan Carl Fredrik Scheffer hävdade att hans storhet framgick av att han med en åtgärd som skulle komma att få eftervärldens tack begränsat sin egen domsmakt. ${ }^{542}$

Andra kvaliteter som kopplades till konungen var vishet, insiktsfullhet och upplysning. ${ }^{543} \mathrm{Han}$ uppgavs vara en filosof som bekantgjorde sin omsorg om egendomsrätten på ett upplyst vis och själv skrev utkastet till grundlagen, vilket vid sidan av hans arbete med att utveckla uppfostringsväsendet vittnade om hans djupsinne. Han var den mest upplyste konung med "de största naturens förmoner" och "den visaste kunskap at dömma om alt det, som länder til sit Lands välfärd", samtidigt som han tillhörde de mest upplysta kännare av konster och vetenskaper som suttit på eller nedanför troner. ${ }^{544}$

Ett annat tema i framställningarna av Gustav III var hans moraliska reslighet. En uttryckt förhoppning om förbättrade seder efter statsvälvningen grundade sig inte bara på lagarna utan än mer på lagstiftaren, vars ändlösa kärlek till dygd och ära skulle jaga lasten på flykten. Det hette att dygden lyste i Gustavs handlingar, ärade kungavärdigheten och krävde lagens okränkbarhet. Det spåddes att Gustavs regering skulle bli en lysande tid med avseende på snillebragder, djärvhet, ädelmod, patriotism, ärlighet och måttfullhet. Mot undersökningsperiodens slut konstaterades att hans författningar faktiskt förädlat tänkande och seder. ${ }^{545}$ Gustav beskrevs i linje med dessa egenskaper som en fridsfurste. Bengt Bergius skildrade det stora nordiska krigets hemska återverkningar och menade dels att krig bidragit till att det frihetstida nyttoarbetet inte fullt ut lyckats, dels att utdragna och bistra krigstillstånd var grymma landsplågor. I vad som sannolikt utgjorde ett försök att övertyga konungen om behovet av grannsämja tillade han att Gustavs "fredälskande sinnelag och förträffliga Stats-konst" ingav hopp om att väpnad konflikt kunde undvikas. ${ }^{546}$ Alla delade dock inte denna pacifistiska inställning. Axel Magnus von Arbin framförde att han inte fruktade grannarnas fredsbrott och att det om olyckan var framme inte skulle saknas soldater fostrade av Gustav, vilka skulle låta sig inspireras av historiska svenska hjältar. ${ }^{547}$

Gustav III framträdde vidare som en nyttofurste, vars regeringssätt utmärktes av vett, idoghet och slöjd. Konungen betraktade med gil- 
lande sina trogna undersåtars ansträngningar att med flit och gagneliga näringar öka sitt välstånd, och under Gustavs spira skulle svårigheterna som behäftade handeln övervinnas och ett friare och mer omfattande varuutbyte åstadkommas. Om han fick leva lika länge som sin namne Gustav Vasa skulle hans regering få gynnsamma konsekvenser inte minst i form av en fördubblad befolkning som var oberoende av utlandet för sin försörjning. ${ }^{548}$ I ett fall, Eric Schröder, var tonläget något mindre entusiastiskt. En kunglig förordning av år 1775 om friare inrikes spannmålshandel skulle alltid ha "et hedrande rum ibland nyttige Författningar, ehuru verkan deraf ännu icke lärer hafva aldeles svarat emot afsigten". 549

En av de mer oförblommerade skildringarna av nyttofursten Gustav III återfinns hos Jean George Lillienberg, som meddelade att positiva exempel inte är verkningslösa när en vis monark stöder och uppmuntrar nyttiga anstalter. Konungen inhämtade ständigt kunskap om ämnen som gjorde riket starkare och mer välmående. Han begrep bergsnäringens värde och hade i likhet med sina stora föregångare inspekterat den, varvid undersåtarna blivit varse överhetens intresse för sådant som rörde rikets väl. Med hans inspirerande nåd kunde näringen förväntas nå än högre höjder, eftersom denna var dess främsta drivkraft. Gustav hade tydligt visat sin omtänksamhet om metallindustrin och gynnat kopparförädlingen, vilket föranlett en rekordexport av kopparsmide. Till följd av dessa satsningar hade manufakturägarna börjat tävla ordentligt med varandra och metallförädlingen fått den största tillväxt. Lillienberg talade om "de sanskyldiga tacksamhets-offer" som Sveriges bergsmän frambar till tronen och önskade att regenten "måtte i sin [livs]tid få höra Närings-idkare i allmänhet sjunga, om [...] deras sällhet, under Konung GUSTAFS Spira, och Bergen derå gifva et fördubbladt genljud". 550

Gustav III skildrades också som en vetenskapernas och de sköna konsternas furste, vilken älskade, beskyddade och uppmuntrade dem och deras idkare. Givet att riken med regenter som drev på nyttiga vetenskaper och visste deras värde var lyckliga kunde Sverige räknas som det mest sorgfria landet. Både riket och Vetenskapsakademien gladdes över Gustavs förträffliga understödjande av vetenskaperna, och akade- 
mien prisade tacksamt Försynen för att ha skänkt den en konung vars beskydd fick vetenskaperna att blomstra till evärdlig ära för hans tid. ${ }^{551}$

Slutligen beskrevs Gustav III som vördad och älskad. Folket höll honom kär och bad till Gud om att den gustavianska tronen skulle konsolideras genom en kronprins. Enligt Joachim Wilhelm Lilliestråle hade undersåtarna satt sin lit till och älskat Gustav redan som kronprins. Samme preses lade sig på en teoretisk nivå när han anförde att kärleken till monarken och fäderneslandet utgjorde villkoret för social harmoni, då denna känsla stärkte samhällsbanden och gjorde så att en anda rådde över allt. ${ }^{552}$ Konungens besvarande av folkets kärlek utgjorde ett givet motiv i talen. Gustav III var en nådig landsfader som styrde mer med kärlek än med fruktan, ömmade för sina lojala undersåtar och eftersträvade deras sällhet. Deras lycka var emellertid inte tillräcklig för honom; han ville även att de skulle känna sina förmåner, hålla av sitt fädernesland, verka för kommande generationer och förnöjda tacka Gud. ${ }^{553}$ Lilliestråle upplyste om att Gustav hyste en faderlig omtanke om sitt folk och fröjdade sig över dess lycka, och om att det var hans nöje att arbeta och tänka för undersåtarna. Konungen tillmättes härvidlag en djup människokärlek: "Den falska styrsel-konst hos honom intet gäller, Som kortsynt, svag och trång, blott thronens fördel ser: Hans föremål är stort, Hans hjerta uplyft mer: För mänsklighetens hjelp vår TITUS tårar fäller: Den har det främsta rum i GUSTAFS höga själ: Han känner ömt och qväls [lider] af hvad Hans land kan trycka: Sin Kronas höga rätt, Sin fördel och Sin lycka Han ser i folkets väl." 554

En variation på samma grundtema kom till uttryck i presidietalens iscensättningar av Gustav III som en medicinskt välgörande furste, som bekymrade sig om sjukdom, vidtog hälsofrämjande åtgärder och tillsammans med sin familj utgjorde ett lysande föredöme genom att låta ympa sig med koppor. ${ }^{555} \mathrm{En}$ annan variation återfinns i framställningarna av Gustavs filantropiska ådra. Carl Sparre redogjorde för hur det ökade tiggeriet väckt konungens medlidande, motiverat honom att i egen hög person begära ett utlåtande från Stockholms magistrat och fått honom att försöka lindra misären. Läkaren Herman Schützercrantz (Schützer) diskuterade monarkens oförfalskade engagemang för fattiga 
barnaföderskor och attribuerade honom en medfödd människokärlek och empati. ${ }^{556}$

Som brukligt var belystes Gustav III:s egenskaper med hjälp av historien. Carl Fredrik Scheffer liknade honom vid den atenske lagstiftaren Solon; båda hade upphävt lagar som kostat åtskilliga människoliv, låt vara att Gustav överträffade sin antike föregångare och att svenskarnas lycka skulle överträffa atenarnas eftersom konungens gärning skulle bli bestående. Scheffer liknade därtill Gustav vid den romerske kejsaren Trajanus, bland annat ifråga om välgörande lynne och band till folket. Även i detta sammanhang gavs den svenske fursten ett försteg framför det antika exemplet, samtidigt som Scheffer anmärkte att monarken alltid på något sätt skulle överskugga forntidens stora män, vad än för jämförelser som gjordes med dem. ${ }^{57}$

Gustav III identifierades alltifrån sin födelse som "den tredje Gustaven", efter Gustav Vasa och Gustav II Adolf. Gustav Vasa utgjorde en viktig referenspunkt i det förflutna, inte minst för den tredje Gustaven själv. ${ }^{558}$ Lilliestråle förutsåg att Gustav III "Den förste GUSTAF likt" skulle frälsa landet från olycka, ge rikskroppen livskraft och göra Sverige lyckligt. En mer subtil parallellisering går att läsa in i Arbins utsaga att krigsvetenskapen, "förädlad i en GUSTAF WASAS händer", betvingade såväl utländska tyranner som inhemska våldsutövare, varefter fred, lugn, sedesförbättring, upplysning, konster och vetenskaper infann sig. ${ }^{559}$ Alla dessa honnörsord känns igen från skildringarna av Gustav III, som Arbin torde ha avsett lika mycket som Gustav Vasa. Hänvisningarna till inrikes våldsverkare och till främmande tyranner kan ur det perspektivet förstås som anspelande på partierna respektive de danska och ryska regenterna.

Nils Adam Bielke konstaterade i sitt presidietal om hushållningen under Gustav Vasa att ämnet borde beröra åhörarna desto mer eftersom de levde i en tid då den bäste konung ärofullt och framgångsrikt väckte minnet av vad "den Förste GUSTAF" gjort för fäderneslandet. De uppmanades be för att den som besatt Gustav Vasas namn och hans ömhet för folket också skulle besitta hans livslängd. Bielke menade att ingen från Karl den stores tid intill det innevarande tidevarvet kunnat mäta sig med Gustav Vasa; "Hjeltar kunna finnas i alla åldrar; men 
där vil Secler til, at alstra GUSTAVER." Gustav III likställdes således av allt att döma med den oförliknelige reformationskonungen. Talet liknade Gustav Vasa vid Julius Caesar och porträtterade honom som en stor, vis och lärd furste med ett ädelt hjärta. Försynen hade sänt den hjältemodige monarken att rädda riket, som han lyft ur slaveri och våld samt lösgjort från de problem som orsakats av orkeslöshet, okunnighet, vrede, upproriskhet och utländsk förslagenhet. Han föreställdes därutöver som en formidabel näringsfurste med livaktigt intresse för ekonomin och fredlig välståndsökning, och som en lagförbättrare och ordningsam far för sitt folk, upplivad av kärlek till fäderneslandet och omsorg om undersåtarna. Gustav Vasas utomordentliga kvaliteter hade fått folket att älska honom innerligt, efter att det förvissats om att han oupphörligt aktade på dess bästa. ${ }^{560}$

De karaktärsdrag och gärningar Bielke tillskrev Gustav Vasa påminde starkt om dem som associerades med Gustav III i presidietalen. Det är med hänsyn till den explicita sammankopplingen av de två Gustaverna mer än sannolikt att den historiska tillbakablicken också syftade på samtida förhållanden. Utsagorna om våld, träldom och utländska illfundigheter lär ha anspelat på både frihetstiden och den katolska unionstiden, då det svenska riket hade varit invecklat med Danmark och Vatikanen.

Wargentin följde Bielke i spåren när han i sitt svar betonade att Gustav Vasa hade få uppenbara likar och att han varit en insikts- och kärleksfull landsfader, vars arbete syftat till ett mäktigare rike med en stor, välmående befolkning. Gustav Vasa knöts liksom hos Bielke tydligt till Gustav III: "Lyckligt det Land, som länge får styras af en så vis och öm Fader! Lyckligt Sverige, som åter ser en GUSTAF på Thronen, brinnande af samma hjertelag [goda sinnelag] emot sina undersåtare! Himmelen förläne Honom ock samma lycka och rätt Kongliga förnöjelse, at, efter en lång och ärefull Regering, få se sit Rike, genom allmänna hushållningens förbättring, försatt, utur största vanmagt, til högsta välstånd och anseende!"561

Den 2 maj 1792, drygt en månad efter Gustav III:s död den 29 mars samma år, höll ämbetsmannen Zacharias Zachariae Plantin ett tal som inleddes med en veklagan över den mördade konungen. Vetenskapsaka- 
demiens medlemmar sades vara vana vid att på sina möten uppleva en tillfredsställelse som kom sig av att de verkade för allmännyttan, under goda lagar och i sämja och lugn. Nu avslöjade de bedrövade ledamöternas klädedräkt och förskräckta ansikten en smärtsam förlust: "Svea Rike har förlorat Sitt Öfverhufvud, Vetenskaperne en Älskare och vår Academie sin Höga Beskyddare." ${ }^{562}$

Plantin förklarade att alla tre Gustaverna brytt sig om såväl ärorika krigsbragder som vetenskaper. Saknaden efter Gustav III var så mycket större eftersom hans kärlek till vetenskaperna anvisade hans regering en strålande plats i deras historia och honom en framskjuten position i annalerna. Ingen vetenskap hade förfördelats under den genialiske sanningsälskarens styre, då naturforskningens utmärkta beskydd väckt förundran. Till det kom att konungen ömmade för ungdomens uppfostran och på alla vis sökte sprida verklig upplysning för att undersåtarna skulle tillgodogöra sig ett fritt och lagbundet samhälles förmåner, vilket ännu inte alldeles förverkligats. Plantin diskuterade även Gustavs stora påverkan på litteraturen och den konstnärliga verksamheten. Genom språkets och smakens förkovran hade "det gamla Afguderiet för utländingars nog medelmåttiga företräden, som hittils qväft [kvävt] all egen upkomst" lyckligtvis försvunnit, "hvarföre ock Sverige nu ej behöfver Roms biträde, at i Marmorn uttrycka sin tacksamhet på GUSTAF Den III:djes Graf" ${ }^{563}$ I likhet med Gustav Vasa före honom hade Gustav III befriat riket från utländskt, enkannerligen romerskt, inflytande.

Johan Carl Wilcke hävdade i sitt svar till Plantin att den hädangångne monarkens dygder alltid vida överskridit Vetenskapsakademiens förmåga att berömma honom och att hans tal på ett värdigt sätt formulerat organisationens sorg. Akademisekreteraren betonade också ledamöternas ledsnad, men lade till att hela landet genljöd av bedrövelse. ${ }^{564}$ De postuma beskrivningarna av Gustav III reproducerade som synes flera av de teman som varit tongivande under hans regeringstid, vilken fortsatte att förbindas med enighet, frihet, sanning, dygd, nytta, upplysning och kulturens och lärdomens befordrande.

Kronprinsen Gustav Adolf, den blivande Gustav IV Adolf, relaterades från första stund till kungafamiljens lärdomsbeskydd. Anders Sparrman framförde vid hans födelse på hösten 1778 Vetenskapsakademiens för- 
hoppning att Gustav III:s efterträdare skulle bli en vetenskapsgynnare av samma rang som sin far. I detta sammanhang tecknades en idealbild av det Sverige tronföljaren skulle komma att regera över:

Himmelen upfylle våra brinnande önskningar!!! så skall den efterlängtade Prinsen, då Han en gång uplyfter Sin Spira öfver et redan lyckligt Folk, dana et Saturni Tidehvarf för Sina glada Undersåtare, hvilka, uplyste af redan gynnade och florerande Vetenskaper, skola med deras snille-foster än mer hedra och gagna Hans tid och efterkommande Secler. Då, om icke förr, skola Människo-kärlek och Patriotisme, jämte Vetenskaper och Slögder, på Svenska kölar föras och utbredas til Södra Verlds-halfvan, samt fördubblade återflyta til Europa och vår älskade Nord.

Wilcke anmälde senare i samma anda att den upplysning informatorn Nils von Rosenstein inpräntat hos rikets högt värderade kronprins, "Samtidens glädje, Framtidens hopp", skulle göra eftervärlden säll. ${ }^{565}$

Plantin riktade sig efter Gustav III:s död till Gustav IV Adolf, som bar "et älskadt Namn och med GUSTAVERS Blod ärft deras kärlek för Fosterbygden". Han frambar en önskan om att den käre Vasaättling Försynen nu korat till rikets överhuvud skulle få skörda frukten av sin innerligt saknade fars visa insatser för att skapa fria och laglydiga undersåtar. Talet smickrade också Gustav Adolfs förmyndare och farbror, hertig Karl. Plantin hoppades att de sköna anlag som till folkets glädje så tidigt visat sig hos Gustav Adolf skulle nå sin fulla potential under tillsyn från denne hjälte, som Gustav utsett till den omyndige konungens stöd. Karl skulle leda den unge härskaren till sann ära och dygd, och med Guds hjälp och svenskarnas mod bevara hans tron, "som in- och utländsk tvedrägt, i Vasarnas tid, väl förmått skaka, men ej öfverända kasta". ${ }^{566}$ Vetenskapsakademiens ledamöter anpassade sig således liksom 1772 synbarligen friktionsfritt i sina presidietal till det förändrade politiska läget genom att snabbt flytta över sina lojaliteter och vända sig till den nya regimen. Den nye regenten framställdes analogt med den gamle som en Gustavers och Vasars arvtagare, under det att inarbetade teman som undersåtlig frihet och enighet, kunglig dygd, kärleksbandet mellan furste och folk samt monarkens gudomliga mandat fortfor att åberopas. 
Frihetstiden ställdes efter statsvälvningen vanligen i en ogynnsam dager och kontrasterades därvid mot det bättre gustavianska tidevarvet. Gustav III lade beslag på värdeordet "frihet", medan den föregående perioden tillskrevs falsk frihet, motsättningar, självsvåld, godtycke, korruption, svaghet och ett förfall som fört riket till undergångens rand. ${ }^{567}$ Presidietal refererade till frihetstidens förvirring, bullersamma förändringar och försämrade inrättningar. Enligt Rosenstein den yngre hade det under denna tid förelegat en tro att friheten kunde äga bestånd "utan personlig säkerhet, med urtima Domstolar och förtryckande grundsatser" och att "alt hulpit [hjälpt], blott vissa Medborgare förlorade". ${ }^{568}$

Carl Fredrik Scheffer använde tydligtvis historien som en projektionsyta för såväl frihetstiden som det karolinska enväldet. Han menade att antikens Grekland präglats av instabilitet, förföljelse, konflikt och maktkamp, företeelser som var oförenliga med den sanna lycksaligheten. De gamla grekerna hade ömsom upphöjt, älskat och åtlytt, ömsom vanärat, förkastat och förvisat samma män, ofta bara för att de ledsnat på att höra dem berömmas. Folket förtrycktes ena stunden av det värsta envälde och hängav sig den andra åt det skamligaste själsvåld. Detta tillstånd berodde på konstlade regeringslagar som var "fulle af oenighets-frön", oförmögna att åstadkomma jämvikt och i konflikt med naturens ordning. Scheffer skyllde den romerska republikens missförhållanden på regeringslagarnas obeständighet och mångfald, medan folk och senat liknades vid två folkslag som drevs av ett konstant begär att inkräkta på varandras rättigheter. Han avskydde och äcklades av senatens orättvisa, arrogans, hårdhet och folkförakt, liksom av menighetens olydnad, ansvarslöshet, bångstyrighet och försummande av sina plikter. Kejsardömets brist på lagar var emellertid inte heller något att hurra för. Scheffer kom fram till att romarna "både under Frihets tiden och under Enväldet" varit lika olyckliga som strålande; de hade likt grekerna hemfallit åt rivalitet och osämja, alltid i frihetens namn men utan att veta vad den faktiskt innebar. ${ }^{569}$ Scheffers terminologi gör det troligt att han även avsåg det karolinska och det frihetstida Sverige. Detsamma kan sägas om attributen osämja, självsvåld och falsk frihet som ju under den gustavianska eran frekvent tillmättes frihetstiden.

Frihetstiden verkar också ha vilat tungt över Scheffers skildring av det 
barbariska feodalsamhället, där folket levde i träldom och stormännen trots sitt självsvåld och sin makt inte kände någon lycka: "De oroade hvarannan [varandra] inbördes, stridde om företrädet, täflade om alla Borgerliga förmoner, grepo til vapen vid minsta anledning til missnöje, och som Öfver-Herren var för svag, at någonsin göra sig lydd, så blef i et så inrättadt Samhälle alt öfverlämnadt til våld, och den svagare altid et rof för den mägtigare.” Välstånd, säkerhet och ordning lyste med sin frånvaro, konsterna, handeln och jordbruket var illa däran, folket utnyttjades av makthavarna ${ }^{570}$ Utsagorna om oordning, osäkerhet och interna slitningar torde ha åsyftat frihetstiden lika mycket som medeltiden. Den svage överherre som inte kunde komma till rätta med våldet och förtrycket var inte endast den generiske feodalfursten utan även Adolf Fredrik.

En indirekt polemik mot frihetstiden går vidare att urskilja i Scheffers resonemang kring olika juridiska system. En sorts länder hade lagar som fick den styrande och undersåtarna att oavlåtligt frukta varandra och formellt gjorde den förre beroende av de senare, låt vara att denne i praktiken kontrollerade dem genom deras korruption, vilken blev till "en Stats-lära" som upphöjde de mest lastbara. Lagarna gav visserligen sken av att vara till för den enskildes och det allmännas säkerhet men kunde inte förhindra beständiga oroligheter, de egenmäktigas raseri eller de sedligaste medborgarnas förorättande. I ett annat slags rike vidtog det härskande partiet under "en påstådd Frihet, [...] stundom af okunnighet, oftare af harm och bitterhet emot Gen-Partiet [...] mått och författningar til landets förödande; likt Envålds-Herren deruti, at bägge erkänna ingen Lag, utan styra efter godtycko". ${ }^{571}$ Samtida iakttagare förnam säkerligen en rad likheter mellan respektive system och det frihetstida Sverige - närmare bestämt korruption, självsvåld, tvedräkt och falsk frihet.

Scheffer riktade vid några tillfällen en mer direkt kritik mot frihetstiden. Antika och samtida europeiska lagars fel hade varit än mer kännbara i riket under det gångna halvseklet, då lagstiftningen lidit av omfattande, sedesfördärvande brister och krävt en myckenhet blod, i linje med partiandans grymhet och på grund av bitterhetens och hämndens föreskrifter. Han fann det beklagligt att frihetens verkliga 
innebörd var oklar i ett rike som så länge och träget uppehållit sig vid och idealiserat den. Denna reflektion utmynnade i en regelrätt diatrib mot frihetstiden, som Scheffer benämnde "missfostret":

jag vågar tilspörja [fråga] hela vår opartiska Allmänhet, huru ofta detta ordet [frihet] blifvit missbrukadt, huru oförsynt sjelfva saken blifvit bårtblandad med alla de Passioner, som upeldat hvar enskild Medlem af detta Samhället? Den äregiruge och storsinte Medborgaren har kallat Frihet, at få styra Riket såsom Ledare af et Parti; den penning-giruge, at få sälja sitt Tankesätt, och ofta sina dyrbaraste Rättigheter i Samhället; den late och vällustige, at få upoffra sina skyldigheter åt sina nöjen; den sjelfsvåldige, at få följa obehindrad sitt tycke, och lyda ingen mer än sig sjelf; den orolige och egennyttige, at få upblåsa tvedrägts-andan, upägga [uppegga] Partierne, och ymsom [ömsom] stå med bägge, til at säkrare vinna egen fördel $i$ alla skiften och alla hvälfningar.

Här återfinns karakteristiska inslag i den gustavianska bilden av frihetstiden, inte minst den falska friheten, vilken kan kopplas till Scheffers skepsis gentemot "fullkomliga Republiker", som av för honom okända skäl kallades "Fria Stater". ${ }^{572}$

Sven Bunge diskuterade ett tidsligt ospecificerat men klart frihetstida Sverige, där styresmännen saknade övertygelse om sin egennyttas sammanfallande med allmännyttan och framtvingade flit genom lagen, vilket satte dem i motsatsställning till människans naturliga frihetsbegär. Oenighet utgjorde ett särmärke, delvis till följd av konstitutionen, som kunde göra att makthavarna hyste sinsemellan diametralt olika åsikter, varvid ytterligheter uppstod. En bättre tid hade förvisso varit i antågande, men friheten uteblev likafullt medan tvånget kvarstod. Bunges domslut över frihetstidens hushållning var föga gynnsamt. Den strikta uppdelningen mellan stads- och landsbygdsnäringar hade varit av ondo och såväl jordbruket som bergshanteringen missvårdats, den sistnämnda så till den grad att han inte ville fördjupa sig i frågan för att slippa göra "en obehagelig målning". Okunskap om riket och de rätta ekonomiska grundsatserna hade vållat ostadighet i näringarna och spritts genom otaliga stridsskrifter, vilkas virriga uppslag och tomma 
ord som regel förvillat läsarna. De få genomtänkta texterna hade generellt sett inte beaktats. ${ }^{573}$

Bunge var inte den ende ledamot som uppmärksammade frihetstidens ekonomiska och ekonomisk-politiska olägenheter. Lillienberg noterade att Trollhättans slussar när de väl färdigställts skulle hedra perioden men hade annars inte mycket positivt att tillägga. Han ogillade de betydande satsningarna på vanskötta och avsigkomna fabriker som bearbetade utländska råämnen, om än intentionerna bakom dem varit goda. Skakningar hade spillt över från "en konstlad och ostadig rörelse-art”, alltså manufakturväsendet, till bergshanteringen, som trots stora felgrepp och omvälvningar i hushållningen och politin förblivit stabil; näringen hade inte för inte gjort mest för att kompensera de förluster riket åsamkats genom olycksaliga och kostsamma krig. Gustaf Adolf Leijonmarck uppgav att oordningar och misskötsel inom näringarna och rörelserna riskerade vara till förfång för utrikeshandeln, vilket nyliga - det vill säga frihetstida - skeenden visade. Mindre utvecklade näringar borde som regel inte premieras på bekostnad av mer utvecklade, och det var nyttigt att vinnlägga sig om flera näringar som kunde förstärka varandra. Han förklarade att riket upplevt tider med annorlunda principer och önskade att varken ett sådant ledsamt förfaringssätt eller finans- och penningväsendets tidigare problem skulle upprepas i framtiden. ${ }^{574}$

Frihetstidens undermåliga lagstiftning var ett annat ämne som berördes i de gustavianska presidietalen. Lilliestråle observerade att ständerna länge klagat över sjuka lagar, att inget botemedel stått att finna och att sjukdomen kanske förvärrats från en riksdag till en annan genom otillräckligt motiverade författningar. Carl Sparre anmärkte att den frihetstida ordningen hade respekterats någorlunda inledningsvis och frambringat författningar som skulle ha kunnat vara nyttiga, om inte deras växande antal gjort det omöjligt för ämbetsmännen att verkställa dem. Makthavarna var självsvåldiga och laglösa, och tvingades till slut vända sig till Adolf Fredrik för hjälp. Sparre alluderade sannolikt på frihetstiden när han menade att kuvandet av osämja, missbruk och förtryck resulterade i omtanke, lugn och idoghet, och att en rättfärdig politi måste ge vika för hemska skuggor om "förvänd Stats-konst" satte 
egenmäktighet över allmän och enskild säkerhet, om tvångsmedel förknippades med ett menligt ämbetsmannavälde "til Medborgares förtryck och Tyranniserande" samt om mångvälde och självsvåld uppfattades som frihetens kärna fram till dess att de bringade regeringssättet till avgrundens rand. ${ }^{575}$

En mer sammansatt syn på frihetstiden uttrycktes av Sandels, som slog fast att fred och frihet efter Karl XII:s död blivit riksdagens högsta ändamål. Båda hade gjorts till föremål för heliga löften och hanterats klokt och värdigt, samtidigt som kunglig myndighet och rätt aktats. Han påpekade dock att detta gällde enbart Ulrika Eleonoras och i viss mån Fredrik I:s regering, eller "Regeringssättet, såsom nytt", när ständerna trots den politiska splittringen ivrade för att bistå sin överhet och läka rikets djupa sår. ${ }^{576}$

Sandels redogörelse för den tidiga frihetstidens ekonomiska politik var övervägande neutral eller positiv. Det hette till exempel att regeringen gynnat manufakturer och hantverk, och att Sverige upphjälpts och kommit att åtnjuta ett handelsöverskott. Sandels uppvisade en tydligt apologetisk attityd till hattpartiet då han hävdade att 1738-39 års riksdag lagt en rejälare grund för slöjdernas och manufakturernas tillväxt. Deras privilegier och importförbuden gav effekt, och en "allmän täflan [...] för slöjde-näringar och Manufactur-inrättningar" infann sig som inte ens förberedelserna inför hattarnas ryska krig stäckte. Riksdagen befrämjade särskilt textilfabrikerna, varav flera nådde framgång - inte minst klädtillverkningen, som framgångsrikt hämmade importen av utländska plagg. Många förtjänstfulla fabriksanstalter tillkom och deras korta livslängd berodde inte på avsaknaden av nödvändig uppmuntran, utan på att stödet missbrukades. Frihetstiden tillerkändes även andra ekonomiska landvinningar, som att lantbruket förbättrats avsevärt och att nya växter introducerats. Allt hade likväl inte varit frid och fröjd. Ingen kunde "göra sig annat begrep om Rikets tilstånd, om näringar, om handel, än såsom altid vaklande". Merparten av den vinst hushållningen borde ha genererat hade försvunnit, och Sveriges penningproblem hade kvävt de fina inrättningar som gynnats på senare tid. De monetära bekymren, tilltagande lyx och import av umbärliga 
varor gjorde att landet inte kunde konkurrera ifråga om produktion, export och sjöfart. ${ }^{57}$

Sandels levererade också kritiska synpunkter på det närmast förflutnas politik. Han angav att "den så kallade frihets tiden" dragits med olika ekonomiska rättesnören och motstridiga tänkesätt, vilka ledde till förföljelser. De författningar som stadgades vid de sista frihetstida riksdagarna överlevde sällan längre än en mandatperiod, och partimotsättningarna betvingade själva förnuftet: "Besynnerligast var, at alle kände oredan i penning-verket, och dess tryckande följder; men icke ens medborgare i Samhället af uplyst förstånd och god vilja kunde under flere Riks-möten förena sig om hjelpmedlen." Sandels ifrågasatte vidare hattarnas krig och ekonomiska politik. Näringarna må ha fått omfattande uppmuntran, men de ansenliga hinder som de mötte skulle ha avgått med segern om det inte varit för statsvälvningen. Manufakturväsendet var snedvridet, eftersom den med rätt kontakter kunde sko sig på det allmänna genom belöningar eller lån som sedermera avskrevs. Pengarna gick ofta till lyxkonsumtion och emellanåt till alldeles för stora lokaler. ${ }^{578}$

Några presidietal gav frihetstiden merendels goda vitsord. Bengt Bergius meddelade 1780 i en sammanfattning av de fyrtio år som gått sedan Vetenskapsakademien grundades att det karolinska enväldets oarter antingen var borta eller på väg att övervinnas. Frihetstiden buntades sålunda samman med den gustavianska eran och positionerades tillsammans med den mot det karolinska tidevarvet. Hattpartiet bedömdes välvilligt. Den "Flock af ädelsinta och driftiga Medborgare, som verkade besluten på den näst före detta 40-år[ig]a tidehvarf gående Riksdagen [1738-39]" hade förändrat folkets lynne till det bättre, medan deras patriotism inspirerat till akademiens instiftande och till en berömvärd strävan för såväl nyttiga konster och vetenskaper som landets väl. Mycket hade förkovrats och hushållningen expanderat: näringarna uppmuntrades, jordbruket bedrevs förnuftigt och planmässigt, bergshanteringen konsoliderades och tillväxte, handeln och penningrörelsen tog fart, handslöjder idkades nitiskt, inhemska råmaterial förädlades, svenska kläder producerades, folkbristen motverkades, den fattige men flitige bereddes utväg till förtjänst. Bergius krönte sitt försvar av hattarna 
med tesen att friheten förutom från Sveriges självständiga fortbestånd utgått från rikets sanna förbättring. Han medgav att utvecklingen varit varken snabb eller fullkomlig, vilket inte kunnat förväntas med hänsyn till att egenmäktighet, krig, missämja och annat kommit emellan, "men grunden var i en god stund lagd, och den står i många hufvudsakeliga delar ännu qvar". ${ }^{579}$

En kontrastering av frihetstiden mot det karolinska enväldet till den förra periodens fördel påträffas även hos andra ledamöter. Naturalhistorikern Olof Swartz tog upp den serie av krig och olyckor som under 1700-talets första två årtionden skadat hushållning och vetenskap, liksom de fredligare makthavare som därefter vidtagit nödvändiga åtgärder för att tillfredsställa behoven. Jordbruket, handeln, bergshanteringen och fisket hade fått regeringens fulla uppmärksamhet: "Förordningar utgåfvos, Inrättningar gjordes, Förslager sattes i verket och drefvos med fördel, samt fullkomnades til Statens heder och nytta." De styrande hade bemödat sig om att sprida nyttiga kunskaper och förbättra ekonomin samtidigt som en naturalhistoriens guldålder infallit tack vare Linné. Eric Prosperin uppmärksammade att Kungliga Vetenskaps-Societeten i Uppsala etablerats vid en tidpunkt då Sverige balanserat på fördärvets rand, pinat av krig, svält och pest. Dess ursprungliga ändamål var att erbjuda en distraktion från alla bedrövelser. Vetenskapsakademien hade däremot inrättats när landet haft fred i två decennier, näringarna tillvuxit ovanligt mycket och svenskarna nästan börjat tröttna på sin välfärd och lycka. ${ }^{500}$ Huruvida Bergius, Swartz eller Prosperins värderingar av frihetstiden och det karolinska enväldet hade bäring på den gustavianska autokratin är svårt att avgöra; det kan inte uteslutas att en sådan avsikt förelåg.

När frihetstidens defekter behandlades i anslutning till Gustav III och hans regering var syftet rimligen att kontrastera dem mot varandra för att framhäva och förhärliga konungen. Läkaren Nils Dalberg fastställde att riket räddats från undergången 1772 - ett alltid anmärkningsvärt år som var ett av historiens lyckligaste, om än också ett av de värsta på länge på grund av svåra farsoter. Sjukdomarna härrörde från en utbredd missväxt som förvärrats av att den politiska splittringen omöjliggjort effektiv distribuering av säd till de drabbade områdena. ${ }^{581}$ 
Nils Adam Bielke talade om blinda och yra folk som höll

lagen för träldom, ordning för tvång, sjelfsvåld för rättigheter, och frihet för en myndighet at obehindradt få göra dårskaper: hvilkas motbjudande vilja, värdig följeslagare af et trångt begrep [förstånd], sätter sig emot de hälsosammaste författningar, och klandrar alt, hvad ej i deras hjerna uprunnit. Oförnöjde med alt, kasta sig utan eftertanka, utur den ena ytterligheten i den andra: som, jäsande af högmod, söfde [sövda] i lättja, dränkte i yppighet, tryckte af fattigdom, fale [till salu] för den mästbjudande, med allmänt bästa i munnen, hysa nedriga och enskilda [egennyttiga] afsickter i hjertat: Regerings-sjuke, oenige sins imellan, afvundsjuke på hvarannan [varandra], sökande hälst sin upkomst på medborgares förtryck och det allmännas bekostnad: hos hvilka änteligen [slutligen] all dygd, ära och kärlek för Fäderneslandet äro utkolnade [utslocknade]. Et sådant Folkslag är det olyckligaste af alla. Det står ej at hjelpa, utan tilskapar sin egen ofärd, och rusar til sin oundvikliga undergång.

Bielke ställde detta slags folk mot en sort som styrdes av en kärleksfull furste, vilken månade om de underlydandes frihet, säkerhet och äganderätt, hade "Fäderneslandet" till valspråk samt titulerade sig "den Förste Medborgaren ibland et rättskaffens fritt folk". Om undersåtarna fyllda av flit, laglydnad, trohet, enighet, ära och dygd sökte leva upp till sin monark och infriade hans förväntningar var deras framtidsutsikter strålande. ${ }^{582}$ Gustav III:s valspråk var just "Fäderneslandet" och konungen hade redan 1771 utmålat sig som den förste medborgaren bland ett fritt folk; han kom under hela sin regering att knyta termen "medborgare" till kungavärdigheten. ${ }^{53}$ Bielkes tydliga anspelning på Gustav gör det sannolikt att hans resonemang om yra och blinda folk handlade om frihetstiden, som på vedertaget manér förbands med egenmäktighet, söndring och falsk frihet.

Sandels framförde att näringarna under frihetstiden hotats av egennytta och antipati, vilka snart skulle ha triumferat om det inte varit för den lyckliga statsvälvningen. Han använde uppenbarligen 1500talet som en spegel för samtiden när han skildrade hur Försynen sänt Gustav Vasa för att rädda Sverige från värsta elände och vanmakt. Fast konungen omgivits av oroligheter, uppror och stämplingar motiverade 
av" in- och utrikes bitterhet, afvund och egennytta" hade han skyndsamt lyft upp ett i generationer skövlat och förtryckt fädernesland. Gustav Vasas älskade namn frammanade alltid hågkomsten av hans stordåd, som skickat egennytta, oordning, våld, tyranni, vidskepelse och andliga villfarelser på dörren. Hans tidevarv var "det första GUSTAVIANSKA" och oförglömligt som den svenska hushållningens första lyckosamma period. Utsagorna bör i hög grad ha varit ämnade att föra tankarna till den tredje Gustaven, som ju gestaltades som en gudagiven riksbefriare och nyttofurste analog med Gustav Vasa. ${ }^{584}$

Endräkt hade redan under frihetstiden varit ett ideal i Vetenskapsakademien, med avseende på både samhället och den egna organisationen. Presidietal framförde ståndpunkterna att oenighet och partier varslade om ett lands förstörelse och att enighet skulle utmärka såväl akademiens "samhälle" som samhället i stort så att Sverige kunde upphjälpas. ${ }^{55}$ Även gustavianska tal kommenterade Vetenskapsakademiens inre sammanhållning. Det konstaterades att akademien alltid utmärkts av samförstånd, att dess ädlaste egenskap var sämja och gemensam nit samt att ledamöterna såg vänskap, förtroende och hövlighet som sin kollektiva själ varför inga avsteg från endräkten tolererades. ${ }^{586}$

Om frihetstiden hade erbjudit falsk frihet tillhandahöll Gustav III:s regering den äkta varan. Carl Fredrik Scheffer kungjorde att den sanna friheten var hälsosam och oundgänglig för det allmänna bästa. Den utgjorde raka motsatsen till de försyndelser som tidigare haft namn av frihet och tillmätts hela den tyngd och alla de företräden som endast hörde "den egenteliga äkta Friheten" till. Den sanna friheten innebar att de lastbara inte kunde förverkliga sina begär och att lagen var ensamt rådande, vilket var det enda som kunde trygga samtliga invånares säkerhet - "hvad man i alla tider med den Politiska Friheten förstått". Frihetstidens lagar hade lyckligt eliminerats genom konungens nya och helt unika grundlag, som till skillnad från "de mäste fria Staters" motsvarigheter inte var ett planlöst lappverk utan skapad vid ett enda tillfälle. Gustavs konstitution bar löfte om varaktighet eftersom den var vis och välavvägd - präglad av en fast grund, tydlighet, frånvaro av förtryck samt nogsam balans mellan folkets frihet och regentens myndighet. Författningen säkerställde den äkta friheten, givet att monarken hade 
befogenhet att härska, freda och försvara men inte att förtrycka, störa eller attackera. Undersåtarna åtnjöt säkerhet och frihet i allt som rörde det enskilda, som hade bättre skydd i Sverige än någon annanstans. ${ }^{587}$

Scheffer röjde en långtgående optimism inför den gustavianska eran, under vilken konungens sunda politik skulle få enastående konsekvenser för riket. Grundlagen skulle föra med sig maximal lycka, den naturliga ordningen respekteras, privategendomen vårdas med andakt, näringarna beskyddas och ges stor frihet, vetenskaper och konster nå sin högsta potens. Den förståndiga lagstiftningen och "oinskränkta Friheten" skulle åstadkomma flit och förbättrade seder samt visa att industrins enda hinder bestod i tvång och felaktiga eller alltför många lagar. ${ }^{588}$

Friheten var ett återkommande gustavianskt ledmotiv. Sandels erinrade om att riket ibland befunnit sig i en olycklig situation - frihetstiden - och om "en lyckelig utgång" - statsvälvningen - som blev desto lyckligare av att inbyggarna efter denna med större förtröstan än under den så kallade frihetstiden kunde glädja sig åt "en laglig, en oskattbar frihet och säkerhet”. Lilliestråle förkunnade att Gustav III skaffade undan oskick och lät friheten komma till sin rätt. Han citerade Plinius den yngres hyllning av Troja, som nu fick avse den svenske monarken: "Du befaller oss vara frie; vi äro det. Du befaller oss frambära hvad vi tänke: vi frambäre. Han skall derföre altid få, hvad Han öfvertygat oss om, och förmärka, at så ofta vi bruke den frihet Han oss gifvit, lyde vi Honom." Kloka tänkare hade visat att vetenskaperna trivdes i fria länder, vilket betydde att de trivdes allra bäst i Sverige, där äkta frihet var mest stadgad. Carl Peter Thunbergs beskrivning av japanernas frihet hade påtagliga gustavianska övertoner, eftersom den enligt honom inte var av det slag som tenderade att övergå i tygellöshet och självsvåld, utan en lagbunden frihet som omfattade alla. Han riktade samtidigt kritik mot Sverige, vars jordbruk sades vara mer ofritt än det japanska. ${ }^{589}$

Friheten diskuterades utförligt av Rosenstein den yngre, som frångick de vedertagna, regimtrogna ståndpunkterna i den gustavianska Vetenskapsakademien. Han ansåg att lycksalighet förutsatte rättigheterna personlig frihet och säkerhet - "fritt bruk af våra förmögenheter, säkerhet under detta bruk" - och att tvång och träldom utgjorde det värsta onda. Dessa rättigheter gick att kombinera med alla lagbundna 
regeringssätt, monarkiska eller republikanska, och kunde inte med rättvisa undanhållas människorna. Resonemanget utmynnade i två radikala ställningstaganden, förespråkandet av tankefrihet och tesen att upplysning var en rättighet: "Skaparen har ej skänkt oss förgäfves Förståndet, icke förgäfves gjort Tankan til det friaste i naturen, icke förgäfves satt henne [den] utom människors våld. Huru har då någon dödlig trodt sig äga rättighet, at förhindra Förståndets bruk, trodt sig äga förmåga at fjättra tankan?” Svenskarna kände den personliga friheten eftersom de var fria genom lagarna..$^{590}$

Lagstiftningen skulle ur Rosensteins synvinkel ge människor säkerhet och frihet i utövandet av deras färdigheter, men avhålla sig från onödigt tvång och från att motverka det naturliga framåtskridande som bottnade i "den mäst verksamma drift i människo-själen". Ett repressivt system var inte bara fåfängt och orättvist, utan dömt att gå under. Rosenstein hävdade vidare att all lydnad utgick från lagarna, vilka både mäktiga och svaga måste underkasta sig. Han framställde laglydnaden som helt central för samhällsordningen. Denna lydnad skulle dock inte vara blind utan upplyst; den som regerade utifrån lagen blev säkrast hörsammad och de lagar som gemene man trodde på säkrast efterlevda. ${ }^{591}$ Argumentationen anspelade på Gustav III:s "andra revolution", den för Rosenstein misshagliga förenings- och säkerhetsakten 1789 - ett försök att återinföra Gustav II Adolfs regeringsform som gav konungen mer eller mindre absolut makt. Den eliminerade ständernas initativrätt inom lagstiftningen och upphävde rikets råd, medan suveränen tillskansade sig rätten att starta krig och full kontroll över förvaltningen. ${ }^{592}$

Säkerhet var ett annat viktigt tema i de gustavianska presidietalen men förekom liksom enigheten och sämjan redan i frihetstida tal, som skildrade holländarnas säkerhet till liv och egendom i positiva termer och stipulerade att envar hade rätt till sitt liv och sin egendom. ${ }^{593}$ Det sistnämnda var ett framträdande politiskt debattämne under frihetstidens sista år, förmodligen som en reaktion på partiförföljelserna och den åtföljande rättsosäkerheten. ${ }^{594}$

Gustavianska akademimedlemmar deklarerade att konungen inriktade sig på undersåtarnas säkerhet och egendomsrätt. Han uppgavs återupprätta allmän och enskild säkerhet och göra lagen till ett trygghetens 
värn, vars okränkbarhet dygden fordrade. Det segment av mänskligheten som Gud tilldelat honom var i besittning av alla sina rättigheter och fick sålunda optimal uppmuntran. Säkerhet att njuta frukterna av sitt arbete garanterade, vid sidan av den arbetande befolkningens upplysning, landets förbättring, och invånarna kunde glädjas åt en ny tid som den store monarken inlett genom att bemöda sig om såväl friheten som säkerheten. ${ }^{595}$ Ett antal presidietal diskuterade äganderätten, samhällets ömtåligaste band, som gav nytta och skulle bereda alla säkerhet. Det hette att Gustav ömmade för egendomsrätten och att politin tryggade den säkerhet om liv och egendom som han försäkrat sitt folk. ${ }^{596}$ Rosenstein den yngre hade en delvis fientlig inställning till äganderätten, som enligt honom lett till ekonomisk ojämlikhet och därmed till fler bekvämligheter, överflöd, lyx och allt ont människor klagade över. Han förhöll sig likväl negativ till Spartas avskaffande av egendomsrätten, liksom till romarnas fruktlösa och naturvidriga ansats att vända bort intresset från materiella ting. Äganderätten utgjorde ytterst ett villkor för en riktig frihet och inga lagar hade åtlytts mer än de som säkerställde liv och egendom. ${ }^{597}$

Frihet och säkerhet var återkommande värden i Gustav III:s Sverige, där de präglade både hans självbild och propaganda och Vetenskapsakademiens presidietal och politiska ideologi. Inte ens den så kritiskt sinnade Rosenstein låg alltför långt borta från det mentala och retoriska ramverk som monarken nötte in under sin tid vid riksrodret.

Den inverkan på Vetenskapsakademiens politiska ideologi som närheten till de frihetstida regenterna hade var märkbar, men går inte att jämföra med effekterna av närheten till hattpartiet, medan samröret med den gustavianska kungamakten fick lika stora konsekvenser som samröret med hattarna.

Samtliga konungar under undersökningsperioden - Fredrik I, Adolf Fredrik och Gustav III - gestaltades som drivande nyttofurstar, under vilkas styren hushållningen, näringarna, vetenskaperna och landet förbättrades och nådde nya höjder. Alla tre beskrevs också som stora, nådiga, milda, visa, kultiverade, omsorgsfulla, idoga och patriotiska 
regenter älskade av folket. Adolf Fredrik och Gustav III porträtterades i motsats till Fredrik I som landsfäder och föredömen för gemene man. Kronprins- och kungaparet Adolf Fredriks och Lovisa Ulrikas insatser för lärdomen framhölls, vilket torde ha hängt samman med deras relation till Vetenskapsakademien. Analysen bekräftar sammantaget att svenska monarker fortsatte besitta en stark symbolisk makt under frihetstiden, inte minst med hänsyn till hushållningen.

Den begränsade kungamakten var ett ovanligt ämne i presidietalen under Fredrik I:s regering, men blev mer frekvent under 1750-talets första hälft och upptakten till det misslyckade rojalistiska statskuppsförsöket 1756. Förändringen sammanföll med tilltagande friktion mellan kungaparet och hattregimen, och med att interaktionen mellan kungahuset och akademien försvagades för att till sist avstanna. Efter kuppstämplingarnas avslöjande förbigick talen i ett års tid kungligheterna med tystnad, och hänvisningarna till dem var som regel få och opersonliga fram till 1762. Hattpartiets närmande till monarkerna resulterade då $i$ att de under en period kom att framställas på ungefär samma sätt som före 1750-talets slitningar. Under mössornas maktinnehav 1765-69 minskade referenserna till kungligheterna på nytt, låt vara i lägre grad än efter 1756 års händelser, medan närvaron ökade igen efter deras allierade hattarnas återkomst till makten 1769. Skiftena i presidietalens hantering av kungahuset åskådliggör att denna var avhängig monarkernas förhållande till hattarna och understryker att Vetenskapsakademien utgjorde en integrerad del av partiets nätverk och maktapparat. Ledamöterna var likafullt inte sena att anpassa sig och sina tals budskap efter statsvälvningen 1772, när deras och akademiens lojaliteter skyndsamt flyttades över på den nya regimen.

Partistriderna och deras negativa följdverkningar togs upp av flera ledamöter mot frihetstidens slut. Temat fortlevde och förstärktes under den gustavianska tiden, då den tidigare epoken tillskrevs självsvåld, osämja, egennytta, godtycke, korruption, svaghet, tvång, undermålig lagstiftning, falsk frihet och hotande undergång. Det hände dock att frihetstiden attribuerades en övervägande eller delvis gynnsam ekonomisk utveckling, oftast i samband med att den ställdes mot det karolinska 
enväldet och det stora nordiska kriget. Åtminstone för Bengt Bergius och Sandels tycks försvaret av den i hög grad ha varit ett försvar av hattarna.

Gustav III betraktades från första början som "den tredje Gustaven" och parallelliserades framgent med sina berömda namnar, framför allt Gustav Vasa. Han blev vid sitt trontillträde föremål för omfattande smicker, vilket kan förklaras med de stora förhoppningar som knöts till honom i skuggan av de rådande krisstämningarna och med en tidstypisk rojalistisk tendens som anammades av ett flertal hattar. Å andra sidan riktade några av de senfrihetstida ordförandena kritik mot historiska autokratier, som av allt att döma fick fungera som projektionsytor för antirojalistiska attityder. Vetenskapsakademiens förbindelser med regenten blev av naturliga skäl mycket viktigare efter statsvälvningen. Gustav intog en betydligt mer framskjuten plats i presidietalen än sina företrädare, och de egenskaper som tillmätts dem skruvades upp ett snäpp i skildringarna av honom. Han kom också att till skillnad från Fredrik I och Adolf Fredrik omges av en utvecklad religiös retorik, som passade väl med talens ödesmättade skildringar av frihetstiden. Ledamöterna föreställde i likhet med den kungliga propagandan Gustav som en befriare och frälsare från oordning - hans styre var frihetstidens antites, en era av enighet, trygghet och äkta frihet. En avvikande röst var Rosenstein den yngre, som tog till sig det kungliga politiska språket men använde det för att förorda tankefrihet och kritisera förenings- och säkerhetsakten.

Vetenskapsakademiens idéskapande kring regenterna harmonierade liksom idéskapandet kring hattarna med akademiens uppfattningar om samhällsledningen och samhället i stort. Den politiska ideologin förblev sig lik över olika områden. Nästa kapitel behandlar hur organisationen uttryckte sin närhet till makthavarna och eliten samtidigt som dess syn på den egna samhällsrollen granskas. 

KAPITEL 6

\section{Vetenskapsakademien, samhället och makten}

Om de föregående kapitlen vikts åt Vetenskapsakademiens idéer om samhället, dess politiska och ekonomiska ideologi, skall det följande ägnas åt sammanslutningens samröre med samhällsledningen. Detta undersöks med hjälp av teoribildningen kring karisma, som också används för att analysera presidietalens framställningar av akademiens roll i samhällsgemenskapen. Kapitlet är i huvudsak tematiskt upplagt och består av tre avsnitt, varav det första uppehåller sig vid Vetenskapsakademiens självbild och de två andra vid relationen till makten.

\section{Den samhällsnyttiga akademien}

Presidietalen betecknade ofta Vetenskapsakademien som ett samhälle. Den ansågs i linje med det ha lag, lagar och grundlagar precis som ett sådant. ${ }^{598}$ Ett frihetstida tal liknade rentav akademien vid en sorts idealsamhälle, då den var "et Samfund, hvars inrättning är så vis, och som i sin utöfning öfverträffar hvad en Plato[n] skulle förmodat". ${ }^{599}$ Flera gustavianska ledamöter laborerade med en lärd och en politisk gemenskap som i någon mån reflekterade varandra. De diskuterade den lärda och den politiska världen, och vetenskapliga och politiska samhällen som var fördelaktiga för människosläktet respektive endast beaktade sin egen nytta. Ett mer utvecklat resonemang kring de båda gemenskaperna återfinns hos Joachim Wilhelm Lilliestråle, som berörde "hvälfningar i lärdoms-verlden, som någorlunda likna, och äfven haft något sammanhang med dem i den politiska”. Han menade vidare att 
den goda myntstock som var högst nyttig för de samhälleliga rörelserna motsvarades av ett rikt språk i det lärda samfundet. ${ }^{600}$

En implicit parallellisering av den lärda och den politiska sfären kan skönjas i Bengt Bergius föreskrifter om vilka uppgifter som tillkom Vetenskapsakademiens sekreterare och preses. Sekreteraren, som jämfördes med pendeln i ett urverk, hade att bevaka stadgarnas efterlevnad, upprätthålla balansen mellan vetenskaperna, akta på ledamöterna och mana på dem som slutade dra sitt strå till stacken. Ordföranden skulle ge "lif och anda åt alla förrättningar, samt med upmärksamt öga hålla invärtes [inre] hushållningen i sitt rätta skick. Han har ock myndighet nog til Grund-Reglornas och all ordnings handhafvande". ${ }^{601}$ Bergius instruktioner till akademiens främsta funktionärer företedde påtagliga likheter med presidietalens framställningar av rikets styrande. Det tillkom bägge att kontrollera och driva på sina underlydande och att bevara jämvikten och ordningen i sitt samfund.

Enligt Dena Goodman hade de lärdas republik i likhet med statsmakten en diskursivt och institutionellt definierad politisk kultur, vilket gör det möjligt att tolka den som ett slags motpart till staten, "a polity parallel to the monarchy but entwined with it". ${ }^{602}$ Vetenskapsakademien jämställde som reflektionerna ovan visar i någon utsträckning den egna sammanslutningen och de lärdas republik med det omgivande samhället. Det är dock inte rimligt att dra alltför stora växlar på detta, eftersom ledamöterna stod i ett beroendeförhållande till samhällets mäktiga och säkerligen visste var den verkliga makten låg.

Naturforskare närmade sig samhällsledningen genom sociala nätverk, inom vilka deltagarna ömsesidigt iscensatte sig själva, samt genom sina ansträngningar i nyttans tjänst. Deras nyttiga arbete med såväl natur som hushållning gjorde att de kunde presentera sig som experter och medlare mellan den naturliga och den samhälleliga världen. Nyttoarbetet gav dem också ett betydande politiskt och socialt inflytande som tillät dem att uttala sig om hur samhället skulle ordnas; kunskap översattes till makt. ${ }^{603}$ Denna logik kom till uttryck i Vetenskapsakademien, som förenade natur- och samhällskunskap och brann för nyttigt vetande till Sveriges fromma - inte minst i presidietalen, där den ekonomiska patriotismen framträdde som "program och världsbild". ${ }^{604}$ 
Vetenskapsakademiens och ledamöternas gagneliga insatser utgjorde ett ledmotiv i de frihetstida talen. ${ }^{605}$ Akademien var den första inrättningen i sitt slag som genom sina grundlagar ålagt sig själv att fokusera på hushållningen och därmed associerade eller allmännyttiga vetenskaper. Organisationens intresse för praktisk nytta och allmänhetens håg för de publicerade rönen skilde den från andra akademier, och "ingen inrättning [hade], med mindre kostnad för Kronan och det allmänna, gjort bättre skäl för sig, än denna”. Ledamöter angav att sammanslutningen prioriterade svenskarnas nytta och nöje, ägnade sig åt samhällets fundament och satte det gemensammas väl högst; inga sysslor förutom dem som gynnade detta lovvärda syfte beaktades. Medlemmarna uppmanades att lägga all tid på att bistå sitt kära fädernesland och frambringa ymnigt med frukt till rikets båtnad. ${ }^{606}$ De gustavianska talen höll fast vid nyttotematiken. Vetenskapsakademien föreställdes som ett synnerligen nyttigt samfund, alltigenom uppfyllt av iver för det allmänna bästa. Sammanslutningens stora och ädla ändamål bestod i användbara vetenskapers uppodling, spridning och tillämpning med sikte på samhällets förbättring och välbefinnande. Akademien hade varit det första lärda sällskapet att vid sidan av "de höga vetenskaper" inlemma de eftersatta praktiska och nyttiga vetenskaperna, vilkas utveckling alltid legat ledamöterna varmast om hjärtat. ${ }^{607}$

Akademisekreterarens svar uppmärksammade ofta de avgående ordförandenas eller presidietalens nytta. ${ }^{608}$ Johan Carl Wilcke meddelade att den berömvärda sedvänjan att vid ordförandeskapets nedläggande ta upp ett för vetenskaperna och samhället nyttigt ämne så ofta givit nytt och viktigt stoff att samtiden inte utan anledning förde presidietalen till "de vackraste arbeten, hvarmed Academien bemödat sig för Efterkommande". ${ }^{609}$ Presides påpekade också nyttan av sina egna tal eller talen generellt. ${ }^{610}$ De uppgav bland annat att ett antal presidietal belyst något av värde för rikets väl, att ett par tal förmedlat åtskilligt till medicinalväsendets och allmänhetens nytta samt att medlemmarna var vana att vid bytet av ordförande trakteras med intelligenta anföranden som gav det allmänna uppbyggliga lärdomar. ${ }^{611}$

De många utsagorna om Vetenskapsakademiens allmännytta går att se som exponenter för karisma, inte minst utifrån idén att akademien 
befattade sig med samhällets fundament. Denna tolkning kan hämta stöd i ett annat genomgående tema, sammanslutningens patriotiska nit. ${ }^{612}$ Det hävdades att den frihetstida Vetenskapsakademien hölls samman av patriotism och drevs av kärlek till fäderneslandet, vars bästa utgjorde organisationens främsta ändamål och upplivade verksamheten; ledamöterna fann sanningen särskilt angenäm om den rörde rikets förbättring. ${ }^{613}$ Vetenskapsakademiens strävan efter nytta beskrevs som en självpåtagen skyldighet gentemot fäderneslandet att "på alt möjeligt sätt befordra dess vältrefnad" som varje medlem borde göra till sin plikt. Akademien fick en religiös sanktion när det gjordes gällande att Försynen skickat ledamöterna för att upplysa den svenska nationen om allt som hade med gemensamt väl att göra. ${ }^{614}$ Under gustaviansk tid hette det att Vetenskapsakademien frambar offer i "detta Vetenskaperne helgade Tempel, Fäderneslandet" och uteslutande brydde sig om Sveriges ära och medborgarnas nytta. Organisationen förnöjdes mest av fäderneslandets och vetenskapernas förbättring, och dess publikationer kännetecknades lika mycket av sann patriotism som av gedigen kunskap. ${ }^{615}$ Akademien kunde samtidigt framställas som en universalistisk institution, då den enligt uppgift osjälviskt verkade för att gagna mänskligheten och var till avsevärd nytta för såväl denna som fäderneslandet. En sammanslutning som Vetenskapsakademien skulle addera till Guds ära "jämte vårt Rikes, ja i vissa delar hela Människo-slägtets, redbara förmån". ${ }^{616}$

Betraktelserna ovan kan kopplas till medlemmarnas föreställningar om lärdomens välsignelser för Sverige, främmande länder och mänskligheten överlag. Konster och vetenskaper gestaltades som vägvisare till människans timliga lycksalighet som hade fått allmänt bifall, gjorde stor nytta i världen och syftade till allas väl samt vittnade om ett lands upphöjdhet och sällhet. ${ }^{617}$ Vetenskapsakademiens skrifter, exempel och ansträngningar hade övertygat om att vetenskaperna utgjorde grundvalen för ett rikes välmåga; samhällets styrka samvarierade med vetenskapernas uppodling och tenderade avta genom deras vanvård - det kunde inte bli lyckligt, beundrat eller föredömligt dem förutan. Det var därför en svår förbrytelse att behandla dem styvmoderligt, något som kontrasterades mot Vetenskapsakademiens förmånliga gärning och bedrifter. ${ }^{618}$ Ett par presidietal anmärkte att vetenskapen och Vetenskapsakademien 
förtjänade tacksamhet. Wilcke tog upp vetenskapernas nytta och "den förbindelse som Samhället är deras idkare skyldig”. Carl Rudenschöld menade att det inte anstod honom att redovisa vad det allmänna var förpliktigat akademien, som till skillnad från de flesta andra lärda sällskap inte belastade överheten genom personliga subsidier och ansåg sig nog belönad om den kunde vara till nytta. ${ }^{619}$

I några fall poängterades vetenskapens centrala roll för själva människoblivandet. Vetenskaper och konster hade avgränsat människan från resten av djuren och lärt henne att "göra jorden fruktsam, at taga skatter utur hårda Berg och djupa Haf, at försvara sig för [mot] öfvervåld, at bereda sig väg på sjelfva böljorna til de fjärmaste Länder: med et ord, at skaffa och tilreda [tillfredsställa] sina flästa behof". Vetenskaperna beskrevs som de rätta redskapen för människans förädling, vilka i samspel med ett upparbetat vett gjorde att hon stod över och rådde på djuren; med det vetenskapliga kunnandet kom makt över skapelsen. ${ }^{620}$

Kunskapens ekonomiska nytta åberopades av ett antal ledamöter, framför allt under frihetstiden. Presidietal förfäktade att vetenskapen ådagalade de bästa sätten att nyttja allting och att samtidens nya, fredliga och förbättringsorienterade "stats-klokhet" var oupplösligt förenad med dess upphjälpande: "hvar nu Vetenskaper och Konster florera, där finnes oförnekeligen allmänt välstånd; och hvar detta anträffas, där behöfver man icke vidare fråga efter tilståndet af de förre”. De inhemska näringarnas beaktansvärda tillväxt sammanföll med vetenskapernas nogsamma uppmuntran, medan handslöjderna förbättrades märkbart när de lärda omsatte sina kunskaper i praktiken. Mycket av okunskapens mörker hade jagats på flykten när genuin lärdom vunnit aktning och inflytande, och de "Ljus i Nationen" som tänt varandra skulle leda vägen och utveckla hushållningen med övriga invånares bistånd. ${ }^{621}$

Genom sin patriotiska nyttosträvan och nit och sitt arbete med vetenskaper av stort värde för riket fick Vetenskapsakademien en centralitet som gör att den kan definieras som en arena där karisma alstrades, i kraft av det nära och djupa sambandet med samhället och dess ödesfrågor. Akademien befann sig i samhällsgemenskapens mitt tillsammans med makthavarna, och idéerna om vetenskapens nytta för mänskligheten och roll för människoblivandet gav organisationen en ännu mer central 
position i tillvaron. Det ter sig mot bakgrund av detta som följdriktigt att de kunskapsägande framställdes i termer av en elit. Johan Browallius hävdade att de fåtaliga snillen som förbättrade och utökade näringarna var väsenligt större än sina landsmän och borde ha betydligt högre status än dem. En likartad ståndpunkt företräddes av Anders Johan von Höpken: "fä äro de, som äga Snille och kumskap [sic], få, som äro hugade åt en ofta otacksam Menighet at upoffra sin ro och sin hälsa. Få, som tro sig vara rikeligen belönte uti Samvetsro allena, och uti den enda förnöjelsen, at hafva fullgjordt sina plikter." ${ }^{22}$

Nils von Rosenstein förde ett ingående resonemang kring de lärdas medverkan i det politiska styret. Han uppgav att vetenskapens utövare inte hade del i regeringskonsten och ofta bedömts vara odugliga till offentliga ämbeten, vilket dock bara demonstrerade att teoretiska kunskaper var otillräckliga, inte att de var obehövliga eller onyttiga. Med rätt praktisk erfarenhet skulle tvärtom riktiga filosofer överträffa "vanans och erfarenhetens myndiga söner" och dem "som taga sin vana at befalla människor, sin slipning i verlden och umgänget för skicklighet; som af sin egen okunnighet döma til kunskapers onödighet”. Rosenstein drog utifrån det och Fredrik II:s av Preussen exempel slutsatsen att filosoferna borde vara regenter eller regenterna filosofer. Han fann också att de lärda tyglade, ledde och upplyste de styrande samt utgjorde källan till majoriteten av Europas konstitutionella förbättringar. Deras ansträngningar på det teoretiska planet innebar att de kunde dela makthavarnas ära och möda. Å andra sidan hängde ett rikes upplysning i första hand på styresmännens dito. Filosoferna skulle inte råda ensamma och var inte de enda som stod för upplysning inom politiken, där alla dygdiga och stora maktägande som sökte människornas lycksalighet fyllde samma funktion. Erfarenhet och praktiska göromål vägde tungt, och både teoretiker och styresmän kunde fara vilse. ${ }^{623}$ Rosensteins utläggning var trots dessa förbehåll det mest fullödiga uttrycket för akademiens syn på de lärda som en elitgrupp.

Vetenskapsakademiens nationella och internationella ryktbarhet framhölls i talen, huvudsakligen under frihetstiden, vilket ytterligare bidrog till att ge inrättningen en central symbolisk ställning. Den hade genom att inympa begåvade svenskar i "sin egen kropp [...] vunnit full 
styrka och hög aktning öfver hela jordklotet”. Europa gav dagligen prov på sin tacksamhet mot akademien, som värdesattes av alla lärda europeiska sällskap och tävlade med de yppersta bland dem. Det fanns knappt någon svensk som inte kände stolthet över sammanslutningens status $\mathrm{i}$ utlandet, vilket lovordade den, eftertraktade dess snillrika bragder och imiterade inriktningen på slöjder, handel och ekonomi. Fäderneslandet gladdes åt att organisationens ljus skyndsamt nått överallt och riktat blickarna mot Norden snarare än mot Italien. ${ }^{624}$ Olof Celsius tillskrev det internationella anseendet en metafysisk dimension när han höll före att Gud beskyddade Vetenskapsakademien och genom ledamöternas flit gjort den så pass prisad att organisationens skrifter begärligt efterfrågades söder om Alperna. Han avslutade sin redogörelse med en önskan om att akademien skulle fortsätta uppbära gudomligt stöd samt bli en rikets huvudpelare och prydnad för Norden. ${ }^{625}$ Gustavianska presidietal förklarade att Vetenskapsakademien på kort tid förvärvat den lärda världens respekt så att medlemskap blivit åtråvärt, och att akademiens glans sträckte sig lika långt som vetenskaperna. Högsinta män som brunnit för kunskaper och det allmänna bästa hade genom dess grundande tänt ett ljus som snart spritt sig till de mest fjärran trakter. ${ }^{626}$

Ledamöterna drog sig inte heller för att påtala Vetenskapsakademiens inrikes berömmelse. Frihetstidens akademi var hyllad och älskad i fäderneslandet, där allmänheten vant sig vid att få rön av mycket hög standard och uppskattade inte minst medlemmarnas lovvärda och nyttiga arbete. ${ }^{627}$ Under den gustavianska perioden uppmärksammades att svenskar gärna lyssnade på organisationens tal och att "Allmänhetens aktning, Europas lof-ord, höga Herrars gunst, Konungars Nåd och beskydd" alltid varit akademiens följeslagare. ${ }^{628}$

Ett antal presidietal berörde Vetenskapsakademiens befintliga eller framtida bedrifter. Frihetstida ordförande noterade att Handlingarna förmedlat åtskilligt nyttigt som annars nog aldrig skulle ha ådagalagts till det allmänna, samt att akademien gjort samlevnaden behaglig och böjt "hela folkhopen ifrån mörker til ljus, ifrån gissningar til sanningar, och ifrån onyttigt gräl til visdom". Landet skulle bli lyckligt om sammanslutningen snart avkastade sådana nyttiga frukter som svarade mot medlemmarnas ambitioner. Mest långtgående var Carl Gustaf Löwen- 
hielm, som slog fast att samtiden genom Vetenskapsakademien under loppet av två årtionden skapat mer ekonomisk kunskap än några av de föregående århundradena. ${ }^{629}$

Dessa utsagor implicerade i likhet med yttrandena om akademiens ryktbarhet att organisationen utgjorde en central punkt i tillvaron. De blev något färre i de gustavianska presidietalen, som meddelade att Vetenskapsakademiens föredöme låg till grund för Sveriges berömvärda lantbrukssällskap, att Handlingarna bidragit avsevärt till att förbättra huvudnäringen jordbruket samt att akademien och Jacob Faggot spelat en avgörande roll för skiftesreformen, som med tanke på sin framgång och nytta torde sakna motstycke i de ekonomiska krönikorna. Carl Christopher Arfvedson uppgav att ledamöternas arbete och exempel

haft de lyckeligaste fölgder. De til Samhällets välgång och förkofran mäst ländande kunskaper äro satte i sin fulla dag; flere skadeliga fördomar och falska begrepp om den allmänna hushållningen, hvilka förledt Allmänheten och ofta verkat de största misstag i författningarna, äro försvundne. Hvad kan för et Folk vara angelägnare, än allmän uplysning och sunda begrepp, fotade på osvikeliga grunder i de vetenskaper, som närmast leda til allmänt väl och enskild båtnad? Hvad kan för goda Medborgare vara mera tilfredsställande, än at därtil bidraga?630

Wilckes svar till Arfvedson bekräftade talets verklighetsuppfattning. Han lyfte fram att Vetenskapsakademien alltsedan 1739 fokuserat på verkligt allmännyttiga konster och vetenskaper - däribland hushållningen och handeln - som den på alla sätt sökt stärka, jämte fliten. Genom denna orubbliga hängivenhet befordrades Sveriges väl. Sammanslutningen hade haft lyckan att i detta sitt värv alltid vara lierad med "Män, hvilkas mogna erfarenhet, stadgade insigt och rena nit för allmänt väl, på mångfallt sätt gagnat, stadgat och förkofrat så väl Academiens egen varelse, som framgång af Dess nyttiga föremål [ändamål]”. Wilcke illustrerade den typen av individer med namn som Jonas Alströmer, Faggot och Niclas Sahlgren, som sades göra vidare kommentarer överflödiga. ${ }^{631}$ Hans uppräkning visar hän mot Vetenskapsakademiens approprieringar av 
samhällsledningen, vilka liksom de ovan analyserade föreställningarna om akademien fick den att framstå som en central och karismatisk arena.

\section{Approprieringar och smicker}

Vetenskapsakademien tenderade i samband med sina närhetsmarkeringar till makthavare och representanter för eliten att uppvärdera dem för maximal effekt. Akademien var visserligen en aktör i egen rätt, men kom genom approprieringarna av samhällsledningen att ta del av dess karisma och även på denna väg inta en central bildlig ställning i den sociala och politiska gemenskapen. De nära kontakterna med eliten och makthavarna framgick tydligt i presidietalen, inte minst genom att uppräkningar av bemärkta ledamöter omfattade ämbetsmän, politiker och politiskt inflytelserika näringsutövare. Rosenstein den yngre nämnde att flera förutvarande presides hade fått honom att blygas när han tillträdde sitt ordförandeskap - "LINNÉER, KLINGENSTJERNOR, POLHEIMAR, WALLERIER, TESSINER och EHRENSWÄRDAR". Olof Swartz riktade strålkastarljuset mot strävsamma medborgare som i det gemensamma bästas tjänst utforskat naturens ekonomi under frihetstiden och som eftervärlden aldrig borde glömma bort. Bland dem återfanns akademimedlemmar av samhällsledande slag, som Jonas Alströmer, Carl Wilhelm Cederhielm och Löwenhielm, jämsides med lärda ledamöter. Samuel Sandels förtecknade ett antal avlidna medlemmar för att åskådliggöra att Sverige kunde mäta sig med andra upplysta länder ifråga om konster och lärdom. På hans lista stod inte bara lärda som Anders Celsius och Samuel Klingenstierna utan också samhällsledande personer som Claes Grill, Carl Hårleman och Carl Gustaf Tessin. Till dem som gjort särskilt betydande insatser för Vetenskapsakademien räknade Sandels exempelvis Alströmer, Celsius, matematikern och akademisekreteraren (1744-49) Pehr Elvius, Grill, Hårleman och Carl von Linné. ${ }^{332}$

Vetenskapsakademiens band till statsmakten diskuterades emellanåt i talen. En ordförande informerade om att han å akademiens vägnar uppvaktat "Högre orter" och hoppades på ett förmånligt utfall av detta. En annan fäste blicken på sammanslutningens funktion som statlig 
remissinstans när han förkunnade att Kongl. Maj:t och ständerna hyste så stort förtroende för Vetenskapsakademien att de utbad sig om ett omdöme varje gång något ärende föll inom ramarna för organisationens kompetenser. I ett sammanhang beskrevs ledamöterna som "högt uplyste Herrar och män, hvilkom af högre ort är blifvit anförtrodt, at uptänka och författa medel til et genare och det allmänna gagnande upfostringssätt". ${ }^{633}$

Presidietalen innehöll en rad uppgifter om donationer till Vetenskapsakademien från samhällets övre skikt, kungligheterna och ständerna. ${ }^{634}$ Gåvorna förklarades möjliggöra för akademien att ära nyttiga rön, uppmuntra lärda och inspirera till förmånlig konkurrens. I samband med att "en ädelmodig Medborgare" skänkt akademien ett rundligt belopp för jordbrukets förbättring reflekterades det över hur organisationen eggades "på alt sätt, med Nåd ifrån Thronen, med välvilja på alla sidor". Varken en nådig överhet eller välvilligt inställda medborgare hade dröjt med att stötta sammanslutningen, som raskt konsoliderats och förhoppningsvis skulle bli än mer blomstrande med tanke på sina mecenaters gunst. ${ }^{63}$ Enligt Sandels hade Vetenskapsakademiens välgörare varit viktiga för verksamheten och skänkt substantiella belopp. Akademien uppbar räntan på det kapital rådmannen Sebastian Tham avsatt till offentliga vetenskapsföreläsningar, som en favör från hans arvingar och Riddarhuset, vars direktion var vänligt stämd till organisationen. Konungen, Stockholms stads magistrat och hedervärda medborgare som Claes Grill gav generösa summor till Vetenskapsakademiens astronomiska observatorium, medan andra försåg den med instrument, böcker och naturalier. Bland de senare märktes Fredrik Sparre, som av kärlek till vetenskaperna lämnade akademien sin kvarlåtenskap och liksom Tham fick en medalj (jetong) slagen över sig. ${ }^{636}$

Framställningarna av mecenatskapen var i flera fall analoga med Vetenskapsakademiens gestaltningar av samhällsledningen som drivande i den ekonomiska och sociala utvecklingen. Pehr Wilhelm Wargentin ansåg det vara nobelt och berömvärt att välborna och respekterade män vinnlade sig om vetenskaperna och vetenskapsmännen. Han framhävde vikten av de många engagerade mecenater som understött goda ansatser, uppmuntrat begåvningar och förstått att få fram mogna frukter hos 
dem som besuttit lovande frön; mecenaternas gärning inspirerade till ädel tävlan, försatte allt i rörelse och gjorde så att konster och vetenskaper grönskade. De som lade mycken möda och dryga kostnader på att upprätta mineraliesamlingar var lika relevanta som de som visste att ordna och begagna sig av samlingarna. Akademien häftade följaktligen i tacksamhetsskuld till åtskilliga medborgare utöver sina grundare och medlemmar. ${ }^{637}$

Höpken uppehöll sig vid dem som givmilt bistått Vetenskapsakademien och vid de rikliga förmåner som kommit den till del, inte minst Grills och Riddarhusets bidrag till observatoriebyggandet. Det gick inte an att negligera akademiens "odödeliga förbindelser [...] emot vissa Herrar och Män" som gynnat observatoriet och därför alltid borde uppbära tacksamhet. Han fastställde härvidlag att vetenskaperna får liv genom uppmuntran och att Försynen ibland väcker upplysta och ansedda personer - mänsklighetens prydnader, efterkommandes förebilder - som stimulerar kunskap och förnuft. De mäktigas understöd identifierades i linje med detta som huvudorsaken till vetenskapernas lyckliga tillstånd i samtiden. ${ }^{638}$ Ett snarlikt perspektiv anlades av Bengt Bergius:

Magnater eller höga Herrar äga altid en mägtig kraft til Vetenskapers främjande i margfallig [mångfaldig] måtto, synnerligen genom det [att] de hägna, upelda och underhjelpa deras nitiska, och merendels betryckta, stundom ock försagda, idkare. Lyckeligt, när sådane Herrar tillika fått nog insigt i dessa fria konster, för at förstå deras rätta dyrd [dyrbarhet], ty då saknas aldrig omtankan och viljan at befordra deras upkomst, kunnandes tilfällen dertil gifvas många. Så sinnade Magnater kunna visserligen, utan minsta arbetsamma åtgärd på sjelfva Lärdoms-fältet, obeskrifveligen gagna ett Vetenskaps-Samhälle, med hvilket de sig förbinda, ty de göra dess ädla tänkesätt gällande genom det kraftiga intryck de verka hos Allmänheten med sin upmuntrande föresyn, de pryda och uplifva sammankomsterna med sin flitiga närvarelse, de gifva eftertryck åt författningarna [stadgarna] med sitt anseende, och de uprätthålla ordning medelst sin myndighet. För öfrigt kunna de ofta ogement bidraga til en Vetenskaps framsteg, genom någon dess Idkares [upp]muntrande och framdragande i rättan timma. 
Den sista tesen belystes med hjälp av naturalhistorien och Linné, vilken tack vare magnater och mecenater kunnat följa sin håg och förbättra vetenskapen han älskade. ${ }^{639}$

Vissa resonemang kring donationer och mecenatskap var framåtblickande och kan därmed misstänkas ha syftat till övertalning. Anders Sparrman lyfte fram Vetenskapsakademiens erkänsla mot höga välgörare som Carl Albrecht Rosenadler och Ulric Scheffer, vilkas gåvor med säkerhet skulle föranleda fler. Han lovade att beständigt nedteckna donatorernas namn så att de skulle förbli ihågkomna och hedrade. Bengt Bergius uppgav att akademien, som nått framgång utan skattemedel eller "synnerligt uplyftande genom Öfverhetens arm", tacksamt drog sig till minnes alla ynnestbevis och på senare tid sett medborgare nästan konkurrera med varandra om att stödja organisationen. Denna tävlan skulle med största säkerhet fortgå och ett sådant bakvänt tänkande troligen aldrig kunna uppstå att "Magnater skola finna sig förmörkade af något nedlåtande ibland lärda, fast mindre lysande, Män". ${ }^{640}$

Det frihetstida kungahusets kontakter med Vetenskapsakademien uppmärksammades ofta före det rojalistiska statskuppsförsöket 1756. Ledamöter diskuterade "de dyra Ljus" som ärade akademien med uppmuntran och beskydd och det förtroende sammanslutningen åtnjöt hos sin nådiga överhet. ${ }^{641}$ Fredrik I figurerade vanligen tillsammans med kronprinsen Adolf Fredrik. Det kungliga stödet angavs ha förstärkt Vetenskapsakademien påtagligt och gjort att den kunnat etablera värdefulla utländska kontakter. Kongl. Maj:ts och kronprinsens beskydd hölls för att manifestera Guds vilja, och akademien skulle allt framgent betrakta det som en förmån utan motstycke och prisa Adolf Fredriks nåd, som "högre Samfund ej ens våga sig at äska". ${ }^{642}$ Carl Didrik Ehrenpreus gjorde gällande att lärda sällskaps existens var beroende av furstens beskydd och styrka, varför akademien aldrig nog kunde lovorda Fredrik I:s höga tankar och stora avsikter. Fredrik hade gunstigt stadfäst Vetenskapsakademien, varefter Adolf Fredrik av kärlek för den blivit dess medlem och även tagit på sig rollen som skyddsherre för att öka uppmuntran av vetenskaperna, konsterna och slöjderna, välfärdens och lycksalighetens enda grunder. Ehrenpreus yrkade på kraftsamling "til en så huld och nådig Konungs nöje: til en så ädel Arf-Furstes hugnad 
och glädje: til en så vördnads värdig mild Prinsessas [Lovisa Ulrika] längtan och åstundan och til Svea Hopps fägnad”. Talet registrerade att Adolf Fredrik deltog i den aktuella sammankomsten och att han för första gången bevistat akademien under Ehrenpreus presidium, samtidigt som kronprinsparet och deras son Gustav porträtterades som den svenska lärdomens garanter. ${ }^{643}$

Carl Fredrik Piper konstaterade efter Fredrik I:s frånfälle att vetenskaperna hade revitaliserats och Vetenskapsakademien tagit sin gudabenådade början under hans styre. Eftersom monarken godkänt stadgarna och skänkt akademien dess "första styrka" var ingenting skäligare än att den visade sin vördnad vid hans grav. Piper växlade därpå över till att hylla den nye konungen, som utfäst sig att förbli Vetenskapsakademiens skyddsherre. Wargentins svar till Piper betonade liksom talet inrättningens band till både Fredrik och efterträdaren Adolf Fredrik, vilken upptagits som ledamot, gjort akademien till sin egen och skänkt den nytt liv genom sitt beskydd. Såväl vetenskapernas och Vetenskapsakademiens mognad och blomstring som rikets bestående sällhet var att vänta av hans regeringstid. ${ }^{644}$

Adolf Fredrik blev än mer approprierad efter sitt trontillträde. Konungen sades ha nedstigit från tronen och tagit säte i akademien så att vetenskaperna fick nödvändigt beskydd och kom till rätt användning. Hans "visa styrsel och öma omvårdnad" utgjorde sammanslutningens "Lif och Styrka". Medlemmarna gladde sig åt den kungliga omvårdnaden och tog del av dess ljuvligaste frukter. Det ålåg dem att bära fram säkra och klara nyttouppslag till den milde landsfadern, som sedan skulle tillämpa deras idéer. Carl Fredrik Scheffer parallelliserade politik och lärdom när han anförde att regentens övertygelse om välfärdens nära samband med vetenskaper och konster fått honom att bli Vetenskapsakademiens huvud, varigenom Sveriges och vetenskapernas styren förenades och upplivades av en anda. ${ }^{645}$

Den mest långtgående approprieringen av Adolf Fredrik påträffas hos Höpken, som förklarade att monarkens deltagande gjorde dagen då Vetenskapsakademiens astronomiska observatorium invigdes alltigenom härlig. Akademien hade önskat och fått njuta nåden av sin skyddsherres närvaro, som stimulerade vetenskaperna och bringade riket lycka. Sam- 
tidigt framhölls Adolf Fredriks allmänna medverkan i organisationens verksamhet: "Vi hafve sedt, Mine Herrar! den sitta ypperst ibland Oss, som Försynen och Ständers val satt ypperst öfver folket. Vi hafve sedt vår Konung taga sit säte ibland Vetenskaper och dess idkare, ibland åtskillige arter af Snilles-gåfvor.” Höpken pekade på den positiva effekt en upplyst överhets beskydd hade på Vetenskapsakademien och frågade retoriskt om några varit mer gynnade av konung och riksdag än ledamöterna. Även Lovisa Ulrika smickrades och knöts till akademien, ${ }^{646}$

Som framgått av det föregående kapitlet marginaliserades kungligheterna i presidietalen efter det misslyckade statskuppsförsöket 1756. Samma mönster kan urskiljas med avseende på Adolf Fredriks beskydd, som väsentligen kom att förbigås med tystnad fram till 176o-talets slut. De enda som dessförinnan kommenterade hans förhållande till Vetenskapsakademien var Carl Knutberg, som nämnde konungens status av skyddsherre, och Wargentin, som delvis knöt sammanslutningens framgångar till den höga överhetens gunst. ${ }^{647}$ En appropriering av Adolf Fredrik i samma stil som före kuppstämplingarna infann sig först på hösten 1769, när kungaparets allierade hattarna segrat på riksdagen och John Jennings diskuterade den nåd akademiens beskyddare visat när han upplåtit ett hus till organisationen. Vetenskapsakademien hade avgivit den mest underdåniga tacksägelse och försäkran om fortsatt strävan efter att förverkliga syftet med Kongl. Maj:ts omtanke - "Samtidas och Efterkommandes väl, igenom ljus och kunskaps utspridande". Jennings inflikade dock att sekreta utskottet, alltså ständerna, hemställt om den kungliga favören. Han beskrev vidare hur kungafamiljen, i synnerhet Lovisa Ulrika, hedrat de hädangångna ledamöterna Dalin och Klingenstierna, vilket föranlett akademien att betyga sin vördnad genom präglandet av ett par medaljer. ${ }^{648}$

Wargentins svar till Jennings noterade att dennes presidium kännetecknats av högst angenäma händelser och varit lyckosamt för Vetenskapsakademien. Sekreteraren åberopade i likhet med Jennings ständerna, vilka givit röst åt sin uppskattning av sammanslutningens verksamhet. Svaret smickrade också hatten Jennings, som meddelades ha agerat till akademiens fromma i sekreta utskottet, genom att framföra att hans ordförandeskap inlett en ny epok i organisationens historia. ${ }^{649}$ 
Det var av allt att döma viktigt att inte ensidigt hylla monarkerna och att balansera dem mot riksdagen och hattpartiet.

Approprieringarna av Adolf Fredrik överlevde hans död. Carl Johan Cronstedt tillkännagav en tid efter hans frånfälle att inget av Vetenskapsakademiens systersällskap haft större orsak till erkänsla eller smärtsammare grund för sorg. Fäderneslandet sörjde en välvillig och patriotisk far, akademien en vetenskapsälskare, hög ledamot och aktad beskyddare. Ledamöterna mindes tacksamt hur kronprinsen Adolf Fredrik "ej ansåg dessa Titlar vara under Dess [sin] värdighet, ej [h]eller sedermera trodde Thronen däraf kunna fördunklas", vilket gjorde att han inte lät sitt engagemang stanna vid det formella. Vetenskapsakademien hade frekvent haft anledning att uppskatta hans förtroende och dess synpunkter upprepade gånger bemötts med respekt. Vetenskaperna hade frodats under ett beskydd som skulle få Adolf Fredrik att gå till historien som Cosimo de Medicis och Ludvig XIV:s like. Wargentins svar behandlade utöver medlemmarnas sorg och den döde konungens förhållningssätt till akademien efterträdaren Gustavs intresse för vetenskaper och konster, liksom hans förmåga att befordra dem. ${ }^{650}$

Den blivande Gustav III associerades tidigt med Vetenskapsakademien. Det gjordes gällande att varken akademien eller fäderneslandet skulle sakna styrka eller glädje så länge Försynen lät det nyfödda kronprinsbarnet "tilväxa i en grönskande Sällhet". Som nybliven regent utökade Gustav akademiens lokaler, vilket framställdes som en lycklig början, ett nådebevis och ett tecken på fortsatt kungligt beskydd. ${ }^{651}$

Sandels uppgav att både Gustav III och Vetenskapsakademien sörjde förlusten av Adolf Fredrik och att den nye furstens liv var sammanflätat med akademiens: "Imellan dem, som på en [vid samma] tid upväxa, under en och samma tilsyn, knytes ofta i spädare åren ett band, som i den tilkommande tiden hvarken höghet, eller myckenhet af omsorger förmå uplösa." Sammanslutningen hade i förskräckelse över sin beskyddare Adolf Fredriks bortgång vänt sig till hans arvtagare, och det med fullständig förtröstan eftersom den nye konungen ännu mera än sin företrädare strålat av kärlek till vetenskaperna, de fria konsterna och hushållningen. Ledamöternas lycka över att Gustav tagit på sig rollen som organisationens skyddsherre hade sedan hållits vid liv genom kunglig 
uppmuntran. Hans regering skulle bli mer lysande än någon annans och vittne till akademiens framsteg. ${ }^{652}$ Sandels fastslog att monarkers omtanke varit mer betydelsefull än donatorer för Vetenskapsakademien, som behövde kungligt godkännande och beskydd. Samme ordförande skildrade de två föregående regenternas, främst Adolf Fredriks, insatser för akademien och delaktighet i dess verksamhet. Han riktade sig direkt till Gustav med utsagan att en inrättning som existerade för rikets skull och hedrats med så upplysta och nådiga monarkers uppmärksamhet tillhörde konungen. ${ }^{653}$

Redogörelsen för företrädarnas gynnsamma inställning kan tolkas som ett försök att pådyvla den unge monarken en fördelaktig och aktiv hållning till Vetenskapsakademien, speciellt med tanke på att Sandels tilltalade och vävde in honom i sin utblick. En liknande ansats kan skönjas i Wargentins svar, vilket framhävde akademiens åtnjutande av regenters utmärkta nåd och den nye beskyddarens "med Blodet ärfda och genom egen uplyst öfvertygelse förvärfvade höga ynnest för Vetenskaper”, som bådade gott inför framtiden och skulle addera till organisationens lycka. ${ }^{65}$

Konung Gustav III:s första besök vid Vetenskapsakademien högtidlighölls i ett tal av Carl Rudenschöld som hade denna begivenhet till ämne. Rudenschöld lyfte fram Gustavs ställning som beskyddare och akademiens tacksamhet, underdånighet och tillfredsställelse över att regenten ärade mötet med sitt deltagande. Talet angav att ledamöterna strävade efter att vara honom värdiga och göra sig förtjänta av hans nåd, som de hoppades få fortsätta ta del av. ${ }^{655}$ Den nådige skyddsherren Gustav och hans hedrande närvaro liksom Vetenskapsakademiens känslor inför den återkom i flera presidietal i begynnelsen av det gustavianska tidevarvet. ${ }^{656}$ Tematiken utbroderades på olika sätt. Till exempel var Gustav, enligt Nils Rosén von Rosenstein som vände sig direkt till honom, inpräntad i hjärtat hos alla ledamöter som värdesatte vetenskaper och visste vad konungen gjorde för dem. Det skulle bli lätt för medlemmarna att verka under en regent som redan före sin tronbestigning värnat vetenskaperna och oaktat sin börd bedömts vara kungamakten värdig. ${ }^{657}$

Gustav III återgäldade Vetenskapsakademiens smicker och approprie- 


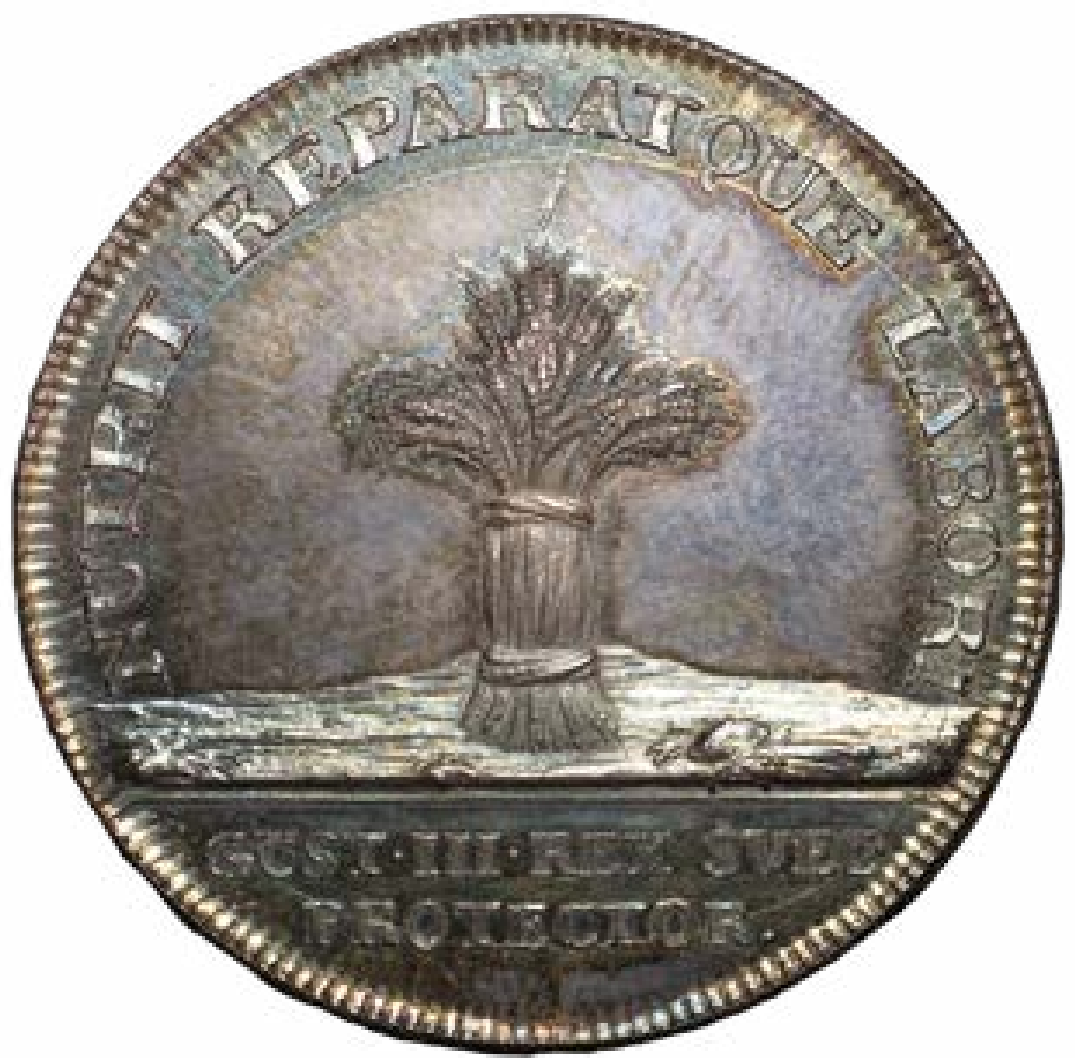

Bild 11. Gustaf Ljungberger, medalj slagen för att högtidlighålla att Gustav III blev Vetenskapsakademiens beskyddare 1771. Foto: Uppsala universitetsbibliotek.

ringar i ett svar till Rudenschöld, där han tydligt sökte bekräfta bilden av sig själv som en vetenskapsfurste i Fredrik I:s och Adolf Fredriks efterföljd. Konungen beskrev akademien som en allmännyttig, framgångsrik och för fäderneslandet ärofull institution. Han betygade inte endast sin välvilja och sitt beskydd, utan klargjorde även att han avsåg att sätta sig in i dess arbete, tillägna sig kunskaper genom att närvara vid sammankomsterna samt uppmuntra vetenskaperna med sitt exempel. ${ }^{658}$

Närhetsmarkeringarna till Gustav III fortgick med oförminskad styrka efter statsvälvningen, som sades innebära ljusare utsikter för 
Vetenskapsakademien än någonsin förr ${ }^{659}$ Det fastslogs att konungen i sitt beskydd av olika institutioner hade ett särskilt öga till akademien, vilken han såg som en juvel i sin krona. Sammanslutningen värdesatte att han fungerade som dess skyddsherre och gjorde sig hoppfullt förvissad om att relationen skulle bestå så länge naturens lagar tillät. Vetenskapsakademien hade fått så många nådebevis att bara deras förtecknande riskerade upplevas som inställsamt. Ingen hade erfarit Gustavs stimulerande verkan mer än hans akademi och ingen var mer förpliktigad att kombinera sina tacksamhetsyttringar med trofasta önskningar om hans sällhet. Organisationen presenterades därutöver som en katalysator för kunglig kraft - alltså karisma: "de lifligaste strålar ifrån sjelfva Konunga-Thronen blifva hitspridde, [för] at, sedan de här gifvit full dag, med fördubbladt återsken falla tilbaka på sit ursprung, den klara och välgörande Solen, at så mycket kraftigare lysa, gagna och uplifva det allmänna". ${ }^{600} \mathrm{I}$ ett tal inbegrep markerandet av närhet till monarken hans efterträdare, då ledamöterna bad för en kronprins och framtida skyddsherre med samma gynnsamma egenskaper som glänste på Gustavs tron. ${ }^{661}$

Konungens medverkan vid mötena förblev ett ledmotiv i presidietalen. Ledamöter menade att inget annat vetenskapssamhälle i så hög grad torde kunnat förnöja sig över sin överhets närvaro och att de inte var tillräckligt vältaliga för att uttrycka Vetenskapsakademiens tillfredsställelse över sin skyddsherres hedrande deltagande i sammankomsterna. Både akademien och riket gladde sig över regentens beskydd av vetenskaperna, men hans besök gjorde organisationens glädje än större; de skedde ofta på hans vilotid och hade en såväl uppmuntrande som statushöjande effekt. Carl Rudenschöld kommenterade Gustav III:s närvaro vid det möte där han avgick, och hävdade att sammanslutningen var ensam i sitt slag om att beskyddas av en upplyst domare som inte ansåg det under sin värdighet att lägga tid på den. Denna ära krävde desto mera av Vetenskapsakademien och gav näring åt en strävan att göra Gustavs regering strålande och vördnadsfullt ihågkommen. ${ }^{662}$

De teman som präglade beskrivningarna av Gustav III:s förhållande till Vetenskapsakademien gick igen efter hans död. Zacharias Zachariae Plantin framställde konungen som en vetenskapernas vän, som bistått 
snillen, ärat dem som förenat patriotism, flit och utvecklade kunskaper samt månat om att stimulera upptäckten av nya sanningar och kanalisera redan kända sådana i rätt riktning. Akademien hade alltid varit en älskad mottagare av den saknade beskyddarens omsorg och Gustav hade vid flera tillfällen hedrat sammankomsterna med sin närvaro. Wilckes svar fortsatte på det inslagna spåret. Sekreteraren uppehöll sig vid den stora förlusten av en välvillig furste, som resolut kopplades till organisationen:

Detta Hus, som GUSTAF sjelf til boning för dem [vetenskaperna] utsett: med Sin höga Närvaro dertil helgat och ofta hedrat: - Detta Bord, hvarvid GUSTAF Sjelf tagit säte och öfvervarit Våra Högtider och Våra öfverläggningar: - Academiens Samlingar, prydde med Kongl. gåfvor af Dess [hans] Hand: - Academiens förmögenhet, riktad [berikad] af Dess gynnande Nåd: - Våra Arbeten, nådigt gillade, nådigt öfversedde: - Alt detta, och mycket mera, påminner om och framkallar Vår sorg, Vår saknad, Vår innersta känsla af mistning; framkallar Minnet af en vördad och älskad SKYDDSHERRE, en KONUNG, Hvars Majestät äfven spridt välgörande strålar til denna Vetenskapernas inskränktare krets. ${ }^{663}$

Tyngdpunkten kom nu att överföras på den omyndige Gustav IV Adolf. Plantin deklarerade att Vetenskapsakademien skulle fortsätta att utforska och förmedla nyttiga sanningar under dennes beskydd, Wilcke att akademien troget förlitade sig på den dyrbare unge regenten och på kungahuset, utan vars beskydd "bästa viljan stadnar i kraftlöst bemödande". ${ }^{664}$ Detta visar, liksom utsagorna om Adolf Fredriks livgivande verkan och solen Gustavs strålar, på Vetenskapsakademiens smak för och anammande av kunglig karisma.

Under frihetstiden positionerade sig akademien av uppenbara skäl också nära riksdagen. Presidietal meddelade att inga var mer gynnade av de höglovliga ständerna än ledamöterna och att den gunst Vetenskapsakademien åtnjöt framgick av bland annat att sammanslutningen fått äran att publicera Tessins korrespondens med kronprins Gustav. Riksdagen bidrog till uppförandet av det astronomiska observatoriet och ständernas manufakturkontor avsatte jämte andra offentliga institutioner på akademiens inrådan ansenliga medel till medlemmen, 


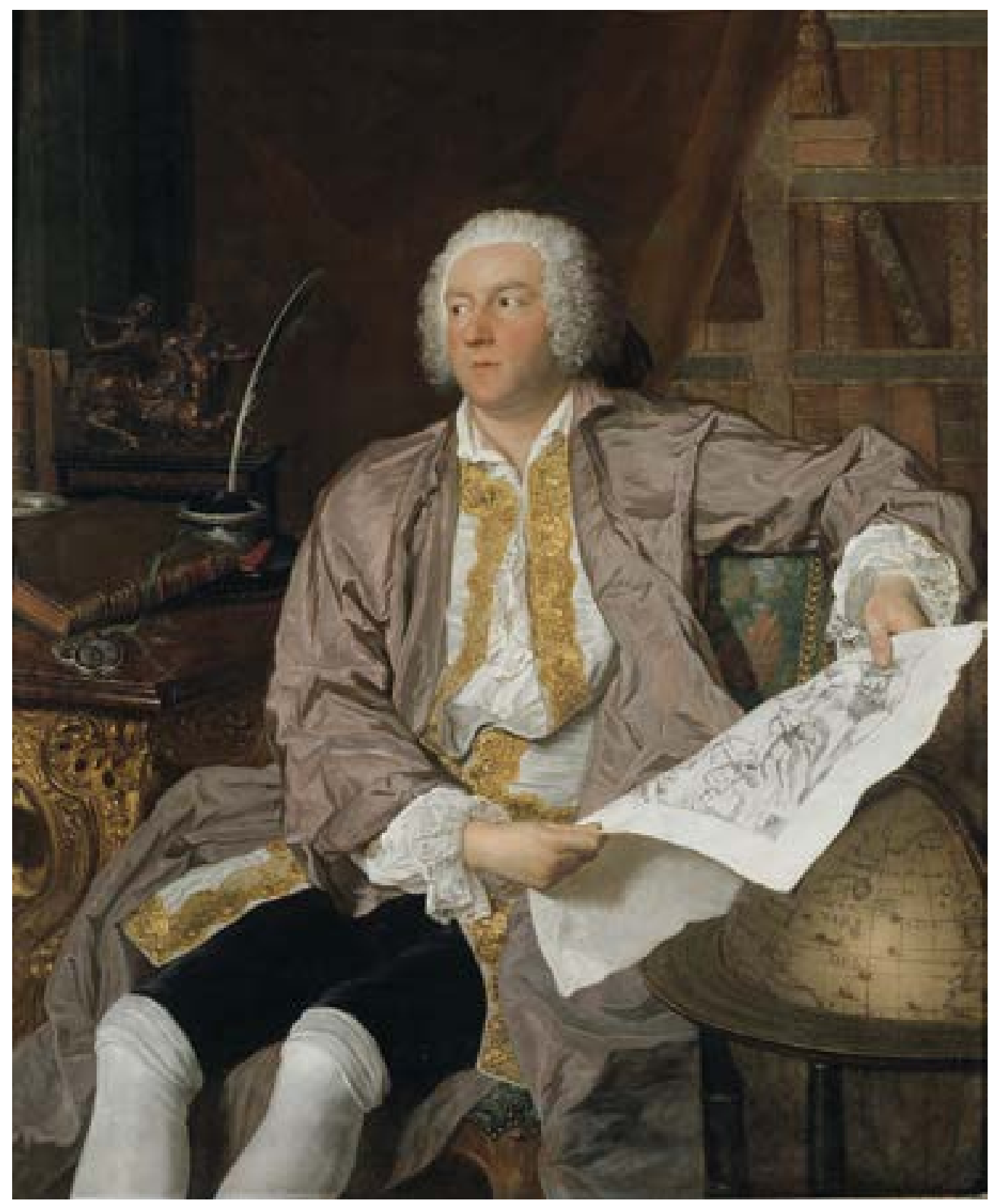

Bild 12. Joseph Aved, Greve Carl Gustaf Tessin (1695-1770). Foto: Nationalmuseum. Hattledaren Tessin var en av Vetenskapsakademiens högst uppsatta mecenater. 
naturalhistorikern och Linnélärjungen Pehr Kalms nordamerikanska resa. Under den gustavianska eran förbigicks huvudsakligen riksdagen med tystnad. ${ }^{665}$

De frihetstida talen var angelägna om att appropriera hattpartiets ledarskikt och ta del av dess karisma. Jennings illustrerade Vetenskapsakademiens ansträngningar för det allmänna bästa och för byggandet av Trollhätte kanal med "vår TESSIN, vår EKEBLAD, vår LIEVEN, vår EHRENSVÄRD", som energiskt sökte fullända det enda sentida projekt som rätteligen kunde jämställas med de driftiga romarnas. Ett antal ledamöter kan förmodas ha anspelat på samma skikt av prominenta hattar som Jennings ringade in. Det hette att åtskilliga av landets högsta män höll ordförandeposten för hedervärd och att den utan hänsyn till samhällsställning kunde växla mellan "en af Riksens ypperste" och någon från medelståndet. ${ }^{666}$ Akademien hade många "purpurklädda Herrar" - det vill säga makthavare - i sina led och vid ett tillfälle var glädjande nog över hälften av de nya riksråden medlemmar i organisationen. Abraham Bäck framhöll de höga herrarnas intresse för allt som kunde gagna fäderneslandet, inte minst den samhällsnyttiga Vetenskapsakademien, vars verksamhet de utgjorde en integrerad del av: "Vi äre så lyckelige at hafva Riksens höga Män i detta vårt Samhälde. En har hedrat Academien med sit arbete, och vi fägne oss at se hans namn i våra handlingar. En har icke längesedan behagat anföra detta vitra Sällskapet, och gifver oss dageliga prof, det [att] han icke mindre hägnar Vetenskaper, än han sjelf är kännare af dem. Det är Honom som vi hafve til en stor del at tacka, för det snille och Vett begynner hos oss lysa up utur mörkret." ${ }^{\prime 67}$

Ledamöterna närmade sig också hattledningen med hjälp av smicker. De förkunnade att regeringen var patriotisk och vaksam på välfärden, liksom att vetenskaper och konster vantrivdes utan högt beskydd och att svenskarna borde anse sig lyckliga som genom regeringens prisvärda agerande fick uppleva en så värdefull fördel; framtida generationer skulle lovorda dem som oförtröttligt bemödat sig om förbättring. Carl Fredrik Adelcrantz jämförde indirekt riksråden med Jean Baptiste Colbert och Agrippa. Han slog fast att Sveriges erfarna riksråd givit de fria konsterna gedigna prov på sitt kraftfulla stöd och upplysta tänkande, 
samt att riksdagens åtgärder för dessa konsters förbättring snart skulle ge allmänheten ("det Allmänna") en ny anledning att berömma regeringens strävan efter rikets sanna väl. ${ }^{668}$

Även de gustavianska presidietalen komplimenterade och gjorde anspråk på ledande politiker och ämbetsmän. Vetenskapsakademien beskrevs som en samlingspunkt för Sveriges mest framstående och lärda män, och som ett sammanhang där de förra tävlade om att föra vetenskaperna inför tronen. Akademien hade lyckan och turen att samla många höga herrar, som alltid ville landets bästa och upprepade gånger demonstrerat sin entusiasm för vetenskaperna. Dessa var "både på snillets och hjertats sida vördnadsvärda" och fann i Vetenskapsakademien "sin yppersta vederqvickelse under ledigheten från ämbetsbördor". De hade inte försummat seden att hålla tal vid nedläggandet av ordförandeskapet, ett ämbete som sannerligen var viktigt när det bekläddes av makthavare som kunde utverka nytta och förmåner åt sammanslutningen. Eric Prosperin förklarade att det aldrig saknats vetenskapsälskare bland rikets förnämligaste män och att akademien kunde skatta sig lycklig i ett läge då dessa "ej tro sin Purpur lida därigenom, at de räkna Sig för våra Medbröder”. De lärda fick nödvändig kunskap om världen genom umgänget med dem, och purpurns likställande med vadmalen gav allmänheten utmärkta exempel på högaktning av vetande och genuin förtjänst, varvid den inre äran tillerkändes lika stort värde som sina yttre attribut. ${ }^{669}$

Flera hattpolitiker gjordes individuellt till föremål för smicker och appropriering. Till dem hörde Henning Adolph Gyllenborg, vilken karakteriserades som en vetenskapsälskare och beskyddare av akademien. Han besannade enligt uppgift fullt ut den patriotiska flit för vetenskaperna, fäderneslandet och nyttiga anstalter som allmänt ansågs vara nästan medfödd hos personer med namnet Gyllenborg. Carl Fredrik Scheffer befanns vara en av de män som borgade för rikets välgång genom sina handlingar och genom att värdera sina höga ämbeten uteslutande utifrån deras förmåga att bidra till det gemensamma bästa. Detta synsätt färgade allt han företog sig, också i förhållande till de lärda och Vetenskapsakademien. ${ }^{670}$ Tessin var inte bara "Rikets stora Man" utan även Vetenskapsakademiens höga ledamot och "uplyste Lärdoms-älskare", vars 
uppmuntrande närvaro fattades organisationen när han inte längre bodde i Stockholm. Presidietalen framställde honom som den främsta källan till akademiens kraft och lyster, som ett geni och ett föredöme för de övriga medlemmarna och som upphovsmannen bakom de oskattbara brev till kronprins Gustav sammanslutningen publicerat. ${ }^{671}$ Höpken tillskrevs egenskaper som förnuft, flit, vetenskaplig böjelse och litterär eminens. Sandels tog upp den tillgivenhet och tacksamhet ledamöterna kände för att han hade lagt grunden till Vetenskapsakademiens förvaltning och framgång; han älskades av och älskade akademien, efterfrågades som ordförande och sekreterare och förgyllde sekreterarposten genom att utgöra dess förste innehavare. Det var synnerligen glädjande att såväl Höpken som hans medgrundare Linné ännu fanns i livet. Under mössornas styre berömde Bengt Bergius dels Cederhielm, dels Höpken, som kallades Vetenskapsakademiens "stora Stiftare, det än lysande Alpha uti vår Ledamots-längd, hvars Purpur vi mindre vörda, än Dess [hans] dråpeliga [förträffliga] egenskaper och förtjenster" ${ }^{672}$

Det hände att mössor som Sten Carl Bielke, det före detta riksrådet Gustaf Bonde och Matthias Alexander von Ungern-Sternberg behandlades på samma sätt som sina politiska meningsmotståndare. Till exempel framhävdes Bondes beskydd av akademien och vetenskaperna, som han uppgavs älska och ägna sig åt under lediga stunder. I samband med Bonde gjordes iakttagelsen att höga herrars ära fördubblades av att de hyste kärlek till och bedrev vetenskaper. ${ }^{673}$ När mössorna satt vid makten uttryckte Rosenadler sin glädje över att få efterträdas som preses av en sådan stor herre som Löwenhielm och över att medlemmarnas samfällda val av honom lyckligen infriats. ${ }^{674}$

De enskilda gustavianska politiker och ämbetsmän som presidietalen smickrade och markerade närhet till hade många gånger ett förflutet $\mathrm{i}$ hattväldet. Fastän frihetstiden utsattes för hård kritik förkastades alltså inte periodens individuella politiska aktörer, som ofta kom att gå den nya regimens ärenden. ${ }^{675}$ Carl Fredrik Scheffers strävsamhet för näringarna, konsterna, vetenskaperna och Vetenskapsakademien lyftes fram, och det fastställdes att en gynnsam framtid aldrig varit mer tryggad eftersom rikets välfärd nu vilade i så pålitliga händer. Sven Bunge, en skyddsling till bröderna Carl Fredrik och Ulric Scheffer, sades besitta 
ett välbekant ädelt tänkande som säkerställde hans stöd till akademien, vars goda tillstånd hänfördes till både Gustav III och vetenskapsälskarna kring tronen, det vill säga högt uppsatta figurer som Bunge. ${ }^{676}$ Andra tidigare hattar som komplimenterades och approprierades var Matthias Benzelstierna, riksrådet Melcher Falkenberg, Jean George Lillienberg, Carl Rudenschöld och Carl Sparre. ${ }^{677}$

Till denna kategori hörde också Höpken, vilken som förut framför allt associerades med Vetenskapsakademiens tillkomstskede. Det påtalades att Höpken hade stiftat akademiens visa lagar och var lycklig nog att få se det nyttiga han planterat bära avsedd frukt. Sammanslutningen delade denna tillfredsställelse med sin förträfflige grundare, som fortfarande lände akademien till heder och kunde hålla efter sin älskade skapelse ${ }^{678}$ Rosenstein den yngre gestaltade strax efter Höpkens död i maj 1789 honom som en tacksamt ihågkommen välgörare och beskyddare:

När blifver tiden för oss, at icke känna och nämna denna förlust? När, at icke sakna et Snille, sällsynt, djupt, skarpt, eldigt och starkt, äfven under ålderdomens tiltagande bräckligheter? när, at icke sakna hans kunskaper, mogne, vidsträckte, uplysande? när, hans ömhet för Academien, hans verksamma nit, hans upmuntrande närvaro? när, hans kärlek för vetenskaperne, icke tilgjord, men upriktig? när, det beskydd han lemnade deras Idkare? et beskydd som de utan rodnad kunde emottaga, efter[som] det gafs utan högmod [...] och när et Tidehvarf upkommer, som icke delar vårt anspråk at äga Grefve HÖPKEN, så måtte detta Tidehvarf icke känna saknaden genom brist af dess [hans] Likar, icke klaga at dess [hans] efterdöme varit utan verkan. ${ }^{679}$

Inte alla politiker och ämbetsmän som berömdes och relaterades till den gustavianska Vetenskapsakademien hade en bakgrund i hattarnas krets. Bland dem som saknade en sådan förankring märks hovanknutna figurer som Nils Adam Bielke och den framlidne hovsekreteraren Pehr Rydman, före detta mössor som Lilliestråle samt personer med vag koppling till frihetstidens politiska liv, som statssekreterarna Elis Schröderheim (Schröder) och Johan Gustaf von Carlson. ${ }^{680}$ Merparten av dem som approprierades och smickrades tillhörde likafullt de 
gamla hattnätverken, som verkar ha behållit mycket av sin vitalitet efter statsvälvningen.

Vissa presidietal förmedlade en starkt egalitaristisk uppfattning om Vetenskapsakademien som har givit genljud i den historiska forskningen. ${ }^{681}$ Frihetstida ledamöter deklarerade att presidiet allena utgjorde sammanslutningens högsäte och att medlemmarna ställde sig likvärdigt positiva till högre och till ringare kollegor på ordförandeposten. Lika entusiasm för vetenskaperna utjämnade allt anseende och gjorde alla lika, samtliga turades om att lyda och befalla, oberoende av den sociala rangordningen. Enbart lärdomen var bedömningsgrund i en fri akademi, där envar mättes efter sitt förstånd och sitt uppsåt. Johan Clason upplyste om att Vetenskapsakademien högaktade förtjänst och uteslutande fäste vikt vid flit, förnuft och vetenskap, inte ämbetsvärdighet. Clason anmärkte emellertid samtidigt att han efterträtt den högt uppsatte greve Piper som preses. Andra ordförande vittnade om hur hedersamt det var att bli upphöjd till en framträdande position av "Höga och Visa Män” och om att Clas Ekeblads maka Eva, akademiens enda kvinnliga ledamot under 1700-talet, förtjänade titeln rikets yppersta kvinna lika mycket för sina egenskaper som för sitt förnämliga stånd. ${ }^{682}$

Vetenskapsakademiens egalitarism förblev ett tema under den gustavianska tiden. Presidietal gjorde gällande att förtjänst endast utgick från strävsamhet, förstånd och vetenskap, inte från slumpmässiga eller tillfälliga faktorer som börd, ålder och ämbetsvärdighet. Akademiens snille och vett hade sedan dess grundande dragit till sig "äfven de högste Konungens och Rikets Männ, at här lika som glömma sin Ätt, sin Höghet och sina stora Värf, at blanda sig ibland lägre Medborgare, och at taga nöje i umgänge ibland sådane, som kallas Vetenskapers Söner”. Sveriges högsta herrar tävlade med anspråkslösa vetenskapsidkare och presides hämtades från båda grupperna. ${ }^{683}$

Som det föreliggande avsnittet visat intog samhällshierarkin trots allt en framskjuten plats i Vetenskapsakademien; traditionalistiskt tänkande samexisterade och överlappade med meritokratiskt. ${ }^{684}$ Denna dubbelhet kan förbindas med Jacob Orrjes iakttagelse att den tidigmoderna periodens lärda mekaniker skulle vara såväl fria och socialt gränsöverskridande aktörer som lojala och undergivna ämbetsmän i ett hierar- 
kiskt system. Eftersom deras gränsöverskridanden var förväntade och ansågs vara nyttiga för det allmänna betraktades de inte som ett hot mot det bestående. ${ }^{685}$ Samma synsätt tycks ha varit aktuellt i akademien.

Karisman som flöt ur organisationens egna göranden korresponderade mot det meritokratiska idealet och karisman som härrörde från samhällsledningen mot den nedärvda sociala rangordningen. Det är frestande att betrakta den senare som överordnad den förra.

\section{Övertalning och kritik}

En viktig aspekt av Vetenskapsakademiens interaktion med samhällsledningen var ledamöternas försök att påverka den senare i vissa riktningar, som regel till att ta sig an olika företeelser, verksamheter och näringar. Dessa försök kunde vara direkta och distinkta, som när ett presidietal hävdade att en regerings huvudansvar bestod i att öka befolkningen och sätta näringsmedlen i rörelse, eller som när akademien enligt ett tal väntade sig att en ledamots insikter skulle ges en särställning i en lagrevision. Övertalningen kunde också vara mer indirekt och förtäckt, som när ett av sekreterarens svar betonade vetenskapernas nytta inom lagstiftningen, i synnerhet med avseende på ekonomiska författningar, vilkas oundgängliga rådgivare de var: "Ju mera Lagstiftaren [...] är af goda kunskaper uplyst, och ju närmare han följer Naturen, desto mera välgrundadt och varaktigt blifver hans verk." Ett annat belysande exempel på mer försiktig övertalning återfinns i en utläggning om ansatser att stimulera handslöjder som bringat välstånd och ökat överhetens makt utomlands. Även om Sveriges överhet hade premierat ett antal slöjder fortfor metallproduktionen att vara eftersatt; det fanns dock hopp om att den skulle få samma omtanke. ${ }^{686}$

Påverkansförsöken kunde vara nog så påtagliga. Rosenstein den yngre var förvissad om att hans uttolkning av folkens rättigheter tilltalade en rättvis och upplyst regering. Han informerade makthavarna om tre sätt att förebygga "folkyra": att styra folket väl och göra det lyckligt, att successivt upphäva vad som var oskäligt och rätteligen kunde kritiseras samt att upplysa menigheten. Han frågade retoriskt varför dessa åtgärder inte prövades när inga andra förslog och ansåg de styrande som vidtog 
dem vara välsignade. Rosenstein konstaterade vidare att det tillföll de mäktiga, primärt regenten, att uppdaga den odödliga och nyttiga sanningen; detta var fursten skyldig både sin egen ära och sitt folk, vilket hade rätt till sällhet. Gustav Vasa åberopades som en positiv förebild medan den spanske konungen Filip II och påven Sixtus V, vilka lönlöst motarbetat reformationen, fungerade som avskräckande exempla. Resonemanget utmynnade i en rättfram uppmaning till samtidens monarker, främst Gustav III: "Konungar! I [ni], som viljen finna et rum i Minnets Tempel, väljen emellan GUSTAFS [Vasa] eller PHILIPS och SIXTI odödlighet. Valet bör icke blifva eder svårt." ${ }^{\prime 67}$ Den förste Gustaven användes här för att övertala den tredje i en subversiv anspelning på regimens självbild och historiebruk.

Carl Fredrik Scheffer tog avstånd från autokrati när han observerade att alla måste frukta för sin säkerhet i samhällen där envåldshärskarens godtycke var grundlagen och där ett enda felsteg från den självtillräcklige fursten kunde förstöra helhetens väl. Kejsartidens Rom fick tjäna som ett varnande och 1700-talets Kina som ett föredömligt exempel. Kinesernas begrepp om ömsesidiga rättigheter och skyldigheter ledde enligt Scheffer till harmoni i form av det mest obegränsade välde och den mest fullständiga undergivenhet i världen. Deras kejsare sågs och upplevde sig själv som en far för folket, vars bästa utgjorde hans enda mål. ${ }^{688}$ Måltavlan för argumentationen mot envälde var med tanke på att Scheffer höll sitt presidietal just efter statsvälvningen rimligen Gustav III, som därmed avråddes från att försöka tillvälla sig otillbörlig makt.

Scheffer underströk också fredens fördelaktighet; den var en förutsättning för ett lycksaligt samhälle och vid sidan av säkerheten allt som behövdes för att människan skulle kunna nyttja sina förmågor. Han förklarade i linje med det att Gustav III förstod att krig fördes i självförsvar, att förbättrandet av fäderneslandet gav mer status än erövringar och att sann ära ställde krav på en fridsam hållning mot grannländerna. Tillsammans med monarkens personlighet och fredliga lagar borgade dessa Gustavs insikter för en lugn regeringsperiod. Samtidigt tålde konungen inte att bli förolämpad. ${ }^{689}$ Hela denna diskussion, i synnerhet den sista kommentaren, bör läsas mot bakgrund av att Sverige vid tidpunkten för Scheffers tal befann sig i en utsatt situation och hotades 
av ett militärt ingripande från Danmark och Ryssland, som ogillade konungens politiska nyordning. ${ }^{690}$

Övertalningen gällde inte minst vetenskaperna. Till exempel diskuterade Faggot behovet av fler lantmätare med bättre materiella villkor som skulle fullkomna deras för Kongl Maj:t och riket nyttiga konst. Det allmänna hade en skyldighet att underhålla Lantmäteriverket om det skulle förbli livaktigt, något som Faggot underdånigt framfört "å hög ort". Andra ledamöter målade med bredare penseldrag. Adelcrantz menade att det var till stor lycka för de fria konsterna "när deras refvor blifva uptäkte af sådane Män, som icke allenast äga de uplyste egenskaper, som fordras til deras kännedom, utan ock magt och mod dem samma at bota. Så väsendteliga förändringar äro icke et ögnablicks verk; men en vis Regering tvingar tiden, och förekommer Allmänhetens hopp". ${ }^{691}$

Vetenskapsakademiens läkare var särskilt tydliga med vad de ville att makthavarna skulle uträtta. Zacharias Johan Strandberg tillskrev dem som helar kroppen första rummet i mänskligheten och argumenterade för mer resurser från rikets ledning: "konsten ökes ej utan kostnad. Gifven oss Hospitaler så inrättade, som vi vele. Gifven åt vissa af oss tilräckeligt underhåll, på det vi, som nästan endast måtte arbeta för födan, må då kunna arbeta på vår vetenskaps tilväxt.” Herman Schützercrantz vände sig delvis till de besuttna när han skildrade den franske konungen Ludvig XV:s stöd till en kirurgisk akademi och hur en av dennes livläkare donerat medel till kirurgin: "Kunna väl rikedomar ädelmodigare användas? Önskeligt vore, at vittre och förmögne, hvar och en i sitt förehafvande, fölgde et så lysande efterdöme!" Han adresserade sannolikt makthavarna när han meddelade att svensk kirurgi under en upplyst regering så småningom skulle nå Frankrikes nivå, samt att inhemska kirurger utan ersättning börjat lära ut sitt ämne och med ringa biträde skulle kunna få till stånd en lika förmånlig inrättning som Paris kirurgiska akademi. Han avrundade betecknande nog sin redogörelse med en hyllning till vetenskapsfursten Adolf Fredrik och reflektionen att önskningar tillkommer alla medan deras förverkligande är avhängigt de mäktiga. ${ }^{692}$

Läkaren Casten Rönnow tillkännagav medicinens överhöghet och efterfrågade ett större lasarett i Stockholm efter fransk förlaga, vilket 
hela Sverige skulle bekosta. Han vände sig likväl framför allt till Gustav III, som givet sin kärlek till vetenskaperna och folket torde hitta sätt att främja medicinen i sitt land. Sjukhusen var ytterst nyttiga och oumbärliga för Sveriges invånare, kungahuset inräknat, och då läkekonsten strävade efter att rädda såväl monarkens lojala undersåtar som honom själv, förtjänade den hans beskydd. Gustavs belöning skulle bli både samtida och framtida lovord. Wargentins svar ställde sig bakom talets budskap och uppgav att Vetenskapsakademien inte betvivlade att konungen skulle leva upp till Rönnows och akademiens önskemål. ${ }^{693}$

De övertalningsförsök som riktade sig till konungarna kan i flera fall ses som ett uttryck för en furstespeglande tradition. Bengt Ferrner föreställde sig en ideal regent som styrd av förnuft och erfarenhet lade all sin möda på att göra folket lysande och lyckligt. Den upplyste härskaren kom till rätta med fördomen att klimatet förfördelade hans folk genom att uppfostra undersåtarna till ljus och förstånd. Även om han själv inte fick bevittna slutresultatet av sin gärning var det de efterkommandes omdöme som betydde något för en stor monark, och de skulle frambära tacksamhetsoffer till den som räddat dem från förtryckande fördomar. Ferrner underlät inte att ge besked om mera exakt vem han hade i åtanke: "Jag känner en sådan Regent, och de, som komma efter mig, finna lätteligen igen honom af de spår, som han lemnat efter sig." Enligt Sandels beaktade en klok monark att vetenskaper och hushållning gynnade rikets välfärd och ära. Utan bistånd mådde vetenskaperna inte bättre än själen i en sjuk eller misskött kropp, och eftersom en furste formade sitt folk innebar dennes åsidosättande av dem att de nedvärderades, försvann ur blickfånget och inte kunde dras fram ur sina gömslen utan speciella hedersbevis och förmåner. Vetenskapliga sammanslutningars bidrag till lärdomen berodde på de mäktigas beskydd och ett anseende som vanns genom att makten trivdes i dem. Vetenskapsakademiens bedrifter var följaktligen en konsekvens av det stöd den fătt, och dess astronomiska observatorium åskådliggjorde regenters möjligheter att befordra nyttiga företeelser. Nils Adam Bielke ansåg att stränghet utan nåd var hårdhet och kunde urarta $\mathrm{i}$ tyranni, men likställde samtidigt godhet utan stränghet med svaghet och bedömde denna brist vara mer riskabel för samhället. Ordning måste råda, författningar implementeras 
med eftertryck och ett ostyrigt folk ibland tuktas med ovarsammare metoder. Wargentins svar till Bielke inleddes med ett citat från den medeltida furstespegeln Konunga- och höfdingastyrelsen om att en rik menighet hedrade och en fattig vanhedrade regenten, vilket sekreteraren instämde med. ${ }^{694}$

Bielke och Wargentin var inte ensamma om att väva in den svenska historien i sina påverkansförsök. Till exempel sökte Faggot troligen influera Adolf Fredrik då han tog upp tidigare monarkers intresse för lantmäteriet och geografikunskapen. Den dåvarande kronprinsen hade "med blodet ärft sina Stora företrädares vishet ock dygd"; han kunde inte annat än främja deras avsikter på området och därigenom sin och Sveriges gemensamma välmåga. Ett övertalningsförsök i historisk skrud går att urskilja även hos historikern Anders Anton von Stiernman (From), som anförde att Oden vetat att "klokhet, ädla Vettenskaper, höga och nyttiga tings älskande och befrämiande, äro Regenters klaraste kikare, alla länders dyrbaresta skatter och ägodelar, och att uppå dem fotar sig bägges sällhet, styrkia och förkofring" ${ }^{695}$ En del utsagor om förflutna och samtida utländska furstar kan också antas ha haft en dimension av övertalning, som när det hette att Europas monarker tävlade om att driva konster och vetenskaper så långt som möjligt, eller att Fredrik III av Danmark insett att regenters omsorg om vetenskaperna var det säkraste sättet att åstadkomma deras blomstring. ${ }^{696}$

Det hände att de styrande mer eller mindre explicit ifrågasattes i presidietalen. Ulric Rudenschöld hänförde böndernas alltför vidlyftiga skogsbruk till myndigheternas bristfälliga reglering. Erik Salander slog fast att ämbetsmännen inte alltid besatt nödvändiga kunskaper om slöjderna och att undermåliga slöjdprodukter var en följd av sanktionerad oordning, vilken liknades vid ogräs och skylldes på de som hade makt men underlät att agera och teg och tillät. Han drog en parallell till hur okontrollerade barn hemföll åt självsvåld och skadade såväl sig själva som andra - något föräldrarna bar ansvaret för. ${ }^{697}$

Rosenstein den yngre var en av de mest kritiskt sinnade ledamöterna. Han tog explicit avstånd från maktfullkomliga furstar i ett resonemang som tidsligt sammanföll med Gustav III:s förenings- och säkerhetsakt: 
Intet är naturligare, än at Konungar skola älska sin magt. Men huru många Regenter hafva icke öfverdrifvit sina anspråk, och lekt med människors rättigheter derföre, at de icke känt dessa senare. Konung JACOB I. [av Storbritannien] trodde såsom en Tros-artikel, at dess [hans] magt var ensamt af Gudomligt uphof och oinskränkt; at dess undersåtare hade en ovilkorlig skyldighet at lyda utan minsta rättighet til gensägelse eller motstånd. Om han haft en annan öfvertygelse, är troligt, at denna verkeligen milda och välmenande Konung icke genom obilliga [orättmätiga] påståenden lagt grund til sin Sons och hela sin ätts olycka.

Argumentationen kan tolkas som en förmaning till Gustav med anledning av hans allt större maktfullkomlighet. Samma perspektiv går att anlägga på fler inslag hos Rosenstein, exempelvis hans teser att makt utan motbalans är farlig och att återhållsamhet utgör ett av de band upplysningen lägger på människorna och en anhalt på vägen mot dygden. Han hänvisade inte för inte tydligt till den pågående inhemska debatten om kungamaktens omfattning då han uppmärksammade svenskarnas kännedom om att folket borde beskatta sig självt, en värdefull rättighet som fortfarande var aktuell. Denna betraktelse alluderade på att konungen genom förenings- och säkerhetsakten ursprungligen tänkte ge sig själv rätt att via ett extraordinärt riksdagsutskott besluta om skatter när han behövde ytterligare medel, en förändring som emellertid aldrig blev av. ${ }^{698}$

Rosenstein tog spjärn mot historien för att underbygga sina politiska satser. Han framställde Julius Caesar som en demagog, brottsling och förtryckare, och gestaltade dennes motståndare som frihetens försvarare. Rosenstein hoppades på att få bevittna födelsen av Theopomper som hörsammade "Statens och Medborgarnes rättmätiga fordringar"; en fotnot klargjorde att Theopompos var en spartansk monark som begränsade kungamakten och förankrade den i lagarna. Samtidigt trodde han att envåldshärskare som den romerske kejsaren Nero, Kristian II av Danmark eller Henrik VII av England inte var gångbara i samtiden. Fastän människan ännu bar på despotismens frön skulle det gängse tänkandet avhålla den grymmaste regent från att ta efter dessa suveräner. Upplysningen fättrade monarkerna, vilket tillsammans med den 
furstliga dygden gjorde att det europeiska land som uppvisade den mest oinskränkta kungamakten, Frankrike, under en rad konungar styrts med lika mycket humanitet, mildhet och rättvisa som de flesta riken. Rosenstein försvarade vidare det befintliga gustavianska systemet. Han fann att Sverige inåt behövde "all frihetens varsamhet, trygghet och säkerhet" och utåt "mot Mägtiga Grannar all Enväldets enkelhet, skyndsamhet, samdrägt och styrka". För att landet inte skulle slitas sönder krävdes "en stark motvigt i en endas hand". ${ }^{699}$ Kritiken av regimen och det bestående hade sina gränser; Gustav III:s statsvälvning var legitim, men hans förenings- och säkerhetsakt var det inte eftersom den gjorde kungamakten alltför dominerande.

Ett angrepp på de kungliga maktambitionerna går även att utläsa i ett tal av Axel Magnus von Arbin, som 1787 riktade hård kritik mot Karl XI:s "stora hvälfning" i grundlagen, alltså det karolinska enväldets införande. Karls handlande uppgavs ha motiverats av äregirighet, eventuellt också av hämndlystnad, och "uphögt Svea välde i et vådeligt välstånd, i anseende til därigenom verkade Inrikes gäsningar och utrikes Magters, antingen misstroende, eller afund". ${ }^{700}$ Mellan raderna skymtar det sengustavianska Sveriges såväl inre som yttre spänningar, året innan konungens ryska krig bröt ut.

Hattarna startade två misslyckade och impopulära revanschkrig, först mot Ryssland (1741-43), sedan mot Preussen (1757-62). Kriget mot Ryssland var ett försök att dra fördel av att olika fraktioner där rivaliserade om makten och utkämpades med franskt stöd. Efterspelet inbegrep landavträdelser från svensk sida och att det ryska hovet dikterade valet av Adolf Fredrik till Fredrik I:s efterträdare. Pommerska kriget utgjorde ett led i det världsomspännande sjuårskriget, vars huvudkontrahenter var Storbritannien och hattpartiets allierade Frankrike, som förlorade den segdragna kraftmätningen. Hattregeringen inträdde i konflikten efter påtryckningar från fransk och österrikisk sida med målet att återta de områden som avträtts till Preussen 1720. En separatfred utan gränsändring kunde slutas genom att Lovisa Ulrika å Sveriges vägnar förhandlade med sin bror Fredrik II. ${ }^{701}$

Det är ofta svårt att avgöra huruvida allmänt hållna uttalanden om fred och krig i presidietalen före, under och efter hattarnas krigspro- 
jekt handlade om deras utrikespolitik, stora nordiska kriget eller en principiell och kosmopolitiskt färgad ståndpunkt. Vissa utsagor avsåg dock helt klart hattregimens krig. Bäck berörde den farliga smitta, Uppsalafebern, som det ryska kriget vållat och Claes Grill noterade de förluster landet lidit när det under samma krig tvingats nyttja främmande skepp för import av livsmedel. Svenskpomraren Johan Fredrik Krygers hemtrakter var pommerska krigets skådeplats. Han gav prov på en pacifistisk tendens året efter dess utbrott, då han ondgjorde sig över väpnade konflikters negativa effekter. Kryger angav visserligen att "äldre och nyare förbindelser" berättigade att fria samhällen förde krig, men "endast för freden [sic] skul", varför ett sådant företag inte blev långvarigt. ${ }^{702}$

Gustav III:s ryska krig (1788-90) var liksom hattarnas båda krig kontroversiellt. Det syftade i likhet med dem till återerövrande av förlorat territorium och hade inte heller en gynnsam utgång för Sverige. ${ }^{703}$ Rosenstein den yngre, som opponerade sig mot konflikten, förkunnade att monarker slösat bort undersåtarnas liv och rikedomar på fruktlösa och onödiga krig, även om de ofta varit ute efter att befordra det allmännas väl jämte sin egen ära. De militära dygderna måste ständigt näras, varför det var bättre att bygga ett rike på tillväxande industri; krigsorienterade länder gick sitt fördärv till mötes. ${ }^{704}$

Kryger och Rosenstein till trots var motståndet mot hattarnas och Gustav III:s krig lika litet som övrig kritik av makten framträdande i presidietalen, vilket förstärker intrycket av Vetenskapsakademien som dess lojala bundsförvant.

Detta kapitel har skärskådat Vetenskapsakademiens självbild och akademiens interaktion med samhällsledningen. Vetenskapsakademien beskrevs ofta som ett samhälle med lagar, och flera av presidietalen laborerade med en lärd och en politisk gemenskap som i någon utsträckning speglade varandra och var diskursivt jämställda. Sammanslutningens och medlemmarnas nyttosträvan utgjorde ett tema genom hela undersökningsperioden. Presidietalens nytta, akademiens befintliga eller framtida bedrifter samt det omgivande samhällets tacksamhetsskuld gentemot 
den och lärdomen diskuterades. Vetenskapsakademiens patriotiska nit var ett annat ledmotiv, samtidigt som organisationens arbete i mänsklighetens tjänst togs upp. Vetenskapen framställdes som gynnsam för fäderneslandet, andra riken och hela det mänskliga släktet, och som essentiell för själva människoblivandet. Ett tredje återkommande ämne var akademiens nationella och internationella anseende.

Vetenskapsakademiens nyttoansträngningar, patriotism och hantering av värdefull kunskap gav den en bildlig centralitet i samhällsgemenskapen. Akademien kan mot bakgrund av detta ses som en arena där karisma genererades i kraft av inrättningens inveckling med samhället och dess ödesfrågor. Vetenskapsakademien fanns i samhällets mitt tillsammans med makthavarna, medan föreställningarna om vetenskapens nytta för mänskligheten och betydelse för att uppnå status av människa beredde den och akademien en än mer central position i tillvaron. Det framstår därmed bara som följdriktigt att samhällets kunskapsägande kontrasterades mot den okunniga menigheten. Den mest fullödiga yttringen av Vetenskapsakademiens uppfattning om de lärda som en elitgrupp stod Rosenstein den yngre för när han argumenterade för deras medverkan i det politiska styret.

Presidietalen markerade närhet till och approprierade samhällsledningen, varvid Vetenskapsakademien tog del av maktens strålglans och även på det viset placerades i samhällets mitt. Akademien kunde härvid addera till samhällsledningens karisma genom att förstärka den visavi samhället. De nära förbindelserna med makthavarna och eliten framgick på flera sätt: uppräkningar av bemärkta ledamöter inkluderade ämbetsmän, politiker och politiskt inflytelserika näringsidkare; relationen till statsmakten berördes; donationer från elitpersoner, kungligheter och ständerna noterades; mecenaters stora och livgivande inverkan poängterades. Det avtryck monarkerna gjorde på Vetenskapsakademien genom beskydd, uppmuntran och närvaro vid sammankomsterna intog en särställning i presidietalens utläggningar om samhällsledningens främjande av organisationen.

Adolf Fredriks nära förhållande till Vetenskapsakademien påtalades ofta innan det rojalistiska statskuppsförsöket 1756, varefter konungens beskydd marginaliserades fram till dess att de politiska konjunkturerna 
förändrats avsevärt. Under frihetstiden positionerade sig ledamöterna vidare nära ständerna och hattpartiets ledarskikt, vilkas beskydd av akademien lyftes fram. Det synliggjordes att hattledningen som grupp deltog i verksamheten, och ett antal hattar gjordes individuellt till föremål för appropriering medan endast ett fåtal mössor vederfors samma ära. De gustavianska talen gjorde också anspråk på rikets högt uppsatta politiker och ämbetsmän, varav många hade ett förflutet i hattregimen.

En del presidietal förmedlade en utpräglat egalitaristisk syn på Vetenskapsakademien som gått igen inom den historiska forskningen om organisationen. Det föreliggande kapitlet har dock givit vid handen att samhällshierarkin kastade långa skuggor över akademien. Vetenskapsakademien hade förvisso egalitära inslag - till exempel dikterade dess kunskapssyn att alla kunde begripa och bidra till lärdomen - men det innebär inte att sammanslutningen som helhet kan karakteriseras på ett sådant vis. ${ }^{705}$ Det är frestande att betrakta karisman från samhällsledningen, vilken svarade mot den vedertagna sociala ordningen, som överordnad karisman från akademiens egna göranden, vilken svarade mot det meritokratiska idealet.

En viktig aspekt av Vetenskapsakademiens samspel med de styrande var ledamöternas ansatser att påverka dem i vissa riktningar och få dem att ta sig an olika företeelser, verksamheter och näringar. Övertalningen handlade inte minst om vetenskaperna och kan när den riktades till regenterna i flera fall tolkas som ett uttryck för en furstespeglande tradition. Till det kom att presidietal emellanåt utsatte makthavarna för mer eller mindre uttalad kritik. Övertalningsförsöken och ifrågasättandena indikerar en vilja att korrigera och sätta sig över samhällsledningen som överensstämmer med akademiens hävdande av sin och lärdomens framskjutna roll i den mänskliga samlevnaden. Denna vilja var likväl begränsad och underordnad tjänstvilligheten gentemot makten. 



\section{Det villrådiga samhället}

Denna bok har analyserat Vetenskapsakademiens idéskapande kring samhället under perioden 1739-1792 mot bakgrund av organisationens nära kontakter med samhällsledningen - det vill säga eliten och makthavarna - för att åskådliggöra det tidigmoderna samspelet mellan politik och vetenskap. Detta idéskapande har förståtts i termer av politisk och ekonomisk ideologi. Samröret med makten och akademiens uppfattning om sin roll i den mänskliga samlevnaden har undersökts med hjälp av teoribildningen kring karisma. Studieobjektet har varit de tryckta presidietalen, som hade stor spridning och uppehöll sig vid generella, principiella och politiska teman.

Studien visar att Vetenskapsakademien lutade åt det traditionalistiska hållet och påverkades starkt av banden till makten. Akademiens politiska och ekonomiska ideologi präglades av en tilltro till samhällsledningens ingripanden i och reglering av samhällsgemenskapen, liksom av att makthavarna och eliten tillskrevs en central status i samhället, vilket uppfattades som socialt statiskt och ekonomiskt dynamiskt. Denna samhällssyn spelade överlag det bestående i händerna.

Det samhälle som framträdde i presidietalen reflekterade och skulle vägledas av naturen, som det var sammanlänkat med inom ramarna för ett gudomligt bestämt system. Både natur och samhälle kännetecknades av rangordning, stabilitet, saktfärdighet, komplementaritet och ömsesidighet. Allmänt och enskilt betraktades som analoga storheter medan det gemensammas väl ansågs sammanfalla med individens bästa, låt vara inte automatiskt eller nödvändigtvis. Människor hade liksom skapelsens övriga komponenter olika ändamål och makthavarna skulle styra dem till rätt sysslor; underförstått skulle alla vara tillfreds med 


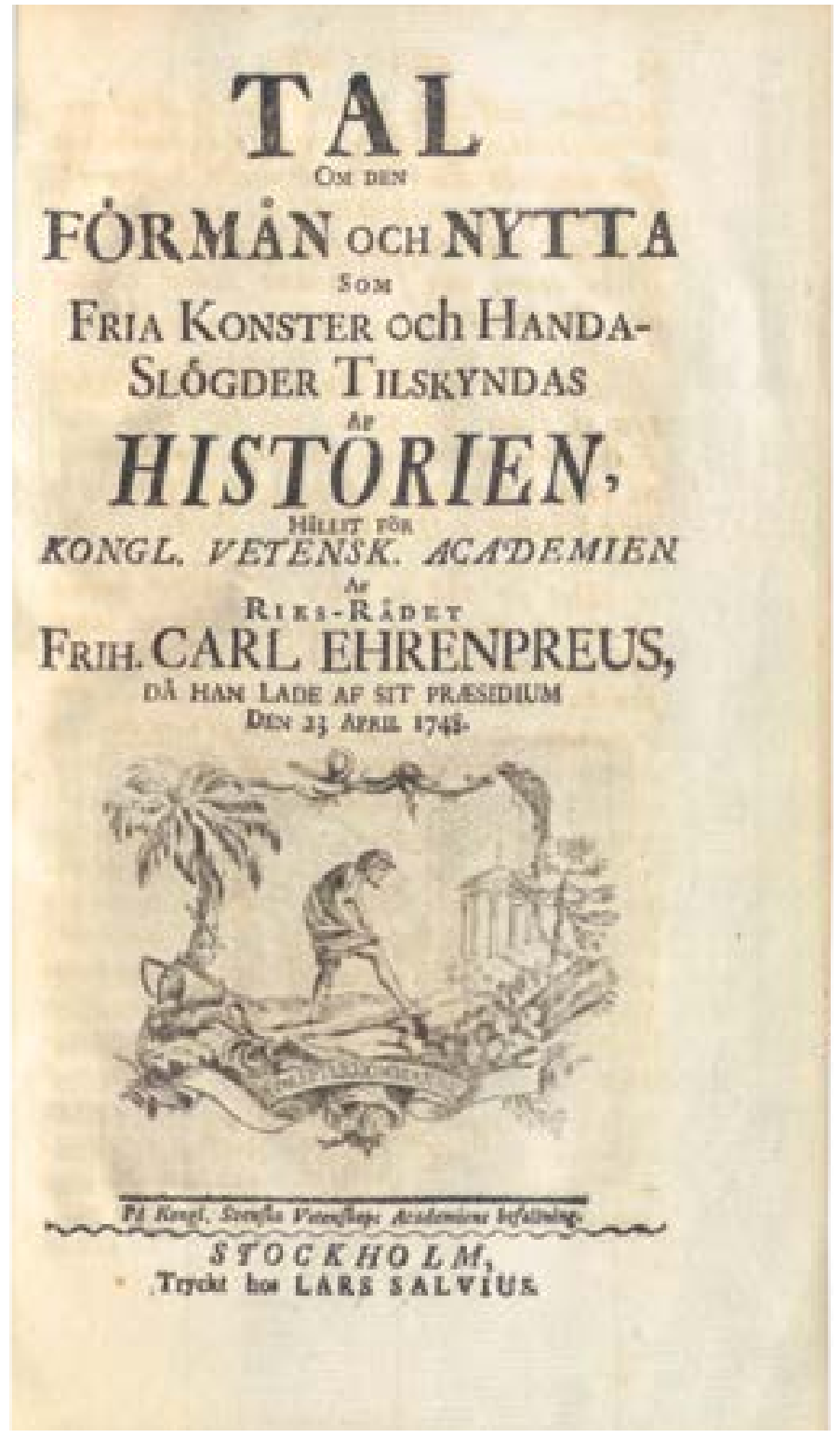

Bild 13. Titelsida till Carl Didrik Ehrenpreus Tal om den förmån och nytta som fria konster och handaslögder tilskyndas af historien (1748). Foto: Uppsala universitetsbibliotek. 
sina lotter i livet. Flera ledamöter förespråkade social rörlighet i form av snillevalet, som innebar att ungdomars utbildning skulle avgöras av anlag istället för av härkomst, men detta behövde inte ha radikala övertoner. Samhället förknippades generellt med hierarki, ståndsfunktionalism, harmoni och jämvikt.

Samhällets ursprung och utveckling ställdes i ett naturrättsligt och stadieteoretiskt ljus; framstegs- och civilisationstron vilade tung över utblickarna mot dess historia. Samhällsgemenskapens tillkomst förklarades oftast med de mänskliga behoven och osäkerheten i det församhälleliga tillståndet, vilket vanligen värderades lägre än det samhälleliga. Gustavianska ledamöter uppvisade ett större intresse för de enskilda människorna, deras bevekelsegrunder som samhällsvarelser och deras rättigheter. Några beskrev samhället som summan av sina beståndsdelar, och fler än under frihetstiden värderade egennyttan förmånligt. Gustavianska presides tenderade samtidigt att vara mer uttalat skeptiska till förändringar och att betona lag och säkerhet mer än vad de frihetstida gjorde.

Den tänkta världs- och samhällsordningen illustrerades och förstärktes med olika slags bilder, som inte sällan förekom sida vid sida. Bilderna utgick från människokroppen, djur och växter, maskiner och instrument, byggnader och skepp. En gemensam nämnare var att de inskärpte samhällets funktionalistiska dimension och gjorde den samhälleliga tillvaron mer effektiv och rationell än i verkligheten. Vanligast förekommande var de kroppsrelaterade bilderna, som enklast torde låtit sig förenas med det korporativa ståndssamhället.

Många ledamöter föreställde sig att samhällsledningen - fursten, ständerna, regeringen, de förnäma och de förmögna - drev samhället framåt och utgjorde garanten för invånarnas välmåga. Den mänskliga gemenskapens välgång var avhängig energiska och vaksamma makthavare som kontrollerade folket och fick det att bete sig på rätt sätt. Den kontroll medlemmarna hade i åtanke kunde vara nog så detaljerad och associerades med både samhället som helhet och en rad områden inom det. Presidietalen graviterade följaktligen mot paternalism, något som också yttrade sig i en omhändertagande och filantropisk inställning till gemene man. 
Samhällsgemenskapen tillmättes för det mesta en dikotomisk struktur; den bestod av närande och tärande, höga och låga, förståndiga, upplysta och kunniga respektive oförståndiga, oupplysta och okunniga. Det grundläggande motsatsparet högt-lågt kunde framställas på olika sätt, men uttrycktes för det mesta i en uppdelning i ståndspersoner och menighet. Oaktat exakt vilken terminologi som användes skulle samhällets högre skikt inspirera folket med sitt föredömliga agerande.

Synen på menigheten var övervägande auktoritär och negativ, även om ett antal ledamöter värderade folket positivt eller blandade ofördelaktiga omdömen med fördelaktiga. Vetenskapsakademien bekände sig visserligen till idén om en formbar människa, men det samtida folket värderades lågt, till skillnad från framtidens upplysta motsvarighet. Tidigare forskning har gjort gällande att 170o-talets andra hälft utmärktes av en ny, mer välvillig attityd till de lägre samhällslagren, samtidigt som människan i större utsträckning kom att betraktas som kapabel att styra sig själv och av egen kraft medverka till det allmänna bästa. Denna utveckling är bortom det filantropiska engagemanget inte påfallande i akademiens presidietal, som fortfor att sluta upp bakom synsättet att folket var oförmöget och måste föras till samhällsviktig dygd.

Vetenskapsakademiens politiska ideologi befäste och förstärkte samhällsledningens centrala status genom att gestalta den som samhällets kraftkälla och menighetens förmyndare. När akademien gick de samhällsledandes ärenden gick den även sina egna, eftersom organisationen och åtskilliga av dess medlemmar hade djupa försänkningar i det hierarkiska system som uttolkades.

Sammanslutningens förbindelser med hattarna reflekterades $i$ att den under partiets första, långa maktinnehav merendels positionerade sig nära regeringens ekonomiska politik. Presidietalen framhävde och förordade slöjder, produktförädling, arbetsfördelning, minskad import och en bättre handelsbalans. Vetenskapsakademiens hattvänliga ekonomiska ideologi påverkade också medlemmar med avvikande åsikter om hushållningen. Vissa diskuterade ekonomisk självreglering, men sådana tankar förblev perifera under hattpartiets första tid vid makten. Ledamöterna fäste vidare avseende vid frihetstidens nyttiga landvinningar och de styrandes betydelse för utvecklingen. Dessa gynnsamma omdömen 
kan i hög grad förstås som smicker av hattarna, även om monarkerna och de förutvarande makthavarna delvis omfattades av dem.

Akademien solidariserade sig väsentligen med hattpartiet under det krisdrabbade 1760-talet, om än hård kritik riktades mot dess politik kring och efter mössornas maktövertagande 1765. Ett par ledamöter kom nu att lägga tonvikt vid konkurrens, som i ett tal tog sig ut som en kraft i egen rätt, och social kritik blev ett påtagligt fenomen i Vetenskapsakademien från och med mössornas styre. Det tärande frälset målades i mörka färger medan samhällets närande element, speciellt borgarna, värdesattes. Kritiken hade emellertid instrumentella övertoner och klara gränser.

Trots att presidietalen under mössregimen mer än förut innehöll formuleringar om ekonomisk självreglering och delvis problematiserade hattpolitiken, hushållningen och aspekter av samhället, gav majoriteten av dem prov på hattvänliga ställningstaganden, låt vara oftast i reviderad form. Efter hattarnas återkomst till makten intog flera ledamöter en i hög grad positiv hållning till handel, medan idéer om nyttofrämjande konkurrens ökade i styrka. Konkurrensen stod tematiskt nära avreglering och föreställningar om ett mer självgående samhälle, varför detta kan tolkas som ett tecken på en bredare och djupare förändring i den ekonomiska ideologin. Tävlan beskrevs dock överlag som en funktion av makthavarna, snarare än som någon autonom ekonomisk kraft. Den ekonomiska självregleringen tonades inte för inte ned i talen, som var benägna att med modifikationer knyta an till det ideologiska arvet från hattarnas glansdagar.

Presidietalen speglade den ekonomisk-politiska situationen under det gustavianska tidevarvet, då protektionismen och regleringsivern mjukades upp, intresset för jordbruket tilltog och manufakturpolitiken hamnade i skymundan. Manufakturvänligheten avtog i talen, som om de berörde frågan om näringarnas företräde gemenligen favoriserade lantbruket. Importfientligheten och framhållandet av förädling fortlevde, men utsagorna om import saknade ofta den skärpa som präglat många av de frihetstida talen, medan substituering av importvaror genom acklimatisering av främmande växter ägnades mer uppmärksamhet än förut. Även om ledamöterna liksom tidigare efterlyste arbetsfördelning 
mellan landsorter och näringar, hade de i allmänhet en märkbart mer nyanserad inställning till mångsyssleri. De förde därtill senfrihetstidens hållning till handel och konkurrens vidare. Frihetliga uppslag vann åter mark; ett antal gustavianska ordförande avfärdade tvång och förespråkade en mer eller mindre spontan ordning.

Samtliga undersökningsperiodens konungar framställdes som drivande nyttofurstar, under vilka ekonomin, näringarna, lärdomen och riket förbättrades och nådde nya höjder. Alla attribuerades goda egenskaper som storhet, flit och patriotism och uppgavs vara älskade av folket. Adolf Fredriks och Lovisa Ulrikas insatser för lärdomen framhävdes, vilket bör ha hängt samman med deras förhållande till Vetenskapsakademien. Undersökningen bekräftar sammantaget att svenska monarker fortsatte besitta en stark symbolisk makt under frihetstiden, inte minst ifråga om ekonomin.

Den begränsade kungamakten var ett ovanligt ämne i presidietalen under Fredrik I:s regering, men blev vanligare under 1750-talets första hälft och upptakten till det misslyckade rojalistiska statskuppsförsöket 1756. Förändringen sammanföll med växande friktion mellan kungaparet och hattregimen och med att interaktionen mellan kungahuset och akademien försvagades för att till sist avstanna. Efter kuppstämplingarna förtegs eller nedtonades kungligheterna i talen fram till 1762, när de under en period kom att gestaltas på ungefär samma vis som före 1750-talets slitningar, troligtvis på grund av att hattpartiet närmat sig dem. Under mössväldet tonades de på nytt ned, men närvaron ökade igen efter att deras allierade hattarna återtagit makten. Det är tydligt att behandlingen av kungahuset var beroende av regenternas relation till hattarna och understryker att Vetenskapsakademien utgjorde en integrerad del av partiets sfär. Ledamöterna var likväl inte sena att anpassa sig efter statsvälvningen 1772, då deras och akademiens lojaliteter skyndsamt flyttades över på den nya regimen.

Partistriderna och deras negativa konsekvenser togs upp av ett antal ledamöter mot frihetstidens slut. Temat stod sig under den gustavianska tiden, då den tidigare epoken tenderade att tillskrivas egenskaper som självsvåld, osämja, egennytta, tvång, falsk frihet och hotande undergång. Gustav III sågs som "den tredje Gustaven" och parallelliserades 


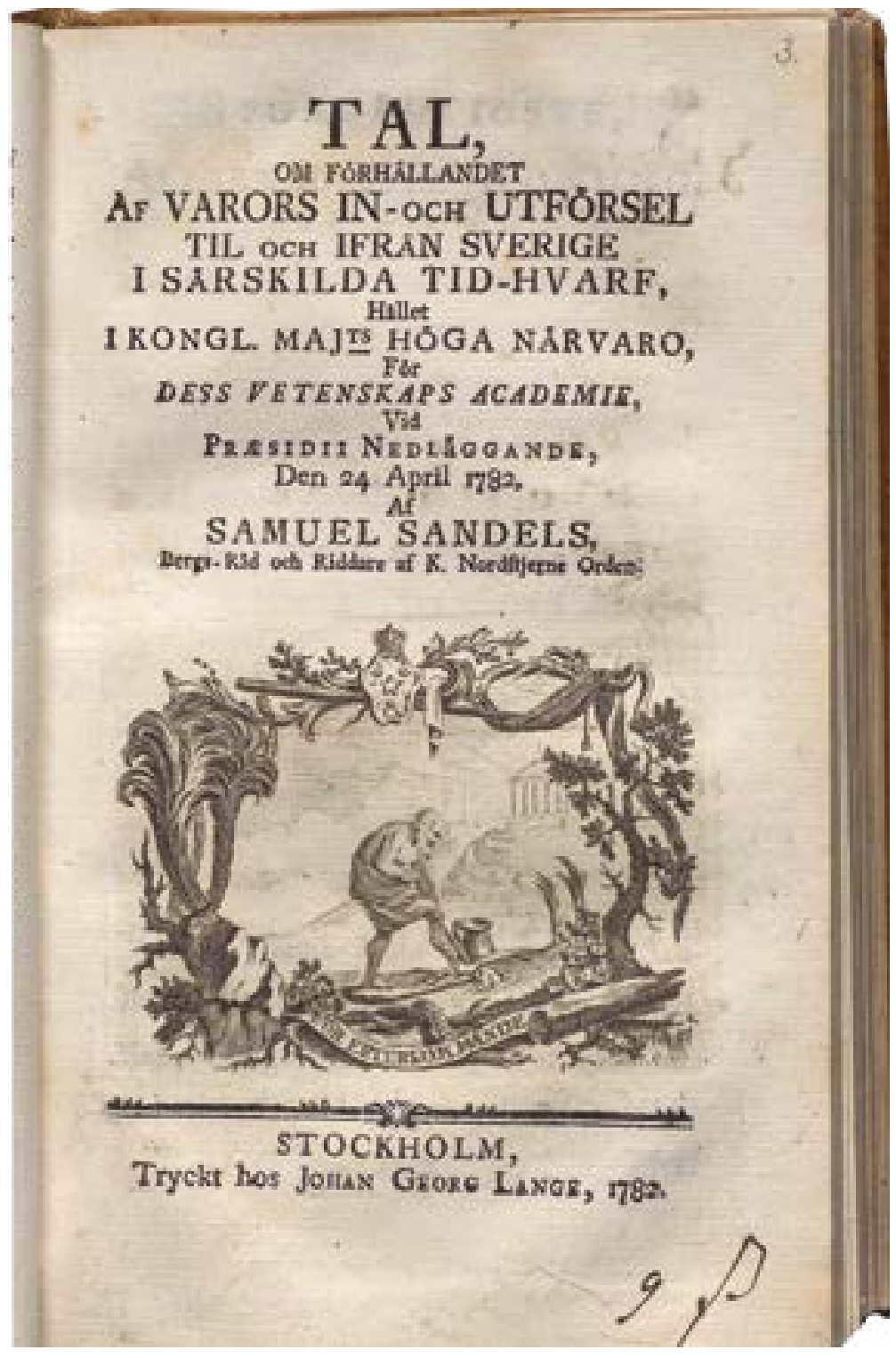

Bild 14. Titelsida till Samuel Sandels Tal, om förhållandet af varors in- och utförsel til och ifrån Sverige i särskilda tid-hvarf(1782). Foto: Uppsala universitetsbibliotek. 
med sina illustra namnar, främst Gustav Vasa. Akademimedlemmarna framställde i likhet med den kungliga propagandan Gustav III som en befriare från oordning och hans styre som frihetstidens antites - en era av enighet, trygghet och sann frihet. Vetenskapsakademiens band till konungen blev av naturliga skäl betydligt viktigare efter statsvälvningen, och han bereddes en avsevärt mer framskjuten plats i presidietalen än sina företrädare, medan de kvaliteter som tillerkänts dem skruvades upp i skildringarna av honom.

Vetenskapsakademien beskrevs som ett samhälle med lagar, medan ledamöter laborerade med en lärd och en politisk gemenskap som i någon mån reflekterade varandra och var diskursivt jämställda. Akademiens och medlemmarnas nyttosträvan utgjorde ett återkommande tema. Ett annat frekvent ledmotiv var Vetenskapsakademiens patriotiska nit, samtidigt som organisationen även ansågs främja hela det mänskliga släktet. Vetenskapen föreställdes som gynnsam för såväl fäderneslandet som främmande länder och mänskligheten, och som essentiell för människoblivandet. Ett tredje beständigt tema var akademiens nationella och internationella ryktbarhet.

Vetenskapsakademiens nyttoarbete, patriotism och hantering av värdefull kunskap gav den en bildlig centralitet i samhället. Akademien kan således ses som en arena där karisma genererades $\mathrm{i}$ kraft av invecklingen med samhällsgemenskapen och dess ödesfrågor. Sammanslutningen befann sig i samhällets mitt tillsammans med makthavarna, vartill kom att idéerna om vetenskapens nytta för mänskligheten och vikt för att uppnå status av människa tilldelade den och akademien en än mer central position i tillvaron. Det framstår bara som följdriktigt att samhällets kunskapsägande kontrasterades mot den okunniga menigheten.

Presidietalen markerade närhet till och approprierade samhällsledningen, vilket gjorde att Vetenskapsakademien fick del av maktens nimbus och även på det viset tog plats i samhällets mitt. Akademien kunde härvidlag addera till samhällsledningens karisma genom att förstärka den visavi samhället. De nära kontakterna med makthavarna och eliten signalerades på flera sätt; relationen till statsmakten berördes, donationer noterades, mecenaters livgivande verkan framhölls. Monarkernas beskydd, uppmuntran och närvaro vid sammankomsterna 
intog en särställning. Under frihetstiden positionerade sig ledamöterna också nära ständerna och hattpartiets ledande skikt. De gustavianska talen fortsatte att göra anspråk på Sveriges högt uppsatta politiker och ämbetsmän, som i många fall hade ett förflutet i hattregimen.

En del medlemmar framförde en starkt egalitaristisk uppfattning om Vetenskapsakademien som reproducerats inom den historiska forskningen om organisationen. Den föreliggande studien har tvärtom demonstrerat att det hierarkiska ståndssamhället kastade långa skuggor över akademien. Vetenskapsakademien hade helt klart egalitära inslag, exempelvis i så måtto att alla troddes kunna tillägna sig och lämna bidrag till lärdomen, men det gör inte att sammanslutningen som helhet kan karakteriseras på ett sådant vis. Det är frestande att betrakta karisman från akademiens egna göranden, vilken svarade mot det meritokratiska idealet, som underordnad karisman från samhällsledningen, vilken svarade mot den hävdvunna sociala ordningen.

En viktig aspekt av Vetenskapsakademiens samspel med de styrande var ledamöternas försök att påverka dem och få dem att ta sig an olika företeelser, verksamheter och näringar. Övertalningen handlade inte minst om vetenskaperna och kan när den riktades till regenterna i flera fall tolkas som ett uttryck för en furstespeglande tradition. Till det kom att presidietal av och till utsatte makthavarna för mer eller mindre explicit kritik. Övertalningen och kritiken antyder en vilja att sätta sig över samhällsledningen som överensstämmer med akademiens syn på sin och vetenskapens roll i den mänskliga samlevnaden. Tjänstvilligheten gentemot makten drog icke desto mindre det längsta strået.

Vissa presidietal uttryckte förvisso åsikter som pekade framåt snarare än bakåt, däribland tilltro till självreglering och till den enskildes förmåga att ta eget ansvar. Men enligt det dominerande tänkesättet var samhället villrådigt och inkapabelt att sköta sig självt. Inom detta mentala ramverk utgjorde samhällsledningens vårdande och vägledande hand en oumbärlig förutsättning för den organiserade mänskliga samlevnadens fortgång och förbättring. Till det kan läggas att de avvikande rösterna - inklusive Nils von Rosenstein, som betecknats som jakobinskt och revolutionärt sinnad - rörde sig med nedärvt tankegods och i varierande grad anammade den rådande samhällsordningen. ${ }^{706}$ 
Ytterligare ett framåtsyftande inslag i presidietalen var Vetenskapsakademiens självbild, som visade hän mot kommande konfigurationer av kunskap och makt. Här kan en koppling göras till de "mandariner" Fritz Ringer identifierat i 1800 -talets tyska samhälle, en kulturell och social elit som i första rummet stödde sig på utbildning och bestod av präster, advokater, läkare, ämbetsmän, skollärare samt professorer. Ringer talar också om tidigmoderna mandariner, som inledningsvis intog en försiktig hållning till följd av sin kringskurna makt och numerära svaghet. I takt med att deras inflytande och status ökade kunde de närma sig den traditionella, adliga eliten och omvandla sina administrativa titlar till hederstitlar, samtidigt som de började insistera på kunskapens och kunskapsbärarnas överhöghet. ${ }^{707}$

Även om Vetenskapsakademiens ledamöter inte hade fullt så drastiska anspråk är det möjligt att tolka många av talens utsagor om medlemmarnas och de lärdas samhällsbetydelse med utgångspunkt i Ringers modell. Med lite god vilja går det att betrakta ledamöterna som proto-mandariner, förelöpare till ett senare tidevarvs mandariner och byråkrater. Dessa förebådade i sin tur en ännu senare tids experter och teknokrater, i vilkas grepp samhället fortfarande befinner sig. ${ }^{708}$ 


\section{Noter}

\section{Inledning}

1 Samuel Sandels, Tal, om Kongl. Svenska Vetenskaps Academiens inrättning och dess fortgång til närvarande tid [...] (Stockholm, 1771), 18 f. Linné noterade senare att det vid tidpunkten för hans avgång inte var "förordnat, att någon oration skulle hållas wid praesidii afläggande, utan endast ett kort tahl och complement; men jag, som ej kunne tala utan att tala om något, giorde talet om Insecterne, som behagade, och där äfter blef mode att orera om något bequämligit argument”. Carl von Linné till Kungliga Svenska Vetenskapsakademien och Pehr Wilhelm Wargentin, 15 juli 1761, i Bref och skrifvelser af och till Carl von Linné [...], 10 vol. (Stockholm, 1907-43), I:2, $244 \mathrm{f}$.

2 Carl von Linné, Tal, om märkvärdigheter uti insecterna [...] (Stockholm, 1739), [6]; Sten Lindroth, Svensk lärdomshistoria: Frihetstiden (Stockholm, 1978), 220. Den första sidan med löpande text räknas här som [1] i Linnés opaginerade tal.

3 För Tal, om märkvärdigheter som ett fysikoteologiskt typexempel, se Tore Frängsmyr, Svensk idéhistoria: Bildning och vetenskap under tusen år. Del 1: 1000-1809 (Stockholm, 2000), 191. För fysikoteologin, se Tore Frängsmyr, ”Den gudomliga ekonomin: Religion och hushållning i 170o-talets Sverige", Lychnos 1971-1972, 220, 230; Sten Lindroth, Kungl. Svenska Vetenskapsakademiens historia 1739-1818, 3 vol. (Stockholm, 1967), I:1, 222 f.; Karin Johannisson, Det mätbara samhället: Statistik och samhällsdröm i 170o-talets Europa (Stockholm, 1988), 77-81.

4 Lisbet Koerner, Linnaeus: Nature and nation (Cambridge, Mass., 1999), 132.

5 Gunnar Broberg, Homo sapiens L: Studier i Carl von Linnés naturuppfattning och människolära (Uppsala, 1975), 43, 78 f., 137. Se även Mattias Legnér, Fäderneslandets rätta beskrivning: Mötet mellan antikvarisk forskning och ekonomisk nyttokult i 170o-talets Sverige (Helsingfors, 2004), $88 \mathrm{f}$.

6 Linné, Insecterna [1], [4].

7 Ibidem [2-4], [16]. Samhället och naturen parallelliserades även genom att insekterna beskrevs i förmänskligande termer. Till exempel försåg Linné getingar med barn och vaggor, trollsländor med "gifto-lagar" och bin med en undersam hushållning. Ibidem [9], [11]. Ett liknande förhållningssätt till djur 
hittas hos andra presides. Se Charles De Geer, Tal om nyttan, som insecterne och deras skärskådande, tilskynda oss [...] (Stockholm, 1744), 5 f., 16 f., 24 f.; Charles De Geer, Tal, om insecternas alstring [...] (Stockholm, 1754), 6-10, 15-20, 25, 32; Bengt Bergius, Tal, om läckerheter, både i sig sjelfva sådana, och för sådana ansedda genom folkslags bruk och inbillning [...] Förra delen (Stockholm, 1785), 119, 161, 173, 215, 218; Johan Gustaf von Carlson, Tal, med strödde anmärkningar öfver foglarnes seder och hushållning [...] (Stockholm, 1789), 2-8, 12, 16. Jämför David Dunér, "Polhem, drönarna och fru Alamode: En studie i dygdemetaforer i frihetstida överflödsdebatt", i Utopin i vardagen: Sinnen, kvinnor, idéer. En vänbok till Elisabeth Mansén, red. Jenny-Leontine Olsson m. fl. (Lund, 2014), $290 \mathrm{f}$.

8 Linné, Insecterna [3].

9 Ibidem [3-4].

10 Ibidem [16]. Någon protodemokratisk ådra kan dock inte skönjas hos Linné och som Donald Worster har konstaterat fanns det "få jämlikhetsivrande demokrater" inom den linneanska sfären. Donald Worster, De ekologiska idéernas historia (1977), sv. övers. (Stockholm, 1996), 67. Jämför Legnér, $88 \mathrm{f}$. Steven Shapin \& Simon Schaffer, Leviathan and the air-pump: Hobbes, Boyle, and the experimental life (Princeton, 1985), 340, citat från idem; Paul Smethurst, Travel writing and the natural world, 1768-1840 (Houndmills, 2012), 197.

Definitionen är hämtad från Martin Melkersson, Staten, ordningen och friheten: En studie av den styrande elitens syn på statens roll mellan stormaktstiden och 180o-talet (Uppsala, 1997), 17.

14 För den senfrihetstida samhällsdebattens radikalisering i ståndsmotsättningarnas och auktoritetskritikens tecken, se Melkersson, 103 f., 148, 159 f.; Jonas Nordin, Ett fattigt men fritt folk: Nationell och politisk självbild i Sverige från sen stormaktstid till slutet av frihetstiden (Stockholm, 200o), 385-418; Jonas Nordin, "Frihetstidens radikalism", i Riksdag, kaffehus och predikstol: Frihetstidens politiska kultur, 1766-1772, red. Marie-Christine Skuncke \& Henrika Tandefelt (Stockholm, 2003). För oppositionen mot Gustav III, se Mikael Alm, Kungsord i elfte timmen: Språk och självbild i det gustavianska enväldets legitimitetskamp 1772-1809 (Stockholm, 2002), 204, 213 f., 220, $224 \mathrm{f}$.

15 Enligt Steven Shapin och Simon Schaffer har vetenskapen alltid varit beroende av att statsmakten betraktat den som meningsfull. Shapin \& Schaffer, 339. För relationen mellan politik och vetenskap i 170o-talets Sverige, se Thomas Kaiserfeld, Krigets salt: Salpetersjudning som politik och vetenskap $i$ den svenska skattemilitära staten under frihetstid och gustaviansk tid (Lund, 2009), 15-17. Bo Lindberg, "Den lärda kulturen", i Signums svenska kulturhistoria: Frihetstiden, red. Jakob Christensson (Lund, 2006), 133; Lindroth, Vetenskapsakademien, I:1, 27-30, 40 f.; Lindroth, Vetenskapsakademien, II, 28 f.; Jonas Nordin, "Anders 


\section{NOTER}

Johan von Höpken: 'Sveriges Tacitus"', i Drottning Lovisa Ulrika och Vitterhetsakademien, red. Sten Åke Nilsson (Stockholm, 2003), 66 f. Det framstår som symptomatiskt att Vetenskapsakademien under sina första tjugofem år på förmånliga villkor bereddes lokaler i Riddarhuset, som hade en historia av samverkan med vetenskapsmän. Lindroth, Vetenskapsakademien, I:1, 78 f., 81 . Även till exempel Manufakturkontoret och Anders Berchs ekonomiprofessur vid Uppsala universitet tillskapades i samband med hattarnas maktövertagande. Nordin, "Höpken", 66 f.; Bengt Hildebrand, Kungl. Svenska Vetenskapsakademien: Förhistoria, grundläggning och första organisation (Stockholm, 1939), 186, 242-45, 326-28; Lindroth, Vetenskapsakademien, I:1, 220; Sven-Eric Liedman, Den synliga handen: Anders Berch och ekonomiämnena vid 17oo-talets svenska universitet (Stockholm, 1986), 63, 70, 216; Merit Laine, "En Minerva för vår Nord": Lovisa Ulrika som samlare, uppdragsgivare och byggherre (Stockholm, 1998), 195 f. Hattpartiet har välfunnet kallats "de nyttiga vetenskapernas politiska röst”. Johan Kärnfelt, Mellan nytta och nöje: Ett bidrag till populärvetenskapens historia i Sverige (Stockholm, 2000), 97.

Manufakturkontoret ansvarade för lån, premier och understöd till fabrikerna. Staffan Högberg, Kungl. Patriotiska Sällskapets historia: Med särskild hänsyn till den gustavianska tidens agrara reformsträvanden (Stockholm, 1961), 36; Thomas Magnusson, Makt och pengar i frihetstidens Sverige: En oligarkis triumfer och slutliga nederlag 1720-1766 (Göteborg, 2020), 119.

18 Sven Widmalm, Mellan kartan och verkligheten: Geodesi och kartläggning 1695-1860 (Uppsala, 1990), 57; Lindroth, Vetenskapsakademien, I:1, 3, 68, 154-59, 363; Koerner, Linnaeus, 105, 165 f.; Hildebrand, 340, 369, 473, 619, 622 f.; Högberg, $53 \mathrm{f}$. Exempelvis invaldes inte de ikonoklastiska ekonomiska författarna Anders Nordencrantz (Bachmanson) och Anders Chydenius, som båda slöt upp bakom mössorna. Hildebrand, 196 f., 622 f.; Lindroth, Vetenskapsakademien, I:1, $365 \mathrm{f}$. Ett undantag från regeln utgjorde historikern och mössan Olof von Dalin (Dalin), som var illa sedd av hattarna på grund av sin rojalism och sitt fritänkeri. Marie-Christine Skuncke, Gustaf III - det offentliga barnet: En prins retoriska och politiska fostran (Stockholm, 1993), 54, 125, 260.

19 Se till exempel Leif Runefelt, Dygden som välståndets grund: Dygd, nytta och egennytta i frihetstidens ekonomiska tänkande (Stockholm, 2005), 154-56; Hildebrand, $619 \mathrm{f}$.

20 Henrik Jakob Wrede, Tal om et borgerligit samhälles eller et land ock rikes rätta styrka, samt sätt ock utvägar at komma der til [...] (1743) (Stockholm, 1747), 17.

21 Lars Magnusson, Äran, korruptionen och den borgerliga ordningen: Essäer från svensk ekonomihistoria (Stockholm, 2001), 33 f.; Lars Magnusson, "Den ekonomiska diskussionen under frihetstiden - ett framlängesperspektiv", i Riksdag, red. Skuncke \& Tandefelt, 35 f.; Legnér, 87. Jämför Melkersson, 202. 
22 Lindroth, Vetenskapsakademien, II, 1-5, 7 f., 22, 25-27, 291 f.; Widmalm, Kartan, 73; Karin Johannisson, "Naturvetenskap på reträtt: En diskussion om naturvetenskapens status under svenskt 1700-tal", Lychnos 1979-1980. "Vitterhet" omspände skönlitteratur, vältalighet, historia, språkvetenskap, musik, måleri, med mera. Ann Öhrberg, Samtalets retorik: Belevade kulturer och offentlig kommunikation i svenskt 17oo-tal (Höör, 2014), 115.

23 Lindroth, Vetenskapsakademien, I:1, 166 f.; Jakob Christensson, Lyckoriket: Studier i svensk upplysning (Stockholm, 1996), 132 f. Konungens senare förhållningssätt till akademien var hövligt men samtidigt tomt och kyligt. Lindroth, Vetenskapsakademien, II, 2, 98.

24 Bland översikterna av akademiens 170o-talshistoria bör nämnas två aktuella antologibidrag, Henrik Björck \& Thomas Kaiserfeld, "Vetenskapsakademien som kunskapspolitisk kamporganisation, 1739-1819" och Thomas Kaiserfeld \& Henrik Björck, "Reella ramar: Ledamöter, byggnader, ekonomi”, båda i Kunskap i rörelse: Kungl. Vetenskapsakademien och skapandet av det moderna samhället, red. Johan Kärnfelt, Karl Grandin \& Solveig Jülich (Göteborg, 2018).

25 Magnus Ekblad, "Den naturkunnige akademieledamoten: Några aspekter på nätverk och symboliska maktresurser under frihetstiden", Historisk Tidskrift för Finland, nr 1 2003; Runefelt, Dygden, till exempel 42-44; Peter Hallberg, Ages of liberty: Social upheaval, history writing, and the new public sphere in Sweden, 1740-1792 (Stockholm, 2003), 52-58, 69-73, 143-48, 150. För Dalin, se not 20 ovan.

26 Se till exempel Frängsmyr, "Ekonomin" och Liedman, Handen.

27 Liedman, Handen, $130 \mathrm{f}$.

28 Roger Chartier, The cultural origins of the French Revolution (1990), eng. övers. (Durham, 1991), 15; Keith Michael Baker, Inventing the French Revolution: Essays on French political culture in the eighteenth century (Cambridge, 1990), $4 \mathrm{f}$.

29 Mårten Snickare, Enväldets riter: Kungliga fester och ceremonier i gestaltning av Nicodemus Tessin den yngre (Stockholm, 1999), 14 f.; Karin Sennefelt, Den politiska sjukan: Dalupproret 1743 och frihetstida politisk kultur (Hedemora, 2001), 17-19; Chartier, 15.

30 Nils Ekedahl, Det svenska Israel: Myt och retorik i Haquin Spegels predikokonst (Hedemora, 1999), 14. Jämför Annie Mattsson, Komediant och riksförrädare: Handskriftscirkulerade smädeskrifter mot Gustaf III (Uppsala, 2010), 16.

31 Lindberg, "Kulturen", 136; Skuncke, Gustaf III, 15-17; Jørgen Fafner, Tanke og tale: Den retoriske tradition $i$ Vesteuropa (1982), 2 uppl. (Köpenhamn, 1991), $62 \mathrm{f}$.

32 Lindroth, Vetenskapsakademien, I:1, 38, 114, 218, 324; Pehr Wilhelm Wargentin, "Svar, gifvet på Kongl. Vetensk. Academiens vägnar [...]", i Bergius (1764) 112. Handlingarna var främst ett organ för nyttiga rön och handfast folkupplysning, och hade en slagsida åt tekniska tillämpningar. Kärnfelt, 89-91; Lindberg, 
"Kulturen", 138 f.; Ekblad, "Akademieledamoten", 179. Det hände att presidietal "av mera speciell natur" trycktes i Handlingarna. Lindroth, Vetenskapsakademien, I:1, 40. För exempel på detta, se Lars Benzelstierna, "Berättelse om åtskillige nyare malm- ock mineral-upfinningar i riket [...]", Kongl. Swenska Wetenskaps Academiens Handlingar 1741, http://hosting.devo.se/kvah/search. html (2017-02-03); Georg Brandt, "Nytt rön angående guldets uplösning uti skedvatten", Kongl. Svenska Vetenskaps Academiens Handlingar 1748, http:// hosting.devo.se/kvah/search.html [hämtad 2020-07-31].

Presidietalen publicerades av olika boktryckare men huvudsakligen av Lars Salvius och Johan Georg Lange. Vissa tal nådde avsevärd framgång och översattes till främmande språk, många recenserades jämte akademiens andra texter i inhemska och utländska lärda tidningar. Ekblad, "Akademieledamoten", 177, 181; Lindroth, Vetenskapsakademien, I:1, 11, 39, 119-21, 127, 132; Lindroth, Vetenskapsakademien, II, 129; Mathias Persson, Det nära främmande: Svensk lärdom och politik $i$ en tysk tidning, 1753-1792 (Uppsala, 2009), passim.

Skuncke, Gustaf III, 17; Lindroth, Vetenskapsakademien, I:1, 38 f., 363.

Inträdestalen är betydligt mer tunnsådda än presidietalen och åminnelsetalens biografiska tyngdpunkt gör att de lämpar sig sämre för denna undersökning. Den som önskar information om individuella ledamöter hänvisas till Cecilia Bergström (red.), För efterkommande: Kungl. Vetenskapsakademiens medaljer 1749-2007 (Stockholm, 2010), där många av dem ges fylliga minibiografier.

36 Jämför Melkersson, 21-24.

37 Legnér, 26; Hallberg, Ages, 143. Jämför Johannisson, Samhället, 114, 145 f.

38 Joel Mokyr, The enlightened economy: An economic history of Britain 1700-1850 (New Haven, 2009), $32 \mathrm{f}$.

39 Andre Wakefield, The disordered police state: German cameralism as science and practice (Chicago, 2009), $6 \mathrm{f} ., 138 \mathrm{f}$.

40 Lindroth, Vetenskapsakademien, I:1, 37-40, 365.

41 Jämför Jennie Nell, Vivat vår monark!: Carl Michael Bellmans panegyrik över Gustaf III 1771-1792 (Lund, 2011), 262; Alm, 96. Det är dessutom djupt problematiskt att skala bort politisk konvenans från historiska texter. Rolv Nøtvik Jakobsen, Gunnerus og nordisk vitskapshistorie (Oslo, 2015), $54 \mathrm{f}$.

42 För "samhälle", se Melkersson, 81. Jämför Joachim Östlund, Lyckolandet: Maktens legitimering $i$ officiell retorik från stormaktstid till demokratins genombrott (Lund, 2007), 178 f., 190; Dan Edelstein, The Enlightenment: A genealogy (Chicago, 2010), 32. För "samfund" hänvisas till undersökningen i den föreliggande boken.

Ett exempel på "samhälle" i bemärkelsen partikulär sammanslutning återfinns hos akademiledamoten Sandels, vilken behandlade olyckliga konstellationer av händelser som emellanåt drabbade "enskilda Personer, Familier, Samhällen, 
til och med hela Riken". Samuel Sandels, Tal, om förhållandet af varors in- och utförsel til och ifrån Sverige i särskilda tid-hvarf [...] (Stockholm, 1782), 16.

Bo Lindberg, Den antika skevheten: Politiska ord och begrepp i det tidig-moderna Sverige (Stockholm, 2006), 71-73.

44 Edelstein, 32; Keith Michael Baker, "Enlightenment and the institution of society: Notes for a conceptual history", i Civil society: History and possibilities, red. Sudipta Kaviraj \& Sunil Khilnani (Cambridge, 2001), $84 \mathrm{f}$.

45 David Carrithers, "The Enlightenment science of society", i Inventing human science: Eighteenth-century domains, red. Christopher Fox, Roy Porter \& Robert Wokler (Berkeley \& Los Angeles, 1995), 234 f.; Christopher Fox, "Introduction: How to prepare a noble savage. The spectacle of human science", i ibidem, 1; Frank Palmeri, "Conjectural history and the origins of sociology", Studies in Eighteenth-Century Culture 37 (2008), 1, 18; Lindberg, Skevheten, 96.

46 Melkersson, 81 f., 176; Lindberg, Skevheten, 95. "Stat" hade vidare "administrativa konnotationer och kunde syfta på organ som ingick i den större, politiska staten". Lindberg, Skevheten, 85.

47 Lindberg, Skevheten, 95.

48 För "stat" i denna bemärkelse, se Melkersson, 15-17, 81.

49 Ibidem, 25.

50 Charles Taylor, Modern social imaginaries (Durham, 2004), 23.

51 För samhällets och samhällssynens förändringar, se Östlund, 160, 178 f., 203; Melkersson, 11 f., 108 f., 147 f., 150, 155-78, 202-04. För den traditionella samhällsordningen och dess fortsatta dominans, se Melkersson, 78-8o, 84 f., 93 f., 107 f., 147, 213, 215, 220 f., citat från idem; Johannisson, Samhället, 15, 29, 44, $99 \mathrm{f}$.

52 Definitionen har hämtat inspiration från Peter Englund, Det hotade huset: Adliga föreställningar om samhället under stormaktstiden (Stockholm, 1989), 16-18; Melkersson, 18 f.; Donald R. Kelley, The beginning of ideology: Consciousness and society in the French Reformation (Cambridge, 1981), 4. Det hade varit möjligt att tala om propaganda istället för om ideologi, men denna term passar mindre väl för presidietalen eftersom den antyder en grad av instrumentalitet och strategisk medvetenhet som de flesta akademimedlemmar sannolikt saknade.

53 Joseph Schumpeter, "Science and ideology", The American economic review 39:2 (1949), 347, 349.

54 Lars Salvius, "Anno 1739 d. 2 iunii", i Svenska Vetenskapsakademiens protokoll för åren 1739, 1740 och 1741 [...], red. Erik Wilhelm Dahlgren, 2 vol. (Uppsala, 1918), I, 3 f.; Lars Magnusson, Merkantilism: Ett ekonomiskt tänkande formuleras (1994), sv. övers. (Stockholm, 1999), 250; Lindroth, Vetenskapsakademien, I:1, 217 f., 230; Högberg, 41. Se även Hildebrand, 380-85, 619 f. Vetenskaps- 
akademiens ekonomiska och samhällsnyttiga ideal förblev livskraftiga in på 180o-talet. Lindroth, Vetenskapsakademien, II, 187.

Ekonomi och vetenskap har haft täta band genom historien och hade det även under 1700-talet, då disciplingränserna tenderade att vara vagare än idag och den ekonomiska kunskapen låg nära i synnerhet naturalhistorien. För vetenskap och ekonomi, se Liedman, Handen, 22-24, 42-44, 74; Lindroth, Vetenskapsakademien, I:1, 217-23; Hildebrand, 381, 383-86; Legnér, 42, 87. För de porösa gränserna mellan discipliner och verksamhetssfärer, se Göran Rydén, "Provincial cosmopolitanism: An introduction", i Sweden in the eighteenthcentury world: Provincial cosmopolitans, red. Göran Rydén (Farnham, 2013), 12, 25.

Vetenskapsakademien iakttog normalt försiktighet ifråga om ekonomiska spörsmål som föll under ämbetsverk som Kommerskollegium. Ett exempel på detta erbjuder historikern Anders Schönberg, som tangerade de politiska hindren för näringarnas rätta interaktion - "fördomar, mindre nyttige Författningar, skadelige interessen och inrättningar vid Näringarne, med mera" - men menade att de skulle kunna föra in på ting som låg alltför långt borta från akademiens ändamål. Schönberg undvek gärna att bege sig ut på "detta vidsträkta och icke altid behageliga fältet”. Hildebrand, 557; Lindroth, Vetenskapsakademien, I:1, 366-68, 375, 377; Anders Schönberg, Tal om näringarnas inbördes förbindelse [...] (Stockholm, 1772), 29.

55 Salvius, 3 .

56 Organisationen har karakteriserats som "en ovanligt enhetlig exponent" för tidsandan, "en samlingsplats för nyttans befrämjare i riket", "en verksam manifestation av den patriotiska utilism som genomsyrade frihetstidens Sverige", "högborgen för den ekonomiska propagandan" och "Kultplatsen framför alla andra för [...] nyttans civism". Eli Heckscher, Svenskt arbete och liv: Från medeltiden till nutid (1941), 10 uppl. (Stockholm, 1985), 148; Runefelt, Dygden, 42; Lindberg, "Kulturen", 133; Lindroth, Vetenskapsakademien, I:1, 219; Christensson, Lyckoriket, 132. Se även Bo Lindberg, "Henrik Hassel - humanist och utilist", Lychnos 1990, 165, 181; Magnusson, Äran, 23.

57 Hildebrand, 645. Se även Lindberg, "Kulturen", 139. I akademigrundaren och hattpolitikern Anders Johan von Höpkens förord till det allra första numret av Handlingarna hette det att dessa varje kvartal skulle ge nya prov på hur ledamöterna "ouphörligen täncka, som Swenske, på Swenskas Wälfärd”. Anders Johan von Höpken, "Förberedelse", Kungliga Vetenskaps Academiens Handlingar 1739-40 [3], http://hosting.devo.se/kvah/search.html [hämtad 2020-07-31].

58 Liedman, Handen, 21, 44, 136; Magnusson, Äran, 17; Emma Spary, "Political, natural and bodily economies", i Cultures of natural history, red. Nicholas Jardine, J. A. Secord \& Emma Spary (Cambridge, 1996), 181; Worster, 37; Elisabeth Mansén, Sveriges historia 1721-1830 (Stockholm, 2011), 148 f.; Jacob 
Orrje, Mechanicus: Performing an early modern persona (Uppsala, 2015), 32 f.; "Konst 3)", Svenska Akademiens ordbok, band 14. På ett annat plan definierades "konst" som "den planerade mänskliga produktionen i vidaste mening". Liedman, Handen, 148. Bredden hos termen "ekonomi" framgår tydligt i Edvard Fredrik Runeberg, Tal, om nyttan och angelägenheten af hushålls-kunskapens bringande til en vetenskap [...] (Stockholm, 1778), $4 \mathrm{f}$.

59 Karl Forsman, "Studier i det svenska 1700-talets ekonomiska litteratur", Historiska och litteraturhistoriska studier 23 (1947), 83.

60 Jämför Magnusson, Merkantilism, 264.

61 Edward Shils, "Charisma" (1968), i Edward Shils, The constitution of society: With a new introduction by the author (Chicago, 1972), 110 f.; Edward Shils, "Charisma, order, and status", American sociological review 30:2 (1965), 201, 205-07, 209. Jämför William Clark, Academic charisma and the origins of the research university (Chicago 2006), 17, där det tidigmoderna universitetet attribueras "routinized or crystallized charisma, vested in clothing, chairs, books, offices, titles, and the like". Jämför också begreppet "symbolisk sanning" i Lorna Weir, "The concept of truth regime", Canadian Journal of Sociology 33:2 (2008), 377. Shils tar sin utgångspunkt i Max Webers teoretiserande. För detta, se Max Weber, On charisma and institution building: Selected papers. Edited and with an introduction by S. N. Eisenstadt (Chicago \& London, 1968).

62 Clifford Geertz, "Centers, kings, and charisma: Reflections on the symbolics of power" (1973), i Clifford Geertz, Local knowledge: Further essays in interpretive anthropology (1983), 3 uppl. (New York, 2000), $122 \mathrm{f}$.

63 Bo Bennich-Björkman har påvisat att de övre skiktens prestige delvis återkastats på företeelser dessa månat om, medan Dwight Atkinson urskilt en tidigmodern "genteel discourse" där gentlemannen hölls för att vara såväl ett socialt och moraliskt ideal som samhällets centrum och maktens källåder. Vetenskapsmännen, som inte sällan var gentlemän, begagnade sig av denna diskurs för att etablera auktoritet, opartiskhet och moralisk resning. Bo Bennich-Björkman, Författaren i ämbetet: Studier i funktion och organisation av författarämbeten vid svenska hovet och kansliet 1550-1850 (Uppsala, 1970), 76; Dwight Atkinson, Scientific discourse in sociohistorical context: The Philosophical Transactions of the Royal Society of London, 1675-1975 (Mahwah, 1999), xxvi f., 149.

64 Enligt Shils besitter lärda och vetenskapsmän karisma genom att de sysselsätter sig med universella mönster och kontroll över naturen, och genom att deras utbildning ger tillträde till samhällets centrala värdesystem och viktiga institutionella roller. Shils, "Order", 208 f. Ekblad har framhållit att det kungliga beskyddet höjde både Vetenskapsakademiens och monarkens status, att akademien gjorde kunskapen till en symbolisk maktresurs samt att hattarna gärna solade sig i sammanslutningens och vetenskapens glans. Ekblad, "Akademieledamoten", $183 \mathrm{f}$. 
65 Olof Celsius, Tal om smak uti den svenska, så bundna, som obundna vältaligheten [...] (Stockholm, 1768), 4, citat från idem; Carl Sparre, Tal, om politie $i$ allmänhet [...] (Stockholm, 1777), 9; Pehr Wilhelm Wargentin, "Svar, gifvet på Kongl. Vetenskaps Academiens vägnar [...]”, i Lilliestråle (1775), 54 f.

Hjalmar Fors har lyft fram hur Bergskollegiums "apparent centrality was a consequence of its remarkable ability to function as a contact zone between different groups in society, as well as between different geographical regions". Hjalmar Fors, The limits of matter: Chemistry, mining and enlightenment (Chicago 2015), 11. Samma poäng kan göras om Vetenskapsakademien.

66 Geertz, "Centers", 124.

67 En åsiktsbrytning inom Vetenskapsakademien gällde svenska språket och ledde till att ett par ledamöter, lantmäteridirektören Jacob Faggot och kompositören Johan Helmich Roman, anslöt sig till det konkurrerande Svenska Tungomålsgillet, som akademien och dess beskyddare Höpken motarbetade och lyckades stoppa. Den så kallade striden om näringarnas företräde handlade om vilken näring som intog första rummet och framför allt borde understödjas. Ett tredje tvisteämne var lyxen, eller yppigheten. Hildebrand, 399-406, 576-78; Lindroth, Vetenskapsakademien, I:1, 364, 366-68; Runefelt, Dygden, kapitel 5, 162-64.

68 För de olika intressena inom akademien, se Widmalm, Kartan, 59 f., 62 f.; Patrik Winton, Frihetstidens politiska praktik: Nätverk och offentlighet 1746-1766 (Uppsala, 2006), 310 f.; Anders Lundgren, "Gruvor och kemi under 1700talet i Sverige: Nytta och vetenskap", Lychnos 2008, 14. Jämför Hjalmar Fors, "Kemi, paracelsism och mekanisk filosofi: Bergskollegium och Uppsala cirka 1680-1770", Lychnos 2007, 184 f.; Hildebrand, 195. För "trading zone", se Peter Galison, "Trading zone: Coordinating action and belief", i The Science Studies reader, red. Mario Biagioli (New York, 1999), 138, 145 f.; Lundgren, 13-15.

69 "Handslöjd", Svenska Akademiens ordbok, band 11; "Slöjd", Svenska Akademiens ordbok, band 28; "Manufaktur", Svenska Akademiens ordbok, band 16; "Manufaktur", Nationalencyklopedin, band 13; Samuel Schultze, Tal om ungdomens upöfvande i landtbruk [...] (Stockholm, 1750), 18.

70 Manufakturerna var manufakturer i kraft av en juridisk definition; verksamheten och produktionen kunde variera avsevärt och komma nära eller i praktiken vara hantverk. Lars Magnusson, "Manufakturerna”, i Frihetstiden, red. Christensson, $221 \mathrm{f}$, $231 \mathrm{f}$.

71 Jämför Runefelt, Dygden, 13-15; Lindberg, "Hassel”, 199; Magnusson, Äran, 79. För en utförlig diskussion om merkantilismbegreppets problematik, se Magnusson, Merkantilism, kapitel 1 och 2.

72 Samtliga bestämningar har hämtats från Svenska Akademiens ordbok, som är standardauktoriteten för ordförklaringar i boken. Vid ett fåtal tillfällen har andra resurser, primärt Svensk ordbok, anlitats. 
73 Lindberg, Skevheten, 53-55.

74 För dessa termer, se Lindberg, Skevheten, 157-59.

75 En preses, astronomen Eric Prosperin, förefaller ha brukat ordet "allmänheten" i meningen "offentlig publik": "Ehuru Allmänheten i sina omdömen nog liknar vatnet, som röres af väder och rinner dit det lutar, kunna dock Hennes, men i synnerhet Efterverldens domar vara goda, när blott oväld fordras. Däremot, om ljus och insigter äfven skola stafva domslutet, torde det medgifvas, at en samling kunnige män taga företrädet, när de, efter sin plägsed [sedvänja], tilstänga vägen til sig för alla biafsigter; Ty då förenas efterverldens oveldughet med samtids kännedom och närmare verkan.” Eric Prosperin, Tal, om Kongliga Vetenskaps Societeten i Upsala [...] (Stockholm, 1791), 7.

76 Sten Carlsson, Ståndssamhälle och ståndspersoner 1700-1865: Studier rörande det svenska ståndssamhällets upplösning (1949), 2 uppl. (Lund, 1973), $18 \mathrm{f}$.

77 Öhrberg, Samtalet, 109 f.; Nordin, Folk, 96 f., citat från idem; Melkersson, 131, $213 \mathrm{f}$.

78 Carola Nordbäck, Lycksalighetens källa: Kontextuella närläsningar av Anders Chydenius budordspredikningar, 1781-82 (Åbo, 2009), 288-9o.

79 Mathias Persson, "Det råa tillståndet: Vetenskapsakademien, vildarna och den koloniala världsordningen", i Kritik och beundran: Jean-Jacques Rousseau och Sverige 1750-1850, red. Jennie Nell \& Alfred Sjödin (Lund, 2017), 126; Orrje, 37; Lindroth, Vetenskapsakademien, I:1, 35, 111, 114 f., 217 f. Jämför Fors, The limits of matter, 14.

8o För exempla, se Nell, 6o, 64, 153; Persson, Främmande, 147 f. För fursten som exemplum, se Skuncke, Gustaf III, 36.

81 Anthony Grafton, "A sketch map of a lost continent: The Republic of Letters" (2007), i Anthony Grafton, Worlds made by words: Scholarship and community in the modern West (Cambridge, Mass., 2009), 18, 21; Anne Goldgar, Impolite learning: Conduct and community in the Republic of Letters 1680-1750 (New Haven, 1995), 2, 6 f., 24 f.; Sverker Sörlin, De lärdas republik: Om vetenskapens internationella tendenser (Malmö, 1994), 17; Dena Goodman, The Republic of Letters: A cultural history of the French Enlightenment (Ithaca, 1994), 16, 18, 23; Lorraine Daston, "The ideal and reality of the Republic of Letters in the Enlightenment", Science in context vol. 4, $\mathrm{nr} 2$ (1991), $374 \mathrm{f}$.

82 Sverker Sörlin har påpekat att vetenskapsmännens dagliga liv utspelade sig inom ramarna för ett i ökande grad nationellt och statligt definierat sammanhang av betraktelsesätt, agendor, karriärvägar, institutioner, ekonomiskt stöd och patron-klientrelationer. Sverker Sörlin, "Science, empire, and enlightenment: Geographies of Northern field science", European review of history 13:3 (2006), 456. För lärda och vittra ämbetsinnehavare, se Orrje, 35; BennichBjörkman, 75 f., 88. Jämför Anne Berg, Kampen om befolkningen: Den svenska nationsformeringens utveckling och sociopolitiska förutsättningar, ca 1780-1860 
(Uppsala, 2011), 48-51, 76 f. För lärdas ställning som ståndspersoner, se Carlsson, Ståndssamhälle, 15-21. Universitetens professorer fördes till prästeståndet och återfanns i den officiella rangordningen. Liedman, Handen, 25, 129; Bennich-Björkman, 62. För de lärda, eliten och nätverken, se Magnus Ekblad, "Ett brev betyder så mycket: Närhet och distans i Carl Gustaf Tessins tidiga 1740-talskorrespondens med Carl Hårleman", i Med börd, svärd och pengar: Eliters manifestation, maktutövning och reproduktion 1650-1900, red. Gudrun Andersson, Esbjörn Larsson \& Patrik Winton (Uppsala, 2003), 65.

83 Wargentin, "Svar", i Bergius (1764), 111.

84 Lisbet Koerner, "Daedalus hyperboreus: Baltic natural history and mineralogy in the Enlightenment", i The sciences in enlightened Europe, red. William Clark, Jan Golinski \& Simon Schaffer (Chicago, 1999), 389; Knut Ove Eliassen, "Introduction", i Æmula lauri: The royal Norwegian society of sciences and letters, 1760-2010, red. Håkon With Andersen m. fl. (Sagamore Beach, 2009), x-xii.; Jonathan B. Knudsen, Justus Möser and the German Enlightenment (Cambridge, 1986), 4, 8, 11-13. För den tyska ständerupplysningen, se även Per Nilsén, Att "stoppa munnen till på bespottare": Den akademiska undervisningen $i$ svensk statsrätt under frihetstiden (Lund, 2001), $51 \mathrm{f}$. Dorinda Outram gör en distinktion mellan kameralistiska och icke-kameralistiska stater; de förra uppvisade mer traditionella idéer om statsmakten och inbegrep Tysk-romerska riket, Ryssland och de nordiska länderna, alltså ungefär samma område som Rausings och Eliassens upplysningar omfattar. Dorinda Outram, The Enlightenment (1995), 2 uppl. (Cambridge, 2005), $33 \mathrm{f}$.

85 Lindberg, "Hassel", 204-06. Se även Christensson, Lyckoriket, 12, 40; Patrik Lundell, Pressen i provinsen: Från medborgerliga samtal till modern opinionsbildning 1750-1850 (Lund, 2002), 28 f., 79, 92; Marie-Christine Skuncke, "Was there a Swedish enlightenment?", i Norden och Europa 1700-1830: Synvinklar på ömsesidigt kulturellt inflytande, red. Svavar Sigmundsson (Reykjavik, 2003), 36. Såväl Fors som Liedman har urskilt en tysk upplysning i Sverige och framställt den som reformistisk, pragmatisk, antiradikal och nytto- och kunskapsorienterad. Liedman registrerar därtill dess kristna slagsida. Hjalmar Fors, Mutual favours: The social and scientific practice of eighteenth-century Swedish chemistry (Uppsala, 2003), 202; Sven-Eric Liedman, "Upplysningstidens tre ansikten", i Ljus över landet? Upplysningen som drivkraft $i$ 17oo-talets svenska vetenskap och vitterhet, red. Paul Hallberg (Göteborg, 2005), 38 f. Ständerupplysningens inflytande på svensk botten tas upp i Nilsén, 401.

86 James E. McClellan III, Science reorganized: Scientific societies in the eighteenth century (New York, 1985), xxii f., 8 f. Ulrich Im Hof har förknippat de vetenskapliga sällskapens expansion med hovens strävanden efter status och menat att vetenskapsmännen gick från "den frisvävande 'lärdomsrepubliken' [...] till de statligt garanterade furstliga akademiernas välorganiserade värld". 
Ulrich Im Hof, Das gesellige Jahrhundert: Gesellschaft und Gesellschaften im Zeitalter der Aufklärung (München, 1982), 115, "Von der freischwebenden 'Gelehrtenrepublik' [...] zur wohlorganisierten Welt der staatlich garantierten fürstlichen Akademien”. Även om denna utsaga bör nyanseras i ljuset av att mecenatskap alltid existerat inom den lärda världen, konsoliderade och förstärkte det nya institutionella läget med all säkerhet de lärdas beroende av samhällsledningen.

87 Stockholmsakademin avvek emellertid från de utländska förlagorna genom såväl sin tonvikt på ekonomi och nytta som sin eklektiska inre struktur. Den företedde ett antal likheter med de ekonomiska sällskap som uppstod runtom $\mathrm{i}$ 1700-talets Europa. Hildebrand, 17, 21, 41; Lindroth, Vetenskapsakademien, I:1, 223-26; McClellan, 86 f. För de ekonomiska sällskapen, se Koen Stapelbroek \& Jani Marjanen, "Political economy, patriotism and the rise of societies", i The rise of economic societies in the eighteenth century: Patriotic reform in Europe and North America, red. Koen Stapelbroek \& Jani Marjanen (Houndmills, 2012).

Royal Society grundades liksom Vetenskapsakademien till dels av politiskt inflytelserika personer och utgjorde från starten 1660 en mötesplats för den brittiska eliten. Under 1700-talet intensifierades sällskapets förbindelser med statsmakten, varvid detta kom att kontrolleras av samma krafter som styrde Storbritannien. Académie des Sciences inrättades och finansierades av franska staten för att förhöja Ludvig XIV:s ära och bidra till fäderneslandets välfärd; den hade högt uppsatta ledamöter och fungerade som en komponent i statsförvaltningen. Académie Royale var ett verktyg för de preussiska furstarna och styrdes först av en enväldig preses utsedd av Fredrik II, sedan av konungen själv. Atkinson, 16 f., 27-30; Lewis Pyenson \& Susan Sheets-Pyenson, Servants of nature: A history of scientific institutions, enterprises, and sensibilities (New York, 1999), 85-87; McClellan, 16 f., 176; Ursula Goldenbaum, "Friedrich II. und die Berliner Aufklärung", i Hofkultur und aufgeklärte Öffentlichkeit: Potsdam im 18. Jahrhundert im europäischen Kontext, red. Günther Lottes \& Iwan D’Aprile (Berlin, 2006), $123 \mathrm{f}$.

88 Lindroth, Vetenskapsakademien, I:1, 27-30. De frihetstida ledamotsvalen utgick frekvent från vänskaps- eller släktskapsförhållanden, men kunde även signalera den invaldes närhet till rådet. Hildebrand, 484, 493 f., 534-36, 540 f., 561-63; Winton, 211.

89 Prosperin, 1.

90 Lindroth, Vetenskapsakademien, I:1, 32; Lindberg, "Hassel", 181; Hildebrand, $460 \mathrm{f}$.

91 Det astronomiska observatoriet färdigställdes 1753 och var ett resultat av samverkan mellan Vetenskapsakademien, ständerna och Stockholms magistrat. Lindroth, Vetenskapsakademien, I:1, 379 f., 382. En kunglig resolution från 1749 


\section{NOTER}

tillerkände akademien ensamrätt på almanacksutgivningen och vinsten av försäljningen. Lindroth, Vetenskapsakademien, I:2, 824, 826 f. För fler exempel på höga herrars interventioner å Vetenskapsakademiens vägnar, se Hildebrand, 73, 362, 364; Nordin, "Höpken", 70 f., 73 f.; N. V. E. Nordenmark, Pehr Wilhelm Wargentin: Kungl. Vetenskapsakademiens sekreterare och astronom 1749-1783 (Uppsala, 1939), 168.

92 Nordenmark, 185; Högberg, 53.

93 Sammanslutningen befann sig i skärningspunkten mellan diverse nätverk. Winton, 300 f. Jämför Kaiserfeld, 146. Ann Öhrbergs iakttagelse att 1700-talets vittra sällskap var "maktgenererande knutpunkter inom och mellan olika nätverk" där gamla allianser stärktes och nya skapades är giltig också för Vetenskapsakademien. Öhrberg, Samtalet, 108. Både akademien och hattnätverken byggde i en inte ringa utsträckning på blodsförvantskap. Hildebrand, $534 \mathrm{f}$., 540 f., 562 f., 570; Ingemar Carlsson, Parti - partiväsen - partipolitiker 1731-43: Kring uppkomsten av våra första politiska partier (Stockholm, 1981), 145-50.

94 Ylva Hasselberg, Leos Müller \& Niklas Stenlås, "Åter till historiens nätverk", i Sociala nätverk och fält, red. Håkan Gunneriusson (Uppsala, 2002), 9, 15 f., 18-23; Ann Öhrberg, Vittra fruntimmer: Författarroll och retorik hos frihetstidens kvinnliga författare (Hedemora, 2001), 56 f.; Winton, 299; Fors, Favours, $9 \mathrm{f}$.

Forskare har kritiserat definitionen av nätverk som horisontella, bland annat utifrån att den riskerar att osynliggöra hierarkiska element i det förgångna. Einar Hreinsson \& Tomas Nilson, "Introduktion", i Nätverk som social resurs: Historiska exempel, red. Einar Hreinsson \& Tomas Nilson (Lund, 2003), 23, 25-29; Jan Samuelson, Eliten, riket och riksdelningen: Sociala nätverk och geografisk mobilitet mellan Sverige och Finland 1720-1820 (Helsingfors, 2008), 32-34. Patrik Winton har utan att explicit anamma ett nätverksbegrepp som inbegriper vertikala förbindelser hävdat att dessa samexisterade med och följde samma principer som de jämbördiga kontakterna, medan Fors talat om nätverk av klienter och patroner. Patron-klientband var vanliga under den tidigmoderna eran och i det svenska 1700-talet; de kanaliserades liksom nätverken i ömsesidiga tjänster och gåvor, och det kan vara svårt att avgöra till vilken kategori en social interaktion skall föras. Winton, 34; Hjalmar Fors, "Matematiker mot linneaner: Konkurrerande vetenskapliga nätverk kring Torbern Bergman", i Vetenskapens sociala strukturer: Sju historiska fallstudier om konflikt, samverkan och makt, red. Sven Widmalm (Lund, 2008), 25, 27; Björn Ryman, Eric Benzelius d. y.: En frihetstida politiker (Motala, 1978), 123-26. Jämför resonemanget i Marie-Christine Skuncke, Carl Peter Thunberg: Botanist and physician. Career-building across the oceans in the eighteenth century (Uppsala, 2014), 25-27. Det går följaktligen att argumentera för att patron-klientband bör beaktas i nätverkssammanhang.

95 Till nätverkets övriga deltagare hörde arkitekten och överintendenten Carl Fredrik 
Adelcrantz, ärkebiskopen Erik Benzelius den yngre, biskopen Carl Fredrik Mennander, kanslirådet och numismatikern Carl Reinhold Berch, arkitekten och överintendenten Carl Johan Cronstedt, officeren Augustin Ehrensvärd, handelsmannen Claes Grill, naturalhistorikern Pehr Kalm, ämbetsmannen Ulric Rudenschöld, riksrådet Carl Fredrik Scheffer, astronomen Mårten Strömer samt bergsrådet Anton von Swab (Swab). Nätverket var som mäktigast inom akademien på 1740-talet. Ekblad, "Akademieledamoten", 174-77, 179-81, 183.

96 Lindroth, Vetenskapsakademien, I:1, 68-70.

97 Jean George Lillienberg, Tal, om svenska bergshandteringens förmåner och hinder [...] (Stockholm, 1776), 4; Lindroth, Vetenskapsakademien, I:1, 154; Hildebrand, 194, 243, 536, 542, 561. Vetenskapsakademien påminde härvidlag om Royal Society, vars ledamöter likaså var verksamma annorstädes och har betecknats som en flytande elit. McClellan, 33. Vetenskapsakademien delade medlemmar med andra samhällsledningen närstående lärda sammanslutningar, som Uppfostringssällskapet och Kungliga Patriotiska Sällskapet, vilket baserade sig på ordenssällskapet Pro Patria. Kungliga Patriotiska Sällskapet var liksom akademien dels vigt åt ekonomi och nytta, dels ett attraktivt forum för prominenta personer, inte minst från hattarnas krets. Organisationen ägnade sig under gustaviansk tid i synnerhet åt jordbruksfrågor. Det av publicisten Carl Christoffer Gjörwell den äldre instiftade Uppfostringssällskapet hade också ett påfallande högreståndsinslag. Båda inrättningarna drogs genom samröret med makthavarna in i det sena 1700-talets statsprojekt. Högberg, 25-31, 33, 61 f., 64 f., 72 f.; Berg, 47 f., 52 f., 77.

98 Maria Cavallin, I kungens och folkets tjänst: Synen på den svenske ämbetsmannen 1750-178o (Göteborg, 2003), 33, 38, 40, 42 f.; Lars Magnusson, Sveriges ekonomiska historia (1996), 4 uppl. (Stockholm, 2010), 269.

99 McClellan, 25 f. Jämför Daston, $370 \mathrm{f}$.

100 För att citera Lindroth var Vetenskapsakademien "ingalunda ett själlöst redskap för den officiella politiken. Men denna angav ändå ramen för Akademiens verksamhet, och vid högtidliga tillfällen avlades självklara trohetsförsäkringar." Lindroth, Vetenskapsakademien, I:1, 362.

\section{Det borgerliga tillståndet}

101 Taylor, 23-28; Edward Harrison, Masks of the Universe: Changing ideas on the nature of the cosmos (1985), 2 uppl. (Cambridge, 2003), 2. Hjalmar Fors har framhållit att en förändring i natursyn har både sociala och vetenskapliga ingredienser, som inte går att skilja från varandra. Fors, The limits of matter, 5. Se även Eric R. Wolf, Europe and the people without history (1982), 2. uppl. (Berkeley, 1997), 389.

102 Johannisson, Samhället, 10, 79, 85 f., 93, 124-26, 164. Den tidigmoderna erans 


\section{NOTER}

intima samspel mellan samhällsuppfattningar och världsbilder kan exemplifieras med fysikoteologin, vars representanter tenderade att försvara det bestående genom att parallellisera samhället och naturen, betona hierarki och underordning samt befria vetenskapliga rön från inopportunt tankegods. Idéströmningen utgjorde en resurs i 1700-talets kulturkamp, där den fick tjäna som vapen mot fritänkeri, materialism, ateism, naturalism och överdriven förnuftstro. John Hedley Brooke, Science and religion: Some historical perspectives (Cambridge, 1991), 6 uppl. (1998), 199, 203, 211 f.; Worster, 67 f.; Lindroth, Lärdomshistoria, 522-24; Tore Frängsmyr, Wolffianismens genombrott i Uppsala: Frihetstida universitetsfilosofi till 170o-talets mitt (Uppsala, 1972), 122, 134, 153 f., 189.

103 Andersson Burnett \& Buchan, ”The Edinburgh connection: Linnaean natural history, Scottish moral philosophy and the colonial implications of Enlightenment thought", i Linnaeus, natural history and the circulation of knowledge, red. Hanna Hodacs, Kenneth Nyberg \& Stephane Van Damme (Oxford, 2018), 163, 172-73; Mathias Persson, "Southern darkness, northern light: 'Civilisation' and 'savagery' in Anders Sparrman's southern African travelogue", South African Historical Journal 71:1 (2019), 15, 18; Charles W. J. Withers \& David N. Livingstone, "Introduction: On geography and enlightenment", i Geography and enlightenment, red. David N. Livingstone \& Charles W. J. Withers (Chicago, 1999), 3, 14.

104 Linda Andersson Burnett \& Bruce Buchan, 172; Nathaniel Wolloch, ”The civilizing process, nature, and stadial theory", Eighteenth-Century Studies 44:2 (2011), 252-54; Elisabeth Rudebeck, Tilling nature - harvesting culture: Exploring images of the human being in the transition to agriculture (Stockholm, 2000), 77; Ter Ellingson, The myth of the noble savage (Berkeley, 2001), 159.

105 Bruce Buchan \& Mary Heath, "Savagery and civilization: From terra nullius to the 'tide of history'", Ethnicities 6:1 (2006), 6-7, 13; Ellingson, 219-20.

106 Larry Wolff, "Discovering cultural perspective: The intellectual history of anthropological thought in the Age of Enlightenment", i The anthropology of the Enlightenment, red. Larry Wolff \& Marco Cipolloni (Stanford, 2007), 10; Larry Wolff \& Marco Cipolloni, "Preface", i Wolff \& Cipolloni, Anthropology, xi; Anthony Pagden, European encounters with the New World: from Renaissance to Romanticism (New Haven, 1993), 13-14; Buchan \& Heath, 6-9, 11-14; Wolf.

107 Carl Fredrik Adelcrantz, Tal om de fria konsters värde och nytta [...] (Stockholm, 1757), 17 .

108 Anders Sparrman, Tal, om den tilväxt och nytta, som vetenskaperne i allmänhet, särdeles natural-historien, redan vunnit och ytterligare kunna vinna, genom undersökningar i Söder-hafvet [...] (Stockholm, 1778), 19 f., 21 f.

109 Outram, 69, 80, 94, 96.

110 Johan Browallius, Känningar af Guds försyn vid nyttiga vetenskapers främjande 
[...] (Stockholm, 1747), 5 f.; Gerhard Meijer, Tal, om det svenska metal-arbetets förkofring [...] (Stockholm, 1747), 5; Zacharias Johan Strandberg, Tal, om de fel, som vid febrars botande hos oss dageligen begås [...] (Stockholm, 1752), 3; Erik Salander, Tal, om slögder [...] (Stockholm, 1754), 8 f.; David von Schulzenheim, Tal, om den rätta ålderdomens ärnående [...] (Stockholm, 1764), 6; Pehr Zetzell, Tal, om en svensk soldats föda i fält [...] (Stockholm, 1764), 9; Erik Gustaf Lidbeck, Tal om planteringar [...] (Stockholm, 1766), 28; Carl Fredrik Scheffer, Tal, om förbindelsen, imellan grund-lagarnas art och folkets sällhet, som efter dem styras skal [...] (Stockholm, 1772), 20; Peter Jonas Bergius, Tal, om frukt-trägårdar och deras främjande i vårt rike [...] (Stockholm, 1780), 98; Nils Dalberg, Tal, om luftens beskaffenhet i stora och folkrika städer [...] (Stockholm, 1784), 13 f., 18; Johan Lorens Odhelius, Dödligheten i Stockholm, $i$ et tal för K. Vetensk. Acad. granskad [...] (Stockholm, 1785), 25.

111 Joachim Wilhelm Lilliestråle, Tal [...] om tale-konsten, des uphof och förbindelse med vetenskaperna [...] (Stockholm, 1784), 23; Lilliestråle, Lag-förbättring, 30; Jacob Faggot, "Svar på Kongl. Vetenskaps Academiens vägnar", i Ankarcrona, 13, citat från idem; Wargentin, "Svar", i Lilliestråle (1775), 55; Nils von Rosenstein, Försök til en afhandling om uplysningen, til dess beskaffenhet, nytta och nödvändighet för samhället [...] (Stockholm, 1793), 54 f.; Runeberg, Nyttan, $5 \mathrm{f}$.

Presidietalen meddelade också att naturens dolda fjädrar överallt gav behagliga föredömen, att allting lyckades när konsten som noggrannast åtlydde naturens allmänna lagar och att konsten skulle förbättra naturföremålen efter naturens mönster. Sven Ljungenstjerna, Tal, om naturkunnighetens uphjelpande och nytta i det allmänna [...] (Stockholm, 1752), 3; Carl Wilhelm Cederhielm, Tal, om vilda träns plantering, i Sverige (1740), (Stockholm, 1748), 27; Carl Gustaf Löwenhielm, Tal, om landt-skötsel [...] (Stockholm, 1751), 13.

112 Forsman, 127; Mikael Ahlund, Landskapets röster: Studier i Elias Martins bildvärld (Stockholm, 2011), 319; Margaret C. Jacob, The Newtonians and the English Revolution, 1689-1720 (Hassocks, 1976), 60-63. Jämför Legnér, 124; P. M. Harman, The culture of nature in Britain 1680-1860 (New Haven, 2009), 29, 33. För samspelet mellan tidigmoderna beskrivningar av natur och samhälle, se även Roy Porter, "Afterword", i Geography, red. Livingstone \& Withers, 422-25. Termen "natur" var sammansatt och omfångsrik. Den hade å ena sidan ett vetenskapligt eller lärt innehåll: "In the universal sense 'nature' denoted the cosmos as designed by God, the structure of material reality and more particular features of the material environment - landforms and organisms, all subject to scientific explanation in terms of laws of nature." I en mer allmän och vardaglig bemärkelse var naturen allt som inte hörde till kulturen, inklusive det uppodlade landskapet. Harman, 3, $335 \mathrm{f}$.

113 Carl Didrik Ehrenpreus, Tal om den förmån och nytta som fria konster och handaslögder tilskyndas af historien [...] (Stockholm, 1748), 15; Löwenhielm, 


\section{NOTER}

Landt-skötsel, 7, 9 f. Jämför utläggningen om den mänskliga reproduktionens och moralens gudomligt stiftade lagar i Sten af Rabbe, Tal, om folk-mängden $i$ äldre och nyare tider [...] (Stockholm, 1771), 32. Indelningen av världen i de tre koncentriska ekonomiska sfärerna gudomlig hushållning (oeconomia divina), offentlig hushållning (oeconomia publica) och privat hushållning (oeconomia privata) under 1700-talet dryftas i Frängsmyr, "Ekonomin", 222 f., 242; Legnér, 86, 88 f. Jämför den naturrättsliga indelningen av lagen i en gudomlig, en naturlig och en borgerlig nivå. Nordin, "Radikalism", 63 f.

Hushållningen uppfattades även i andra fall som ett kitt mellan natur och samhälle. Styckgjutardirektören Gerhard Meijer diskuterade konstens och naturens förening och förkovran genom ekonomin, medan lantmäteridirektören Jacob Faggot kungjorde att denna fogade samman naturen med konsten och gjorde båda gagneliga genom att etablera ordning. Utan hushållningen skulle reda övergå i oreda och det bästa bli det värsta, det räta krokigt, det nyttiga menligt, det höga lågt. Faggot, "Svar", i Ankarcrona, 13; Meijer, 20. Jämför Zetzell, Soldat, $1 \mathrm{f}$.

114 Rosenstein, 200-03, 215; Daniel Melanderhielm, Tal, om angelägenheten af astronomiska observationers beständiga fortsättande [...] (Stockholm, 1792), 66.

115 Bengt Ferrner, Tvisten om vattu-minskningen [...] (Stockholm, 1765), 23 f.; Lilliestråle, Lag-förbättring, 30; Johan Nordenankar, Tal, om strömgångarne i Öster-sjön [...] (Stockholm, 1792), 22. Jämför Bengt Bergius utsaga om att naturen kännetecknades av balans: "Uti alla des gåfvor finnes gemenligen en motvigt." Bengt Bergius, Tal, om läckerheter, både i sig sjelfva sådana, och för sådana ansedda genom folkslags bruk och inbillning [...] Andra delen (Stockholm, 1787), 131.

116 Lilliestråle, Lag-förbättring, 27-29. En lags verkan kunde dessutom vara svår att förutse och svarade oftast i lägre grad än väntat mot den bakomliggande goda avsikten. Ibidem, 31 .

117 Ibidem, 29-33.

118 Rosenstein, 86. En annan preses konstaterade apropå författningsändringar att det var "en ovilkorlig skyldighet, at antagne bruk icke utan nöd-tvång må förkastas och ändras, och i synnerhet icke, utan fullkomligaste föresigt af alla möjeliga olägenheter, som genom förändringen tima kunna”. Sparre, $11 \mathrm{f}$. Se även Sandels, Inrättning, 13 f.; Jacob Gadolin, Tal, om de physiska vetenskapers befordran [...] (Stockholm, 1786), $29 \mathrm{f}$.

119 Rosensteins tal har karakteriserats som revolutionärt, jakobinskt och atypiskt för den sengustavianska Vetenskapsakademien, vars medlemmar inte ägnade sig åt storstilade politiska betraktelser. Det tryckta talet - omarbetat och utvidgat mellan 1789 och 1793 - hörde hemma i ett samhällsklimat väsensskilt från det som var för handen när det koncipierades och lästes upp, givet mordet på 
Gustav III och franska revolutionens radikalisering. En tidigare version finns bevarad men det är omöjligt att veta om det är den ursprungliga, muntliga eller inte. Lindroth, Vetenskapsakademien, II, 26, 38 f.; Torgny T. Segerstedt, Nils von Rosenstein: Samhällets människa (Stockholm, 1981), 307 f., 310 f., 316.

120 Rosenstein, 181. För en ingående analys av Rosensteins tal, se Segerstedt, 263-390.

121 Ahlund, 318-20, 326, 328-30; Melkersson, 83, 146 f.; Karin Sennefelt, Politikens hjärta: Medborgarskap, manlighet och plats i frihetstidens Stockholm (Stockholm, 2011), 162 f.; Östlund, 140 f., 146-48. Religionen fortfor att förstås som en grundval för den mänskliga gemenskapen trots att synen på stat och samhälle sekulariserades genom naturrätten. Ingmar Brohed, Stat - religion - kyrka: Ett problemkomplex i svensk akademisk undervisning under 170o-talet (Stockholm, 1973), 7, 84 f., 90, 96.

122 Runefelt, Dygden, 29 f., citat från idem; Dunér, 295; Nordin, Folk, 328; Skuncke, Gustaf III, 209 f. Den kände naturrättsfilosofen John Lockes inverkan på den svenska debatten och två av Vetenskapsakademiens presidietal, Henrik Jakob Wredes Tal om et borgerligit samhälles eller et land ock rikes rätta styrka, samt sätt ock utvägar at komma der til [...] (1747) och Carl Didrik Ehrenpreus Tal om den förmån och nytta som fria konster och handaslögder tilskyndas af historien [...] (1748), diskuteras i Hallberg, Ages, 56-58.

123 Brohed, 59.

124 Knud Haakonssen, Natural Law and moral philosophy: From Grotius to the Scottish Enlightenment (Cambridge, 1996), 41-47, 62, citat från idem; Johannisson, Samhället, 43; Bo Lindberg, Naturrätten i Uppsala 1655-1720 (Uppsala, 1976), 1, 192 f.; Runefelt, Dygden, 156 f. Jämför Nilsén, 378.

125 Själva termen "naturrätt" förekom inom Vetenskapsakademien hos dels historikern Anders Anton von Stiernman (From), som anförde att forntidens svenskar levde "efter denn naturliga rätten och billigheten", dels köpmannen Johan Clason, som talade om "den naturliga rättigheten, at få se til egen utkomst", vilket emellertid inte hade någon uppenbar bäring på naturtillståndet. Anders Anton von Stiernman, Tal om de lärda vettenskapers tilstånd i Svearike, under hedendoms och påfvedöms tiden [...] (Stockholm, 1758), 3; Johan Clason, Tal, om orsakerna til Sveriges handels omskiften [...] (Stockholm, 1769), 28.

126 Anders Johan von Höpken, Tal, om yppighets nytta [...] (1740) (Stockholm, 1741), 8, 11-13; Anders Johan von Höpken, Tal til Hans Kongl. Majestet och Kongl. Vetenskaps Academien, vid observatorii invigning den 20. sept. 1753 [...] jämte berättelse om samma observatorii byggnad (Stockholm, 1753), 16.

127 Edvard Carleson, Upmuntran til fiskeri-inrättningar i Sverige [...] (Stockholm, 1749), 2 f.; Ehrenpreus, Konster, 4 f., 23, citat från idem. Se även Sandels, Inrättning, 8 .

Ett par presidietal uppehöll sig vid näringarnas och handelns roll i samhäl- 


\section{NOTER}

lets behovsstyrda tillblivelse och fortskridande. Det ena tillmätte näringarna, handeln och samhället ett gemensamt ursprung, där människors behov och oförmåga att själva producera allt de behövt lett till idoghet, utbyten och ömsesidiga beroenden. Det andra stipulerade att behoven, som tilltagit efter "Staters grundande" och i takt med att människorna blivit alltmer involverade med varandra, framtvingat en flit varur konster och vetenskaper sprungit. Lagarnas uppkomst sammanföll med handelns och slöjdnäringarnas. När människan lämnade det oskuldsfulla naturtillståndet och inträdde i det samhälleliga måste "samhäls-lemmarna hafva gifvit den ena åt den andra, anledning til förnöjeligare, beqvämare, yppigare och vällustigare lefnad; detta har åter bragt slögder, handtverk, konst-arbeten, och alle-handa slags Fabriker å banen, hvilka tagit til så fort som kunskap om Naturens ämnen och verkningar gifvit anledning, och människo-hopens tilväxt och lefnadssätt tarfvat". Matthias Alexander von Ungern-Sternberg, Tankar om Sveriges handel och allmänna hushållning [...] (Stockholm, 1752), 2 f.; Edvard Fredrik Runeberg, Tal, om varors värden [...] (Stockholm, 1760), 7-10, 28, citat från idem.

128 Carl Fredrik Mennander, Tal om folkhopens tilväxt, som grunden til rikets näringars upkomst [...] (Stockholm, 1766), 4.

129 Löwenhielm, Landt-skötsel, 5; Wrede, 6.

130 Jonas Alströmer, Tal, om schäferiernas nytta [...] (Stockholm, 1760), 6; Clas Alströmer, Tal, om den fin-ulliga får-afveln [...] (Stockholm, 1770), 5-7. Jämför Schönberg, 6-8.

131 Augustin Ehrensvärd, Tal om ungdomens upfostran til krigsmän [...] (Stockholm, 1743), 19; Augustin Ehrensvärd, Tal om svensk sjömagt [...] (Stockholm, 1767), $28 \mathrm{f}$.

Ett tal hävdade att det bibliska paradisets upphörande tvingat människan till arbete, ett annat använde Kain, Abel och Tubal för att illustrera övergången till den tidsperiod då människan måst förmera de naturgivna resurserna. Wrede, 11; Alströmer, Schäferierna, 6. Se även Höpken, Yppighet, 8 f.; Runeberg, Varor, 7; Bergius, Bad, 2; Carl Rudenschöld, Tal om svenska språkets art och nu varande bruk [...] (Stockholm, 1772), 15.

132 För den gustavianska propagandan, se kapitel 5, "Konungens akademi".

133 Scheffer, Grund-lagarna, 13, 20, 28 f.; Lilliestråle, Lag-förbättring, 40; Rosenstein, 68, citat från idem. För Scheffers relation till Gustav, se Göran Nilzén, ”Carl Fredrik Scheffer", Svenskt biografiskt lexikon, band 31, 520; Skuncke, Gustaf III, 190.

134 Lilliestråle, Lag-förbättring [5]; Scheffer, Grund-lagarna, 24, 27, 29. För kopplingen mellan lag och social harmoni, se även Lillienberg, Förmåner, 22.

135 Runeberg, Nyttan, $11 \mathrm{f}$.

136 Lilliestråle, Lag-förbättring, 7-9, 49-51.

137 Ibidem, 13, 21-24, 32. 
138 Torbern Bergman, Tal, om chemiens nyaste framsteg [...] (Stockholm, 1777), 5-7; Sparrman, 19-22, 26. En mörk betraktelse över det församhälleliga tillståndet återfinns också hos statssekreteraren Elis Schröderheim (Schröder), som deklarerade att samhällsgemenskapen med tiden bibringade fredliga näringar och att ett folk som levde i naturlig jämlikhet, utan att bindas av lagar och överhet, bara kunde skapa rättvisa med våld och bestraffa brott genom självhämnd. Elis Schröderheim, Tal, om den uplysning Sveriges gamla lagar lemna om våre förfäders seder och tänkesätt [...] (Stockholm, 1789), 13, 17.

För Bergmans och Sparrmans negativa Rousseaureception, se Persson, "Tillståndet".

139 Johan Abraham Grill, Tal, om silfvers årliga förande til China, huruvida det är för Europa nyttigt eller skadeligt [...] (Stockholm, 1774), 5; Carl Christopher Arfvedson, Tal, om handels-balancen [...] (Stockholm, 1789), 6.

140 Dalberg, Luften, 22.

141 Bengt Ferrner, Försök at visa, det olika climater icke verka hos folkslagen olika lynnen och själens förmögenheter [...] (Stockholm, 1780), 4 f., 16 f. Ett perspektiv liknande Ferrners anlades av Samuel Sandels, som presenterade bofastheten som en nödvändig konsekvens av jordbruk och boskapshållning. Sandels, Förhållandet, 6.

142 Gadolin, Vetenskaper, 12 f., 15.

143 Rosenstein, 20-22. En medfödd drift fick människorna att uppfinna och uppfylla nya behov, och det ena behovet skapade det andra. Ibidem, 59. Rosensteins uppfattning om vetenskapen som en konsekvens av behoven delades av kanslirådet Gudmund Jöran Adlerbeth. Adlerbeth menade att naturstudiet stammade från det allmänna levernets behov, som jämte de mänskliga själsförmögenheterna drivit fram större naturkännedom. Upptäckten av allt fler nyttigheter hade genererat en praktisk kunskap om naturen som fört med sig vetenskaplig utveckling. Ett mer kultiverat levnadssätt och en åtföljande stegring av begären var förknippade med att naturen gjordes till människans skattdragare. Gudmund Jöran Adlerbeth, Tal om en philosophisk varsamhet vid naturens betraktande [...] (Stockholm, 1790), $6 \mathrm{f}$.

144 Rosenstein, 52, 56, 63 f., 132.

145 Ibidem, 54, 57, 93 f., 129, 175. Rosenstein anförde att det fanns klandervärda, upplysningsfientliga och despotiska regeringar som "glömt sit uphof och ändamålet af deras stiftning" och trampat på de mänskliga rättigheterna, missbrukat sin makt och särbehandlat medborgarna. Andra styrande hade utifrån de bästa och mest välmenande intentioner sökt framtvinga lycksalighet på tvärs mot sina underlydandes önskningar och härvidlag sett dessa som barn att förmynda. Ibidem, $55 \mathrm{f}$.

146 Ibidem, 44-46.

147 Ibidem, 152, 159 f., 163, 166, 176-78. 
148 Ibidem, 88. Utan behovet av andra saknades såväl ett samhälle som begrepp om rättvisa och orättvisa. Ibidem, 89 .

149 Rosenstein ansåg att skriftställare som bröt mot lagar, angrep regeringssätt och smädade monarker borde bestraffas, men även att det var skadligt att driva intoleransen för långt, som i Frankrike. Ibidem, 178, 183.

150 Det rörde sig om "en inskränkning af det vi kalla Naturliga rättigheter och medfödd frihet, et tvång på vissa af våra böjelser och vissa gerningar, som eljest kunnat vara likgiltige, en minskning af det vi kalla naturlig jemnlikhet, och en nödvändighet, at tåla vissa företräden, och hos andra se större förmåner, än dem man sjelf äger”. Ibidem, 181 f., 184 .

151 Rosenstein höll före att upplysningen bidrog till samhällens lycksalighet och beskrev de förbättringar som denna fått till stånd utan skakningar, blodutgjutelse och ödeläggelse. En riktig upplysning kullkastade fördomarna, gav sann övertygelse, väntade rättelse av tiden och förde med sig saktmod, tolerans och "en afsky för våldsamma utvägar. Sällan såg man de Uplyste vara orolige Medborgare". Han varnade för undertryckande av sanningen, som kunde krossa alla hinder, "tränga genom eld och lågor" och segra med hjälp av våld, varvid dess arv blev blodbesudlat och olycksmärkt. "Revolutioner" hade åstadkommit sanna förändringar i tänkandet och den oupplysta menigheten var en härd för oro och jäsning som kunde utmynna i folkresning, fanatism och förstörelse. Rosenstein poängterade att frånvaron av våld vid sanningens realiserande var att föredra och att de häftiga utbrotten var möjliga att undvika. Ibidem, 178 f., 191, 193-97. Budskapet, som tydligt anknöt till Frankrikes pågående revolutionsprocess, var att det låg i samhällsledningens intresse att befordra upplysning för att slippa riskerna associerade med dess hämmande. För argumentationens koppling till franska revolutionen, se Segerstedt, 305.

Presidietalets motto "Veritas visu et mora valescit", 'Sanningen vinner i styrka genom långvariga observationer' - ett citat från den antike historikern Tacitus - kan läsas som en uppslutning bakom långsamma samhällsförändringar. Segerstedt, $323 \mathrm{f}$.

152 Det ålåg skriftställarna att återställa lugn och återkalla människorna till måttfullhet och sans; det var deras rätt att förmedla sanningen och deras plikt att göra det utan skada. Rosenstein, 198-200. Rosenstein tog upp de problem franska revolutionen vållade för det europeiska förbättringsarbetet. Han var noga med att markera avstånd till jakobinismen, även om han också intog en mer neutral position genom att ange att framtiden skulle förkunna dom över revolutionen. De revolutionära skadeverkningarna skulle dessutom till syvende och sist komma att annulleras: "Människorne äga så stort behof af Samhälls lefnaden, at de slutligen måste öfvertygas om riktigheten af alt hvad för Samhället är nödvändigt. Det är ur detta skäl, som man altid sett lugnet återkomma efter skakningarne, lydnaden efter sjelfsvåldet, ordningen efter 
oredan. Man kan vara säker at de rätta och nyttiga begrepen, om de för en tid kunna försvagas och kullslås, en dag skola återtaga sit välde.” Ibidem, 200-03, 215.

Harald Gustafsson, Makt och människor: Europeisk statsbildning från medeltiden till franska revolutionen (Göteborg, 2010), 179 f.; Hallberg, Ages, 138; Legnér, 17; Melkersson, 78, 80.

154 Östlund, 26, 29-31; Nordin, Folk, 334; Alm, 122.

155 Runefelt, Dygden, 28 f., 31 f., 34-36, 44.

156 Pehr Elvius, "Svar, gifvit på Kongl. Vetensk. Academiens vägnar [...]”, i Polhem (1745), 19; Scheffer, Grund-lagarna, 19. Se även Samuel Klingenstierna, Tal, om de nyaste rön vid elektriciteten [...] (Stockholm, 1755), 26.

157 Abraham Bäck, Tal om nyttan som tilflyter läkarekonsten, af et väl inrättadt lazaret eller sjukhus i Stockholm [...] (Stockholm, 1746), 3; Johan Fredrik Kryger, Tal om lagarnas och sedernas verkan på borgerliga näringar [...] (Stockholm, 1767), 18, 25; Mennander, Folkhopen, $5 \mathrm{f}$.

Bergsrådet Samuel Gustaf Hermelin åberopade de enskilda hushållen, de större sammanslutningarna, landsorterna och världens länder och kontinenter som bevis när han uttolkade Skaparens avsikt att inbördes biträde överallt skulle vara för handen. Samuel Gustaf Hermelin, Tal, om näringarnes förhållande uti rikets särskilde lands-orter [...] (Stockholm, 1774), 2.

158 Se även De Geer, Alstring, 25, där det slogs fast att insekter som bildade samhällen var tvungna att leva många tillsammans eftersom de behövde varandras handräckning för sitt uppehälle och sina barns uppfostran.

159 Arthur O. Lovejoy, The great chain of being (1936), ny uppl. (Cambridge, 1998), 59, 186, 205-07.

160 Runeberg, Nyttan, 5; Roland Martin, Tal, om nervers allmänna egenskaper $i$ människans kropp [...] (Stockholm, 1763), 50; Adlerbeth, 41, 52. Se även Johan Carl Wilcke, Tal, om magneten [...] (Stockholm, 1764), 1 f.; Bergius, Läckerheter, II, 104 f., 181. För Sparrman var varje okänd livsform i Söderhavets länder en länk i naturens kedja som väl utforskad fullbordade "nyttan af detta säkraste led-bandet, til så väl skapade tingens vackra och nyttiga sammanhang, som til Skaparens vishet och ärande". Sparrman, 18.

161 Schönberg, 26; Scheffer, Grund-lagarna, 18 f. Se även Adlerbeth, 32; Rosenstein, 14, 71, 84. För Schönbergs politiska hemvist, se Anders Burius, "Anders Schönberg", Svenskt biografiskt lexikon, band 31.

162 Salander, 12; Lillienberg, Förmåner, 5 f.; Pehr Högström, Tal om landt-manna näringar $i$ Wästerbotten, besynnerligen Skellefta soken [...] (Stockholm, 1765), 6; Gustaf Adolf Leijonmarck, Tal, om utsigten för svenska bergshandteringen $i$ framtiden [...] (Stockholm, 1775), 35. Se även Pehr Wilhelm Wargentin, "Svar, gifvit på Kongl. Vetenskaps Academiens vägnar [...]", i Stockenström (1767), 
36 f.; Johan Liljencrantz, Tal, om Sveriges utrikes handel $i$ allmänhet, och den levantiska i synnerhet [...] (Stockholm, 1770), 70; Runeberg, Nyttan, 7.

163 Johan Carl Wilcke, "Svar, gifvet på Kongl. Vetenskaps Academiens vägnar", i Schröder, 23; Runeberg, Nyttan, 17; Schönberg, 13 f. Se även Hermelin, 3, 19, 23.

164 Rosenstein, 32, 84; Sandels, Inrättning, 8 f., $13 \mathrm{f}$. En ledamot anmärkte att de nyttiga och djupsinniga frågor Vetenskapsakademiens ledamöter ägnade sig åt ofta krävde att de begagnade sig av varandras kompetenser och kunskaper. Herman Schützercrantz, Tal, om chirurgiens nuvarande tilstånd [...] (Stockholm, 1755), 1 f. För ömsesidigheten bland vetenskaper och kunskaper, se även Mårten Strömer, Tal om förbindelsen imellan astronomien och styrmans-konsten [...] (Stockholm, 1756), 7; Högström, 6; Wargentin, "Svar", i Stockenström (1767), 36; Sandels, Inrättning, 8; Gadolin, Vetenskaper, 20; Sparrman, 29; Lilliestråle, Tale-konsten, 5 .

Föreställningar om "samhällen" på olika nivåer som analoga storheter återfinns på flera håll i presidietalen, bland annat i Wargentins parallellisering av byn med landskapet och den överordnade samhällsgemenskapen: "Det som plägar säjas om en By, kan med skäl lämpas til hela Riken och Landskaper; så By, som Bonde: så vackert och godt är Landet, som Invånarne äro trefne [aktiva], eftertänksame och flitige at upodla det." Pehr Wilhelm Wargentin, "Svar, gifvet på Kongl. Vetensk. Academiens vägnar [...]", i Tiburtius, 23.

165 Sparrman, 18 f.; Lilliestråle, Tale-konsten, 22.

166 Legnér, 127; Johannisson, Samhället, 120; Runefelt, Dygden, 44.

167 Forsman, 147.

168 Henning Adolph Gyllenborg, Tal, om den omsorg våra förfäder användt til öfverflöds afskaffande [...] (Stockholm, 1757), 14; Leijonmarck, Utsigten, 6 f.; Grill, Silfver, 26 f.; Rosenstein, 37 f., 192. Se även Mennander, Folkhopen, 26; Sandels, Förhållandet, 30.

Dikotomin mellan enskilt och allmänt kunde formuleras på olika vis. Till exempel använde sig Melanderhielm av termerna "Private" och "Publicum", medan Rosenstein den yngre gjorde en distinktion mellan det enskilda respektive det nationella, det allmänna, det gemensamma, det borgerliga, mängden, folket och samhället, men också det allmänmänskliga. Daniel Melanderhielm, Tal, om de mathematiska vetenskapernas nytta i krigskonsten och alla dess särskilda grenar [...] (Stockholm, 1782), 6; Rosenstein, 23, 29, 31, 36, 38, 59, 68, 73, $96 \mathrm{f} ., 128,139$.

169 Se exempelvis Schultze, Ungdomen, 20; Nils Psilanderhielm, Tal, om mineralsamlingar [...] (Stockholm, 1755), 10; Johan Fredrik Kryger, Tal om folkbristens orsaker, verkan och hjelp [...] (Stockholm, 1758), 31; Johan Carl Wilcke, ”Svar, gifvit på Kongl. Vetensk. Academiens vägnar [...]", i Schulzenheim, 44; Carl Gustaf Löwenhielm, Tal om ungdomens upfostran i et välbestäldt regemente 
[...] (Stockholm, 1767), 43; Liljencrantz, 35 f., 49; Alströmer, Får-afveln, 103; Pehr Wäsström, Tal, om skogs, i synnerhet bräders, besparing vid byggnader [...] (Stockholm, 1774), 3; Leijonmarck, Utsigten, 19; Nils Adam Bielke, Tal, om det första lyckliga tidehvarfför Sveriges allmänna hushållning, under Konung Gustaf d. I:s regering [...] (Stockholm, 1776), 16, 26 f.; Melanderhielm, Vetenskaperna, 6; Carl Peter Thunberg, Tal, om japanska nationen [...] (Stockholm, 1784), 3; Rosenstein, 135 .

170 Johan Carl Wilcke, "Svar, gifvet på Kongl. Vetenskaps Academiens vägnar [...]", i Rosenstein, 219; Lilliestråle, Lag-förbättring, 8 f.; Gyllenborg, 3, citat från idem; Sven Bunge, Tal, innehållande några anmärkningar vid landthushållningen $[\ldots]$ (Stockholm, 1775), 11 .

Mennander förfäktade att dygdigt leverne befrämjade såväl det enskilda som det allmänna bästa och målade upp ett tillstånd där goda utkomstmöjligheter reflekterades i befolkningstillväxt, varvid folket sattes i stånd att följa sina preferenser och samhällets önskemål. Mennander, Folkhopen, 30-32.

171 Scheffer, Grund-lagarna, 27; Schönberg, 11 f., 36, citat från idem; Högström, 4. Se även Liljencrantz, 14, 32; Bengt Qvist, Tal, innehållande några anmärkningar öfver metall- och mineralvaror samt deras afsättning [...] (Stockholm, 1776), 4.

172 Ferrner, 14 f.; Runeberg, Nyttan, 12.

173 Rosenstein, 37, 44.

174 Rosenstein, 95 f., 113 f., 116, 118, 120, 123-25, 156, 164 f.; Jean-Jacques Rousseau, "The social contract" (1762), i The social contract and The first and second discourses, red. Susan Dunn (New Haven, 2002), 172. Rosenstein definierade politisk upplysning som "en rätt kännedom af hvad som hör til Samhällets väl och dess medlemmars lycksalighet". Han skilde på enskilda dygder, som rörde samspelet individer emellan, och en allmän dygd, rättvisan, som innefattade och utgjorde grunden för de övriga dygderna. Den som hade det ena tenderade att även äga det andra. Enligt Rosenstein var det inte ett problem att någon på en och samma gång gynnade både sig själv och det allmänna, men en förvänd ordning att sätta det enskilda framför det allmänna. Rosenstein, 120,123 f., 133 .

175 Rosenstein, 51, 70, 152 f., $155 \mathrm{f}$.

176 För denna föreställning, se Nell, 60.

177 Gadolin, Vetenskaper, 11; Gustaf von Engeström, Tal, om vissa svårigheter och andra omständigheter, som möta vid utöfvandet af chymien [...] (Stockholm, 1782), 15. Se även Gustaf von Engeström, Tal om mineralogiens hinder och framsteg i senare åren [...] (Stockholm, 1774), 19; Bunge, 10; Sparrman, 27. Jämför Bergius, Frukt-trägårdar, 6; Schröder, 8-10.

178 Dunér, 288 f.; Runefelt, Dygden, 170 f.; Lindroth, Vetenskapsakademien, I:1, 364. 
179 Mennander, Folkhopen, 5 f.; Herman Schützercrantz, Tal, om den tilväxt och de hinder, som barn-förlossnings-vetenskapen haft, iflere åldrar, til närvarande tid [...] (Stockholm, 1777), 78; Kryger, Lagarna, 12 f., citat från idem. Se även Carl Didrik Ehrenpreus, "Svar, gifvit å Kongl. Vetenskaps Academiens vägnar [...]", i Schultze (1750), 29; Johan Carl Wilcke, Tal, om de nyaste förklaringar öfver norr-skenet [...] (Stockholm, 1778) [4].

180 Ehrensvärd, Ungdomen, 19. Kvintin var liksom pund ett viktmått.

181 Browallius, 7 f.; Lilliestråle, Tale-konsten, 21. Sparrman anlade ett funktionalistiskt perspektiv på naturens utforskande när han gjorde gällande att var och en efter sin lott skulle hjälpa till att undersöka och nyttiggöra naturens skatter. Sparrman, 14 .

182 Carl Carleson, Tal om spanmåls-bristens afhjelpande [...] (Stockholm, 1759), 5; Lilliestråle, Lag-förbättring, 8 f., citat från idem. Se även Carl Hårleman, Tankar $i$ anledning af utländska resor [...] (Stockholm, 1746), 11. Jämför Browallius, $21 \mathrm{f}$.

183 Martin, 46; Ferrner, Försök, $15 \mathrm{f}$.

184 För snillevalet, se Liedman, Handen, 211 f.; Lindroth, Lärdomshistoria, 69; Runefelt, Dygden, 149 f., 162.

185 Browallius, 21-23. Ledamotskollegor till Browallius förespråkade att den som hade läggning för en syssla skulle ledas dit och återgav hur nödvändiga åtgärder för att identifiera begåvningar vidtagits under Fredrik I:s regering "på det denna ädla Trä-Skola må rätt utplantas och et ämne til en närande Lem i Republiquen [riket] ej må få göra sig til blott tärande och ofta ej allena onyttig, utan ock skadelig”. Daniel Ekström, Tal, om järn-förädlingens nytta och vårdande [...] (Stockholm, 1750), 23; Carl Fredrik Piper, Tal, hållit för Kongl. Svenska Vetenskaps Academien [...] (Stockholm, 1751), 5, citat från idem.

Ur Högströms synvinkel hängde människosläktets överlevnad på att en mängd olika behov tillfredsställdes, varför Gud sett till att ett samhälle ägde så många utövare av allehanda sysslor som behövdes för invånarnas trevnad och fortvaro. Målet var att uppnå ett tillräckligt antal människor som av naturen var benägna för alla slags näringar och yrken och alltså av Försynen utsetts till att bedriva dem. Ett villkor för att en riktig och välståndsbringande arbetsfördelning skulle åstadkommas var att varje människa tilläts följa sin böjelse. Högström, $3 \mathrm{f}$.

186 Löwenhielm, Ungdomen, $8 \mathrm{f}$.

187 Sparre, $26 \mathrm{f} ., 32$.

188 Rosenstein, $29 \mathrm{f}$, se även $40 \mathrm{f}$.

189 Ibidem, 148.

190 För exempel på bildspråkets antika rötter, se Nell, 74, 199, 218 f. Samhället gestaltades inte minst med hjälp av bin och myror. Johannisson, Samhället, 102 f.; Dunér, 288. 
191 Dunér, 292-94, 309. Jämför diskussionen om 1600- och 1700-talens allegoriska tänkande i Skuncke, Gustaf III, 71.

192 Pasi Ihalainen, "New visions for the future: Bodily and mechanical conceptions of the political community in eighteenth-century Sweden", i Hopes, red. Karonen, $315 \mathrm{f}$.

193 Bildliga element kan göra det besvärligt att skilja mellan yta och djup i en text, medan frågan om en parallell ansågs existera utanför sitt textuella sammanhang långt ifrån alltid är enkel att besvara. Jämför Broberg, Homo sapiens L., 7-9, 104-05. Sten Lindroth har hävdat att de förbindelser Carl von Linné upprättade mellan samhälle och natur bara var didaktiska instrument eller utslag av en sagostil och väsentligen saknade innehåll: "Inte minst älskade Linné, när han var på det humöret, att förmänskliga, att beskriva naturen och dess innevånare i antropomorfa termer. Han menade just ingenting med det utan gjorde det av pur glädje och därför att han alltid ville vara åskådlig i högsta grad." Andra forskare har varit mer öppna för bildspråkets betydelsebärande dimensioner. Enligt Carola Nordbäck framgår en ofta förbisedd komponent i Anders Chydenius frihetsuppfattning, nämligen hans sammanfogande av naturrätt och fysikoteologi, av hans metaforer, som ådagalägger "en omfattande analogi mellan mekanikens rörelselagar och samhällets naturliga principer. Den centrala kopplingspunkten för analogin var Guds allmakt och skaparkraft." Sten Lindroth, "Linné - legend och verklighet", Lychnos 1965-1966, 62 f.; Nordbäck, 369, 373.

194 Daniel Tilas, Utkast til Sveriges mineral-historia [...] (Stockholm, 1765), $16 \mathrm{f}$. Se även Cederhielm, 5 f.; Kryger, Lagarna, 11; Celsius, 15, 53.

195 Deirdre McCloskey, The rhetoric of economics (1985), 2 uppl. (Madison, 1998), xix.

196 Henrika Tandefelt, Konsten att härska: Gustaf III inför sina undersåtar (Helsingfors, 2008), 25, 31.

197 Edward L. Rubin, Soul, self, and society: The new morality and the modern state (Oxford, 2015); Lynn Hunt, The family romance of the French Revolution (Berkeley \& Los Angeles, 1992), 3.

198 Dunér, 293 f., 309; Melkersson, 78, 81, 83 f.; Skuncke, Gustaf III, 35 f. Se även Johannisson, Samhället, 15, 29; Legnér, 87.

199 Englund, 46; Ihalainen, 317 f., 330-32, 339 f.; Magnusson, "Diskussionen", 36; Skuncke, Gustaf III, 35 f.

200 Jonas Alströmer, Sveriges wälstånd om det will [...] (Stockholm, 1745), 29; Scheffer, Grund-lagarna, 8. Se även Ankarcrona, 8; Hårleman, 4; Johan Clason, Tal, om Sveriges handels omskiften [...] (Stockholm, 1751), 18; Carl Fredrik Scheffer, Tal, hållit för Kongl. Vetenskaps Academien [...] (Anmärkningar om vetenskapers, vitterhets och konsters närvarande tillstånd $i$ vårt rike) (Stockholm, 1755), 13; Gyllenborg, 3; Runeberg, Varor, 40. Emellanåt begagnades 
andra termer, som "regementskroppen", "statskroppen", "den politiska kroppen" och "samhällskroppen". Gyllenborg, 6; Runeberg, Varor, 28; Lilliestråle, Lag-förbättring, 50; Mennander, Folkhopen, 29; Ferrner, Försök, 17; Sparre, 32.

201 Johan Carl Wilcke, "Svar, gifvet på Kongl. Vetenskaps Academiens vägnar [...]", i Arfvedson, 16; Pehr Wilhelm Wargentin, "Svar, gifvet på Kongl. Vetensk. Academiens vägnar [...]", i Jennings (1761), 30.

Det hette också att de förmånliga konsekvenserna av måleriet, bildhuggeriet och arkitekturen spred sig genom det borgerliga samhället med samma nyttiga verkan som blodet i en levande kropp, liksom att överskottet som de förmögna inbetalade till rikets skattkammare strömmade tillbaka ut i rikskroppen på samma vis "som om bloden liknelse-vis sagt är". Adelcrantz, $19 \mathrm{f}$.

202 Kryger meddelade därutöver att Sverige tack vare frihetstiden uppnått den stora fördelen att politiska åderlåtningar inte längre tappade rikskroppen på det friskaste blodet, eftersom krig inte längre fick utkämpas i vinningssyfte. Kryger, Folkbristen, 21, 30; Kryger, Lagarna, 13, 27.

203 Bielke, 35.

204 Wrede, 11, 27; Jacob Faggot, "Svar, på Kongl. Vetenskaps Academiens vägnar", i Wrede, 38; Jacob Faggot, "Svar på Kongl. Vetenskaps Academiens vägnar", i Vallerius, 27.

205 För samhällets lemmar, se Höpken, Yppighet, 18; Ljungenstjerna, 45; Alströmer, Schäferierna, 13; Pehr Wilhelm Wargentin, "Svar, gifvit på Kongl. Vetenskaps Academiens vägnar [...]", i Ungern-Sternberg, 15; Pehr Wilhelm Wargentin, "Svar, gifvit på Kongl. Vetensk. Academiens vägnar [...]", i Kryger (1758), 41; Abraham Bäck, Tal om farsoter, som mäst härja ibland rikets allmoge [...] (Stockholm, 1765), 2, 50; Kryger, Lagarna, 17 f.; Scheffer, Grund-lagarna, 23. Carl Sparre ansåg det åvila politien att skilja "de skadeliga medlemmar från Samhälls-kroppen". Sparre, 32. Den närande arbetade medan den tärande levde på sina medmänniskors arbete. Runefelt, Dygden, 126.

För samhällets invärtes tillstånd och rörelse, se Wargentin, "Svar", i UngernSternberg, 15; Jacob Faggot, Historiens fortsättning om svenska landtmäteriet och geographien [...] (Stockholm, 1760), 23; Scheffer, Grund-lagarna, 7. Runeberg diskuterade samhällslemmar i inbördes rörelse. Runeberg, Varor, $10 \mathrm{f}$. För termen "invärtes" i relation till människokroppen, se Strandberg, Febrar, 6, 30; Schützercrantz, Chirurgien, 6, 8-13; Stiernman, 9.

206 Det noterades bland annat att förbättringar kunde vara foster av sin samtid, att sanningar och inrättningar framföddes samt att lagarna liksom människorna hade en livscykel och tillkom i synd. Rosenstein, 69; Lilliestråle, Lag-förbättring, $33 \mathrm{f}$.

207 Carl Albrecht Rosenadler, Tal, om de närings-medel, som synas kraftigast kunna verka på fäderneslandets förkofran [...] (Stockholm, 1767), 9; Lillienberg, Förmåner, $5 \mathrm{f}$. 
208 Pehr Wilhelm Wargentin, "Svar, gifvit å Kongl. Vetenskaps Academiens vägnar [...]", i Löwenhielm (1751), 6o; Olof af Acrel, Tal om nödvändigheten och förmånen af de chirurgiska handalagens förkortande i utöfningen [...] (Stockholm, 1767), 75; Prosperin, 6.

209 Hårleman menade därutöver att statsmakten ("Kronan") i Frankrike liksom sågs som en i förhållande till undersåtarna autonom varelse. Hårleman, 29, 32. Enligt Olof von Dalin hade Europa blivit som en kropp där makterna var lemmar vilka bistod eller hindrade varandra. Olof von Dalin, Tal vid praesidii afläggande om Sverige i sit ämne och Sverige i sin upodling [...] (Stockholm, 1749), 4.

210 Tore Frängsmyr, Geologi och skapelsetro: Föreställningar om jordens historia från Hiärne till Bergman (Stockholm, 1969), $54 \mathrm{f}$.

211 Daniel Tilas, Stenrikets historia [...] (Stockholm, 1742), 6, 23. Den ekonomiske och vetenskaplige mångsysslaren Mårten Triewald anmärkte att "vatnet, som silar och genomflyter jordenes inelfvor och klyfter gör just det samma til at föda och alstra malmer, samt främja mineraliers tilväxt, som blodet och vätskorna i de lefvande djuren". Såväl vattnets som blodets skapande och närande effekter berodde på de aktiva och levande krafter Gud nedlagt i materien. Bergmästaren Bengt Qvist talade i likhet med Triewald om jordens inälvor, samtidigt som han häcklade och därmed tog avstånd från det gamla försanthållandet att mineralriket liksom djurriket hade fruktsamma invånare. Mårten Triewald, Tal, om ämne och orsaker till metallernes och mineraliernes födo, tilltagande och mognande växt i jorden [...] (1740) (Stockholm, 1748), 11 f.; Bengt Qvist, Tal, innehållande några anmerkningar om en nyttig mineral-samlare [...] (Stockholm, 1782), 10, 21.

Liknande parallelliseringar hittas i flera av talen. Se Eric von Stockenström, Bergsmannanäringens nytta och skötsel [...] (Stockholm, 1749), 10; Tilas, Utkast, 93, 96, 103 f.; Ferrner, Tvisten, 46, 53; Stockenström, Järn-bruk, 7; Adolph Modeer, Tal, om några ämnen, som uti de tre naturens riken förunderligen likna hvarandra, så til utseende, som ock merändels til bruk och nytta [...] (Stockholm, 1791), $2 \mathrm{f}$.

212 För det svenska 1700-talets tankar om smittor i den politiska kroppen, se Ihalainen, 322.

213 Clason, Handels omskiften, 18; Sandels, Förhållandet, 32; Rosenstein, 179 f.; Höpken, Yppighet, 7 f.; Wrede, 17 f. Se även Meijer, 20; Jacob Gadolin, Tal, om gränsorne imellan det vi uti naturen känne, och det vi ännu icke hunnit fatta [...] (Stockholm, 1761), 7; Wargentin, "Svar", i Tiburtius, 24; Kryger, Lagarna, 9 f., 15, 31; Scheffer, Grund-lagarna, 8 f.; Sandels, Förhållandet, 87 f.

214 Shapin \& Schaffer, 299. Presidietalen hävdade att de antika romarnas lyx utgjort en smitta som bekämpats med hälsosamma lagar, att frihetstidens penningbrist var en sjukdom med vederbörlig kur och att myntfotens förändring trots att 
den kanske skulle komma att skaka om rikskroppen kunde vara lika mycket av godo som en medicin vilken syntes förvärra patientens sjukdom när den bröt febern. De som förordade penningpolitiska alternativ till en positiv handelsbalans jämfördes med nyblivna läkare som misstog sårskorpor för läkta sår, och med dåliga trädgårdsmästare som lade om grenarna då roten blivit sjuk eller stammen drabbats av kallbrand. Gyllenborg, 5 f.; Sandels, Förhållandet, 8o; Runeberg, Varor, 40; Wrede, 19 f. Se även Pehr Wilhelm Wargentin, "Svar, gifvet å Kongl. Vetensk. Academiens vägnar [...]", i Carleson (1759), $18 \mathrm{f}$.

215 Clason, Orsakerna, 31 f., 34, 38, 42; Lilliestråle, Lag-förbättring, 10, 26. Växelkontoret var ett statligt organ som tillskapades 1747 för att bringa ned Sveriges växelkurser. Det beskylldes under mössregimen för att istället ha drivit upp dem så att de inblandade kunde sko sig själva. Magnusson, Sverige, 268.

Kryger betecknade det förflutnas hushållning som ett sjukdomstillstånd, framtida generationers sällhet som ett hälsosamt ändamål och hushållningskunskapen som analog med läkekonsten. Samtidens sjuka samhälle skulle helas med kraftfulla ekonomiska åtgärder och med kunskap som den Kryger själv presenterade; kännedom om åkomman utgjorde det första steget på vägen till hälsans återupprättande. Näringarnas brist på folk och folkets brist på näringar var den huvudsakliga sjukdom som vidlådde det utmattade svenska samhället. Det fanns knappt någon sjukdom i den allmänna hushållningen som inte kunde härledas till folkbristen, vilken borde tas upp till diskussion eftersom ignorerandet av sjukdomar gjorde dem vådligare och i värsta fall obotliga. Till rikshushållningens sjukdomar hörde importen, de inhemska varornas ofullkomlighet och dyrhet samt den bristfälliga arbetsfördelningen mellan städer och landsbygd. Kryger, Folkbristen, 3, 8 f., 11-13, 28 f.; Kryger, Lagarna, $4 \mathrm{f}$.

216 Christopher Polhem, Tal öfver den vigtiga frågan: Hvad som vårt kära fädernesland hafver nu måst af nöden til sin ständiga förkofring i längden? [...] (Stockholm, 1745), 7 f.; Grill, Silfver, 25; Browallius, 5, 19 f.; Carl Gustaf Tessin, Kårt tal om svenska språkets rykt och upodlande [...] (Stockholm, 1746), 5; Rudenschöld, Språket, 4. Se även Carl Fredrik Mennander, Tal om bok-handelen i Sverige [...] (Stockholm, 1756); Löwenhielm, Ungdomen, 42; Bergius, Läckerheter, I, 49 .

I ett par sammanhang förekom istället termen "gift". Exempelvis var yppigheten ett "förgift" som kunde göra den politiska kroppen kraftlös. Mennander, Folkhopen, 29; Lilliestråle, Lag-förbättring, 11, 51.

217 Spary, $178 \mathrm{f}$.

218 Fredrik Palmqvist, Tal, om mathematiska vetenskapernas nytta $i$ allmänna lefvernet [...] (Stockholm, 1754), 4; Salander, 7; Alströmer, Sverige, 6, 28. Se även Clason, Handels omskiften, 4; Ungern-Sternberg, 9.

219 Bergius, Läckerheter, I, 16; De Geer, Alstring, 1; Bäck, Farsoter, 50. 
220 Wilcke, "Svar", i Schulzenheim, 43 f. Se även Bunge, 8; Ferrner, Försök, 15, 18, 20; Scheffer, Grund-lagarna, 10; Modeer, 11; Rosenstein, 56, 175.

221 Alströmer, Schäferierna, 5; Ungern-Sternberg, 2; Pehr Wilhelm Wargentin, "Svar, gifvit på Kongl. Vetenskaps Academiens vägnar [...]", i Salander, 19 f.; Rosenadler, 9, 11. Wargentin önskade i ett av sina svar att Alströmers inrättningar för all framtid skulle tillväxa och blomstra. Pehr Wilhelm Wargentin, "Svar, gifvit på Kongl. Vetensk. Academiens vägnar [...]", i Alströmer (1760), 19.

222 Browallius, 36; Pehr Wilhelm Wargentin, "Svar, gifvet på Kongl. Vetenskaps Academiens vägnar [...]", i Löwenhielm (1767), 49 f.; Rabbe, 115 f.; Carl Rudenschöld, Tal, hållne, under Kongl. Majestets höga öfvervaro, uti dess Vetenskaps Academie [...] (Stockholm, 1779), 6.

För ytterligare växtbilder i relation till Vetenskapsakademien, se Tilas, Utkast, 4; Kryger, Lagarna, 31 f.; Sandels, Inrättning, 28, 38; Matthias Benzelstierna, Tal, om vissa hushållsmått at ständigt vidtagas, til at minska landtmannens förlägenhet vid påkommande missväxter, och med detsamma öka jordens årliga afkastning och värde [...] (Stockholm, 1788), 3; Johan Carl Wilcke, "Svar, gifvet på Kongl. Vetenskaps Academiens vägnar [...]”, i Benzelstierna (1788), 16; Johan Carl Wilcke, ”Svar, gifvet på Kongl. Vetenskaps Academiens vägnar [...]”, i Schröderheim, 28. Lärda samhällen hade enligt ett tal fått de snillefrön som naturen och fördelaktiga omständigheter satt att växa och mogna. Prosperin, 7.

223 Alströmer, Schäferierna, 3; Bergius, Läckerheter, I, 11, 14; Melanderhielm, Vetenskaperna, $75 \mathrm{f}$. För fler växtbilder i relation till vetenskaperna, se Gadolin, Gränsorne, 12, 23; Högström, 6; Rabbe, 4; Schützercrantz, Tilväxt, 39 f.; Pehr Wilhelm Wargentin, "Svar, gifvet på Kongl. Vetenskaps Academiens vägnar [...]", i Schützercrantz (1777), 79; Gadolin, Vetenskaper, 25; Fredric Mallet, Tal, om de mathematiska vetenskapers befrämjande til allmännare nytta uti fäderneslandet [...] (Stockholm, 1786), 6, 8; Johan Carl Wilcke, "Svar, gifvet på Kongl. Vetenskaps Academiens vägnar [...]", i Hjelm, 42; Rosenstein, 42.

224 Löwenhielm, Ungdomen, 5, 10; Kryger, Lagarna, 7; Alströmer, Sverige, 8 f., $21 \mathrm{f}$. Carl Sparre fann att politiförvaltningens verktyg utgjorde "driffjädrarne i Machinen, som altid spände och, under Förvaltarens ögon, i rörelse, altid äro i stånd at, vid de minsta känningar han dem gifver, skaffa all den verkan, som påsyftas". Sparre, $33 \mathrm{f}$.

225 Lillienberg, Förmåner, 21; Lilliestråle, Tale-konsten, 7; Gadolin, Vetenskaper, 12; Prosperin, 6; Lilliestråle, Lag-förbättring, 27. Se även Bielke, 41; Schützercrantz, Tilväxt, 57, 68; Ferrner, Försök, 40; Sandels, Förhållandet, 56; Bergius, Läckerheter, I, 14 f.; Axel Magnus von Arbin, Tal, om kongl. svenska fortifications-statens inrättning [...] Fortsättning (Stockholm, 1787), 25; Rosenstein, 87, 90, 93, 170. 226 Pehr Wilhelm Wargentin, "Svar, gifvit på Kongl. Vetenskaps Academiens 


\section{NOTER}

vägnar [...]", i Strandberg (1752), 49; Jean George Lillienberg, Tal, om flera, $i$ senare tiden, skedde förbättringar uti bergs-vetenskapen och handteringen $i$ riket [...] (Stockholm, 1781), $10 \mathrm{f}$.

227 Martin, 4; Sandels, Inrättning, 17; Melanderhielm, Vetenskaperna, 76. Jämför Grill, Silfver, 3. Ett presidietal höll före att akademisekreteraren var "föga annorlunda $[. .$.$] at anse, än som Pendelen i Ur-verket". Bergius, Läckerheter,$ I, 17 .

228 Nils Rosén von Rosenstein, Tal, om en opartisk och förnuftig medici förnämsta göromål [...] (Stockholm, 1746), 15; Pehr Wilhelm Wargentin, ”Svar, gifvit å Kongl. Vetenskaps Academiens vägnar [...]", i Acrel (1750), 41 f.; Ljungenstjerna, 57.

229 Se till exempel Wargentin, "Svar", i Acrel (1750), 43; Wilcke, Magneten, 1; Löwenhielm, Ungdomen, 11; Celsius, 36; Rabbe, 48; Qvist, Mineralvaror, 14, 27 f.; Qvist, Mineral-samlare, 11; Sandels, Förhållandet, 72; Lilliestråle, Talekonsten, 7, 28 f., 45-47; Rosenstein, 18 f., 82, 152, 197, 203, 215.

230 Ehrenpreus, Konster, 23; Prosperin, 5; Scheffer, Grund-lagarna, 6, 29 f.

231 Bergman, 6 f., 40; Bäck, Nyttan, 6. För kroppen som en byggnad, se även Martin, 71; Schulzenheim, 11; Zetzell, Soldat, 7. För världen som en byggnad, se även Gadolin, Gränsorne, 10 f., 16, 29; Gadolin, Vetenskaper, 10.

232 Adlerbeth, 12, 35, 53; Nordenankar, 3. Se även Prosperin, 5; Adlerbeth, 54; Melanderhielm, Angelägenheten, 4, 12, 26 f., 46, 64, $67 \mathrm{f}$.

233 Meijer, 10; Sandels, Inrättning, 28, 38; Lilliestråle, Lag-förbättring, [5 f.], 8-10, jämför 12. Se även Johan Carl Wilcke, "Svar, gifvet, på Kongl. Vetenskaps Academiens vägnar", i Melanderhielm (1792), 71.

234 Orrje, 26 f., 129. Jämför Ihalainen, 315-18, 335; Johannisson, Samhället, 29 f. Ihalainen har uppmärksammat att hattar som Kryger från 1730-talets slut blandade mekaniska och organiska bilder av tillvaron. Ihalainen, 329, 333, 340.

235 Ankarcrona, 8; Stockenström, Bergsmannanäringen, 2; Qvist, Mineralvaror, 27. Se även Jacob Faggot, Historien om svenska landtmäteriet ock geographien [...] (Stockholm, 1747), 10; Lilliestråle, Lag-förbättring, 45.

236 Pehr Wilhelm Wargentin, "Svar, gifvit på Kongl. Vetenskaps Academiens vägnar [...]", i Clason (1751), 7o f.; Pehr Wilhelm Wargentin, "Svar, gifvit på Kongl. Vetensk. Academiens vägnar [...]", i Nordenskiöld, 31.

237 Lindberg, Naturrätten, 124.

\section{Myndiga makthavare, omyndig menighet}

238 Se till exempel Nordin, Folk, 262-66; Maria Adolfsson, Fäderneslandets kännedom: Om svenska ortsbeskrivningsprojekt och ämbetsmäns folklivsskildringar under 1700- och 180o-talet (Stockholm, 2000), 263 f.; Carl Frängsmyr, Klimat 
och karaktär: Naturen och människan i sent svenskt 170o-tal (Stockholm, 200o), 20-22.

239 Rudenschöld, Majestet, 8. Se även Bäck, Farsoter, 8; Carl Reinhold Berch, Tal, om svenska myntets ålder [...] (Stockholm, 1753), 7, 10; Mennander, Bok-handelen, 15; Högström, 14; Kryger, Lagarna, 6; Detlof Heijkenskjöld, Anmärkningar, vid bergs-handteringens åtskilliga öden och omväxlingar [...] (Stockholm, 1768), 12; Anders af Botin, Jämförelse imellan mynts och varors värden $i$ Sverige, uti särskildta tidehvarf [...] (Stockholm, 1771), 5; Nils Rosén von Rosenstein, Tal om pesten, och om dess utestängande ifrån et land [...] (Stockholm, 1772), 6; Bunge, 6; Lilliestråle, Lag-förbättring, 49; Lillienberg, Förmåner, 5; Bergius, Frukt-trägårdar, 50; Bergius, Läckerheter, I, 4; Bergius, Läckerheter, II, 108, 263; Thunberg, 7; Schröderheim, 17; Rosenstein, 211.

240 Alströmer, Sverige, 25 f.; Rudenschöld, Majestet, 6. Se även Acrel, Sjukdomar, 39; Bergius, Bad, 67; Bäck, Farsoter, 10, 13; Carl Johan Cronstedt, Tal, hållet för Kongl. Vetenskaps Academien [...] (Stockholm, 1771), 8; Sandels, Inrättning, 22; Axel Magnus von Arbin, Tal, om kongl. svenska fortifications-statens inrättning [...] (Stockholm, 1773), 30 f., 40, 44; Leijonmarck, Utsigten [3]; Lillienberg, Förmåner, 8; Sparre, 36; Bergius, Frukt-trägårdar, 54; Sandels, Förhållandet, 7, 73. Den kungliga överheten framställdes också som hög. Se exempelvis Pehr Wilhelm Wargentin, "Svar, gifvet, på Kongl. Vetenskaps Academiens vägnar [...]", i Wäsström, 23 f.; Benzelstierna, Hushållsmått, 7; Prosperin, 25.

241 För kungamakten och nåden, se Jonas Nordin, Frihetstidens monarki: Konungamakt och offentlighet i 170o-talets Sverige (Stockholm, 2009), 261.

242 Nordin, Frihetstiden, 21, 82, 219; Volker Sellin, "Regierung, Regime, Obrigkeit", i Geschichtliche Grundbegriffe: Historisches Lexikon zur politisch-sozialen Sprache in Deutschland, vol. 5, red. Otto Brunner (Stuttgart, 1984), 406 f. De svenska ämbetsmännen räknade frekvent sig själva till överheten, vilket stöder en vidlyftig tolkning av denna term. För ämbetsmännens självuppfattning, se Cavallin, 237. Jämför Liedman, Handen, 129; Runefelt, Dygden, 154.

243 Alströmer, Schäferierna, 5; Pehr Wilhelm Wargentin, "Svar, gifvit på Kongl. Vetensk. Academiens vägnar [...]", i Gyllenborg, 19. Se även Stockenström, Bergsmannanäringen, 15 f.; Ekström, 17; Bunge, 6. Wargentin klagade också på att lanthushållningen handlöst lämnats åt sig själv och hoppades att den skulle komma att få någon form av uppmuntran. Wargentin, "Svar", i Carleson (1759), 20.

244 För idén att regenten skulle sörja för det allmänna bästa, se Nilsén, 401.

245 Wrede, 33 f.; Alströmer, Sverige, 27; Ehrenpreus, Konster, 23.

246 Cederhielm, 5, 14, citat från idem; Schultze, Ungdomen, 21; Sandels, Inrättning, 5,38 .

247 Bielke, 45 f.; Ferrner, Försök, 45 f. Se även Bergius, Läckerheter, I, 11 f. Jämför Qvist, Mineralvaror, 26. 


\section{NOTER}

248 Se till exempel Adelcrantz, 43; Kryger, Folkbristen, 11; Faggot, Fortsättning, 15-18, 39; Jennings, Sluss-byggnad, 12-14; Wargentin, "Svar", i Jennings (1761), 31; Liljencrantz, $42 \mathrm{f}$.

249 Kryger, Folkbristen, 25; Alströmer, Sverige, 15 f., 26; Faggot, Historien, 49 f.; Sandels, Inrättning, 11. Schäferierna var "ett slags storjordbruk för fåravel med sikte på att ta fram kvalitetsull till yllemanufakturerna". Klas Nyberg, "Staten, manufakturerna och hemmamarknadens framväxt", i Till salu: Stockholms textila handel och manufaktur 1722-1846, red. Klas Nyberg (Stockholm, 2010), 97.

250 Olof af Acrel, Genaste sättet at inrätta och underhålla et lazaret eller sjukhus, så at det inom få år måtte ärnå en ansenlig tilväxt [...] (Stockholm, 1746), 1 f.; Wrede, 21-24, 26 f., 30 f., 33 .

251 Hermelin, 39, 72; Mallet, 8.

252 Salander, 6-8; Kryger, Folkbristen, 19. Se även Adelcrantz, 25; Wargentin, "Svar", i Jennings (1761), 30.

253 Hårleman, 10-13, 17. Hårleman betraktade därtill Danmarks Kongl. Maj:t som föredömlig vad gällde aktiv inblandning i Ostindiehandel och manufakturer, ett engagemang som sades ha givit gott resultat. Ibidem, 7.

254 Schönberg, $10 \mathrm{f}$.

255 Mattsson, 24 f.; Skuncke, Gustaf III, 35.

256 Adelcrantz, 19 f.; Meijer, 9, 15; Schönberg, 18, 35. Se även Löwenhielm, Landtskötsel, 53 .

257 Bergius, Läckerheter, I, 12; Bunge, 12 f. Jämför Hermelin, 14 f., 39 f., 67, 85; Lillienberg, Förmåner, 14 f.; Hjelm, 12 f., 20; Olof Swartz, Tal, om natural-historiens uphof och framsteg i Sverige [...] (Stockholm, 1794), 30. En ledamot tillmätte allmogen agens när han hävdade att den i Finland jämte frälset besatt en stor mängd skepp som befordrade inrikes transport och uppmuntrade näringar och avsättning. Hermelin, $109 \mathrm{f}$.

258 Reinhart Koselleck, Erfarenhet, tid och historia: Om historiska tiders semantik (1979), sv. övers. (Stockholm, 2004), 54-63; Hans Helander, Neo-Latin literature in Sweden in the period 1620-1720: Stylistics, vocabulary and characteristic ideas (Uppsala, 2004), 482-84; Skuncke, Gustaf III, 36 f., 143; Mattsson, 149-51. Se även Hallberg, Ages, 66-69, 79 f.

259 Sandels, Förhållandet, 7, 18; Dalin, 18; Gyllenborg, 8. Se även Nils Marelius, Tal, om Mälarens utlopp, med geographiska och historiska anmärkningar [...] (Stockholm, 1771), 21, 30; Stiernman, 3, 18; Swartz, 5-9. De fria konsterna bestod av en brokig samling verksamheter: arkitektur, bildhuggeri, konstgjuteri, ingenjörskonst, dans, musik, måleri. Nell, 253.

260 Clason, Orsakerna, 18; Lillienberg, Förmåner, 8; Lillienberg, Förbättringar, 10, 24.

261 Skuncke, Gustaf III, 79, 175, 251, 272; Nell, 69 f., 72; Mattsson, 55, 152 f. 
262 Gustav Vasa befrämjade stadsväsendet, förbjöd utförseln av råkoppar och järnmalm så att metallerna skulle förädlas inom landet och inledde en obehindrad och fri handel med ett flertal länder. Han eftersträvade en nödvändig god ordning bland köpmännen och sökte genom sitt föredöme förbättra deras näring och motverka importen av överflödsvaror. Monarken inriktade sig särskilt på åkerbruket, som utgjorde det säkraste sättet att tillfredsställa behoven, men bergshanteringen gjordes likaledes till föremål för hans ömma omsorg. Bielke, 14 f., 22-29, 32, 35-39, 41-44; Sandels, Förhållandet, 32-37; Swartz, 10-16. För Vetenskapsakademiens syn på Gustav Vasa, se även Clason, Handels omskiften, 18-20, 23-25, 27 f.; Mennander, Bok-handelen, 6 f.; Gyllenborg, 12, 15; Pehr Wilhelm Wargentin, "Svar, gifvet på Kongl. Vetenskaps Academiens vägnar [...]", i Bielke, 48 f.; Benzelstierna, Hushållsmått, $14 \mathrm{f}$.

263 Alströmer, Sverige, 22; Clason, Handels omskiften, 33-37; Heijkenskjöld, Anmärkningar, 12 f.; Clason, Orsakerna, 7; Bielke, 25; Sandels, Förhållandet, 40-43, 45. Se även Faggot, Historien, 8 f., 11-16, 21-32; Pehr Elvius, "Svar gifvit å Kongl. Vetenskaps Academiens vägnar [...]”, i Faggot (1747), 79; Claes Grill, Tal om sjö-fartens nytta och förmån för riket, i synnerhet då han drifves med hembygde och utur egne hamnar utrustade skepp [...] (Stockholm, 1749), 7.

264 Grill, Sjö-farten, 7 f., 12; Sandels, Förhållandet, 61-68. Se även Heijkenskjöld, Anmärkningar, 15; Clason, Orsakerna, 14 f.; Arbin, Fortifications-staten, II, 26 f.; Swartz, 28.

265 För Kristina, Karl X Gustav och den omyndige Karl XI, se Clason, Orsakerna, 11-13; Sandels, Förhållandet, 44. För Karl XII, se Sparre, 36 f.; Liljencrantz, 40 f.; Grill, Sjö-farten, 8 f., 11; Clason, Orsakerna, 17. Samma tänkesätt tillämpades på Gustav Vasa när ekonomiska tillkortakommanden under hans styre härleddes till honom och hans personliga egenskaper. Clason, Orsakerna, $3 \mathrm{f}$.

266 Sparre, 36 f.; Clason, Orsakerna, 17; Grill, Sjö-farten, 8 f., 11; Liljencrantz, 40 f. Mest kritiska var Sandels och samlaren Bengt Bergius. Sandels noterade att allt som byggts upp under Karl XI rivits ned under hans son, vars regering varit rik på militära och hjältemodiga bedrifter men kommit att föröda näringarna och handeln och tömma riket på folk och pengar. Enligt Bergius utmärktes det senkarolinska Sverige av förnedring, vanmakt, torftighet och "snart sagt alla rörelsers matthet och alla näringars uselhet". Folket led, de mäktigare lät bli att hjälpa de svagare och de härskande försummade såväl befolkningens tillväxt och nyttiga sysselsättande som befordrandet av inhemska produkter. Sandels, Förhållandet, 68, 71-73, 76; Bergius, Läckerheter, I, 5 f.

267 Löwenhielm, Ungdomen, 33; Evald Ribe, Tal, om den stora nytta som kunskapen uti physiquen hafwer wid siukdomars igenkiännande ock botande [...] (Stockholm, 1740), 3; Mallet, 17-19.

268 Höpken, Observatorii, 34; Swartz, 16-21, 24 f., 28. Jämför Arbin, Fortificationsstaten, I, 47. 


\section{NOTER}

269 Den antike lydiske monarken Krösus fick åskådliggöra nyttan av yppigheten. Englands lukrativa ylleproduktion förklarades bero på ett antal regenter och Karl den store ha påbörjat en ny era för yllemanufakturerna genom anläggningar som gjorde att de blomstrade. Höpken, Yppighet, 14; Alströmer, Får-afveln, 13-18. Se även Alströmer, Sverige, 20 f.; Salander, 15; Strömer, 12; John Jennings, Tal, om nyttan af segelfarter igenom torra land och berg [...] (Stockholm, 1770), 12; Alströmer, Får-afveln, 21 f., 25, 29 f., 47; Wilcke, Magneten, 15.

270 Ludvig XIV:s minister Jean Baptiste Colbert intog en särställning härvidlag. Carl Johan Cronstedt, Tal, om sten-hus bygnad [...] (Stockholm, 1741), 3; Adelcrantz, 26-29, 40.

271 För Ludvig XIV, se Höpken, Observatorii, 31; Scheffer, Anmärkningar, 6 f.; Pehr Wilhelm Wargentin, "Svar, gifvit på Kongl. Vetensk. Academiens vägnar [...]", i Adelcrantz, 47; Cronstedt, Academien, 9. Bland de övriga gynnarna märktes Alexander den store, Julius Caesar, de romerska kejsarna, Karl den store samt de tysk-romerska kejsarna Fredrik II och Rudolf II. Schützercrantz, Tilväxt, 19, 22, 27, 39 f.; Casten Rönnow, Tal, om förmånen, som hela rikets invånare tilskyndas skulle, af et stort lazarets inrättande här i hufvud-staden [...] (Stockholm, 1774), 6, 13; Melanderhielm, Angelägenheten, 7, 15 f., 19, 24, 65.

272 Ehrenpreus, Konster, 25 f.; Höpken, Observatorii, 18, 26. För familjen de Medici, se även Schützercrantz, Tilväxt, 37; Adelcrantz, 40; Cronstedt, Academien, $8 \mathrm{f}$.

273 Ferrner, Försök, 8 f.; Rosenstein, 104.

274 Hårleman, 32; Liljencrantz, 28, 30 f., 64, 72; Faggot, Historien, 23 f., 30, 37, 40; Mennander, Bok-handelen, 6 f.; Adelcrantz, 27-29; Jennings, Segelfarter, 16 f., 22-25.

275 Rabbe, 25; Jennings, Segelfarter, 8; Schönberg, 10.

276 Dalin, 9; Liljencrantz, 27-31.

277 Liedman, Handen, 92-94, 132; Orrje, 128; Högberg, 13; Wakefield, 15.

278 Carl Leijell, Tal, om anläggningen och nyttan af det slags bärgs-arbete, som stoll-byggnad kallas [...] (Stockholm, 1751), 38-40, 43-46.

279 Pehr Wilhelm Wargentin, "Svar gifvit på Kongl. Vetensk. Academiens vägnar [...]", i Heijkenskjöld (1759), 7, 18; Leijonmarck, Utsigten, 7, 28 f.; Heijkenskjöld, Bärgs-hushållningen, 7, citat från idem. Se även Ekström, 30 f.; Heijkenskjöld, Anmärkningar, 12 f., 15.

280 Gabriel Polhem, Tal, om de i landet befintelga [sic] byggningsämnen [...] (Stockholm, 1760), 17; Samuel Schultze, Tal om glas-makeriet, samt om Kongsholms glas-bruk [...] (Stockholm, 1762), 34; Alströmer, Får-afveln, 35 f.; Johan Lorens Odhelius, K. lazarettet i Stockholm, beskrifvit uti et tal, inför Kongl. Vetenskaps Academien [...] (Stockholm, 1776), 31 f., 38.

281 Kryger, Folkbristen, 11; Schultze, Ungdomen, 4 f.; Ankarcrona, 4, citat från idem; Kryger, Lagarna, 16. Se även Polhem, Fädernesland, 19; Runeberg, Varor, 19 f., 24-30, 39 f., 62; Anton von Swab, Tal om controll-inrättningen för 
guld- silfver- och tenn-arbeten $i$ riket [...] (Stockholm, 1761), 5 f., 8-10, 13 f., 21, 36-38; Tiburtius, 17, 19 f.; Bäck, Farsoter, 29; Lidbeck, 6 f., 31; Alströmer, Får-afveln, $29 \mathrm{f}$.

282 Collegium medicum övervakade enträget det välorganiserade svenska medicinalverket och apoteken var "under jämn tilsyn af kunnige Män vårdade”. Qvist, Mineralvaror, 4 f.; Scheffer, Grund-lagarna, 26; Odhelius, Dödligheten, 9 f.; Sparre, 10 f., 18, 21, 25, 28, 31-34. Se även Hermelin, 21 f.; Lilliestråle, Lagförbättring, 32.

283 Bielke, 11, 14-18, 20, 22-25, 27 f., 30 f., 36-39, 44. Bielke framställde också rikskanslern Axel Oxenstierna som vaksam, medan en annan ledamot gestaltade Karl XI som oförtröttligt vaktande på rikets upphjälpande. Ett presidietal ställde sig positivt till förflutna regenters detaljregleringar av konsumtionen. Det konstaterades att de medeltida ansträngningarna i denna riktning hade varit väl lämpade för sin tid och haft fördelaktiga effekter, exempelvis genom att folket gjorts medvetet om sitt sannskyldiga bästa. Yppigheten i kölvattnet av 160o-talets krig meddelades ha fått den skarpögda regeringen att introducera en omfattande förordning som förhindrat att svenskarna blev utlänningarnas skattdragare. Bielke, 42; Arbin, Fortifications-staten, II, 26 f.; Gyllenborg, 9-13.

284 Hårleman, 25 f., 29.

285 Mary Louise Pratt, Imperial eyes: Travel writing and transculturation (London, 1992), 30 f.; Pehr Wilhelm Wargentin, "Svar, gifvet på Kongl. Vetenskaps Academiens vägnar [...]", i Kryger (1767), 35 f.; Adlerbeth, 20; Johan von Hermansson, Tal, om en ingenieurs inöfning och åliggande förrättningar [...] (Stockholm, 1791), 5 f. Se även Melanderhielm, Angelägenheten, 34 f., 45 f., 59, 61; Wilcke, "Svar", i Melanderhielm (1792), 71.

286 Ehrenpreus, Konster, 24; Mennander, Bok-handelen, 9. Till det kom att konungen, Gustav III, var vaksam på kunskapers befrämjande och att akademiledamöterna skulle bli driftiga då han såg efter deras flit. Swartz, 47; Bergius, Läckerheter, $\mathrm{I}, 11 \mathrm{f}$.

287 Ehrenpreus, Konster, 22 f.; Schultze, Ungdomen, 9; Carleson, Fiskeri, 3 f.

288 Sparre anförde vidare att politin hade till uppgift att näpsa stämplingar, folkskockningar, buller, upplopp, uppvigling och smädeskrifter. Lilliestråle, Lagförbättring, 49; Qvist, Mineralvaror, 4 f.; Sparre, 9, 22, $44 \mathrm{f}$. Se även Bielke, $28 \mathrm{f}$. 289 Hallberg, Ages, 79; Runefelt, Dygden, 21, 26 f., 29 f., 98 f., 154; Melkersson, 84. Wolffianismen hämtade sitt namn från den tyske filosofen Christian von Wolff, som utövade ett kraftfullt intellektuellt inflytande på 170o-talets Europa.

290 Schützercrantz, Chirurgien, 2, citat från idem; Pehr Wilhelm Wargentin, "Svar, gifvet på Kongl. Vetenskaps Academiens vägnar [...]", i Odhelius (1776), 45; Wrede, 27; Lilliestråle, Lag-förbättring, 9, 11, 31. Se även Höpken, Yppighet, 8; Ehrenpreus, Konster, 5; Kryger, Lagarna, 6, 13, 20 f.; Celsius, 30; Rabbe, 109 f.; Odhelius, Lazarettet, 24; Lilliestråle, Tale-konsten, 23; Gadolin, Vetenskaper, 
14. För ett undantag från den allmänt negativa människosynen, se Cronstedt, Academien, 5.

291 Bergius, Läckerheter, II, 3 f.; Höpken, Yppighet, 8; Runeberg, Varor, 8 f., citat från idem; Gadolin, Gränsorne, 29; Bergman, 6, 9 f.; Schönberg, 24, citat från idem. Enligt Höpken var även akademiledamöternas begär underkastade konstant förändring. En liknande syn på lärda återfinns i Sandels, Inrättning, $13 \mathrm{f}$.

292 Sparre, 8, 15; Browallius, $23 \mathrm{f}$.

293 Höpken, Yppighet, $5 \mathrm{f}$. Platons republik är ett fiktivt idealsamhälle styrt av filosofer.

Joachim Wilhelm Lilliestråle konstaterade att förståndets horisont skilde sig avsevärt åt mellan filosoferna och de olärda. Nils von Rosenstein gjorde en distinktion mellan upplysta och oupplysta eller enfaldiga människor; hans tal om upplysningen var inte avsett för Vetenskapsakademien utan för de mindre kunniga bland landsmännen, vilka han tycks ha likställt med allmänheten. Lilliestråle, Tale-konsten, 13; Rosenstein, 4 f., 115, 122. Se även Ferrner, Försök, 40; Johan Carl Wilcke, "Svar, gifvet, på Kongl. Vetenskaps Academiens vägnar [...]", i Dalberg (1784), 30; Gadolin, Vetenskaper, 10, 15 f.; Johan Carl Wilcke, "Svar, gifvet på Kongl. Vetenskaps-Academiens vägnar [...]", i Gadolin (1786), 31.

Akademimedlemmarna hörde förstås till de förståndigas och upplystas skara. De företedde enligt mineralogen Peter Jacob Hjelm tänkesätt som var "skilde ifrån fördomars tvång, och högde öfver Inbillningars välde". Hjelm, 39.

294 För denna tankefigur, se Lindberg, Skevheten, 211.

295 För okunnigheten och oförståndet, se Schultze, Ungdomen, 20, 24; Strandberg, Febrar, 8, 13 f., 42; Adelcrantz, 13; Faggot, Fortsättning, 39; Lidbeck, 29 f.; Liljencrantz, 11; Alströmer, Får-afveln, 73; Bunge, 7 f. För de andra egenskaperna, se Schultze, Ungdomen, 20; Strandberg, Febrar, 42; Clason, Orsakerna, 28; Jennings, Segelfarter, 16 f.; Bunge, 15. Fastän köpmannen John Jennings inte uttryckligen nämnde folket står det klart att gemene man var föremålet för hans missnöje.

296 Bengt Bergius, Tal, om svenska äng-skötseln, och dess främjande genom lönande gräs-slag [...] (Stockholm, 1769), 11 f., 86-9o. Se även Lidbeck, 7, 24, 30.

297 Leijonmarck, Utsigten, 11, 18-21, 28 f. Se även Bunge, 11 f.; Lillienberg, Förmåner, 11-13. Det var en utbredd farhåga att skogen höll på att förstöras och skulle försvinna från Sverige. Vetenskapsakademien fungerade också i detta sammanhang som en kommunikationskanal för makthavarna. Lindroth, Vetenskapsakademien, I:1, 318.

298 Bergius, Frukt-trägårdar, 7-10, 13 f., 112.

299 Bunge, 7; Schultze, Ungdomen, 6 f., 18 f.; Ehrenpreus,"Svar", i Schultze (1750), 28. Se även Leijell, 8; Wargentin, "Svar", i Kryger (1758), 40; Lidbeck, 26; Pehr 
Wilhelm Wargentin, ”Svar, gifvet på Kongl. Vetenskaps Academiens vägnar [...]", i Lidbeck, 40; Rosén von Rosenstein, Pesten, 4; Leijonmarck, Utsigten, 19; Bielke, $13 \mathrm{f}$.

300 Sparre, 12; Runeberg, Nyttan, 6, 15.

301 Stiernman, 66; Melcher Falkenberg, Tal, om vetenskapernas nytta uti lagfarenheten [...] (Stockholm, 1775), 20, citat från idem; Ljungenstjerna, 6o f.; Acrel, Sjukdomar, 12. Se även Gadolin, Gränsorne, 22; Bergius, Bad, 67; Lidbeck, 21 f.; Carl Reinhold Berch, Afhandling om nordiska folkets fordna sjöväsende, så väl til handel, som örlog [...] (Stockholm, 1766), 34; Alströmer, Får-afveln, 73; Sandels, Inrättning, 31; Bielke, 11; Odhelius, Lazarettet, 12 f., 21 f.; Schützercrantz, Tilväxt, 72; Wilcke, Förklaringar, 9; Odhelius, Dödligheten, 11, 27; Bergius, Läckerheter, II, 43.

"Sympati" betecknade den magiska tron att en verkan liknade sin orsak eller att två ursprungligen förenade men sedermera distinkta företeelser påverkades likadant av något som hände den ena av dem. James Frazer, The golden bough: A study in magic and religion (1922), ny uppl. (Ware, 1993), 37.

302 Strömer, 4 f.; Cederhielm, 22; Bergius, Bad, 103 f.; Högström, 11, 16-21. Se även Ulric Rudenschöld, Tal om skogarnes nytjande och vård [...] (Stockholm, 1748), 33; Wargentin, "Svar", i Ungern-Sternberg, 15; Faggot, Fortsättning, 29; Marelius, Mälaren, 31. Jämför Pehr Wilhelm Wargentin, "Svar, gifvet på Kongl. Vetenskaps Academiens vägnar [...]", i Qvist (1776), 29.

303 Hermelin, 18, 21-25, 53, 68 f., 72, 75-77, 87 f., 101, 106; Dalin, 19-21. Se även Schulzenheim, $1-3,11 \mathrm{f}$.

304 Ungern-Sternberg, 7; Nils Dalberg, Tal, om några det svenska climatets förmåner och olägenheter $i$ anseende til hälsan [...] (Stockholm, 1777), 39-41; Mennander, Folkhopen, 10, 15, 21 f., 28, 31 f. Det före detta riksrådet Gustaf Bonde hade efter att han lämnat Vetenskapsakademiens ordförandepost dragit sig tillbaka till sitt "nöjsamma Landt-lefverne" under "löfrika Askars stilla lugn och skugga". Gustaf Bonde, Tal om aske-trädets nytta [...] (Stockholm, 1756), 18. För 1700-talets idealiseringar av lantlivet, se Nell, 222; Martin Lamm, Upplysningstidens romantik: Den mystiskt sentimentala strömningen $i$ svensk litteratur (1918-20), 2 uppl., 2 vol. (Stockholm, 1963), I, $259 \mathrm{f}$.

305 Löwenhielm, Landt-skötsel, 11-13, 16-18, 24 f., 30, 41-44. Jämför Hjelms senare utsaga om att det var på "små nästen, som et Rikes sanna rikedom skal börjas, och vid magt hållas, lika som Hafvet står vid sin högd af de små rännilar, som nedkomma långt bort ifrån bergen”. Även han hade en kluven inställning till menigheten. Hjelm, 29, $31 \mathrm{f}$.

306 Rosenstein talade om en "Class af Medborgare som närmare får vinlägga sig om kunskaper och uplysning". Rosenstein, [1], 30, 35, 38 f., 101 f., 110, 119, 198, $203 \mathrm{f}$.

307 Frågan om vilka sanningar som skulle och borde begripliggöras för folket 


\section{NOTER}

respektive helt sonika godtas av det hörde inte till Rosensteins ämne. Ibidem, 39-41, 181 f., 205-07.

Rosenstein likställde uttryckligen allmänheten med folket. Han rörde sig även med en definition av upplysning som "vissa allmänna kunskaper och en allmän kännedom af människo-snillets framsteg, af vetenskapernes ställning och de hufvudsakeligaste uptäckter". Ibidem, 30, 40.

308 Ibidem, 138 f., 152, 161, 168 f., 180, 205 f., 208, 216. Rosenstein gav också prov på pessimism inför framtiden: "Förgäfves vänta vi at utrota lasterne; at mängden skall blifva dygdig; om med dygd förstås begärens och passionernes fullkomliga tyglande och försakelsen af vårt eget intresse.” Det var däremot inom det möjligas ramar att kanalisera passionerna till nyttiga ändamål, att förebygga deras och egennyttans destruktiva konsekvenser och att kontrollera de odygdiga. Ibidem, $151 \mathrm{f}$.

309 Rosenstein, 144, 165 f., 172 f. Torgny Segerstedt tillmäter tvärtom Rosenstein en positiv syn på partier utifrån dennes presidietal och åminnelsetal över Eric von Stockenström. Segerstedt, $319 \mathrm{f}$.

310 Rättelse hos de samhällsledande var att förmoda när upplysningen röjde de problem egennyttan och passionerna medförde, "stundom af öfvertygelse och dygd hos de Mägtiga, stundom igenom deras passioner; stundom [...] genom det våld den allmänna öfvertygelsen lägger på deras egna tankesätt”. Rosenstein, 152, 154 f., 177 f., 191 f., 210, 212.

311 Tessin, 4, citat från idem; Tiburtius, 17; Carl Knutberg, Upmuntran til allahanda, vid lands-och stads-hushållningen nyttiga ämnens samlande [...] (Stockholm, 1762), 4; Wargentin, "Svar", i Tiburtius, 24; Wargentin, "Svar", i Löwenhielm (1751), 61; Alströmer, Sverige, 10, 26. Se även Ljungenstjerna, 37 f.; Schultze, Ungdomen, 19; Lillienberg, Förmåner, 10.

312 Kryger menade samtidigt att människorna själva bar ett ansvar för sitt tillstånd och att förståndets upplysning även var avhängig deras fysiska, sociala och moraliska belägenhet. Kryger, Folkbristen, 4, 12, 15, 18 f., 29; Kryger, Lagarna, 7-13, 16-21. Jacob Faggot betonade likaså lagarnas makt över levnadssätt och seder. Faggot, Fortsättning, $14 \mathrm{f}$.

313 Polhem, Fädernesland, 9; Schönberg, 11 f.; Alströmer, Sverige, 13, 27-32; Pehr Elvius, "Svar här uppå, gifvit af secreteraren Elvius å Kongl. Vetenskaps Academiens vägnar", i Alströmer (1745), 34; Pehr Elvius, "Svar, gifvit å Kongl. Vetenskaps Academiens vägnar [...]”, i Tessin, 15.

314 Falkenberg, 20; Rönnow, 37; Schultze, Ungdomen, 7-9, 11-18; Löwenhielm, Landt-skötsel, 51 f.; Alströmer, Schäferierna, 12 f.; Bäck, Farsoter, 47-49.

315 Bunge, 14 f.; Faggot, "Svar", i Ankarcrona, 15 f.

316 Knutberg, 5; Browallius, 10, 20-24, citat från idem. Se även Klingenstierna, 28.

317 Sandels, Inrättning, 18; Wargentin, "Svar", i Gyllenborg, 20; Ferrner, Försök, 
6, 18, 24 f.; Bunge, 13, 18 f. Se även Löwenhielm (1751), 53; Wargentin, "Svar", i Tiburtius, 24; Wargentin, "Svar", i Löwenhielm, (1751), 61.

318 Ungern-Sternberg, 7; Carleson, Spanmåls-bristen, 5; Hermelin, 16, 20 f. Idén om storskifte kom ursprungligen från Faggot; reformen, som fick ett begränsat genomslag, gick ut på att samla de utspridda åkertegarna till större enheter, varigenom jordbruket skulle individualiseras och egendomen privatiseras. Den första storskiftesförordningen utfärdades 1757. Mats Morell, "Swedish agriculture in the cosmopolitan eighteenth century", i Sweden, red. Rydén, 76 f.; Legnér, 96.

319 Arfvedson, 9; Dalberg, Climatet, 35; Schröder, 4; Nils Marelius, Tal, om nyttan af topographiska och chorographiska chartor [...] (Stockholm, 1784); Runeberg, Nyttan, 13; Lillienberg, Förmåner, $5 \mathrm{f}$.

320 Bunge, 19; Lilliestråle, Lag-förbättring, 42; Rosenstein, 57 f., 210 f.

321 Tiburtius, 17, 19; Bielke, 13 f., 15-17, 19, citat från idem. Se även Rudenschöld, Skogarne, 25 f., 35-39, 43, 48 f.; Knutberg, 4; Thunberg, 32 f.

322 Ståndspersoner hade enligt Schultze ofta förbättrat sina jordegendomar på ett sådant vis att de förtjänade att utgöra förebilder för andra. Deras exemplariska jordbruk var emellertid inte tillräckligt, utan också ihärdiga bönder borde lockas att bli föredömen för gemene man. Schultze, Ungdomen, 8, 17 f., 20 f.; Clason, Orsakerna, 4. Se även Wrede, 29 f.; Alströmer, Schäferierna, 12 f.

323 Lindroth, Vetenskapsakademien, I:1, 278.

324 Bergius, Frukt-trägårdar, 8-10; Kryger, Lagarna, 18, citat från idem; Schönberg, 32; Sandels, Förhållandet, 51, 82. Allmogen tillmättes i något enstaka fall en analog funktion, som när det noterades att fruktträdgårdarnas ekonomiska nytta ådagalades genom "den sämre Folkhopens exempel" runtom i Europa. Bergius, Frukt-trägårdar, 11.

325 Gyllenborg, 14, 16. Se även Bäck, Farsoter, 15; Leijonmarck, Utsigten, 18; Knutberg, 18.

326 Melkersson, 8o; Adolfsson, 190; Legnér, 196 f.; Sennefelt, Politiken, 123 f. Se även Hallberg, Ages, 148-50, 284 f. Enligt den lutherska hustavlan, som fortfarande var inflytelserik under 1700-talet, bestod samhället av tre stånd, som alla hade en befallande och en lydande del: ett politiskt stånd eller överhetsstånd, ett kyrko- eller lärostånd och ett hushållsstånd. Hilding Pleijel, Från Hustavlans tid: Kyrkohistoriska folklivsstudier (Stockholm, 1951), 17-20, $28 \mathrm{f.,} 33 \mathrm{f}$.

327 För ståndspersoner och menighet, se Bergius, Äng-skötseln, 13; Alströmer, Får-afveln, 102 f.; Hermelin, 33, 74, 92 f., 97. 109. För höga och låga, se Kryger, Lagarna, 14; Ljungenstjerna, 35; Rönnow, 6, 27, 31, 37; Arbin, Fortificationsstaten, II, 33. För rika och fattiga, se Adelcrantz, 18 f.; Wilcke, "Svar", i Dalberg (1784), 32, jämför Bunge, 12 f. Exempel på andra distinktioner är de förnämare och allmänna hopen och frälse respektive ofrälse stånd. Sandels, Förhållandet, 11; Arbin, Fortifications-staten, II, 25. 
328 Bergius, Läckerheter, I, 31 f., 43, 46, 178, 247 f., 263 f. Se även Grill, Silfver, 5, 17 f.; Rosenstein, 61 f., 66, 71, 138, 140, 142, 144, 149, 154; Thunberg, 5, 7, 9 f., 14, 16-20; Odhelius, Dödligheten, 25, 27, 30.

329 Ankarcrona, 4; Wrede, 6 f., 9-11, 28; Kryger, Lagarna, 6, citat från idem.

330 Rosén von Rosenstein, Pesten, 14; Pehr Wilhelm Wargentin, "Svar, gifvit af Kongl. Vetensk. Academiens secreterare", i Bäck (1765), 52, citat från idem. Jämför läkaren Pehr Zetzells anmärkning att "medelmåttan" hade "sit vissa politiska värde" och att det således var dyrbart folk som användes till krigstjänst. Pehr Zetzell, Tal, om sjukligheten i fält, i anledning af Pommerska kriget ifrån år 1757 til 1762 [...] (Stockholm, 1779), 3. Med politiskt värde avsågs den vinst en arbetande människa medförde för statsmakten; det var ingen sällsynthet att invånarnas pekuniära värde definierades i den ekonomiska litteraturen. Johannisson, Samhället, 118, 148-50.

331 Bäck, Farsoter, 4-8, 10-15, 19, 36, 38-40.

332 Rudenschöld, Skogarne, 23; Schönberg, 41; Wargentin, "Svar", i Bielke, 48 f. Se även Lillienberg, Förmåner, 15. Jämför Dalberg, Climatet, 35; Zacharias Zachariae Plantin, Tal, om möjeligheten af svenska målens och vigternas reduction [...] (Stockholm, 1788), 20.

333 Sparre, 13 f., 28, $30 \mathrm{f}$.

334 Jämför Lindroth, Vetenskapsakademien, II, 293 f. För filantropin, se Seppo Salminen, "Religious and intellectual currents", i The Cambridge history of Scandinavia: Volume II, 1520-1870, red. E. I. Kouri \& Jens E. Olesen (Cambridge, 2016), $578 \mathrm{f}$.

335 Benzelstierna, Hushållsmått, 4, citat från idem; Gyllenborg, 14; Rönnow, 36 f.; Pehr Wilhelm Wargentin, "Svar, gifvet på Kongl. Vetenskaps Academiens vägnar [...]", i Rönnow, 40.

336 Odhelius, Lazarettet, 44; Odhelius, Dödligheten, 11; Schützercrantz, Tilväxt, 48, citat från idem; Rosenstein, 89, 123. För Stockholms fattigvård, se även Johan Carl Wilcke, "Svar, gifvet, på Kongl. Vetenskaps Academiens vägnar [...]", i Odhelius (1785), 31. Collegium medicum var ett ämbetsverk som samlade och examinerade alla rikets praktiserande läkare. "Collegium medicum (svenska tiden)", Förvaltningshistorisk ordbok, http://fho.sls.fi [hämtad 2020-07-31].

337 Högberg, 167; Legnér, 87, 103 f., 107, 133, 186; Liedman, Handen, 102.

338 Mokyr, 38; Högberg, 12 f., 74, 165, 167; Legnér, 197; Morell, 72; Leif Runefelt, "Wasting a day chasing a hare: Indolence, self-interest and spatial mobility in the rhetoric about Swedish peasantry, ca. 1750-1850", Ideas in history: Journal of the Nordic Society for the history of ideas 8:1 (2014), 47. Gemene man frånkändes för det mesta agens, initiativförmåga, förstånd, myndighet och kapacitet att ta ansvar för samhällsutvecklingen, då han antogs bry sig mer om det förflutna och nuet än om framtiden. Samhällets högre skikt skulle kommunicera kunskap och vägleda i kraft av att de besatt ansvarsförmåga, vett och tillbörligt 
vetande. Adolfsson, 88-94, 197 f.; Legnér, 186, 197; Cavallin, 159 f., 232, 237 f.; Nordin, Frihetstiden, 15; Melkersson, 84.

339 Högberg, 162 f., 167; Runefelt, Dygden, 172; Melkersson, 130 f.

340 Adolfsson, 201, 263-66; Legnér, 193.

341 För dygd förmedlad genom styrmedel, se Runefelt, Dygden, 177.

\section{Hattarnas akademi}

342 Kaiserfeld, 9, 14; Gunnar Carlquist, "Sten Carl Bielke", Svenskt biografiskt lexikon, band 4; Nordin, "Höpken", 68; Hildebrand, 340 f. Som Karin Sennefelt observerat var sociala hänsyn viktigare än åsiktsmässiga preferenser inom det frihetstida politiska livet. Sennefelt, Politiken, 275. Bielke var inte den enda av Vetenskapsakademiens ledamöter som hade en politiskt oppositionell hållning, även om merparten av de medlemmar vilkas partisympatier är kända slöt upp bakom hattarna. Bland de övriga oppositionsanhängarna märks generalen Carl Cronstedt (Olderman) och landshövdingen Nils von Reuterholm (Esbjörnsson). Hildebrand, 472, 546.

343 Nordin, ”Höpken", 68. Många av hattarna och de tidiga akademieledamöterna hade en bakgrund i det så kallade holsteinska partiet, som velat se Karl XII:s systerson Karl Fredrik av Holstein-Gottorp på den svenska tronen. Carl Wilhelm Cederhielm och hans far Josias, Anders Johan von Höpken och hans far Daniel Niclas samt Mårten Triewald och hans bror Samuel tillhörde denna gruppering, vars ambitioner på 1720-talet stäcktes av kanslipresidenten Arvid Horn. Där fanns också de framtida hattledarna Carl Gyllenborg och Carl Gustaf Tessin liksom den senares far Nicodemus. Hildebrand, 143 f.; Gunnar Carlquist, "Carl Wilhelm Cederhielm", Svenskt biografiskt lexikon, band 8; Carlsson, Parti, 151, 154, 162-65.

344 Carlquist, "Cederhielm"; Olof Jägerskiöld, "Anders Johan von Höpken", Svenskt biografiskt lexikon, band 19; Hildebrand, 139, 354; Nordenmark, 233.

345 Eli F. Heckscher, "Jonas Alströmer", Svenskt biografiskt lexikon, band 1; Hildebrand, 139, 141, 145-48, 153, 249, 254 f., 334.

346 Gunnar Broberg gör i sin doktorsavhandling Homo sapiens L. (1975) gällande att Linné ogillade elitens livsstil, var föga lagd åt politik och är svår att placera in på den politiska kartan. Ett liknande perspektiv anläggs av Jonas Nordin, som menar att Linné saknade ett utvecklat politiskt intresse. Lisbet Rausing framhäver däremot att Linné, trots att han inte formellt bekände sig till något parti eller hyste några varmare känslor för frihetstidens styrelseskick, såg sig som en statstjänare. Hon påpekar att han rörde sig i hattcirklar, att hans vetenskapliga gärning väsentligen sammanföll med hattarnas maktinnehav och i praktiken var nära associerad med deras ekonomiska politik, samt att han stöddes av såväl Höpken som Tessin. Broberg framför i en ny biografi över 


\section{NOTER}

Linné, Mannen som ordnade naturen (2019), uppfattningen att Uppsalabotanikern först var mössa och sedan bytte till hattarna på grund av sitt samröre med ledande politiker inom detta parti. Broberg, Homo sapiens L., 268-70; Nordin, "Höpken", 68; Koerner, Linnaeus, 16 f., 104 f., 166; Gunnar Broberg, Mannen som ordnade naturen: En biografi över Carl von Linné (Stockholm, 2019), 130, 351. Även andra forskare har lyft fram Linnés kopplingar till hattarna, vilka enligt hans egen utsago skämtsamt refererade till honom som "deras Archiater", det vill säga läkare. Hildebrand, 244; Nordin, "Höpken", 68; Göran Nilzén, Carl Gyllenborg: En frihetstida hattpolitiker (Stockholm, 2007), 249-52; Michael Roberts, Sverige under frihetstiden: 1719-1772 (1986), sv. övers. (Stockholm, 1995), 196; Carl von Linné, "Carl Linné potest e casa vir magnus exire: Vita III", i Carl von Linné, Vita Caroli Linnaei: Carl von Linnés självbiografier (Stockholm, 1957), 114-15.

347 Nordenmark, 18 f., 21, 27, 34. För Hårlemans politiska hemvist, se Ekblad, "Brev", $54 \mathrm{f}$.

348 Andra gäster var Anders Anton von Stiernman, Anton von Swab, Daniel Tilas, Abraham Bäck och Nils Rosén von Rosenstein (Rosén; Rosenstein den äldre). Rosenstein fungerade jämte Olof af Acrel som Tessins husläkare. Nordenmark, 56-58, 87; Göran Nilzén, Carl Gustaf Tessin: Uppgång och fall (Stockholm, 2012), $239 \mathrm{f}$.

349 Tabellverket var en förordning om nationell datainsamling som utfärdades 1748, Tabellkommissionen en därpå följande myndighet som inrättades 1756 . Båda upplevde en nedgång under den gustavianska tiden. Nordenmark, 234-38; Lindroth, Vetenskapsakademien, I:1 370-75; Johannisson, Samhället, 97, 156-64, 179. För ett exempel på hur samhällets förbättring förknippades med en stor folkmängd, se Runeberg, Nyttan, 12 f. Det ansågs behövas fler människor för att tillvarata och förädla landets resurser och få till stånd en god hushållning. Runefelt, Dygden, 129.

350 Vid mösspartiets återtagande av makten 1772 tilläts dock Wargentin stanna i kommissionen så länge han själv önskade. Han blev senare ledamot av den gustavianska överdirektion som ledde kanalbyggandet fram till 1779. Nordenmark, 73 f., $272 \mathrm{f}$.

351 Nilzén, Gyllenborg, 248 f.; Hildebrand, 497; Carl Wilhelm Oseen, Johan Carl Wilcke: Experimental-fysiker (Uppsala, 1939), 68 f., 95.

352 Sennefelt, Politiken, 17-19, 272 f.; Winton, 22-24, 295 f., 304 f., 308 f. Jämför det perspektiv som anläggs på frihetstidens partier i Magnusson, Makt, 13 .

353 Jämför Roberts, 157, 177-81, 183; Nilzén, Gyllenborg, 81, 145; Gunnar Wetterberg, Från tolv till ett: Arvid Horn (1664-1742) (Stockholm, 2006), 592-94, 653.

354 Roberts, 186-88, 240-42, citat från idem; Per-Erik Brolin, Hattar och mössor $i$ borgarståndet 1760-1766 (Uppsala, 1953), 138, 409; Cavallin, 241; Nordin, Frihetstiden, 50, 52. 
355 Liedman, Handen, 25, 122 f., 215, citat från idem; Roberts, 186 f., 201 f., 207; Brolin, 45, 67, 81 f., 138, 220. Se även Magnusson, Makt, $186 \mathrm{f}$.

356 Magnusson, Merkantilism, 254-59; Magnusson, Sverige, 231, 233; Magnusson, "Manufakturerna", 224-26, 235; Runefelt, Dygden, 165; Roberts, 186, 191 f.; Brolin, 279, 330, 347 f., 351 f. Hattarnas ekonomiska politik hade rötter i 160otalet men gick närmast tillbaka på 1720- och 1730-talen; manufakturpolitiken fick sitt definitiva genomslag redan på riksdagen 1727-28. Magnusson, Merkantilism, 254 f.; Magnusson, Sverige, 227-29; Magnusson, "Manufakturerna", 223 f.; Lili-Annè Aldman, En merkantilistisk början: Stockholms textila import 1720-1738 (Uppsala, 2008), 53 f., 58 f. Lars Magnusson har påvisat att det var ett reducerat handelsunderskott snarare än en positiv handelsbalans som hägrade för svenska merkantilister. Magnusson, "Diskussionen", 31.

357 Roberts, 160, 170, 188-91; Gunnar Olsson, Hattar och mössor: Studier över partiväsendet i Sverige 1751-1762 (Göteborg, 1963), 253, 259; Brolin, 329, 351.

358 Carl Gustaf Malmström, Sveriges politiska historia från konung Karl XII:s död till statshvälfningen 1772 (1855-77), 6 vol., 2 uppl. (Stockholm, 1893-1901), IV, 416 f., 426-33, 448-51, citat från idem; Runefelt, Dygden, 165-67. Meningsskiljaktigheterna berodde till dels på att partimedlemmar representerade olika segment av förvaltningen, som hade olika idéer om hur den ekonomiska politiken skulle utformas. Runefelt, Dygden, 165.

I fysiokraternas vision reglerades samhället av en inneboende naturlig ordning som inte borde störas. Ett credo var privategendomens helgd, ett annat fri handel och konkurrens, vilket för svensk del avsatte spår i spannmålshandelns avreglering under 1770-talets andra hälft. Morell, 70; Lars Herlitz, Fysiokratismen i svensk tappning 1767-1770 (Göteborg, 1974), 14 f., 20-22, 186.

359 Pehr Wilhelm Wargentin, "Svar, gifvet på Kongl. Vetenskaps Academiens vägnar [...]", i Liljencrantz, 78; Wargentin, "Svar", i Clason (1751), 71; Kryger, Folkbristen, 36; Kryger, Lagarna, 29.

360 För slöjderna, se Hårleman, 34; Adelcrantz, 34; Tiburtius, 4. För produktförädlingen, se Meijer, 16 f.; Dalin, 12 f., 19; Ekström, 6 f., 13-17, 31 f., 35; Pehr Wilhelm Wargentin, "Svar, gifvit å Kongl. Vetensk. Academ. Vägnar [...]”, i Ekström, 41 f.; Mennander, Bok-handelen, 17; Knutberg, 3 f. För exportpremierna, se Mennander, Bok-handelen, 23; Kryger, Folkbristen, 20; Clason, Orsakerna, 35. Jämför Runeberg, Varor, 53-55.

Sten Lindroth har noterat att presidietalen ihärdigt upprepade "den merkantilistiska statsvisdomens grundtankar" och innehöll "den ekonomiska katekesens alla dogmer" ifråga om handelsbalans, förädling, manufakturväsende, folkrikedom och näringsregleringar. Lindroth, Vetenskapsakademien, I:1, 364 .

361 Ehrenpreus, Konster, 4, citat från idem; Dalin, 18; Vallerius, 3 f.; Carleson, Spanmåls-bristen, 4 f., 9; Faggot, "Svar", i Ankarcrona, 14; Faggot, Historien, $50 \mathrm{f}$. 
362 Enligt Alströmer visade Englands exempel att fabrikerna under lång tid "af landets Herre ock Regering, lika som uti ledband" behövde "hielpas, understödias ock väl vårdas, så framt at landet skall kunna göra sig förvissad [sic] om des beständiga fruckter". Riket kunde lika litet som manufakturerna upphjälpas utan de styrande. Wargentin, "Svar", i Alströmer (1760), 18; Alströmer, Schäferierna, 5; Alströmer, Sverige, 8 f., 18-21.

Idealisering av Alströmer var gängse under frihetstiden och återfinns till exempel hos Carl von Linné, som rapporterade att Alströmers Alingsåsverk avslöjade hur långt den kunde komma som ägnade sig åt någonting vist och brann för att tjäna det allmänna - "[e]n sådan gör ofta mer, än många tusende ohogade. För Herr ALSTRÖMS tid woro Manufacturerne hos oss i et djupt mörker, öfwer mästa Riket, som nu kläda och föda så många tusende innom landet." Hildebrand, 328 f.; Carl von Linné, Carl von Linnés Västgöta resa 1746: Faksimiledition efter 1747 års originalupplaga. Andra tryckningen (Malmö, 1956), 129.

363 Salander tillrådde även specialisering inom slöjdsektorn. Wrede, 12-15, 19-21; Salander, 2-7, 9 f., 12-14, 16.

364 Rudenschöld, Skogarne, 49-52; Schultze, Ungdomen, 4-6, 23. För Ulric Rudenschölds partisympatier, se Malmström, V, $57 \mathrm{f}$.

365 Löwenhielm, Landt-skötsel, 11 f.; Piper, 7; Wargentin, "Svar", i Ungern-Sternberg, 15; Pehr Wilhelm Wargentin, "Svar, gifvit på Kongl. Vetensk. Academiens vägnar [...]", i Schultze (1762), 45; Wargentin, "Svar", i Tiburtius, 24; Wargentin, "Svar", i Carleson (1759), 19; Faggot, Fortsättning, 10-13. För debatten om näringarnas företräde, se not 69 i bokens inledning.

366 Hildebrand, 588; Lindroth, Vetenskapsakademien, I:1, 230-36, 240; Legnér, 170; Herlitz, 7, 22 f., 185, 192; Frängsmyr, Idéhistoria, 209.

367 Morell, 70.

368 Melkersson, 84-89, 202 f.; Adolfsson, 177 f., 182, 185-87; Legnér, 92, 127; Runefelt, "Day", 51 f. Mångsyssleri kunde uppfattas som egennyttigt och som stående närmare det oreglerade naturtillståndet, där alla gjorde allt. Vidare ansågs okvalificerat arbete borga för sämre kvalitet och dess utövare inkräkta på näringsverksamheter förbehållna andra. Liedman, Handen, 204; Runefelt, Dygden, $161 \mathrm{f}$.

369 Bönderna skulle begränsa sig till åker, äng, boskapsskötsel, spinneri och beredning av råmaterial. Kryger, Folkbristen, 26-32, $34 \mathrm{f}$.

370 Meijer, 10-12, 14 f.; Hårleman, 5; Ekström, 21 f., citat från idem. Se även Rudenschöld, Skogarne, 20; Clason, Handels omskiften, 18 f.; Runeberg, Varor, 20.

371 Faggot, "Svar", i Vallerius, 27 f.; Martin, 73; De Geer, Alstring, 1 f., citat från idem. För fler exempel på en positiv värdering av vetenskaplig specialisering, se Ljungenstjerna, 41 f.; Schützercrantz, Chirurgien, 7; Sandels, Inrättning, 8.

372 Ett ideal om kunskapsspecialisering förelåg inom det vetenskapliga och tekno- 
logiska program som utgick från 160o-talsfilosofen Francis Bacon. Ledamöters äskanden om lärd arbetsfördelning kan antas ha hämtat inspiration från honom, eftersom han var ett bekant namn i Vetenskapsakademien. För Bacons idé om kunskapsspecialisering, se Mokyr, 58; Kärnfelt, 73 f. För hänvisningar till Bacon i presidietalen, se Ljungenstjerna, 5; Schützercrantz, Tilväxt, 43.

Ekström, 18; Carleson, Fiskeri, 18 f.; Faggot, "Svar", i Ankarcrona, 14. Se även Benzelstierna, Berättelse, 245-48; Alströmer, Sverige, 11-15; Hårleman, 5 f., 15, 34 f.; Faggot, Historien, 50-52; Grill, Sjö-farten, 10-12, 16 f.; Löwenhielm, Landt-skötsel, 36-38, 46-49; Gyllenborg, 12-16; Kryger, Folkbristen, 13; Carleson, Spanmåls-bristen, 3-9, 13-16; Faggot, Fortsättning, 13; Tiburtius, 18; Knutberg, 13 f.; Zetzell, Soldat, 22.

374 Tessin, 6; Alströmer, Schäferierna, 8.

375 Polhem, Fädernesland, 11, 15-21; Heijkenskjöld, Bärgs-hushållningen, 2 f., 6, 10-12, 16; Ankarcrona, 3-7, 10 f.; Ungern-Sternberg, 4-13. Se även Clason, Handels omskiften, 66-68. För Ungern-Sternbergs politiska hållning, se Roberts, $168,172 \mathrm{f}$.

376 Henrik Teofilus Scheffer, Tal, om mynt [...] (Stockholm, 1762), 2 f.; Meijer, 13; Ekström, 31. Se även Berch, Myntet, 2 f.; Runeberg, Varor, 48 f., 52.

Köpmannen Claes Grill framhävde sjöfartens nytta för Sverige. Han angav att det var en oomtvistad och historiskt belagd sanning att den tillhörde de handelsgrenar som gjorde ett land starkt, förmöget och ryktbart, såvida den skedde med egna skepp som utgick från inrikes hamnar. Erfarenheten visade däremot att det var menligt om främmande fartyg förde in utländska produkter och förde ut inhemska tillverkningar. Matematikern Pehr Elvius, akademiens sekreterare 1744-49, anlade en likartad synpunkt på sjöfarten i sitt svar till Grill. Grill, Sjö-farten, 4-11, 17; Pehr Elvius, ”Svar gifvit å Kongl. Vetenskaps Academiens vägnar [...]", i Grill (1749), 19.

Pehr Wilhelm Wargentin, "Svar, gifvit på Kongl. Vetensk. Academiens vägnar [...]", i Strömer, 22; Wargentin, "Svar", i Gyllenborg, 19. Se även Wargentin, "Svar", i Carleson (1759), 19 f.; Johan von Seth, "Svar, gifvit på Kongl. Vetenskaps Academiens vägnar [...]", i Scheffer (1762), 23.

378 Runeberg, Varor, 28; Wargentin, "Svar", i Salander, 19; Wargentin, "Svar", i Kryger (1758), $40 \mathrm{f}$.

379 Kryger, Folkbristen, $22 \mathrm{f}$.

380 Bäck, Farsoter, 11, 28; Löwenhielm, Landt-skötsel, 16, 31-33.

381 Rudenschöld, Skogarne, 9 f., 17; Grill, Sjö-farten, 5, 9-12, 16; Elvius, "Svar", i Grill (1749), 20; Ekström, 13 f.; Leijell, 3 f.; Scheffer, Mynt, 21; Nordenskiöld, 5-7; Jennings, Sluss-byggnad, 12-14, 18, 26-28.

382 Alströmer, Sverige, 24; Dalin, 9 f., 18; Tiburtius, 4. Se även Carleson, Fiskeri, 24 f.; Strömer, 5; Nordenskiöld, 5. 


\section{NOTER}

383 Scheffer, Anmärkningar, 2-7, 11-14; Faggot, Fortsättning, 4-8, 15-27, 29 f., 36, 39.

384 Strandberg, Febrar, 20; Salander, 17; Alströmer, Schäferierna, 15; Ekström, 17.

385 Wargentin, "Svar", i Jennings (1761), 31; Wargentin, "Svar", i Salander, 18-20; Wargentin, "Svar", i Ungern-Sternberg, 15; Wargentin, "Svar", i Ekström, 41.

386 Pehr Wilhelm Wargentin, "Svar, gifvit å Kongl. Vetenskaps Academiens vägnar [...]", i Scheffer (1755), $15 \mathrm{f}$.

387 Se till exempel Rudenschöld, Skogarne, 10 f.; Stockenström, Bergsmannanäringen, 5 f.; Schultze, Ungdomen, 5; Salander, 10, 13 f., 16; Kryger, Folkbristen, 14; Carleson, Spanmåls-bristen, 4 f., 9; Alströmer, Schäferierna, 16; Tiburtius, 8; Wargentin, "Svar", i Tiburtius, 24; Bäck, Farsoter, 44-47.

388 Faggot, Fortsättning, 11-15, 18-20, 36-39.

389 Kryger, Folkbristen, 7, 11, 29. Kryger omtalade därtill de många naturliga fördelar Skaparen givit Sverige, såsom god jordmån, rikliga mängder fisk och ett klimat lämpat för främmande växter. Ibidem, $11 \mathrm{f}$.

390 Heckscher, Arbete, 210, 219 f.; Magnusson, Makt, 288; Leos Müller, Sveriges första globala århundrade: En 170o-talshistoria (Stockholm, 2018), 66; Johannisson, Naturvetenskap, 119.

391 Brolin, 138 f., 239, 333, 337-39, 349 f., 376-80, 394, 409 f.; Lindberg, Skevheten, 165 f.; Roberts, 163, 167, 200, 202, 204 f., 231; Runefelt, Dygden, 167 f., 170.

392 Magnusson, Sverige, 231-33; Högberg, 36; David Löfberg, Det nationalekonomiska motivet i svensk pedagogik under 170o-talet (Uppsala, 1949), 80 f.; Melkersson, 171, 173. Jämför Magnusson, "Manufakturerna”, 224. Mösspartiets räfst innebar framför allt att understöd till olönsam produktion, som sidenodling, drogs in. Nyberg, "Staten", 98, 106; Lindroth, Vetenskapsakademien, I:1, 309 f. Det bottniska handelstvånget förbjöd direktexport från en rad svenska och finska städer. Magnusson, "Diskussionen", 28.

393 Magnusson, Äran, 81 f.; Koerner, Linnaeus, 165 f. Se även Melkersson, 104.

394 Clason, Orsakerna, 43; Tilas, Utkast, 3 f.; Schultze, Glas-makeriet, 2; Bäck, Farsoter, 2. Samma undvikande hållning till problemen går att urskilja under mössornas styre och hattarnas andra maktinnehav. Pehr Wilhelm Wargentin, "Svar, Gifvet på Kongl. Vetenskaps Academiens vägnar [...]", i Heijkenskjöld (1768), 22 f.; Sandels, Inrättning, 27, 33.

395 För Högströms politiska lojaliteter och åskådning, se Olle Frantzén, ”Pehr Högström", Svenskt biografiskt lexikon, band 19. Chydenius motsatte sig principiellt regleringarna av handeln och näringarna. Han var en av de mest hängivna mössorna på riksdagen 1765-66 men kom under ständermötets lopp att avsättas som riksdagsman av sitt eget parti efter att han riktat kritik mot dess politik. Magnusson, Sverige, 223, 235; Magnusson, "Diskussionen”, 26.

396 Högström, $3 \mathrm{f}$.

397 Ibidem, 3-6, 14, 17 f., 21. Talet utmålade det västerbottniska jordbruket som 
dåligt fast tecknade överlag en ljus bild av Högströms egen mönstersocken Skellefteå, där invånarna följde sina naturliga näringsböjelser och näringarna svarade mot behoven. Ibidem, $8 \mathrm{f}$., 11-21.

398 Ibidem, $14 \mathrm{f}$., $17 \mathrm{f}$.

399 Pehr Wilhelm Wargentin, "Svar, gifvet på Kongl. Vetensk. Academiens vägnar [...]", i Högström, 22-24; Högström, 8.

400 Mennander, Folkhopen, 4-6, 8-11, 13-18, 20 f., 23, 26-29.

401 Ibidem, 10, 15, 19, 21-26, 29.

402 Wrede, $29 \mathrm{f}$. Se även diskussionen om Henning Adolph Gyllenborgs förakt för passiva adelsmän i avsnittet "Det oresonliga folket" i kapitlet "Myndiga makthavare, omyndig menighet". Jämför Krygers utpekande av "inbillade förmoner och skiljaktiga rättigheter" som en stötesten för en god ekonomi. Kryger, Folkbristen, 30.

403 Runefelt, Dygden, 146-50.

404 Mennander, Folkhopen, 14, 20-23.

405 Pehr Wilhelm Wargentin, "Svar, gifvit på Kongl. Vetenskaps Academiens vägnar [...]", i Mennander (1766), $33 \mathrm{f}$.

406 Lidbeck, 4 f., 16, 35-37.

407 Wargentin, "Svar", i Lidbeck, $39 \mathrm{f}$.

408 Ehrensvärd påpekade krigsmaktens oundgänglighet för samhället och vände sig emot pacifismen, möjligen i polemik mot Mennander, som året innan kritiserat hattarnas militära äventyr. Ehrensvärd, Sjömagt, 4 f., 9, 20, 27-29.

409 Stockenström, Järn-bruk, 4 f., 8, 20, 26-34. Jernkontoret grundades 1747 som de inhemska brukens intresseorganisation och kreditinstitut. Ett informellt mål var att stärka den restriktiva politik som sökte dämpa stångjärnsproduktionen för att hålla priserna uppe. Förutom att ge lån understödde kontoret forskning och studieresor. Magnusson, Sverige, 257; Lindroth, Vetenskapsakademien, I:1, 324. Stockenström var inte bara en av Jernkontorets grundare utan också en av de sju fullmäktige i dess första ledningsgrupp. Hjalmar Fors, "Erik von Stockenström", Svenskt biografiskt lexikon, band 33, 548 .

410 Stockenström, Järn-bruk, 5, 15, $18 \mathrm{f}$.

411 Rosenadler, $3 \mathrm{f}$.

412 Rosenadler berörde även handeln, som uppgavs gynna alla europeiska nationer, inklusive Sverige. Ibidem, 3-13.

413 Ibidem, 11, 13.

414 Kryger, Lagarna, 9, 17, 20. Löwenhielm nämndes inte vid namn men hänvisningar till hans politiska ställning och tal om uppfostran visar vem som avsågs.

415 Ibidem, 7, 16, 23, $29 \mathrm{f}$.

416 Malmström, V, 313-24; Roberts, $226 \mathrm{f}$.

417 Kryger, Lagarna, 5 f., 9, 16 f., 24. För "frihet" som "privilegium", se avsnittet "Gustaviansk ekonomi" i kapitel 4. 


\section{NOTER}

418 Ibidem, 15, 17 f., 20-24.

419 Pehr Wilhelm Wargentin, "Svar, gifvit på Kongl. Vetenskaps Academiens vägnar [...]", i Ehrensvärd (1767), 31; Wargentin, "Svar", i Stockenström (1767), 36 f.; Wargentin, "Svar", i Kryger (1767), 33.

420 Pehr Wilhelm Wargentin, "Svar, gifvet på Kongl. Vetenskaps Academiens vägnar [...]", i Rosenadler, 15.

421 Löwenhielm, Ungdomen, 3, 8, 16 f., 35 f., 42 f. Löwenhielm uppskattade tilllika den persiska och den kinesiska meritokratin. Ibidem, 18 f., 27, 31. Acrel argumenterade några månader senare för att befordringssystemet borde vara knutet till lärda kvalifikationer. Acrel, Handalag, 76.

$422 \AA$ Å andra sidan vädjade Löwenhielm indirekt till de förnäma och de förmögna, men även till de kunniga, att solidarisera sig med ringare människor. Löwenhielm, Ungdomen, 36-38, 43, $46 \mathrm{f}$.

423 Ibidem, 8 f., 16 f., 23, 30, 33-35, 37, 42 f., 45 .

424 Det antika Aten hade tjänat på att folket bringats till tävlan om att hitta naturalster. Stadens militära framgångar hade sprungit ur såväl rivaliteten med Sparta som nogsam uppsikt över en uppfostran präglad av tävlan - skicklighetens och de stora bedrifternas huvudsakliga drivfjäder. Ibidem, 9, 15 f., 27, 33-35, 37.

425 Wargentin, "Svar", i Löwenhielm (1767), $49 \mathrm{f}$.

426 Bergius, Äng-skötseln, 10, 13, $93 \mathrm{f}$.

427 Ibidem, 7-9, 28-34, 47, 55, 68 f., 85; Pehr Wilhelm Wargentin, "Svar, Gifvet På Kongl. Vetenskaps Academiens vägnar [...]", i Bergius (1769), 96.

428 Hattpolitikens belackare betraktade konkurrens och avreglering som medel för att öka fliten och förbättra ekonomin. Runefelt, Dygden, $172 \mathrm{f}$.

Föreställningarna om självreglering går att relatera till det "sociologiska" angreppssätt som vann mark under 1700-talet och presenterade samhällsgemenskapen som ett fenomen i egen rätt. Rudebeck, 89, jämför 74.

429 Magnusson, Sverige, 233 f.; Magnusson, "Diskussionen", 36 f.; Müller, 85 f.; Runefelt, Dygden, $97 \mathrm{f}$.

430 Liedman, Handen, 17, 132; Harman, 3, 336; Johannisson, Samhället, 26 f.; Magnusson, ”Diskussionen”, 36 f., citat från idem. Jämför Runefelt, Dygden, 160 f.

431 Pagden, 6. Jämför Liedman, Handen, 149.

432 Jennings, Segelfarter, 5 f.; Schönberg, $7 \mathrm{f}$.

433 Liljencrantz, 7-10, 12-15, 18.

434 Clason, Orsakerna, 2, 9-14, 39 f., 42. För den sena frihetstidens sociala motsättningar, se Hallberg, Ages, 168-70.

435 Det brittiska frälsets placering av sin avkomma i de närande stånden lärde barnen att inte förhäva sig över borgarna och fick dem att skaffa sig kunskaper om deras verksamhet. Denna vana gjorde också att adeln inte måste lita till 
statsmakten ("Kronan") för sin försörjning, vilket tidigare varit fallet, liksom i Sverige. Clason, Orsakerna, 4, 8, 41.

436 Liljencrantz, 31-34. För fler historiska exempel, se 27-30. De båda hattarna och köpmännen Claes Grill och Thomas Plomgren diskuteras lite längre fram i detta avsnitt.

437 Adelcrantz, 5, $19 \mathrm{f}$.

438 Liedman, Handen, $196 \mathrm{f}$. Hattarnas maktövertagande har inte för inte tolkats som ett utslag av den nya tjänsteadelns expansion och de gamla jordägande adelssläkternas tillbakagång. Nordin, "Höpken", 66.

439 Rabbe, 46-49, 76, 81, 88-90, 92, 108.

440 Konkurrens ansågs vara förmånlig bortom hushållningen. Till exempel förklarade Carl Rudenschöld språkets utveckling med författares tävlan om att utge allehanda lärda skrifter i kölvattnet av vetenskapernas tillväxt. Rudenschöld, Språket, $5 \mathrm{f}$.

441 Schönberg, 10-12; Sandels, Inrättning, 11, 49 f., citat från idem; Liljencrantz, 18, 72. Se även Alströmer, Får-afveln, 30.

442 Liljencrantz, 6 f., 9 f., 69, 71.

443 Händelser i Frankrike demonstrerade att den levantiska handeln inte tålde att "utan försigtighet vara så lemnad åt sig sjelf, at icke behörig ordning och tilsyn dervid nödvändigt behöfves". Ibidem, 42 f., 47-50, 56, 60-64, 68-72. Levantiska kompaniet grundades 1738 och hade monopol på handeln med den levantiska kusten, men lyckades inte särskilt bra och lades ned 1756. Det omhuldades av och hade djupa försänkningar i hattpartiet. Müller, 45, 49-51.

444 Liljencrantz, 13, 15-17, 20 f., 32. Inte heller folket klarade sig självt i Liljencrantz ögon. Gemene mans okunnighet och oförmåga resulterade $i$ att han arbetade för lite och var onyttig under perioder av arbetsbrist. I ett resonemang som utgick från tanken om arbetsfördelning mellan stad och landsbygd föreställde sig Liljencrantz att bonden efterhand kunde ledas till en för sin ort passande lantslöjd. Denna skulle bedrivas på fritiden och ge rudimentära eller halvfärdiga tillverkningar för fortsatt bearbetning i städerna. Ibidem, $11 \mathrm{f}$.

445 Attityden till folket var i övrigt inte direkt positiv. Alströmer informerade sin publik om att "den sämre och okunnogare hopen" i ekonomiska frågor tenderade att behärskas av sedvanor och fördomar. Gemene man visste inte varför han gjorde som han gjorde men lyckades ändå ibland åstadkomma nyttiga ting. Alströmer, Får-afveln, 13-18, 21-23, 25-30, 47, 49-51, 72 f., 102-04.

446 Liljencrantz, 35, 41 f., 74 f.; Sandels, Inrättning, 14 f., 17, 21, 23, 26 f., 33, 47. En preses, Rabbe, lovordade en avliden mössa, Piper, som varit omtyckt av hattarna. Rabbe, 115. För de omnämnda personernas politiska lojaliteter, se Olof Jägerskiöld, "Carl Fredrik von Höpken", Svenskt biografiskt lexikon, band 19; Elsa-Britta Grage, "Thomas Plomgren", Svenskt biografiskt lexikon, band 29; Bengt Hildebrand \& Staffan Högberg, "Claes Grill", Svenskt biografiskt lexikon, 
band 17; Hans Gillingstam, "Piper, släkt", Svenskt biografiskt lexikon, band 29. Liljencrantz företedde också en välvillig syn på 1756 års riksdag. Liljencrantz, $38,47-49$.

447 Sandels, Inrättning, 11, 39-41. Med skolastisk filosofi torde Sandels ha avsett världsfrånvänd och pedantisk lärdom.

448 Clason, Orsakerna, 20, 22-24, 27-30, 32-37, 42.

449 Schönberg, 15-17, 20, 26 f., 30 f., 34, 36-40. Feniciernas prioriterande av handeln innebar att de "började på den rätta sidan"; köpenskapen satte fart på förädlingen och slöjderna och bringade rikedom och makt. Ibidem, 8 .

450 Ibidem, 13 f., $17,19$.

451 Ibidem, 16, 26 f., 30 f., 34 .

452 Ibidem, 13, 22-25, 40.

453 Ibidem, 17 f., 20, 29 f., 34-36, 40.

454 Ibidem, $11 \mathrm{f} ., 19,32 \mathrm{f}$.

455 Ibidem, 31-33.

456 Pehr Wilhelm Wargentin, ”Svar, gifvet på Kongl. Vetenskaps Academiens vägnar [...]", i Alströmer (1770), 108-10; Pehr Wilhelm Wargentin, "Svar, gifvet på Kongl. Vetenskaps Academiens vägnar [...]", i Jennings (1770), 31 f.; Pehr Wilhelm Wargentin, "Svar, gifvet på Kongl. Vetenskaps Academiens vägnar [...]", i Schönberg, 43 f.; Pehr Wilhelm Wargentin, "Svar, gifvit på Kongl. Vetensk. Academiens vägnar [...]", i Clason (1769), 44. Se även till exempel Wargentin, "Svar", i Liljencrantz, 77 f.; Pehr Wilhelm Wargentin, "Svar, gifvet på Kongl. Vetenskaps Academiens vägnar [...]", i Rudenschöld (1772), $21 \mathrm{f}$. Svaret på Clas Alströmers tal komplimenterade hans far och släkt, "en Stam af äkta Svenska Patrioter, af Människo-vänner och Vetenskaps-älskare”.

För Jennings politiska hemvist, se Staffan Högberg, "John Jennings", Svenskt biografiskt lexikon, band 2o. Sekreta utskottet var fram till statsvälvningen riksdagens tyngsta utskott, som främst ägnade sig åt finansiella och säkerhetspolitiska ärenden och inte inbegrep några representanter för bondeståndet. Nilsén, 107.

457 Löfberg, 82; Magnusson, Sverige, 232, 235; Melkersson, $57 \mathrm{f}$.

458 För nyttotänkandet, se Forsman, 233, 235 f., 238. Omorienteringen mot vitterhet och sköna konster diskuteras i inledningen till den föreliggande boken.

459 Lindroth, Vetenskapsakademien, I:1, 365; Bunge, 6; Mattsson, 49.

460 Bunge, 10 f.; Hermelin, 2, 34, 69-72; Runeberg, Nyttan, $17 \mathrm{f}$. Se även Lillienberg, Förmåner, $10 \mathrm{f} ., 17 \mathrm{f}$.

461 Bielke, 17, $28 \mathrm{f}$. Se även Hjelm, 24. Jämför Carl Sparres utsaga om att politin bevarade gränserna mellan städernas skrån och societeter och skyddade dem mot intrång från obehöriga. Sparre, 25.

462 De vetenskapliga förrättningarna vid bergsstaten skulle gestaltas på samma vis som "i en stor väl inrättad verkstad, där hvar och en sköter sit stycke-arbete, 
och den ene räcker den andra handen, ifrån första rå ämnet, til sista handläggningen, vid den färdiga och förädlade varan”. Därigenom vanns goda och kompetenta arbetare för varje enskilt moment. Rudenschöld, Majestet, 8, citat från idem; Lillienberg, Förbättringar, 6 f., citat från idem. Se även Falkenberg, 21 f.; Rönnow, 33-35.

463 Se till exempel Bergius, Läckerheter, I, 50; Sandels, Förhållandet, 78 ; Odhelius, Lazarettet, 40-42; Hermelin, 3-5, 8-12, 17 f., 23 f., 27 f., 31-34, 38-41, 43, 72 f., 86-89.

464 Qvist, Mineralvaror, 4, 7; Lillienberg, Förmåner, 22; Sandels, Förhållandet, 29-31, 81 .

Avogheten till import gällde inte minst jordbruksprodukter. Ämbetsmannen Eric Schröder förklarade att ett samhälle hänvisat till utlandet för sin bärgning inte hade "et fullkomligt sjelfbestånd" och att upplysningens och författningarnas stora syfte inom lantbruket var självförsörjning ifråga om brödfödan. Han beskrev en förhöjd tull på importerat spannmål under år med goda inrikes skördar som nyttig eftersom den gav svenska jordbrukare ett nödvändigt försteg framför utländska. Wilckes svar konstaterade att födandet av invånarna med inhemsk säd utgjorde ett viktigt ändamål, att svenskarna för närvarande blev "Utlänningen skattskyldige" för spannmålet samt att Vetenskapsakademiens bemödanden om jordbruket ännu inte fått avsedd verkan och gjort riket självförsörjande med säd. Schröder, 4, 8 f., 22; Wilcke, ”Svar", i Schröder, 24. Jämför Bielke, 24 f., 47.

465 Lindroth, Vetenskapsakademien, I:1, 283, 303 f., 306 f., 309-11, 362; Lindroth, Vetenskapsakademien, II, 219. Dessa försök bottnade i en "ekonomisk Rudbeckianism" som var förknippad med en tro på det svenska klimatets fördelaktighet och omhuldades inom Vetenskapsakademien, där rikets oberoende utgjorde en samfälld målsättning. Idealet om självförsörjning kunde hämta stöd i fysikoteologin, enligt vilken Gud nedlagt allt Sverige behövde i landets natur. Forsman, 124, 136, 149 f.; Runefelt, Dygden, 74. Olof Rudbeck den äldre var verksam i det sena 1600 -talets Uppsala och en förgrundsgestalt inom den så kallade göticismen, vars anhängare föreställde Sverige som ett förlovat och utvalt land med enastående klimat, framstående kultur och gamla anor. Persson, Främmande, 220.

Många av det svenska 1700-talets ekonomiska skriftställare menade emellertid att rikets oberoende inte kunde bli absolut och att något slags utrikeshandel alltid skulle vara för handen. Strävan efter autarki gick således att förena med idéer om internationellt varuutbyte. Runefelt, Dygden, 77, 82, 97; Forsman, 149.

466 Sparrman, 5-9; Benzelstierna, Hushållsmått, 8-10; Wilcke, "Svar", i Benzelstierna (1788), 16. Se även Hermelin, 28, 34-36, $39 \mathrm{f}$.

En annan sorts importsubstitution var att ersätta utländska varor med 
inhemska. Wargentin anförde att det egna landet rymde mycket som svenskarna föraktade "men som bekommer och smakar andra folkslag väl, och vi följakteligen äfven, åtminstone i nödfall, kunde nyttja". Peter Jonas Bergius talade sig varm för vin pressat på svenska bär, och Patriotiska sällskapets sekreterare Adolph Modeer kungjorde dels att inhemska växters bomull skulle begagnas jämte den utländska, dels att svensk pors i likhet med nordamerikansk kunde användas för att utvinna vax. Bergius, Frukt-trägårdar, 58, 60; Pehr Wilhelm Wargentin, "Svar, gifvet på Kongl. Vetenskaps Academiens vägnar [...]”, i Bergius (1785), 272; Modeer, 7-9. Jakten på inrikes surrogat för importprodukter var ingen ovanlighet i Vetenskapsakademien eller 1700-talets Sverige. Lindroth, Vetenskapsakademien, I:1, 312 f., 363; Lindroth, Vetenskapsakademien, II, 221 f.

467 Bunge attribuerade dock även dem som ansåg att det inte gick att acklimatisera någonting överhuvudtaget en bristfällig kunskap om rikets naturliga förutsättningar. Bergius, Frukt-trägårdar, 38 f., 46, 53-55; Bergius, Läckerheter, I, 81 f., 92, 104 f., 205-07, 259 f.; Bunge, 8 f. Se även Hjelm, 33.

468 Wargentin, "Svar", i Qvist (1776), 29 f.; Lillienberg, Förmåner, 5; Lillienberg, Förbättringar, 17-20, 23 f. Se även Bielke, 47; Hermelin, 57 f., 6o; Leijonmarck, Utsigten, 34 f.; Qvist, Mineralvaror, 14, 17; Sandels, Förhållandet, 55, 85, 90 f.; Hjelm, 12, 20 f., 37.

469 Hermelin, 28, 76, 80 f., 85; Sparre, 26, 43. Sparrman framställde jordbruket som slöjdernas avkomma, vilket antyder att han betraktade det som underordnat dem. Sparrman, 19.

470 Lillienberg, Förmåner, 19, 21; Leijonmarck, Utsigten, 31, 35; Sandels, Förhållandet, $73,78 \mathrm{f}$., $86 \mathrm{f}$.

471 Bunge, 13; Pehr Wilhelm Wargentin, "Svar, gifvet, på Kongl. Vetenskaps Academiens vägnar [...]", i Bunge, 20; Bielke, 12, citat från idem; Schröder, 3-5, 22. Se även Gadolin, Vetenskaper, $12 \mathrm{f}$.

472 Hjelm, 21; Wilcke, "Svar", i Schröder, 23 f.; Pehr Wilhelm Wargentin, "Svar, gifvet på Kongl. Vetenskaps Academiens vägnar [...]", i Arbin (1773), 58; Wargentin, "Svar", i Bunge, 20.

473 Hermelin, 3, 22 f.; Lillienberg, Förbättringar, 10, 23; Lillienberg, Förmåner, 5 f.; Qvist, Mineralvaror, 7; Runeberg, Nyttan, 12 f.; Swartz, $11 \mathrm{f}$.

474 Zacharias Zachariae Plantin, Tal, om justering och pröfning af mätnings- och vägnings-verktygen [...] (Stockholm, 1792), 7; Hermelin, 94; Bielke, 35; Grill, Silfver, 3-6, 27; Pehr Wilhelm Wargentin, "Svar, gifvet, på Kongl. Vetenskaps Academiens vägnar [...]", i Grill (1774), 29 f. Se även Qvist, Mineralvaror, 14, 16 f., 27 f.; Sandels, Förhållandet, 20; Thunberg, 3.

475 Qvist, Mineralvaror, 28; Leijonmarck, Utsigten, 26.

476 Bielke, 35-38. Se även Lillienberg, Förmåner, 15.

477 Sandels, Förhållandet, 31; Grill, Silfver, 26; Arfvedson, 8-12. Jämför utsagorna 
om balans i den svenska hushållningen i Pehr Wilhelm Wargentin, "Svar, gifvet, på Kongl. Vetenskaps Academiens vägnar [...]", i Hermelin, 114; Leijonmarck, Utsigten, 22, $29 \mathrm{f}$.

478 Runeberg, Nyttan, 18; Arfvedson, 7 f.; Hjelm, 23-25, 32. Se även Bunge, 7-11; Benzelstierna, Hushållsmått, $14 \mathrm{f}$. Naturalhistorikern och Linnélärjungen Carl Peter Thunberg pläderade för att bönderna skulle befrias från olika former av tvång, varvid den japanske lantbrukaren fick utgöra ett föredöme. Varken tegskifte eller allmänning låg denne i fatet när han skulle nyttiggöra och dra vinst av sin jord. Thunberg ogillade dessutom tullar, som lyckosamt saknades $i$ Japan. Thunberg, 32 f., 41. Tegskiftet var den nedärvda uppdelningen av jorden i tunna remsor, tegar, inom ramarna för gemensamma gärden. ”Tegskifte", Nationalencyklopedin, band 18.

Hjelms önskemål om få eller färre förordningar kan jämföras med Lillienbergs uppfattning att en liten statsapparat var att föredra, då " $i$ anseende til den politiska styrelsen af et land, mera uträttas, igenom et mindre antal af skickelige och väl lönte Embets- och Tjenste-män”. Lillienberg, Förbättringar, 6.

Rosenstein, 109, $157 \mathrm{f}$.

480 Schröder, 11-13, 17-22; Wilcke, "Svar", i Schröder, 24.

481 Sandels, Förhållandet, 25, 55-59, 68, 91.

482 Detta kan jämföras med ett resonemang hos Lillienberg, som höll före att ingen borde förargas över att "en omtänkt [omtänksam] Regering icke lemnat Bergsbruket handlöst, utan det samma understödt, med sådane förmåner, som passat sig, efter tider och omständigheter”. Hans redogörelse för regeringsunderstödet inbegrep mestadels friheter: frälsefrihet, tullfrihet, frihet från knekthållning samt personliga friheter och förmåner för dem som lokaliserat malmfyndigheter. Det rörde sig om ståndssamhälleliga undantag och privilegier, till skillnad från frånvaro av tvång, som i exempelvis en ledamotskollegas förmenande att lagar som skadade näringarnas utveckling och frihet skulle förbättras. Lillienberg, Förmåner, 13 f.; Lilliestråle, Lag-förbättring, 39 f.

483 Melkersson, 171; Runefelt, Dygden, 160.

484 Hermelin, 71; Bergius, Frukt-trägårdar, 10. Tävlan urskildes även i naturen, till exempel mellan fysikaliska krafter i en kropps rörelse. Gustaf Adolf Leijonmarck, Tal, om kast-linjen [...] (Stockholm, 1783), 3 f.; Modeer, 4.

485 Lillienberg, Förbättringar, 10-12.

486 Prosperin, 4 f., 7. Se även Gadolin, Vetenskaper, 17; Mallet, 13.

487 Rudenschöld, Majestet, 6; Hjelm, 2; Odhelius, Lazarettet, 3; Benzelstierna, Hushållsmått, 4. Se även Pehr Wilhelm Wargentin, "Svar, gifvet på Kongl. Vetenskaps Academiens vägnar [...]", i Lillienberg (1781), 25; Bergius, Läckerheter, I, 13 .

488 Bunge, 10; Schröder, 8-10. Se även Engeström, Mineralogien, 19; Sparrman, 27; 
Bergius, Frukt-trägårdar, 6; Engeström, Svårigheter, 15; Gadolin, Vetenskaper, 11.

489 Lilliestråle, Lag-förbättring, 38 f.; Sandels, Förhållandet, 50; Bunge, 15. Jämför synen på förmögna i Bergius, Läckerheter, II, $180 \mathrm{f}$.

Johan Lorens Odhelius konstaterade att förmögna eller förnäma patienters inbilskhet, självsvåld och nycker vållade beaktansvärda problem, liksom att deras insisterande på traditionell vård kunde göra att de avled av sjukdomar som sjukhusens fattiga botades från. Odhelius, Lazarettet, 40.

490 Gadolin, Vetenskaper, 11; Arbin, Fortifications-staten, II, 6 f.

491 Rosenstein, 109, 115 f., 138, 176.

492 De mindre bemedlade blev olyckliga av en ojämlikhet som gjorde att människor hindrades från att eftersträva lycksalighet, att somliga fick ensamrätt på fördelar och att de med större förmåner använde sig av dem för att förtrycka andra. Det fanns dessutom situationer som krävde en begränsning av människors nyttjande av sina rikedomar och deras rätt till vad de anskaffade, till exempel när yppigheten och överflödet blev samhällsskadliga eller uttryck för orättvisa. Rosenstein slog fast att förmögenhetsfördelningen generellt blivit jämnare, vilket samhället säkerligen tjänat på. Rosenstein, 57, 60-62, 182-86. För utsagan om jämlikhet som en trolig referens till franska revolutionen, se Segerstedt, 303 .

493 För kontrasterandet av handeln och slöjderna mot lantbruket, se Magnusson, "Diskussionen", $36 \mathrm{f}$.

494 Legnér, $91 \mathrm{f}$.

\section{Konungarnas akademi}

495 Laine, 16 f.; Lindroth, Vetenskapsakademien, I:1, 161; Orrje, $133 \mathrm{f}$.

496 Hildebrand, 407; Lindroth, Vetenskapsakademien, I:1, 161-66; Nordenmark, 182 f.; Oseen, 269 f.; Christensson, Lyckoriket, 132. Adolf Fredrik utsågs redan som kronprins 1747 till akademiens beskyddare.

497 Lindroth, Vetenskapsakademien, I:2, 164 f., 639; Nordenmark, 40, 52 f., 141 f.; Hildebrand, 336, 450 f., 468, 658-6o.

498 Matti Klinge, "Naturlig teologi och naturrätt”, i Matti Klinge m.fl., Helsingfors universitet 1640-1990, 3 vol. (Helsingfors, 1988-91), I, 677; Nilsén, 104, 106, citat från idem; Skuncke, Gustaf III, 11; Nordin, Frihetstiden, 276.

499 Barrington Moore Jr., Injustice: The social bases of obedience and revolt (1978) (London \& New York, 2015), 20-22.

500 Cederhielm, 5, 14; Wrede, 33 f.; Ehrenpreus, Konster, 3, 27; Carleson, Fiskeri, 6, 20 f.; Stockenström, Bergsmannanäringen, 22; Schultze, Ungdomen, 7, 24; Ekström, 36. Se även Alströmer, Sverige, 24; Grill, Sjö-farten, 9; Ehrenpreus, "Svar", i Schultze (1750), 29; Acrel, Sjukdomar, 38. 
501 Piper, 4-8, 10; Cederhielm, 5, 14.

502 Sandels, Inrättning, 11, 22; Clason, Orsakerna, 26 f., 31 f.; Stockenström, Järnbruk, 26.

503 Stockenström, Bergsmannanäringen, 22 f.; Schultze, Ungdomen, 21 f., 24 f.; Löwenhielm, Landt-skötsel, 54. Se även Ehrenpreus, "Svar", i Schultze (1750), 29.

504 Acrel, Sjukdomar, 38; Löwenhielm, Landt-skötsel, 54. Se även Alströmer, Sverige, 24; Ehrenpreus, Konster, 27; Schultze, Ungdomen, 25; Ehrenpreus, ”Svar", i Schultze (1750), 29.

505 Piper, 8-10.

506 Adelcrantz, 42; Bergius, Bad, 66.

507 Clason, Handels omskiften, 67; Leijell, 56-58; Ljungenstjerna, 64; Sandels, Inrättning, 37 f.; Scheffer, Mynt, 21; Ungern-Sternberg, 12 f.; Wargentin, ”Svar", i Ungern-Sternberg, 15 .

508 Adelcrantz, 42 f.; Höpken, Observatorii, 5; Knutberg, 23; Leijell, 56; Ljungenstjerna, 64 f.; Sandels, Inrättning, 37 f., 40-42; Scheffer, Anmärkningar, 7. Se även Piper, 9; Wargentin, "Svar", i Adelcrantz, 47.

509 Faggot, Historien, 77, citat från idem; Clason, Handels omskiften, 67; Ehrenpreus, Konster, 27, citat från idem; Rudenschöld, Skogarne, 55; Carl Fredric Ribe, Tal om ögonen [...] (Stockholm, 1748), 28. Referensen till Vasaätten anknöt till kronprinsens status av "den tredje Gustaven", varom mera i nästa avsnitt.

Gustav komplimenterades emellanåt jämsides sin bror Karl, den framtide Karl XIII. De båda kungabarnen var rikets "käraste ögnastenar" och garanter för en bestående lycksalighet i näringarna. Sverige skulle ha fördel av och nå sällhet med de omsorgsfulla, dygdiga och folkälskande prinsarna, vilka kunde hämta inspiration i sina stora föräldrars föredöme. Stockenström, Bergsmannanäringen, 23, citat från idem; Schultze, Ungdomen, 25; Ehrenpreus, "Svar", i Schultze (1750), 29; Löwenhielm, Landt-skötsel, 54.

510 Wrede, $5 \mathrm{f}$.

511 Salander, 6; Höpken, Observatorii, 10 f. För förhållandet mellan hattarna och kungaparet, se Skuncke, Gustaf III, 123 f., 126. För förhållandet mellan kungahuset och Vetenskapsakademien, se Lindroth, Vetenskapsakademien, I:1, 164.

512 Mennander, Bok-handelen, 14, 25 f. För kungaparet och statskupplanerna, se Nilsén, 233; Claes Rainer, Lovisa Ulrika: Konst och kuppförsök (Stockholm, 2019), kapitel 21, 23. För Tessins konflikt med Adolf Fredrik och Lovisa Ulrika, se Hildebrand, 610 f., 614; Lindroth, Vetenskapsakademien, I:1, $132 \mathrm{f}$.

513 Adelcrantz, 27-29, 42 f., 35 f.; Kryger, Folkbristen, 37. För 1756 och 1758 års rojalistiska stämplingar och deras efterspel, se Skuncke, Gustaf III, 183 f. Sekreterarens svar till Adelcrantz balanserade kungaparets vinnläggande om de fria konsterna och riksdagens ansträngningar på området. Wargentin, "Svar", i Adelcrantz, 47. 
514 Faggot, Fortsättning, 4 f., 8 f., 16-19, 21, 23 f., 30; Swab, 14 f., 17 f., 20-28, 30, 36, 39; Jennings, Sluss-byggnad, 10, 13, 25, 28. För kronprinsens bibliotek och höga överhetens nit, se Stiernman, 117, 119 f.; Alströmer, Schäferierna, 12.

515 Knutberg, 23; Carl Lehnberg, Tal, om optikens och refractions telescopers förbättring i senaste tider [...] (Stockholm, 1762), 20.

516 Skuncke, Gustaf III, 254, 256.

517 Bergius, Bad, 66 f.; Pehr Wilhelm Wargentin, "Svar, gifvet på Kongl. Vetenskaps Academiens vägnar [...]", i Ferrner, (1765), 56; Bäck, Farsoter, 10, 13, 22 f., 29, 50. Se även Schulzenheim, 25; Zetzell, Soldat, 29.

518 Malmström, V, 292 f; Malmström, VI, 17 f., 58-60; Nordin, Frihetstiden, $50,52$.

519 Celsius, 5; Ehrensvärd, Sjömagt, 21; Heijkenskjöld, Anmärkningar, 19; Lidbeck, 5; Zacharias Johan Strandberg, Tal, om de fel, som vid chroniska sjukdomars botande i allmänhet begås [...] (Stockholm, 1765), 16; Pehr Wilhelm Wargentin, "Svar, gifvit på Kongl. Vetensk. Academiens vägnar [...]", i Strandberg (1765), $39 \mathrm{f}$.

520 Löwenhielm, Ungdomen, 9 f, 19-21.

521 Stockenström, Järn-bruk, 34.

522 Clason, Orsakerna, 34-38; Jennings, Segelfarter, 27-29; Wargentin, "Svar", i Jennings (1770), 30-32. Bengt Bergius tog fasta på kungabarnens ympning med smittkoppor, som var av yttersta vikt och befäste "det stora hopp, som hela Allmänheten grundar på Deras dyrbara lif”. Bergius, Äng-skötseln, 93.

523 Cronstedt, Academien, 3-9; Sandels, Inrättning, 11, 32, 37, 39-42.

524 För rojalismen, se Ingemar Oscarsson, '"Rikets Frihet, Borgerlig Frihet, SkrifFrihet': Gjörwell och Den politiske Aristarchus 1769-72", i Riksdag, red. Skuncke \& Tandefelt, 316; Olsson, 183; Sven Rydberg, Svenska studieresor till England under frihetstiden (Uppsala, 1951), 348; Nordenmark, $78 \mathrm{f}$.

525 Cronstedt, Academien, 5; Pehr Wilhelm Wargentin, "Svar, gifvet, på Kongl. Academiens vägnar [...]", i Cronstedt (1771), $12 \mathrm{f}$.

526 Schönberg [3 f.], 41 f.; Rosén von Rosenstein, Pesten [1 f.], 22; Pehr Wilhelm Wargentin, "Svar, gifvet, på Kongl. Vetenskaps Academiens vägnar [...]", i Botin, 41 f.; Samuel Sandels, Tal, då Kongl. Vetenskaps Academien i underdånighet anhöll, och Kongl. Majestet $i$ nåder täcktes emottaga academien, såsom protector [...] (Stockholm, 1772) [2]. Se även Sandels, Inrättning, 3 f.; Carl Rudenschöld, ”Til Kongl. Majestet, på Kongl. Vetenskaps Academiens vägnar [...]", i Tal hållne i Kongl. Vetenskaps Academien, då Hans Kongl. Majestet första gången benådade academien med sin höga närvarelse [...] (Stockholm, 1772), 3 f.; Wargentin, "Svar", i Schönberg, 44.

527 Schönberg, [4], $41 \mathrm{f}$.

528 Schönberg, 42; Rudenschöld, Språket, 4, 20. För Konunga- och höfdingastyrelsen, se Michael Nordberg, I kung Magnus tid: Norden under Magnus Eriksson 1317-1374 (Stockholm, 1995), 153. 
529 Rudenschöld, Språket, 15. Ett tidsligt närliggande tal av Rudenschöld anlade likaledes en negativ syn på tvedräkt när det fastställde att Vetenskapsakademien var en gemenskap "där intet misstroende, ingen afund, intet parti-agg fătt inrymme, eller annan täflan har rum, än den, att alla i gemen, och hvar och en i sin krets, må i görligaste måttan upfylla deras skyldigheter, såsom nitfulla Undersåtare, och nyttiga Medborgare, för Samtid och Efterverld”. Rudenschöld, Majestet, 4.

530 Rosén von Rosenstein, Pesten, $21 \mathrm{f}$.

531 Clason, Orsakerna, 37; Sandels, Inrättning, 11; Liljencrantz, 76.

532 Clason, Orsakerna, 17, 22; Sandels, Inrättning, 11; Rabbe, 76.

533 Celsius, 5 .

534 Lindberg, Skevheten, 168; Nordin, "Höpken", 81-83, 85 f.; Koerner, Linnaeus, 31; Skuncke, Gustaf III, 271 f.; Nordenmark, 78 f.

535 Tandefelt, 99 f., citat från idem; Alm, 70-73, 83 f., 114; Oseen, 184, 250, 274; Lindroth, Vetenskapsakademien, I:1, 166; Christensson, Lyckoriket, 132.

536 Skuncke, Gustaf III, 36, 166, 241, 252, 272, 274, 281; Mattsson, 55 f.; Hallberg, Ages, 233 f., 251 f., 263-65, 267, 277 f. Regimens självbild och propaganda behandlas utförligt i Mikael Alms Kungsord i elfte timmen, Jennie Nells Vivat vår monark! och Henrika Tandefelts Konsten att härska.

537 Scheffer, Grund-lagarna, 4 f., 29; Pehr Wilhelm Wargentin, "Svar, gifvit på Kongl. Vetenskaps Academiens vägnar [...]", i Scheffer (1772), $31 \mathrm{f}$.

538 Lilliestråle, Lag-förbättring, [5 f.], 52; Melanderhielm, Vetenskaperna, 76; Wilcke, Förklaringar, [3 f.], 104-06. Se även Sparre, 38, 43; Sandels. Förhållandet, 91. För solsymboliken kring tidigmoderna monarker, se Skuncke, Gustaf III, 36, 78,80 .

539 För hänvändelser, se Scheffer, Grund-lagarna, 4 f., 29; Rönnow [3 f.]; Bunge [3]; Leijonmarck, Utsigten [3]; Lilliestråle, Lag-förbättring [3], 7, 52; Bielke [3 f.], 6; Rudenschöld, Majestet [3 f.]; Sandels, Förhållandet [3 f.]; Schröderheim [1 f.]. För karaktärsteckningar och referenser, se Wargentin, "Svar", i Arbin (1773), 57 f.; Lindblom, 4; Wäsström, 4 f.; Grill, Silfver, 5; Lilliestråle, Lag-förbättring, 36, 44-46; Qvist, Mineralvaror, 27; Bergius, Läckerheter, I, 11 f.; Lillienberg, Förbättringar, 10, 19, 21 f.; Sandels, Förhållandet, 82, 90; Arbin, Fortificationsstaten, II, 4 f., 25, 113; Mallet, 18 f.; Swartz, 46 f.; Johan Carl Wilcke, "Svar, gifvet på Kongl. Vetensk. Acad. vägnar”, i Plantin (1792), $28 \mathrm{f}$.

540 För ospecificerade syftningar, se Odhelius, Lazarettet, 11, 19 f., 43; Wargentin, "Svar", i Odhelius (1776), 47; Odhelius, Dödligheten, 26-28; Mallet, 14. För syftningar på Gustav III, se Sparre [3-6], 38-40, 44; Wilcke, Förklaringar [4]; Odhelius, Dödligheten, 28; Plantin, Målen, 22. Kungl. Maj:t hänförde sig till "hela regeringsmakten, det vill säga konungen i rådet" men går inte alltid att hålla isär från konungen och hans person. Nordin, Frihetstiden, 21.

541 För mildhet, se Leijonmarck, Utsigten [3]; Lilliestråle, Lag-förbättring [3]; 


\section{NOTER}

Sparre, 8; Schützercrantz, Tilväxt, 77; Rudenschöld, Majestet [4]; Mallet, 18. För storsinthet, se Lilliestråle, Lag-förbättring [3]. För generositet, se Swartz, 41 f. För storhet, se Arbin, Fortifications-staten, I, 54; Rönnow, 27; Bunge, 19; Lilliestråle, Lag-förbättring [6]; Lillienstrand, 22; Melanderhielm, Vetenskaperna, 76; Lilliestråle, Tale-konsten, 40; Odhelius, Dödligheten, 30; Gadolin, Vetenskaper, 30. För makt, se Wargentin, "Svar", i Bunge, 2o. För effektivitet, se Plantin, Målen, 8. Flera av egenskaperna - mildhet, godhet, välvilja, arbetsamhet - nämndes i Scheffer, Grund-lagarna, 30.

542 Enligt Scheffer var Gustav dessutom stor nog att inte vilja förolämpa främmande makter. Sparre, 45; Scheffer, Grund-lagarna, 24, 28. För epiteten stormäktigaste och allernådigaste, se Lillienberg, Förmåner, 3; Bielke [3]; Dalberg, Climatet [3]; Bergman [3]; Wilcke, Förklaringar [3]; Sandels, Förhållandet [3]; Schröderheim [1].

543 För vishet och insiktsfullhet, se Arbin, Fortifications-staten, I, 55; Wäsström, 22; Grill, Silfver, 5; Lilliestråle, Lag-förbättring [3], [5], 52; Lillienberg, Förmåner, 20; Qvist, Mineralvaror, 4; Sparre, 8, 39, 41, 44 f.; Wilcke, Förklaringar [4]; Runeberg, Nyttan, 20; Lilliestråle, Tale-konsten, 40; Odhelius, Dödligheten, 30; Mallet, 15. För upplysning, se Arbin, Fortifications-staten, I, 54; Rudenschöld, Majestet [4]; Plantin, Målen, 8.

544 Scheffer, Grund-lagarna, 21 f., 25-27; Melanderhielm, Vetenskaperna, 76, citat från idem. För Gustav som lagförbättrare, se även Sparre, 40 f.; Lilliestråle, Lag-förbättring, 45-48. En ledamot ansåg honom vara kompetent att döma om akademiemedlemmarnas uppslag och övriga förtjänster, en annan hoppades att den upplyste regenten skulle bemöta lärda som ville göra hushållningskunskapen till en vetenskap på samma sätt som Fredrik II av Preussen uppträtt mot filosofen Christian von Wolff. Bergius, Läckerheter, I, 12; Runeberg, Nyttan, 24.

545 Scheffer, Grund-lagarna, 26; Lilliestråle, Lag-förbättring [3 f.]; Ferrner, Försök, 46; Schröderheim [2].

546 Bergius, Läckerheter, I, 5 f., 8, 11; Scheffer, Grund-lagarna, 27 f.

547 Arbin, Fortifications-staten, I, 55.

548 Lilliestråle, Lag-förbättring [4]; Qvist, Mineralvaror, 4 f., 27; Bielke, 47. Se även till exempel Grill, Silfver, 5; Hermelin, 112; Leijonmarck, Utsigten, 35 f.; Pehr Wilhelm Wargentin, "Svar, gifvet på Kongl. Vetenskaps Academiens vägnar [...]", i Leijonmarck (1775), 37 f.; Runeberg, Nyttan, 20; Sandels, Förhållandet, 82, 90; Marelius, Nyttan, 19.

549 Schröder, 5.

550 Lillienberg, Förmåner, 4, 8, 20, 22; Lillienberg, Förbättringar, 10, 19 f., 22.

551 Lilliestråle, Tale-konsten, 40; Rönnow, 27; Gadolin, Vetenskaper, 30; Melanderhielm, Vetenskaperna, 76; Bunge [3]; Wilcke, "Svar", i Schröderheim, 28. Se även Qvist, Mineralvaror, 4 f.; Sparre, 42; Pehr Wilhelm Wargentin, "Svar, 
gifvet på Kongl. Vetenskaps Academiens vägnar [...]”, i Bergman, 48; Wilcke, Förklaringar, 106 f.; Sparrman, 29; Schröderheim [1 f.]; Swartz, 46 f.; Prosperin, 38.

Ett tal tog upp monarkens värnande om praktiska vetenskaper och inordnade därvid honom i en inhemsk tradition av furstligt beskydd jämte Gustav II Adolf och Adolf Fredrik. Mallet, 15, $18 \mathrm{f}$.

552 Scheffer, Grund-lagarna, 30; Sparrman, 29; Lilliestråle, Lag-förbättring [5], 52. Se även Bielke [4]; Sparre, 45; Wargentin, "Svar", i Bielke, 50.

553 Scheffer, Grund-lagarna, 30; Per Wilhelm Wargentin, "Svar, gifvet på Kongl. Vetenskaps Academiens vägnar [...]", i Lillienberg (1776), 24; Wargentin, "Svar", i Rönnow, 40; Rönnow, 27; Sparre, 45; Bunge, 19. Se även Bielke, 46 f.; Wargentin, "Svar", i Bielke, 49; Qvist, Mineralvaror, 4 f.; Melanderhielm, Vetenskaperna, 76.

554 Lilliestråle, Lag-förbättring [4 f.].

555 Dalberg, Climatet, 34; Odhelius, Lazarettet, 11, 26, 28, 30; Sparre [5], 39-42.

556 Sparre, 39: Schützercrantz, Tilväxt, $76 \mathrm{f}$.

557 Scheffer, Grund-lagarna, 29 f. Lilliestråle liknade Gustav III vid Titus och tycks ha parallelliserat honom med Lykurgos, som hemkommen från sina resor erfarit sitt folk vara "så godt som aldeles regerings-löst". Det fastslogs att Lykurgos varit "af et älskadt Konunga-blod", uppvisat stor insikt och talegåva samt försett sitt folk med en lagbunden frihet. Lilliestråle, Lag-förbättring [4], 14. Det är rimligt att anta att denna beskrivning hade bäring på frihetstiden och Gustav, som var en erkänt skicklig talare och hade befunnit sig på resande fot när Adolf Fredrik avled. Insiktsfullheten och den lagbundna friheten harmonierade med den gängse bilden av konungen och hans regim i de gustavianska presidietalen.

558 Skuncke, Gustaf III, 251 f., 272; Hallberg, Ages, 265 f.

559 Lilliestråle, Lag-förbättring [5]; Arbin, Fortifications-staten, I, 8.

560 Bielke, 6, 9-19, 22-32, 35-44, 47.

561 Wargentin, "Svar", i Bielke, 48-50.

562 Plantin, Justering, 3, 7.

563 Ibidem, 3-6.

564 Wilcke, "Svar", i Plantin (1792), 28 f.

565 Sparrman, 30; Wilcke, "Svar", i Rosenstein, 221.

566 Plantin, Justering, $6 \mathrm{f}$.

567 Nell, 224; Mattsson, 47; Hallberg, Ages, 261, 273, 278, 287.

568 Rudenschöld, Majestet, 7; Bergius, Läckerheter, I, 4; Rosenstein, 216.

569 Scheffer, Grund-lagarna, 6-9, 20.

570 Ibidem, $9 \mathrm{f}$.

571 Ibidem, $15 \mathrm{f}$.

572 Ibidem, 14, 21-23, 26, 29. 


\section{NOTER}

573 Bunge, 8-10.

574 Lillienberg, Förmåner, 9, 19-21; Leijonmarck, Utsigten, 31, 35.

575 Lilliestråle, Lag-förbättring, 45 f.; Sparre, 26, 34 f., 37 f. Se även Lillienberg, Förmåner, 21.

576 Sandels, Förhållandet, 73.

577 Ibidem, 73 f., 76-78, 82-84, 86-89.

578 Ibidem, 79-82, $88 \mathrm{f}$.

579 Bergius, Läckerheter, I, 5-8.

580 Swartz, 29 f., 40 f.; Prosperin, 8 f.

581 Dalberg, Climatet, $23 \mathrm{f}$.

582 Bielke, $46 \mathrm{f}$.

583 För "den förste medborgaren", se Mattsson, 55. Carl Sparre var först ut i akademien med att beteckna Gustav som den förste medborgaren och förklarade att regenten såg det som "sin Ära, at tillika vara den ypperste, den Förste Medborgaren!!!” Andra ledamöter anmärkte att själve fursten i en upplyst tid fann sig hedrad att kallas den förste medborgaren och att han skänkt sina medborgare en oskattbar skriv- och tryckfrihetslag. Sparre, 41, 45; Rosenstein, 159; Lilliestråle, Tale-konsten, 40.

584 En liknande parallellisering kan urskiljas i framställningarna av Karl XI, vars förmyndarregering attribuerades maktmissbruk och egenintresse. Sandels berättade om betungande pålagor, en växande "Kronoskuld" och hårda inrikes motsättningar. Missnöjet växte och skvallrade om en stundande "hvälfning", varefter Karl XI använde sin envåldsmakt för att reda ut problemen och befrämja undersåtarnas välmåga. Sandels, Förhållandet, 31 f., 44 f., 60 f., 82. För parallelliseringar av riksbefriarna Gustav Vasa och Gustav III, se Mattsson, 55; Hallberg, Ages, $265 \mathrm{f}$.

585 Dalin, 21; Alströmer, Sverige, 27, 32. Se även Polhem, Fädernesland, 4 f., 9; Ehrenpreus, Konster, 23; Ehrenpreus, "Svar", i Schultze (1750), 29; Meijer, 3; Ekström, 2; Strandberg, Sjukdomar, 1; Wargentin, "Svar", i Strandberg (1765), 39 f.; Liljencrantz, 75.

586 Rudenschöld, Majestet, 10 f.; Bergius, Läckerheter, I, 15.

587 Scheffer, Grund-lagarna, 21-24, $29 \mathrm{f}$.

588 Ibidem, 24-27.

589 Lilliestråle uppgav att undersåtarna inte drog sig för att framlägga sanningen inför tronen då den tilltalade och vägledde konungen, som till sin egen odödliga ära givit dem en ovärderlig skriv- och tryckfrihetslag. Sandels, Förhållandet, 89; Lilliestråle, Lag-förbättring [2-4]; Lilliestråle, Tale-konsten, 40; Thunberg, 10, 32 f. Se även Bunge, 5, 7 f.; Wargentin, "Svar", i Scheffer (1772), 32; Bielke, 46 f.; Qvist, Mineralvaror, 4; Schröderheim, $2 \mathrm{f}$.

590 Rosenstein, 51-54, 67, 210.

591 Ibidem, 54 f, 58, 63, 67, 153-55. 
592 För Rosensteins syn på och ifrågasättande av Gustavs förenings- och säkerhetsakt, se Segerstedt, 157-60, 301, 323. För förenings- och säkerhetsakten, se Segerstedt, 318; Leif Landen, Gustaf III: En biografi (Stockholm, 2004), 283 f.; Mattsson, 43, 205.

593 Alströmer, Sverige, 26; Hårleman, 17. Se även Bäck, Farsoter, 13.

594 Nilsén, 365.

595 Bielke, 46; Bunge, 13, 19; Lilliestråle, Lag-förbättring [4]; Wargentin, ”Svar", i Scheffer (1772), 32.

596 Benzelstierna, Hushållsmått, 14; Hermelin, 20 f.; Lillienberg, Förmåner, 22; Scheffer, Grund-lagarna, 25; Sparre, 23. Se även Lilliestråle, Lag-förbättring, 52.

597 Äganderätten var förbunden med den personliga friheten och säkerheten. Rosenstein, 64-67, 70 f., 156.

\section{Vetenskapsakademien, samhället och makten}

598 För Vetenskapsakademien som samhälle, se till exempel Pehr Elvius, "Svar, gifvit på Kongl. Vetenskaps Academiens vägnar [...]", i Hårleman, 40; Bäck, Nyttan, 1 f.; Berch, Myntet, 1, 34; Pehr Wilhelm Wargentin, "Svar, gifvit på Kongl. Vetenskaps Academiens vägnar [...]", i De Geer (1754), 40; Tilas, Utkast, 4; Sandels, Inrättning, 3, 13 f., 25, 30; Grill, Silfver, 3, 28; Dalberg, Climatet [4], 5, 31; Bergman, 45; Qvist, Mineral-samlare, 3; Adlerbeth, 3 f. Andra lärda sällskap gestaltades på samma sätt. Pehr Wilhelm Wargentin, "Svar, gifvit på Kongl. Vetensk. Academiens vägnar [...]", i Bonde, 20; Sandels, Protector [2]; Prosperin, 2, 4-7, 38. Vetenskapsakademien etiketterades också som ett samfund. Se exempelvis Browallius, 37; Berch, Myntet, 2; Wilcke, Magneten, 3; Bergman, 43 f.; Leijonmarck, Kast-linjen, 22; Melanderhielm, Angelägenheten, 3 . Beskrivningarna av organisationen som ett samhälle eller samfund har tidigare uppmärksammats i Hallberg, Ages, 144-48.

För Vetenskapsakademiens lag eller lagar se till exempel Carl Didrik Ehrenpreus, "Svar gifvit å Kongl. Vetenskaps Academiens vägnar”, i Rudenschöld (1748), 57, 59; Heijkenskjöld, Bärgs-hushållningen, 1; Ferrner, Tvisten, 3 f.; Kryger, Lagarna, 4, 31; Sandels, Inrättning, 13, 19, 23; Falkenberg, 3; Bielke, 5 f.; Odhelius, Lazarettet, 3, 44; Zetzell, Sjukligheten, 5, 54; Rudenschöld, Majestet, 5, 11; Schröderheim [2], 24; Carlson, 2. Bengt Bergius angav att seden att hålla ett tal vid ordförandeskapets nedläggande "blifvit likasom en lag". Bergius, Läckerheter, I, 19. Även andra lärda sammanslutningar tillskrevs lagar. Prosperin, 13, 16, 34, 39, 56 .

599 Odhelius, Lazarettet, 3.

600 Plantin, Justering, 4; Sandels, Inrättning, 13; Lilliestråle, Tale-konsten, 6, 30.

601 Bergius, Läckerheter, I, 16-18. Jämför Carl von Linnés parallellisering av sig själv med Gustav III: "In line with his own lawgiving inclinations, Linnaeus 
greeted with delight Gustav III's absolutist coup d'état in 1772, which closed off Sweden's Era of Freedom and ended its chaotic parliamentary rule. In his own realm of science, he saw himself as an enlightened despot. Espousing 'laws', Linnaeus wanted to transform botany [...] into a legislated code administered from a single center." Koerner, Linnaeus, 31.

602 Goodman, $1 \mathrm{f}$.

603 Orrje, 125 f., 130, 133, 156; Spary, 192-95.

604 Lindroth, Vetenskapsakademien, I:1, $217 \mathrm{f}$.

605 Se till exempel Cederhielm, 3, 12, 29 f.; Polhem, Fädernesland, 22 f.; Clason, Handels omskiften, 65; Höpken, Observatorii, 5-10; Alströmer, Schäferierna, 3 f., 11; Knutberg, 17 f.; Mennander, Folkhopen, 4; Cronstedt, Academien, 9; Bergman [3], 43; Wilcke, Förklaringar [4], 104, 106.

606 Wargentin, "Svar", i Rosenadler, 14; Sandels, Inrättning, 15 f., 48, citat från idem; Faggot, "Svar", i Wrede, 39; Wilcke, "Svar", i Schulzenheim, 45; Triewald, 22-24.

607 Schützercrantz, Tilväxt, 78; Prosperin, 1 f.; Gadolin, Vetenskaper, 29; Hermelin, 1 f.; Arfvedson, 3 f., 14, citat från idem. Se även Hjelm, 2 f.; Rosenstein, 4, 217; Plantin, Justering, 3, $6 \mathrm{f}$.

608 Se till exempel Pehr Elvius, "Secreteraren Pehr Elvii härå gifne svar, på Kongl. Vetenskaps Academiens vägnar", i Ribe (1748), 31; Pehr Elvius, ”Svar, gifvit å Kongl. Vetensk. Academiens vägnar [...]", i Dalin, 24; Seth, 22; Wargentin, "Svar", i Bergius (1764), 112; Wargentin, "Svar", i Strandberg (1765), 40; Wargentin, "Svar", i Alströmer, (1770), 109; Pehr Wilhelm Wargentin, "Svar, gifvet, på Kongl. Vetenskaps Academiens vägnar [...]", i Bergius (1780), 117 f.; Pehr Wilhelm Wargentin, "Svar, gifvet på Kongl. Vetenskaps Academiens vägnar [...]", i Qvist (1782), 30; Johan Carl Wilcke, ”Svar, gifvet på Kongl. Vetenskaps Academiens vägnar [...]", i Nordenankar, 23.

609 Wilcke, "Svar", i Schröder, 23.

610 Se exempelvis Polhem, Fädernesland, 3 f.; Ehrenpreus, Konster, 1; Scheffer, Mynt, 1; Mennander, Bok-handelen, 3; Kryger, Folkbristen, 2; Wilcke, Magneten, 2 f.; Ferrner, Tvisten, 4; Jennings, Segelfarter, 3 f.; Fredrik Henrik af Chapman, Tal, om de förändringar, som örlogs-skepp undergått, sedan canoner började på dem nyttjas [...] (Stockholm, 1770), 2; Rosén von Rosenstein, Pesten, 3; Schönberg [4]; Bunge, 6; Sparre, 7 f.; Wilcke, Förklaringar, 8; Dalberg, Luften, 3; Benzelstierna, Hushållsmått, 4; Hjelm, 2. Flera akademimedlemmar gestaltade presidietalen som en etablerad och nyttig sedvana. Swab, 4; Prosperin, 2; Odhelius, Lazarettet, 4; Bergius, Läckerheter, I, $18 \mathrm{f}$.

611 Alströmer, Sverige, 3; Strandberg, Febrar, 22; Grill, Sjö-farten, 4.

612 Se till exempel Wargentin, "Svar", i Kryger (1758), 39; Runeberg, Varor, 3 f.; Lidbeck, 3; Kryger, Lagarna, 3 f., 31; Sandels, Inrättning, 12, 16, 39; Hermelin, 2; Ferrner, Försök, 46; Schröderheim, 4; Johan Carl Wilcke, "Svar, gifvet, på 
Kongl. Vetenskaps Academiens vägnar [...]”, i Plantin (1788), 32; Benzelstierna, Hushållsmått, 3; Adlerbeth, 57.

613 Höpken, Observatorii, 8; Liljencrantz, 3, 39; Sandels, Inrättning, 12; Wargentin, "Svar", i Löwenhielm (1751), 60; Wargentin, "Svar", i Rosenadler, 15; Wargentin, "Svar", i Strandberg (1765), 40.

614 Lidbeck, 3, citat från idem; Alströmer, Får-afveln, 105.

615 Wilcke, "Svar", i Schröderheim, 28, citat från idem; Wilcke, Förklaringar [4]; Lillienberg, Förbättringar, 1; Sparre, 8. Gustavianska ordförande utmålade akademigrundarna som goda patrioter; de hade månat om fäderneslandets ära och Vetenskapsakademiens "höga ändamål" ursprungligen varit "Samtids och Efterkommandes uplysning, samt Fäderneslandets dermed förknippade sällhet [...] En afsigt, som nogsamt framlyser ur Academiens visa Grundreglor”. Rudenschöld, Majestet, 5; Bergius, Läckerheter, I, 8.

616 Gyllenborg, 1 f.; Alströmer, Får-afveln, 4; Lillienberg, Förmåner, 4; Bergius, Läckerheter, I, 10, citat från idem.

617 Runeberg, Nyttan, 3; Sparre, 23; Elvius, "Svar", i Tessin, 13. Se även till exempel De Geer, Nyttan, 3 f.; Elvius, "Svar", i Hårleman, 38 f.; Browallius, 14-16, 18; Scheffer, Anmärkningar, 12-14; Kryger, Folkbristen, 11; Pehr Wilhelm Wargentin, "Svar, gifvit på Kongl. Vetensk. Academiens vägnar [...]", i Wilcke (1764), 42 f.; Sandels, Inrättning, 7 f.; Scheffer, Grund-lagarna, 10 f., 13 f.; Lilliestråle, Lag-förbättring, 9 f.; Bergman, 41; Zetzell, Sjukligheten, 4 f.; Melanderhielm, Vetenskaperna, 73.

618 Wilcke, Förklaringar, 104; Plantin, Justering, 4; Löwenhielm, Ungdomen, $1 \mathrm{f}$.

619 Wilcke, "Svar", i Dalberg (1784), 29 f.; Rudenschöld, Majestet, 7 f.

620 Pehr Wilhelm Wargentin, "Svar, gifvet på Kongl. Vetenskaps Academiens vägnar [...]", i Berch, (1766), 43, citat från idem; Bergman, 5 f.; Schützercrantz, Tilväxt, 4 f. Jämför Sparrman, 5 .

621 Knutberg, 6; Scheffer, Anmärkningar, 13, citat från idem; Schönberg, 36; Meijer, 7 f., 12, citat från idem. Se även Ljungenstjerna, 2; Salander, 16 f.; Kryger, Folkbristen, 36; Sandels, Inrättning, 7 f.; Bergman, 42. Under Gustav III:s regering blev uttalandena om kunskapens ekonomiska nytta färre. Ett tal angav att "den kunskap, som angår djurens och tingens naturliga art och verkningar" hörde till "all hushållning [...] för at kunna lämpa hushålls-anstalterna derefter, til ändamålets säkraste vinnande”. Ett annat redogjorde för hur bergsvetenskapen fått insteg bland brukens och bergverkens ägare, med åtskilliga förbättringar som följd. Runeberg, Nyttan, 6 f., citat från idem; Lillienberg, Förmåner, 9 f.

622 Browallius, 24; Anders Johan von Höpken, "Svar gifvit å Kongl. Vetenskaps Academiens vägnar [...]", i Carleson (1749), 28. Se även Ferrner, Försök, 41.

623 Rosenstein, 8o-84, 206.

624 Acrel, Handalag, 75, citat från idem; Gyllenborg, 2; Tilas, Utkast, 4; Acrel, Sjukdomar, 2; Polhem, Vetenskaperne, 17; Wargentin, "Svar", i Rosenadler, 14 f.; 


\section{NOTER}

Dalin, 1. Se även Löwenhielm, Landt-skötsel, 3; Mennander, Bok-handelen, 15; Alströmer, Schäferierna, 3; Rabbe, 3; Sandels, Inrättning, 35. En ledamot hänförde namnkunnigheten till bland annat Adolf Fredriks höga beskydd, en annan tillkännagav att de utländska systerorganisationerna lovprisade akademiens förträffliga lycka att beskyddas av Gustav III, vars gunst de själva försökt erhålla. Rudenschöld, Skogarne, 2; Sandels, Protector [2].

625 Celsius, 61. Flera ordförande nämnde att Vetenskapsakademiens Handlingar var kända och omtyckta utomlands. Höpken, Observatorii, 9; Alströmer, Får-afveln, 105; Sandels, Inrättning, 25; Rudenschöld, Majestet, 7; Bergius, Läckerheter, I, 3.

626 Rudenschöld, Majestet, 7; Gadolin, Vetenskaper, 3; Swartz, 34. Jämför Bergman [4].

627 Tilas, Utkast, 4; Wargentin, "Svar", i Ungern-Sternberg, 15; Höpken, Observatorii, 8; Scheffer, Anmärkningar, 1 f.; Bäck, Nyttan, 2; Bergius, Bad, 1. Se även Rudenschöld, Skogarne, 2; Höpken, "Svar", i Carleson (1749), 28. Handlingarna och akademiens övriga publikationer konstaterades vara inrikes kända. Sandels, Inrättning, 25; Bergius, Läckerheter, I, 3.

628 Wilcke, Förklaringar, 105 f., citat från idem; Benzelstierna, Hushållsmått, 12. Jämför Bergius, Frukt-trägårdar, 3; Mallet, 6; Adlerbeth, 57.

629 Acrel, Handalag, 75; Stockenström, Järn-bruk, 1 f., citat från idem; Cederhielm, 5; Löwenhielm, Landt-skötsel, 35. Se även Rosén von Rosenstein, Medici, 2; Tessin, 4; Ehrenpreus, "Svar", i Rudenschöld (1748), 59; Wrede, 12; Löwenhielm, Landt-skötsel, 12; Höpken, Observatorii, 8; Bonde, 17; Jennings, Sluss-byggnad, 4; Martin, 74; Jennings, Segelfarter, 25. En del presides hoppades eller ansåg att eftervärlden skulle ha skäl att komplimentera Vetenskapsakademien. Triewald, 24; Polhem, Fädernesland, 23; Löwenhielm, Landt-skötsel, 35, 49. Jämför Ehrenpreus, Konster, 28; Ljungenstjerna, 66.

630 Rudenschöld, Majestet, 8; Schröder, 3 f.; Benzelstierna, Hushållsmått, 5; Arfvedson, 3 f. Se även Bergius, Frukt-trägårdar, 8; Benzelstierna, Hushållsmått, 3-6, 9, 12; Prosperin, 7 f.

631 Wilcke, "Svar", i Arfvedson, $15 \mathrm{f}$.

632 Rosenstein, 2; Swartz, 42; Sandels, Inrättning, 26 f., 47.

633 Faggot, Historien, 75 f.; Sandels, Inrättning, 48 f.; Hårleman, 34, citat från idem.

634 För donationer från samhällsledande, se Bäck, Nyttan, 36; Meijer, 21; Faggot, Historien, 76; Löwenhielm, Landt-skötsel, 56-58; Palmqvist, 25-27; Gyllenborg, 16 f.; Carleson, Spanmåls-bristen, 16 f.; Knutberg, 23; Bergius, Bad, 108 f.; Zetzell, Soldat, 32; Strandberg, Sjukdomar, 38; Grill, Silfver, 28; Lillienberg, Förbättringar, 3 f.; Hjelm, 39 f.; Carlson, 19. För kungligheterna, se Ehrenpreus, Konster, 31; Acrel, Sjukdomar, 40. För ständerna, se Mennander, Bok-handelen, $25 \mathrm{f}$.

635 Rudenschöld, Majestet, 6; Wargentin, "Svar", i Arbin (1773), 57 f., citat från 
idem; Klingenstierna, 28. Se även Scheffer, Anmärkningar, 6; Sparrman, 30 f.; Swartz, 45 f. Den ädelsinnade medborgaren var med tanke på tidpunkten, 1773, rimligen Sahlgren, som strax innan givit en donation för att befrämja lantbruket. Lindroth, Vetenskapsakademien, I:1, 147.

636 Sandels, Inrättning, 28-30, 33, 35, 42, 45-47. Olof Celsius karakteriserade den bortgångne Claes Grill som en nyttig ledamot, som mottagit Vetenskapsakademiens och alla rättänkande medborgares kärlek för sina frikostiga insatser för vetenskaperna och fäderneslandet. Celsius, 6o. För den så kallade Thamiska donationen, se Lindroth, Vetenskapsakademien, I:1, 45 f., 51 f. För Fredrik Sparres donation, som gick till att belöna först gagneliga rön i Handlingarna, senare svar på prisfrågor, se ibidem, 142-45.

637 Wargentin, "Svar", i Bonde, 19; Pehr Wilhelm Wargentin, "Svar, gifvit å Kongl. Vetenskaps Academiens vägnar [...]", i Psilanderhielm, 16; Pehr Wilhelm Wargentin, "Svar, gifvet, på Kongl. Vetenskaps Academiens vägnar [...]", i Sandels (1771), 51 f.; Wargentin, "Svar", i Scheffer (1755), 15. En akademiemedlem behövde inga bevis för att de mäktigas kärlek utgjorde ett av de verksammaste sätten att befordra vetenskaperna, medan en annan förfäktade att kemins lyckliga ställning framför allt berodde på "upmuntran af de Höga och Magtegande" som gjorde att snillen "likasom täfla[de] med hvarannan [varandra], at göra nya uptäckter". Swartz, 30; Engeström, Svårigheter, 2, citat från idem.

638 Höpken, Observatorii, 13, 31, 36-39, 43, 45-48.

639 Bergius, Läckerheter, I, $12 \mathrm{f}$.

640 Sparrman, 30-33; Bergius, Läckerheter, I, 4, 13.

641 Dalin, 22, citat från idem; Wargentin, "Svar", i Ekström, 43; Vallerius, $24 \mathrm{f}$.

642 Browallius, 36 f.; Pehr Elvius, "Svar gifvit å Kongl. Vetenskaps Academiens vägnar [...]", i Browallius, 40, citat från idem. Konungen liknades vid ett resligt och världskänt palmträd som under en lång och välsignad tid givit Sverige föda och skugga, medan Adolf Fredrik föreställdes som ett härligt fruktträd vilket småningom skulle ta palmens plats. Fredrik utmålades också som Vetenskapsakademiens livgivande sol och planterare och akademien som ett palmträd. Rudenschöld, Skogarne, 55; Cederhielm, 30.

643 Ehrenpreus, Konster, 27-32.

644 Piper, 4, 7 f.; Pehr Wilhelm Wargentin, ”Svar, gifvit å Kongl. Vetenskaps Academiens vägnar [...]", i Piper, $12 \mathrm{f}$.

645 Schützercrantz, Chirurgien, 32 f.; Scheffer, Mynt, 21, citat från idem; Scheffer, Anmärkningar, 13. Se även Faggot, Historien, 76-78; Ungern-Sternberg, 12; Psilanderhielm, $13 \mathrm{f}$.

646 Den stora drottningen skulle fullkomna vad Vetenskapsakademien endast förberett. Höpken, Observatorii, 3-7, 9-11, 34, 36.

647 Knutberg, 23; Wargentin, "Svar", i Strandberg (1765), 39.

648 Jennings, Segelfarter, 27-29. 
649 Wargentin, "Svar", i Jennings (1770), 30-32.

650 Cronstedt, Academien, 7-9; Wargentin, "Svar", i Cronstedt (1771), 12 f.

651 Ribe, Ögonen, 28, citat från idem; Wargentin, "Svar", i Botin, 41 f.

652 Sandels var hedrad av att ha fått ombesörja traderingen men hoppades att ingen ytterligare skulle äga rum under hans eller de övriga medlemmarnas livstid. Sandels, Protector [1-3]; Sandels, Inrättning, 3 f., 49 f.

653 Det förklarades till exempel att Adolf Fredrik både som kronprins och konung upplivade Vetenskapsakademien, som vann inspiration och anseende genom hans besök och den kraft som åtföljde hans välvilja. Alla de tre senaste konungarna var på väg att få medaljer slagna över sig, i enlighet med organisationens vilja att visa tacksamhet gentemot sina mecenater och markera väsentliga tilldragelser i sin historia. Sandels, Protector [2 f.], 22, 30 f., 33, 35; Sandels, Inrättning, 36 f., 46.

Gustavianska presidietal lade emellanåt beslag på frihetstidens furstar. Det hette bland annat att en nådig överhet inte varit sen att hedra den nygrundade akademien med sin omvårdnad och att dess framåtskridande förutsatt kungligt beskydd. Adolf Fredriks roll av skyddsherre berördes av Bengt Bergius, som för att inte väcka en alltför tung sorg knappt mer än nämnde honom vid namn. Den framlidne konungen hade visserligen influerats av mecenaterna Tessin, Hårleman och Clas Ekeblad men även "af egen prisvärd böjelse" engagerat sig för fria konster och snillrikhet. Rudenschöld, Majestet, 6; Wargentin, "Svar", i Bergius (1785), 10, 270 f. Se även Mallet, 19.

654 Wargentin, "Svar", i Sandels (1771), $51 \mathrm{f}$.

655 Rudenschöld, Majestet, $3 \mathrm{f}$.

656 Wargentin, "Svar", i Rudenschöld (1772), 21; Rosén von Rosenstein, Pesten [1]; Schönberg [3 f.].

657 Rosén von Rosenstein, Pesten [1 f.], 22. Se även Schönberg [3 f.].

658 Gustav III, "Kongl. Majestets nådiga svar", i Tal hållne i Kongl. Vetenskaps Academien, $5 \mathrm{f}$.

659 Wargentin, "Svar", i Scheffer (1772), 32. Se även Wargentin, "Svar", i Arbin (1773), 58; Rönnow, 39; Nils Lindblom, Tal, om angelägenheten och nyttan af några artillerie-försöks anställande [...] (Stockholm, 1774), 3 f.; Pehr Wilhelm Wargentin, "Svar, gifvet, på Kongl. Vetenskaps Academiens vägnar [...]”, i Lindblom, 14; Wargentin, "Svar", i Bunge, 20; Sparre, 41; Pehr Wilhelm Wargentin, "Svar, gifvet på Kongl. Vetenskaps Academiens vägnar [...]", i Sparre, 46 f.; Wargentin, "Svar", i Bergman, 48; Wilcke, Förklaringar, 104 f.; Rudenschöld, Majestet, $8 \mathrm{f}$.

660 Bergius, Läckerheter, I, 11 f.; Dalberg, Climatet [3 f]; Wilcke, Förklaringar [4]; Schützercrantz, Tilväxt, 3, citat från idem.

661 Sparrman, $29 \mathrm{f}$.

662 Leijonmarck, Utsigten [3 f.]; Rönnow [3 f.]; Bielke [3 f.]; Bunge [3 f.]; Schröder- 
heim [1 f]; Rudenschöld, Majestet [3 f.], 5. Se även Lillienberg, Förmåner, 3 f.; Bergman [3]; Sparre [ 3 f.]; Bergius, Frukt-trägårdar, 3; Sandels, Förhållandet [3 f.].

663 Plantin, Justering, 4, 6; Wilcke, "Svar", i Plantin (1792), 28 f.

664 Plantin, Justering, 6; Wilcke, "Svar", i Plantin (1792), 30.

665 Höpken, Observatorii, 36, 44 f., 47 f.; Mennander, Bok-handelen, 25 f.; Browallius, 37.

Wargentin markerade närhet till några riksdagsmän när han gav röst åt Vetenskapsakademiens fröjd över att ha fått återse ledamöter som besökte Stockholm för ständermötet 1778-79. Pehr Wilhelm Wargentin, "Svar, gifvet, på Kongl. Vetenskaps Academiens vägnar [...]", i Strussenfelt, 40.

666 Jennings, Sluss-byggnad, 4; Dalin, 21 f.; Ekström, 1, citat från idem. Lieven var rimligen hattriksrådet Hans Henric von Liewen.

667 Rudenschöld, Skogarne, 1 f., citat från idem; Meijer, 1 f.; Bäck, Nyttan, 35 f. Purpur fungerade ofta som en symbol och ett kodord för värdighet och makt. "Purpur 3)", Svenska Akademiens ordbok, band 21.

668 Kryger, Folkbristen, 11; Salander, 16 f.; Adelcrantz, 43.

669 Dalberg, Climatet, 5; Wilcke, Förklaringar, 105; Rönnow, 39; Bergius, Läckerheter, I, 13, 18, citat från idem; Engeström, Mineralogien, 3; Prosperin, 4, 24. Se även Rudenschöld, Majestet, 11; Qvist, Mineral-samlare, 11.

670 Wargentin, "Svar", i Gyllenborg, 20 f.; Wargentin, "Svar", i Scheffer (1755), 16. Även hattarna Ehrenpreus, Claes Grill, Piper och Carl Rudenschöld smickrades och kopplades till Vetenskapsakademien. Pehr Elvius, ”Svar gifvit å Kongl. Vetenskaps Academiens vägnar [...]", i Ehrenpreus (1748), 35 f.; Schultze, Glas-makeriet, 38; Sandels, Inrättning, 33; Rabbe, 115; Wargentin, "Svar", i Rudenschöld (1772), $21 \mathrm{f}$.

Vissa hattar lovordades utan att knytas till akademien. Carl Gyllenborg hyllades i egenskap av Uppsala universitets kansler och sades ha vunnit odödligt rykte bland de lärda. Hårleman tillmättes fördelaktiga kvaliteter och en prisvärd nytta för konung och fädernesland. Rosén von Rosenstein, Medici, 42-46; Ferrner, Tvisten, 27; Höpken, Observatorii, 44; Jennings, Sluss-byggnad, 9.

671 Hårleman, 36, citat från idem; Acrel, Sjukdomar, 27; Tilas, Utkast, 7, citat från idem; Rosén von Rosenstein, Medici, 1 f.; Mennander, Bok-handelen, 25 f. Tessin namngavs visserligen inte av Hårleman, men en upplysning om att den man som avsågs hade verkat för att naturalhistoriker skulle få följa med Ostindiska kompaniets skepp ger vid handen att det rörde sig om honom. Jämför Lindroth, Lärdomshistoria, 241.

672 Berch, Myntet, 34; Scheffer, Anmärkningar, 3; Sandels, Inrättning, 14 f., 17, 21, 23 f.; Bergius, Äng-skötseln, 93. 
673 Dalin, 10; Leijell, 58 f.; Wargentin, "Svar", i Ungern-Sternberg, 15 f.; Wargentin, "Svar", i Bonde, $19 \mathrm{f}$.

674 Rosenadler, 13. För Löwenhielm, se även Swab, 14.

675 För kritiken av frihetstiden, se avsnittet "Gustav III och den politiska nyordningen" i kapitlet "Konungarnas akademi". Frihetstida hattar som Carl Gyllenborg, Jonas Alströmer och Augustin Ehrensvärd fick likaledes goda vitsord. Swartz, 30; Benzelstierna, Hushållsmått, 11; Melanderhielm, Vetenskaperna, 17; Lindblom, $4 \mathrm{f}$. Akademigrundarna betecknades som utomordentligt ädla män, medan Ekeblad, Hårleman och Tessin framställdes som stora och saknade ledamöter med strålande karaktärsdrag liksom ett lovvärt intresse för att upphjälpa vetenskaper och konster. Tessin angavs ha tagit Linné under sina vingar och sett till att han adlades. Bergius, Läckerheter, I, 8-10; Swartz, 39.

676 Wargentin, "Svar", i Scheffer (1772), 31 f.; Wargentin, "Svar", i Bunge, 2o. För Bunges relation till Ulric och Carl Fredrik Scheffer, se Erik Naumann, "Sven Bunge", Svenskt biografiskt lexikon, band 6 .

677 I Benzelstiernas fall smickrades också hans släkt, då Benzelierna enligt uppgift sedan länge varit kända som stora vetenskapsbefordrare. Wilcke, "Svar", i Benzelstierna (1788), 16; Pehr Wilhelm Wargentin, "Svar, gifvet på Kgl. Vetenskaps Academiens vägnar [...]", i Falkenberg, 24; Pehr Wilhelm Wargentin, ”Svar, gifvet, på Kongl. Vetenskaps Academiens vägnar [...]", i Rudenschöld (1779), 13 f.; Wargentin, "Svar", i Lillienberg (1776), 24; Wargentin, "Svar", i Lillienberg (1781), 25 f.; Wargentin, "Svar", i Sparre, 46 f. Rudenschöld smickrades även i Zetzell, Sjukligheten, 54; Bergius, Frukt-trägårdar, 3. För de politiska lojaliteterna, se S. Hildebrand, "Matthias Benzelstierna", Svenskt biografiskt lexikon, band 3; "Falkenberg, Melker", Svenskt biografiskt handlexikon, band 1; Göran Nilzén, "Jean Georg Lillienberg", Svenskt biografiskt lexikon, band 23; Ulla Johanson, "Carl Rudenschöld", Svenskt biografiskt lexikon, band 30; Rolf Hagstedt, "Carl Sparre", Svenskt biografiskt lexikon, band 32.

678 Rudenschöld, Majestet, 5 f.; Benzelstierna, Hushållsmått, 3 f. Se även Johan Carl Wilcke, "Svar, gifvet på Kongl. Vetenskaps Academiens vägnar [...]", i Adlerbeth, 58.

679 Rosenstein, $2 \mathrm{f}$.

680 Wargentin, "Svar", i Bielke, 50; Wargentin, "Svar", i Grill (1774), 30; Wargentin, "Svar", i Lilliestråle (1775), 55 f.; Johan Carl Wilcke, "Svar, gifvet, på Kongl. Vetenskaps Academiens vägnar [...]", i Lilliestråle (1784), 47 f.; Wilcke, "Svar", i Schröderheim, 25 f.; Johan Carl Wilcke, "Svar, gifvet på Kongl. Vetenskaps Academiens vägnar [...]", i Carlson, 21 f. För de politiska lojaliteterna, se Gunnar Carlquist, "Nils Adam Bielke", Svenskt biografiskt lexikon, band 4; Lisbeth Näslund, "Joachim Wilhelm Liliestråle", Svenskt biografiskt lexikon, band 23; Torkel Stålmarck, "Elis Schröderheim", Svenskt biografiskt lexikon, band 31; Erik Naumann \& Carl Forsstrand, "J Gustaf Carlson", Svenskt biografiskt lexi- 
kon, band 7. Rydman var naturvetenskapligt intresserad och testamenterade ett mikroskop och en summa pengar för prisfrågor till akademien. Lindroth, Vetenskapsakademien, I:1, $153 \mathrm{f}$.

681 Se till exempel Lindroth, Vetenskapsakademien, I:1, 27; Kärnfelt, 81; Koerner, Linnaeus, 105 f.; Hallberg, Ages, 144-48, 150, 170; Lindberg, "Kulturen”, 134, 140.

682 Mennander, Bok-handelen, 2; Martin, 3 f.; Pehr Wilhelm Wargentin, "Svar, gifvit på Kongl. Vetenskaps Academiens vägnar [...]", i Lehnberg, 24; Gyllenborg, 2; Clason, Handels omskiften, 1 f., 65; Ribe, Ögonen, 1, citat från idem; Sandels, Inrättning, 25. Eva Ekeblad utgjorde snarast ett slags hedersledamot. Lindroth, Vetenskapsakademien, I:1, $23 \mathrm{f}$.

683 Bergius, Läckerheter, I, 15; Hjelm, 2; Schützercrantz, Tilväxt, 3 f., citat från idem; Odhelius, Lazarettet, 3.

684 Linné gjorde inte för inte en distinktion mellan akademiens "arbetare" och "magnater" - de förstnämnda skulle frambringa rön och de sistnämnda "upmuntra och befordra". Vid den ceremoni som markerade inträde i Vetenskapsakademien fick retoriken enligt Sten Lindroth "en pompösare prägel, när någon eftertrådd rikets herre tog introduktion". Till det kan läggas att åminnelsetalen i flera fall hölls av en ledamot vars samhällsställning låg nära den avlidnes. Carl von Linné till Kungliga Svenska Vetenskapsakademien, 3/1 1765, http://linnaeus.c18.net [6] [hämtad 2020-07-31]; Lindroth, Vetenskapsakademien, I:1, 18; Ekblad, "Akademieledamoten", $180 \mathrm{f}$.

685 Orrje, $201 \mathrm{f}$.

686 Mennander, Folkhopen, 7; Lilliestråle, Lag-förbättring, 46; Wargentin, "Svar", i Lilliestråle (1775), 55, citat från idem; Meijer, 17-19. Se även till exempel Carleson, Fiskeri, 23; Schultze, Ungdomen, 20, 22; Leijell, 34-36, 38 f., 41 f., 44 f., 55 f.; Palmqvist, 3, 5, 12 f., 23 f.; Kryger, Folkbristen, 21-25, 31-36, 38; Carleson, Spanmåls-bristen, 5-10, 12-16; Tiburtius, 16 f., 19-21; Knutberg, 11 f., 19 f., 23 f.; Tilas, Utkast, 6 f., 25, 88, 102; Lidbeck, 24-35, 37; Clason, Orsakerna, 30 f.; Hermelin, 16-18, 20-23, 108 f.; Wäsström, 3-5, 15, 22; Lillienberg, Förmåner, 8 f., 13 f., 19-22; Odhelius, Lazarettet, 41-43; Runeberg, Nyttan, 13-15, 24; Lillienberg, Förbättringar, 10; Dalberg, Luften, 26 f., 29; Thunberg, 32 f.; Mallet, 8 f., 11-19; Hjelm, 14 f., 32; Plantin, Målen, 8-10, 13, 18 f., 22 f.

687 Rosenstein, 181, 184, $196 \mathrm{f}$.

688 Scheffer, Grund-lagarna, 8 f., 15-18.

689 Ibidem, $27 \mathrm{f}$.

690 Erik Lönnroth, Den stora rollen: Kung Gustaf III spelad av honom själv (Stockholm, 1986), 66, $68 \mathrm{f}$.

691 Faggot, Historien, 40-45; Adelcrantz, 25. Se även Browallius, 35; Melanderhielm, Vetenskaperna, 76; Wargentin, "Svar", i Adelcrantz, 47; Cronstedt, Academien, 7-9. 


\section{NOTER}

692 Strandberg, Febrar, 14, 19-22, 32; Schützercrantz, Chirurgien, 28-32. Se även Rosén von Rosenstein, Medici, 41; Acrel, Lazaret, 16; Schulzenheim, 25, 40 f.; Bäck, Farsoter, 5-8, 10-15, 28 f., 31, 40 f., 44-50.

693 Rönnow, 6 f., 27, 36; Wargentin, "Svar", i Rönnow, 40. Rönnow diskuterade dessutom hur allmännyttigt det skulle vara om konungen agerade för en anatomisk disciplins inrättande i Uppsala; han erbjöd sig att själv skänka till den och Stockholmslasarettet om Gustav tog första steget. Talet slutade med ett bistert allvarsord till dem som inte hjälpte till med sjukhuset: "Jag lägger, för öfrigt, på deras Samveten, som dertil bidraga kunna, och det icke göra, alla de olyckeliga händelser, som dymedelst [därigenom] i framtiden ofelbart öfverkomma Rikets Invånare af högre och lägre stånd, så til helsan som lifvet.” Rönnow, $38 \mathrm{f}$.

694 Ferrner, Försök, 9 f.; Sandels, Inrättning, 5 f., 9, 28, 35; Bielke, 13 f.; Wargentin, "Svar", i Bielke, 48 f. Se även Lilliestråle, Lag-förbättring [5]; Qvist, Mineralsamlare, 7; Sparre, 28.

695 Faggot, Historien, 76 f.; Stiernman, 3. Se även Sandels, Förhållandet, 94; Lindblom, $3 \mathrm{f}$.

696 Bergman [4]; Swartz, 16 f. Se även Pehr Wilhelm Wargentin, "Svar, gifvet, på Kongl. Vetenskaps Academiens vägnar [...]", i Sparrman, 37; Bergius, Fruktträgårdar, 12.

697 Rudenschöld, Skogarne, 49; Salander, 6 f., 10. Se även Faggot, Historien, 28 f.; Bäck, Farsoter, 44-46; Rudenschöld, Språket, 11-14, 16 f.; Lillienberg, Förmåner, 13.

698 Rosenstein, 115, 173, 210. För förenings- och säkerhetsakten och beskattningen, se Lönnroth, 198; Nell, 156; Mattsson, 205.

699 Rosenstein hävdade därtill att ett blandat regeringssätt inte lämpade sig för stora riken som det romerska imperiet och att romarna knappt kunnat föreställa sig "en Lagbunden Monarchie", som överlag lyst med sin frånvaro i antikens vidsträckta och fullkomligt despotiska riken. Det enda sättet för ett sådant rike att bevara friheten var "representerande Fullmägtige". Ibidem, 73 f., 120, 126, 160 f., 163 f., $215 \mathrm{f}$.

700 Arbin, Fortifications-staten, II, $5 \mathrm{f}$.

701 Ingemar Carlsson, Olof Dalin och den politiska propagandan inför "lilla ofreden": Sagan Om Hästen och Wår-Wisa i samtidspolitisk belysning (Lund, 1966), 183, 189 f.; Nilsén, 16o-62, 238 f., 336; Malmström, V, 151 f.; Roberts, 164, 207.

702 Bäck, Farsoter, 30, 32; Grill, Sjö-fart, 10; Kryger, Folkbristen, 20 f., 36 f. Pommerska kriget förefaller ha haft en apologet i Pehr Zetzell, som lade skulden för nederlaget på olyckliga omständigheter, närmare bestämt "salt proviant, vako [vaka] och kroppsmödor". Zetzell, Soldat, 31.

703 Lönnroth, 121, 239 f.; Nell, 135, 154.

704 Rosenstein, 113, 147 f. Arfvedson nämnde de revor ett krig lämnade efter sig, 
men det är inte alldeles lätt att veta vad som avsågs. Arfvedson, 11. För Rosensteins inställning till Gustav III:s krig, se Segerstedt, 143, 147, 150 f., 161.

Ett negativt förhållningssätt till krig återfinns också på andra håll i Rosensteins tal, till exempel i hans diskussion om den romerska republikens skavanker, där det fastställs att en "liten Stat som gör krig och eröfringar til sit hufvudyrke, skall antingen misslyckas och blifva et rof för en starkare och lyckligare; eller om den lyckas, falla genom sin egen storlek och missbruket af den Militariska magten”. Rosenstein, 130 f., 141, 172, 174.

705 För den egalitära kunskapssynen, se Kärnfelt, 90-92.

\section{Det villrådiga samhället}

706 För Rosensteins jakobinska och revolutionära sinnelag, se Lindroth, Vetenskapsakademien, II, 26, 39.

707 Fritz K. Ringer, The decline of the German mandarins: The German academic community, 1890-1933 (Cambridge, Mass., 1969), 5-8. Jämför dels resonemanget om 1700-talets svenska universitetslärda hos Sven-Eric Liedman, dels Joel Mokyrs urskiljande av tre elitgrupperingar i 1700-talets Storbritannien som genom dialog och allianser med varandra förändrade de brittiska institutionerna. Nämligen välmående jordägare, nyrika inom köpenskap, finans och manufakturer samt en "intellectual elite of philosophers" som teoretiserade normativt kring statens uppgifter. De sistnämndas makt flöt ur deras prestige och retoriska förmåga, vilka satte dem i stånd att övertala de övriga om innebörden av ett gott samhälle. Liedman, Handen, 15 f.; Mokyr, $395 \mathrm{f}$.

708 Jämför perspektivet på Pehr Kalm och hans Åbostudenter i Mathias Persson, "The professor and the body politic: Pehr Kalm and the social imaginary in eighteenth-century Turku", COLLeGIUM: Studies across Disciplines in the Humanities and Social Sciences, vol. 16 (2014), 124. 


\section{Källor och litteratur}

\section{Källor}

Acrel, Olof af, Genaste sättet at inrätta och underhålla et lazaret eller sjukhus, så at det inom få år måtte ärnå en ansenlig tilväxt [...] (Stockholm, 1746).

-, Tal, om fostrets sjukdomar i moderlifvet [...] (Stockholm, 1750).

—, Tal om nödvändigheten och förmånen af de chirurgiska handalagens förkortande i utöfningen [...] (Stockholm, 1767).

Adelcrantz, Carl Fredrik, Tal om de fria konsters värde och nytta [...] (Stockholm, 1757).

Adlerbeth, Gudmund Jöran, Tal om en philosophisk varsamhet vid naturens betraktande [...] (Stockholm, 1790).

Alströmer, Clas, Tal, om den fin-ulliga får-afveln [...] (Stockholm, 1770).

Alströmer, Jonas, Sveriges wälstånd om det will [...] (Stockholm, 1745).

—, Tal, om schäferiernas nytta [...] (Stockholm, 1760).

Ankarcrona, Theodor, Tal om förbindelsen emellan landtbruk, manufacturer, handel ock siöfart [...] (Stockholm, 1744).

Arbin, Axel Magnus von, Tal, om kongl. svenska fortifications-statens inrättning [...] (Stockholm, 1773).

—, Tal, om kongl. svenska fortifications-statens inrättning [...] Fortsättning (Stockholm, 1787).

Arfvedson, Carl Christopher, Tal, om handels-balancen [...] (Stockholm, 1789).

Benzelstierna, Lars, "Berättelse om åtskillige nyare malm- ock mineral-upfinningar i riket [...]", Kongl. Swenska Wetenskaps Academiens Handlingar 1741, http:// hosting.devo.se/kvah/search.html [hämtad 2020-07-31].

Benzelstierna, Matthias, Tal, om vissa hushållsmått at ständigt vidtagas, til at minska landtmannens förlägenhet vid påkommande missväxter, och med detsamma öka jordens årliga afkastning och värde [...] (Stockholm, 1788).

Berch, Carl Reinhold, Afhandling om nordiska folkets fordna sjöväsende, så väl til handel, som örlog [...] (Stockholm, 1766).

—, Tal, om svenska myntets ålder [...] (Stockholm, 1753). 


\section{KÄLLOR OCH LITTERATUR}

Bergius, Bengt, Tal, om läckerheter, både i sig sjelfva sådana, och för sådana ansedda genom folkslags bruk och inbillning [...] Förra delen (Stockholm, 1785).

—, Tal, om läckerheter, både i sig sjelfva sådana, och för sådana ansedda genom folkslags bruk och inbillning [...] Andra delen (Stockholm, 1787).

—, Tal, om svenska äng-skötseln, och dess främjande genom lönande gräs-slag [...] (Stockholm, 1769).

Bergius, Peter Jonas, Tal, om kalla bad i gemen, och Loka badningar $i$ synnerhet [...] (Stockholm, 1764).

—, Tal, om frukt-trägårdar och deras främjande i vårt rike [...] (Stockholm, 1780).

Bergman, Torbern, Tal, om chemiens nyaste framsteg [...] (Stockholm, 1777).

Bielke, Nils Adam, Tal, om det första lyckliga tidehvarfför Sveriges allmänna hushållning, under Konung Gustaf d. I:s regering [...] (Stockholm, 1776).

Bonde, Gustaf, Tal om aske-trädets nytta [...] (Stockholm, 1756).

Botin, Anders af, Jämförelse imellan mynts och varors värden i Sverige, uti särskildta tidehvarf [...] (Stockholm, 1771).

Brandt, Georg, "Nytt rön angående guldets uplösning uti skedvatten”, Kongl. Svenska Vetenskaps Academiens Handlingar 1748, http://hosting.devo.se/kvah/ search.html [hämtad 2020-07-31].

Browallius, Johan, Känningar af Guds försyn vid nyttiga vetenskapers främjande [...] (Stockholm, 1747).

Bunge, Sven, Tal, innehållande några anmärkningar vid landthushållningen [...] (Stockholm, 1775).

Bäck, Abraham, Tal om farsoter, som mäst härja ibland rikets allmoge [...] (Stockholm, 1765).

-, Tal om nyttan som tilflyter läkarekonsten, af et väl inrättadt lazaret eller sjukhus i Stockholm [...] (Stockholm, 1746).

Carleson, Carl, Tal om spanmåls-bristens afhjelpande [...] (Stockholm, 1759).

Carleson, Edvard, Upmuntran til fiskeri-inrättningar i Sverige [...] (Stockholm, 1749).

Carlson, Johan Gustaf von, Tal, med strödde anmärkningar öfver foglarnes seder och hushållning [...] (Stockholm, 1789).

Cederhielm, Carl Wilhelm, Tal, om vilda träns plantering, i Sverige (Stockholm, 1748).

Celsius, Olof, Tal om smak uti den svenska, så bundna, som obundna vältaligheten [...] (Stockholm, 1768).

Chapman, Fredrik Henrik af, Tal, om de förändringar, som örlogs-skepp undergått, sedan canoner började på dem nyttjas [...] (Stockholm, 1770).

Clason, Johan, Tal, om orsakerna til Sveriges handels omskiften [...] (Stockholm, 1769).

—, Tal, om Sveriges handels omskiften [...] (Stockholm, 1751).

Cronstedt, Carl Johan, Tal, hållet för Kongl. Vetenskaps Academien [...] (Stockholm, 1771). 


\section{KÄLLOR OCH LITTERATUR}

-, Tal, om sten-hus bygnad [...] (Stockholm, 1741).

Dahlgren, Erik Wilhelm (red.), Svenska Vetenskapsakademiens protokoll för åren 1739, 1740 och 1741 [...], 2 vol. (Uppsala, 1918), I.

Dalberg, Nils, Tal, om luftens beskaffenhet i stora och folkrika städer [...] (Stockholm, 1784).

—, Tal, om några det svenska climatets förmåner och olägenheter $i$ anseende til hälsan [...] (Stockholm, 1777).

Dalin, Olof von, Tal vid praesidii afläggande om Sverige i sit ämne och Sverige i sin upodling [...] (Stockholm, 1749).

De Geer, Charles, Tal, om insecternas alstring [...] (Stockholm, 1754).

-, Tal om nyttan, som insecterne och deras skärskådande, tilskynda oss [...] (Stockholm, 1744).

Dunn, Susan (red.), The social contract and The first and second discourses (New Haven, 2002).

Ehrenpreus, Carl Didrik, "Svar gifvit å Kongl. Vetenskaps Academiens vägnar", i Rudenschöld (1748).

—, ”Svar, gifvit å Kongl. Vetenskaps Academiens vägnar [...]”, i Schultze (1750).

-, Tal om den förmån och nytta som fria konster och handaslögder tilskyndas af historien [...] (Stockholm, 1748).

Ehrensvärd, Augustin, Tal om svensk sjömagt [...] (Stockholm, 1767).

—, Tal om ungdomens upfostran til krigsmän [...] (Stockholm, 1743).

Ekström, Daniel, Tal, om järn-förädlingens nytta och vårdande [...] (Stockholm, 1750).

Elvius, Pehr, "Secreteraren Pehr Elvii härå gifne svar, på Kongl. Vetenskaps Academiens vägnar", i Ribe (1748).

—, "Svar här uppå, gifvit af secreteraren Elvius å Kongl. Vetenskaps Academiens vägnar”, i Alströmer (1745).

—, "Svar gifvit å Kongl. Vetenskaps Academiens vägnar [...]”, i Browallius.

—, "Svar, gifvit å Kongl. Vetensk. Academiens vägnar", i Dalin.

—, "Svar gifvit å Kongl. Vetenskaps Academiens vägnar [...]”, i Ehrenpreus.

—, "Svar gifvit å Kongl. Vetenskaps Academiens vägnar [...]”, i Faggot (1747).

—, "Svar gifvit å Kongl. Vetenskaps Academiens vägnar [...]”, i Grill (1749).

—, "Svar, gifvit på Kongl. Vetenskaps Academiens vägnar [...]", i Hårleman.

—, "Svar, gifvit på Kongl. Vetensk. Academiens vägnar [...]", i Polhem (1745).

—, "Svar, gifvit å Kongl. Vetenskaps Academiens vägnar [...]", i Tessin (1746).

—, "Svar här uppå, gifvit af secreteraren Elvius å Kongl. Vetenskaps Academiens vägnar", i Alströmer (1745).

Engeström, Gustaf von, Tal, om vissa svårigheter och andra omständigheter, som möta vid utöfvandet af chymien [...] (Stockholm, 1782).

—, Tal om mineralogiens hinder och framsteg i senare åren [...] (Stockholm, 1774). 


\section{KÄLLOR OCH LITTERATUR}

Faggot, Jacob, Historien om svenska landtmäteriet ock geographien [...] (Stockholm, 1747).

—, Historiens fortsättning om svenska landtmäteriet och geographien [...] (Stockholm, 1760).

—, "Svar på Kongl. Vetenskaps Academiens vägnar", i Ankarcrona.

—, "Svar på Kongl. Vetenskaps Academiens vägnar", i Vallerius.

—, "Svar, på Kongl. Vetenskaps Academiens vägnar", i Wrede.

Falkenberg, Melcher, Tal, om vetenskapernas nytta uti lagfarenheten [...] (Stockholm, 1775).

Ferrner, Bengt, Försök at visa, det olika climater icke verka hos folkslagen olika lynnen och själens förmögenheter [...] (Stockholm, 1780).

—, Tvisten om vattu-minskningen [...] (Stockholm, 1765).

Gadolin, Jacob, Tal, om de physiska vetenskapers befordran [...] (Stockholm, 1786).

-, Tal, om gränsorne imellan det vi uti naturen känne, och det vi ännu icke hunnit fatta [...] (Stockholm, 1761).

Grill, Claes, Tal om sjö-fartens nytta och förmån för riket, i synnerhet då han drifves med hembygde och utur egne hamnar utrustade skepp [...] (Stockholm, 1749).

Grill, Johan Abraham, Tal, om silfvers årliga förande til China, huruvida det är för Europa nyttigt eller skadeligt [...] (Stockholm, 1774).

Gustav III, "Kongl. Majestets nådiga svar", i Tal hålne i Kongl. Vetenskaps Academien.

Gyllenborg, Henning Adolph, Tal, om den omsorg våra förfäder användt til öfverflöds afskaffande [...] (Stockholm, 1757).

Heijkenskjöld, Detlof, Anmärkningar, vid bergs-handteringens åtskilliga öden och omväxlingar [...] (Stockholm, 1768).

—, Tal om bärgs-hushållningen i gemen [...] (Stockholm, 1759).

Hermansson, von, Johan, Tal, om en ingenieurs inöfning och åliggande förrättningar [...] (Stockholm, 1791).

Hermelin, Samuel Gustaf, Tal, om näringarnes förhållande uti rikets särskilde lands-orter [...] (Stockholm, 1774).

Hjelm, Peter Jacob, Tal, om hvarjehanda brukbara ämnens nyttigare användande [...] (Stockholm, 1788).

Hårleman, Carl, Tankar i anledning af utländska resor [...] (Stockholm, 1746).

Högström, Pehr, Tal om landt-manna näringar $i$ Wästerbotten, besynnerligen Skellefta soken [...] (Stockholm, 1765).

Höpken, Anders Johan von, "Förberedelse", Kungliga Vetenskaps Academiens Handlingar 1739-40, http://hosting.devo.se/kvah/search.html [hämtad 2020-07-31].

—, "Svar gifvit å Kongl. Vetenskaps Academiens vägnar [...]", i Carleson (1749).

—, Tal, om yppighets nytta [...] (1740) (Stockholm, 1741). 


\section{KÄLLOR OCH LITTERATUR}

-, Tal til Hans Kongl. Majestet och Kongl. Vetenskaps Academien, vid observatorii invigning den 20. sept. 1753 [...] jämte berättelse om samma observatorii byggnad (Stockholm, 1753).

Jennings, John, Tal, om nyttan af segelfarter igenom torra land och berg [...] (Stockholm, 1770).

—, Tal om Trollhätte sluss-byggnads öden [...] (Stockholm, 1761).

Klingenstierna, Samuel, Tal, om de nyaste rön vid elektriciteten [...] (Stockholm, 1755).

Knutberg, Carl, Upmuntran til allahanda, vid lands- och stads-hushållningen nyttiga ämnens samlande [...] (Stockholm, 1762).

Kryger, Johan Fredrik, Tal om folkbristens orsaker, verkan och hjelp [...] (Stockholm, 1758).

—, Tal om lagarnas och sedernas verkan på borgerliga näringar [...] (Stockholm, 1767).

Lehnberg, Carl, Tal, om optikens och refractions telescopers förbättring i senaste tider [...] (Stockholm, 1762).

Leijell, Carl, Tal, om anläggningen och nyttan af det slags bärgs-arbete, som stollbyggnad kallas [...] (Stockholm, 1751).

Leijonmarck, Gustaf Adolf, Tal, om kast-linjen [...] (Stockholm, 1783).

—, Tal, om utsigten för svenska bergshandteringen i framtiden [...] (Stockholm, 1775).

Lidbeck, Erik Gustaf, Tal om planteringar [...] (Stockholm, 1766).

Liljencrantz, Johan, Tal, om Sveriges utrikes handel $i$ allmänhet, och den levantiska i synnerhet [...] (Stockholm, 1770).

Lillienberg, Jean George, Tal, om flera, i senare tiden, skedde förbättringar uti bergs-vetenskapen och handteringen i riket [...] (Stockholm, 1781).

—, Tal, om svenska bergshandteringens förmåner och hinder [...] (Stockholm, 1776). Lilliestråle, Joachim Wilhelm, Tal, om lag-förbättring [...] (Stockholm, 1775).

—, Tal [...] om tale-konsten, des uphof och förbindelse med vetenskaperna [...] (Stockholm, 1784).

Lindblom, Nils, Tal, om angelägenheten och nyttan af några artillerie-försöks anställande [...] (Stockholm, 1774).

Linné, Carl von, Bref och skrifvelser af och till Carl von Linné [...], 10 vol. (Stockholm, 1907-43), I:2.

—, "Carl Linné potest e casa vir magnus exire: Vita III", i Linné (1957).

-, Carl von Linnés Västgöta resa 1746: Faksimiledition efter 1747 års originalupplaga. Andra tryckningen (Malmö, 1956).

-, Carl von Linné till Kungliga Svenska Vetenskapsakademien, 3/1 1765, http:// linnaeus.c18. net [hämtad 2020-07-31].

—, Tal, om märkvärdigheter uti insecterna [...] (Stockholm, 1739).

—, Vita Caroli Linnaei: Carl von Linnés självbiografier (Stockholm, 1957).

Ljungenstjerna, Sven, Tal, om naturkunnighetens uphjelpande och nytta i det allmänna [...] (Stockholm, 1752). 


\section{KÄLLOR OCH LITTERATUR}

Löwenhielm, Carl Gustaf, Tal, om landt-skötsel [...] (Stockholm, 1751).

—, Tal om ungdomens upfostran i et välbestäldt regemente [...] (Stockholm, 1767).

Mallet, Fredric, Tal, om de mathematiska vetenskapers befrämjande til allmännare nytta uti fäderneslandet [...] (Stockholm, 1786).

Marelius, Nils, Tal, om Mälarens utlopp, med geographiska och historiska anmärkningar [...] (Stockholm, 1771).

—, Tal, om nyttan af topographiska och chorographiska chartor [...] (Stockholm, 1784).

Martin, Roland, Tal, om nervers allmänna egenskaper i människans kropp [...] (Stockholm, 1763).

Meijer, Gerhard, Tal, om det svenska metal-arbetets förkofring [...] (Stockholm, 1747).

Melanderhielm, Daniel, Tal, om angelägenheten af astronomiska observationers beständiga fortsättande [...] (Stockholm, 1792).

-, Tal, om de mathematiska vetenskapernas nytta i krigskonsten och alla dess särskilda grenar [...] (Stockholm, 1782).

Mennander, Carl Fredrik, Tal om bok-handelen i Sverige [...] (Stockholm, 1756).

-, Tal om folkhopens tilväxt, som grunden til rikets näringars upkomst [...] (Stockholm, 1766).

Modeer, Adolph, Tal, om några ämnen, som uti de tre naturens riken förunderligen likna hvarandra, så til utseende, som ock merändels til bruk och nytta [...] (Stockholm, 1791).

Nordenankar, Johan, Tal, om strömgångarne i Öster-sjön [...] (Stockholm, 1792).

Nordenskiöld, Carl Fredrik, Tal om nyttan aföfverflödigt vattens uttappande utur insjöar, kärr och måssar i Finland [...] (Stockholm, 1758).

Odhelius, Johan Lorens, Dödligheten i Stockholm, i et tal för K. Vetensk. Acad. granskad [...] (Stockholm, 1785).

-, K. lazarettet i Stockholm, beskrifvit uti et tal, inför Kongl. Vetenskaps Academien [...] (Stockholm, 1776).

Palmqvist, Fredrik, Tal, om mathematiska vetenskapernas nytta $i$ allmänna lefvernet [...] (Stockholm, 1754).

Piper, Carl Fredrik, Tal, hållit för Kongl. Svenska Vetenskaps Academien [...] (Stockholm, 1751).

Plantin, Zacharias Zachariae, Tal, om justering och pröfning af mätnings- och vägnings-verktygen [...] (Stockholm, 1792).

—, Tal, om möjeligheten af svenska målens och vigternas reduction [...] (Stockholm, 1788).

Polhem, Christopher, Tal öfver den vigtiga frågan: Hvad som vårt kära fädernesland hafver nu måst af nöden til sin ständiga förkofring i längden? [...] (Stockholm, 1745).

Polhem, Gabriel, Tal, om de i landet befintelga [sic] byggningsämnen [...] (Stockholm, 1760). 


\section{KÄLLOR OCH LITTERATUR}

-, Tal om mathematiske vetenskapernes nytta uti åtskilliga bygnaders varaktiga sammansätningar [...] (Stockholm, 1745).

Prosperin, Eric, Tal, om Kongliga Vetenskaps Societeten i Upsala [...] (Stockholm, 1791).

Psilanderhielm, Nils, Tal, om mineral-samlingar [...] (Stockholm, 1755).

Qvist, Bengt, Tal, innehållande några anmerkningar om en nyttig mineral-samlare [...] (Stockholm, 1782).

—, Tal, innehållande några anmärkningar öfver metall- och mineralvaror samt deras aftsättning [...] (Stockholm, 1776).

Rabbe, Sten af, Tal, om folk-mängden i äldre och nyare tider [...] (Stockholm, 1771).

Ribe, Carl Fredric, Tal om ögonen [...] (Stockholm, 1748).

Ribe, Evald, Tal, om den stora nytta som kunskapen uti physiquen hafwer wid siukdomars igenkiännande ock botande [...] (Stockholm, 1740).

Rosenadler, Carl Albrecht, Tal, om de närings-medel, som synas kraftigast kunna verka på fäderneslandets förkofran [...] (Stockholm, 1767).

Rosén von Rosenstein, Nils, Tal, om en opartisk och förnuftig medici förnämsta göromål [...] (Stockholm, 1746).

—, Tal om pesten, och om dess utestängande ifrån et land [...] (Stockholm, 1772).

Rosenstein, von, Nils, Försök til en afhandling om uplysningen, til dess beskaffenhet, nytta och nödvändighet för samhället [...] (Stockholm, 1793).

Rousseau, Jean-Jacques, "The social contract" (1762), i Dunn (red.) (2002).

Rudenschöld, Carl, Tal, hållne, under Kongl. Majestets höga öfvervaro, uti dess Vetenskaps Academie [...] (Stockholm, 1779).

_, "Til Kongl. Majestet, på Kongl. Vetenskaps Academiens vägnar [...]”, i Tal hållne i Kongl. Vetenskaps Academien.

—, Tal om svenska språkets art och nu varande bruk [...] (Stockholm, 1772).

Rudenschöld, Ulric, Tal om skogarnes nytjande och vård [...] (Stockholm, 1748).

Runeberg, Edvard Fredrik, Tal, om nyttan och angelägenheten af hushållskunskapens bringande til en vetenskap [...] (Stockholm, 1778).

—, Tal, om varors värden [...] (Stockholm, 1760).

Rönnow, Casten, Tal, om förmånen, som hela rikets invånare tilskyndas skulle, af et stort lazarets inrättande här i hufvud-staden [...] (Stockholm, 1774).

Salander, Erik, Tal, om slögder [...] (Stockholm, 1754).

Salvius, Lars, "Anno 1739 d. 2 iunii", i Dahlgren.

Sandels, Samuel, Tal, då Kongl. Vetenskaps Academien i underdånighet anhöll, och Kongl. Majestet i nåder täcktes emottaga academien, såsom protector [...] (Stockholm, 1772).

-, Tal, om förhållandet af varors in- och utförsel til och ifrån Sverige i särskilda tid-hvarf [...] (Stockholm, 1782).

—, Tal, om Kongl. Svenska Vetenskaps Academiens inrättning och dess fortgång til närvarande tid [...] (Stockholm, 1771). 


\section{KÄLLOR OCH LITTERATUR}

Scheffer, Carl Fredrik, Tal, hållit för Kongl. Vetenskaps Academien [...] (Anmärkningar om vetenskapers, vitterhets och konsters närvarande tillstånd $i$ vårt rike) (Stockholm, 1755).

-, Tal, om förbindelsen, imellan grund-lagarnas art och folkets sällhet, som efter dem styras skal [...] (Stockholm, 1772).

Scheffer, Henrik Teofilus, Tal, om mynt [...] (1753) (Stockholm, 1762).

Schröder, Eric, Tal, om nyttan af en utvidgad handel med inrikes spanmål [...] (Stockholm, 1792).

Schröderheim, Elis, Tal, om den uplysning Sveriges gamla lagar lemna om våre förfäders seder och tänkesätt [...] (Stockholm, 1789).

Schultze, Samuel, Tal om glas-makeriet, samt om Kongsholms glas-bruk [...] (Stockholm, 1762).

—, Tal om ungdomens upöfvande i landtbruk [...] (Stockholm, 1750).

Schulzenheim, von, David, Tal, om den rätta ålderdomens ärnående [...] (Stockholm, 1764).

Schützercrantz, Herman, Tal, om chirurgiens nuvarande tilstånd [...] (Stockholm, 1755).

-, Tal, om den tilväxt och de hinder, som barn-förlossnings-vetenskapen haft, $i$ flere åldrar, til närvarande tid [...] (Stockholm, 1777).

Schönberg, Anders, Tal om näringarnas inbördes förbindelse [...] (Stockholm, 1772).

Seth, Johan von, "Svar, gifvit på Kongl. Vetenskaps Academiens vägnar [...]", i Scheffer (1762).

Sparre, Carl, Tal, om politie i allmänhet [...] (Stockholm, 1777).

Sparrman, Anders, Tal, om den tilväxt och nytta, som vetenskaperne i allmänhet, särdeles natural-historien, redan vunnit och ytterligare kunna vinna, genom undersökningar i Söder-hafvet [...] (Stockholm, 1778).

Stiernman, Anders Anton von, Tal om de lärda vettenskapers tilstånd i Svearike, under hedendoms och påfvedöms tiden [...] (Stockholm, 1758).

Stockenström, Eric von, Bergsmannanäringens nytta och skötsel [...] (Stockholm, 1749).

—, Tal om svenska järn-bruksnäringen, samt om Järn-Contoiret [...] (Stockholm, 1767).

Strandberg, Zacharias Johan, Tal, om de fel, som vid chroniska sjukdomars botande $i$ allmänhet begås [...] (Stockholm, 1765).

—, Tal, om de fel, som vid febrars botande hos oss dageligen begås [...] (Stockholm, 1752).

Strussenfelt, Alexander Michael von, Tal, om fästningars nytta och bruk samt byggnads-sätt [...] (Stockholm, 1780).

Strömer, Mårten, Tal om förbindelsen imellan astronomien och styrmans-konsten [...] (Stockholm, 1756). 
Swab, Anton von, Tal om controll-inrättningen för guld-silfver-och tenn-arbeten $i$ riket $[\ldots]$ (Stockholm, 1761).

Swartz, Olof, Tal, om natural-historiens uphof och framsteg i Sverige [...] (Stockholm, 1794).

Tal hållne i Kongl. Vetenskaps Academien, då Hans Kongl. Majestet första gången benådade academien med sin höga närvarelse [...] (Stockholm, 1772).

Tessin, Carl Gustaf, Kårt tal om svenska språkets rykt och upodlande [...] (Stockholm, 1746).

Thunberg, Carl Peter, Tal, om japanska nationen [...] (Stockholm, 1784).

Tiburtius, Tiburtz, Tal om Öster-götlands förmoner och olägenheter [...] (Stockholm, 1761).

Tilas, Daniel, Stenrikets historia [...] (Stockholm, 1742).

—, Utkast til Sveriges mineral-historia [...] (Stockholm, 1765).

Triewald, Mårten, Tal, om ämne och orsaker till metallernes och mineraliernes födo, tilltagande och mognande växt i jorden [...] (1740) (Stockholm, 1748).

Ungern-Sternberg, Matthias Alexander von, Tankar om Sveriges handel och allmänna hushållning [...] (Stockholm, 1752).

Vallerius, Göran, Tal emellan mathesin och physiquen om deras verkan och nytta uti bärgs-väsendet [...] (1744) (Stockholm, 1747).

Wargentin, Pehr Wilhelm, ”Svar, gifvit å Kongl. Vetenskaps Academiens vägnar [...]", i Acrel (1750).

—, "Svar, gifvit på Kongl. Vetensk. Academiens vägnar [...]", i Adelcrantz.

—, "Svar, gifvit på Kongl. Vetensk. Academiens vägnar [...]", i Alströmer (1760).

—, "Svar, gifvet på Kongl. Vetenskaps Academiens vägnar [...]”, i Alströmer (1770).

—, "Svar, gifvet på Kongl. Vetenskaps Academiens vägnar [...]”, i Arbin (1773).

—, "Svar, gifvet på Kongl. Vetenskaps Academiens vägnar [...]”, i Berch (1766).

—, "Svar, gifvet på Kongl. Vetensk. Academiens vägnar [...]", i Bergius (1764).

—, "Svar, gifvet på Kongl. Vetenskaps Academiens vägnar [...]”, i Bergius (1769).

—, "Svar, gifvet, på Kongl. Vetenskaps Academiens vägnar [...]”, i Bergius (1780).

—, "Svar, gifvet på Kongl. Vetenskaps Academiens vägnar [...]”, i Bergius (1785).

—, "Svar, gifvet på Kongl. Vetenskaps Academiens vägnar [...]”, i Bergman.

—, "Svar, gifvet på Kongl. Vetenskaps Academiens vägnar [...]", i Bielke.

—, "Svar, gifvit på Kongl. Vetensk. Academiens vägnar [...]", i Bonde.

—, "Svar, gifvet, på Kongl. Vetenskaps Academiens vägnar [...]”, i Botin.

—, "Svar, gifvet, på Kongl. Vetenskaps Academiens vägnar [...]", i Bunge.

—, "Svar, gifvit af Kongl. Vetensk. Academiens secreterare”, i Bäck (1765).

—, "Svar, gifvet å Kongl. Vetensk. Academiens vägnar [...]", i Carleson (1759).

—, "Svar, gifvit på Kongl. Vetenskaps Academiens vägnar [...]", i Clason (1751).

—, "Svar, gifvit på Kongl. Vetensk. Academiens vägnar [...]", i Clason (1769).

—, "Svar, gifvet, på Kongl. Academiens vägnar [...]", i Cronstedt (1771).

—, "Svar, gifvit på Kongl. Vetenskaps Academiens vägnar [...]", i De Geer (1754). 


\section{KÄLLOR OCH LITTERATUR}

—, "Svar, gifvit på Kongl. Vetenskaps Academiens vägnar [...]”, i Ehrensvärd (1743).

—, "Svar, gifvet på Kongl. Vetenskaps Academiens vägnar [...]”, i Ehrensvärd (1767).

—, "Svar, gifvit å Kongl. Vetensk. Academ. vägnar [...]”, i Ekström.

—, "Svar, gifvet på Kgl. Vetenskaps Academiens vägnar [...]”, i Falkenberg.

—, "Svar, gifvet på Kongl. Vetenskaps Academiens vägnar [...]”, i Ferrner (1765).

_, "Svar, gifvet, på Kongl. Vetenskaps Academiens vägnar [...]”, i Grill (1774).

—, "Svar, gifvit på Kongl. Vetensk. Academiens vägnar [...]”, i Gyllenborg.

—, "Svar gifvit på Kongl. Vetensk. Academiens vägnar [...]”, i Heijkenskjöld (1759).

_, "Svar, gifvet på Kongl. Vetenskaps Academiens vägnar [...]", i Heijkenskjöld (1768).

—, "Svar, gifvet, på Kongl. Vetenskaps Academiens vägnar [...]”, i Hermelin.

—, "Svar, gifvet på Kongl. Vetensk. Academiens vägnar [...]", i Högström.

—, "Svar, gifvet på Kongl. Vetensk. Academiens vägnar [...]", i Jennings (1761).

—, "Svar, gifvet på Kongl. Vetenskaps Academiens vägnar [...]”, i Jennings (1770).

—, "Svar, gifvit på Kongl. Vetensk. Academiens vägnar [...]", i Kryger (1758).

—, "Svar, gifvet på Kongl. Vetenskaps Academiens vägnar [...]", i Kryger (1767).

—, "Svar, gifvit på Kongl. Vetenskaps Academiens vägnar [...]”, i Lehnberg.

_, "Svar, gifvet på Kongl. Vetenskaps Academiens vägnar [...]”, i Leijonmarck (1775).

_, "Svar, gifvet på Kongl. Vetenskaps Academiens vägnar [...]”, i Lidbeck.

—, "Svar, gifvet på Kongl. Vetenskaps Academiens vägnar [...]", i Liljencrantz.

_, "Svar, gifvet på Kongl. Vetenskaps Academiens vägnar [...]", i Lillienberg (1776).

_, "Svar, gifvet på Kongl. Vetenskaps Academiens vägnar [...]”, i Lillienberg (1781).

_, "Svar, gifvet på Kongl. Vetenskaps Academiens vägnar [...]”, i Lilliestråle (1775).

—, "Svar, gifvet, på Kongl. Vetenskaps Academiens vägnar [...]”, i Lindblom.

—, ”Svar, gifvit å Kongl. Vetenskaps Academiens vägnar [...], i Löwenhielm (1751).

—, "Svar, gifvet på Kongl. Vetenskaps Academiens vägnar [...]", i Löwenhielm (1767).

_, "Svar, gifvit på Kongl. Vetenskaps Academiens vägnar [...]", i Mennander (1766).

—, "Svar, gifvit på Kongl. Vetensk. Academiens vägnar [...]", i Nordenskiöld.

—, "Svar, gifvet på Kongl. Vetenskaps Academiens vägnar [...]", i Odhelius (1776).

—, "Svar, gifvit å Kongl. Vetenskaps Academiens vägnar [...], i Piper.

—,"Svar, gifvit å Kongl. Vetenskaps Academiens vägnar [...]”, i Psilanderhielm.

—, "Svar, gifvet på Kongl. Vetenskaps Academiens vägnar [...]", i Qvist (1776).

—, "Svar, gifvet på Kongl. Vetenskaps Academiens vägnar [...]", i Qvist (1782).

_, "Svar, gifvet på Kongl. Vetenskaps Academiens vägnar [...]”, i Rosenadler.

—, "Svar, gifvet, på Kongl. Vetenskaps Academiens vägnar [...]", i Rudenschöld (1772).

—, "Svar, gifvet på Kongl. Vetenskaps Academiens vägnar [...]”, i Rudenschöld (1779).

—, "Svar, gifvet på Kongl. Vetenskaps Academiens vägnar [...]”, i Rönnow.

—, "Svar, gifvit på Kongl. Vetenskaps Academiens vägnar [...]", i Salander.

—, "Svar, gifvet, på Kongl. Vetenskaps Academiens vägnar [...]", i Sandels (1771).

—, ”Svar, gifvit på Kongl. Vetenskaps Academiens vägnar [...]”, i Scheffer (1755). 
—, "Svar, gifvit å Kongl. Vetenskaps Academiens vägnar [...]", i Scheffer (1772).

—, "Svar, gifvit på Kongl. Vetensk. Academiens vägnar [...]", i Schultze (1762).

_, "Svar, gifvet på Kongl. Vetenskaps Academiens vägnar [...]", i Schützercrantz (1777).

—, "Svar, gifvet på Kongl. Vetenskaps Academiens vägnar [...]", i Schönberg.

—, "Svar, gifvet på Kongl. Vetenskaps Academiens vägnar [...]", i Sparre.

—, "Svar, gifvet, på Kongl. Vetenskaps Academiens vägnar [...]", i Sparrman.

—, "Svar, gifvit på Kongl. Vetenskaps Academiens vägnar [...]", i Stockenström $(1767)$.

—, "Svar, gifvit på Kongl. Vetenskaps Academiens vägnar [...]”, i Strandberg (1752).

—, "Svar, gifvit på Kongl. Vetensk. Academiens vägnar [...]", i Strandberg (1765).

—, "Svar, gifvet, på Kongl. Vetenskaps Academiens vägnar [...]", i Strussenfelt.

—, "Svar, gifvit på Kongl. Vetensk. Academiens vägnar [...]", i Strömer.

—, "Svar, gifvet på Kongl. Vetensk. Academiens vägnar [...]”, i Tiburtius.

—, "Svar, gifvit på Kongl. Vetenskaps Academiens vägnar [...]", i Ungern-Sternberg.

—, "Svar, gifvit på Kongl. Vetensk. Academiens vägnar [...]", i Wilcke (1764).

—, "Svar, gifvet, på Kongl. Vetenskaps Academiens vägnar [...]", i Wäsström.

Wilcke, Johan Carl, "Svar, gifvet på Kongl. Vetenskaps Academiens vägnar", i Adlerbeth.

—, "Svar, gifvet på Kongl. Vetenskaps Academiens vägnar [...]”, i Arfvedson.

—, "Svar, gifvet på Kongl. Vetenskaps Academiens vägnar [...]", i Benzelstierna (1788).

—, "Svar, gifvet på Kongl. Vetenskaps Academiens vägnar [...]”, i Carlson.

—, "Svar, gifvet på Kongl. Vetenskaps Academiens vägnar [...]", i Dalberg (1784).

—, "Svar, gifvet på Kongl. Vetenskaps-Academiens vägnar [...]", i Gadolin (1786).

—, "Svar, gifvet på Kongl. Vetenskaps Academiens vägnar [...]", i Hjelm.

_, "Svar, gifvet, på Kongl. Vetenskaps Academiens vägnar [...]”, i Lilliestråle (1784).

—, "Svar, gifvet på Kongl. Vetenskaps Academiens vägnar", i Melanderhielm (1792).

—, "Svar, gifvet, på Kongl. Vetenskaps Academiens vägnar [...]", i Nordenankar.

—, "Svar, gifvet, på Kongl. Vetenskaps Academiens vägnar [...]", i Odhelius (1785).

—, "Svar, gifvet, på Kongl. Vetenskaps Academiens vägnar [...]", i Plantin (1788).

-,"Svar, gifvet på Kongl. Vetensk. Acad. vägnar", i Plantin (1792).

—, "Svar, gifvet på Kongl. Vetenskaps Academiens vägnar [...]", i Rosenstein (1793).

—, "Svar, gifvet på Kongl. Vetenskaps Academiens vägnar”, i Schröder.

—, "Svar, gifvet på Kongl. Vetenskaps Academiens vägnar [...]", i Schröderheim.

—, "Svar, gifvit på Kongl. Vetensk. Academiens vägnar [...]", i Schulzenheim.

—, Tal, om de nyaste förklaringar öfver norr-skenet [...] (Stockholm, 1778).

—, Tal, om magneten [...] (Stockholm, 1764).

Wrede, Henrik Jakob, Tal om et borgerligit samhälles eller et land ock rikes rätta styrka, samt sätt ock utvägar at komma der til [...] (Stockholm, 1747). 


\section{KÄLLOR OCH LITTERATUR}

Wäsström, Pehr, Tal, om skogs, i synnerhet bräders, besparing vid byggnader [...] (Stockholm, 1774).

Zetzell, Pehr, Tal, om en svensk soldats föda i fält [...] (Stockholm, 1764).

-, Tal, om sjukligheten i fält, $i$ anledning af Pommerska kriget ifrån år 1757 til 1762 [...] (Stockholm, 1779).

\section{Litteratur}

Adolfsson, Maria, Fäderneslandets kännedom: Om svenska ortsbeskrivningsprojekt och ämbetsmäns folklivsskildringar under 1700-och 180o-talet (Stockholm, 2000).

Ahlund, Mikael, Landskapets röster: Studier i Elias Martins bildvärld (Stockholm, 2011).

Aldman, Lili-Annè, En merkantilistisk början: Stockholms textila import 1720-1738 (Uppsala, 2008).

Alm, Mikael, Kungsord i elfte timmen: Språk och självbild i det gustavianska enväldets legitimitetskamp 1772-1809 (Stockholm, 2002).

Andersen, Håkon With m.fl. (red.), Emula lauri: The royal Norwegian society of sciences and letters, 1760-2010 (Sagamore Beach, 2009).

Andersson, Gudrun, Larsson, Esbjörn \& Winton, Patrik (red.), Med börd, svärd och pengar: Eliters manifestation, maktutövning och reproduktion 1650-1900 (Uppsala, 2003).

Andersson Burnett, Linda \& Buchan, Bruce, ”The Edinburgh connection: Linnaean natural history, Scottish moral philosophy and the colonial implications of Enlightenment thought”, i Hodacs, Nyberg \& Van Damme (red.) (2018).

Atkinson, Dwight, Scientific discourse in sociohistorical context: The Philosophical Transactions of the Royal Society of London, 1675-1975 (Mahwah, 1999).

Baker, Keith Michael, "Enlightenment and the institution of society: Notes for a conceptual history", i Kaviraj \& Khilnani (red.) (2001).

-, Inventing the French Revolution: Essays on French political culture in the eighteenth century (Cambridge, 1990).

Bennich-Björkman, Bo, Författaren i ämbetet: Studier i funktion och organisation av författarämbeten vid svenska hovet och kansliet 1550-1850 (Uppsala, 1970).

Berg, Anne, Kampen om befolkningen: Den svenska nationsformeringens utveckling och sociopolitiska förutsättningar, ca 1780-1860 (Uppsala, 2011).

Bergström, Cecilia (red.), För efterkommande: Kungl. Vetenskapsakademiens medaljer 1749-2007 (Stockholm, 2010).

Biagioli, Mario (red.), The Science Studies reader (New York, 1999).

Björck, Henrik \& Kaiserfeld, Thomas, "Vetenskapsakademien som kunskapspolitisk kamporganisation, 1739-1819", i Kärnfelt, Grandin \& Jülich (red.) (2018).

Broberg, Gunnar, Homo sapiens L: Studier i Carl von Linnés naturuppfattning och människolära (Uppsala, 1975). 
-, Mannen som ordnade naturen: En biografi över Carl von Linné (Stockholm, 2019). Brohed, Ingmar, Stat - religion - kyrka: Ett problemkomplex i svensk akademisk undervisning under 170o-talet (Stockholm, 1973).

Brolin, Per-Erik, Hattar och mössor i borgarståndet 1760-1766 (Uppsala, 1953).

Brooke, John Hedley, Science and religion: Some historical perspectives (1991), 6 uppl. (Cambridge, 1998).

Brunner, Otto (red.), Geschichtliche Grundbegriffe: Historisches Lexikon zur politisch-sozialen Sprache in Deutschland, vol. 5 (Stuttgart, 1984).

Buchan, Bruce \& Heath, Mary, "Savagery and civilization: From terra nullius to the 'tide of history'", Ethnicities 6:1 (2006).

Burius, Anders, "Anders Schönberg", Svenskt biografiskt lexikon, band 31.

Carlquist, Gunnar, "Carl Wilhelm Cederhielm", Svenskt biografiskt lexikon, band 8 .

-, "Nils Adam Bielke", Svenskt biografiskt lexikon, band 4.

-, "Sten Carl Bielke", Svenskt biografiskt lexikon, band 4.

Carlsson, Ingemar, Olof Dalin och den politiska propagandan inför "lilla ofreden": Sagan Om Hästen och Wår-Wisa i samtidspolitisk belysning (Lund, 1966).

-, Parti - partiväsen - partipolitiker 1731-43: Kring uppkomsten av våra första politiska partier (Stockholm, 1981).

Carlsson, Sten, Ståndssamhälle och ståndspersoner 1700-1865: Studier rörande det svenska ståndssamhällets upplösning (1949), 2 uppl. (Lund, 1973).

Carrithers, David, "The Enlightenment science of society", i Fox, Porter \& Wokler (red.) (1995).

Cavallin, Maria, I kungens och folkets tjänst: Synen på den svenske ämbetsmannen 1750-1780 (Göteborg, 2003).

Chartier, Roger, The cultural origins of the French Revolution (1990) (Durham, 1991).

Christensson, Jakob, Lyckoriket: Studier i svensk upplysning (Stockholm, 1996).

- (red.), Signums svenska kulturhistoria: Frihetstiden (Lund, 2006).

Clark, William, Academic charisma and the origins of the research university (Chicago, 2006).

Clark, William, Golinski, Jan \& Schaffer, Simon (red.), The sciences in enlightened Europe (Chicago, 1999).

Daston, Lorraine, "The ideal and reality of the Republic of Letters in the Enlightenment", Science in context, 4:2 (1991).

Dunér, David, "Polhem, drönarna och fru Alamode: En studie i dygdemetaforer i frihetstida överflödsdebatt", i Olsson et al (red.) (2014).

Edelstein, Dan, The Enlightenment: A genealogy (Chicago, 2010).

Ekblad, Magnus, "Den naturkunnige akademieledamoten: Några aspekter på nätverk och symboliska maktresurser under frihetstiden", Historisk Tidskrift för Finland, nr 12003. 


\section{KÄLLOR OCH LITTERATUR}

—, "Ett brev betyder så mycket: Närhet och distans i Carl Gustaf Tessins tidiga 1740-talskorrespondens med Carl Hårleman”, i Andersson, Larsson \& Winton (red.) (2003).

Ekedahl, Nils, Det svenska Israel: Myt och retorik i Haquin Spegels predikokonst (Hedemora, 1999).

Eliassen, Knut Ove, "Introduction", i Andersen et al (red.) (2009).

Ellingson, Ter, The myth of the noble savage (Berkeley, 2001).

Englund, Peter, Det hotade huset: Adliga föreställningar om samhället under stormaktstiden (Stockholm, 1989).

Fafner, Jørgen, Tanke og tale: Den retoriske tradition i Vesteuropa (1982), 2 uppl. (Köpenhamn, 1991).

"Falkenberg, Melker", Svenskt biografiskt handlexikon, band 1.

Fors, Hjalmar, "Erik von Stockenström", Svenskt biografiskt lexikon, band 33.

-, "Kemi, paracelsism och mekanisk filosofi: Bergskollegium och Uppsala cirka 1680-1770", Lychnos 2007.

—, "Matematiker mot linneaner: Konkurrerande vetenskapliga nätverk kring Torbern Bergman", i Widmalm (red.) (2008).

-, Mutual favours: The social and scientific practice of eighteenth-century Swedish chemistry (Uppsala, 2003).

-, The limits of matter: Chemistry, mining and enlightenment (Chicago, 2015).

Forsman, Karl, "Studier i det svenska 170o-talets ekonomiska litteratur", Historiska och litteraturhistoriska studier 23 (Helsingfors, 1947).

Fox, Christopher, "Introduction: How to prepare a noble savage. The spectacle of human science", i Fox, Porter \& Wokler (red.) (1995).

Fox, Christopher, Porter, Roy \& Wokler, Robert (red.), Inventing human science: Eighteenth-century domains (Berkeley \& Los Angeles, 1995).

Frantzén, Olle, "Pehr Högström", Svenskt biografiskt lexikon, band 19.

Frazer, James, The golden bough: A study in magic and religion (1922), ny uppl. (Ware, 1993).

Frängsmyr, Carl, Klimat och karaktär: Naturen och människan i sent svenskt 170otal (Stockholm, 200o).

Frängsmyr, Tore, ”Den gudomliga ekonomin: Religion och hushållning i 170o-talets Sverige", Lychnos 1971-1972.

—, Geologi och skapelsetro: Föreställningar om jordens historia från Hiärne till Bergman (Stockholm, 1969).

—, Svensk idéhistoria: Bildning och vetenskap under tusen år. Del 1: 10oo-1809 (Stockholm, 200o).

-, Wolffianismens genombrott i Uppsala: Frihetstida universitetsfilosofi till 1700-talets mitt (Uppsala, 1972).

Förvaltningshistorisk ordbok, http://fho.sls.fi [hämtad 2020-07-31]. 


\section{KÄLLOR OCH LITTERATUR}

Galison, Peter, "Trading zone: Coordinating action and belief”, i Biagioli (red.) (1999).

Geertz, Clifford, "Centers, kings, and charisma: Reflections on the symbolics of power" (1973), i Geertz (2000).

-, Local knowledge: Further essays in interpretive anthropology (1983), 3 uppl. (New York, 200o).

Gillingstam, Hans, "Piper, släkt", Svenskt biografiskt lexikon, band 29.

Goldenbaum, Ursula, "Friedrich II. und die Berliner Aufklärung", i Lottes \& D’Aprile (red.) (2006).

Goldgar, Anne, Impolite learning: Conduct and community in the Republic of Letters 1680-1750 (New Haven, 1995).

Goodman, Dena, The Republic of Letters: A cultural history of the French Enlightenment (Ithaca, 1994).

Grafton, Anthony, "A sketch map of a lost continent: The Republic of Letters" (2007), i Grafton (2009).

-, Worlds made by words: Scholarship and community in the modern West (Cambridge, Mass., 2009).

Grage, Elsa-Britta, ”Thomas Plomgren", Svenskt biografiskt lexikon, band 29.

Gunneriusson, Håkan (red.), Sociala nätverk och fält (Uppsala, 2002).

Gustafsson, Harald, Makt och människor: Europeisk statsbildning från medeltiden till franska revolutionen (Göteborg, 2010).

Haakonssen, Knud, Natural Law and moral philosophy: From Grotius to the Scottish Enlightenment (Cambridge, 1996).

Hagstedt, Rolf, "Carl Sparre", Svenskt biografiskt lexikon, band 32.

Hallberg, Paul (red.), Ljus över landet? Upplysningen som drivkraft i 17oo-talets svenska vetenskap och vitterhet (Göteborg, 2005).

Hallberg, Peter, Ages of liberty: Social upheaval, history writing, and the new public sphere in Sweden, 1740-1792 (Stockholm, 2003).

Harman, P. M., The culture of nature in Britain 1680-1860 (New Haven, 2009).

Harrison, Edward, Masks of the Universe: Changing ideas on the nature of the cosmos (1985), 2 uppl. (Cambridge, 2003).

Hasselberg, Ylva, Müller, Leos \& Stenlås, Niklas, "Åter till historiens nätverk”, i Gunneriusson (red.) (2002).

Heckscher, Eli, "Jonas Alströmer", i Svenskt biografiskt lexikon, band 1.

-, Svenskt arbete och liv: Från medeltiden till nutid (1941), 10 uppl. (Stockholm, 1985).

Helander, Hans, Neo-Latin literature in Sweden in the period 1620-1720: Stylistics, vocabulary and characteristic ideas (Uppsala, 2004).

Herlitz, Lars, Fysiokratismen i svensk tappning 1767-1770 (Göteborg, 1974).

Hildebrand, Bengt, Kungl. Svenska Vetenskapsakademien: Förhistoria, grundläggning och första organisation (Stockholm, 1939). 


\section{KÄLLOR OCH LITTERATUR}

Hildebrand, Bengt \& Högberg, Staffan, "Claes Grill”, Svenskt biografiskt lexikon, band 17 .

Hildebrand, S., "Matthias Benzelstierna", Svenskt biografiskt lexikon, band 3 .

Hodacs, Hanna, Nyberg, Kenneth \& Van Damme, Stephane (red.), Linnaeus, natural history and the circulation of knowledge (Oxford, 2018).

Hof, Im, Ulrich, Das gesellige Jahrhundert: Gesellschaft und Gesellschaften im Zeitalter der Aufklärung (München, 1982).

Hreinsson, Einar \& Nilson, Tomas, "Introduktion", i Hreinsson \& Nilson (red.) (2003).

- (red.), Nätverk som social resurs: Historiska exempel (Lund, 2003).

Hunt, Lynn, The family romance of the French Revolution (Berkeley \& Los Angeles, 1992).

Högberg, Staffan, "John Jennings", Svenskt biografiskt lexikon, band 20.

-, Kungl. Patriotiska Sällskapets historia: Med särskild hänsyn till den gustavianska tidens agrara reformsträvanden (Stockholm, 1961).

Ihalainen, Pasi, "New visions for the future: Bodily and mechanical conceptions of the political community in eighteenth-century Sweden", i Karonen (red.) (2009).

Jacob, Margaret C., The Newtonians and the English Revolution, 1689-1720 (Hassocks, 1976).

Jakobsen, Rolv Nøtvik, Gunnerus og nordisk vitskapshistorie (Oslo, 2015).

Jardine, Nicholas, Secord, J. A. \& Spary, Emma (red.), Cultures of natural history (Cambridge, 1996).

Johannisson, Karin, Det mätbara samhället: Statistik och samhällsdröm i 17oo-talets Europa (Stockholm, 1988).

_, "Naturvetenskap på reträtt: En diskussion om naturvetenskapens status under svenskt 1700-tal", Lychnos 1979-1980.

Johanson, Ulla, "Carl Rudenschöld", Svenskt biografiskt lexikon, band 30.

Jägerskiöld, Olof, "Anders Johan von Höpken", Svenskt biografiskt lexikon, band 19.

—, "Carl Fredrik von Höpken", Svenskt biografiskt lexikon, band 19.

Kaiserfeld, Thomas, Krigets salt: Salpetersjudning som politik och vetenskap $i$ den svenska skattemilitära staten under frihetstid och gustaviansk tid (Lund, 2009).

Kaiserfeld, Thomas \& Björck, Henrik, "Reella ramar: Ledamöter, byggnader, ekonomi”, i Kärnfelt, Grandin \& Jülich (red.) (2018).

Karonen, Petri (red.), Hopes and fears for the future in early modern Sweden, 1500-180o (Helsingfors, 2009).

Kaviraj, Sudipta \& Khilnani, Sunil (red.), Civil society: History and possibilities (Cambridge, 2001).

Kelley, Donald R., The beginning of ideology: Consciousness and society in the French Reformation (Cambridge, 1981).

Klinge, Matti, "Naturlig teologi och naturrätt”, i Klinge m.fl. (1988-91).

—, m.fl., Helsingfors universitet 1640-1990, 3 vol. (Helsingfors, 1988-91), I. 


\section{KÄLLOR OCH LITTERATUR}

Knudsen, Jonathan B., Justus Möser and the German Enlightenment (Cambridge, 1986).

Koerner, Lisbet, "Daedalus hyperboreus: Baltic natural history and mineralogy in the Enlightenment", i Clark, Golinski \& Schaffer (red.) (1999).

-, Linnaeus: Nature and nation (Cambridge, Mass., 1999).

Koselleck, Reinhart, Erfarenhet, tid och historia: Om historiska tiders semantik (1979), sv. övers. (Stockholm, 2004).

Kouri, E. I. \& Olesen, Jens E. (red.), The Cambridge history of Scandinavia: Volume II, 1520-1870 (Cambridge, 2016).

Kärnfelt, Johan, Mellan nytta och nöje: Ett bidrag till populärvetenskapens historia i Sverige (Stockholm, 200o).

Kärnfelt, Johan, Grandin, Karl \& Jülich, Solveig (red.), Kunskap i rörelse: Kungl. Vetenskapsakademien och skapandet av det moderna samhället (Göteborg, 2018).

Laine, Merit, "En Minerva för vår Nord": Lovisa Ulrika som samlare, uppdragsgivare och byggherre (Stockholm, 1998).

Lamm, Martin, Upplysningstidens romantik: Den mystiskt sentimentala strömningen i svensk litteratur (1918-20), 2 uppl., 2 vol. (Stockholm, 1963), I.

Landen, Leif, Gustaf III: En biografi (Stockholm, 2004).

Legnér, Mattias, Fäderneslandets rätta beskrivning: Mötet mellan antikvarisk forskning och ekonomisk nyttokult i 170o-talets Sverige (Helsingfors, 2004).

Liedman, Sven-Eric, Den synliga handen: Anders Berch och ekonomiämnena vid 170o-talets svenska universitet (Stockholm, 1986).

—, "Upplysningstidens tre ansikten", i Hallberg (red.) (2005).

Lindberg, Bo, Den antika skevheten: Politiska ord och begrepp i det tidig-moderna Sverige (Stockholm, 2006).

—, "Den lärda kulturen", i Christensson (red.) (2006).

—, "Henrik Hassel - humanist och utilist", Lychnos 1990.

—, Naturrätten i Uppsala 1655-1720 (Uppsala, 1976).

Lindroth, Sten, Kungl. Svenska Vetenskapsakademiens historia 1739-1818, 3 vol. (Stockholm, 1967), I:1, II.

—, "Linné - legend och verklighet", Lychnos 1965-1966.

—, Svensk lärdomshistoria: Frihetstiden (Stockholm, 1978).

Livingstone, David N. \& Withers, Charles W. J. (red.), Geography and enlightenment (Chicago, 1999).

Lottes, Günther \& D’Aprile, Iwan (red.), Hofkultur und aufgeklärte Öffentlichkeit: Potsdam im 18. Jahrhundert im europäischen Kontext (Berlin, 2006).

Lovejoy, Arthur O., The great chain of being (1936), ny uppl. (Cambridge, 1998).

Lundgren, Anders, "Gruvor och kemi under 1700-talet i Sverige: Nytta och vetenskap", Lychnos 2008.

Löfberg, David, Det nationalekonomiska motivet i svensk pedagogik under 17ootalet (Uppsala, 1949). 


\section{KÄLLOR OCH LITTERATUR}

Lönnroth, Erik, Den stora rollen: Kung Gustaf III spelad av honom själv (Stockholm, 1986).

Magnusson, Lars, "Den ekonomiska diskussionen under frihetstiden - ett framlängesperspektiv", i Skuncke \& Tandefelt (red.) (2003).

—, "Manufakturerna", i Christensson (red.) (2006).

—, Merkantilism: Ett ekonomiskt tänkande formuleras (1994), sv. övers. (Stockholm, 1999).

—, Sveriges ekonomiska historia (1996), 4 uppl. (Stockholm, 2010).

-, Äran, korruptionen och den borgerliga ordningen: Essäer från svensk ekonomihistoria (Stockholm, 2001).

Magnusson, Thomas, Makt och pengar i frihetstidens Sverige: En oligarkis triumfer och slutliga nederlag 1720-1766 (Göteborg, 2020).

Malmström, Carl Gustaf, Sveriges politiska historia från konung Karl XII:s död till statshvälfningen 1772 (1855-1877), 6 vol., 2 uppl. (Stockholm, 1893-1901), IV-VI.

Mansén, Elisabeth, Sveriges historia 1721-1830 (Stockholm, 2011).

Mattsson, Annie, Komediant och riksförrädare: Handskriftscirkulerade smädeskrifter mot Gustaf III (Uppsala, 2010).

McClellan III, James E., Science reorganized: Scientific societies in the eighteenth century (New York, 1985).

McCloskey, Deirdre, The rhetoric of economics (1985), 2 uppl. (Madison, 1998).

Melkersson, Martin, Staten, ordningen och friheten: En studie av den styrande elitens syn på statens roll mellan stormaktstiden och 180o-talet (Uppsala, 1997).

Mokyr, Joel, The enlightened economy: An economic history of Britain 1700-1850 (New Haven, 2009).

Moore Jr., Barrington, Injustice: The social bases of obedience and revolt (1978) (London \& New York, 2015).

Morell, Mats, "Swedish agriculture in the cosmopolitan eighteenth century", i Rydén (red.) (2013).

Müller, Leos, Sveriges första globala århundrade: En 170o-talshistoria (Stockholm, 2018).

Nationalencyklopedin, band 13, 18.

Naumann, Erik, "Sven Bunge", Svenskt biografiskt lexikon, band 6.

Naumann, Erik \& Forsstrand, Carl, "J Gustaf Carlson", Svenskt biografiskt lexikon, band 7 .

Nell, Jennie, Vivat vår monark!: Carl Michael Bellmans panegyrik över Gustaf III 1771-1792 (Lund, 2011).

Nell, Jennie \& Sjödin, Alfred (red.), Kritik och beundran: Jean-Jacques Rousseau och Sverige 1750-1850 (Lund, 2017).

Nilsén, Per, Att "stoppa munnen till på bespottare": Den akademiska undervisningen i svensk statsrätt under frihetstiden (Lund, 2001). 


\section{KÄLLOR OCH LITTERATUR}

Nilsson, Sten Åke (red.), Drottning Lovisa Ulrika och Vitterhetsakademien (Stockholm, 2003).

Nilzén, Göran, "Carl Fredrik Scheffer", Svenskt biografiskt lexikon, band 31.

-, Carl Gustaf Tessin: Uppgång och fall (Stockholm, 2012).

-, Carl Gyllenborg: En frihetstida hattpolitiker (Stockholm, 2007).

—, "Jean Georg Lillienberg", Svenskt biografiskt lexikon, band 23.

Nordberg, Michael, I kung Magnus tid: Norden under Magnus Eriksson 1317-1374 (Stockholm, 1995).

Nordbäck, Carola, Lycksalighetens källa: Kontextuella närläsningar av Anders Chydenius budordspredikningar, 1781-82 (Åbo, 2009).

Nordenmark, N. V. E., Pehr Wilhelm Wargentin: Kungl. Vetenskapsakademiens sekreterare och astronom 1749-1783 (Uppsala, 1939).

Nordin, Jonas, "Anders Johan von Höpken: 'Sveriges Tacitus'”, i Nilsson (red.) (2003).

-, Ett fattigt men fritt folk: Nationell och politisk självbild i Sverige från sen stormaktstid till slutet av frihetstiden (Stockholm, 2000).

-, Frihetstidens monarki: Konungamakt och offentlighet i 17oo-talets Sverige (Stockholm, 2009).

—, "Frihetstidens radikalism", i Skuncke \& Tandefelt (red.) (2003).

Nyberg, Klas, "Staten, manufakturerna och hemmamarknadens framväxt", i Nyberg (red.) (2010).

- (red.), Till salu: Stockholms textila handel och manufaktur 1722-1846 (Stockholm, 2010).

Näslund, Lisbeth, "Joachim Wilhelm Liliestråle", Svenskt biografiskt lexikon, band 23 .

Olsson, Gunnar, Hattar och mössor: Studier över partiväsendet i Sverige 1751-1762 (Göteborg, 1963).

Olsson, Jenny-Leontine m.fl. (red.), Utopin i vardagen: Sinnen, kvinnor, idéer. En vänbok till Elisabeth Mansén (Lund, 2014).

Orrje, Jacob, Mechanicus: Performing an early modern persona (Uppsala, 2015).

Oscarsson, Ingemar, "'Rikets Frihet, Borgerlig Frihet, Skrif-Frihet': Gjörwell och Den politiske Aristarchus 1769-72", i Skuncke \& Tandefelt (red.) (2003).

Oseen, Carl Wilhelm, Johan Carl Wilcke: Experimental-fysiker (Uppsala, 1939).

Outram, Dorinda, The Enlightenment (1995), 2 uppl. (Cambridge, 2005).

Pagden, Anthony, European encounters with the New World: from Renaissance to Romanticism (New Haven, 1993).

Palmeri, Frank, "Conjectural history and the origins of sociology", Studies in Eighteenth-Century Culture 37 (2008).

Persson, Mathias, Det nära främmande: Svensk lärdom och politik i en tysk tidning, 1753-1792 (Uppsala, 2009).

—, "Det råa tillståndet: Vetenskapsakademien, vildarna och den koloniala världsordningen", i Nell \& Sjödin (red.) (2017). 


\section{KÄLLOR OCH LITTERATUR}

-, "Southern darkness, northern light: 'Civilisation' and 'savagery' in Anders Sparrman's southern African travelogue", South African Historical Journal 71:1 (2019).

-, "The professor and the body politic: Pehr Kalm and the social imaginary in eighteenth-century Turku", COLLeGIUM: Studies across Disciplines in the Humanities and Social Sciences, vol. 16 (2014).

Pleijel, Hilding, Från Hustavlans tid: Kyrkohistoriska folklivsstudier (Stockholm, 1951).

Porter, Roy, "Afterword", i Livingstone \& Withers (red.) (1999).

Pratt, Mary Louise, Imperial eyes: Travel writing and transculturation (London, 1992).

Pyenson, Lewis \& Sheets-Pyenson, Susan, Servants of nature: A history of scientific institutions, enterprises, and sensibilities (New York, 1999).

Rainer, Claes, Lovisa Ulrika: Konst och kuppförsök (Stockholm, 2019).

Ringer, Fritz K., The decline of the German mandarins: The German academic community, 1890-1933 (Cambridge, Mass., 1969).

Roberts, Michael, Sverige under frihetstiden: 1719-1772 (1986), sv. övers. (Stockholm, 1995).

Rubin, Edward L., Soul, self, and society: The new morality and the modern state (Oxford, 2015).

Rudebeck, Elisabeth, Tilling nature - harvesting culture: Exploring images of the human being in the transition to agriculture (Stockholm, 2000).

Runefelt, Leif, Dygden som välståndets grund: Dygd, nytta och egennytta i frihetstidens ekonomiska tänkande (Stockholm, 2005).

-, "Wasting a day chasing a hare: Indolence, self-interest and spatial mobility in the rhetoric about Swedish peasantry, ca. 1750-1850", Ideas in history: Journal of the Nordic Society for the history of ideas 8:1 (2014).

Rydberg, Sven, Svenska studieresor till England under frihetstiden (Uppsala, 1951). Rydén, Göran, "Provincial cosmopolitanism: An introduction", i Rydén (red.) (2013). -, (red.), Sweden in the eighteenth-century world: Provincial cosmopolitans (Farnham, 2013).

Ryman, Björn, Eric Benzelius d. y: En frihetstida politiker (Motala, 1978).

Salminen, Seppo, "Religious and intellectual currents", i Kouri \& Olesen (red.) (2016).

Samuelson, Jan, Eliten, riket och riksdelningen: Sociala nätverk och geografisk mobilitet mellan Sverige och Finland 1720-1820 (Helsingfors, 2008).

Shapin, Steven \& Schaffer, Simon, Leviathan and the air-pump: Hobbes, Boyle, and the experimental life (Princeton, 1985).

Schumpeter, Joseph, "Science and ideology", The American economic review 39:2 (1949).

Segerstedt, Torgny T., Nils von Rosenstein: Samhällets människa (Stockholm, 1981). Sellin, Volker, "Regierung, Regime, Obrigkeit", i Brunner (red.) (1984). 


\section{KÄLLOR OCH LITTERATUR}

Sennefelt, Karin, Den politiska sjukan: Dalupproret 1743 och frihetstida politisk kultur (Hedemora, 2001).

—, Politikens hjärta: Medborgarskap, manlighet och plats ifrihetstidens Stockholm (Stockholm, 2011).

Shils, Edward, "Charisma" (1968), i Shils (1972).

-, "Charisma, order, and status", American sociological review 30:2 (1965).

-, The constitution of society: With a new introduction by the author (Chicago, 1972).

Sigmundsson, Svavar (red.), Norden och Europa 1700-1830: Synvinklar på ömsesidigt kulturellt inflytande (Reykjavik, 2003).

Skuncke, Marie-Christine, Carl Peter Thunberg: Botanist and physician. Careerbuilding across the oceans in the eighteenth century (Uppsala, 2014).

-, Gustaf III - det offentliga barnet: En prins retoriska och politiska fostran (Stockholm, 1993).

—, "Was there a Swedish enlightenment?", i Sigmundsson (red.) (2003).

Skuncke, Marie-Christine \& Tandefelt, Henrika (red.), Riksdag, kaffehus och predikstol: Frihetstidens politiska kultur, 1766-1772 (Stockholm, 2003).

Smethurst, Paul, Travel writing and the natural world, 1768-1840 (Houndmills, 2012).

Snickare, Mårten, Enväldets riter: Kungliga fester och ceremonier i gestaltning av Nicodemus Tessin den yngre (Stockholm, 1999).

Spary, Emma, "Political, natural and bodily economies", i Jardine, Secord \& Spary (red.) (1996).

Stapelbroek, Koen \& Marjanen, Jani, "Political economy, patriotism and the rise of societies", i Stapelbroek \& Marjanen (red.) (2012).

-, (red.), The rise of economic societies in the eighteenth century: Patriotic reform in Europe and North America (Houndmills, 2012).

Stålmarck, Torkel, "Elis Schröderheim", Svenskt biografiskt lexikon, band 31.

Svenska Akademiens ordbok, band 11, 14, 16, 21, 28.

Svensk ordbok.

Svenskt biografiskt handlexikon, band 1.

Svenskt biografiskt lexikon, band 1, 3, 4, 6, 7, 8, 17, 19, 20, 23, 29, 30, 31, 32, 33 .

Sörlin, Sverker, De lärdas republik: Om vetenskapens internationella tendenser (Malmö, 1994).

-, "Science, empire, and enlightenment: Geographies of Northern field science", European review of history 13:3 (2006).

Tandefelt, Henrika, Konsten att härska: Gustaf III inför sina undersåtar (Helsingfors, 2008).

Taylor, Charles, Modern social imaginaries (Durham, 2004).

Wakefield, Andre, The disordered police state: German cameralism as science and practice (Chicago, 2009).

Weber, Max, On charisma and institution building: Selected papers. Edited and with an introduction by S. N. Eisenstadt (Chicago \& London, 1968). 


\section{KÄLLOR OCH LITTERATUR}

Weir, Lorna, "The concept of truth regime", Canadian Journal of Sociology 33:2 (2008).

Wetterberg, Gunnar, Från tolv till ett: Arvid Horn (1664-1742) (Stockholm, 2006).

Widmalm, Sven, Mellan kartan och verkligheten: Geodesi och kartläggning 16951860 (Uppsala, 1990).

- (red.), Vetenskapens sociala strukturer: Sju historiska fallstudier om konflikt, samverkan och makt (Lund, 2008).

Winton, Patrik, Frihetstidens politiska praktik: Nätverk och offentlighet 1746-1766 (Uppsala, 2006).

Withers, Charles W. J. \& Livingstone, David N., "Introduction: On geography and enlightenment", i Livingstone \& Withers (red.) (1999).

Wolf, Eric R., Europe and the people without history (1982), 2. uppl. (Berkeley, 1997).

Wolff, Larry, "Discovering cultural perspective: The intellectual history of anthropological thought in the Age of Enlightenment", i Wolff \& Cipolloni (red.) (2007).

Wolff, Larry \& Cipolloni, Marco, "Preface", i Wolff \& Cipolloni (red.) (2007).

-, (red.), The anthropology of the Enlightenment (Stanford, 2007).

Wolloch, Nathaniel, "The civilizing process, nature, and stadial theory", EighteenthCentury Studies 44:2 (2011).

Worster, Donald, De ekologiska idéernas historia (1977), sv. övers. (Stockholm, 1996).

Öhrberg, Ann, Samtalets retorik: Belevade kulturer och offentlig kommunikation i svenskt 170o-tal (Höör, 2014).

-, Vittra fruntimmer: Författarroll och retorik hos frihetstidens kvinnliga författare (Hedemora, 2001).

Östlund, Joachim, Lyckolandet: Maktens legitimering $i$ officiell retorik från stormaktstid till demokratins genombrott (Lund, 2007). 


\section{Personregister}

Acrel, Olof af 91, 161

Adelcrantz, Carl Fredrik 37, 137, 165, 217,224

Adolf Fredrik $65,67,73,115,117,141$, 159, 161-169, 183, 185, 193-194, 208-211, 226, 228, 230, 238

Agrippa 165, 217

Alfonso XI av Kastilien 140

Alströmer, Clas 42, 140, 159

Alströmer, Jonas $42,65,67,72,73,96$, 105-106, 110, 114, 159, 204, 205

Alströmer, Patrick 159

Arbin, Axel Magnus von 155, 175, 178, 228

Arfvedson, Carl Christopher 151, 204

Augustus 165

Benzelstierna, Matthias 147, 220

Bergius, Bengt 132, 133, 175, 187-188, 195, 198, 207, 208, 219

Bergius, Peter Jonas 9o, 148, 166

Bergman, Torbern 45

Bielke, Nils Adam 62, 83, 84, 146, 151, $178,178-179,189,220,225-226$

Bielke, Sten Carl 105, 219

Bonde, Gustaf 219

Broberg, Gunnar 11

Browallius, Johan 59, 202

Bröt-Anund 77

Bunge, Sven 98, 145, 148, 153-154,

184-185, 219-220

Bäck, Abraham 51, 100-101, 120, 122, $166,217,229$
Carlson, Johan Gustaf von 220

Cederhielm, Carl Wilhelm 105, 132, 160, 205, 219

Celsius, Anders 107, 205

Celsius den yngre, Olof 171, 203

Chydenius, Anders 120

Clason, Johan $65,77,99,136-137,141$, 160, 167-168, 171, 221

Colbert, Jean Baptiste $80-81,165,217$

Cronstedt, Carl Johan 168, 169, 211

Dalberg, Nils 188

Dalin, Olof von 16, 92, 168, 210

d’Argenson, René Louis de Voyer de

Paulmy 64, 84

De Geer, Louis 81, 137

Dunér, David 61

Ehrenpreus, Carl Didrik 38, 85, 208-209

Ehrensvärd, Augustin 42, 57, 125, 129

Ekblad, Magnus 16, 32

Ekeblad, Clas 32, 107

Ekeblad, Eva 221

Ekedahl, Nils 17

Eliassen, Knut Ove 30

Elisabet I av England 80

Elvius, Pehr 205

Faggot, Jacob 63, 112, 116, 118, 204, 224, 226

Falkenberg, Melcher 220

Ferrner, Bengt 46-47, 55, 166, 225 


\section{PERSONREGISTER}

Filip II av Spanien 223

Forsman, Karl 25

Frans I av Frankrike 79

Fredrik I 72, 125, 159, 160-161, 164, 167 186, 193-194, 208-209, 213, 238

Fredrik II av Preussen 166, 202, 228

Fredrik III av Danmark 226

Gadolin, Jacob 47, 154

Geertz, Clifford 26

Goodman, Dena 198

Grill, Claes 140, 205, 206, 207, 229

Gustaf Adolf Leijonmarck 149

Gustav II Adolf 77-79, 172, 192

Gustav III 13, 15, 16, 43, 66, 68, 69, 73, $78,83,85,98,101,105,138,145,148$, $152,159,162,169,170,172-180,182$, 188, 189, 190-194, 195, 211-215, 220, $223,225,226,228,238,240$

Gustav IV Adolf 180, 181, 215

Gustav Vasa 77-78, 83, 84, 99, 142, $146,151,172,174,178-180,189-190$, 195, 223, 240

Gyllenborg, Carl 32, 107, 140

Gyllenborg, Fredrik 107

Gyllenborg, Henning Adolph 99, 218

Hallberg, Peter 16

Harrison, Edward 35

Henrik IV av Frankrike 8o

Henrik VII av England 227

Hermelin, Samuel Gustaf 92, 146, 149

Hildebrand, Bengt 15

Hjelm, Peter Jacob 151

Horn, Arvid 32

Hårleman, Carl 32, 64, 74-75, 84, 107, 205

Högström, Pehr 55, 92, 120-122, 129, 157

Höpken, Anders Johan von 32, 41, 80,
$87,105-107,109,132,140,164,171$, 202, 207, 209-210, 219, 220

Ihalainen, Pasi 61

Jennings, John 144, 168, 210, 217

Johannisson, Karin 16

Julius Caesar 179, 227

Kalm, Pehr 217

Karl den store 178

Karl X Gustav 79, 136

Karl XI 77, 79, 153, 155, 228

Karl XII 79

Klingenstierna, Samuel 107, 140, 168, 205, 210

Knudsen, Jonathan 30

Knutberg, Carl 165, 210

Kristian II av Danmark 227

Kristina 79, 136

Kryger, Johan Fredrik 32, 51, 57, 62, 66, 97, 109, 113, 115, 118-119, 127-129, 165,229

Legnér, Mattias 16

Lehnberg, Carl 166

Leijell, Carl 81

Leijonmarck, Gustaf Adolf 149, 185

Lidbeck, Erik Gustaf 124

Liedman, Sven-Eric 16

Liljencrantz, Johan $32,80,133,137,138$, 139,140

Lillienberg, Jean George 32, 77, 78, $147,148,149,153,176,185,220$

Lilliestråle, Joachim Wilhelm 38-39, $43-45,54,65,68,69,154,177,178$, $185,191,197,220$

Lindberg, Bo 21

Lindroth, Sten 14, 15, 18

Linné, Carl von 11, 12-13, 32, 105, 107, 171, 205 


\section{PERSONREGISTER}

Lovisa Ulrika 161-162, 164-165, 166, $167,168,194,209,210,228,238$

Ludvig XIV 79, 80, 165

Ludvig XV 224

Lykurgos 138

Löwenhielm, Carl Gustaf 31, 32, 38, $59,66,93,112,127,130-131,132,138$, $157,161,167,203,205$

Magnus Ladulås 77

Mallet, Fredric 74

Mandeville, Bernard 57

McClellan, James 33

McCloskey, Deirdre 61

Melanderhielm, Daniel 38, 66

Melkersson, Martin 21

Mennander, Carl Fredrik 41, 51, 122-124, 164-165

Minos 130, 167

Mirabeau, Victor Riquetti de 104

Nero 227

Nordencrantz, Anders 57

Nordenmark, N. V. E. 15

Nordin, Jonas 72

Oden 226

Odhelius, Johan Lorens 82

Orrje, Jacob 221

Oseen, Carl Wilhelm 15

Palmstierna, Nils 32

Piper, Carl Fredrik 112, 160, 161, 209

Plantin, Zacharias Zachariae 179-180, 181, 214-215

Plinius den yngre 191

Plomgren, Thomas 140

Prosperin, Eric 31, 188, 218

Pufendorf, Samuel von 86,133

Qvist, Bengt 146
Rabbe, Sten af 138,171

Rausing, Lisbet 30

Ringer, Fritz 242

Rosenadler, Carl Albrecht 126-127, 130, 159, 208, 219

Rosenstein, Nils von 38, 93-96, 151, 181, 202, 241

Rosén von Rosenstein, Nils

(Rosenstein den yngre) 39, 47-50, $53,54,55-56,60-61,69,70,98,102$, $107,155-156,158,170,182,191-192$, 193, 195, 205, 212, 220, 222-223, 226-228, 229, 230

Rousseau, Jean-Jacques 45-46

Rudenschöld, Carl 71, 170, 201, 212, 214, 220

Rudenschöld, Ulric 111, 226

Runeberg, Edvard Fredrik 43, 55, 115, 146, 151

Runefelt, Leif 16

Rydman, Pehr 220

Rönnow, Casten 224

Sahlgren, Niclas 159, 204

Salander, Erik 32, 111, 164, 226

Sandels, Samuel 11, 53, 140-141, 147, 149, 152, 154, 160, 168-169, 171, 186-187, 189, 191, 195, 205, 206, 211-212, 219, 225

Scheffer, Carl Fredrik 43, 52, 109, $116,118,162,171,172-174,175,178$, 182-184, 190-191, 209, 218, 219, 223

Scheffer, Ulric 107, 208, 219

Schröder, Eric 152, 154, 176

Schröderheim, Elis 220

Schultze, Samuel 99, 111, 161

Schumpeter, Joseph 24

Schützercrantz, Herman 177, 224

Schönberg, Anders 52, 53, 57, 75,

141-144, 158, 170

Sennefelt, Karin 107 


\section{PERSONREGISTER}

Shils, Edward 25

Sixtus V 223

Skuncke, Marie-Christine 18

Solon 178

Sparre, Carl 6o, 70, 83, 85, 101, 149, $174,177,185,220$

Sparre, Fredrik 159, 206

Sparrman, Anders 37, 45, 53, 147, 180, 208

Stiernman, Anders Anton von 226

Stockenström, Eric von 125-126, 160-161, 167

Strandberg, Zacharias Johan 166, 224

Swartz, Olof 188, 205

Taylor, Charles 21, 35

Tessin, Carl Gustaf 31, 32, 107, 109, 114, $140,165,205,215,218$

Tham, Sebastian 81, 206

Theopompos 227

Thunberg, Carl Peter 191

Tilas, Daniel 61,64
Titus 168

Trajanus 178

Triewald, Mårten 105-106

Ulrika Eleonora 72, 160, 171, 186

Ungern-Sternberg, Matthias

Alexander von 114, 219

Wargentin, Pehr Wilhelm 18, 26, 30, $32,68,72,84,102,107,109,110$, 112 , 115, 117, 121-122, 124, 129-130, 131-132, 133, 144, 148, 150, 157, 166, 168, 169, 171, 174, 179, 206, 209, 210, 211, 212, 225, 226

Wilcke, Johan Carl 66, 107, 148, 152, 180, 181, 199, 201, 204, 215

Winton, Patrik 107-108

Wrede, Henrik Jakob 15, 63, 111, 123, 164

Yngve Frej 77 



